\title{
Colonial sugar production in Nyanza: (Kibos-Muhoroni) the Asian initiative, the genesis, and development of Kenya's sugar industry, 1903-1963
}

Godriver A. N. Wanga Odhiambo

West Virginia University

Follow this and additional works at: https://researchrepository.wvu.edu/etd

\section{Recommended Citation}

Odhiambo, Godriver A. N. Wanga, "Colonial sugar production in Nyanza: (Kibos-Muhoroni) the Asian initiative, the genesis, and development of Kenya's sugar industry, 1903--1963" (2010). Graduate Theses, Dissertations, and Problem Reports. 3563.

https://researchrepository.wvu.edu/etd/3563

This Dissertation is protected by copyright and/or related rights. It has been brought to you by the The Research Repository @ WVU with permission from the rights-holder(s). You are free to use this Dissertation in any way that is permitted by the copyright and related rights legislation that applies to your use. For other uses you must obtain permission from the rights-holder(s) directly, unless additional rights are indicated by a Creative Commons license in the record and/ or on the work itself. This Dissertation has been accepted for inclusion in WVU Graduate Theses, Dissertations, and Problem Reports collection by an authorized administrator of The Research Repository @ WVU.

For more information, please contact researchrepository@mail.wvu.edu. 
COLONIAL SUGAR PRODUCTION IN NYANZA: (KIBOS-MUHORONI) THE ASIAN INITIATIVE, THE GENESIS, AND DEVELOPMENT OF KENYA'S SUGAR INDUSTRY, 1903-1963

GODRIVER A. N. WANGA ODHIAMBO

\author{
DISSERTATION \\ Submitted to Eberly College of Arts and Sciences \\ At West Virginia University \\ In Partial Fulfillment of the Requirements for \\ The Degree of Doctor of Philosophy in History
}
Robert M. Maxon Ph.D., Chair
Joseph M. Hodge Ph.D.
Mark Tauger Ph.D.
Brent McCusker Ph.D.
James Siekmeier Ph.D.

\author{
Morgantown, West Virginia \\ 2010
}

Keywords: Kenya, Colonial Sugar Industry, Nyanza, Kibos, Muhoroni, Development 


\section{ABSTRACT \\ Colonial Sugar Production in Nyanza: (Kibos-Muhoroni) The Asian Initiative, The Genesis, and Development of Kenya's Sugar Industry, 1903-1963}

\section{Godriver A. N. Wanga Odhiambo}

This study analyses Asian sugar production in colonial Nyanza examines the Asian initiative and the development of commercial cane farming in Central Nyanza. Therefore, the work provides a different perspective on Asian initiative in agriculture and provides a framework on which to understand the persistent state of insufficiency in Kenya's sugar industry.

The study mainly relied on primary sources, secondary sources and oral interviews. These sources were derived from the Kenya National Archives, Nairobi, Syracuse University's Bird Library, Ohio University Library, Moi University Library Eldoret and West Virginia University Library. The primary materials included annual reports of the Department of Agriculture, District annual reports, Provincial reports, monthly intelligence reports, colonial officials' correspondence, and correspondence from East Africa India National Congress. Oral interviews were also conducted to verify some information while the secondary sources were used to supplement the sources.

The study is organized in ten chapters that follow the major trends in the development of the sugar industry in Central Nyanza highlighting the emerging themes. Chapter One sets the establishment of the study through the statement of the research problem. Questions to be investigated and the objectives of the study are identified. Also, a critique of reviewed literature is undertaken which examines Asians' agricultural initiative in Kenya and the methodology adopted in the study is described Chapter Two establishes the background for the study through analysis of the movement and settlement of Asians in colonial Kenya and their subsequent settlement in Kibos-Muhoroni. It specifically identifies the Asians involved in farming. Chapter Three traces the migration and settlement of the Luo people into Nyanza Province of Kenya and particularly in Central Nyanza. It examines the indigenous economy that prevailed before the penetration of the Asian capital through commercial cane growing in Central Nyanza and question of land that arises out of such penetration.

Chapter Four discusses the genesis and the growth of the Asian commercial cane farming in the Kibos-Muhoroni area as a result of the establishment of the first sugar mill in Kenya, the Victoria Nyanza Sugar Company. The chapter also examines the progress during the world wars as vigorous experimentation took place. Specifically, the chapter discusses the transformations that took place during the post World War II period that ushered in the entrenchment of Asian capital in the manufacturing of sugar as well.

Chapter Five discusses the transportation, acceptance of cane and the manufacturing of sugar. Chapter Six gives an analysis of marketing of sugar and how the colonial state controlled the distribution and sale of sugar together with the challenges faced by the cane farmers and manufacturers due to the colonial state's marketing policies. In Chapter Seven, the work focuses on the pertinent issue of labor that is needed in any agricultural industry, the shortages, wages and working conditions and how the colonial government, in an attempt to solve the labor crisis, created discriminative policies that favored settler farmers and left the Asian farmers struggling for labor. Chapter Eight analyses the many challenges faced by the Asian cane farmers and reveals how the Asian farmers took the initiative to solve some of those problems by organizing themselves into various groups as the colonial state neglected the cane farmers and failed to see 
the sugar industry as part of the wider colonial economy. Chapter Nine discusses the socioeconomic impact of the Asian settlement at Kibos-Muhoroni and the subsequent introduction of commercial cane farming in Central Nyanza where both positive and negative aspects are assessed. It emerges that the positive economic effects had a far reaching impact. Chapter Ten presents the summary and conclusions drawn from the study. 


\section{ACKNOWLEDGEMENTS}

The success of this study was as a result of support of many individuals and institutions. I wish to acknowledge the support of my advisor, Professor Robert Maxon who taught me during my Masters degree at Moi University and encouraged scholarly work. Professor Maxon also encouraged me to pursue the Ph.D. program that saw me admitted to West Virginia University and I feel greatly honored to have benefited from his tutelage. I will always be indebted to his efforts, sacrifice of the trips he made to Syracuse to discuss the chapters, patience, valuable suggestions and guidance during the writing of this dissertation without which the task would not have been completed. I wish also to thank the members of my dissertation committee, Professors Joseph Hodge, Brent McCusker, James Siekmeier and Mark Tauger for their contributions and encouragement. I also wish to thank Lemoyne College for offering me a fellowship that greatly facilitated the writing of the dissertation. Special thanks to Jennifer Macintosh of the Office of Social Justice for the Minority Doctorate Program award that saw the starting of the program and the Department of History West Virginia University for the generous offer of teaching assistantship and also for facilitating my research in Kenya during the summer of 2009. I wish to thank the staff of Kenya National Archives for their expertise and help especially Richard Ambani. In addition I would like to recognize the assistance of Professor Peter Odhiambo Ndege and Dr. Anne Nangulu both of Moi University for their selfless efforts in getting crucial materials whenever I needed help. I am also indebted to the many interviewees who welcomed me to their homes and gave valuable information especially Mohinder Singh of Kibos, Vajv of Kisumu and Hezborn Atudo of Kibos. My gratitude goes to my research assistants, Harrison Onyango and Tony Nyaoke. I wish also to recognize my graduate colleagues, Dr. Ken Moindi, Raymond Keller, Kiva Mola, Zoa Williams, and Charles Stainment 
for their honesty, encouragement and fruitful discussion of the drafts. I am also indebted to Hal Gorby and Donna MacIsaac for their technical help during the write up. I also wish to thank Mrs. Yudalis Keller for her hospitality in hosting me on several occasions in her home whenever I came to Morgantown for consultations during the final stages of this write up. Special thanks to Mrs. Felicia Maxon who welcomed me to her home always and made me feel at home thousands of miles away.

Finally I feel honored and indebted to my family to have allowed me to pursue my dream. I recognize the efforts of my husband Eng. C.L. Odhiambo for taking care of the family during my long absence, my children Yophi, Joy, and Noel for missing out on that crucial supervision during your teenage years. For the time put here was really yours. I thank whole heartedly my sister Vena, who stepped in on many occasions to help out my children when I was away.

This work is dedicated to my late father who encouraged to pursue my academic dream; Mzee Cosmas Wanga Nyakiamo who passed on during the course of the program.

“NIULOTU SOIFU” (It is well dad). 


\section{Table of Contents}

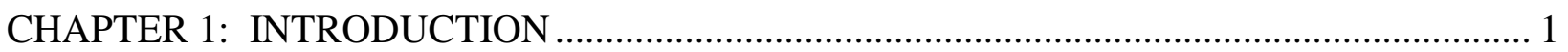

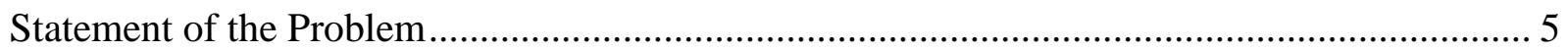

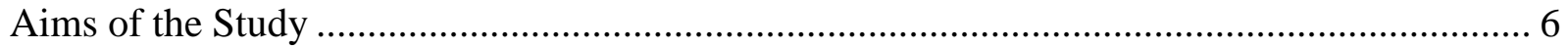

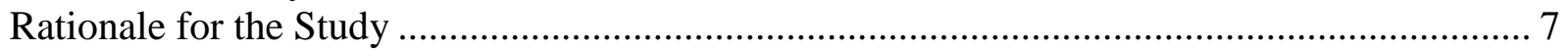

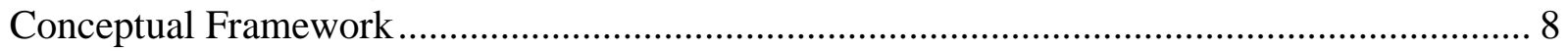

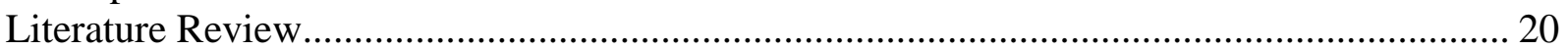

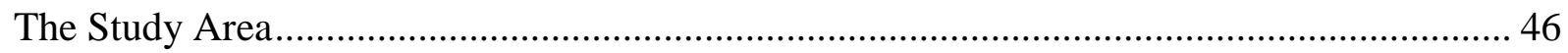

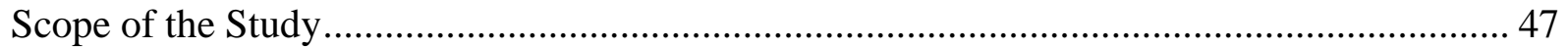

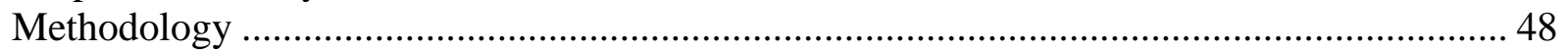

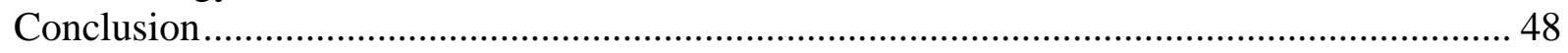

CHAPTER 2: HISTORICAL BACKGROUND OF INDIANS IN KENYA ………................... 49

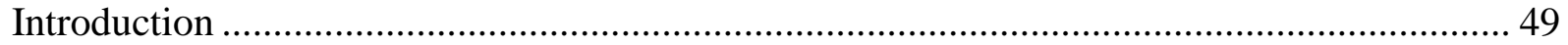

Migrations and Settlement................................................................................................. 49

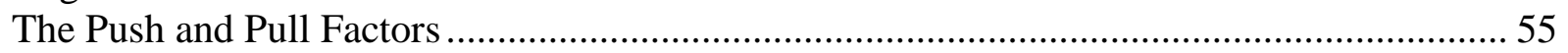

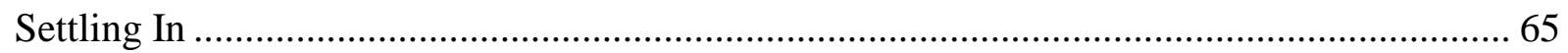

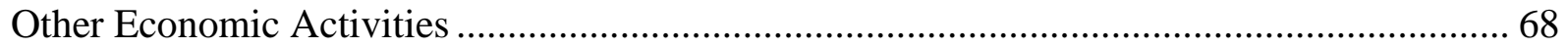

Settlement Patterns ………………………………………............................................ 72

Settlement at Kibos-Muhoroni .......................................................................................... 74

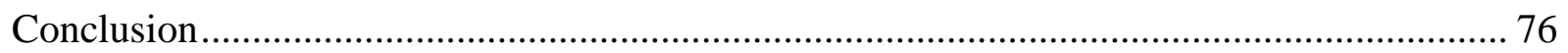

CHAPTER 3: INDIGENOUS ECONOMY, POLITICS OF LAND AND THE GENESIS OF ASIAN SUGARCANE AGRICULTURE …………….................................................... 77

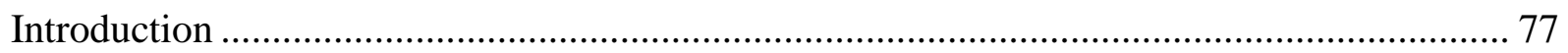

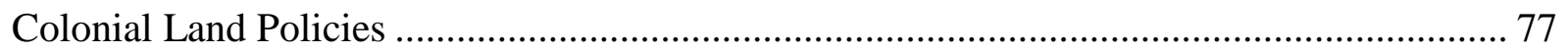

Politics of Land: Asians vs. Europeans ................................................................................. 92

Nyanza Province: Background of the Administrative Areas ..................................................... 97

Settlement and Beginning of Cane Farming at Kibos ....................................................... 101

The Movement and Settlement of the Luo in Nyanza Province .............................................. 105

Indigenous Land Tenure System........................................................................................ 109

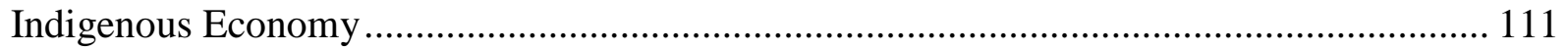

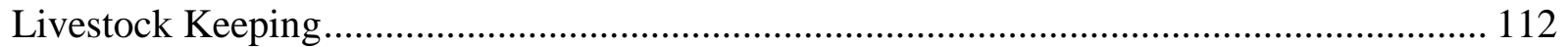

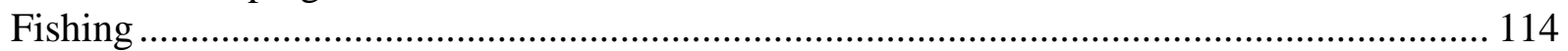

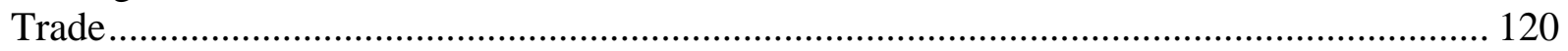

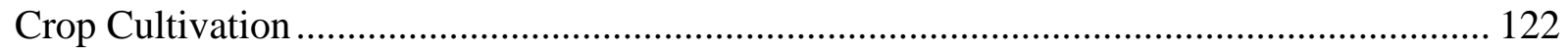

Asians vs. Africans: Conflict of Interest .......................................................................... 125

CHAPTER 4: ASIAN SUGARCANE FARMING IN COLONIAL NYANZA …........................... 129

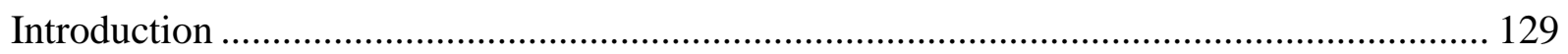

Asian Sugarcane Farming in Colonial Nyanza: The Pre-World War I Period, 1903-1913 ... 130

Sugar Cane Farming During the World War I Period, 1914 up to 1923................................. 140

Sugar Production during the interwar Period, 1924 to 1938 .................................................. 144

Sugarcane Farming During the World War II Period, 1939 up to 1949 ................................. 160

Expansion of Sugarcane Farming in Post War Period, 1950 to 1963 ...................................... 165 
Agricultural Aspects of Sugarcane growing in Colonial CN .......................................... 168

Technical Aspects, State support and their Impact in Colonial Sugarcane Farming ............. 178

Sugarcane Variety Trials Miwani -Kibos Area ............................................................. 183

Experiments on the Possible Irrigation of Sugarcane farming .......................................... 191

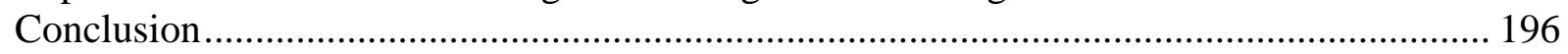

CHAPTER 5: TRANSPORTATION AND PRODUCTION OF SUGAR IN .............................

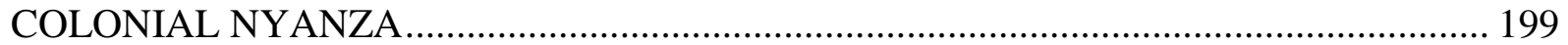

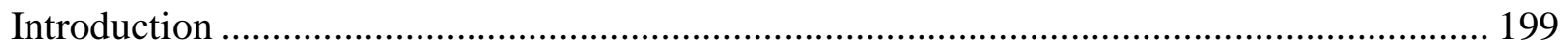

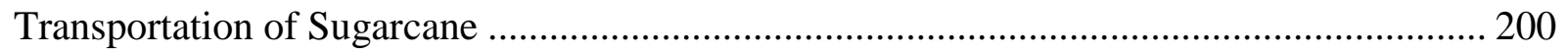

Sugarcane Transport by the Kenya-Uganda Railway ...................................................... 205

The Conveyance and Acceptance of Cane by the Miller ................................................. 211

Payment and Pricing of Sugarcane............................................................................. 214

Production of Sugar: Within the Factory Processing ........................................................ 221

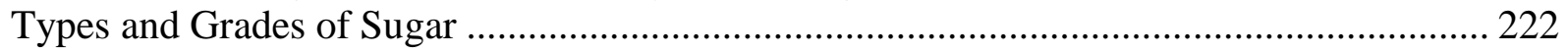

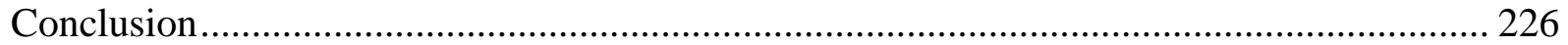

CHAPTER 6: MARKETING OF SUGAR IN COLONIAL NYANZA ................................ 228

Introduction: Background to marketing in colonial Nyanza, 1930-1940 ............................ 228

The Colonial State and the Sugar Market 1930-1940 .................................................... 231

Colonial State Control Over the Sugar Market 1940-1950 ............................................... 234

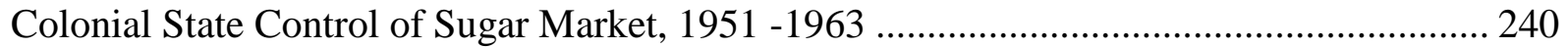

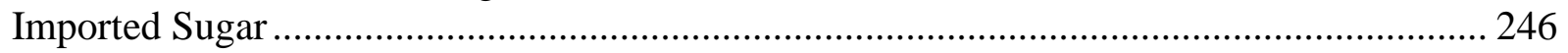

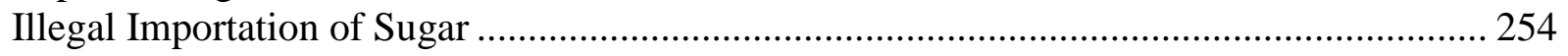

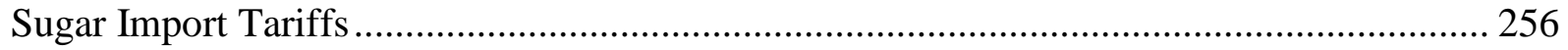

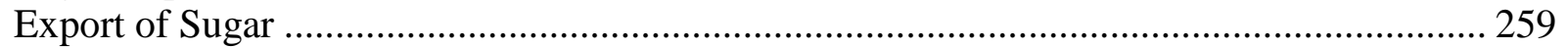

Marketing and Distribution of Sugar in Colonial CN ................................................... 264

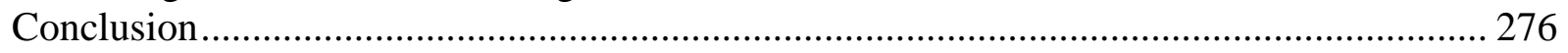

CHAPTER 7: LABOR IN NYANZA SUGAR FARMING ............................................ 279

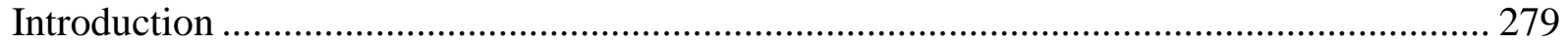

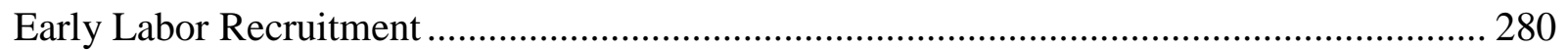

World War I and Post War labor Conditions .................................................................... 285

Depression Period and Labor Shortages on Sugarcane Farms ............................................ 295

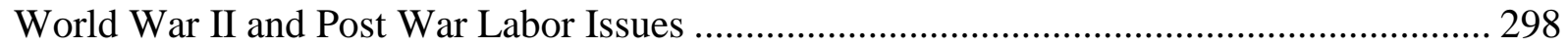

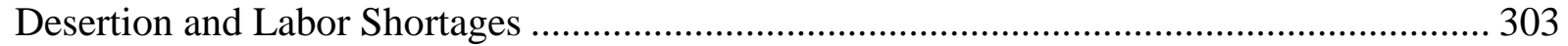

Working Conditions in Sugarcane Plantations and Factories ......................................... 306

Terms of Service for Laborers in the Sugar Industry ..................................................... 306

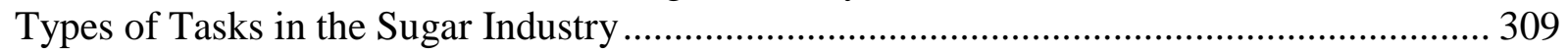

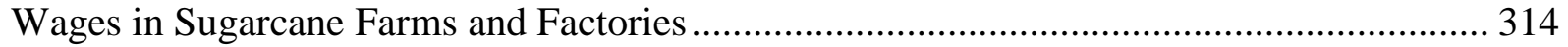

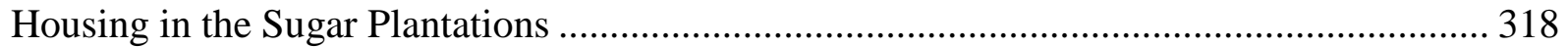

Labor Unrest in the Sugar Industry ........................................................................ 322

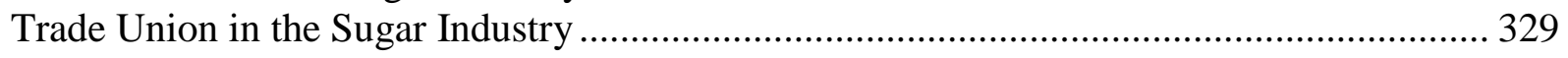

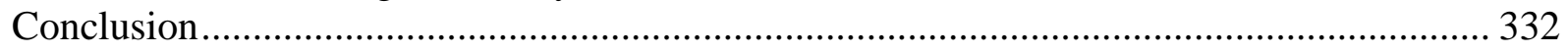


CHAPTER 8: CHALLENGES OF SUGARCANE GROWING IN COLONIAL NYANZA.. 334

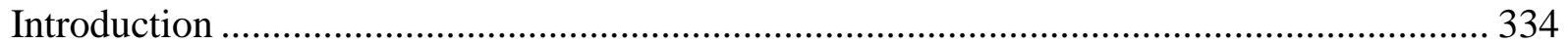

Colonial State Policies and Their Impact on Cane Farming ............................................ 334

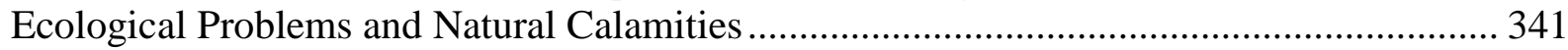

Financial Constraints of the Asian Cane Farmers ......................................................... 346

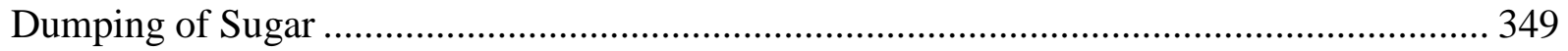

Lack of Harmony: Farmers and Manufacturers ......................................................... 352

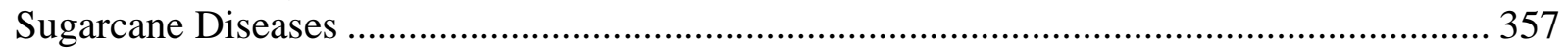

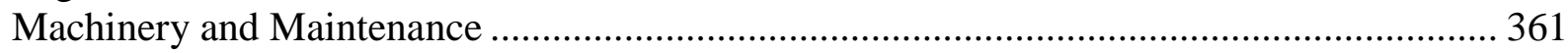

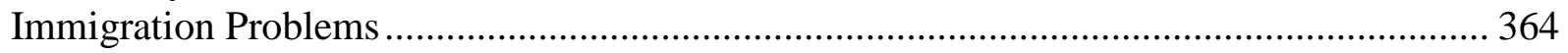

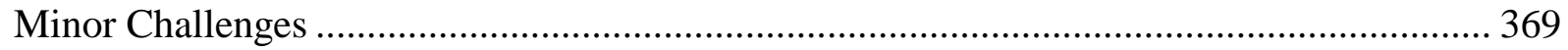

The Asian Cane Farmers’ Initiatives Towards Meeting the Challenges .............................. 370

The Nyanza Farmers Cooperative Society (NFCS) ...................................................... 372

The Agricultural Production Sub-Committees................................................................ 373

The Nyanza Indian Farmers Association (NIFA) ........................................................ 377

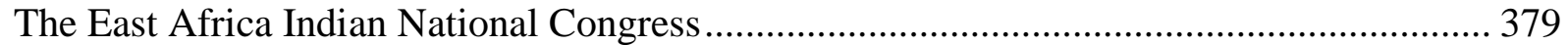

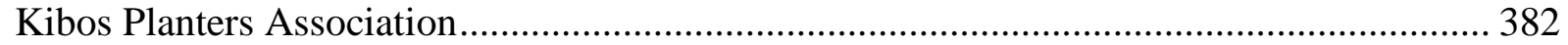

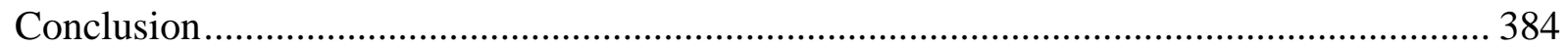

CHAPTER 9: SOCIAL AND ECONOMIC IMPACT OF ASIAN CANE FARMING IN

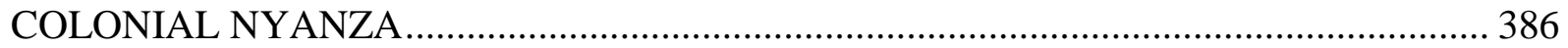

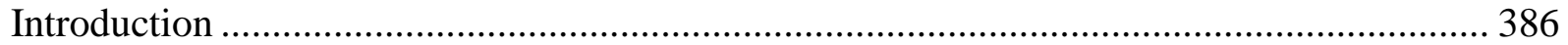

Asian Impact on Commercial Sugarcane farming: African Cane farmers 1930s-1963......... 387

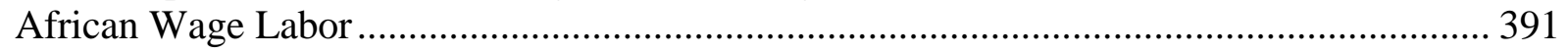

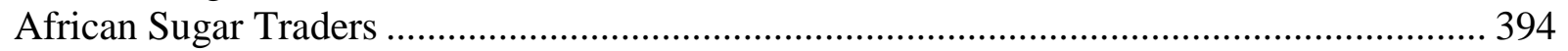

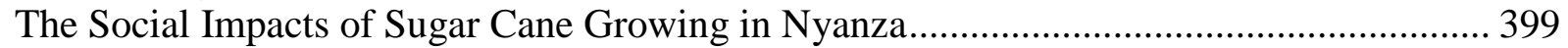

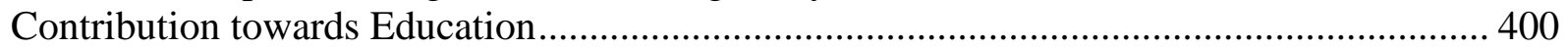

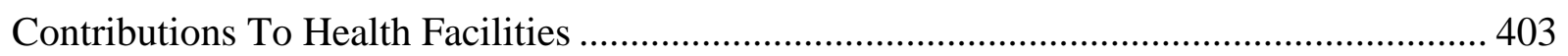

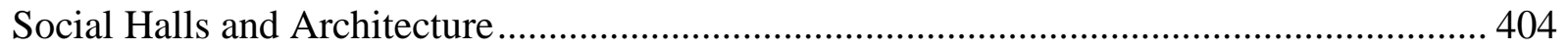

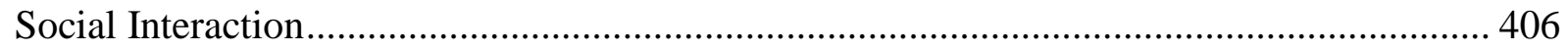

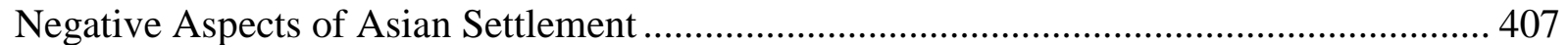

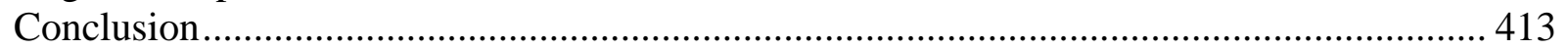

CHAPTER 10: SUMMARY AND CONCLUSIONS ..................................................... 415

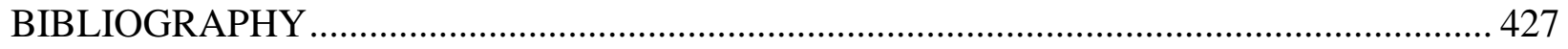




\section{List of Tables}

Table 4.1: Kibos Indian Settlement and Land Acreage, 1913

Table 4.2: Muhoroni Indian Settlement Farms Granted on Two Years Occupation

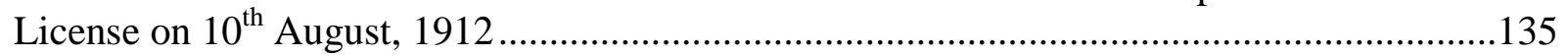

Table 4.3: European Settlers at Muhoroni, 1911 ................................................................139

Table 4.4: Performance of the Sugar Companies, 1925-1932 _.............................................149

Table 4.5: Sources of sugar produced by Victoria Nyanza Sugar Coy, 1924-1934 _..................157

Table 4.6: The number of Asian Farmers and Acreage Held in the Kibos-Muhoroni Area, 1947

Table 4.7: Miwani Sugar Mills Production, 1953-1960 .......................................................168

Table 4.8: Estimated Cost of Cultivation of Sugar Cane per acre, 1946 .................................177

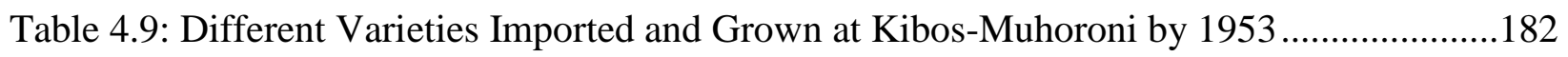

Table 4.10: Trials comparing Yields of Plant Crop and Ratoon Crops, planted in 1950 ...........184

Table 4.11: Sugarcane Planted on Red Soil, Miwani Estate and Harvested 1955.....................186

Table 4.12: Trials on Yields and Sucrose Content Planted on Black Soil and Harvested, 1955 Miwani.

Table 4.13: Sugar Variety Trial - on Yield and Sucrose Content, Miwani Estate, 1953...........188

Table 4.14: Sugar Variety Trial on Yields and Sucrose, Miwani Estate, 1954 .........................189

Table 4.15: Experiments on Sugarcane Spacing, Chemelil, 1949-1955..................................190

Table 4.16: Possible Acreage to Benefit from Irrigation, 1953 ............................................193

Table 4.17: Approximate Amount of water required for Irrigation, 1953...............................195

Table 5.1: Proposed Prices of Sugar and Cane, 1947 ..........................................................219

Table 6.1: Production of Sugar and Jaggery in the nine areas, 1948 .....................................239

Table 6.2: Markets/Trading Centers with Prices of Sugar per Pound, CN, 1957......................244 


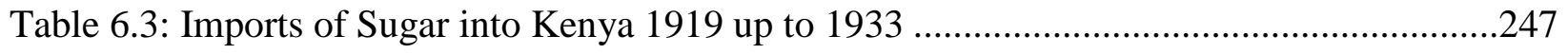

Table 6.4: Comparative Prices of Imported Ugandan and Kenyan-Miwani Sugar, 1961 ...........251

Table 6.5: Comparative Prices of Imported Refined and Miwani Refined Sugars, 1961 ...........252

Table 6.6: Exports of Sugar from Kenya, 1924-1952 ……........................................................260

Table 6.7 Export of Wheat and Wheat Flour from Kenya 1924-1946...................................................... 263

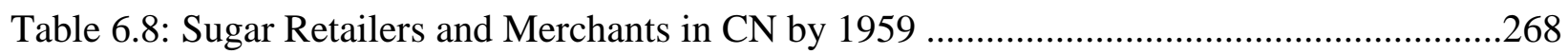

Table 6.9: Production, Consumption and import of Sugar in Metric tons, 1955-1963 ...............273

Table 7.1: Factory Labor Force ………………………........................................................313

Table 7.2: Housing space at Miwani Sugar Company, 1954......................................................321

Table 8.1: Impact on sugar production by locusts, 1929-1932 ..................................................345

Table 8.2: Comparative Ugandan Exports to Kenya and Tanganyika, Dec 1955-Feb. 1956.......351

Table 9.1: Sugar Traders in Alego Location, and the monthly allocation, May 1954..................396

Table 9.2: African Sugar Distributors-Uncollected Sugar, Jan 1958 ...........................................398

Table 9.3: Distribution and Density of African Population CN District, 1948 ............................410 


\section{List of Maps}

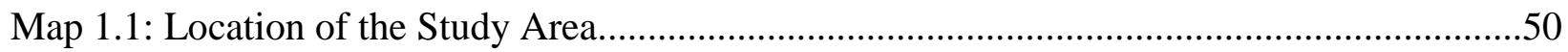

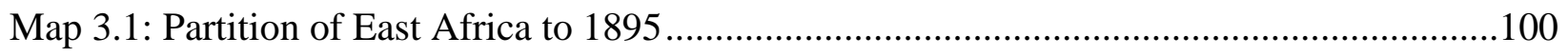

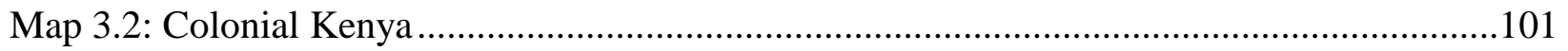

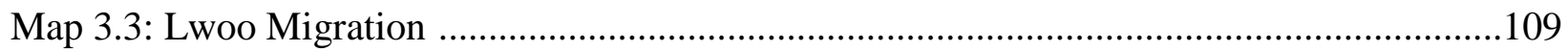

Map 4.1: Asian Sugarcane Plantations ..........................................................................137 


\section{ABBREVIATIONS}

AAO

$\mathrm{AO}$

CCDB

CEC

CK

CKDAR

$\mathrm{CN}$

CNDAR

$\mathrm{CO}$

DAO

DC

DO

DofAAR

EAINC

GMR

IBEAco

K-L

K-LDAR

KDQR

KNA

KSM

KUSPW

Lab

LegCo

LIR

LNC

LRNo

NADAR

NFCS

NK
Assistant Agricultural Officer

Agricultural Officer

Central Commodity Distribution Board

Committee of Economic Co-operation

Central Kavirondo

Central Kavirondo District Annual Report

Central Nyanza

Central Nyanza District Annual Report

Colonial Office

District Agricultural Officer

District Commissioner

District Officer

Department of Agriculture Annual Report

East Africa Indian National Congress

Guaranteed Minimum Return

Imperial British East Africa Company

Kisumu-Londiani

Kisumu-Londiani District Annual Report

Kisumu District Quarterly Report

Kenya National Archives

Kisumu

Kenya Union of Sugar Plantation Workers

Labour Department Files

Legislative Council

Labour Inspection Report

Local Native Council

Land Registration Number

Native Affairs Department Annual Report

Nyanza Farmers Cooperative Society

North Kavirondo 
NIFA

NZA

PADO

PAO

PC

PS

SAO

SK

TE Pass
Nyanza Indian Farmers Association

Nyanza

Provincial Agrarian Development Officer

Provincial Agricultural Officer

Provincial Commissioner

Permanent Secretary

Senior Agricultural Officer

South Kavirondo

Temporary Entry Pass 


\section{CHAPTER 1}

\section{INTRODUCTION AND STATEMENT OF THE PROBLEM}

Africa remains as an underdeveloped continent many years after nation-states gained their independence. This economic stagnation is partly due to colonial policies, population growth, land scarcity, bad governance, and poor ecology. ${ }^{1}$ This has led, among other things, to inadequate food production in Africa; impacting greatly on agriculture. Food scarcity has therefore been a major concern of African countries and African governments have struggled with this issue. Yet a close examination reveals how colonial policies of creating dependencies with emphasis on cash crop production laid the foundation of producing for export, leading to food insecurity.

It is clear that agricultural production forms the basis of economic development in Africa and Kenya in particular. The colonial states pursued policies that were geared towards making the colonies dependencies. This policy was embedded in the concept of "trusteeship" whereby the colonial powers established colonies "for the common good of both the metropolis and the colonized". ${ }^{2}$ However, the colonized states were turned into dependencies, in that colonial states produced crops needed by the metropole. Many studies have been done on European settler agriculture and peasant farming in Kenya, yet very little work has focused on the Asian agricultural efforts.

Indeed, Africa, and Kenya in particular, continue to suffer from insufficiency of some foodstuffs, such as sugar, hence, poverty and underdevelopment have also remained and impacted Kenyan development plans since independence. As a consequence, declining food

\footnotetext{
${ }^{1}$ Martin Shanguhyia, “The State, Ecology, and Society in Western Kenya: Soil Erosion and Conservation in Vihiga”, Ph.D. Dissertation, West Virginia University, 2007, 2.

${ }^{2}$ See David Meredith, “The British Government and the Colonial Economic Policy, 1919-1939”, Economic History Review, 28, No. 3, (1975), 484-499. (These policies were not inclusive among the three tier society).
} 
production and lack of self-sufficiency in food stuffs have persisted. ${ }^{3}$ Sugar production falls within this category.

To understand Africa in general, and Kenya's food insufficiency in particular, it is imperative to look at the historical colonial policies that deeply pushed Kenya to dependency status. Therefore, we can argue that Kenya's insufficiency in sugar production could be partly due to the agrarian policies of the colonial state. The colonial state enacted land policies that impacted agriculture since the economic policies favored European settlers whereby the settlers got more land than the Africans and Asians. Yet, availability of fertile land is crucial in any production.

Nevertheless, the colonial state did not believe the African economy to be viable enough to make the colony self-sustaining; the colonial state believed that settler farming could sustain the state, hence, neither were efforts made to improve Asian farming since they were viewed as possible competitors to the European settlers. Therefore, the colonial state entrenched measures to discourage Asian farming especially in the fertile highlands. However, studies reveal that Asians were capable farmers; some came from farming backgrounds in India, as this study seeks to investigate.

However, the policies were full of contradictions possibly due to tensions within the colonial state such as between the different departments, for example, between the administrators and the department of agriculture. Secondly, Colonial policy also changed after World War II. Before the war, the colonial state was unresponsive and more negligent; however after the war, the state was more supportive and responded adequately as the colony embarked on postwar

\footnotetext{
${ }^{3}$ See N. Chazan and T.M. Shaw, “The Political Economy of Food in Africa” in N. Chazan \& T.M. Shaw eds., Coping with Africa’s Food Crisis (Boulder: Lynne Reinner, 1988), 2.
} 
developments plans. The contradiction emerges as the colonial state started to support the sugar manufacturing industry that was soilidly under Asian capital by late 1940s.

Be that as it may, the sugar industry in Kenya owes its origin to the Asian community. Asians were the first to grow sugar commercially in western Kenya. Initially, many Asian farmers supplied the Victoria Nyanza Sugar Company with produce. The company was founded by G.R. Mayers, the Australian pioneer who set up the company as the first large scale sugar operator in Nyanza Province in 1923. Three years later the Madhvani Group International of India, led by Muljibhai Madhvani, established a second sugar factory: the Associated Sugar Company at Ramisi in the Coast province. These were privately owned firms that relied on their large scale plantations as well as sugar produced by Asian farmers to feed the factories. Therefore, this Asian cane production was the first pioneering external linkage in Kenya's sugar industry. These two companies remained in operation in Kenya from 1920s to the mid-1960s, though the Victoria Nyanza mill was purchased by an Asian capitalist in 1947. By the latter date sugar processing factories were established at Muhoroni, Sukari and Manoni. However, the production of these two firms was not adequate to meet internal demand and so about 65 percent of sugar was imported from outside. ${ }^{4}$

This Asian link in Kenya’s sugar industry continued after independence. For example, in 1966, although the East African sugar industries (Muhoroni) as part of the Million Acre scheme was established by the Kenya government through the help of Agency for International Development (AID), the management of the firm was entrusted to the Mehta Group, an Asian multinational which was also involved in the construction of the firm. Mehta Group International also managed another sugar industry in South Nyanza built in 1979: The Sony Sugar Company.

\footnotetext{
${ }^{4}$ Kenya National Archives (KNA): PC/NZA/3/2/34, Nyanza Indian Farmers Association to Sir Robert BrookePopham, $28^{\text {th }}$ September 1939 . The association sent a petition giving the history of sugarcane farming in Nyanza. Also KNA: BV/6/613, Sugar Export Quota, 1938.
} 
Today external linkages have continued to play a crucial role in cane production in the independent state. Chemelil Sugar Factory in Nyanza was established with aid from Britain. Consequently, the management was placed in British hands through the Bookers Agricultural Technical services of Britain. This was followed later by Mumias Sugar Company established in 1973. The Nzoia Sugar Company was built in 1978, in Western Province, with foreign aid from France and was placed under the management of a French company, French Technisure. ${ }^{5}$ Given the viability of cane production in Kenya, it was expected that the full utilization of the factory capacity by these sugar companies would go a long way towards meeting the local demands for sugar. It was hoped that this, in turn, would save the country's foreign exchange spent on sugar imports; with such savings being channeled to other critical sectors such as health, clean water and education. Unfortunately, this has not been the case. Consequently this situation draws attention to a need to examine the production of sugarcane in Kenya. Despite the potentiality of cane growing in Kenya, certain pertinent questions remain. For instance, why did cane production performance stagnate in colonial times and remained so during the independence period? Why did the colonial government not support the farmers, yet there was local demand?

This dissertation will focus on a micro-study approach whereby the Asian cane producers initiative will be investigated, the market problems encountered, and, also evaluate the colonial state's support or otherwise, for sugar production. ${ }^{6}$ The investigation will strive to capture the role played by Asians in the production of sugar in Kenya, its success and failures, particularly in the Kibos-Muhoroni area and its environs such as Chemelil, Muhoroni, Kibigori and Miwani.

\footnotetext{
${ }^{5}$ Shadrack Nasongo, "Multilateral Imperialism in Kenya's Sugar Industry: The Political Economy of Transnational Corporations", Nigerian Journal of International Affairs 26 (2000): 56-77. For more discussion on the establishment of Asian sugar firms, see Peter Wanyande, "Management Politics in Kenya's Sugar Industry:

Towards an Effective Framework", African Journal of Political Science 6 (2001): 123-140.

${ }^{6}$ The terms "Asians and Indians" will be used interchangeably throughout the text to denote people from the Indian sub-continent.
} 


\section{STATEMENT OF THE PROBLEM}

For over a century the Asian community played, and continues to play, a significant economic role in Kenya. The development of the sugar industry in Kenya is inextricably linked to the history of Asian agricultural settlement in the country. However, both the colonial state and independent Kenya ignored their contribution. Therefore it is worth examining the extent of their economic role in agriculture, especially in cane production, given the fact that sugar is an essential food commodity. Unfortunately, it has not received much consideration in scholarly works like other crops such as tea, coffee, cotton, etc., especially its production in the colonial period and any socio-economic development that ensued, as a result of this initiative. This neglect could be due to the erroneous assumption that Asians were not farmers.

Thus the main question will be to investigate how the Asian cane production came into play in an initially predominantly settler dominated agriculture and later in a Kenya emphasizing peasant farming. Contrary to the belief which linked the poor Asian agricultural performance to their disdain of cultivation, the study seeks to examine the production of sugarcane by Asians in Colonial Kenya, and ascertain or refute the belief that Asians were not or could not be good farmers. Settler agriculture enjoyed support from the colonial state although by the 1930s it was still unsuccessful. This study examined support given to the Asian cane farmers in KibosMuhoroni area and what competing dynamics emerged between the Asians and the settlers, and also between Asians and Africans.

The research seeks to investigate how the Asian economy was viable for the success of the colonial state; for instance, the taxes paid assisted in running the colony. Also, why the Asians succeeded in trade and not in large scale farming? The study also investigates the impact of the cane growing, socially and economically on the Luo community. For example, the study 
aims to investigate how the changing consumption patterns of the Africans (drinking tea) influenced the constant demand for sugar during the colonial period, and what role the state played, if any, to influence the production. In short, what factors hindered or bolstered the production of sugar? Did the Asian cane farmers receive support like the European wheat farmers in the Highlands?

The work focuses on Asian sugar farming especially from the 1930s. This is because during the 1930s, the colonial state, in a bid to cope with the stress of the great depression, enacted measures to encourage new production especially from African farmers. Thus, the study will investigate if these measures applied to the Asian sugar farmers too in as far as the colonial state support was advanced. The contradictions that emerged, for instance the diverse colonial agricultural policies that entailed spurring settler production and peasant farming, ${ }^{7}$ while at the same time, controlling the production of Asian farming, and in particular cane farming at KibosMuhoroni, will be explored.

\section{AIMS OF THE STUDY}

The basic aim of the study was to examine sugarcane farming and the production of commercial sugar in Kenya following the establishment of Victoria Nyanza Sugar Company in 1923 by an Australian. The role of the state in production policies and controlling means of production, such as land, labor, and market, was also examined. Specifically the study focused on the following issues.

1. To evaluate the Asian cane production in Kibos-Muhoroni area and how the local community was impacted. How did the Luo community respond to the new crop?

\footnotetext{
${ }^{7}$ Peasants here refer to African rural households engaged in agricultural production both for subsistence and market using family labor. See F. Ellis, Peasant Economics: Farm Households and Agrarian Development (Cambridge: Cambridge University Press, 1988), 9-13.
} 
2. To examine the suitability of the area for cane growing. Why were Asians only allowed in specific areas?

3. To investigate challenges and success of the Asian cane farming. What state policies were initiated? Was restriction on Asian acquisition of land only as a consequence of settler interests or also African interests? How did politics come into play? Was land available for Asians? What were the sources of the seed capital to start farming?

4. To investigate the colonial state support towards cane production. For instance, what subsidy if any, had been granted? Were credit facilities and or agricultural technical advice available? What were the successes or failures, and what factors were responsible? Who controlled the market?

5. What was the role of the state, especially in policy making during the colonial period? Did it boost or curtail sugarcane productions? Why was there inadequate response, yet there was a ready market?

6. To assess the contribution of the Asian sugar economy to the growth of Kisumu town and its environs. Did the Asians socially/economically contribute to growth of Kisumu town by settling in Kibos?

7. Was the Kenya-Uganda railway an asset to the cane farmers?

\section{RATIONALE FOR THE STUDY}

Economic history is an important discipline in Kenya historiography. Adequate discussion of Kenya's colonial economic history must encompass the Asian initiative. Although a lot of work has looked at trade and transport, their economic role would be incomplete without examining their effort in agriculture. It is imperative that this area be studied comprehensively so as to capture their success and failure, and to demystify the assumption that Asians were nothing but traders.

Secondly, Kenya’s economic history has attracted many scholars; yet despite this, very little work has been done on the Asian role, especially in agriculture. They played a very significant role. Their economic activities included sugarcane production which led to the beginning of commercial sugar production in Kenya in 1920s, with the establishment of Victoria Nyanza Sugar Company in 1923 and the Associated Sugar Company (Ramisi) at the Coast in 
1927. ${ }^{8}$ The Asians were involved in both farming and milling of sugar cane. Thirdly, although successful studies have been done on colonial Kenya for crops such as maize, tea, cotton, coffee, etc., very little has been done on Asian sugar production in Kenya. Asians traditionally contributed to the economic backbone of East Africa, in particular, Kenya, through various forms of entrepreneurship, such as retail and wholesale trade, transport industry, all of which have been captured in Kenya's historiography, except the sugar cane production that needs to be detailed and reassessed.

Therefore the historical study of the contribution of Asians to the agricultural economy of Kenya deserves more attention. This will not only correct the historical imbalance but will also bring in the Asian initiative in the economy of colonial Kenya which spiraled into independence period and cannot be complete without the assessment of the Asian agricultural initiative in the colonial era. Moreover, this research will strive to depict how insufficiency of sugar in colonial Kenya and independent Kenya has persisted. Finally, it is hoped that by correcting the historical imbalance, the Asians and Kenya people at large will appreciate their contribution and remove the Asians from socio-economic and political limbo to which they have been relegated in independent Kenya, and improve Kenya’s capacity of cane production.

\section{CONCEPTUAL FRAMEWORK}

Many analyses of economic development in colonial and post-colonial Africa and Kenya in particular have been linked with the faulty premise of modernization theory, which emerged in the 1950s and 1960s. Modernization examined the transition from traditional to modern

\footnotetext{
${ }^{8}$ Nasongo, “Multilateral Imperialism”, 57.
} 
principles of social-economic organization and political development which involved a movement towards democratization and equality. ${ }^{9}$ Therefore it envisaged modern values being transmitted to the periphery among the elite through education and technology transfer. Exponents of modernization approach, such as Tony Killick believed that at a certain stage during the transition, a sustained economic growth would be possible. This stance has been criticized by dependency scholars such as Walter Rodney who blamed colonial capitalism for the underdevelopment and arrived at the conclusion that African development was only possible when a radical break with the international system took place. Similarly, Colin Leys believed that modernization theory could not be used effectively to analyze issues in Africa and the Third World since it was American centered and was engrossed mainly with the containment of communism during the cold war period. Moreover, Leys also critiqued the modernization assumption that Third World backwardness was an 'original' backwardness and not created by colonialism.

Other critics include Samuel Huntington who rejected the concept of political development and economic growth advancing at the same time as postulated by the classical modernization school of thought. His main concerns are that modernization leads to higher expectation as a result of social mobility and as such, people became more politically involved in their governments in ways that arrests its proper function, hence the need for a strong authoritative government to control the people, promote trade, and steer economic development. Therefore, according to Huntington, the theory is flawed since it postulated that social mobilization and economic development would lead to political stability, yet it emerges that there is often more stability in countries with the lowest per capita incomes, than in countries which are less poor. More crucially, in the transition from traditional to modern society, it

\footnotetext{
${ }^{9}$ Colin Leys, The Rise and Fall of Development Theory (London: James Currey, 1996), 66.
} 
appeared that economic development made things more unstable and volatile, a condition of political uncertainty ensued, marked by violence, corruption and coups, which are the anti-thesis of political development. Therefore, he advocated for strong governments to enhance political and economic growth more effectively.

Therefore, one of the major criticisms of modernization theory and dependency theory was that both focused too much on the state as the main force behind development in colonial and post-colonial Africa. For example, Cynthia Enloe points out that efforts to tackle problems of economic development have been confined within the framework of nation-states which continues to pursue ineffective policies. ${ }^{10}$ In agrarian societies, this seems to curtail the farmers’ efforts, due to the fact that the colonial and post-colonial state used policies that were discriminative and often led to differentiation between regions and social groupings. ${ }^{11}$ Moreover, the inability of the government to provide proper infrastructure could also limit the farmers' initiatives. Also the colonial state was responsible for the introduction of models which emphasized production of commodities of interest to the metropolitan powers at the expense of indigenous food production systems. Furthermore, most of these policies failed since the ecology of the concerned areas was not taken into consideration; such was the case of the peanut production in Tanzania. ${ }^{12}$

Thus, scholars such as Joseph Makoha, Paul Richards, and Robert Chambers criticize the assumption of modernization and dependency theorists that portray the state as the best agent of development and relegates the farmers as ill informed actors and too conservative to make

\footnotetext{
${ }^{10}$ Cynthia, H. Enloe, Ethnic Conflict and Political Development (Boston: Little Brown, 1973), 7.

${ }^{11}$ Robert Maxon, “The Establishment of the Colonial Economy”, in W. Ochieng' and R. Maxon, eds., An Economic History of Kenya (Nairobi: East African Educational Publishers, 1992), 63-74.

${ }^{12}$ Carl T. Fumagalli, “An Evaluation of Development Projects Among the East African Pastoralists”, in Phillip Stevens, Jr. ed., Social Sciences Involvement and African Development Planning (Waltham: Crossroads Press, 1978), 49-63.
} 
changes necessary to bring about economic progress. ${ }^{13}$ Instead, they prefer what might be called situation specific and development-relevant approaches. This view is depicted by Stephen Bunker who challenged these assumptions and portrays how the peasant Bagisu coffee farmers in Uganda engaged the state by forming organizations that took care of their interests when faced with the threat of poor marketing conditions. ${ }^{14}$ Therefore, farmers have proved time and again that they are involved and willing to interact with government. Similarly, Robert Bates agrees that modernization has great pitfalls and advances the view that in Kenya, the state and the market play complementary roles rather than substitutes. Therefore, both Bates and Bunker advance Rational Choice Theory where farmers are seen as interacting with market forces effectively due to institutions put in by the state, such as infrastructure and accessibility of markets. As such, both state and market are important.

Other studies of economic issues in Africa, and Kenya in particular, have also been pegged on dependency and underdevelopment models, which dominated debates and policy analysis in the 1970s and 1980s. Dependency, which critiqued modernization saw no benefits from the metropolitan influences since foreign investment led to drain of wealth from the periphery to the metropole. Thus, the dependence theory linked the lack of development in Africa to foreign capital. Proponents of this theory such as Walter Rodney, Ali Mazrui, and Andre Gunder Frank emphasized the profit outflow. The scholars argue that Africa and the Third World were denied the opportunity of developing healthy trade relations with other parts of the world leading to dependency that "arrested" development. ${ }^{15}$ One criticism that can be

\footnotetext{
${ }^{13}$ Joseph Makoha, The District Focus: Conceptual and Management Problems (Nairobi: American Press Research Bureau, 1985), 66.

${ }^{14}$ Stephen G. Bunker, Peasants Against the State: The Politics of Market Control in Bugisu Uganda (Chicago: The University of Chicago Press, 1991), 13.

${ }^{15}$ Leys, The Rise and Fall of Development Theory, 33-34. For more discussion on exploitation of resources by foreign capital see also Walter Rodney, How Europe Underdeveloped Africa (Dar es Salam: Tanzanian Publishing House, 1972), vii, 213-222; Ali Mazrui, “Tools of Exploitation”, documentary film.
} 
made of dependency theory is that the theory tends to zero in on the ramification of colonialism, and hence is inadequate in analyzing economic issues in Africa almost half a century after the end of colonialism.

Leys, who initially supported the theory, for example changed and critiqued it arguing that the theory was not only too general and ambiguous but also that the prevailing underdevelopment in Third World was not due to the underdeveloped state of affairs in those countries but rather it was because of the historical world process whereby developed market economies subordinated those of the Third World countries. ${ }^{16}$ Therefore, both Leys and Rodney advocated for a complete delink from the international trade, if African countries and Third World countries are to develop. They thus postulate that these countries need to develop their own markets internally.

Similarly, Gunder Frank also argued that capitalist growth was not possible for the periphery as long as it was linked to the metropole due to marginalization. Therefore, he recommended a stronger action, such as a complete revolution capable of leading to an autonomous growth through cutting links with the metropole. ${ }^{17}$ This stance was criticized by the classical Marxists who accused the dependency theorists of advancing the possibility of an alternative path to development which the periphery could follow free from capitalist development, unevenness and irrationality, which they perceived as impossible. Dependency, in a rejoinder challenged the Marxist assumption that capitalism would lead to the eventual industrial development of the whole periphery. According to dependency this was not possible due to the side effects of capitalism, such as uneven economic growth, marginalization, and pauperization. However, some Marxist scholars, such as Geoffrey Kay and John Sender,

\footnotetext{
${ }^{16}$ Leys, The Rise and Fall of Development Theory, 46.

${ }^{17}$ Andre Gunder Frank as quoted in Leys, The Rise and Fall of Development Theory, 148.
} 
acknowledged that although capitalism was universal, it surely did not guarantee sustained economic growth everywhere. ${ }^{18}$ Therefore, it emerges clearly that both the dependency and modernization theorists saw the need of the state to step up since the state was the center of development.

However, the neo-liberals emerging in the 1980s and 1990s criticized the dependency approach, and did not believe that capitalism would give way to socialism. They critiqued the state model arguing that although market capitalism led to economic growth, inflated public sectors prevented the market from doing its job. Proponents such as P.T. Bauer and Deepak Lal believed that the state could be overbearing by regulating and dictating to markets which could destroy them despite the fact that state provides infrastructure. ${ }^{19}$ Therefore, the neo-liberals argued that states were inefficient, corrupt, and parasitic, hence, not stimulators of growth and so advocated for unrestricted market. ${ }^{20}$ Therefore, scholars such as Leys postulate that the state is needed (but not too much) and only when the market does not work well. Leys therefore advanced solutions based on the reduction of government spending and getting the state out of the market by giving up policies on exchange rate controls, subsidies, and redistributive taxation that would impact on prices.

Other scholars, such as John Toye, criticized the neo-liberal argument claiming that it did not add up to a theoretical justification for the claims that there would be maximum benefits accrued from an unrestricted market. ${ }^{21}$ Similarly, other scholars are of the view that economic development in Africa should not only be analyzed using such paradigms alone. For instance, Richards and Chambers portray how such models fall short on the African agricultural economy

\footnotetext{
${ }^{18}$ Ibid.

${ }^{19}$ Leys, The Rise and Fall of Development Theory, 17.

${ }^{20}$ Ibid., 19.

${ }^{21}$ Ibid.
} 
in particular. ${ }^{22}$ They argue that dependency and neo-liberal models were too general, operating from a macro-oriented approach and therefore do not analyze adequately the agricultural development in Africa which demands a more specific approach such as farmers' perspectives. Frans Schurman supported this view arguing that there was need of a new theory sensitive to the diversity of the Third World situations: a new approach that would depart from generality but allow room for a "micro" as well as “macro" level approach. ${ }^{23}$

Due to disillusionment with the inadequacies of the grand theories of development and underdevelopment and modernization, which confine themselves in trying to explain what happened in the past, this study seeks to employ the rational choice model which emerged in the late 1980s and early 1990s which advanced the view that individuals make rational choices. Rational choice examines things from a micro-level perspective, focusing on specific studies such as the role of peasants and farmers.

Consequently, the rational choice model will be relevant in the study of the Asian farmers. The model utilizes concepts of innovation, adaptation and commercialization as conceptual tools for interpreting the encounter that Asian cane farmers experienced in farming. The central idea here is that an efficient economy is made possible by institutions that permit individuals to benefit by doing things which facilitate development, such as the provision of incentives. This concept of innovation will be used to portray the inherent dynamism and entrepreneurship of the Asian community when faced by challenging situations and also reveal that they were not only traders, but also farmers. Proponents of this theory include Steven Bunker and Robert Bates. Bates, who did extensive work in Kenya, revealed that African

\footnotetext{
${ }^{22}$ Paul Richards, Indigenous Agricultural Revolution: Ecology and Food Production in West Africa (London: Hutchinson and Company, 1985), 13. See also Robert Chambers, Rural Development: Putting the Last First (London: Longman Publishers, 1983), 85.

${ }^{23}$ Leys, The Rise and Fall of Development Theory, 27.
} 
governments kept produce prices down since it was politically rational so as to maintain stability and security. Bates, in his two books, emphasized the market and the state as the engine for economic surplus. ${ }^{24}$ Talbott agrees that the theme of innovation is important since it entails innovations in techniques and practices. His work shows how various communities in colonial Kenya used practices of inter-cropping, to produce a variety of crops due to the small size of land owned by peasants. ${ }^{25}$ Indeed historically people in Africa have proved able to adapt well to diverse conditions such as irregular rainfall patterns and shrinking land holdings. Commercialization will be examined from the point of view of how the Asians interacted with the market under the colonial economy, especially on food production. Adaptation, on the other hand, will be used to underscore the variety of techniques adopted in cane production in a foreign country and how the Asians coped with contradictory colonial policies, such as promoting cash crop production during the depression of 1930s, while at the same time enforcing measures to control production and marketing of produce. This contradiction emerged due to the fact that the state gave priority to political stability and the interests of the settlers. Hence, the colonial state had to reinforce the status quo and this curtailed the state's efforts to radically transform agriculture in Kenya. For example, the colonial state limited the immigration of Asians into Kenya, even though some had the much needed agricultural expertise.

Early proponents of what would become the rational choice model include Polly Hill whose concepts of innovation and adaptation were used successfully to portray how peasant farmers, given the right environment succeed. She examined how immigrant communities from north Ghana moved into southern Ghana and were able to bring more land under cocoa

\footnotetext{
${ }^{24}$ Robert Bates, Beyond the Miracle of Market: The Political Economy of Agrarian Development in Kenya (new edition) (Cambridge: Cambridge University Press, 2005), 88-89. See also Robert Bates, Markets and States in Tropical Africa.

${ }^{25}$ I. D Talbott, “African Agriculture” in W. Ochieng' and R. Maxon eds., An Economic History of Kenya 78.
} 
production and in some cases were able to "inherit" farms whose owners had become bankrupt due to poor markets and crop diseases. These migrant Ghanian farmers played a significant role in cocoa farming. ${ }^{26}$ Therefore, availability of markets becomes crucial in such analysis. Her work shows how the migrant planters exhibited resilience and determination in the face of a turbulent colonial economy and were able to make cocoa production a successful venture. Another pertinent finding of Polly Hill's work reveals the nature of the migrant farmers and their responsiveness to economic incentives. She portrays how the cocoa farmers made remarkable responses to economic stimuli coupled with determination to succeed. This is shown through the willingness of the farmers to migrate, invest and reinvest in the acquisition of more land as a major feature of their economic success. ${ }^{27}$ Could this relate to the Asian immigrant case in Kenya? Although their success could be attributed to their organization skills, financing production and marketing of cocoa, it emerges that for this to succeed, the state played a crucial role in creating infrastructure and marketing structures that ensured the farmers' success. These findings help to point to concepts that will be valuable for the research on Asian farmers in Kenya. For instance, in answering questions such as: Was infrastructure adequate? Who controlled the market? And, who had the right to determine prices of sugar and why?

Anne Nangulu also used the rational choice model; she employed the concepts of innovation and adaptability as the components in her analysis of coping mechanisms in West Pokot. She argued that the Pokot made rational choices and utilized available resources such as land, water, and labor to facilitate food production. ${ }^{28}$ Therefore, these concepts can be used to examine how the Asians produced sugarcane in Kibos-Muhoroni area, by also utilizing the same

\footnotetext{
${ }^{26}$ P. Hill, The Migrant Cocoa Farmers of Southern Ghana: A Study in Rural Capitalism (Oxford: International African Institute, 1977), 3.

${ }^{27}$ Ibid.

${ }^{28}$ Anne Nangulu, "Food Security and Coping Mechanisms in Kenya’s Marginal Areas: The case of West Pokot,” Ph.D. Dissertation, West Virgina University, 2001, 17.
} 
resources that Nangulu found among the Pokot. Adaptation and innovation hence lend themselves to the analysis of the Asian farmers and how they adapted to Kenya given the fact that some had no money to start farming and how to face the different geographical setup and the ecology of Kibos-Muhoroni.

Similarly, Nicholas Makana also used the same concepts of innovation and commercialization successfully in his analysis of peasant households in Bungoma district. His work shows how the peasants interacted with market strategies devised by the colonial state and how the households were incorporated into the colonial economy in Kenya between 1930 and 1960, and how this impacted the indigenous economic systems. ${ }^{29}$ Makana’s findings reveal how the peasant household in the Bugoma district made choices in dealing with the contradictory nature of the colonial economic policies by on the one hand spurring and controlling production, and on the other hand, by determining where produce would be marketed. These findings support the rational choice theory's assumption that people are rational individuals capable of maximizing utilities and capable of being integrated into wider economies. ${ }^{30}$ Therefore, the major point in rational choice is that both market and state are important. The state has to provide rules and the right kind of policies to ensure economic "take off".

The innovativeness and entrepreneurship of the Asians was also analyzed within the political economic framework. Political economy can also be perceived as the study of the conditions under which production takes place within states, and also approaches related to studying economic and political issues within states. Thus, political economy can be used to analyze how individuals and groups with common economic interests have used politics to effect

\footnotetext{
${ }^{29}$ Nicholas Makana, “Changing Patterns of Indigenous Economic Systems: Agrarian Change and Rural Transformation in Bungoma District 1930-1960”, Ph.D. Dissertation, West Virginia University, 2005, ii.

${ }^{30}$ Leys, The Rise and Fall of Development Theory, 34-36.
} 
changes beneficial to their interests. In Kenya the capitalist system introduced by colonialism comprised of many forms of production; for instance, settlers, peasants, and also Asians.

Also in analyzing the contradictions that beset the colonial state's policies, whereby the colonial state was found always reluctant to help the Asian cane farmers, new institutional theory has been employed. The new institutional theory, also known as neo- institutionalism, was based on post World War II upheavals, such as the collapse of communism which raised questions about the relations of institutions to political and economic change. This theory focuses on the state as central to any study of politics. ${ }^{31}$ According to Immergut, an individual may make a political choice that deviates from choices made by the same individual under other circumstances ( the same could be said of governments). The author argues that such a change was because the individual may perceive that the outcome envisioned was not feasible; hence he/she voted for an alternative that had more advantage of being realized. ${ }^{32}$ In this study the theory is used to show how the state constantly made decisions that inhibited Asian cane farming. Moreover, institutionalists aim to analyze why such actors make such choices over other equally plausible alternatives. Consequently, the new institutional theory aims to expose and analyze the discrepancy between "potential" interests and those expressed through political interests. Generally, the new institutionalism is grounded on the fact that political demands that are expressed in politics do not always reflect the preferences of many individual groups since various institutional factors influence the political processes that adjudicate among conflicting interests and hence may privilege some interests group over the others. ${ }^{33}$ This is because political institutions, state structures, and state interest group relations and policy networks all

\footnotetext{
${ }^{31}$ Ellen M. Immergut, “The Theoretical Core of the New Institutionalism” Journal of Politics and Society 26 no.1 (1998): 5-34.

${ }^{32}$ Ibid., 7.

${ }^{33}$ Ibid.,17.
} 
influence the political process. Equally, political economies are structured by close interactions among economic, social and political actors that work differently in different situations. ${ }^{34}$ Immergut arrived at the conclusion that political institutions and government policies may facilitate the interests of particular groups by recognizing the legitimacy of particular claims and even providing such groups with opportunities. ${ }^{35}$ As such, this theory becomes useful in analyzing why the colonial state supported the settler farmers over the Asian cane growers believing that the settler agriculture had the potential to financially sustain the colony.

This theory has been used successfully by Stan du Plessis and Sophia du Plessis in analyzing Zambia's economic decline. The authors arrived to the conclusion that the state decisions were important since it was the main actor in economic development. Using the theory, the authors were able to quantify that the poor quality of institutions in Zambia and failure to protect property and contract rights by the state played a significant role in Zambia's economic decline. ${ }^{36}$

Political economy was therefore used in this study in analyzing how production was influenced by state policies, the market, and politics. Bruce Berman and J. Lonsdale argue that different modes of production were in a way linked at the level of exchange and were dominated by the most advanced mode which was the capitalist mode. ${ }^{37}$ This concept focuses on specific economic means of production such as land and labor, all controlled by the political situation within the state. For instance by the mid- $20^{\text {th }}$ century, agricultural production was intensified by the demands of the colonial rule and by the opportunities available for the commodities to boom

\footnotetext{
${ }^{34}$ Ibid.

${ }^{35}$ Ibid., 20.

${ }^{36}$ Stan du Plessis and Sophia du Plessis, "Explanation for Zambia’s Economic Decline”, Development Southern Africa 23 no. 3 (2006): 326-369.

${ }^{37}$ Bruce Berman and John Lonsdale, “Coping with the Contradictions: The Development of the Colonial State 18951914” in Bruce Berman and John Lonsdale, Unhappy Valley, Conflict in Kenya and Africa Book One: State and Class (London: James Curry, 1992), 78.
} 
which were partly determined by the political scenario. Therefore, the state could be seen as the most important force behind economic reproduction or accumulation of political reproduction or social control. ${ }^{38}$ This concept has been used to analyze political and economic questions that faced the Asians in light of agricultural production. For instance, was taxation on cane growers fair? Were the trade tariffs viable? Who controlled the market?

Therefore, political economy has been employed in this study to analyze questions set out for this study. Specific issues such as land and labor policies and the relationship between the state and the farm owners in as far as supply of labor to non-settler farms are concerned, has been investigated. Moreover, the establishment of estate production meant appropriation of African land. ${ }^{39}$ Such aspects consequently are important in this study. Questions examined include who gets land in Kenya and in what agriculturally viable zones, and the role of the state and its power in directing the means of production.

\section{LITERATURE REVIEW}

The problem of sugar insufficiency can no longer be ignored in Africa and Kenya in particular. Many scholars have done works on major crops including sugar in Africa. For instance, Allen W. Ezra investigated the production of sugar and coffee in $19^{\text {th }}$ Century Liberia. His findings indicate that the problem of labor was compounded by a scarcity of draft animals to be used in plows due to trypanosomiasis which killed many livestock. This in essence obstructed the development of the sugar industry since many planters depended also on oxen-powered mills. Ezra points out that half of the immigrants who engaged in cane production were ex-slaves who

\footnotetext{
${ }^{38}$ Ibid., 79.

${ }^{39}$ Ibid., 91.
} 
arrived in Liberia penniless. ${ }^{40}$ This parallels the status of most of the Asian immigrant small scale cane farmers in Kibos. The Liberian immigrants just like most Asian cane farmers, lacked capital to invest in large scale sugar plantations. Thus the Liberian case will shed light in investigating how Asians coped with labor issues and financial resources.

Moreover, a lack of self-sufficiency in sugar production has continued to impact the economy of Kenya. The development of this trend is worrying and needs to be addressed adequately. Yet, there are areas in Kenya that this kind of agriculture can be practiced satisfactorily. The colonial Nyanza Province is such a place as the region has varied natural endowments which contribute to varied economic potential. ${ }^{41}$ Consequently, the Asian sugar industry of Kibos-Muhoroni added to the diversification of Nyanza's economy. This view is corroborated by Gavin Kitching who examined the intensification of agricultural production in parts of central Kenya and the Nyanza Province during the colonial time and arrived at the conclusion that the diversification led to participation, especially of Africans, within the colonial economic system who engaged in farming, operating mills and shops and buying lorries for transportation. Such initiatives were also common among Asians as discussed by Mangat and Robert Gregory. ${ }^{42}$

Nevertheless, farming formed the main backbone of the colonial economy. Ironically the colonial state pursued only the settler and peasant farming under the dual policy which the state first implemented under Governor Sir Robert Corydon in the 1920s. Maxon argues that this, in

\footnotetext{
${ }^{40}$ Allen William Ezra, “Sugar and Coffee: A History of Settler Agriculture in $19^{\text {th }}$ Century Liberia”, Ph.D. Dissertation, Florida International University, 2002, viii.

${ }^{41}$ Hugh Fearn, An African Economy: A Study of the Economic Development of Nyanza Province of Kenya (London: Oxford University Press, 1961), 26.

${ }^{42}$ For studies on Asian entrepreneurship and transport industry in Kenya, see J. S. Mangat, A History of Asians in East Africa 1886-1945 (Oxford: Clarendon Press, 1969); Robert Gregory, South Asians in East Africa: An Economic History 1890-1980 (Boulder: West View Press, 1993).
} 
theory, propounded support for both European and African agriculture but in practice favored European settler production. $^{43}$

Needless to say, Kenya's situation was unique since like South Africa it was endowed with a suitable climate which attracted European settlers. The presence of Asians thus led to a competitive scenario which was prone to racial tension. Hence, the presence of these two races impacted greatly on the history of the colony, and particularly in agriculture, due to unfair colonial agricultural policies. Most of the early existing literature during the colonial period focused on the European settlers’ initiative in agriculture. Activities of Asians seem to have been neglected. However, by the early 1960s, scholars started capturing Asian history. Among the first writers were L.W. Hollingsworth Asians of East Africa ${ }^{44}$ and George Delf Asians in East Africa. ${ }^{45}$ These pioneering works were quite valuable, but were general surveys that dealt with Asian migrations into East Africa. These works have major shortcomings in that they lacked focus on sugar, proper documentation, and also made limited use of primary sources. However, to understand the Asian farming initiative during the period in question, the social-economic background, and the role that they played, requires the investigation on major themes which include the Asians in Kenya, their political struggle, and the role of the state especially in regard to control on land, labor, market, and Asian economic initiative, especially on the sugarcane production at Kibos-Muhoroni. Thus, pertinent questions emerge, such as; in what ways did labor and market impact production? Who among the Asians were involved? How did politics affect production/ sugar industry? Consequently, the literature review below will evolve around these central themes and questions.

\section{Asians in Kenya: who are they?}

\footnotetext{
${ }^{43}$ Robert Maxon, East Africa: An Introductory History (West Virginia University Press, 1994), 204.

${ }^{44}$ L.W. Hollingsworth, Asians of East Africa (London: Macmillan and Company, Ltd., 1960).

${ }^{45}$ George Delf, Asians in East Africa (London: Oxford University Press, 1963).
} 
Many scholars have examined contributions of a few pioneer Indian entrepreneurs and not farmers. For instance, Shanti Pandit, Asians in East and Central Africa ${ }^{46}$ is a biographical work, unfortunately only focusing on prominent Asians such as Aldina Visram. This does not provide the whole economic history since we know that the petty merchants-dukawallas (from Hindi words, "dukaan" meaning store and "walla" meaning owner) played a prominent role in the development of Kenya's economy. Focusing on prominent Asians alone does not give us the big picture; the petty traders too made major contributions, and were a major part of the Asian entrepreneurships and the Kenyan economy. These petty merchants and poor Asians engaged in almost all economic activities in Nyanza. For instance, they monopolized the fishing trade operating dhows from Wadh Konyimbo, Kisumu, Kendu, Nanga, and Kamito. ${ }^{47}$ The same could be said of small farmers who included Asian cane farmers. L.D. Smith argues that small farmers had more land under food crops of all kinds and that by 1950s, had increased their cultivated areas with important market products and produced some of Kenya’s export crops. ${ }^{48}$

Other studies that present Asian perspectives were also undertaken by Dharam P. Ghai (ed.) Portrait of a Minority ${ }^{49}$ and Haraprasad Chottopadhyaya's book, Indians in Africa: A Social Economic Study. ${ }^{50}$ Ghai's book is a collection of essays including historical and political surveys prepared for a symposium. Thus, it has a more general outlook covering themes such as the Asian community's problems. On the other hand, Haraprasad's book is broad in nature glossing over Africa in general, focusing especially in South Africa. It is more of a socio-

\footnotetext{
${ }^{46}$ Shanti Pandit, Asians in East and Central Africa (Nairobi: Panco Publishers, 1963).

${ }^{47}$ E. S. Atieno Odhiambo "Economic Mobilization and Political Leadership: Oginga Odinga and the Luo Thrift Trading Corporation" in Aloo Ojuka and William Ochieng' eds., Politics and Leadership in Africa (Nairobi: East African Literature Bureau, 1974), 143.

${ }^{48}$ L.D. Smith, “An Overview of Agricultural Development Policy” in Judith Heyer, et al. eds., Agricultural Development in Kenya: An Economic Assessment (Nairobi: Oxford University Press, 1976), 124; see also Judith Heyer and J.K. Waweru, "The Development of the Small Farm Areas” in Agricultural Development in Kenya, 191194.

${ }^{49}$ Dharam P. Ghai ed., Portrait of a Minority (London: Oxford University Press, 1965).

${ }^{50}$ Haraprasad Chottopadhyaya, Indians in Africa: A Social Economic Study (Calcutta: Bookland Private, Ltd., 1970)
} 
economic study, and has few chapters on Indians in Kenya. It uses a general approach without focusing on specifics such as Asian agriculture in East Africa, and Kenya, in particular.

Many writers, especially of Asian origin, have also written on the social history of their people. For example, Purnima Mehta Bhatt “A History of Asians in Kenya 1900-1970" examines the social organization of the Asians in Kenya, zeroing in on fundamental issues such as the caste system, kinship, family, and also how World War I, the events prior to World War II, and the post Mau Mau period politically impacted the Asians. ${ }^{51}$ The economic role of Asians in this work is limited to trade and middle level employment in the colonial administration. For instance, almost the entire clerical staff on the Kenya-Uganda railway was Indians. Bhatt contends that very few were engaged in agriculture, but even then, he does not expound on the Asian agricultural initiative.

Agehananda Bharati's work Asians in East Africa: Jayhind and Uhuru ${ }^{52}$ and H.S. Morris The Indians in Uganda, ${ }^{53}$ both illustrate the Asian ethnographic representation in Kenya and Uganda respectively. However, Bharati attempts to discuss the farming prowess of the Asians and demystify the assumptions that they shied from agriculture. He points out that Asians owned large tracts of sugarcane land near Kisumu; this land was effectively managed by Sikhs of the Jat Caste who had been farmers back in India. These Sikh cane growers around Kibos and Eldoret in the Kenya highlands succeeded in portraying the resilience and profit-orientedness of the Asian farmers. ${ }^{54}$ Moreover, it is well documented that Asians had big sisal plantations in Tanganyika where they produced approximately $22.95 \%$ of the total sisal produced in the colony by 1960. Archival sources also abound with materials on Asian farmers at Kibos. For example,

\footnotetext{
${ }^{51}$ Purnima Mehta Bhatt, “A History of Asians in Kenya 1900-1970”, Ph.D. Dissertation, Howard University, 1976.

${ }^{52}$ Agehananda Bharati, Asians in East Africa, Jayhind and Uhuru (Chicago: Nelson-Hall Company Publishers, 1972).

${ }^{53}$ H.S. Morris, The Indians in Uganda (London: Weidenfeld and Nicolson, 1968).

${ }^{54}$ Bharati, Asians in East Africa: Jayhind and Uhuru, 103.
} 
Asians also grew other crops in Kibos that included maize, red pepper, and ceara rubber. For instance rubber was grown by Indersingh and Munish Ram of plot No. 15 Kibos. ${ }^{55}$ They also grew simsim and vegetables, kept cattle, and even asked the colonial government for commonage in free grazing areas. All of these portray the Asians as resilient farmers.

Mangat also corroborates this view, arguing that even the petty traders took up market gardening to supply fresh vegetables to the rail working gangs. Some Asians also settled at Mazeras in Ukambani where they grew fruits. This shows that they did not shy away from farming. Indian resilience in agriculture may have been curtailed by settler politics. For instance, initially Asian farming was supported as was indicated by Sir Charles Eliot who on taking the governship in 1900 initially supported Asian initiative when he asserted that:

The Indians seem likely to become intermediaries between Europeans and natives, and if they were allowed by the Indian government to settle, would probably do much to develop the natural resources of the country by cultivating rice and practicing other forms of agriculture. ${ }^{56}$

This was a view supported by Bhatt who argues that the majority of the Asian immigrants came from rural agricultural backgrounds in India.

Other scholars believe that cultural institutions such as caste could hinder progress among Asians. This was also found as an impediment where family ties and other practices come into play. For example, Gerishon Ikiara's argument on the theory of "cultural determinism” explains that there is differential in economic development levels found between developed countries and developing countries based on culture. J.L Sadie corroborates this view and suggests that there is a need to break with culture as a pre-requisite to economic progress. Stressing on this point, he asserts ". . . What is needed is a revolution in totality of social, cultural, and religious

\footnotetext{
${ }^{55}$ Kenya National Archives (KNA): PC/NZA/3/22/1/5 Sugar General.

${ }^{56}$ Sir Charles Eliot, The East Africa Protectorate, as quoted in Bhatt, 54.
} 
institutions and habits ... their psychological attitude; their philosophy and way of life.”57 This argument could well fit into the Asian scenario.

Among the Asians some immigrants had to discard their cultural beliefs especially of the restriction of their work ability based on the caste system. This enabled them to venture into various economic activities in Kenya. Higgins seems to support Ikiara. He points out that any culture or society is capable of achieving economic advancement as long as they receive support and recognition by the policy makers. He argues that economic development can be achieved “as long as policy makers are able to recognize within a particular culture those elements that contribute to rising productivity and income."58 In other words, policy makers should acknowledge cultural diversity and allow economic activities regardless of cultural background. This fact becomes relevant in Kenya's economic history given the fact that Kenya had a threetier society; issues pertaining to cultural diversity emerge.

Therefore to understand the Asian agricultural initiative in Kenya, we need to look at their social, cultural, and economic setup. This broader perception will enhance the understanding of their quest for prosperity in Kenya, and reveal who they were and particularly which group was involved in farming.

Therefore, several scholars have documented the various Asian groups in Kenya and the specific economic roles that they played. Studies by Richard McCormack, John Okumu, George Delf, Haraprasad Chattopadyaya, Purnima Bhatt, and Agehananda Bharati all serve as valuable

\footnotetext{
${ }^{57}$ J.L. Sadie, "Social Anthropology of Economic Underdevelopment” in D.E. Novak and R. Lekachman eds., Development and Society: The Dynamics of Social Change (New York: St. Martins Press, 1964), as quoted by Gerishon Ikiara "Entrepreneurship, Industrialization and the Nation Bourgeosie in Africa" in Ulf Himmelstrand, Kabiru Kinyanjui and Edward Mburugu, eds., African Perspectives on Development: Controversies, Dilemma and Openings (Nairobi: East African Educational Publishers, 1994), 124.

${ }^{58}$ B. Higgins, Economic Development: Principles, Problems and Policies (New York: W.W. Norton and Co., 1968) as cited in Ikiara “Entrepreneurship, Industrialization”, 125.
} 
sources about the various groups in Kenya. ${ }^{59}$ McCormack and Delf trace their economic roles back to their country of origin, while Haraprasad links those activities back home to the roles they assumed once in Kenya.

These authors agree that most Asians came to Kenya through the port of Bombay on the West Coast of India. They originated from one of the four areas: the coastal belt around Cutch, Rojaputani and the Central Provinces, Punjab and Goa. The groups spoke one of the four indigenous languages represented by the regions such as Gujarati, Hindi, Punjabi and Konkani among Goans. ${ }^{60}$ The Asians in Kenya could best be classified according to their religious communities; Muslims, Hindus, Sikh, Christians, and the Parsee.

\section{MUSLIMS}

One-third of Kenya’s Indian populations are Muslim. They are divided into three groups; the Ismaili Khojas, the Bohra, and, the Ithna'ashris.

\section{Ismaili Khoja}

The Khojas were originally Hindu traders living in the upper Sind area of North West India before converting to Islam, so they did not engage in farming in Kenya. Many came to Kenya during the colonial period. By 1960 Khojas totaled 17,000 in Kenya. The word Khoja means "honorable discipline”. This sect does not make a pilgrimage to Mecca and are led by their famous religious leader, The Aga Khan. ${ }^{61}$ The Khojas are very progressive, well educated

\footnotetext{
${ }^{59}$ Richard McCormack, Asians in Kenya: Conflict and Politics (Brooklyn: Theo. Gaus’ Son, Inc., 1971), John Okumu, "Kenya 1900-1930: A Study in Conflict”, Ph.D. Dissertation, University of California, 1966. Delf, Asians in East Africa; Chattopadyaya, Indians in Africa, Bhatt, “A History of Asians in Kenya 1900-1970”, and Bharati, Asians in East Africa: Jayhind and Uhuru.

${ }^{60}$ McCormack, Asians in Kenya: Conflict and Politics, 13.

${ }^{61}$ Delf, Asians in East Africa, 6.
} 
and in most cases are professionals. During colonial times they served as bankers, clerks, doctors, and restaurant owners.

\section{Bohras}

The other Muslim group was the Bohras. Bohra is a Gujerati word derived from the word “Vohoru” meaning "to trade."62 Unlike fellow Muslims, they offer three daily prayers "Salat" instead of the orthodox five. The Bohras came to East Africa early and by 1871 about 600 of them had settled at Zanzibar and Mombasa. Originally they are from Cutch and Karachi.

Many Bohras thus were traders, iron mongers, tinsmiths, and watchmakers. A well known Bohra family which was very enterprising in East Africa generally, and Kenya in particular, was the Jeevanjee family led by pioneer Sir Tayabali, H. A. Jeevanjee.

\section{The Ithna'ashris}

The other largest Gujarati-speaking Muslim group is that of the followers of the “eleventh Imam” the Ithna'ashris, who came from Punjab. Little literature exists on this group in Kenya.

\section{HINDUS}

The Hindus also came early; by 1841 they were already residing at Mombasa. Many came from Cutch and belonged to the Bhattia sect who were strict vegetarians. The Hindus are divided into sects such as Patels who came from Gujarat and speak Gujarati, Lohanas from Cutch who speak Cutchi, and the Jains from Gujarat. The Jains are a branch of Hindus, but deny the authority of the Hindu Scriptures; and are further divided into "Vanik" and "Visa Oshwal" classes. Although Jainism initially forbade agriculture as a profession since it entailed

\footnotetext{
${ }^{62}$ Chattopadhyaya, Indians in Africa, 350.
} 
destroying the microbic life, the Oshwals of Porbandar were farmers. ${ }^{63}$ In Kenya they became professional traders and engaged in commerce; the most outstanding Jain includes Dr. Manu Chandaria in Kenya while other leading Hindus include A.B. Patel and S.G. Amin. Hindus in particular excelled in business and were described by western travelers as "Jews of East Africa." ${ }^{64}$

However, the majority of Indians, both Hindus and Muslims, who came to Kenya took to trade and commerce and shop-keeping. In East Africa, including Kenya, these traders were known as "Banyans" and were seen as a money making class.

\section{SIKHS}

The Sikhs came from Punjab. The Sikhs were further divided into Jats who were farmers who farmed at Kibos and Eldoret, and also were used in military services, and the Ramagarhia Sikhs who were basically skilled laborers (Fundis). By 1960, there were about 20,000 Sikhs in Kenya. They are believed to be assertive and are popularly know as "Singh". Basically they were mechanics, carpenters, and railmen. ${ }^{65}$

Nevertheless, Sikhs are believed to be the most adaptable Indians. Bharati attributes this to their ideology. For instance, their religious doctrines are unsophisticated. In India, all Sikhs were farmers and so the majority of the Jat sect of Sikhs who came to Kenya were farmers. ${ }^{66}$ Back at home in India they were known for their resilience. Bharati describe the Jats as farmers with a semi-legendary background of heroism and soldiering and that the Jat farmer has the selfperception image of being a farmer-soldier. ${ }^{67}$ In Kenya, the Jats were among the pioneer farmers at Kibos settlement. Later a number of Jats bought considerable tracks of rich land from

\footnotetext{
${ }^{63}$ Ghai ed., Portrait of a Minority, 40.

${ }^{64}$ Chattopadhyaya, Indians in Africa, 351.

${ }^{65}$ Ibid.

${ }^{66}$ Ibid., 69.

${ }^{67}$ Ibid., 70.
} 
departing white South Africans and the white settler farmers in the former white highlands of Kenya between Eldoret and Nakuru on the dawn of independence. ${ }^{68}$ This indicates their resilience in agriculture. Consequently, this study will focus on this small group of Asians who were farmers even back at home: specifically the Jat Sikhs, but were later joined by few other Asians Castes.

\section{CHRISTIANS (Catholics)}

This group mainly consisted of Goans.They formed less than $10 \%$ of the Asian community in Kenya by 1962. They came from a tiny Portuguese colony of Goa, south of Bombay, and disliked being classified as Indians. They have mixed blood having inter-married with the Portuguese and have adopted Portuguese names such as D'Souza (sometimes referred to

as de Souza), to indicate their ancestry. ${ }^{69}$ They were well educated and during colonial period held clerical jobs in banks, civil service, and many also served as teachers in mission schools, and lawyers. They spoke English, Portuguese, and their Indian Vernacular known as Konkani. Many became involved with politics, especially supporting the Freedom Struggle, for instance, Pio Gama Pinto and Fitzval R.S. de Souza. Bharati, in his work Asians in East Africa: Jayhind and Uhuru, is of the view that Goans have the belief that India is a Hindu country and due to their religious background they would rather identify with Portugal than the so-called "Heathen" India. ${ }^{70}$ However, as an Asian community, they were reputed for honesty and reliability.

\section{PARRSEE}

This group was the smallest in number, less than 1\% of Kenyan Indian population; they were originally refugees from Persia, running away from religious persecution from Muslims;

\footnotetext{
${ }^{68}$ Ibid., 71.

${ }^{69}$ Delf, Asians in East Africa, 9.

${ }^{70}$ Bharati, Asians in East Africa: Jayhind and Uhuru, 19.
} 
they practiced Zoroastrianism. ${ }^{71}$ However, they were well educated, affluent bankers and lawyers, but most did not make Kenya their home. They came on temporary assignments, for instance, to manage Indian banks and then went back home. ${ }^{72}$

\section{Racial Rivalry and Political Struggle}

Racial rivalry exists almost everywhere in the world, especially targeting minority outsiders. For example, Chirot compares two prominent entrepreneurial minorities in today's world by analyzing the European Jews and the Southeast Asian Chinese. He portrays how these two groups are successful in entrepreneurship, often subjecting them to discrimination and persecution as minorities. Thus his analogy raises pertinent issues that occur such as brutal Sinicism against Chinese in some parts of Southeast Asian countries; for instance, the expulsion of the Chinese community in Vietnam after $1975 .^{73}$ Thus Chirot concludes the dislike directed to entrepreneurial minorities can be attributed to the outsiders' success which makes native populations jealous. ${ }^{74}$ Chirot's work becomes relevant to the study of Asian cane farmers at Kibos-Muhoroni since they too experienced hostilities not only from the white settlers and the Africans but also the colonial state.

Similarly, although studies in Asian economic endeavors have been broad-based with greater emphasis on their role in entrepreneurship, the other key research area has been on Asian political struggles in Kenya. Struggles for equality have been captured in many debates such as the Indian question. Therefore, this study also investigated how colonial politics, especially settler politics, and the ecology of the area led to success or impeded the Asian sugar production

\footnotetext{
${ }^{71}$ Dana April Seidenberg, “The Asians and Uhuru: The Role of a Minority Community in Kenya Politics 19391969”, Ph.D. Dissertation, Syracuse University, 1979, 7.

${ }^{72}$ Bharati., Asians in East Africa: Jayhind and Uhuru, 22.

${ }^{73}$ Daniel Chirot and Anthony Reid eds., Essential Outsiders: Chinese and Jews in the Modern Transformation of Southeast Asia and Central Europe (Seattle: University of Washington Press, 1997), 5.

${ }^{74}$ Ibid., 6.
} 
in Kibos-Muhoroni area. Questions as to why the sugarcane production in Uganda was a success story, and not in Kenya, were investigated. For instance, what impacted it most? Was it the ecological or political situation? Given the fact that colonial Kenya was a three tier society with Europeans, Asians and Africans all involved in economic and political struggles, it became imperative to examine the performance of Asian cane farmers at Kibos, taking into consideration that the Asians in Kenya experienced a very unfriendly state, which led to bitter political rivalry between Asians, and especially the European settlers.

Political aspects of Asians in East Africa and Kenya, in particular, have also been studied by many scholars. For example, Richard McCormack’s work Asians in Kenya: Conflict and Politics. $^{75}$ and Robert Gregory’s Quest for Equality: Asian Politics in East Africa 1900-1969, ${ }^{76}$ and India and East Africa: A History of Race Relations Within British Empire are political studies covering the colonial period, Asian roles in trade unions and political struggles for equality in Kenya. Gregory argues that the quest for political equality thwarted the process of making Kenya a white colony like Rhodesia. Other scholars discussing this issue include: William K. Hancock’s work Survey of British Commonwealth Africans: Problems of Nationality 1918-1936, ${ }^{77}$ Marjorie Dilley, British Policy in Kenya Colony, ${ }^{78}$ C.F. Andrew's work, The Indian Question in East Africa, ${ }^{79}$ and Maxon's Struggle for Kenya: The Loss and Reassertion of Imperial Initiative 1912-1923. ${ }^{80}$ These all discuss "the Indian Question" focusing on the struggle for equality in Kenya in the 1920s. Asians challenged the colonial administration on its

\footnotetext{
${ }^{75}$ McCormack, Asians in Kenya: Conflicts and Politics.

${ }^{76}$ Robert Gregory, Quest for Equality: Asian Politics in East Africa 1900-1969 (New Delhi: Orient Longman, Ltd., 1993); Robert Gregory, India and East Africa: A History of Race Relations in the British Empire (Oxford: Clarendon Press, 1971).

${ }^{77}$ William K. Hancock, Survey of British Commonwealth Africans: Problems of Nationality 1918-1936 (Latham: Oxford University Press, 1942).

${ }^{78}$ Marjorie Dilley, British Policy in Kenya Colony (New York: Thomas Nelson and Sons, 1937).

${ }^{79}$ C.F. Andrews, The Indian Question in East Africa (Nairobi: Swift Press, 1921).

${ }^{80}$ Robert Maxon, Struggle for Kenya: The Loss and Reassertion of Imperial Initiative 1912-1923 (London: Associated University Presses, 1993), 52-54, 160-173.
} 
policy of segregation and wanted common suffrage; many supported the Africans in their political struggle. Other scholars who discuss Indian political initiative include Charles Bennett and Dana April Seidenberg's two monumental works: "The Asians and Uhuru: The Role of A Minority Community in Kenya 1939-1960.”81 This work examines the demography and the political activities of the Asian community and examines the economic aspects of the Indians life in relation to their political activities. This approach leaves a yawning gap since, although economy and politics are complimentary, one cannot be used to discuss the other adequately. Unfortunately, in Seidenberg's work, this has been the case. The second work; Uhuru and The Kenya Indians: The Role of a Minority Community in Kenya Politics 1939-1963, a book derived from the dissertation, is more focused on political issues in colonial Kenya; the author looks at the Asian political activities examining the political associations, the press, and the trade unions and depicts a rich interplay between political activities and the economic role of the Asians. ${ }^{82}$ Indian perspective on this emotive issue has been captured in many books and journals such as the Indian Review, Hindustan Review, Young India and the Kenyan, Indian newspapers such as the Colonial Times and the Kenya Daily Mail.

Kenya scholars have also attempted to examine the Asian political aspect. For example, John Okumu's study “Kenya 1900-1930: A Study in Conflict” portrays the racial/political scenario in Kenya which also impacted agriculture in the sense that by the time the European settlers arrived, they found the Indians who had a long contact with the Africans along the coast firmly established in trade and expanding. Thus, the arrival of the settlers meant that any program which had hitherto encouraged the settlement of Indians on land was to be abandoned,

\footnotetext{
${ }^{81}$ Seidenberg, “The Asians and Uhuru”, 1979.

${ }^{82}$ Dana April Seidenberg, Uhuru and the Kenya Indians: The Role of a Minority Community in Kenya Politics 19391963 (New Delhi: Vikas Publishing House, 1983). See also Charles J. Bennett, "Persistence Amid Adversity: The Growth and Spartial Distribution of the Asian Population in Kenya 1902-1963”, Ph.D. Dissertation, Syracuse University, 1976.
} 
and Indians could only get limited land for settlement, located in areas not suitable for European settlement. ${ }^{83}$ This led to racial tension between the Asians and Europeans in Kenya.

\section{Colonial State Policy: Land}

However, to understand the Asian agricultural initiative, there is need to analyze issues dealing with colonial agriculture and economic means of production in colonial Kenya. Therefore, certain themes become predominant. This research seeks to investigate how the Asians accessed these means and to what extent. Consequently this necessitates the literature review to adopt a thematic approach to reflect issues such as land, labor, market, and Asian economic initiative in Colonial Kenya, which are important in this study which views Asian agricultural production of sugar at Kibos, as a process that has political, economic, and social importance.

A lot of literature exists on the land policies of the colonial state in Kenya. The colonial state played a significant role in establishing control of the means of production, controlling the pace of economic development and actually making it a dependent economy. In as much as it propagated for self-sufficiency and self-sustainability, it played a contradictory role. For instance, the state engaged in land appropriation and actually came up with policies that favored the European settler economy. For example, Van Zwanenberg with Anne King, point out that production in Kenya was specifically made to favor the settler. Even Africans, let alone Asians, cultivation of cash crops was discouraged, especially before the $1930 \mathrm{~s}^{84}$ This was meant to prevent competition and was done through enforcing economic policies in Kenya that did not favor Asian cane production. These policies included land and labor regulations.

\footnotetext{
${ }^{83}$ Okumu, “Kenya 1900-1930,”191.

${ }^{84}$ R. Van Zwanenberg with Anne King, An Economic History of Kenya and Uganda 1800-1970 (Atlantic Highlands: Humanities Press, 1975), p. 204.
} 
Therefore many land policies were enacted in various ordinances. For instance, Sorrenson argues that the 1915 ordinance favored settlers and increased the leases to 999 years, and so entrenched alienation of African land which was later decided to be sold at public auction. ${ }^{85}$ Other scholars who discuss land policies include George Bennett, McGregor Ross, Maxon, and Maxon and Ofcansky who all agree that the land policies excluded the Indians from the Highlands. ${ }^{86}$ This caused land issues to antagonize Europeans and Indians in the colony. The Indians were infuriated by their exclusion from the White Highlands.

The Indians put up a spirited fight and initially refused to discuss the option of occupying the lowlands. They were adamant and wanted the Highlands opened to them. This struggle has been vividly discussed by Maxon in his book, Struggle for Kenya: The Loss and Reassertion of Imperial control 1912-1923. ${ }^{87}$ These works are important since they indicate that the Indians had no choice but to resort to the lowland areas around the lake basin, such as Kibos-Muhoroni and Miwani which were less fertile areas. Ironically these areas were not empty as argued by Hugh Fearn in An African Economy: A Study of the Economic Development of Nyanza Province of Kenya. He points out that the Luos who inhabited this area felt pressure on land and demanded compensation for their alienated land. ${ }^{88}$ This was in accordance with the Kenya Land Commission Report of 1934.

Other authors who discuss the Kenya Land Commission and Asian Struggle for land include Maxon, Breen, Bharati, Gregory, and Sorrenson pointing out how crucial this issue was.

\footnotetext{
${ }^{85}$ M.P.K Sorrenson, Origins of European Settlement in Kenya (Nairobi: Oxford University Press, 1968), 140.

${ }^{86}$ Robert Maxon and Thomas P. Ofcansky, Historical Dictionary of Kenya $2^{\text {nd }}$ ed., (London: The Scarecrow Press, 2000), 701. For more discussion see George Bennett, Kenya: A Political History (Nairobi: Oxford University Press, 1963), 10-18, 19-28. W. McGregor Ross, Kenya From Within: A Short Political History (London: Cass Publishers, 1968), 42-72.; and, Maxon, Struggle for Kenya, 161-277.

${ }^{87}$ Maxon, Struggle for Kenya, 161-277.

${ }^{88}$ Fearn, An African Economy, 91. See also Rita Breen, “The Politics of Land: Kenya Land Commission (1932-1933) and its Effects on Land Policy in Kenya”, Ph.D. Dissertation, Michigan State University, 1976 for discussion on the Kenya Land Commission chaired by Sir William Morris Carter.
} 
This struggle not only involved Asians but also Africans whose land had been alienated. The findings of the Commission becomes relevant to the study in establishing if the Africans, and specifically the Luos of Kibos, were compensated land and also to establish their reaction to the alienation, and whether the Asian views were considered when the Commission conducted its research.

Moreover, scholars such as Okoth-Ogendo, Seidenberg, Maxon, Hellen Tilley and Stephen Orvis also discusses land policies, especially after World War II that saw the enforcement of the Swynnerton Plan, a plan that emphasized also the use of extension services to transform agriculture. Okoth-Ogendo, who is critical of the Swynnerton Plan, argues that land policies which were put in place favored European settlers and were not workable. ${ }^{89}$ On the other hand, Steven Orvis, who examined the land policy in as far as ownership of private land is concerned, states that this led to the integration of the peasantry into the global market. Thus a parallel will be drawn from this view to see if the Asian cane farmers become integrated with the global market. This policy of private ownership also resulted in the creation of landed and landless people. ${ }^{90}$

Thus existing literature reveal the contradictory nature of the colonial state especially its policies on land and cash crop production. We see the state conceding to settlers' demands, but also giving land to Asians. Therefore, the state was a contradictory institution influenced by different groups in the formulation of its policies. For instance, during the 1930s depression and

\footnotetext{
${ }^{89}$ F.H. Okoth-Ogendo “African Land Tenure Reform” in Judith Heyer et al. eds., Agricultural Development, 157. For more discussion on land policies and the Swynnerton Plan see Stephen Orvis, The Agrarian Question in Kenya, (Gainesville: University Press of Florida, 1997), 3. Seidenberg,"“The Asians and Uhuru”, 55. Also in the wake of the Great Depression on 1930, policies to spur economic recovery were enacted. See further discussion by Hellen Tilley, “The African Survey, Ecological paradigms and British Colonial Development 1920-1940” in William Beinant and JoAnn McGregor eds. Social History and African Environment (Oxford: James Currey, 2003), 110. Maxon, East Africa, 203-204.

${ }^{90}$ Orvis, The Agrarian Question in Kenya, 3.
} 
during World War II, we find the state supporting more production in agriculture, and by mid1950s intensive policies are enacted to help the African farmers.

\section{Colonial State Policy: Labor}

Usually the alienation of land was closely associated with the need for labor. Therefore, labor questions remain dominant in any economic study, whereby certain pertinent issues emerge such as recruitment of a sufficient labor force and the training of the laborers, especially in handling new technology. Thus the colonial government and settlers devised a means of control over the labor supply to support the settler farming system. Several scholars have discussed the labor issues. For example, L.D. Smith and Maxon agree that these methods entailed measures to increase labor supply such as the introduction of the hut tax and the poll tax on all males over sixteen years old. ${ }^{91}$ Moreover, Wolff asserts that there was also an imposition of import duties on many of the consumer goods that the Africans purchased. Wolff expands on this issue, stating that more measures were undertaken, for instance, that the formation of the Department of Native Affairs in 1907 was specifically done to ensure labor supply, by encouraging coercion, whereby people were forced to work not only on public projects but also for private employers as well. ${ }^{92}$ According to the author, the 'Pass' was also introduced as a means of control over labor supply. $^{93}$ This being the case, it therefore becomes pertinent to examine if the Asian cane farmers benefited from such measures too.

\footnotetext{
${ }^{91}$ L.D. Smith, “An Overview of Agricultural Development Policy” in Judith Heyer, et al. eds., Agricultural Development in Kenya, 115; Maxon, East Africa, 203-205.

${ }^{92}$ R.D. Wolff, The Economics of Colonialism, Britain and Kenya 1870-1930 (New Haven: Yale University Press, 1974), 100.

${ }^{93}$ Ibid.
} 
Moreover, Berman and Lonsdale contend that control of labor was entrenched through support and sanctions of the colonial state. ${ }^{94}$ Hence, labor recruitment and control were therefore left in the hands of the European labor recruiters and individual estate owners. According to the authors, this leeway led to abuse of African workers by settlers. ${ }^{95}$ The authors also raise a pertinent issue that would be relevant in this study. They point out that in the postWorld War I period, African peasants also were trying to reconstruct and engage more in commodity production. This then created a conflict for the demand for their labor; this situation was further compounded by the fact that the labor exporting zones were also the major areas where peasant commodity production developed greatly. ${ }^{96}$ Scholars discussing this conflict include Maxon, Fiona D. Mackenzie and Gavin Kitching. The authors agree that the settlers had to compete for African labor.

Consequently, in sugar production, labor mobilization becomes a very crucial factor for the industry. Various tasks, such as weeding and cutting of the cane, depended on manual labor. Although scholars such as Gavin Kitching argued that there was a gross under-utilization of male labor in colonial Kenya, ${ }^{97}$ this could hardly be said of the Luo or Indian laborers. However, Tiyambe Zeleza and Clayton and Savage have also done great work in Kenya's labor history. Unlike Kitching, Clayton and Savage argue that the Africans did not think of themselves as idle as they were involved in specific tasks seasonally such as clearing new grounds, craftwork and

\footnotetext{
${ }^{94}$ Bruce Berman and John Lonsdale, “Crises of Accumulation, Coercion and the Colonial State: The Development of Labour Control System 1919-1929” in Bruce Berman and John Lonsdale, Unhappy Valley, Book One (London: James Currey, 1992), 110. See also, Maxon, Struggle for Kenya, 86.

${ }^{95}$ Berman and Lonsdale, “Crises of Accumulation”,, 105.

${ }^{96}$ Ibid.

${ }^{97}$ Gavin Kitching sidelines the role played by male labor in supporting the pre-colonial economy. For more discussion on this, see, Gavin Kitching, Class and Economic Change in Kenya (London: Yale University Press, 1980), 14-19. For more discussion on the labor force see Fiona D. Mackenzie, Land, Ecology and Resistance in Kenya 1880-1952 (Portsmouth: Heineman, 1998), 188.
} 
building of huts. ${ }^{98}$ In most cases, the Africa life in the reserve areas was not fully understood and so lack of visible work, especially during some periods, was seen as idleness. Moreover, the mere alienation of African land meant that the African basic means of production was deprived and so many became increasingly involved in wage labor specifically to meet their tax obligation. ${ }^{99}$ This becomes pertinent to this study in finding out specifically which periods were farm workers engaged mostly in Asian farms and if they joined any workers union.

\section{Market: its role in production.}

The colonial state played a crucial role in determining the success of agricultural production. Indeed it determined what crops would be produced and prices to be offered for the produce. Many scholars have studied these phenomenons. For example, Peter Ndege arrived at the conclusion that the colonial state even determined the structure and nature that the market would take. ${ }^{100}$ John Lonsdale and Bruce Berman have also examined the colonial state and its role in enforcing economic change. ${ }^{101}$ The authors argue that the colonial state responded partly due to its self-interest of attaining self-sufficiency and so was under pressure to rely on tax revenue as opposed to funding from the British treasury. However, in the attempt, contradictions clearly emerged since the state made efforts to spur peasant and settler agriculture and support the interests of the British capital and its own interests while at the same time promoting the interest of local classes within Kenya. This meant that the colonial state had to redefine itself and its role within Kenya's political economy. This led to crisis and contradictions in the

\footnotetext{
${ }^{98}$ Anthony Clayton and Donald Savage, Government and Labour in Kenya 1895-1963 (London: Frank Cass and Company, Ltd., 1974), 25.

${ }^{99}$ Tiyambe Zeleza, “The Colonial Labour System in Kenya” in W.R. Ochieng and R.M. Maxon eds. , An Economic History of Kenya (Nairobi: East African Educational Publishers, Ltd., 1992), 173.

${ }^{100}$ The role of the colonial state in control of the market has well been studied by Peter Ndege. See Peter Ndege "Struggle for the Market: The Political Economy of Commodity Production and Trade in Western Kenya, 19291939”, Ph.D. Dissertation, West Virginia University, 1993.

${ }^{101}$ J. Lonsdale and B. Berman, "Coping with the Contradictions: The Development of the Colonial State in Kenya, 1895-1914”, Journal of African History 20 (1979): 490.
} 
colony’s economic structure, depicting the state as having "relative market autonomy". ${ }^{102}$ For instance, Asian agriculture, although vibrant in Uganda, seems not to have done well in Kenya, due to colonial economic policies. For example, the state supported settler agriculture in growing wheat that had no ready market, while it was reluctant to support the Asian sugarcane farming that had a ready local market. Thus, this stance taken by the state becomes important in examining the rationale behind its policy of ignoring the Asian production. In the same vein, Kitching, Maxon and Ofcansky agree that the state played quite a pivotal role in directing agriculture in Kenya since 1930. This, Kitching indicates, was done through enactment of policies which included seed distribution, promotion of new technology, agricultural extension services, and the extension of the market. ${ }^{103}$ These policies form part of the research questions which will be investigated.

Robert Bates also highlights the role of the state in influencing development of the rural economies. He points out the political underpinning of the colonial state in its economic intervention which emphasized on institutions such as "cooperatives". ${ }^{104}$ In most cases the cooperatives were controlled by the state. Bates' analysis is significant to this study since it will help examine the challenges faced in marketing, given the bureaucratic nature of the market in colonial period. Furthermore, Bates in his later work expounds more on marketing and states that those in control of institutions such as the marketing also helped to determine who excelled in the economic life through control. ${ }^{105}$ Hence, questions such as whether the sugar marketing boards were fair and independent will be investigated? This is important in analyzing the

\footnotetext{
${ }^{102}$ Bruce Berman, Control and Crisis in Colonial Kenya: The Dialectic of Domination (London: James Currey, 1990), 3.

${ }^{103}$ Kitching, Class and Economic Change, 101-104. See also, Maxon and Ofcansky, Historical Dictionary of Kenya, 9.

${ }^{104}$ Robert H. Bates, Markets and States in Tropical Africa: The Political Basis of Agricultural Policies (Berkeley: University of California Press, 1984), 4.

${ }^{105}$ Robert H. Bates, Beyond the Miracle of Market: The Political Economy of Agrarian Development in Kenya (Cambridge: Cambridge University Press, 1989), 11.
} 
interaction of the Asians and the market in colonial Kenya, given the fact that government institutions were very powerful and controlling. African peasant farmers could outwit the colonial marketing institutions as depicted in the work of Stephen Bunker, who portrays how peasants (Bagisu) had an ambivalent relationship with the state in which the state recognized its reliance on peasant produce and hence permitted the peasants to engage the state by allowing them to have considerable say on their produce. ${ }^{106}$ Bunker thus uses the Bagisu experience to show how peasants can mobilize themselves into good leadership and organization, and exert pressure on the state to get more concessions in terms of more fair and lucrative pricing of their produce. Given the demand that existed in the ready market for sugar in Kenya, Bunker's findings are relevant since they will lead to the investigation of the Asian cane growers experiences to determine if they were organized enough to put pressure on the colonial state, that significantly supported the white settler production.

Similarly, many scholars agree that market opportunity is important and a key variable in successful production. For example, Maxon in his comparative study of the Gusii and people in Vihiga conclude that market opportunity was important in providing impetus for rural households to develop farming that could enhance income and contribute to national development. ${ }^{107}$ Kitching acknowledges this fact and argues that by May 1942, the maize and produce control introduced a guaranteed minimum price for maize producers, which increased maize production. ${ }^{108}$

Heyer, in her work, contends that the marketing system in any agricultural development is crucial since it can be a strong encouragement to agricultural development or it can be a real

\footnotetext{
${ }^{106}$ Bunker, Peasants Against the State, 13.

${ }^{107}$ Robert Maxon, Going Their Separate Ways: Agrarian Transformation in Kenya 1930-1950, (London: Associated University Press, 2003), 10.

${ }^{108}$ For an elaborate discussion, see: Kitching, Class and Economic Change, 109, 134.
} 
hindrance. She further argues that what is needed is an efficient marketing system which performs its function at a low cost while ensuring producers are appropriately remunerated. ${ }^{109}$ This view is supported by Van Zwanenberg and King. The authors point out that marketing is important since it is the vital link between the producers and the consumers. Without the link which is the marketing mechanism, the producers' crops are bound to be destroyed in the field. ${ }^{110}$ These marketing mechanisms include collecting the product, processing it, acting as wholesalers, and financing or providing credit to the producers. The authors contend that marketing is complex and that each product has a different system through which it is processed, marketed, and sold and so the efficiency of marketing is essential. ${ }^{111}$ These are all important factors in this study. For instance, how the cane farmers delivered their cane to the mills becomes crucial to the study since cane needs to be harvested at the appropriate time.

Van Zwanenberg and King also discuss how organized marketing occurred in Kenya by the 1920s which led to a more centralized form of marketing. It emerges that the colonial state could also intervene in pricing. The authors therefore postulate that this was crucial, especially during price fluctuation of export commodities in the world market, since it affected prices locally. However, they argue that the support against such fluctuations was given by the colonial government but mostly to those groups with political influence such as the white settlers. ${ }^{112}$ Therefore, by the 1920s, the European producers found it necessary to control production and marketing in such a way so as to monopolize the growing of valuable crops, receive highest prices for their produce and regulate the market so that Africans did not have access to it. This was done through the establishment of institutions such as marketing boards which basically

\footnotetext{
${ }^{109}$ Judith Heyer, “The Marketing System” in Judith Heyer et al. eds., Agricultural Development in Kenya, 313.

${ }^{110}$ Van Zwanenberg with King, An Economic History of Kenya and Uganda, 201.

${ }^{111}$ Ibid.

${ }^{112}$ Ibid., 204.
} 
served the interest of the white farmers. It is no wonder that William Jones argues correctly that marketing boards flourished in British colonies in Africa but found their most fertile soil in Kenya where there were approximately twenty-seven such boards in the colonial period and that these boards had legal control over almost everything that was produced in Kenya; ${ }^{113}$ the Asian sugar being no exception. Such being the case, this finding is valuable in the proposed study. Crucial questions arise such as: did Asians have a say in sugar prices; were credit facilities available and adequate? These questions become pertinent to the study. It is in this light that the research will examine how the market supported the Asian cane production. For instance, the statutory trading authorities will be investigated.

\section{Economic Initiative and Asian Sugar Industry}

Many studies have documented the economic contribution by the Asian community during the colonial period in East African generally. Gregory’s India and East Africa: A History of Race Relations within the British Empire; South Asians in East Africa: and Mangat A History of the Asians in East Africa have examined Asian economic role in East Africa, generally. ${ }^{114}$ Mangat's main concerns are with the immigration and settlement of Asians in East Asia. It is a well researched work, however broad based, capturing the political activities of Asians in Kenya, Uganda, and Tanganyika up to 1945. Both the authors' works deal with the Asian entrepreneurship which included wholesale and retail trading and transport industry. Robert Gregory's work, South Asians in East Africa: An Economic and Social History, is a tremendous study of the Asian economic role in East Africa. Generally he challenges the notion that Indians were not interested in farming. He gives detailed data describing the Asian initiative at Kibos

\footnotetext{
${ }^{113}$ William O. Jones "Agricultural Trade Within Tropical Africa: Historical Background” in Robert H. Bates and Michael F. Lofchie eds., Agricultural Development in Africa: Issues of Public Policy (New York: Praeger Publishers, 1980), 26.

${ }^{114}$ See Gregory India and East Africa, 395-396. For a detailed discussion on Asian economy in East Africa see also Gregory, South Asians in East Africa and Mangat, A History of Asians in East Africa.
} 
regardless of the lack of support from the colonial government. ${ }^{115}$ He compares the acreage under cultivation in Kibos, which was $70 \%$ of household plots cultivated, with that of the European settlers in the white highlands which was underutilized, i.e. less than $10 \%$ and concludes that the Asian effort at Kibos was tremendous. Although most authors dismiss the Kibos settlement as a total failure, Gregory is of a different view, arguing that for three decades, despite lack of adequate support, the Kibos sugar settlement grew steadily and served as an example of a small scale Asian agriculture. Therefore, there is need for reassessment to establish this new perspective.

Moreover, Gregory's work has greatly contributed to the study of Asian agriculture, especially the sugar plantations in Uganda and Tanzania. In Kenya, although he examines trade and transport, he touches very little on agriculture. Secondly, his analysis stops at the end of World War II. This does not give us the more specific analysis of economic policies of the postworld War II period that were adopted by the colonial state such as the Swynnerton Plan of 1954 and its impact on Kenya's agriculture. Hence, it leaves a yawning gap for the Asian sugar farming in Kenya, which is not as well discussed as the case of cane production in Uganda. This study therefore seeks to continue with the work of Prof. Gregory and bridge this gap by investigating the Asians role in production of sugar in colonial Kenya, particularly at Kibos.

Although Seidenberg also points out that the Indians were engaged in other economic activities such as farming and fishing, there is no explicit discussion on these two areas. She concludes that farming was limited and that majority of Asians congregated in urban centers partly due to the fact that the colonial government would not allow Asians to own land in most parts of the colony. ${ }^{116}$

\footnotetext{
${ }^{115}$ Gregory, South Asians in East Africa, 241.

${ }^{116}$ Seidenberg, "The Asians and Uhuru”, 8.
} 
Other scholars dealt with Asian economic role in Kenya. For example, Zarwan gives a detailed analysis of the Asian businessman in Kenya, especially the Oshwals. ${ }^{117}$ John Okumu, on the other hand, attempts to discuss Asian agriculture by pointing out that the railway coolies who had some experience in farming in India were encouraged to remain in East Africa as settlers. He erroneously concludes that most of the Indians in Kenya were not very much interested in buying land. ${ }^{118} \mathrm{He}$, however, acknowledges that a small number of 30 Asians acquired land at Kibos. This assumption of Indians lack of interest in farming is wrong given the fact that the white highlands in Kenya were highly contested by the Asians and became a major part of the Indian question. It was not for lack of interest, Gregory argues, that the Indian settlement scheme failed, but rather because land available to them was not suitable for agriculture, as compared to the white highlands. Although earlier historians concluded that the Asian agricultural scheme was a failure, this work on the Asian sugar industry in CN demonstrates that it was not the case. Possibly the earlier scholars arrieved at that conclusion due to the 30 year rule placed on accessing archival sources.

Finally, few scholars have attempted to analyze, specifically, the sugar industry in East Africa from a more general perspective. For example, Charles S. Frank, in his work The Sugar Industry in East Africa, broadly examined the sugar industry in East Africa, comparing the three countries of Kenya, Uganda, and Tanganyika during the colonial period. His main concerns, however, were geared towards looking at the degree of cooperation among the three countries especially in areas of marketing and distribution. Thus, his work, though a great contribution is more of a comparative analysis and so does not focus on the Asian cane production in Kenya. However, his work reveals how Uganda had a consistent surplus of production over consumption

\footnotetext{
${ }^{117}$ John L. Zarwan, “Indian Businessmen in Kenya During the Twentieth Century: A Case Study”, Ph.D. Dissertation, Yale University, 1977.

${ }^{118}$ Okumu, “Kenya 1900-1930”, 189.
} 
between 1955 and 1963 ranging between 10,000-50,000 tons while Kenya had a persistent shortfall during the same period. ${ }^{119}$ Frank further compares the economic policies put in place and arrives at the conclusion that the policies affected the East African countries in terms of distribution. Maxon corroborates this view and submits that in Uganda by the 1920s, large sugarcane plantations and processing plants were established by Asian entrepreneurs such as N.K. Mehta and M. Madhvani. Moreover, sugarcane farming was prone to do well and had an advantage over cotton and coffee since it found an already expanding local market, ${ }^{120}$ and so did not have to depend on exports to distant markets. Although in Uganda the industry progressed rapidly, the same could not be said of Kenya. Hence, the need to capture the variables in Kenya is important. Pertinent questions need to be investigated, for instance, why did Kenya have persistent shortfalls in cane production during the period under review?

From the forgoing it is evident that little work has been done on Asian agriculture in Kenya and particularly on Asian sugar production at Kibos-Muhoroni area. This research therefore seeks to pick up from where Prof. Gregory left off and embark on a rigorous microstudy of the Asian sugar production at Kibos-Muhoroni.

\section{THE STUDY AREA}

Kibos-Muhoroni area is found in Nyanza Province of Kenya; the area is about six miles from Kisumu. This area includes Kibos, Chemelil, Kibigori and Muhoroni. ${ }^{121}$ It is an area that does not drain well with unreliable rainfall. The soil is rich especially at the foothills of Nandi hills down up to about a mile; there is also sandy loam soil. Far from the foothills of Nandi hills, the area turns swampy with badly drained black cotton soil which varies in fertility. The fertility decreases as it moves towards the Mombasa/Kisumu rail line.

\footnotetext{
${ }^{119}$ Charles S. Frank, The Sugar Industry in East Africa, (Nairobi: East African Publishing House, 1965), 2.

120 Maxon, East Africa, 192.

${ }^{121}$ KNA: AK/ 11/50, Sugar Growing Areas.
} 
The area has an elevation of between 3,800-4,200 feet. The rainfall average is 50" (inches) per annum which is suitable for sugarcane cultivation. There are three main seasons in the year: heavy rains (late March-June), short rains (July-November), and dry season with light rains (December-early March).

The sugar growing area was situated along the Kenya-Uganda railway line from Kibos to the east of Muhoroni. This area was acquired and occupied by Asians starting in $1903 .{ }^{122}$ The Asian cane production covered almost 46,000 acres of land. By 1910, a number of Asian cane farmers owned several farms. ${ }^{123}$

\section{SCOPE OF THE STUDY}

This study of the sugar plantation economy of the Asians begins in 1903 when Asians began to have farms in Kenya, particularly at Kibos, under 99 year leases, a scheme inaugurated in April 1903 by Commissioner Sir Charles Eliot, as a special Indian settlement area. ${ }^{124}$ The work examines the changes brought by World War I, leading to the post War period and zeroes in with the period starting in the 1930s due to the Agrarian changes undertaken by the colonial state to cope with the great depression. It further deals with the developments brought by World War II that led to change in agrarian policy to meet the demands of the war that led to development of the sugar industry. The focus of the analysis also lies within 1950s that saw changes in colonial policies, especially after the Swynnerton Plan of 1954 which brought agrarian changes in Kenya. This allows us to study the development of the Asian sugar industry during the post-World War II period. The study ends in 1963 when Kenya attained independence ending the colonial era.

\footnotetext{
${ }^{122}$ Ibid.

${ }^{123}$ KNA: PC/NZA3/22/1/2, Kibos Indian Settlement 1910-1912.

${ }^{124}$ Joshia O. Osamba, “A Forgotten Minority: The Case of Asian Sugar Plantation Owners in Nyanza Province, Kenya.” A paper presented at Historical Association in Kenya Annual Conference. Moi University, Eldoret, July 1998, 2-3. See also Sorrenson, Origins of European Settlement, 37.
} 


\section{METHODOLOGY}

This research was based on primary and secondary data. Primary sources were obtained from Ohio University library (Athens), Syracuse University’s Bird Library, and the Kenya National Archives, and Ministry of Agriculture Library in Nairobi. Secondary information was gathered from West Virginia University’s Wise Library. Also the following libraries were accessed in summer 2009: The Macmillan Library, the Aga Khan Foundation Library, Maseno University, Kenyatta University, Jomo Kenyatta University of Agriculture and Moi University’s Margaret Thatcher Library.

Field research was conducted in the Kisumu area where members of the Asian Association of East Africa were interviewed. Selected homesteads in Kibos-Muhoroni area were visited for observations and interviews. Here former cane workers, drivers and the farm owners both large scale and small scale were interviewed specifically the few existing Asian farmers were sought. Also interviewed were the skilled factory workers.

The field research employed the use of "snowball sampling” method. This method involves a series of interviews conducted in stages. Initially a few informants were identified who have the requisite characteristics. These in turn identified others who were eligible for more interviews.

\section{CONCLUSION}

Existing literature has revealed that Asians were innovative entrepreneurs and were quite willing to do farming if they had fertile lands, contrary to the belief that Asians were not in line with farming and that their area of operation was defined in trade (wholesale and retail), and other activities such as transport. This chapter gives the preamble for the need to study the colonial economic experiences of the Asian farmers in Kibos-Muhoroni in order to ascertain 
their role and capture their initiatives in farming. It strives to give a broader picture of the Asian economy and also provide a basis for interpretation of the present day dilemma of insufficiency of sugar in Kenya, regardless of the fact that Kenya has a high potential of attaining selfsufficiency in sugar production. Most importantly, it has raised crucial research questions emanating from the existing literature, which has exposed gaps in the economic history of Asians in Kenya, which the study seeks to answer. The research questions basically will investigate, therefore, how Asian cane production performed in a predominately settler and, later, peasant economy. 
Map 1.1: Location of the Study Area ( Shaded dark area)

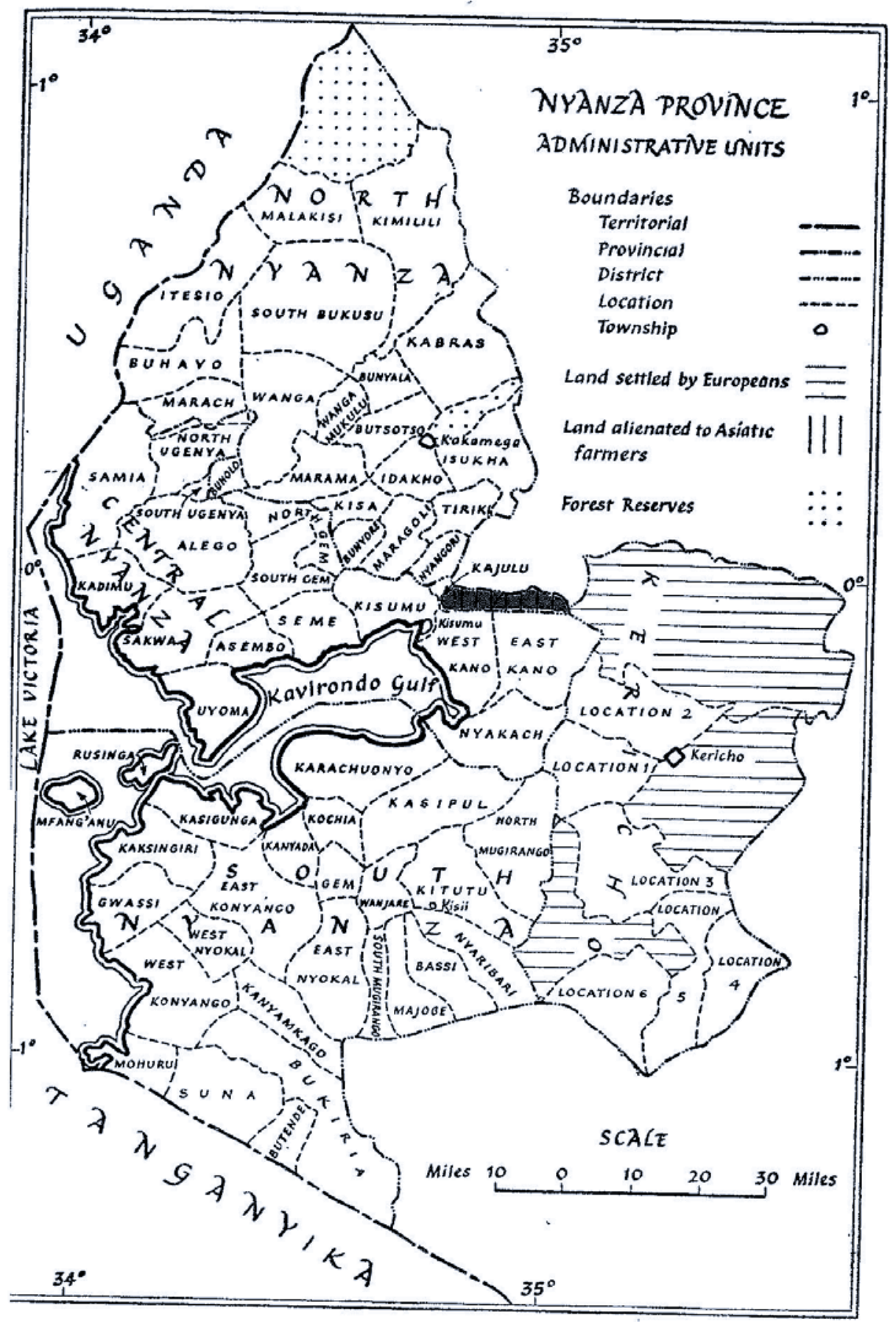

Adapted from H. Fearn, An African Economy, 19. 


\section{CHAPTER 2}

\section{HISTORICAL BACKGROUND OF INDIANS IN KENYA}

\section{Introduction}

This chapter aims at discussing the background and coming of Asians into Kenya. The chapter also deals with migrations, push and pull factors, responsible for the migrations, settlement patterns, what Asians experienced when they arrived in Kenya, and, some of the diverse economic activities that they engaged in. These economic activities included retail and wholesale trade, transport industry, civil service, and the eventual settlement at Kibos

\section{Migrations and Settlement}

The history of the interactions between India and the East African Coast predates European imperialism in East Africa. This interaction started as far back as the first millennium, B.C. when immigrants from present day India and Pakistan settled in Zanzibar and the East African Coast engaging in the extensive Indian Ocean trade. ${ }^{1}$ This interaction brought many Asians to the coast. Mangat, in his book A History of Asians in East Africa 1886-1945, traces the genesis of the Asians in East Africa, to the second century, when there was an extensive trade network in the Indian Ocean which attracted merchants and seamen from India, Persia, and Arabia. $^{2}$ These groups established a long history of commercial links with East Africa and played an active role in the financial and commercial life of the area. Mangat argues that the presence of Asian merchants and seafarers was made possible due to geographical proximity and the knowledge and availability of the trade winds. Evidence of this earliest contact was found in the Greek sailors guide "the Periplus of the Erythraean Sea” in the first century, A.D., which

\footnotetext{
${ }^{1}$ Gregory, South Asians in East Africa, 1.

${ }^{2}$ Mangat, A History of the Asians in East Africa, 1.
} 
indicated the trade network in the Indian Ocean and the role that the Indian merchants played along the coast by supplying cotton cloth and beads, while at the same time shipping from the east coast, ivory, gum copal and incense.

Mangat further points out that evidence of early Asian contact with the east coast was established by the excavations of Indian made glass beads along the coast and in Zimbabwe. The Asians were able to use small sailing ships through the Persian Gulf and the Red Sea into Egypt, Axum and Kush. While another route was by sailing, using a direct ocean route to the coast of East Africa, at that time referred to as Rhapta. ${ }^{3}$

Before 1500 A.D., Arabs, Indians, and other people from Asia monopolized the Indian Ocean trade. Many of the Indian traders along the east coast of Africa were Hindus and Muslims. However, the coming of Portuguese along the East Coast drastically impacted the free flow of trade in the region. Later, with the establishment of Omani Arab rule at the coast, many more Indians moved to East Africa.

Gregory's South Asians in East Africa: an Economic and Social History gives the best account of Asian migration into East Africa. He divides these movements into four phases starting from the $2^{\text {nd }}$ Millennium, B.C. to 1840 . He argues that by 1498, when DaGama explored the coast, Asians were already in Zanzibar, Pemba, Malindi, and Mombasa. While by 1833, Indian traders were already established at the coast as customs collectors. The early Indian immigrants were attracted by the Indian Ocean trade and eventually settled at the coastal towns.

Therefore, the first group of Asians was basically trading with the coast and their settlement increased with the transfer of Seyyid Sayyid's capital from Oman to Zanzibar in 1840. Many Asians residents of Oman followed him to Zanzibar to engage in the lucrative international trade.

${ }^{3}$ Gregory, South Asians in East Africa, 10. 
Similarly, British interests at the coast also indirectly encouraged Indian merchants. This was because Britain, during the $19^{\text {th }}$ Century, aimed at controlling the sea route to India and abolishing slave trade in the western side of the Indian Ocean and replacing it with legitimate trade. Thus during the short lived “Owen Protectorate” over Mombasa in 1824 to 1826 a policy to support Indian merchants trading under British flag in legitimate commerce was initiated, as an effort to combat slave trade. ${ }^{4}$ This encouraged more traders to come to the coast. Moreover, the opening of a British consulate in Zanzibar in 1841 also encouraged Indian traders. This was because the government of India helped in the growth of British diplomatic influence over Seyyid Sayyid in Zanzibar, which in turn helped the Indian traders carry on commerce peacefully due to the support extended to them by the British consulate.

However, it is important to note that even with the change of political control over the East African coast from one power to another, the Indian merchants continued to play a key role in commerce and the general economic life of the region. For instance, during Seyyid's rule between 1840 and 1856, Indian trade and migration to Zanzibar and Mombasa increased. They became bankers, shopkeepers, merchants, and financial advisers to the Sultan and also some were money lenders "Banyans." 5 This trend continued up to the 1890s. For example, in Zanzibar alone the Indian population by 1887 was estimated to be 3,086. Indian traders followed the Arab caravans which moved into the interior in search of goods, such as ivory and slaves, from the source. A few Indians set up trading centers along these caravan routes. For example, Musa Muzuri, a Khoja from Surat, traded in ivory in Unyamwezi and eventually set up his base at Koroqwe. ${ }^{6}$ Other centers included Bagamayo, Dar es Salam Tanga, Pangani, and Ujiji. Mombasa also experienced an increase in the population of Indians; by 1873, this was estimated

\footnotetext{
${ }^{4}$ Mangat, A History of the Asians in East Africa, 3.

${ }^{5}$ Gregory, India and East Africa, 19.

${ }^{6}$ Ibid., 35.
} 
to be about 533. ${ }^{7}$ The Indians monopolized trade along the coast together with other traders like the Arabs. Local people encouraged them since they were able to provide commodities that were much needed. This encouragement was seen, for example, during the Abushiri rebellion, when the Indians were assured of their security as the Europeans (Germans) were attacked. It is also important to note that the early immigrants did not bring their families (wives) along, possibly due to uncertainties. This situation was to change later.

Moreover, the Indian penetration into the interior of Kenya, as with the rest of East Africa, was facilitated by the declaration of imperial interests over the region by both Britain and Germany. After the conclusion of the Berlin agreement in 1885, Britain, as was the case with all European powers, quickly consolidated her imperial gains on the ground by the establishment of administrative networks. In Kenya, since the British did not have immediate plans to establish a fully operational administrative network, this task was handed over to the Imperial British East Africa Company (IBEAco) which was granted a royal charter in September 1888 under which it got a free hand to open up and develop the interior through the establishment of administrative, transport, and commercial infrastructure. ${ }^{8}$

Therefore, the IBEAco, which had a strong background in India where the British had already established a colony, recognized the desirability of incorporating manpower from India as it established itself in Kenya. It was generally held that Indians were good entrepreneurs and farmers who could help spur the economic productivity of the region. The company therefore supported Indian migration and even toyed with the idea of establishing permanent Indian settlements in the region, and this, it was also hoped, could help alleviate the problems of overpopulation back in India. As the company established itself in the hinterland it relied on

\footnotetext{
${ }^{7}$ Ibid., 37.

${ }^{8}$ Ibid., 47, 48.
} 
indentured labor from India to serve in the nascent administrative network and also in the military and the police force.

After the successful signing of the 1890 Anglo-German treaty that formally ended the reign of the Omani Arab aristocracy over the region, save for the coastal strip, plans were put in place to construct a railway within the British sphere of influence. Thus in 1891, Captain J.R.L. Macdonald, who had worked for seven years in India on railway construction and defense, was contracted to survey the route for the railway and, in his report of March 1893, strongly recommended the employment of Indian labor. This, he argued, could help solve the problem of obtaining African labor which was viewed as difficult, given the general hostility of the Africans to company administration. Macdonald's sentiments were shared by other company administrators like Frederick Lugard who believed that Indian settlement was most likely to follow the construction of the railway. This would help to develop the economic viability of the region. $^{9}$ Hence, it is quite clear that from the onset, the company considered Indians very favorably, and this encouraged their migration to Kenya in large numbers in the succeeding decades.

Consequently, the second wave of Asian migration was much larger than the first one. It occurred between 1890 and 1914, after the start of colonial rule. During this period, the British through the IBEAco assumed control of the interior and later accorded Indians a prominent part in the development of the East Africa Protectorate. The founders of IBEAco, led by Sir William Mackinnon, all hoped to provide an outlet to India's surplus population by encouraging Indian traders and the agricultural class to come to East Africa. ${ }^{10}$ Thus, the second wave, made up of mostly traders, also penetrated to the interior of East Africa.

\footnotetext{
${ }^{9}$ Ibid., 49.

${ }^{10}$ Ibid., 47.
} 
When the Foreign Office in London eventually assumed direct control of territory between the Uganda and the coast on June $15^{\text {th }}, 1895$, and renamed it the East Africa Protectorate, plans to construct the railway were implemented. The British colonial administration employed the use of Indian labor to build the railway. Therefore, between 1895 and 1914, the British imported 37,747 Asians, mainly from Punjab. ${ }^{11}$ Out of the workforce that came to Kenya, 16,312 returned to India, 2,495 died, 6,454 were invalidated by disease and work accidents; only 7,000 opted to remain in East Africa on expiration of their three-year contract. ${ }^{12}$ Hence the argument by the European settlers that the Asians were "crowding" the East Africa Protectorate was not valid at all. However, some of these Indians who did not go back practiced farming while others engaged in various economic activities.

During this period the colonial administration used Indian labor in jobs such as clerks, customs officials, and subordinate staff. These Indian recruits initially were mainly Parsees and Goans. Also for the IBEAco to establish its control in East Africa, it had to recruit Indian troops. Apart from active military duty, the colonial government also relied heavily on indentured labor from India to serve in the police force and help in restoring law and order, since the Africans resisted. Their military efforts will be subsequently discussed later in the chapter.

The third wave, which took place during the interwar period, was facilitated by a free immigration policy. This movement led to an increase in population. The majority came due to the effects of the 1930s economic depression that impacted British India leading to the relocation of Asians to other countries, such as Burma, Ceylon, and the East African countries including Kenya. For example, there was a tremendous increase in population between 1921 and 1931.

\footnotetext{
${ }^{11}$ Gregory, South Asians in East Africa, 10.

${ }^{12}$ Mangat, A History of the Asians in East Africa, 39.
} 
By 1939, the Asian population in East Africa had risen to $105,000{ }^{13}$ The majority of the Asians settled in the interior of Kenya. This number was to be increased by the fourth wave of migration which started at the end of World War II, and the increase in numbers continued until after Kenya attained independence in 1963. A majority of these Asian migrants lived in towns and trading centers. These communities consisted of Hindus, Christians, Sikhs, and Muslims. Each of these sects retained their traditions and maintained a strong cohesive social group. ${ }^{14}$ However, this intense communal identification and interaction also impacted them negatively in that it tended to isolate the Indians from other races in Kenya. On the other hand, Indian adaptability and flexibility led to other success in that although they came from a very stratified background, once in Kenya, their caste system was not much adhered to. For example, although the Shahs, Patels, Ismailis, and Sikhs were traditionally farmers back in India, almost all became businessmen once in Kenya, with the exception of the Sikhs of Jat who did not abandon their desire to engage in farming.

\section{The Push and Pull Factors}

People normally tend to go from places of limited prospects to those areas which seem to have greater opportunities. This has come to be known as the "push" and "pull" factors. ${ }^{15}$ Several authors have examined the causes of this great migration of the Asians into East Africa and Kenya in particular. These factors can be categorized as economic, social, and political. The scholars include Seidenberg, Zarwan, Bhatt, Gregory, Delf, and McCormack. All the authors agree that economic motivation acted as a great push and pull factor. Gregory asserts that most early traders were attracted to the coastal towns such as Zanzibar and Mombasa due to

\footnotetext{
${ }^{13}$ Gregory, South Asians in East Africa, 13.

${ }^{14}$ Hollingsworth, The Asians of East Africa. 3.

${ }^{15}$ For more explanation on these concepts, see William Petersen, “A General Typology at Migration”, American Sociological Review 23 (1958): 256-266.
} 
commerce. Seidenberg supports this view and acknowledges that many were lured to trade. ${ }^{16}$ Similarly, Bhatt corroborates this view, arguing that extensive trade opportunities were an important impetus to Indian migration. ${ }^{17}$ With the establishment of colonial rule, not only did the trade increase, but also the British found it necessary to encourage the immigration of the Indian merchant class so as to open up the protectorate. The colonial state realized that the Indian merchant would be helpful in exploiting resources which were much needed for attaining the goal of self-sustainability. Commenting on this stance, a British administrator in 1896 asserted that:

Such immigration is good and for the benefit of the country, and we should encourage it by every means in our power. This class of immigrants is possessed of some means and (what often goes with money) some intelligence and enterprise. ${ }^{18}$

Consequently, immigrants were early on encouraged to come to the colony. Most of the Asian early traders became middlemen who then facilitated the exchange of goods in the interior markets. Some of these traders, starting from humble beginnings, became prominent and great financiers: for example, Aliboy M. Jeevanjee and Allidina Visram. However, the majority remained retail traders herein referred to as dukawallas.

Needless to say, Asian resilience in trade cannot be underestimated. As the colonial economy developed, they contributed to it immensely. For instance, the African peasants in the rural areas depended on their role as middlemen. They sold their produce to the Asians who then resold it to the urban areas and also traded basic items to the Africans from their petty shops (duka). The trade thus acted as a pull factor and they succeeded in remote areas. Their expertise

\footnotetext{
${ }^{16}$ Seidenberg, "The Asians and Uhuru," 1. Gregory discusses the economic motivation that brought Asians to East Africa; he contends that the Shahs, Patels and Ismailis left their farming occupation to do business in East Africa. See Gregory, South Asians in East Africa, 22.

${ }^{17}$ Bhatt, "A History of Asians in Kenya", 44.

${ }^{18}$ KNA: PUB.1/1/1/6, Correspondence of Department of Revenue and Agriculture, Government of India, $4{ }^{\text {th }}$ of August, 1896, "Emigration Records and Correspondence 1856-1900”. See also Seidenberg, "The Asians and Uhuru”, 6-7.
} 
and mercantile skills earned them recognition even from the settlers who disliked them. For example, commenting on their resilience, Sidney Kelson, a settler, wrote in his diary in 1923:

Food supplies were readily available ... I was able to do most of my shopping at the Indian store. Indian traders had long penetrated deep in East Africa and established themselves in townships and isolated trading posts as far afield as the Belgian Congo. They were dotted all over Kenya, often in the most unexpected places ... While the white man played tennis or golf, the Indian shopkeeper in his little round hat and shirt-tails hanging out, toiled on then bedded down on his shop counter when his long days work was done. ${ }^{19}$

What Kelson describes was a common feature of many Asians' lives. The Dukawallas indeed opened up Kenya as they opened shops in remote parts of the country and also along the railway line. Most of these traders belonged to the Visa Oshwal Community (popularly known as "Shahs"). Oshwals mostly belonged to the "Vaishya" or the trading caste. Many came from the fifty-two villages around Jamnagar. Scholars such as Zarwan argue that they played a significant role which had great ramifications, such as the introduction of the currency and, most importantly, the creation of demand which stimulated economic growth and greatly impacted the economic history of Kenya. ${ }^{20}$

However, economic conditions also acted as push factors, in that the poor economic conditions back at home undoubtedly were a major factor. Most migrants came from poor villages and farms. Although Gujarat, Cutch, and Maharashtra, where many free immigrants came from, were fairly fertile areas, these regions were dependent on monsoon winds for rainfall, and when the winds failed, they became barren. Hence drought and famine was a common feature recurring every two to three years. ${ }^{21}$ Therefore, most Asians came to Kenya due to hopes of rising above their poverty. Gregory acknowledges that although the push and pull factors varied with individuals, their impact was felt among various communities. For

\footnotetext{
${ }^{19}$ Sidney T. Kelson as quoted in Seidenberg, "The Asians and Uhuru”, 21.

${ }^{20}$ Zarwan, "Indian Businessmen ", viii. The author discusses in depth about Asian traders in Kenya.

${ }^{21}$ Gregory, Quest for Equality, 6.
} 
instance, his work reveals that it was the hope of better economic opportunity that drove various groups such as the Hindus, Muslims, Sikhs, and Christians to come to Kenya. ${ }^{22}$

Other economic pull factors included opportunities for employment in government services, crafts, and especially construction, carpentry and masonry where the Sikhs thrived. ${ }^{23}$ Bhatt, however, gives a different economic perspective. According to him, the push factors included the establishment of British rule in India which led to the decline of the cottage industries, especially handicrafts, since it led to flooding of the Indian market with cheap readymade goods from British industries. Hence, many who had been self-employed were dislodged from their occupations and so chose to move to Kenya where their skills were much sought for and could enable them to earn a living. ${ }^{24}$ This was also compounded due to demand for skilled workers in Kenya which led to the importation of Indian coolies needed for the construction of the railway, subordinate staff in positions such as clerical services in the colony, and other indentured workers whose skills were much needed, such as artisans and masons.

Scholars such as Hollingsworth, Chattopadhyaya, Seidenberg, Gregory and McCormack all discuss the recruitment of the Indian laborers to work on the railway and other opportunities for skilled laborers. These jobs offered prospects of earning a better salary than in their country, as was the case of Goans, who were highly educated and needed jobs. Moreover, they were not traders like other Asians. For Goans, the prospects of opportunities abroad attracted many since the job market in Goa was saturated. ${ }^{25}$ Therefore, many Goans moved to Kenya where they offered services such as clerks, typists, accountants, doctors, lawyers, priests and teachers. By 1904, for example, most clerical posts in the provinces and districts in Kenya were filled by

\footnotetext{
${ }^{22}$ Ibid., 7.

${ }^{23}$ Ghai ed., Portrait of a Minority, 18. Seidenberg also discusses Asian artisans who engaged in skilled and semiskilled occupations. See Seidenburg, "The Asians and Uhuru”, 8.

${ }^{24}$ Bhatt, "A History of Asians in Kenya”, 44.

${ }^{25}$ Gregory, Quest for Equality, 6.
} 
Goans. ${ }^{26}$ Although they were paid less than Europeans, still the wages which they received were better than those offered in India or Goa. Seidenberg clearly demonstrates the variance in wage earnings among the civil service employees in colonial Kenya. The author acknowledges that in the three tier situations, the Asians were paid less than the Europeans while, the Africans were paid less than the Asians. There was deep economic discrimination in the jobs. For instance, by 1950, approximately sixty-three percent of Asians were engaged in civil service work earning between $£ 180$-359 per annum while for the same jobs the Europeans earned between $£ 600$-2000 per annum. ${ }^{27}$

Secondly, the Asians also migrated due to environmental factors that had greatly impacted their home areas. Several authors posit this argument. They include Mangat, Hollingsworth, and McCormack. Mangat's argument that the dry arid Cutch country made farming difficult and so most people resorted to commerce as a source of livelihood is corroborated by other scholars. ${ }^{28}$ The Sind, which was also an important migration spot, was also more of a desert and any livelihood was difficult to earn. These environmental factors contributed to recurrent famines. For example, the famine of 1899-1901 was believed to be so severe that it resulted in many deaths and forced many Asians, especially the Patels, to move to Kenya. Furthermore, between 1899 and 1900 Gujarat also experienced severe famine leading to acute food shortages; hence many left their homes. Therefore the environment of these areas was behind the push factors which made many Indians seek openings elsewhere.

Moreover, these were coupled with environmental disasters which affected India. By the late $19^{\text {th }}$ Century Indians experienced many calamities. For example, the plagues of the 1890 s

\footnotetext{
${ }^{26}$ Mangat, A History of the Asians in East Africa, 74.

${ }^{27}$ Seidenberg, "The Asians and Uhuru”, viii.

${ }^{28}$ Mangat, A History of the Asians in East Africa, 14. For more environmental reasons see McCormack, Asians in Kenya: Conflict and Politics, 1. Hollingsworth, The Asians of East Africa, 6; and Ghai ed., Portrait of a Minority, 6.
} 
killed many people and forced many to move to Kenya. The plagues were recurrent and had great ramifications. For instance, the 1896 plague in Bombay destroyed businesses, disorganized trade and greatly affected the mill industry there so much that Bombay suffered a mass exodus of people due to a high mortality rate which impacted greatly on its economy. ${ }^{29}$ Other disasters included cyclones, locust invasions, and floods that caused a lot of hardships. Many of the effected people moved to the east coast of Africa and many settled at Mombasa.

Environmental factors were diverse, including the climatic conditions in some areas of India. India is an area of high humidity. Consequently, other scholars such as Hollingsworth contend that the climate in East Africa, and Kenya in particular, was far better than India. McCormack shares this belief indicating, that most Goans migrated after recurrent outbreaks of malaria epidemics in Goa. ${ }^{30}$ Yet, even in Kenya the immigrants faced challenges posed by malaria.

Thirdly, there were also social factors that pushed the Asians out of their homes. These included population pressure, marriage obligations, religious intolerance and sheer adventure. Gregory points out that although some immigrants came from fertile areas that were well watered, where farming was possible, these endeavors were curtailed since the areas were overpopulated. His findings indicate the increase in Indian's population, which was partly caused by the introduction of modern medicine with the establishment of the Raj, resulted from a fall in the death rate. Hence, this helped to spur the immigration of many people. ${ }^{31}$ The trend in India's population growth was alarming and needed an outlet. For example, by 1847 the population was 133 million; half a century later, by 1901, the population had increased to 236

\footnotetext{
${ }^{29}$ Zarwan, "Indian Businessmen”, 57.

${ }^{30}$ Hollingsworth, The Asians of East Africa, 6. For further discussion on climatic effects see also McCormack, Asians in Kenya: Conflict and Politics, 1.

${ }^{31}$ Gregory, Quest for Equality, 5.
} 
million and by 1961 was 439 million. ${ }^{32}$ This was part of the reason why the early colonial officials supported Indian immigration.

Moreover, most of the people who moved to Kenya were comprised of young people, and the poor, who were in need of a means of survival. It was these categories of people that moved to Kenya. Population pressure impacted even the fertile areas as the land increasingly became insufficient; therefore, even the agricultural classes migrated due to the increasing pressure on land. For example, in Gujarat, an area where many immigrants came from, the population density by 1911 was 532 people per square mile while in 1941 it rose to 640 people per square mile. ${ }^{33}$ This impacted greatly on agricultural production and influenced the decision to move, as the land holdings increasingly became smaller and the soils exhausted.

Similarly marriage obligation was a factor for migration; Bhatt has discussed this issue. The author indicates that the lack of resources in terms of money to pay for marriages acted as a push factor. This was because some people migrated to escape pressures from oppressive customs that demanded that they pay dowry during the marriage of their daughters. ${ }^{34}$ This became difficult particularly in areas where agriculture could not provide resources, let alone support large families, especially the poor. Hence, this frustrated many families. However, this also acted as a pull factor since most young men, who had come to Kenya earlier, would go back to India or send for wives back home after they felt financially stable. This was a common trend among the early migrants. Marriages were normally arranged between families and so young men depended on their families back home to get wives for them. Then the wives would be called to come to Kenya.

\footnotetext{
${ }^{32}$ Ibid., 6.

${ }^{33}$ Bhatt,“A History of Asians in Kenya”, 43. On population pressure, see also Zarwan, “Indian Businessmen”, 30. Zarwan indicated that population growth led to land pressure which brought about changing economic patterns due to inefficient production.

${ }^{34}$ Bhatt, “A History of Asians in Kenya”, 44.
} 
Other groups also moved because of what was perceived as religious persecution. For instance, the Parsees, who had embraced Zoroastrianism and who initially had fled Persia due to the persecution of the $16^{\text {th }}$ Century, had by then settled first in Bombay and later also moved to Kenya. Since India was dominated by Hindus and Muslims, fear of another persecution from the well established religions in India might have encouraged some of them to move to Kenya. ${ }^{35}$ Moreover, events during the $19^{\text {th }}$ Century also indicate how religious persecution of the Nasserpuria Memon Muslims in the Sind region occurred, sending many of the sect members fleeing to the East African coastal towns such as Mombasa and Zanzibar. The Memon Muslims were mainly weavers and cloth dealers by profession, and they carried this practice to East Africa and Kenya in particular, where there was no stiff competition. As weavers, many had been dislodged from their occupation by British manufactured goods.

Other Asians could be said to have migrated because of adventure. This was especially found among the young who Bhatt describes as moving out to escape the boring village life. This group was motivated by the spirit of adventure, and excitement, having heard success stories from early immigrants. Hence, the desire to cross the ocean and visit new lands was overwhelming. ${ }^{36}$ Stories of successful people, for example renowned businessman Nanji Kalidas Mehta who arrived in East Africa at the tender age of fourteen or Mepabhai Vershi Shah who boarded a German steamer and came to East Africa when he was only thirteen years of age, captivated many youngsters. Yet some moved due to the phenomenon described by Bhatt as "chain migration." According to the author, some early Indian immigrants, mostly the young men, contributed to the migration of their relatives. This was because these young men, once in Kenya, had worked hard as apprentices. Once they had attained financial stability, they sent for

\footnotetext{
${ }^{35}$ Gregory, Quest for Equality, 19. See also McCormack, Asians in Kenya: Conflict and Politics, 2-3.

${ }^{36}$ Bhatt, “A History of Asians in Kenya”, 47.
} 
other family members, such a uncles, young brothers, and even wives. ${ }^{37}$ This process was bound to repeat itself leading to more migrations.

Politically, as mentioned earlier, Indian troops had been used in Kenya for a long time. Their coming dates back during the reign of Seyyid Sayyid (the Sultan of Zanzibar) who employed Baluchi mercenaries recruited from the Makran Coast on the shores of the Arabian Sea. This group was used in his campaigns against the towns of Mombasa and Pate. After the defeat of these areas, Seyyid left behind 150 Baluchi troops as a garrison at Fort Jesus in Mombasa.

Later, during the partition of East Africa, more trained Indians were also bought to serve in the military by the IBEAco. The first group to arrive was the $17^{\text {th }}$ Madras Sappers. These soldiers were known as the Sepoys. In 1889 Sir William Mackinnon, the President of IBEAco, sought permission of the government of India to recruit the sepoys for service in East Africa. ${ }^{38}$ The Indian government conceded and allowed the recruitment of 200 men from around Delhi to come to serve in the military on a three year contract. This group consisted mainly of Sikhs. Although initially the Indian government had opposed sporadic recruitment, especially from Punjab, it emerges that more were recruited. Later, in July 1895, after the protectorate was transferred to the British crown, three hundred more Punjabis were added to the force to serve alongside 300 Swahilis and 100 Sudanese soldiers. Thus the sepoys joined the military force known as the East African Rifles that was established to man the area. This East African Rifles existed for six and a half years. ${ }^{39}$ They were used in the conquest and pacification of the region. For instance, they took part in expeditions against Mbaruk of Takaungu along the coast and the

\footnotetext{
${ }^{37}$ Ibid., 51.

${ }^{38}$ Delf, Asians in East Africa, 39.

${ }^{39}$ Ibid.
} 
Ogaden Somali in Jubaland between 1898 and 1901. ${ }^{40}$ Another group, consisting of the Fourth Bombay rifles also was brought. The East African Rifles was later merged into the Kings African Rifles in $1902 .^{41}$ It is important to note that after conquest, the Colonial Office advocated for a scheme to settle the Indian soldiers. The sepoys were to be offered land for settlement. However, this scheme was not implemented.

By 1913, when it was believed that the African troops had sufficient training, it was decided to discontinue the use of the Indian troops on health grounds, since many were falling sick. A year later, with the outbreak of World War I, more troops were brought in an attempt to capture Tanga and blockade Dar-es-Salam, the German East African main port. In the battle of Tanga, many Indian soldiers were used, and approximately 820 Indian soldiers died in the battle. As recognition towards the war effort, the settlement scheme issue was revisited, when General W. H. Manning, the Inspector General of the King African Rifles, prepared a memorandum to the Foreign Office in which he proposed that Asian soldiers should be offered land in areas which were not suitable for European settlement. Once again the plan was abandoned. It emerges then, that one reason why Indian agriculture did not feature prominently in colonial Kenya was because these proposed agricultural schemes were dismissed. ${ }^{42}$

Lastly, another reason for the advancement of migration was the security factor. For example, other immigrants were driven by the fact that they felt they were British citizens and as such believed they could be offered security and freedom to excel under the British flag. This decision can be said to have been impacted by the fact that during the early $20^{\text {th }}$ Century, the British encouraged the migration and participation of the Indians in the colonial economic development of Kenya. A case in point is the advice and encouragement of Indian leaders which

\footnotetext{
${ }^{40}$ Hollingsworth, Asians of East Africa, 39.

${ }^{41}$ Chattopadhyaya, Indians in Africa, 354.

${ }^{42}$ Ibid.
} 
provided stimuli to move. Accordingly, the Ismaili leader H.H. the Aga Khan is on record to have encouraged his followers to take the advantage of the opportunities offered by the British Empire to migrate and make Kenya their new home. ${ }^{43}$

\section{Settling In}

The journey to Kenya took between three weeks or even more depending on the weather. Coming from a background of poverty many had borrowed money to undertake the voyage. Others spent their entire savings on the fare alone, which by 1900 was about 10 rupees (Rs. 10) by dhow and 35 rupees by steamers. Many used a dhow because it was cheaper.(a traditional Arab sailing vessel with one or more lateen sails) Therefore, many arrived at the coast with nothing or only few rupees at hand, and with little information of the prevailing conditions in the colony. ${ }^{44}$ Moreover, the journey was not easy; they endured hardships such as sleeping on the decks. They had to cook their own food, and so one had to have enough provisions for the journey whose time of disembarking could only be guessed. Lack of medical services during the journey made it more difficult and many fell sick.

Once they arrived at the coast, in most cases, they were quarantined for a week. ${ }^{45}$ This was necessary since some came from the plague zone areas in India. However, many were received by friends and relatives who had preceded them. Those who had none were assisted by other Indians or charitable organizations that provided them with food and lodging until they found some means of survival. By the 1920s, for example, there was the existence of informal eating places (messes) run by a charity such as the Meghji Ladha and Co. which had branches in Mombasa and Nairobi. It offered accommodations to many Indians, providing free food and

\footnotetext{
${ }^{43}$ Bhatt, "A History of Asians in Kenya”, 46.

${ }^{44}$ Gregory, Quest for Equality, 8.

${ }^{45}$ Ibid., 7.
} 
lodging until employment was secured. ${ }^{46}$ This helped the immigrants to settle. Similarly there were other organizations, such as the Mombasa Indian Association founded in 1901 and the East African Indian National Congress (EAINC) founded in 1914 that assisted the Asians with migration issues, obtaining trading licenses and lending money to the immigrants. ${ }^{47}$

Needless to say, most were assisted by the patron-client system that was widely entrenched among the Asians. This system enabled the new immigrants (mostly young men) to settle in by serving as an apprentice to someone who had come earlier and who in most cases was older and had already established themselves financially. ${ }^{48}$ The young men who came as apprentices also had their fare paid by the patron. A client was thus dependent on the patron, not only for food and lodging, but also his job. In return, the young man not only learned skills while working for the patron, but also did errands and even took care of his patron's children. Once the apprentice had accumulated enough skills, he would either be put in charge of a new branch of the business, or the patron would help to set him up with his own business. ${ }^{49}$ In cases of retail shops, the client would borrow the first stock from his patron's shop. Therefore, the patron-client system helped many immigrants to adopt, adjust, and settle in Kenya.

Regardless of this assistance, the immigrants still faced many challenges. Their problems were as diverse as their reasons for coming. For instance, among the coolies who built the Kenya-Uganda railway, the assistance discussed above was rare. Having been contracted back in their country, many had no time to adjust. Though they were employed, once in Kenya they experienced atrocious living conditions. Most of their dwellings were temporary and overcrowded. Moreover, they, like other Asians, faced challenges of tropical diseases, such as

\footnotetext{
${ }^{46}$ Zarwan, “Indian Businessmen”,52.

${ }^{47}$ Ibid., 75.

${ }^{48}$ Bhatt, "A History of Asians in Kenya”, 46-51.

${ }^{49}$ Ibid., 52.
} 
malaria, that killed many. For instance, in 1897 during the month of January alone, about fifty percent of the coolies were sick. ${ }^{50}$ Some suffered from dysentery, scurvy, ulcers, and jiggers, while others died from the recurrent plagues that broke out in the Indian Bazaars of Nairobi in 1902.

Among the Indians who came to Kenya, the coolies can be said to have suffered most. Not only had they to deal with the diseases but also the man-eating lions of Tsavo that killed quite a number. Food also posed a formidable problem, especially among the Hindus generally and specifically the Jains who were strict vegetarians and were not accustomed to eating food not prepared by anyone outside their caste. This problem was compounded by the fact that early immigrants had insufficient money to buy food such as vegetables and spices. Needless to say, the Asians also faced discrimination which was enforced by the colonial government. They were separated from the Africans and Europeans by discriminating legislation in the form of land alienation and segregation in townships, both in places of residence and business areas.

Another problem experienced by the immigrants was language. Apart from the Goans and the Patels who were well educated and spoke English fairly well, and so could easily get a job with the government, the rest had a difficult time. For example, many Punjabi who lacked knowledge of English and skills in business had to look for other means, such as menial employment with someone from their own community first. They had to learn English and sometimes Kiswahili before venturing into the civil service or setting up their own businesses. This was not only akin to Punjabi's; generally only a few could speak English, Arabic, or Kiswahili. Hence, they had to learn new languages apart from making other social adjustments. Therefore, we can argue that once in Kenya, the immigrants basically experienced several weeks

\footnotetext{
${ }^{50}$ McCormack, Asians in Kenya: Conflict and Politics, 19.
} 
and months of uncertainty and led a precarious life trying to determine how to get employment and settle.

After a year or two, most settled in well and were able to eke out a living on their own, engaging in various economic activities even in the most remote parts of the colony. Their success could therefore be attributed to their stoic discipline, perseverance, and resilience. Many worked for long hours ranging between fourteen to eighteen hours a day. ${ }^{51}$ Luxuries were shunned and any profits accrued were reinvested in their economic ventures. This was the secret behind their success.

\section{Other Economic Activities}

Existing scholarship has generally been dismissive of the Asian farming initiative in Kenya and has instead focused on other economic activities discussed above. It emerges that most of the Indian railway workers worked as surveyors, clerks, and masons and draughts men. However, some of the laborers recruited from India also served as administrators in the protectorate, in the public works department, road construction, the post office and as customs officials. In the civil service, they were found generally in the middle level positions, a situation where they were later challenged by emerging elite Africans.

However, the vast majority of the Indians who settled in Kenya became involved in business starting with small dukas (shop) along the railway line and major roads. In towns they opened their stores within settlements which were known as "bazaars" in urban centers like Mombasa, Machakos, Kisumu, Yala, Kisii, Mumias, and Nairobi among others. Moreover they were able to penetrate the very remote areas. They experienced great difficulties such as poor transport, hostility from local communities, disease and theft. Hollingsworth, in The Asians of

\footnotetext{
${ }^{51}$ Gregory, Quest for Equality, 8.
} 
East Africa, notes that their success was due to industry and business acumen. For example, those who were self-employed worked for seven days a week from dawn to dusk and were content with small turnovers. Among the successful ones were A.M. Jeevanjee, Allidina Visram, Gulamali Meghji, T. K. Meghji, Nanji Kalidas Mehta, Hasham Jamal and Muljibhai Madhvani among others. While Asians were involved in different business activities, early traders were supported by the colonial government. For example, Adamjee Alibhoy was invited to Machakos by the Provincial commissioners for Ukamba Province, John Ainsworth, to set up a business in 1898. Others set up businesses on their own since the colonial administration supported their business activities. For example, Gulam Hussein Abdulla Datto established an auctioning firm in Nairobi as well as a successful retail shop, while Deroda Shamji Harji and A.M Jeevanjee established a successful construction company, building most government offices, post offices, and railway stations along the line from Mombasa to Kisumu. ${ }^{52}$ The success of Indian entrepreneurship attracted many others to migrate to the colony as their success stories reached back home (India). The colonial administration also facilitated this by making the Indian Rupee the official currency for the colony in 1898. Moreover, the opening of the National Bank of India as the official bank of the protectorate was a booster to their economic endeavors. ${ }^{53}$ Hence, when Sir Edward C. Buck, secretary of the department of revenue and agriculture in the Indian government, visited the protectorate in 1905, he acknowledged the fact that the colony was suitable for tropical products and that the Indian experience could be put in use. ${ }^{54}$

Whereas many were involved in retail and wholesale firms, a few specialized in one type of commodity, mainly hardware or provision of textiles. However, the majority had a variety of stock such as cattle feed, blankets, tea, merikani cloth, beads, hoes, pangas, knives, sweets, etc.

\footnotetext{
${ }^{52}$ Mangat, A History of the Asians in East Africa, 55.

${ }^{53}$ Gregory, India and East Africa, 67. Deroda Shamji Harji became a leading building contractor in Kisumu.

${ }^{54}$ Bhatt, “A History of Asians in Kenya”, 57-58.
} 
all in one shop. As trade expanded, others became involved in the import and export trade. For example, Karimjee Jeevanjee became involved in the supply of petroleum to East Africa. ${ }^{55}$

Indians also engaged in processing activities, engaging in activities like oil milling, ginning of raw cotton, and extracting tannin from wattle bark. For example, by 1910 Allidina Visram had established four cotton gins and six mills for manufacturing sesame at Mombasa. However, their efforts were later curtailed by big multinational companies like Brooke Bond that was established by the help of the colonial state and was involved in processing and supplying of tea in Kenya. Thus, most Asian industries did not get sufficient help from the state so they remained small until the 1950s.

However, by 1920, Asians moved into road transport. For example, they started to use reconditioned cars, lorries, and motorcycles in conveyance of goods. These were mainly military vehicles which were converted into civilian use. The Asians carried Africans to and from the labor areas and even reached the remotest part of the colony. Even in road transport they excelled, so that when barred by the legislation from operating on specific roads, they devised alternate parallel routes and put their lorries in areas not reached by many Europeans in the transport industry. The rapid development in road transport by Asians such as Gulamali Meghji, Nanji Kalidas Mehta, and Noor Mohamed Walji, ${ }^{56}$ who dominated the Kakamega-Kisumu road and other routes, not only revolutionized the transport system in Kenya but also challenged and rivaled the government and European transport industry. Their activities led to rapid development in road transport. They effectively competed and dislodged the Europeans from this sector. This was not only due to their ability to reach the remote areas, but also due to the fare cuts that they enforced.

\footnotetext{
${ }^{55}$ Gregory, South Asians in East Africa, 55.

${ }^{56}$ Ibid., 125.
} 
In short, the history of Indian business enterprise in Kenya during this period is a story of success and fortune making. Even though not all Indians made fortunes in Kenya, their resilience and success was due to their self-discipline and sacrifice. Commenting on this, Bhatt asserted; "The typical Indian trader worked for long hours and operated on a very small profit margin. His success in business can be attributed to his frugal habits and propensity to save”. ${ }^{77}$ Many of them operated businesses deep in the interior and faced all sorts of difficulties such as poor transport, hostile local people, wild animals, theft of merchandise, and diseases. However, many succeeded, such as A.M Jeevanjee. Therefore, there was practically no part of the country with a potential for business that the Indians did not venture into. In rural areas, they provided markets for farm produce such as maize, beans, and potatoes.

Asians also excelled in agriculture. For example, their success was also noted in investment in sisal and sugar estate plantations. For instance, Muljibhai Madhvani started sisal estates in Kenya, while Hasham Jamal was among those who started a cane plantation at Muhoroni which later became a complex settlement scheme for cane farmers that produced jaggery. In animal husbandry, Agit was the first Asian to have a pig farm at Kibos. Although it was difficult to get land in Kenya, the few who practiced agriculture decided to settle on the Indian settlement scheme at Kibos where they grew cotton, rice, chillis, sim-sim,( also known as sesame) rubber, and later, sugarcane. This project was not a complete failure, as portrayed by most authors. Gregory, in South Asians in East Africa: an Economic and Social History, challenges this notion and gives data to support the Asian initiative at Kibos. ${ }^{58}$ Similarly, other Asians settled in Mazeras in the Ukamba Province where they grew fruits. Moreover, the growth

\footnotetext{
${ }^{57}$ Bhatt, “A History of Asians in Kenya”, 69.

${ }^{58}$ Gregory, South Asians in East Africa, 241.
} 
of sugarcane farming in Kenya can be attributed to the Asian agricultural initiatives, an indication that they could be successful farmers just like the Europeans and Africans.

\section{Settlement Patterns}

The earliest Indian immigrants, who were basically traders prior to the establishment of colonial rule, settled in the coastal region where they pursued economic activities. In contrast, the immigrants who came after 1895 exhibited different patterns of settlement. They mostly followed the railway line into the interior, setting up shops along the route. These settlements, though very modest, were important since they supplied the laborers and the railway staff with food and other basic necessities. This in turn led to flourishing markets and towns such as Voi, Kibwezi, Machakos, Nairobi, and Kisumu. Most traders were also concentrated in towns where they did their business due to the fact that the state controlled and restricted their operations in specified areas. This was enforced through a series of government ordinances that prohibited trading in areas not prescribed by government regulations. ${ }^{59}$ The purpose of these regulations was that they were meant to constrain the spatial distribution of the Asian population in Kenya. ${ }^{60}$ Consequently, some African districts were closed to Asians for trading during the first quarter of the $20^{\text {th }}$ Century. Moreover, due to settler politics, Asians found it difficult to own land. Ordinances were enacted to bar them from the white highlands which frustrated their quest for agricultural land. Since the Asians could not own land everywhere they might have wished, their choices were limited to living in towns and major market centers. Moreover, the towns offered desirable educational, social, and cultural amenities that attracted them. Asians also settled near the European farmers. These areas were not only secure, but they also offered opportunities to

\footnotetext{
${ }^{59}$ Bhatt, “A History of Asians in Kenya”, 71.

${ }^{60}$ Bennett, "Persistence Amid Adversity”, 93.
} 
supply both the white farmers and the African workers with basic necessities such as soap, sugar, etc.

The Indian social system (caste) also had a significant role in determining where the Asians settled. Accordingly, Asians congregated in specific areas due to the process of "calling." This was when earlier immigrants called their relatives such as brothers, sisters, and wives who had initially been left behind. This then influenced the decision as to where to settle, since most people tended to settle in areas which already had a good number of their caste members. Also, new arrivals tended to settle where communal aid could be easily accessed. ${ }^{61}$ The family and social groupings played a significant role in social networking which was important not only for social support but also links to jobs through family connections. Therefore, we can conclude that the settlement patterns in most cases were not necessarily out of choice but were determined by socio-political and economic conditions in Kenya.

Therefore it emerges that the Indians tended to settle in urban areas though a few had stores in remote areas of the interior. This concentration could be explained by the fact that few Indians were engaged in agriculture. Moreover, the government was not interested in supporting their agriculture as a measure to stop their quest for the fertile land in the white highlands. Policies were put in place that discouraged Indian farming. For example, by 1902 it became an official government policy to deny Indians access to agriculturally high potential areas such as the white highlands. Accordingly, Sir Charles Eliot, then commissioner of the protectorate, declared in 1902 that "the protectorate is a white man's country." This position was contradictory, or a change of view. Only two years earlier, when he assumed office, he had supported the Indian enterprise. Having changed his position in 1902, Eliot set in place a policy that excluded Indians from getting any land allocation in the highlands. This meant that the

\footnotetext{
${ }^{61}$ Zarwan,“Indian Businessmen”, 68.
} 
Indians were then relegated to earn a living in the urban centers in business activities, with the majority engaged in retail trade. Furthermore, the government policy that compelled the Indians to conduct their businesses in towns and in specific areas favored a policy of concentration in matters of town development schemes. This led to segregations in towns. The justification for segregation was based on health and sanitation grounds. This was a move that was counterproductive since it led to overcrowding in Indian settlements that let to sporadic outbreaks of plague. The discrimination that characterized the protectorate's land policies would be repeated throughout the colonial period.

\section{Settlement at Kibos-Muhoroni}

Following the completion of the Kenya-Uganda railway in 1901, the colonial state had to look for a means to make the railway pay for its construction costs and also help in making Kenya a self-reliant, self-sustaining colony. Since Kenya was not endowed with minerals, agriculture was therefore seen as a possible means towards this sustainability. Asian settlement was one avenue pursued, as this chapter makes clear. The initial reaction to Asian immigrants was friendly, and the colonial state welcomed the idea of Indian settlement in the colony.

However, this stance gradually changed, Eliot's change of mind may have been caused by the fact that by 1902 there were about 30 European settlers in the country who strongly opposed the granting of any agricultural land to Asians, especially in what became the White Highlands. In an effort to keep the Asians out of the white highlands, Eliot recommended that Asian settlement should be confined to the low lands which were considered unsuitable for European settlement.

Therefore, in April 1903, he inaugurated a special Indian settlement area at Kibos. Kibos was a railway stop in the lowlands of the Nyanza basin. Some of the indentured Asian laborers 
who had opted to remain in Kenya after the expiration of their contracts together with ex-railway workers formed the group of the first thirty pioneer Asian settlers. Out of these, the majority were Sikhs from Punjab who were traditionally an agricultural community. They were mostly poor. The pioneer settlers were allotted land holdings which ranged from three to one hundred acres. About sixty percent of the plots were freehold while the rest were on 99-year leaseholds. ${ }^{62}$ The Foreign Office initially was interested in pursuing Asian farming and allocated 1,000 pounds for initiating the scheme. Due to politics within the colony, only 308 pounds was used to settle the pioneer settlers. ${ }^{63}$ Initially, these farmers were also given other assistance, such as oxen, seeds, and hoes, to start farming. The farmers were under the direction of Mr. D. D. Waller, the acting paymaster of Kings African Rifles in the treasury department. He was relieved of his duties and given the responsibility of being in charge of the Kibos project. Under his direction, the scheme started with the farmers experimenting with many crops. They initially cultivated crops such as rubber, maize, rice, cotton, sesame, (simsim) chiraco (green grams), linseed, and sugarcane. The first sugarcane was cultivated by Umar Din in Muhoroni. The crop soon became popular among other pioneer Asian settlers when they realized that sugarcane could thrive well in this area. And so by 1906 most pioneer Asian settlers were cultivating the crop. From this modest beginning, the Asian agricultural settlement at Kibos expanded as many Asians began to acquire more land in the Kibos-Muhoroni area. Between 1903 and 1915, Asian cane farmers obtained land ranging from three acres to one hundred acres. Later, between the 1940s and 1950s, the farms acquired were bigger as more farmers settled in the area. The largest Asian farm was that of Imhazalhi and sons; this was a London based Asian Company which acquired

\footnotetext{
${ }^{62}$ Osamba, “A Forgotten Minority”, 3.

${ }^{63}$ McCormack, Asians in Kenya: Conflict and Politics, 26.
} 
about 4,500 acres in Kibos, under a 99-year lease. This estate was registered as the Kisumu Rubber Estate. $^{64}$ These leases expired in 2002.

\section{Conclusion}

In this chapter, the major migration waves of the Asians into Kenya have been discussed. It has emerged that the movement into Kenya was gradual and involved various pull and push factors. However, the overriding reasons were economic betterment. The coming of British colonial rule accelerated the movement into Kenya since as British subjects the Asians took advantage of the security it provided and the economic opportunities offered under British rule. This chapter has demonstrated that the settlement patterns were dictated by the social, economic, and political conditions within the colony. The chapter has also demonstrated the diverse economic activities that the Asians engaged in, including starting up farming at Kibos. The pioneer farmers were very responsive despite the policies put in place by the colonial state and the nature of the prevailing pre-colonial economies of the area which constitute the basis of analysis in the next chapter.

\footnotetext{
${ }^{64}$ KNA: AGR 6/4308, Miwani Farms, $7^{\text {th }}$ May, 1910.
} 


\section{CHAPTER 3}

\section{INDIGENOUS ECONOMY, POLITICS OF LAND AND THE GENESIS OF ASIAN SUGARCANE AGRICULTURE}

\section{Introduction}

This chapter aims at discussing the nature of the indigenous land tenure system, among the Luo, and how it impacted the indigenous economy. The Luo people occupy the Kisumu, Siaya, and South Nyanza districts of Nyanza Province in Kenya. The chapter also surveys the pre-colonial economic activities of the people living in the area under review before the advent of the Asian cane farmers. These activities included livestock production, farming, fishing, and traditional industries like basketry, salt production, woodwork, and trade. This analysis therefore focuses on land as an important means of production. The chapter also examines the politics of land, using the colonial land policies as a background of the struggle for land between the Asians and the European settlers and also between Asians and the Africans (Luos). Finally the chapter discusses the penetration and establishment of Asian sugarcane farming.

\section{Colonial Land Policies}

Land policies enacted by the colonial state were based on many assumptions and misconceptions. For example, not all land was free or not in use at all since there were buffer zones between communities and also some areas were left for pasture or to restore fertility as most Kenyan communities practiced shifting cultivation. Moreover, by the 1890s most communities in Kenya had suffered from rinderpest and smallpox that had reduced the population of both livestock and people. Therefore, the idea of empty land was a colonial construction. McGregor Ross, supports this view but blames this misconception on stories told by early travelers who described totally unoccupied lands, yet the travelers did not understand 
the African land usage. ${ }^{1}$ This was on reason why the land issue became controversial with the onset of the colonial period.

With conquest and control of Kenya, the colonial administration started straight away to appropriate land. As early as 1897, land within the railway zone was appropriated under the Indian Land Acquisition Act of $1894 .{ }^{2}$ Land policies were constantly reviewed to accommodate the wishes of the colonists. As early as 1897, the Indian Land Acquisition Act of 1894 was amended and a new set of regulations made that gave the commissioner of the East Africa Protectorate the power to sell freehold land within the Sultan’s domain. ${ }^{3}$ The 1897 act was also designed to secure land for public works such as construction of rails and roads. Using Indian land laws as a basis, an order-in-council was consequently enacted the following year which put the railway zone under the commissioner giving him more power. Extensive land alienation ensued in 1903 with the coming of the South African white settlers to Kenya. McGregor Ross and Okoth-Ogendo concur that when the Foreign Office took over control of the colony from IBEAco on the $1^{\text {st }}$ of July, 1895, land grabbing took root. This was because in the same month, when Sir Arthur Hardinge, the British consul general at Zanzibar became commissioner of the East Africa Protectorate, land was made cheap. For example, the commissioner could easily give certificates to people to hold and occupy land for a term not exceeding twenty-one years. This was later amended when on $29^{\text {th }}$ December 1897 the Indian land act was modified. This allowed the commissioner to grant a person a certificate authorizing him to occupy land for a term not exceeding 99 years. ${ }^{4}$ Claim over land was by proof of titles, and given the fact that the Africans by then had no titles, their land could be alienated. The Kibos-Muhoroni area was also

\footnotetext{
${ }^{1}$ Ross, Kenya From Within, 42.

${ }^{2}$ Sorrenson, Origins of European Settlement, 49.

${ }^{3}$ Okoth-Ogendo, “African Land Tenure Reform”, 154.

${ }^{4}$ Ross, Kenya From Within, 42.
} 
to be affected by this regulation. Therefore, in Kenya, right from the onset of the colonial rule, land decisions were in the hands of the commissioner who could be influenced or make injurious decisions not only to the African people but also the Indians as will be discussed later.

Moreover, due to the policy of making the colony self-sufficient, early commissioners pressured the imperial government to allocate land to European settlers. For example, Sir Arthur Hardinge was not satisfied by the 1897 regulations and so in October 1898, he forwarded a settler demand for freehold or the 999 year lease to the Foreign Office for perusal and consideration. These views were then incorporated in the 1901 order-in-council which gave the commissioner power to dispose of unoccupied land; this was designated as crown land. The 1901 order-in-council authorized the commissioner to sell, grant leases, or dispose of land. The specifics of the terms were laid down in the Crown Lands Ordinance of 1902.

The actual colonization of land by Europeans was facilitated by the new commissioner to the East Africa Protectorate, Sir Charles Eliot, who came to the protectorate when a definite land policy was badly needed. The colonial government felt the need to prevent land speculations, especially along the railway, but had to be careful not to lock up areas in the hands of few individuals. Thus the need to prevent speculation and the need for the colony to be selfsustaining proved difficult. This paradox made it hard to have a specific land policy. ${ }^{5}$ The settlers and concessionaires wanted freehold grants, but the Foreign Office was reluctant to allow speculation yet it wanted to attract settler capital. Since the colonial government had erroneously believed that the state could depend on the settler economy, the state therefore worked towards large acreages of arable land to be made available to settlers. For instance, Eliot in 1902 reiterated that the 1897 regulations were unsuitable and that the settlers' demand for freehold titles was proper. He became convinced that the highlands were suitable for permanent European

\footnotetext{
${ }^{5}$ Sorrenson, Origins of European Settlement, 44.
} 
settlement, comparing them to New Zealand and certain parts of Australia. He was determined to introduce the necessary legislation. Using powers granted to him by the 1901 order-incouncil, Eliot drew up a notice to permit the sale of agricultural land and the lease of pastoral land. The land issue became more complicated, but rather than face hostility from Eliot and the settlers, Lord Lansdowne, the Secretary of State in the Foreign Office, approved the notice.

In 1903, Eliot further drew up rules for lease and sale of pastoral land. For instance, leases up to 10,000 acres were to be rented at 1 anna per acre. These rules were published, but the Treasury in London was wary and urged caution to safeguard against speculations. Furthermore, the Colonial Office also urged the Foreign Office not to allow the sale of land to pastoralists. Thus, in December 1903, Lansdowne sent a dispatch to Eliot requesting him to take the matter into consideration. However, Eliot ignored the advice and went ahead and made a controversial offer to the two South African white settlers, Robert Chamberlain and A.S. Flemmer, of freehold grants of 10,000 acres each. ${ }^{6}$

Therefore, it can be argued that Eliot indeed championed the white colonization of land in the East Africa Protectorate. He wanted more settlers to come to the protectorate and was not content with limited publicity, so he printed a notice describing land regulations, climate and shipping facilities, and requested the Foreign Office to distribute the copies in Britain and the colonies. Following this advertisement, applications were received from America, South Africa, Europe, Australia, and New Zealand by mail and even cable. Not everybody supported this process. For example, W.D. Ellis, an official of the Colonial Office, rejected Eliot's and the settler position and emphasized that the East Africa Protectorate should not be turned into another Natal. ${ }^{7}$

${ }^{6}$ Ibid., 65.

${ }^{7}$ Ibid., 85. 
However, it was not until later in 1903 that the Foreign Office realized that alienation of land was becoming quite problematic, especially the alienation of Maasai land. Yet still, the settlers continued to push for more grants and were agitated by the possibility of a Jewish settlement. Throughout the year 1904, the settlers were adamant and continued to pressure for more land. Moreover, the influx of more South African settlers to the protectorate made matters worse. The settlers believed that if the protectorate was transferred from the Foreign Office to the Colonial Office they would gain, since they were of the view that the Colonial Office would be more sympathetic to their case. Be that as it may, there were also changes taking place in London which culminated into the protectorate being transferred, together with Uganda and British Somaliland, from the Foreign Office to the Colonial Office on $1^{\text {st }}$ April 1905. Unfortunately the land problem could not be easily solved. ${ }^{8}$

The Colonial Office now took over responsibility for land policy, among other issues. The change brought no quick solution. Sorrenson argues that the Colonial Office was also to blame for the tensions in East Africa Protectorate. His argument was that the Colonial Office introduced legislation based on the laws passed by the governments in Australia and New Zealand. These legislations, which were designed to prevent accumulation of land and enforce sub-division of large estates, introduced a policy that was not successful in Kenya since it was not adhered to due to pressure from settlers. Thus, confusion became a significant aspect of Colonial Office land policy; this was because the office was against speculation as a matter of policy. Enforcement of the regulations proved difficult. ${ }^{9}$ Maxon, in Struggle for Kenya, examines how the settlers opposed land proposals and the implementation of policies by the Colonial Office. The settlers were supported by Belfield who opposed a land tax and rejected

\footnotetext{
${ }^{8}$ Bennett, Kenya: A Political History, 18.

${ }^{9}$ Sorrenson, Origins of European Settlement, 94.
} 
the 99 year term, demanding a longer term of 999 year lease. ${ }^{10}$ Yet the settlers were against the same terms being extended to the Asian farmers of Kibos.

However, since the major objective of the Colonial Office was to look for a workable land policy, the Colonial Office refused to give in on the question of land tax and antidummying. Hence A.C. Tannahill, a land ranger in the East Africa Protectorate land department, was given the task to solve this issue. He reviewed the land policy in the protectorate and recommended 999 year leases to the delight of the settlers, with revision of rent every 33 years; he strongly recommended land allocation through the auction system. Tannahill believed that there should be no limit to accumulation of land as long as the lands were developed. ${ }^{11}$ But even this was not obvious; most settler land was not developed as compared to the Asian farms.

Moreover, arable land for all was not sufficient in Kenya. So the establishment of settler farms in the most fertile areas of the white highlands generated a lot of tension and competition between the settlers, Asians and Africans as well. For example, while the Asians were excluded from the White Highlands, the Africans were also denied land rights under the western form of tenure; moreover, Africans were forced to vacate lands they occupied and were pushed to the reserves which generated a lot of tension among the three races in Kenya. ${ }^{12}$

This being the case, therefore, an East Africa land committee was set up to review Tannahill's recommendation. The Colonial Office committee agreed that the lease years be reduced to 99 years. The Secretary of State accepted these recommendations and ordered Governor Sir Henry Belfield to prepare a new land ordinance. Belfield, a graduate from Oxford, was the Governor of Kenya between 1912-1917. He was initially not a favorite of the settlers when appointed. However, he was later to become their chief advocate. For instance, he

\footnotetext{
${ }^{10}$ Maxon, Struggle for Kenya, 56.

${ }^{11}$ Sorrenson, Origins of European Settlement, 135.

${ }^{12}$ Breen, “The Politics of Land”,17.
} 
influenced the passing of the Crown Lands Ordinance of 1915 and the enactment of the kipande system. ${ }^{13}$ Belfield did not want a new ordinance that would reverse the leases to 99 years, arguing that the drafting of the new ordinance would take time; for he was in favor of settler urgency. ${ }^{14}$ Governor Belfield, due to his desire to please the settlers, also insisted that it was not possible to prevent dummying and illegal transfers of land, and was supported by the settlers. ${ }^{15}$ He attacked the Colonial Office land policy and put pressure on it to yield to his demands. Indeed, as pointed out by Sorrenson, Belfield was not converted by the settlers on his arrival to the protectorate, but rather had accepted settlers' views long before he left London. ${ }^{16}$ This in itself was a paradox, given the fact that Belfield was chosen by the Colonial Office since the protectorate needed a compromise over the land policy. The Colonial Office, tired of wrangles with no solutions by the successive governors, was in a mood to compromise over land policy, and had erroneously believed Belfield was the man for the job. Instead Belfield became the settlers' crusader.

Therefore, Belfield continued to make changes, and by August 1913 the last restrictions against land accumulations were removed. The Colonial Office was forced to accept the principal of an open market in land, in as far as the Europeans were concerned. Thus, by $8^{\text {th }}$ February 1914, a Crown Lands bill was completed, introduced to the Legco and eventually sent to London. It was not all smooth sailing, in London. The Colonial Office was forced to scrutinize the bill because of protest from some Liberal MPs. Edmund Harvey, a strong parliamentary champion of African land rights, objected to the bill's inclusion of the lands occupied by Africans, or reserves, to be included in the Crown lands. Harvey felt this inclusion

\footnotetext{
${ }^{13}$ Maxon and Ofcansky, Historical Dictionary, 31.

${ }^{14}$ Maxon, Struggle for Kenya, 58.

${ }^{15}$ Dummying is the obtaining of land under someone else's name. In Kenya it was common practice for settlers to obtain land using their children's names.

${ }^{16}$ Sorrenson, Origins of European Settlement, 132.
} 
was theft since as Crown land it meant the colonial state could take the said lands. He objected to this power being given to the colonial state on land. ${ }^{17}$ The bill was also contested by the coast communities since it jeopardized earlier transactions made under Muslim law. However, Belfield ignored the protest and the bill was passed into law in 1915, taking advantage of the fragile situation due to the war. The Crown Lands Ordinance of 1915 thus favored Belfield's views and the demands of the settlers. The Colonial Office nullified its own policies partly because of the fear of antagonizing the settlers with the onset of World War I since their support was badly needed. Moreover, other issues were at play as portrayed by Maxon who argues that the Colonial Office gave up the struggle to impose the workable land regulation due to the unwillingness of Belfield and the settlers, and the governors’ ill health. ${ }^{18}$

Thus the Crown Lands Ordinance of 1915 was a complete departure from the earlier Colonial Office principles. For example, leases were to be for 999 years, and there was to be no restriction on transfers once the full purchase price had been paid unless the transfer was between different races, upon which the governor would veto. Moreover, the policy that barred accumulation was abandoned, and there was no restriction on bidding except conditions of auction could state if non-Europeans were allowed to bid. Generally, it emerges that the 1915 ordinance was more of a complete victory to the settlers and the colonial state officials who supported them. According to Sorrenson, it depicted the inability of the Colonial Office to impose an unpopular policy. ${ }^{19}$ This policy was also biased against Asians since while Asians held leases of 99 years, the settlers were granted 999 year leases. Moreover, the Asians were

\footnotetext{
${ }^{17}$ Maxon, Struggle for Kenya, 62.

${ }^{18}$ Ibid., 63.

${ }^{19}$ Sorrenson, Origins of European Settlement, 141.
} 
initially restricted as to the amount of land they could hold per grant. For example, they could not hold more than 100 acres per grant. This applied to those who settled before $1915{ }^{20}$

Despite this restriction for Asians on the grounds that there was not enough arable land, the Colonial Office still decided to put in place a soldier settlement scheme for war veterans. To achieve this, a land settlement commission was appointed by Belfield in 1917, chaired by the Attorney General J. Barth. This commission finished its work late in 1918, but did not recommend the settling of Asians or Africans who also contributed towards the war effort. For example, many Indian soldiers died at the battle of Tanga. The scheme was implemented by Governor Sir Edward Northey who replaced Belfield in 1919. Northey set out the terms for eligibility for the scheme where he clearly stated that they must be British subjects. He knew that this claim would be hotly contested by the Asians; hence, he categorically indicated that applicants must be "purely of European extraction engaged in active service present war."21

Northey did not want the ex-Indian soldiers to be settled in the colony, believing that the European farming was sufficient. Stressing this point, Northey insisted that European farming had "greater advantages to the Protectorate itself and to the local natives than by importation from another portion of the empire of immigrants of another race., ${ }^{22}$ Moreover, Northey rarely consulted the Colonial Office in the execution of the scheme. The Colonial Office, as early as 1919, warned him against taking land from the African reserves for the implementation of the scheme, regardless of the fact that the Land Settlement Commission had suggested that land be taken from the Kikuyu reserve. Despite the warning, Northey allowed land of approximately one hundred square miles be alienated from the Nandi reserve.

\footnotetext{
${ }^{20}$ KNA: PC/NZA/3/22/2-16, Kibos Indian Settlement 1910-1916.

${ }^{21}$ Maxon, Struggle for Kenya, 143.

${ }^{22}$ Ibid., 162.
} 
Therefore, the post-war period did not change the situation in regards to land holdings by Asians and Africans. Moreover, the land issue became complicated when in 1921 a High Court judgment declared that traditional African land rights were nullified when Kenya became a Colony in 1920. This then rendered Africans tenants of the Crown on their own land. ${ }^{23}$ However, the world economic situation forced the colonial state to make other economic changes in the Colony. In 1922 the colonial state implemented the dual policy under Governor Sir Robert Corydon. The intensions of the policy were good since it propagated for the development of both white farmers in the highlands and Africans. The dual policy was meant to spur the economy so as to protect the colony from the economic problems caused by the depressed economy after the war. The Colonial Office supported the policy for the same reason. However, the policy ignored the Asian farmers already making tremendous strides at Kibos-Muhoroni. Although the dual policy was meant to support even the Africans, it emerges that it favored European production. For example, the findings of the Ormsby-Gore Commission of 1924, chaired by Sir William Ormsby-Gore, reiterated this fact. Although the commission supported the dual policy, it was critical of the fact that little had been done to improve African agriculture. Most importantly, it drew attention to the fear that Africans had over loss of their lands, after hearing the views presented to it by the Africans and the missionaries who demanded the protection of native lands. Thus, the Ormsby-Gore Commission championed this fact. ${ }^{24}$

Therefore, in March 1927, the Secretary of State for the Colonies, Leopold Amery, gave instructions to the new governor of Kenya, Sir Edward Grigg, to report on the progress of the reserves. He was to especially recommend ways to secure them permanently, i.e. to have the boundaries of the reserves fixed. Hence, the fear of Africans over their land led to a bill being

\footnotetext{
${ }^{23}$ Bennett, Kenya: A Political History, 54.

${ }^{24}$ Maxon and Ofcansky, Historical Dictionary, 213.
} 
introduced in the Leg Co in 1928. The bill stated clearly that land taken from an African reserve for public use had to be replaced by land of equal value added to the reserve. Further, it stated that the local native council had to be consulted before any such alienation occurred. This bill was eventually passed into an ordinance, The Native Lands Trust Ordinance of 1930, amid settler opposition. ${ }^{25}$ It is worth noting that when the bill was tabled in the LegCo, despite the ferocious uncompromising stand of the European elected members, it received unequivocal support from the elected Asian representatives. Furthermore, leases for any land taken from the African reserves became limited to 33 years. ${ }^{26}$ Things seemed to move in favor of Africans with the changes at the Colonial Office and takeover by Lord Passfield in 1929. The security of African lands seemed promising. Lord Passfield reiterated his support for security of African lands in his two papers of June, 1930, that came to be known as the 'Passfield Pledge' whereby he promised to ensure security of the reserves as provided in the Native Lands Trust Ordinance of $1930 .{ }^{27}$

Nevertheless, the Colonial Office wanted the protectorate to be settled by "big men," colonists with sufficient capital to develop farming or plantation industries and to employ African labor in pursuit of their self-sustaining policy. Suffice it to say, the ideal colonists in this respect, were white settlers like the Grogans and the Delameres, and so long as one had capital the Colonial Office was not concerned on how much land he obtained. ${ }^{28}$ This was indeed a contradiction of its earlier policy. The 1915 ordinance deprived the Africans of all land rights and disinherited them. At the same time, the colonial state prevented the Asians from acquiring

\footnotetext{
${ }^{25}$ Maxon and Ofcansky, Historical Dictionary, 191.

${ }^{26}$ KNA: PC/NZA/1/25, Memorandum, Copy of Petition by Kavirondo Natives to the House of Commons.

${ }^{27}$ Priscilla M. Shillaro, A Failed Eldorado: Colonial Capitalism, Rural Industrialization, African Land Rights in Kenya and the Kakamega Gold Rush 1930-1952 (New York: University Press of America, 2008), 27.

${ }^{28}$ Sorrenson, Origins of European Settlement, 147.
} 
suitable agricultural lands even though there were Asians who had enough money to buy land if they were allowed to.

The land struggle not only involved Asians but also Africans whose land had been alienated. Rita Breen in her dissertation "The Politics of Land: The Kenya Land Commission (1932-1933) and it's Effects on Land Policy in Kenya”, is of the view that the land problem was so difficult that the Colonial Office felt that the appointment of a commission was the best way to solve the land problem in Kenya. ${ }^{29}$ Critics of this argue that this was basically Britain's idea of not tackling a problem directly. Thus the Kenya Land Commission, set up in 1932, chaired by Sir William Morris Carter, a former Chief Justice in Uganda who was believed to have had firsthand knowledge of African land problems. The commission was entrusted with the problem of investigating land issues in Kenya. Nevertheless, the membership of the commission was heavily contested as some members were accused of being stakeholders on land; hence they were not impartial. Moreover, neither Asians nor Africans were represented on the commission. Africans were denied representation on the grounds that the colonial state feared that an African could not represent views of all Africans but only the interests of his tribe. Breen argues that contrary to this, the African was denied a chance to air his views since the colonial government was aware that he would not only do it well, but also challenge the land policies. ${ }^{30}$

Thus, although the Kenya Land Commission was constructed to investigate African land claims and solve the problem, it worked to the contrary. It emerges that two terms of reference had been included in an attempt to appease the settlers. For example, the commission was to define the area generally known as the "highlands" in which persons of European decent were to have a privileged position according to Devonshire White Paper of 1923. This meant

\footnotetext{
${ }^{29}$ Breen, “The Politics of Land", 52.

${ }^{30}$ Ibid., 60.
} 
entrenchment of special European land rights. This was not only a curious task for the commission but it also interfered with the commission's duties in determining African rights. ${ }^{31}$ It was therefore not surprising when the Kenya Land Commission submitted its final report on $7^{\text {th }}$ July 1933, it dismissed African views as extravagant, unreliable, and biased. The commission acted in total disregard of the "Passfield Pledge" as discussed earlier. The policy on alienation was not adhered to fully. Despite the fact that the Kavirondo Taxpayers Welfare Association petitioned the commission to compensate the Luo, whose land had been alienated to Asians at Kibos, the Luo farmers got nothing.

The commission published its report in 1934, and its recommendations were biased since its main objective was not fairness to Asians or Africans. Rather it assisted the government to achieve their goal of supporting settler land accumulation by eliminating the basis for African land claims and grievances. ${ }^{32}$ The Asians also were ignored. This highlights why the Asians were relegated to the lowlands of Nyanza at Kibos. Consequently, it appears that settler politics in Kenya, and in Britain’s Colonial Office, impacted land decisions and policies within the colonial government. Not surprisingly, dissatisfaction among Asians and Africans continued.

Moreover, other pro-settler policies were enacted following the recommendations of the Kenya Land Commission. For instance, the Kenya Highland order-in-council of 1939 came into effect on $1^{\text {st }}$ March 1939. It entrenched European privileges in the white highlands and defined the boundaries of what was to be the "Native Lands" as those set out in the Native Lands Trust Ordinance. These lands were to be administered as per the provisions of the Native Land Trust Ordinance. However, the rights of an individual were undefined and not secure. These "Native

\footnotetext{
${ }^{31}$ Ibid., 62.

${ }^{32}$ Ibid., 113.
} 
Lands" included the various lands reserved for African usage and included temporary reserves, the native settlement area and communal reserves. ${ }^{33}$

Following the post-World War II period, another land policy was enacted since the Department of Agriculture wanted a change in the land tenure system which was meant to revamp agriculture in Kenya. Thus, in its report of 1952, the department was in favor of the enclosure of land in African areas and the granting of individual rights of occupancy to land. The department saw that proper land use and development could only take place after enclosure and individual ownership was established, and criticized African land tenure systems, arguing that the land could not be cultivated intensively under them. Therefore, a program of land tenure reform, entailing consolidation of fragments into large holdings, was emphasized. ${ }^{34}$ This led to the implementation of the Swynnerton Plan of 1954 which advocated for the amalgamation of fragmented lands into economic farming units. The latter could facilitate the application of sound intensified farming. ${ }^{35}$ The plan also emphasized the use of extension services to transform agriculture through provisions of field officers or agricultural experts to help the farmers. The plan also recommended security of African land tenure through land registration and acquisition of titles; this process created a market for land which became a commodity for sale.

Unfortunately in Nyanza, the Luo people did not immediately embrace the Swynnerton Plan. Archdeacon W. Owen of the Anglican Church had earlier called attention to this fact and argued that the Africans viewed the registration fee charged, as buying their own land. ${ }^{36}$ Scholars, such as Professor Okoth-Ogendo, were also critical of the Swynnerton Plan. He was of

\footnotetext{
${ }^{33}$ Ministry of Agriculture Animal Husbandry and Water Resources, African Land Development in Kenya (Nairobi: Government Printer, 1962), 233.

${ }^{34}$ Colony and Protectorate of Kenya, Department of Agriculture Annual Report 1956 (Nairobi: Government Printer, 1958), 2.

${ }^{35}$ Roger J.M. Swynnerton, A Plan to Intensify the Development of African Agriculture in Kenya (Nairobi: Government Printer 1954), 9.

36،"Evidence by Archdeacon Owen”, in Great Britain, Kenya Land Commission Evidence and Memoranda Vol. 2 (London: HMSO, 1934), 2201.
} 
the view that land policies put in place favored European settlers. The author argues that the Swynnerton Plan fell short of being successful and workable since it destroyed the customary land tenure, disturbed the equilibrium between patterns of land use and available land, and, moreover, was only adopted to try and correct the errors and tensions created by the colonial state’s policies. $^{37}$

Furthermore, the colonial state's lack of competency in understanding the ecology of different areas was evident when it gave rights to the District Commissioner (DC) to prevent people from moving from one location to another. For example, in the Kano plains near Kisumu, such as Ahero and parts of Kibos, the communities were used to practicing transhumance for a long time. This was a way of life shaped by environmental factors such as wet and dry seasons of the area under review. During the dry season, the people moved near the water points for the herds, while during the wet season they moved to the hills to avoid the overflowing of rivers, e.g. the Nyando, and flooding of the plains. ${ }^{38}$ So preventing the people moving to higher grounds during floods, or not allowing them to return after the floods was a problem. It is practices like this that made it difficult for the Luos to embrace the consolidation program as quickly as was expected.

Suffice to say, colonial land policies were marked by confusion and were contradictory and insufficient. It emerges that the policies in most cases ignored the Asian interest while at that same time they were not committed to safeguarding African land rights. The lack of a firm decision on the part of the Colonial Office and the arm twisting by settlers undermined any good intensions, leading to racially biased policies that generated a lot of tension among the three races as will be discussed subsequently.

\footnotetext{
${ }^{37}$ Okoth-Ogendo, “African Land Tenure Reform”, 157.

${ }^{38}$ Maxon, East Africa, 59.
} 


\section{Politics of Land: Asians vs. Europeans}

From the foregoing, it emerges that land in Kenya was an emotive issue and involved struggle by various groups. For instance, the Indians too wanted a share of good fertile land as British subjects and also due to their efforts in the World War I. However, as early as 1903, Eliot instructed the land office that no grants except of small plots were to be made to Indians between Machokos Road and Fort Ternan. ${ }^{39}$ This was the beginning of the official exclusiveness of the White Highlands. This racial segregation of land grants had been Eliot's desire.

Moreover, European settlers began to arrive in the country after 1903, mainly from South Africa, and their numbers continued to increase in the following decades. ${ }^{40}$ Eliot thus became the architect for exclusive white settlement of the highlands and tried all ways possible to relax land acquisition laws in order to encourage settlers from South Africa and Europe. He made it clearly known that no non-white would be allocated land between Kibwezi and Fort Ternan. Towards this end, Eliot got active support of the settlers led by men like Lord Delamere and Col. Ewart S. Grogan, who themselves acquired a lot of land in the colony. Eliot's successors, Sir Donald Stewart (1904-1906) and Sir James Hayes Sadler (1906-1909), also upheld the exclusive land policy on the racial basis. Their argument was that the highlands were too small to be allocated to any other race apart from the Europeans. Thus, in October 1904, Stewart appointed a land committee, which was incidentally chaired by Lord Delamere. The committee erroneously recommended that there was plenty of land in the lowlands, where the Indians could settle. There was no reason for Asians to hold land in the white highlands. ${ }^{41}$ Suffice it to say, the transfer of the protectorate from the Foreign Office to the Colonial Office in 1905, seemed to swing things clearly to favor the settlers. For example, the new Liberal Secretary of State for the

\footnotetext{
${ }^{39}$ Bennett, Kenya: A Political History, 13.

${ }^{40}$ Their numbers had reached 3,175 in 1911 from 506 in 1901. See Mangat, Asians in East Africa, 97.

${ }^{41}$ Stewart toLyttleton, 14 August, 1905 as quoted by Gregory in India and East Africa, 76.
} 
Colonies, Lord Elgin, in a dispatch in July 1906 to the newly appointed Governor Sir James Sadler, asserted that:

it would not be in accordance with the policy of His Majesty's Government to exclude any class of his subjects from holding land in any part of a British protectorate; but that, in view of the comparatively limited area in the protectorate suitable for European colonization, a reasonable discretion will be exercised in dealing with applications for land on the part of the natives of India and other non-Europeans. ${ }^{42}$

This policy was further reaffirmed in 1907 when Governor Sadler, at the instigation of Lord Elgin, established an advisory Land Board. Due to settler influence, the board discouraged any form of Indian settlement of the highlands. Elgin made this position clear in another dispatch to the governor in March 1908 when he stated that:

it is not consonant with the views of His Majesty's Government to impose legal restrictions on any particular section of the community, but as a matter of administrative convenience, grants in the upland area should not be made to Indians. ${ }^{43}$

Thus the policy of not issuing land to Indians in the white highlands was effectively sealed by the enactment of a new land act in December 1912 by Belfield. The act put restrictions on transfers of land in the protectorate to people who were not of European origin, obviously targeting first and foremost the Asians who seemed to have enough resources to buy the land, and also to some extent the Africans. ${ }^{44}$

Asians opposed the new land regulation. Their main argument was that it was irrational for them to be denied land in the highlands, yet they had equal rights as subjects of the British Empire. However, as the protectorate became increasingly identified as a white settler colony, the Indians faced other restrictions as well. The most notable one, that also affected their

\footnotetext{
${ }^{42}$ Ibid.,77. Sadler had initially served as a commissioner of the East Africa Protectorate from 1905 until his appointment as governor.

${ }^{43}$ Quoted in Bennett, Kenya: A Political History, 24.

${ }^{44}$ Ibid., 79, 93. See also Bhatt “A History of Asians in Kenya”, 81.
} 
farming, was in regard to immigration. The Indians challenged such biased regulations arguing that as British subjects they should enjoy the right to protection against deportation from any British territory: and more so, Kenya. Yet throughout the protectorate efforts were being made, especially by the settlers, to restrict Indian immigration. This could partly be attributed to the Indian quest for land, among other issues. For example, as early as 1907, the governor had alluded to this in a report which stated that:

There is a tendency amongst the white settlers in the uplands to keep the Indian, not only out of the uplands, but out of the country altogether. The spirit is akin to that prevailing in Natal and elsewhere and is due to the fact that the white cannot compete in the least with the Indian shopkeeper for supplies of provisions and articles in the daily use or as a petty trader. ${ }^{45}$

Therefore, it was evident that the white settlers opposed Asians partly due to fear of possible competition for land and also in entrepreneurship. Indeed, what the settlers were doing in Kenya was something they had learned to perfect from their experiences in South Africa. The white settlers, as was the case was in South Africa, viewed the Indians as competitors rather than as complimenting them by contributing to the development of the colony.

Drawing support both locally and from the Indian diaspora, members of the Mombasa Indian Association, founded in 1900 by L.M. Savle, Allidina Visram and brothers A.M. and T.M. Jeevanjee were able, on several occasions, to petition on emerging critical issues like the alienation of the highlands to the whites. For example, in early 1905, the association managed to successfully petition the acting commissioner, Frederick Jackson, who then pledged that no favoritism would characterize the development of the protectorate. However, their joy was short lived as the administration appointed a commission to re-examine the land ordinances. As noted above, the commission recommended that there was a very small area in the protectorate suitable

\footnotetext{
${ }^{45}$ As quoted in Bhatt, “A History of Asians in Kenya”, 82.
} 
for European settlement and as such the area could not accommodate both the Asians and Europeans. Therefore, the area should be reserved only for the white settlers. ${ }^{46}$

The Asian community, responding to this stance, held a meeting in April 1906 and demanded equal rights. The settlers too held a meeting, in June 1906, and reaffirmed their position that the highlands were a preserve of the Europeans. Stressing on this point, the meeting passed a resolution that:

This meeting pledges itself to offer the most determined opposition to the attempts of British Indians to be allowed to take up land in such highlands, and insists upon the Imperial Government reserving for European settlement the only part of the protectorate suited to Europeans, and to which they have the exclusive right by reason of the deficit in protectorate expenditure defrayed from contributions by the British taxpayer, and by reason of a great number of the white settlers having come into the country on the faith of its being reserved for Europeans. $^{47}$

This resolution was important as it helped point the direction the history of the protectorate was taking as the settlers seemed to be favored by the colonial authorities, although there was no clear cut policy on the seizure of the highlands by the white settlers. ${ }^{48}$

Nevertheless, Asians became more vocal and organized in their fight for rights which included land rights. In 1906, for example, the Indian Association of Nairobi was formed under the chairmanship of Allidina Visram, who had also shifted his business base to Nairobi. The Nairobi association carried on the struggle. Later in the same year, led by A.M. Jeevanjee, the association sent a delegation to London where they hoped to solicit for support from the larger Indian diaspora community and organizations like the All-India Islamic League which had its headquarters in London. This group also met with officials of the imperial government. This visit would become the first of a series led by Jeevanjee which helped to popularize the Indian

\footnotetext{
${ }^{46}$ Ibid., 79.

${ }^{47}$ As quoted in Ibid., 80.

${ }^{48}$ Sorrenson, Origins of European Settlement, 159-175. Sorrenson points out that there was no official statement on the alienation of the highlands until the Elgin Pledges of 1908.
} 
cause, as the Indian problem, not only in Kenya but also in East Africa generally. It also was brought to the attention of major newspapers like the Chronicle.

Moreover, Indian protest continued afterwards in various ways. The next notable development during this period was the formation of East Africa Indian Congress (EAINC) on $7^{\text {th }}$ March 1914. Its president was T.M Jeevanjee. One of the most significant resolutions of the congress was the reiteration of the "fundamental principle right of the Indians lawfully settled or residing within the protectorate to complete and full equality of treatment before the law.” Thus the Congress pledged “to oppose by all means any attempt at encroachments upon its rights.”49 This stance was greatly challenged by the settlers and the colonial state.

When Northey came to the colony in 1919, he felt that the Indians should be excluded from the highlands. However, they could be allowed to acquire a small area in the lowlands. The Indians, on the other hand, refused to discuss the selection of land in the lowland regions which could be made available to them; they also did not want to discuss details of demarcation of residential and commercial areas of townships and challenged the principle of segregation. With a volatile situation at hand, the Indians, with the help of the India Office, tried to put pressure on the Colonial Office to come up with a policy that would be beneficial to them. However, the Colonial Office could not dictate to the adamant colonial state whose policy was that the highlands would continue to be reserved for Europeans only, and that neither grants nor transfer of land to Indians in the white highlands would be permitted. ${ }^{50}$ This issue was strongly contested by Indians, and it was consequently moved to the Colonial Office. The issue was eventually put to rest by the Devonshire White Paper of 1923 in which the official policy of segregation of the white highlands was accepted even though urban segregation was abandoned.

\footnotetext{
${ }^{49}$ KNA: PUB.1/1/1/6, East Africa Indian National Congress Papers-Resolutions of the Annual Meeting in 1915.

${ }^{50}$ Bennett, Kenya: A Political History, 13.
} 
Nevertheless, it did not make it any easier for Indians or Africans to get land in the highlands. Therefore, the Asian farmers had no choice but to accept the settlement in Nyanza.

In fact the settlement and starting of Asian farming in Kibos had coincided with the colonial state's takeover of the Eastern Province of Uganda and the eventual restructuring of western Kenya administratively. This shift of the boundary was due to political and economic factors which impacted Nyanza Province greatly and had a great effect on Asian settlement there.

\section{Nyanza Province: Background of the Administrative Areas}

The completion of the Uganda Railway in 1901 changed the administrative landscape of the Nyanza Province. Not only did it stimulate the economy but also enhanced the administration of the colonial state since accessibility to the interior was now easy. Despite this, the completion of the railway also created more problems, in that it left the state with a debt of $£ 5.5$ million. ${ }^{51}$ Nyanza Province was initially known as Kisumu and had three administrative districts, namely Elgon, Kisumu, and Ugaya. The province was to experience geographical restructuring when on $1^{\text {st }}$ April 1902 Lord Lansdowne issued directives for the Eastern Province of Uganda to be retransferred to Kenya. This was to keep the railway under a single administration. ${ }^{52}$ Moreover, there was a great push to make the railway pay partly for the monies spent in its construction and also to help towards attaining self-sufficiency which actually encouraged the colonial administration to allow Asian settlement at Kibos. Hence the east shore of Lake Victoria and most parts of the fertile Rift Valley highlands were incorporated within the East African Protectorate. Moreover, when John Ainsworth, a colonial administrator who had served in Machakos, Nairobi, and briefly at Naivasha, was transferred to Kisumu as a Provincial

\footnotetext{
${ }^{51}$ C.C. Wrigley, "Kenya: The Patterns of Economic Life 1902-1945” in Vincent Harlow and E.M. Chilver eds., History of East Africa, Vol. 1, (Oxford: Oxford University Press 1965), 209-210.

${ }^{52}$ Maxon and Ofcansky, Historical Dictionary, xvi.
} 
Commissioner (PC) in 1907, changes took place. Ainsworth felt the need to change the administrative structure of the province. It was his belief that the existing name of the province was inadequate and misleading because the province, its major town and the surrounding district were all known by the same name: Kisumu. Hence, he saw the need to change the administrative structure of the province. ${ }^{53}$ Therefore, he embarked on a rigorous campaign to change the names. He proposed the province to be renamed Nyanza or Kavirondo. His first proposal did not receive due consideration and the idea was shelved. However, he made a second proposal suggesting that not only should the Province be Nyanza, but also for the three administrative districts, Elgon, Kisumu, and Ugaya to be renamed North, Central, and South Kavirondo respectively. This second proposal was successful and the names, adopted in October 1909, and were in use until $1948 .^{54}$

North Kavirondo (NK) was occupied by the Luyia people and the Iteso, Central Kavirondo (CK), which included Siaya, Kisumu and some of the southern Luyia people, was occupied by primarily by Luo, while South Kavirondo (SK) was occupied by the Luo, Gusii, and the Kuria (Watende) people. However, other districts existed such as Lumbwa (Kericho) and the Nandi. Administrative changes continued to take place. For example, in 1929, Nzoia Province was created and the Nandi district previously in Nyanza was transferred to it. During the same period, Kisumu-Londiani (K-L) district was created within the Nyanza Province for easier administration of the area settled by the European and Asian farmers. Thus, Kibos-Muhoroni area was initially within CK and then K-L. However, the K-L district was later abolished in $1948 .^{55}$

\footnotetext{
${ }^{53}$ Robert Maxon, John Ainsworth and the Making of Kenya, (Lanham: University Press of America, 1980), 185. ${ }^{54}$ Ibid., 186.

${ }^{55}$ Maxon and Ofcansky, Historical Dictionary, 202. See also Colony and Protectorate of Kenya: Report on Native Affairs 1939-1945 (Nairobi: Government Printer, 1947), 6.
} 
Unfortunately, Ainsworth's choice of the name Kavirondo was heavily contested especially in NK district by the Luyia people who found the name derogatory since it meant people who squat. Thus it was not surprising when the name was replaced with North Nyanza in 1948. North Nyanza was again split in 1956 to create two districts North Nyanza, with headquarters at Kakamega, and Elgon Nyanza, which had its headquarters at Bungoma. On the other hand, CK and SK were renamed Central and South Nyanza. ${ }^{56}$ It emerges therefore that restructuring of the administrative areas was characterized not only by ethnicity but also the geographical locality. After 1948, the Kibos-Muhoroni area was administered as part of CN (CN) that included Kisumu. Other changes took place in 1963 when Nyanza Province was much reduced in size as North Nyanza and Elgon Nyanza districts became part of Western Region while Kericho district was moved to Rift Valley Region. Hence, Nyanza Region (later Nyanza Province) was reduced to only CN, Kisii, and South Nyanza districts. ${ }^{57}$ Today, South Nyanza has been divided to create other districts such as Suba, Gucha, Migori, Homabay, and Nyamira. However, for the purposes of this study we will confine ourselves to the pre-1963 administrative areas of Nyanza Province, whereby the area under review was part of the CK, K-L, and CN districts.

\footnotetext{
${ }^{56}$ Report on Native Affairs 1939-1945 6.

${ }^{57}$ Maxon and Ofcansky, Historical Dictionary, 202-203.
} 


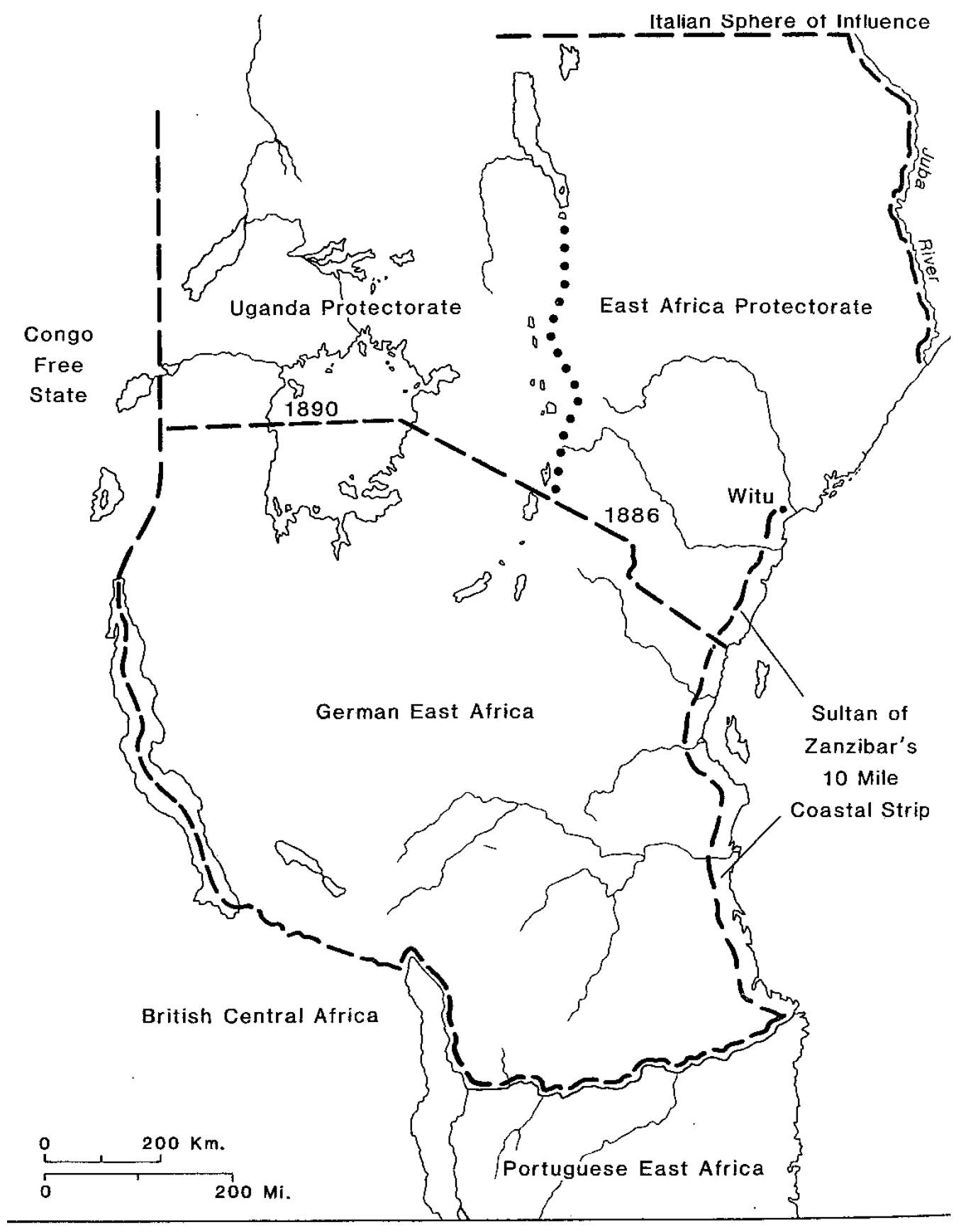

Source: Adopted from Maxon, East Africa: An Introductory History (2 ${ }^{\text {nd }}$ Edition),132. 


\section{Map 3.2: Colonial Kenya}

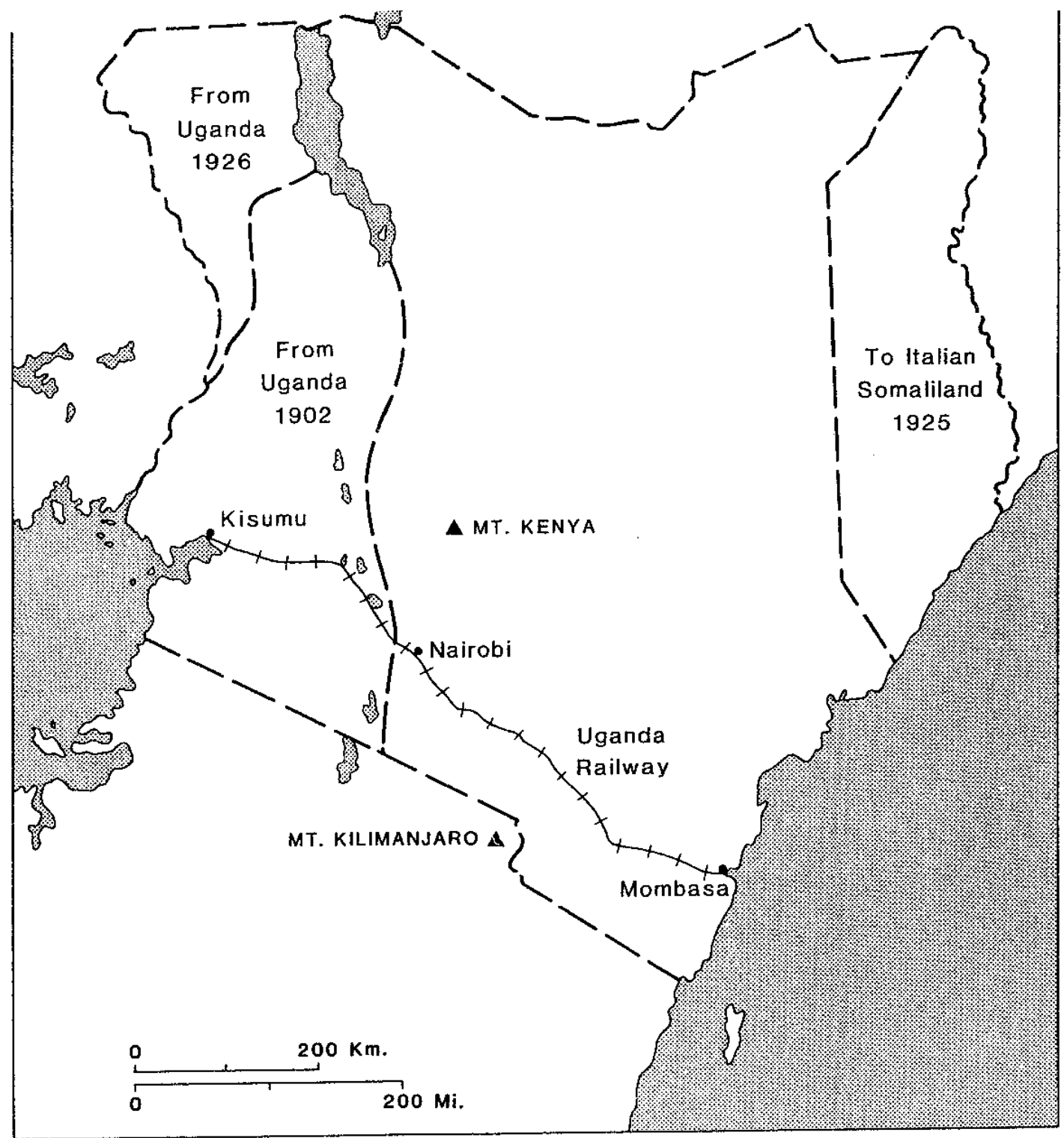

Source: Adopted from Maxon, East Africa: An Introductory History (2 ${ }^{\text {nd }}$ Edition), 156.

\section{Settlement and Beginning of Cane Farming at Kibos}

Therefore, it emerges that the administrative boundaries in colonial Kenya that were changed in 1902 brought the western highlands into Kenya. Due to the policy put in place to exclude the Asians from the white highlands, the British fostered only a small-scale settlement of 
Asian agriculturalists in the colony. The site was Kibos which is a railway stop in the lowlands north of Kisumu town, an area which was deemed unsuitable for European settlement. ${ }^{58}$ Moreover, the government restricted ownership of land by Asians even in this area. While the European settlers could be granted thousands of acres, Asians were initially only limited to 100 acres per grant. ${ }^{59}$ The few who settled at Kibos took to farming. This agricultural initiative began in earnest in 1903, although archival sources indicate that there was acquisition of land by Asians as early as $1901 .^{60}$ The first thirty pioneers who were granted land at Kibos-Miwani in 1903 acquired the farms under freehold or on a 99-year lease. The majority of the pioneer farmers were Sikhs (Jats), and about sixty percent of the farms they took up were on freehold, while the rest were leasehold of 99 years.

The thirty pioneers were helped to settle by Mr. D.D. Waller, as earlier discussed. He directed the surveying of land and the allotment of the farms. They were also given limited financial assistance, seeds and draft animals for two years, and this was to be repaid within a stipulated time. These Indians therefore started agriculture by experimenting with crops such as rice, cotton, sesame, linseed, maize, chiroco, and chillis. They also kept animals such as cattle and even pigs. Moreover, commercial sugarcane farming was also introduced in Kenya by these Asians. These pioneer settlers saw its potential and began to grow sugarcane intensively at Kibos in 1906. By 1910, many of the Indian farmers who had settled in the area were applying for more acres of land to carry out cane farming, although the governor had already ruled that no more than 50 acres should be allocated to Indians. ${ }^{61}$

\footnotetext{
${ }^{58}$ Gregory, South Asians in East Africa, 240.

${ }^{59}$ Ross, Kenya From Within, 314.

${ }^{60}$ See Table 3.1.

${ }^{61}$ KNA: PC/NZA/3/22/1/9, Kibos Indian Settlement 1910-1912.
} 
The project also suffered when, shortly after he initiated the promising scheme, Waller was transferred to Kisumu to pick up judicial duties; hence, he had limited time to supervise the scheme. This made C. W. Hobley, assistant deputy commissioner in charge of Nyanza Province, to request a full-time supervisor. His recommendations were ignored. Although the Kibos settlement started from a modest beginning, sugarcane farming became popular as more Asians began to acquire land in the area. Over the next three decades, sugarcane farming at Kibos grew steadily, despite lack of sufficient government support. This experience revealed the resilience of the productivity of Asian small-scale farmers. For example, they demonstrated their efficiency in land use whereby out of the total 10,935 acreage held, they cultivated 7,645 acres, approximately seventy percent of the holding.

This differed greatly from the European farms in the white highlands, which had only five percent of their land under cultivation. ${ }^{62}$ Berman explains this poor performance by the white settlers as being due to the fact that many had never farmed before and were quite inexperienced, coupled with their reluctance to do manual work on their farms which made them to be totally dependent on African labor. ${ }^{63}$ His views were shared by Mr. V. Liversage, the colonial government's agricultural economist, who believed the settler farmers were grossly inefficient due to lack of knowledge of farming practices. Thus, compared to the Asian cane farmers, the European farmers in the highlands were, before 1939, unable to use their land effectively. Berman maintains that an average settler farmer with about 2,600 acres of land was only able to bring about 269 acres under cultivation; a mere 10-12 percent of the total land. ${ }^{64}$

On the other hand, the number of Asian farmers growing cane at Kibos and Muhoroni increased by the mid-1940s. Most of the farmers by 1947 had bought their farms at government

\footnotetext{
${ }^{62}$ Gregory, South Asians in East Africa, 241.

${ }^{63}$ Berman, Control and Crisis in Colonial Kenya, 133.

${ }^{64}$ Ibid., 134 .
} 
auctions or from previous holders and paid twenty cents per acre rent to the government. ${ }^{65}$

Though the pace was slow, there were about eighty farmers, as indicated in the nine areas stipulated below, who owned a total of about 46,000 acres of land. These Kibos-Muhoroni

Indian farms included holdings in the areas of Kibos, Muhoroni, Miwani, Chemelil, and

Kibigori. The areas were divided categorically as follows:

\section{Area 1: Miwani Sugar Estate which was owned by Devjibai K. Hindocha, Ltd.}

This area had 3,615 acres of cultivated cane with a capacity of producing over 9,000 tons of white cane. The estate did not produce jaggery normally.

\section{Area 2: The area was owned by nineteen Indian farmers and one European.}

These farms were located about four miles west of the Miwani sugar factory.

It covered approximately 2,500 acres, all of which was under cane cultivation. However, the area also produced jaggery and utilized up to fifty acres towards this course. Area 2 had a capacity to produce approximately 4,230 tons of white sugar.

\section{Area 3: Indian Farms}

This area was situated at Kibos, west of the railway line. The area was owned by thirty-three farmers, and the estimate of the total acreage under cane production was 2,580. The area produced also jaggery and did not have an adequate plantation trolley line to transport cane for production of white sugar. The area under cane cultivation had a capacity of producing 2,400 tons of jaggery.

\section{Area 4: Miwani Estates: Indian Farms}

This area was settled by about fifty-six families of Indian farmers as early as 1903. The land was not so rich but was situated near the factory and better served by communication. The area had 1,300 acres of cane intended for production of white sugar of approximately 1,300 tons.

\section{Area 5: Kibigori Indian Farms}

This area had a total of twelve farms with a total acreage of 710, with 500 acres of cane under cultivation. It had a capacity of 600 tons of jaggery. The area had smaller farms and lighter soil on hilly land and was less suitable for cane.

\section{Area 6: Chemelil Indian Farms}

The area consisted of nine Indian farms with a total of 510 acres of cane, but most was used to produce jaggery. These farms lacked any road communication with Kibigori or Muhoroni; hence, the railway was the only viable means of transport.

\footnotetext{
${ }^{65} \mathrm{KNA}: \mathrm{DC} / \mathrm{CN} / 1 / 3 / 1$, CKDAR, 1947.
} 


\section{Area 7: Chemelil Estates - owned by Miwani Sugar Mills.}

The area covered approximately 2,000 acres under cane cultivation. This area, during the 1947-1948 period, produced 1,540 tons of white sugar out of 1,000 acres, and the other 1,000 acres was used in the production of 1,330 tons of jaggery.

\section{Area 8: Muhoroni Indian Farms}

The area consisted of six Indian farmers and one Arab cane farmer. It had a total of 150 acres of cane and had a capacity to produce 1,080 tons of cane. All of it went to producing jaggery.

\section{Area 9: Muhoroni Sugar Factory and Estate}

The farm was owned by several Indians who produced cane for white sugar. ${ }^{66}$

A close examination of these farms clearly indicates that not only was a substantial acreage of land alienated, but also that farms were well organized into areas. Also the willingness of the farmers to engage in agricultural production was evident. However, the area where the Asians settled had already been occupied by the Luo people, and so the alienation dislodged some of the Luo from their land. The Luos, during their migration and settlement in Kenya, had pushed out some communities as will be discussed subsequently.

\section{The Movement and Settlement of the Luo in Nyanza Province}

The movement of the Luo into Kenya began sometime between 1490 and 1650 with the eventual settlement in Nyanza. This area constituted Siaya, Kisumu, and Homa Bay districts which formed the majority of the administrative areas of Nyanza Province before 1989. The movement of the Luo was commonly known as the Luo invasion since most of the earlier occupants of the areas around Lake Victoria were pushed out. The migration began due to various factors such as need for pasture for their herds. Thus, they moved from their cradle land around Wau situated near river Meridi in modern southern Sudan. Some of the Luo neighbors at

${ }^{66}$ KNA/ AK/11/50, Report by W.M. Lyne Watt on Sugar Growing Areas, August 1947. 
Wau included the Dinka in the west, Nuer in the north, while the Azande lived in the south and east of Wau. ${ }^{67}$ These neighbors, just like the Luo, were pastoralist and so constant tension emerged as a result of competition for pasture, with the Dinka constantly attacking the Luo. Hence, the Luo moved southward, and settled at Pubungu-Pakwach before their movement into Uganda. In Uganda they sojourned briefly before moving into Kenya in small groups at intervals of between twenty to fifty years.

The movement of the Luo into Kenya and their settlement can be divided into four main groups, namely Joka-Jok, Joka-Owiny, Joka-Omollo, and lastly a mixed Bantu group, the Abasuba. The Joka-Jok, who consisted of the first wave of invasion, are believed to have moved from the Sudan to Acholiland in northern Uganda, and then they moved into Busoga before arriving in Kenya between 1490-1600 A.D. This group, which claimed direct decent from the legendary Ramogi Ajwang, then moved to Ligala in Samia where they stayed for three generations before moving to Got Ramogi. At Got Ramogi, a split occurred when Julu and Odongo, son of Nyikal together with their followers, moved and settled at Sakwa Waringa before moving to the various surrounding areas. For example, Odongo settled eventually near today's Asembo and Seme locations and became the founder of Jo Seme. Julu moved near Kisumu and founded the Kajulu people of Kisumu. Owidi also later moved from Ligala, settled at Kisumu, and is the forefather of the Jokisumo. ${ }^{68}$

The Joka-Owiny, led by Owiny (Sigoma), moved from Padhola in Sudan into Uganda and settled at Budama before moving through Mbale and Tororo, eventually moving into Eastern Busoga where they too stayed for three generations. Between 1560 and 1625, this group moved to Samia, then to Got Ramogi where they stayed briefly. They left, led by Alego son of Mumbo,

\footnotetext{
${ }^{67}$ William R. Ochieng', An Outline History of Nyanza up to 1914 (Nairobi: East African Literature Bureau, 1974), 19.

${ }^{68}$ Ibid., 23.
} 
and crossed the Yala River moving eastward and settling at Bungu Oburu, driving out the Bantu speaking people who had occupied that land. ${ }^{69}$ They named the area Alego after their leader. These are the forefathers of the present day Kadimo, Kogelo, Karuoth, Karapul, Kamot, and Konya in Kano.

Joka-Omollo moved from Alur in Sudan into northern Bunyoro in Uganda and then proceeded south of Lake Kyoga to Ibanda in Busoga where they stayed for approximately fifty years before moving to Samia. They eventually moved into Nyanza settling at Yimbo Kadimo between 1540 and 1600. Here they stayed for about four generations before moving to Alego. From Alego, some moved and settled at Gem, Ugenya, and the South Nyanza areas of Kochia and Kanyada.

Due to pressure of others coming to the region, some members of Joka-Omollo migrated from Alego and settled in Uyoma. Joka-Chwanya from Sakwa also moved and are believed to have been the first Luo group to move from Uyoma into South Nyanza between 1730 and 1760 . They were then followed by Jo-Wagwe, Jo-Kano, Joka-Nyadhiang, all settling at Kanyamwa briefly before moving again due to pressure on land. For example, a group led by Rachuonyo moved and settled at West Karachuonyo, Ndara Kokoth and Kasipul Kabondo. Other groups led by four brothers, Adem, Rungu, Bwoch, and Ler, also left Kanyumwa, moved westward and settled at Karungu where they displaced the Ugu and Sunga people after a fierce battle. The latter moved to the Butende area of modern Tanzania.

The groups of Adem and Ler eventually settled at Kadem, while Rungu and his group settled at Sori and Bwoch, finally settling at Kabwoch. The fourth group, the Abasuba was nonLuo speakers who believe they are descendants of the Abakunta, political refugees who ran away from atrocities of Kabaka Semakokiro of Buganda. This group settled along the shores of Lake

\footnotetext{
${ }^{69}$ Ibid., 26, 27.
} 
Victoria in South Nyanza, occupying Kaksingri, Kasigungu and the Gembe Hills. Most of the Abasuba settled on Mfwangano Island with some settling in Rusinga Island. This group, though partially assimilated like the Manyala, should not be treated as part of the Luo people. Their history, culture, geographical location and numbers, raise serious questions as to what constitutes a tribe. However, this forms a body of another research. That said, it is important to note that the Luo movement and colonization of parts of Nyanza was long and haphazard. Thus, the Luos, led by Owidi, who settled around Kisumu (Jo Kisumo), Kajulu led by Julu and the Kamot, and the Konya people in Kano are most probably the predecessors of the Luo who occupied the Kibos-Muhoroni area before the advent of colonialism. 


\section{Map 3.3 : Lwoo Migrations to East Africa}

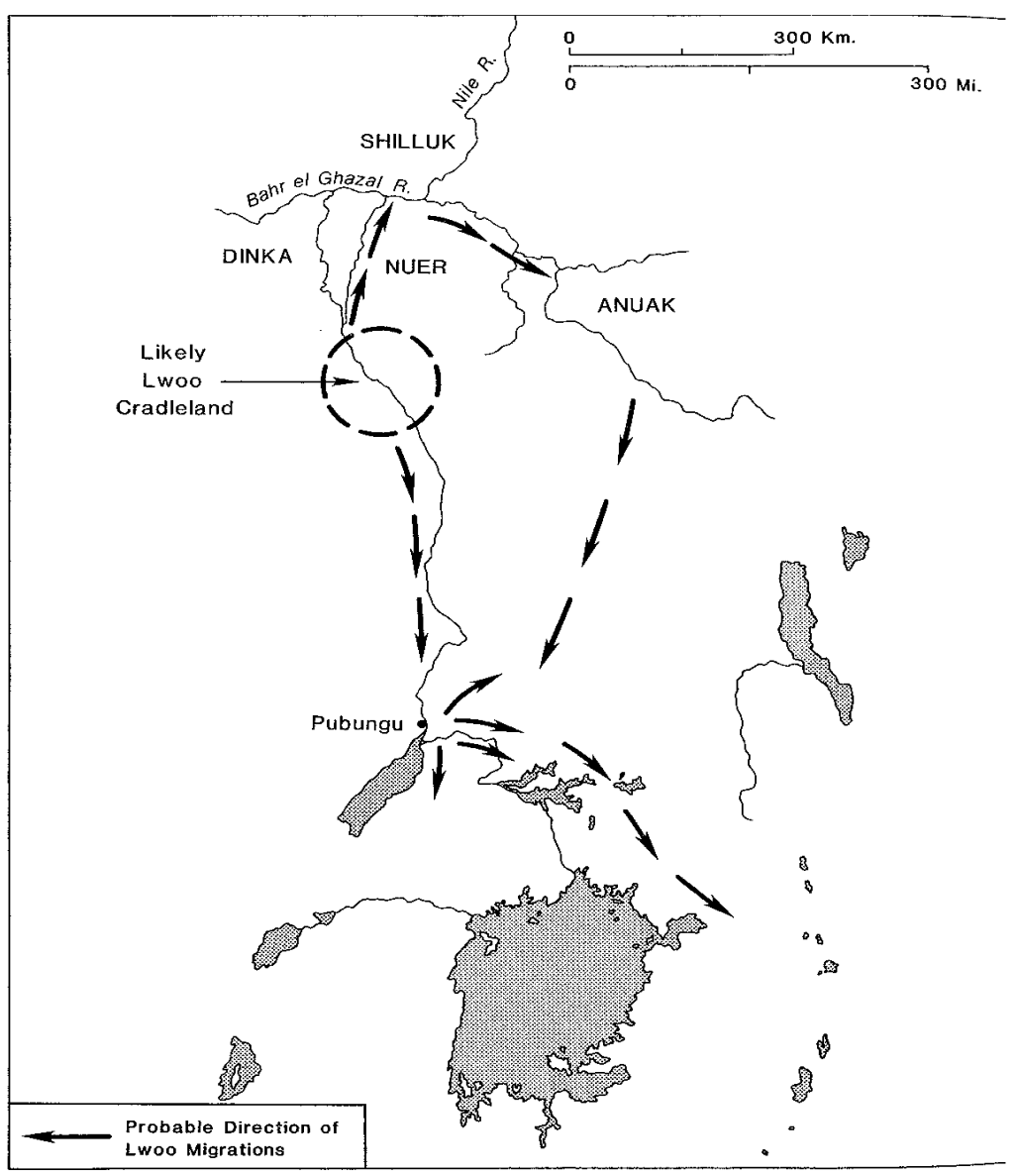

Source: Adopted from Maxon, East Africa: An Introductory History ( $2^{\text {nd }}$ Edition), 60.

\section{Indigenous Land Tenure System}

The Luo occupied their current lands in Nyanza through conquest during their invasion of the province as discussed in the preceding section. This gave them rights of occupancy. Hence, and tenure systems in pre-colonial Kenya varied from one area to another in accordance to the 
customary law of the tribe. ${ }^{70}$ However, the land tenure system in pre-colonial Kenya has been viewed as backward and wasteful due to fragmentation which resulted from the practice of shifting cultivation of subsistence crops during this period. Due to the fact that there was plenty of land, a farmer would open up a new piece of land when the other one was exhausted, leaving it to fallow, to be reused again. Also, new lands were opened up due to the risk aversion. When this process was repeated over time, it led to a situation whereby the farmer could usually end up with a number of small fragmented pieces of land scattered over several miles. ${ }^{71}$ This situation made it very difficult to supervise these farms. Moreover, indigenous economic practices were quite dynamic and such a system of tenure therefore guaranteed unlimited access to land which was the major means of production. Generally land was communally owned in most parts of Kenya, Nyanza being no exception.

These lands had been acquired through rights of first occupancy after clearing or by conquest or initial hunting rights. ${ }^{72}$ The custodian of the land was often the individual clan which was comprised of a close knit kinship group. Therefore, rights to land were defined by membership of a kinship group. This system put in place measures that guarded against landlessness by making it difficult for a person to trade it without the consent of the kin. Land was seen as a form of wealth belonging to the entire clan and as such everyone was expected to safeguard it. This view is corroborated by Norman Humphrey who points out that the land was perceived as a form of communal wealth of a particular tribe or clan and had to be safeguarded. ${ }^{73}$

\footnotetext{
${ }^{70}$ African Land Development in Kenya, 234.

${ }^{71}$ Ibid., 235.

${ }^{72}$ Maxon, Going Their Separate Ways, 24. For more discussion on communal ownership of land in Kenya, see also Gunter Wagner, The Bantu of Western Kenya with special reference to Vugusu and Logoli, Vol. II: Economic Life (London: Oxford University Press, 1956), 75-84.

${ }^{73}$ Norman Humphrey, Liguru and the Land: Sociological Aspects of Some Agricultural Problems of North Kavirondo (Nairobi: Government Printers, 1947), 19-20.
} 
Although his work is based on the Luyia of then North Kavirondo, the same principle applies to the Luo people.

The Luo, being a patrilineal society, thus ensured that a person could gain access to land through inheritance of ancestral land or by clearing virgin lands. Inheritance was based on communal lineage rights and not individual rights. Sons inherited from the father's land. The amount of land a man expected to inherit depended mainly on the size of the area occupied by the clan and family. However, with the growth of the population and the continual process of sub-division of the land through inheritance, the holdings became increasingly insufficient. Clans also had tenants at will or "jodak" who obtained the use of land through clan elders, after keen observation or on recommendation by a clan elder. In most cases the stranger had a distant relative in the specific host clan as land was held by all. Therefore, land, an important factor in a traditional productive system, was governed by specific, but unwritten, rules.

\section{Indigenous Economy}

The indigenous economic practice in Luo Nyanza was based on access to land and other natural resources. Just like most African communities before colonialism, the indigenous economy was diverse and vibrant. In $\mathrm{CN}$, the economy developed mainly around livestock keeping, fishing, traditional industries, trade and agriculture. However, cattle keeping was the

preference among the Luo. ${ }^{74}$ In these economic activities, labor was divided along gender lines as will be discussed subsequently.

\footnotetext{
${ }^{74}$ Fearn, An African Economy, 32.
} 


\section{Livestock Keeping}

Within the indigenous economy, livestock production was predominant during the precolonial economy. The social and economic significance of cattle influenced the Luo to value cattle. The ecology of the area (open plain) also contributed to the suitability of cattle keeping in that a large expanse of grazing land was available. This was significant since traditional cattle keeping required an abundance of grazing land, as the animals were allowed to graze on the open fields, except those under cultivation. They used common water points like rivers and even common salt licks, especially near the lake. Cattle keeping were a source of savings as it translated into accumulation of wealth, which enhanced the social status of a person. Having more cattle, as such, could make a person occupy a privileged position among the community such as "Ruoth" (chief). Differentiation in wealth therefore was determined by such variables as the size of a household head's herd. ${ }^{75}$ Being cattle keepers, the Luos designated communal grazing fields where the young men looked after the cattle.

Availability of cattle also enabled a person to have more wives: another wealth indicator. Moreover, the cattle complex had an immediate logic in that it also served as a store of convertible wealth. It provided a degree of economic security within the traditional society against risks such as crop diseases, locusts, and drought. Cattle were also very valuable to the Luo community since they provided milk and blood. Their skins were used as a form of clothing, and to make the shield; and also, bags were made from the hide. The cattle dung was used for fuel as well as plastering walls and floors. It appears that nothing was wasted from the cow. Cattle also provided ghee, manure, bedding, and its waste was burnt at night as a form of insecticide to keep away and kill mosquitoes while their horns made wind pipe instruments.

\footnotetext{
${ }^{75}$ Maxon, Going Their Separate Ways, 28. See also Talbott, “Agricultural Innovation and Policy Changes in Kenya in the 1930s”, Ph.D. Thesis, West Virginia University, 1976, 10. According to Talbott, cattle in most communities of Kenya were used not only as a medium of exchange but also as collateral to secure obligations.
} 
Cattle also provided a major means of exchange in that they assisted in economic exchange to obtain land use and labor of other people. Every homestead had its own kraals where cattle were kept.

To minimize dissemination by disease or drought, the Luos, just like other pastoralists, loaned their cattle to friends and relatives who lived in a different areas as a risk aversion strategy. In most cases, the person used the cattle for milking and looked after the cattle, but could not slaughter them. This loaning of livestock cemented friendship and kinship ties and also widened the social networks of an individual. ${ }^{76}$ It was more of a reciprocal relation full of trust. This was also an important coping mechanism adopted during the famine period.

Socially, livestock keeping was important among the community especially in rituals such as burial ceremonies. This was mainly found among elderly people or important male members of the community. When they passed on, large herds of cattle would be used in a ceremony of appeasing the spirit, "tero-buru”. Then a large number of cattle would be driven into the dead man's compound causing a stampede which was believed to chase away evil spirits and also appease the dead. A great man's death would be celebrated by slaughtering many cows during the funeral to befit his status in the society. Cattle could occasionally be used for sacrificial purposes, especially when the community faced calamities such as drought, pestilence, or frequent thunderstorms which were perceived by the people as the ancestral spirits not being happy; hence, the need to cleanse themselves. In many cases, sheep were used, but for serious situations the cattle would be used. Livestock was also commonly used as compensation for injuries. For instance, if a person injured another person in a fight, and in most cases where blood was shed, he would be fined by the clan. Payment would be in the form of livestock.

\footnotetext{
${ }^{76}$ William Ochieng', “Kenya's Internal and International Trade in the Nineteenth Century”, in W.R. Ochieng' and R.M. Maxon eds., An Economic History of Kenya, 37.
} 
Cattle were also used for compensation where death occurred through fighting. Thus the importance of cattle cannot be underestimated since those who did not have cattle were often

scorned. ${ }^{77}$ However, cattle keeping could be affected by drought, hence, the Luos engaged in other economic activities such as fishing.

\section{Fishing}

Fishing was predominant among the Luos who lived near Lake Victoria. They spent a large part of their time fishing. Fish were caught by hooks, basket nets, and the fence traps, and fishing was important as fish formed one of the basic foods for the people. Surplus was dried (sun-drying) or smoked as a means of preservation and was then sold in the local market. Initially, the markets were limited to only about seven to ten miles from the beaches of the lake where most fish were caught. However, this was to change later and fish could be sold as far as the boundary of the Luo and Gusii people where it was bartered in exchange for grain. ${ }^{78}$

The Luo fished a variety of species such as "ngege" (Tilapia esculenta) which was the most important to the community. Related species of the "ngege" such as the "mbiru" (Tilapia variabili) was also common. Lungfish, (Protopteus aethiopicus) was found in rivers and near the papyrus reeds of the lake. This species was very large in size and highly prized, while Bagrus "Seu", which is the largest predatory fish in the lake, was not numerous. "Ngege" exceeded all other species in economic importance due to the quality of its flesh and convenient size for travelling to trade. The smallest species, known locally as "omena”, was more like a sardine in size and was caught by the special traps known locally as "ngogo". Many methods were employed in fish farming such as the "ngogo" which was made from papyrus stalks, and canoes

\footnotetext{
${ }^{77}$ Ochieng', An Outline History of Nyanza, 50.

${ }^{78}$ Fearn, An African Economy, 31.
} 
"yiye" made of wood and propelled with single paddles "ngayi" were employed. ${ }^{79}$ The Luos also employed hooks, fence traps, and other methods which involved the use of line and basket nets dipped in water. These are conical baskets wide at the bottom with a hand hole on top. In most cases, this method was used for a small volume of fish harvest meant for subsistence and not for market. The fish farmers who participated in the market devised methods of catching fish in large numbers. For example, during the colonial period they improved the "ngogo" which they used to enclose a particular water area known to have fish; then fishermen drew the net on to the shore after enclosing the fish in the net. These modified "ngogo" were mostly handmade nets usually sewn from khaki cotton material.

Most of the fishing households were able to support themselves adequately. Many combined fishing with agriculture and cattle keeping. Fishing was seen as an art; its success involved a deep understanding of the nature of the lake and rivers. Therefore, the belief that the Africans were irrational is demystified as shown by the high intelligence involved in fish farming. Even with the establishment of colonial rule whereby several new methods of catching fish were introduced, such as using readymade fishing nets, the Luo continued to use their traditional methods alongside the new methods, often resulting in a better catch. Moreover, the colonial state interfered with traditional methods through imposing control and regulations on fishing nets which entailed the use of manufactured nets which benefitted the government through increased sales. This inadvertently discouraged the already thriving industry which Africans had of handmade nets. Fishing was basically done by men; however, the women assisted in sun-drying the fish and selling (bartering).

\footnotetext{
${ }^{79}$ Stella Worthington and E.Barton Worthington, Inland Waters of Africa (London: Macmillan and Co., Ltd, 1933), 18.
} 


\section{Figure 3.1: Ngege and Mbiru}

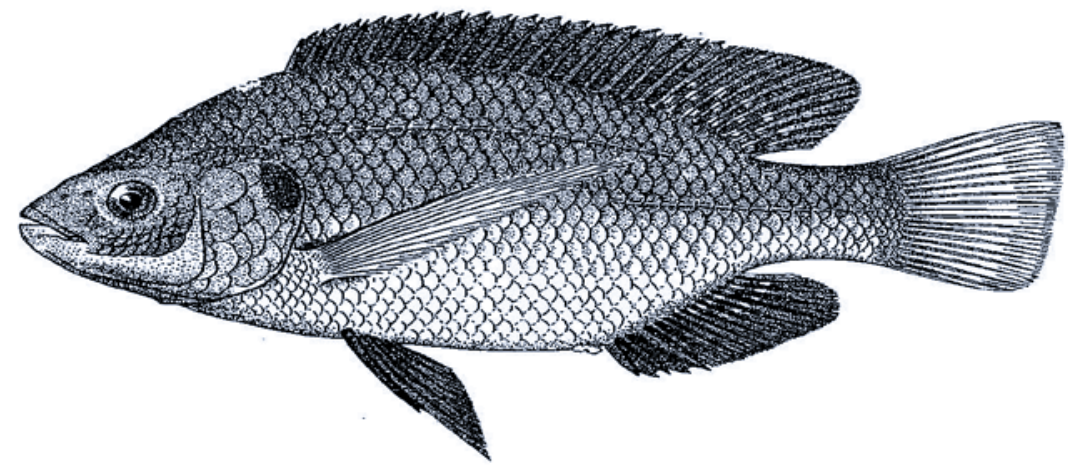

\section{Adopted from S. and E. B \\ Worthington Inland Waters of Africa}

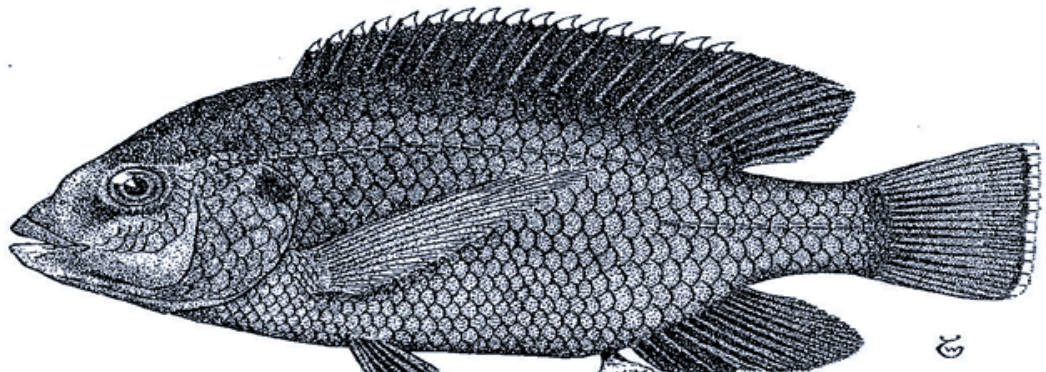

Fig. 3.-Ngege and Mriru.

The upper drawing is of the Ngege, Tilapia esculenla, the lower one the Mbiru, $T$. variabilis. Both specimens are mature males. It is seen that the ngege has more scales on the body and on the cheek. The shape of the head is also different. The ngege is brownish in colour, but the mbiru is bluish, with scarlet tips to the rays of the back and tail fins. (The scarlet tips are shewn white in this drawing.)

in the Annals and Magazine of Natural History, 10, ii, Pl. IX, 1928.

Mbiru is found in very shallow water while ngege are found only in places where there is a derable area of water about 60 feet in depth and at a distance of about a mile from the shore. ${ }^{80}$

\footnotetext{
${ }^{80}$ Worthington and Worthington, Inland Water of Africa, 25.
} 


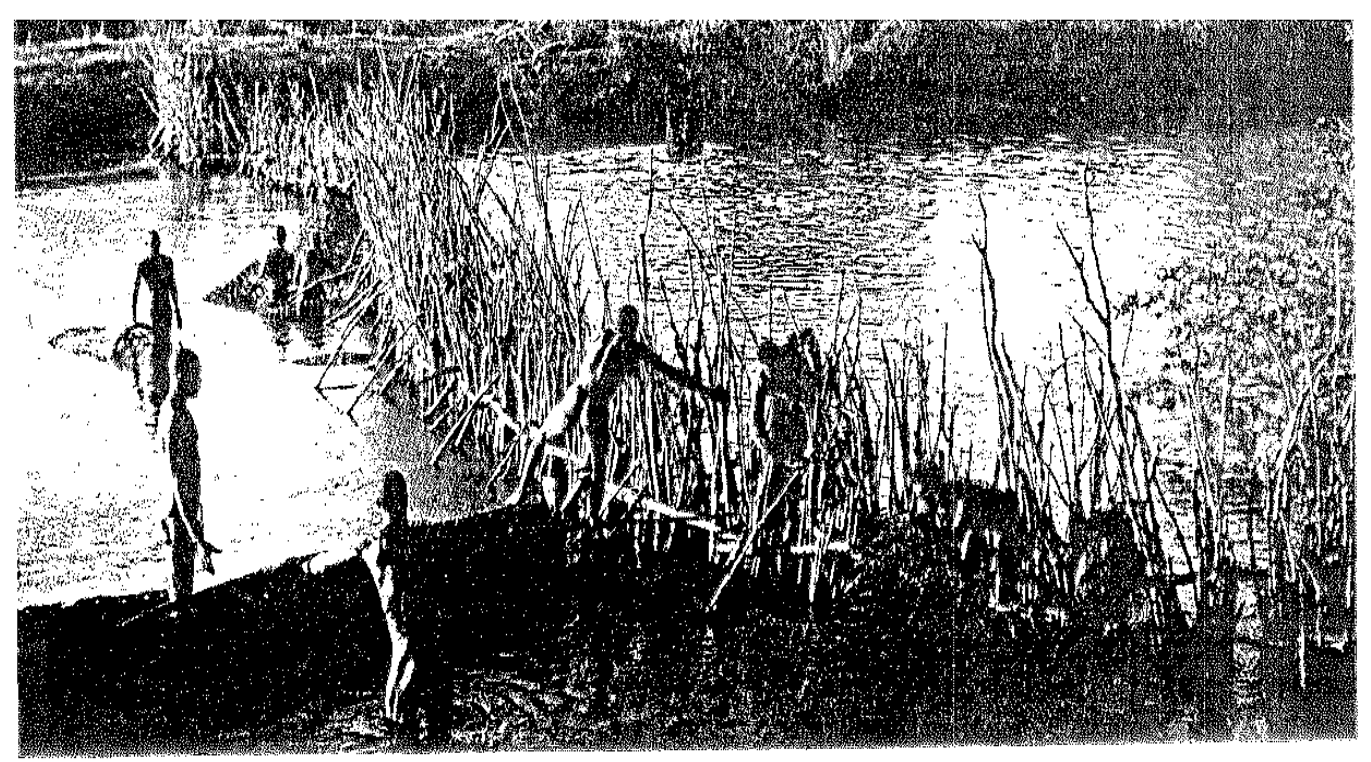

JALUO FISHERMEN BUSY WITH THEIR KEK OR RIVER FENCE

Openings are left at intervals in the fence and opposite each is fixed a basket trap.
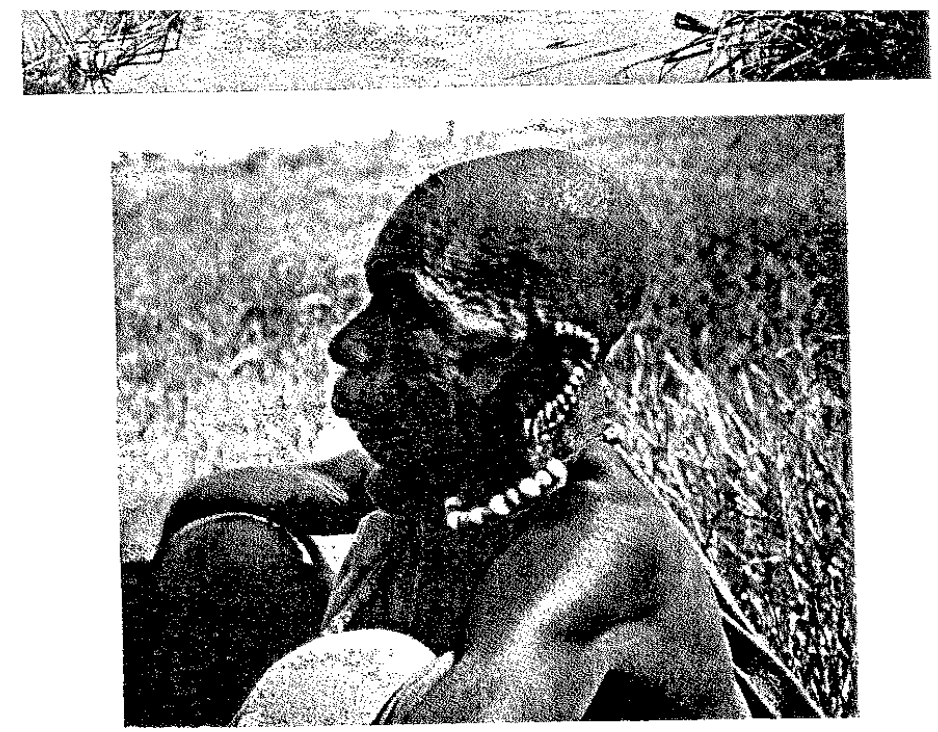

Above: A SMALL TYPE OF NGOGO OR MOVABLE FENCE BEING AOOVO: A SMALIN THE KAVIRONDO GULF, LAKE VICTORIA

The

the fish are concentrated and can be dipped out with baskets.

Below: AN OLD JALUO FISHERMAN

His ear-rings are heirlooms handed down from generation to generation.

Source: Adopted from, Worthington and Worthington, Inland Waters of Africa, 88. 


\section{Traditional Industries}

Despite the fact that the Luos were engaged in cattle keeping and fish farming, the community also was involved in other economic activities in various traditional industries. Apart from fishing, the Luos also engaged in other economic activities especially during the off farm period. Thus, the Luos of CN were involved in other economic practices such as clay-work, basketry, woodwork, and the salt industry. Most of the commodities made were for self sustainability while surplus was traded to the neighboring communities such as the Luyia and the Gusii. These industries were important since the income and or accrued benefits helped to support the agricultural and pastoral activities of many communities in Kenya, the Luo being no exception. $^{81}$

Clay-work was an important industry among the Luo. Luos engaged in making pots and smoking pipes. Pots were used for different purposes in the households such as storage. This included storage of water, grain, and smoked fish. The pots could also be used for carrying water from the lake or the rivers, cooking, and also for ritual purposes. There were also special pots, mostly big in size, that were meant for brewing local sorghum beer, "kongo" and smaller ones for serving the beer. Specific pots had different names and different purposes. For example, the small sized pot, "ahigla", was for cooking; specifically fish. The big sized pot, “dag-pi”, was meant for water storage. Pottery was an art, just like fishing; not everyone was engaged in it. Those who did pottery work observed rules and regulations. For instance, the work could not be done during any mourning period when a member of the community was dead nor could ovulating women go near the pots during fire burning. This they believed brought a bad omen leading to cracking of most pots during the process. Specialists knew where the best

\footnotetext{
${ }^{81}$ Simiyu Wandiba, “Crafts and Manufacturing Industries” in Ochieng' and Maxon eds., An Economic History of Kenya, 17.
} 
clay could be found, and in most cases the skills were passed down from one generation to another. Among the Luos, pots were generally made by women. Simiyu Wandiba's work also reveals that this was the common trend among most of the Kenyan communities with the exception of a few male potters found among the Bukusu and the Kabras. ${ }^{82}$ Pots were also used for boiling and storing herbal medicine and ritual ceremonies such as rain making.

Similarly, basketry was also an important industry among the Luo. Baskets, just like pots, were made in different sizes depending on their use and had different names. For example, there were the big ones used as containers for storing food stuffs, such as root crops. These included "adita" and "atonga." Others were used for serving of food purposes for instance, "odheru"/ "oteo." Basically these were traditional trays. Smaller ones also served as bowls "ogudu" for keeping food such as sorghum bread. The bowls were woven from special grass. Many baskets were also made especially for storing and easy transportation of fish to the local markets among the Gusii. Many were made from grass, plant fibers and creeper fibers, or woven out of reeds that grew in swampy places, such as the Yala swamp, along the riverbeds and also along the shore of Lake Victoria.

Other forms of basket making involved makings mats for sleeping "par" and doors which were woven from papyrus reeds. ${ }^{83}$ Also, some baskets were made for fishing traps. Although basket making was predominately a women's job, big baskets, or special ones, were made by men, e.g. fishing traps. Grainairies were also made as big baskets and then set up off the ground and were basically made by men. On the other hand, woodwork was not widespread among the Luos, but there were specialists who engaged in making dug-out canoes "yie" for

\footnotetext{
${ }^{82}$ Ibid., 21.

${ }^{83}$ E.S. Atieno Odhiambo, "Economic Mobilization and Political Leadership: Oginga Odinga and Luo Thrift and Trading Corporation to 1956”, in Aloo Ojuka and William Ochieng' eds., Politics and Leadership in Africa (East African Literature Bureau: Nairobi, 1975), 142.
} 
fishing and transportation purposes in the Lake Victoria region. These canoes were made from big logs of special trees and were hollowed out using chisels. ${ }^{84}$ Others specialized in making the three-legged stools mostly used by old men and women in the community.

The salt industry was also found among the Luo and Luyia of North Nyanza district. In CN, the Luo had two main methods of producing traditional salt, "kado". The first one entailed the burning of certain, specific vegetation matter which included reeds, special types of grass, leaves of specific trees, peels of green bananas and elusine husks. ${ }^{85}$ These ingredients were burnt and the ashes put in a pot with holes in it; then water would be poured through a filter and collected in another vessel which was placed beneath the pot. This particular salt was used for cooking, especially vegetables. Among the Luos who lived near the lake around Homa Bay, Kendu Bay, and Kisumu salty water from the banks of the lake would be collected and boiled until it evaporated leaving behind a brownish substance which would then be baked in hot ashes to produce the hardened salt "kat-sero." Before the finishing process, the salt would be put into cone shaped baskets/containers to dry. These reed containers made storage and transport easy. Salt production was also mainly done by women. This particular salt was not only used for cooking, but also for medicine. It was, and still is, believed to help with a congested chest. Apart from these traditional industries, the Luos also engaged in economic activities such as trade.

\section{Trade}

Trade is an important economic activity which has been necessary in all civilizations due to diverse resources found in various places. This view is corroborated by Charles Ambler who postulates that economic variation often led to trade involving communities with ecological

\footnotetext{
${ }^{84}$ Wandiba, “Crafts and Manufacturing Industries”, 28.

${ }^{85}$ Ibid., 23.
} 
differences ${ }^{86}$ Trade in pre-colonial western Kenya could be divided into two. First was the Lake Victoria trade which was more international since it connected the fishing industry of the three East African countries and had existed for a long time, and had well established links. ${ }^{87}$ For example, people from Buganda and Busoga of Uganda not only traded with the Abakunta and later Abasuba of Mfwangano Island but also the Luo of the Yimbo Kadimo area. This trade continued even in colonial times when the boundary was redrawn to put the then eastern Uganda into Kenya. Trade items brought from Uganda included iron ornaments such as leg rings and bangles, and most importantly bananas locally known as "ugeke." These were exchanged for fish, goats, and sheep. Also the Mfwangano people sold fish to the people of the mainland such as Kaksingiri, Roo, and Ragwe. From the mainland traders, the people of Mfwangano, and Rusinga got milk, hide, goats, and sheep to barter at Mohuru and Musoma in Tanganyika.

The Abakunta's trading link was the most interesting. They would sail to Busoga to exchange goods for bananas, "ugeke", and iron implements. Bananas were for their own consumption, but iron was traded to the Luos of Yimbo on their way home. From Yimbo they also got poisoned arrows to sell to the mainland. The people of Yimbo also captured people who they sold into slavery to Buganda and Busoga people. Other slaves were retained in Mageta Island to work on cassava plantation. ${ }^{88}$

The Luo also participated in regional trade with their neighbors, such as the Gusii and the Luyia. For example, the Gusii, who occupied the fertile highlands, traded with the Luo who were predominately cattle keepers. The Gusii traded grain, spears, arrowheads manufactured at Kitutu and North Mugirango. Soapstone was an important item of trade found at the hill tops of Majoge. The Luos used the soapstone dust for decoration among the heroes especially those

\footnotetext{
${ }^{86}$ Charles Ambler, as quoted in Ochieng' "Kenya’s Internal and International Trade”, 39.

${ }^{87}$ Ochieng', An Outline History of Nyanza, 58.

${ }^{88}$ Ibid., 60.
} 
who were courageous enough to kill a lion or leopard. ${ }^{89}$ Axes and leopard skins were also exchanged for fish. The Luos used the leopard skin as dressing for clan elders during ceremonies. The Gusii got salt, cattle, hides, ghee, milk, drums, baskets, and pots from the Luos. Baboon skins were also special commodities sold to the Luo magicians and witchdoctors to make their concoctions; this item was highly priced and was bartered to Luos especially by the Wanjare Gusii. ${ }^{90}$ With the Luyia, the Luo traded livestock and livestock products in exchange of grain, clay pipes, hoes, and iron ore, especially from the Samia, who also exported boats to the Luos. One boat would exchange for five bulls. From Bunyala the Luos imported canoes. Trade in foodstuffs was mainly conducted by women who in most cases were protected by members of the communities such as the warriors. However, the exchange of livestock, canoes, and hides was mainly conducted by men from the communities involved. Thus trade and marketing were based on the requirements of the communities or villages involved, to supplement the own local consumption. However, the Luo also practiced agriculture, although the areas they settled in were not as fertile as the lands of their neighbors, such as the Gusii.

\section{Crop Cultivation}

The ecology of Nyanza is important in trying to understand the farming practices adopted by the Luos in the area under review. In most cases, the natural environment determines the activities of a particular people. Van Zwanenberg and King contend that man is basically an adapter since he has the ability to manipulate and adapt to his environment. ${ }^{91}$ The same could be said of the Luo who adapted and picked up farming as an economic activity. Moreover, we find that the presence of Lake Victoria impacted the area due to the effects of conventional rainfall

\footnotetext{
${ }^{89}$ Ibid., 63.

${ }^{90}$ Van Zwanenberg with King, An Economic History of Kenya and Uganda, 149. See also Ochieng' "Kenya's Internal and International Trade”, 39.

${ }^{91}$ Van Zwanenberg with King, An Economic History of Kenya and Uganda, xvi.
} 
patterns making farming possible. The area had two rainy seasons; the long and the short rains with an average of fifty inches. Sometimes they had to contend with rain failures and delays. Furthermore, the agricultural potentiality of an area is also marked by the type of soil in the region. The soils of Kibos-Muhoroni varied tremendously. For instance, the area near the Nandi foothills was very fertile, but the soil became poorer as one moved towards the Kenya/Uganda railway line. However, the area along the river Nyando had good cotton soil.

Thus the Luo farmed to supplement the fishing and livestock keeping as their main source of livelihood. In the indigenous land tenure system, almost everybody owned land and so those who wanted to could engage in farming. The Luos practiced shifting cultivation to rest the land. However, in the Kibos-Muhoroni area, most people also practiced transhumance due to the fact that the area was prone to flooding. Hence, the farming pattern was influenced by the ecology of the area. Moreover, the characteristics of traditional farming in Nyanza were marked by fragmentation just like other parts of Kenya. This occurred as a result of the traditional land tenure system where land was subdivided to kin. Although this method has been criticized as backwards and unproductive, it minimized the possibility for destruction of crops from natural disasters such as locusts, hailstorms, and tropical storms. Basically, this was a kinship mode of production where the farms were worked by family members, mainly a man, his wife, and their children. The men normally engaged in clearing the bushes, opening virgin lands, and breaking up of the ground while women and girls did much of the sowing, cultivation and weeding. During weeding and harvesting, it was common for families to seek the help of other members of the clan and friends, known locally as "Josaga", who carried out the task and were repaid in kind, either through provision of reciprocal labor or by giving food and traditional beer "kongo" at the end of the day's work. 
Many tools were used in farming, for example, axes which were used to fell trees and uproot tree stumps, while machetes were used for clearing the bush. The Luos basically used hoes for digging and weeding. Hoes were imported from the Samia who had a well developed iron working technology. Crops cultivated included sorghum, finger millet, sweet potatoes, and varieties of vegetables. Women kept small vegetable gardens near the villages, in most cases behind the homestead. These were known as "orundu" where they grew also pumpkins which had originated from the Americas and by the late $15^{\text {th }}$ Century had reached East Africa via the West coast of Africa. With the onset of colonial rule, the Luo planted other crops such as mtama and wimbi (elcusine grain) and cassava (manioc), mainly for subsistence. However, delays in rainfall which were sometimes experienced made the Luo to supplement farming with other activities such as fishing, as earlier discussed.

It has emerged from the foregoing discussion that the Luos engaged in various economic activities within the indigenous economy. Not only did they practice cattle keeping which was very significant to the community, but also fishing in the nearby rivers and Lake Victoria. Other economic activity involved trading with the neighboring communities, such as the Gusii in the South and the Luyia in North Kavirondo districts. Apart from trading, the Luos also were involved in production of many goods through the thriving traditional industries that existed which included woodwork, pottery, basketry, and salt making. Last, but not the least, the Luos also practiced agriculture which was made possible through acquisition of land based on indigenous land tenure system which ensured and safeguarded against landlessness. The Luos thus cultivated a variety of crops using the kinship mode of production where labor was provided by the individual household. However, this pre-capitalist mode of production was primarily undertaken for subsistence purposes. Needless to say, in these indigenous economic activities, it 
has emerged that labor was divided along gender lines. Like any production based on land, the coming of Asian farmers had a huge impact. Not only did it create tension between the Luos and the Asians, but also it brought the introduction of commercial farming. Most significantly, the onset of colonialism and the settlement of Asians eroded this traditional agricultural system since it not only introduced cash crop farming, as in the case of sugar at Kibos, but also a new concept of land ownership.

\section{Asians vs. Africans: Conflict of Interest}

With the establishment of colonial rule, the entry of non-natives such as Europeans and Asians into Nyanza Province was of much concern to the people. Land was alienated and the traditional agricultural system was interfered with. For example, the kinship mode of production slowly started to ebb away. A new concept of land ownership, and labor as a commodity, was introduced which impacted heavily on the indigenous production. For instance, in Kibos the colonial state had alienated land for Asian settlement by 1903. During this period the people in the area had no means to contest the situation successfully due to the colonial regulations put in place which demanded that each tribe could only claim land which it had occupied in precolonial times. If this could not be proven, then the land could be alienated without compensation. Moreover, by 1930, Nyanza experienced population growth and so the Luos of Kibos-Muhoroni, through the Kavirondo Taxpayers Welfare Association, claimed that the land settled by the Asians belonged to them under the traditional system of land tenure, despite the fact that it had been alienated under the Crown Lands Ordinance of 1902. Therefore, in 1933 the Kavirondo Taxpayers Welfare Association submitted a memorandum during a hearing of the 
Kenya Land Commission. The association thus demanded compensation for the land alienated for Asian settlement. ${ }^{92}$

Unfortunately the Kenya Land Commission did not make any recommendation for the compensation to the Luo community at Kibos. Yet the Luo claim over the land was justified since it was not an empty land. The area, being on the edge of Luo land though not farmed, was used for grazing purposes and also acted as a buffer zone between them and the Nandi people. Moreover, by allocating this land to the Asians it also prevented the two communities from natural expansion should their population increase.

Despite the fact that CN experienced very little alienation of land before 1930, Africans were opposed to any type of land alienation in the province. Yet Asians were attracted to the province not just for sugar growing but also due to the perceived opportunity it could offer in trading and sale of African produce. These opportunities encouraged many Asians to move to Nyanza Province.

Needless to say arable land was very limited in Kenya as a whole, and so it was not surprising when the Africans (Luos) received very little help from the colonial state. This was due to the fact that the state had initially believed that the peasant economy was not viable towards making the colony self-sustaining. Moreover, there was dissatisfaction between the Asians and the Africans who felt that the colonial state was not helping them enough. On the other hand, the Asians were receiving preferential treatment, such as being given land and trading licenses. The racial strain was also a result of what the Africans perceived as the monopoly of wholesale and retail trade in the province. The Africans were becoming frustrated at being outwitted by the Asians in trading. It was this feeling of let down by the colonial state that made the Kavirondo Taxpayers Welfare Association start cooperative self-help groups in the

\footnotetext{
${ }^{92}$ Fearn, An African Economy, 93.
} 
1920s, particularly in grain milling, which competed effectively with the Asians in the processing of the local produce. ${ }^{93}$

Nevertheless, Africans had no capital to rival the Asians in trade or in establishing the sugar farms. Moreover, mistrust existed between the Africans and the Asians. The latter were perceived as people who came to make money, accumulate and go back to their country. This dislike has been broadly discussed by Atieno Odhiambo who concludes that the emergence of the Luo Thrift Corporation was basically a rebellion by the Luo against the Asian monopoly in trade in Nyanza, and generally against the colonial state which ignored African entrepreneurship. ${ }^{94}$

Thus we find that the settlement of Asians at Kibos was not welcomed openly by the local community since by extension their settlement led later to loss of land that was a buffer zone and was used for grazing. Yet when we examine the contribution of the Asian community to the economy of Nyanza before 1930, we find that the Asians did a lot towards building the economy through the export of produce. They also contributed in agricultural progress through their experimentation with many crops which benefitted the area later. Although it was small scale, crops like rice and chili, later proved worthwhile. In trade, despite the fact that they were also perceived negatively as being dishonest, they boosted trade by bringing to the local people new consumer goods, such as bicycles and soap, which were exchanged for the local grown produce, such as millet. This settlement of Asians at Kibos had an impact on the people they found in the area, especially the introduction of commercial sugarcane farming as will be discussed later.

\footnotetext{
${ }^{93}$ Atieno Odhiambo, “Economic Mobilization and Political Leadership”, 143.

${ }^{94}$ Ibid., 145-155.
} 


\section{Conclusion}

This chapter has examined the migration of the Luos into Kenya and their subsequent settlement in Nyanza Province and particularly CN district. The chapter has also discussed the indigenous land tenure system and the indigenous economies that the Luos of Kibos-Muhoroni engaged in before the advent of Asian cane farming. Colonial land policies have also been discussed, and it emerged that they were biased against the Asians which led to a lot of racial tension especially between the Asians and the white settlers who were prepared to do anything to keep the Asians not only out of the fertile lands but also out of the colony. The land controversy also affected the Luos who made efforts to have their voices heard, but were ignored by the Kenya Land Commission. They were neither allowed to get lands in the fertile highlands, nor were they compensated for land alienated to Asians. The chapter also introduces the eventual colonization of Kibos by Asians and the beginning of Asian agricultural initiative at Kibos and especially beginning of the sugar plantations which were categorically divided into nine areas as earlier discussed that forms part of discussion in the subsequent chapters. 


\section{CHAPTER 4}

\section{ASIAN SUGARCANE FARMING IN COLONIAL NYANZA}

\section{Introduction}

The previous chapter discussed the indigenous land tenure system and the pre-colonial economies that prevailed in $\mathrm{CN}$ district before the penetration of the Asian farming. The chapter also examined the colonial land polices, the settler politics and how they affected the Asian farmers in Kenya, particularly in getting land. However, we saw that by 1903 a sizable number of Asian farmers settled at Kibos, dislocating some of the Luos in the process. These Asians then started mixed farming, keeping cattle and even introduced the rearing of pigs while experimenting with various crops including sugar. The farmers were settled in nine areas.

This chapter discusses how Indians eventually embarked on sugar cane growing as a major crop despite that fact that they continued to keep animals and grow few other crops such as maize. It also examines their initiative in sugarcane growing over the years, particularly how their numbers, land holdings and sugarcane farms increased in acreage alongside settler farming in the area. European farmers were also involved in cane growing, besides other crops like sisal and coffee. It discusses the agricultural aspects of cane farming in colonial Nyanza and the many challenges faced. The chapter also examines their performance in sugarcane farming during the colonial period. It finally illuminates the technical assistance given to the farmers by the colonial state through experimentations carried out in various areas of cane farming using different paradigms such as trials for sucrose, drought resistant varieties, irrigation and spacing among others. These experiments, which facilitated the expansion of the sugar industry, were quite important. Despite problems faced, such as environmental factors, lack of capital to buy 
machinery, diseases among others, the sugar industry was able to overcome the challenges by 1950 to be a vibrant industry in CN.

\section{Asian Sugarcane Farming in Colonial Nyanza: The Pre-World War I Period, 1903-1913}

The beginning of Asian farming in Kenya was not easy. The pioneer growers started farming in earnest after European settlers had begun to cultivate in the white highlands. These European settlers acquired land much earlier than the Asians. For example, by 1902 there were about 30 European settlers in Kenya, and they did not want the Asians to be given land. The opposition was not only based on racial prejudice, but also fear of possible competition. This view is corroborated by McGregor Ross who argued that the white settlers did not want Asians to benefit from possible land speculations. ${ }^{1}$ Thus due to pressure from settlers, Asians had a difficult time in getting land, while European settlers were offered generous grants by Eliot. Later, Eliot conceded and advocated for Asians to be settled at Kibos, as stated in the earlier chapter. By this time there was already a sizeable population of Asians in the country. ${ }^{2}$ When the Asian settlement scheme was inaugurated, the very first pioneers were 12 Indian laborers who got between 5 and 15 acres. A few months later, they were joined by other ex-railway workers, and the number increased to 30 farmers. The farm size also increased, from between 50 to 100 acres. Most of these were poor; hence, they were given seeds, farm tools and a little financial assistance.

It is thus clear that the pioneer Asian settlers of Kibos were mainly ex- railway workers. Some were offered land along the railway line between Kibos and Muhoroni. ${ }^{3}$ The land occupied, as discussed in the preceding chapter, was not empty; hence, some Luos were

\footnotetext{
${ }^{1}$ McGregor Ross, Kenya from Within, 309.

${ }^{2}$ Sorenson, Origins of European Settlement, 37.

${ }^{3}$ M.F. Hill, Permanent Way: Story of the Kenya- Uganda Railway and Harbours (Nairobi: East African Railway and Harbours , 1949), 253-254.
} 
displaced with minimal compensation. For example, Anyang' Nyong’o indicates that about 37 villages in the Kibos area and another 60 in Miwani were alienated to the Asians. ${ }^{4}$

The Asian farmers then started growing a variety of crops, including rice, cotton, sesame and linseed. The numbers of these Asian farmers increased a little, from 30 farmers in 1903 to 34 in 1907, when four more Punjabi farmers were able to join the Kibos settlement after the visit by Waller, who had initially surveyed the land and allotted the plots, to India in an effort to recruit more farmers. This was as a result of the recommendation by Sir Edward C. Buck, the secretary of the Department of Revenue and Agriculture in the Government of India, who had visited the protectorate earlier in 1905 . He advocated for more Indians to go to Kibos because he was impressed by the work of the pioneer settlers. The four Punjabis who were able to come from India acquired 600 acres. $^{5}$

This trend of more colonization of the lowland was to continue for in 1912, 21 more Asian farmers were able to acquire land in the Kibos-Muhoroni area through government auction near Muhoroni Township. Each obtained 50 acres; hence, about 1,051 acres was added to the Asian holdings. During the same period, another 21 Asian farmers rented farms at Muhoroni. All this attests to the fact that Asians were increasingly becoming interested in farming in the region. The result was that by 1913 there were approximately 75 farmers in the Kibos-Muhoroni area with a total acreage of 2,623.55. ${ }^{6}$ This acreage was greatly increased when, during the same period, the London based Asian company; Messrs Imhazali \& Sons-purchased a large estate, the Kisumu Rubber Estate, at Kibos. The latter contained 6,122 acres of land. Fearn erroneously

\footnotetext{
${ }^{4}$ Peter Anyang' Nyong’o, “The Development of a Middle Peasantry in Nyanza”, Review of African Political Economy 20 (1981): 110.

${ }^{5}$ Gregory, India and East Africa, 70.

${ }^{6}$ KNA: DC/CN/1/5/1, Kisumu District Annual Report (KDAR) 1912-13.
} 
refers to the estate as owned by a European firm contrary to the archival sources. ${ }^{7}$ This fact is corroborated by Osamba in his work on the Asian farmers in Kisumu district where he discuses the struggles of the Asian rubber company which belonged to the Imhazalhi family. ${ }^{8}$ Therefore, it emerges that, contrary to existing literature, the total acreage of Asian farms, small scale and large scale, amounted to approximately 8,734 acres in $1913 .{ }^{9}$ Hence, we find that from the initial number of 12 pioneers in 1903, by 1913 there were approximately 35 Indian farmers settled in the Kibos settlement scheme as indicated in the table below.

Table 4.1: Kibos Indian Settlement and Land Acreage, 1913

\begin{tabular}{|c|c|c|c|c|}
\hline Farm No. & Farmer & Acreage & Type of lease & Price/Rent \\
\hline 1 & Kharka Ram \& Labu Ramm & 39.40 & Freehold & Rs. 200/= \\
\hline $1 \mathrm{~A}$ & Kharka Ram \& Labu Ramm & 60.67 & Freehold & \\
\hline 2 & Vali Hasham \& Co. & 50.0 & Freehold & Rs. $100 /=$ \\
\hline 3 & Chowdri Ram Jowaya & 25.00 & Freehold & Rs. $50 /=$ \\
\hline 4 & Mokanjee & 50.00 & Freehold & Rs. $100 /=$ \\
\hline 5 & George Mathew & 45.5 & Freehold & ------------ \\
\hline $5 \mathrm{~A}$ & George Mathew & 58.0 & Freehold & ------------- \\
\hline 6 & Jagat Singh \& Surean Singh & 54.9 & Freehold & Rs. $210 /=$ \\
\hline $6 \mathrm{~A}$ & Jagat Singh \& Surean Singh & 50.9 & Freehold & \\
\hline 7 & Gujar Ram & 35.2 & Freehold & Rs. 70/= \\
\hline $7 \mathrm{~A}$ & Malawa Ram Probdial & 51.0 & Freehold & Rs $100 /=$ \\
\hline 8 & Harriram Probdial\&Co & 50.0 & Freehold & Rs. 200/= \\
\hline $8 \mathrm{~A}$ & Harriram Probdial \&Co & 50.0 & Freehold & \\
\hline 9 & Veharibhay C. Patel & 50.0 & Freehold & Rs. $200 /=$ \\
\hline 9A & Veharibhay C. Patel & 50.0 & Freehold & \\
\hline 10 & Pala Singh & 30.84 & $\begin{array}{l}\text { Leasehold } 99 \text { yrs. } \\
\text { from 1-1-09 -rent }\end{array}$ & Rs. $18 /=$ \\
\hline 11 & Jagat Singh \& Surean Singh & 88.2 & $\begin{array}{l}\text { Leasehold } 99 \text { yrs. } \\
\text { from 1-6-10 }\end{array}$ & Rs. 29/= \\
\hline 12 & $\begin{array}{l}\text { A.A. Visram \& Jan Mohamed } \\
\text { Giga }\end{array}$ & 50.00 & Freehold & Rs. $100 /=$ \\
\hline $12 \mathrm{~A}$ & $\begin{array}{l}\text { A.A. Visram \& Jan Mohamed } \\
\text { Giga }\end{array}$ & 50.00 & Freehold & Rs. $100 /=$ \\
\hline 13 & Malawa Ram Probdial & 24.50 & $\begin{array}{l}\text { Leasehold } 2 \text { yrs. } \\
\text { from 5-2-11 }\end{array}$ & Rs. $17 /=$ \\
\hline
\end{tabular}

${ }^{7}$ Fearn, An African Economy, 96.

${ }^{8}$ Osamba, “A Forgotten Minority”, 3.

${ }^{9} \mathrm{KNA}$ : DC/CN/1/5/1, KDAR 1912-13. 


\begin{tabular}{|c|c|c|c|c|}
\hline 14 & Gulam Moyud Din & 50.00 & Freehold & Rs. $100 /=$ \\
\hline 15 & Mohamed Din Alla Jawaya & 25.00 & Freehold & Rs. 50/= \\
\hline 16 & Gujar Ram & 50.00 & Freehold & Rs. $100 /=$ \\
\hline 17 & Gujar Ram & 50.00 & Freehold & \\
\hline 18 & Abdul Majid \& Chetu & 100.50 & Freehold & Rs. $200 /=$ \\
\hline 21 & Dewa Singh \& Sodager Singh & 7.60 & $\begin{array}{l}\text { Leasehold } 99 \text { yrs. } \\
\text { from 1-1-09 }\end{array}$ & Rs. $15 /=$ \\
\hline 22 & Karaka Ram \& Labu & 7.0 & $\begin{array}{l}\text { Leasehold } 99 \text { yrs. } \\
\text { from 1-1-09 }\end{array}$ & Rs. $15 /=$ \\
\hline 23 & Koloo Ram & 14.40 & $\begin{array}{l}\text { Leasehold } 99 \text { yrs. } \\
\text { from 1-1-09 }\end{array}$ & Rs. 15/= \\
\hline 24 & Bhai Dan Devi & 79.00 & $\begin{array}{l}\text { Leasehold } 99 \text { yrs. } \\
\text { from 1-1-09 }\end{array}$ & Rs. $27 /=$ \\
\hline 26 & Koloo Ram & 12.0 & $\begin{array}{l}\text { Leasehold } 99 \text { yrs. } \\
1-1-09\end{array}$ & Rs. 15/= \\
\hline 27 & Koloo Ram & 36.4 & $\begin{array}{l}\text { Leasehold } 99 \text { yrs. } \\
\text { from 1-1-09 }\end{array}$ & Rs. 19/= \\
\hline 39 & Jamna Dass Karamsi & 54.4 & $\begin{array}{l}\text { Leasehold } 99 \text { yrs. } \\
\text { from 1-6-10 }\end{array}$ & Rs. 23/= \\
\hline 40 & Gurma Singh \& Buta Singh & 50.0 & $\begin{array}{l}\text { Leasehold } 99 \text { yrs. } \\
\text { from 1-6-10 }\end{array}$ & Rs. $22 /=$ \\
\hline 41 & Gobind Ram \& Koloo Ram & 50.0 & $\begin{array}{l}\text { Leasehold } 99 \text { yrs. } \\
\text { from 1-6-10 }\end{array}$ & Rs. $22 /=$ \\
\hline 42 & Jagat Singh \& Surean & 44.0 & $\begin{array}{l}\text { Temporary } \\
\text { occupancy for } 2 \\
\text { yrs. from 5-2-11 }\end{array}$ & Rs. $21 /=$ \\
\hline 43 & Inder Singh \& Munshi Ram & 50.0 & $\begin{array}{l}\text { Leasehold } 99 \text { yrs } \\
\text { from 1-11-10 }\end{array}$ & Rs. $22 /=$ \\
\hline 44 & Ladha Ram & 50.0 & $\begin{array}{l}\text { Leasehold } 99 \text { yrs. } \\
\text { from 1-6-10 }\end{array}$ & Rs. 22/= \\
\hline 45 & Sadhu Singh & 50.0 & $\begin{array}{l}\text { Leasehold } 99 \text { yrs. } \\
\text { from 1-6-10 }\end{array}$ & Rs. $22 /=$ \\
\hline 46 & Malawa Ram Probdial & 50.0 & $\begin{array}{l}\text { Leasehold } 99 \text { yrs. } \\
\text { from 1-9-10 }\end{array}$ & Rs. 22/= \\
\hline 47 & Jagat Singh \& Surean Singh & 14.60 & Freehold & Rs. 30/= \\
\hline 48 & $\begin{array}{l}\text { Messrs Imhazalhi \& Sons } \\
\text { (Kissumu Rubber Estate) }\end{array}$ & $6,122.0$ & $\begin{array}{l}\text { Leasehold } 96 \text { yrs. } \\
\text { from 5-1-10 }\end{array}$ & Rs. 920/= \\
\hline
\end{tabular}

Source: KNA: DC/CN/1/5/1, KDAR 1912-13.

The above data indicates that as early as 1913 there was one European, a George Matthew, among the farmers. He later sold his farm to Bresler and Starr. The table also revealed that the terms of occupancy were not the same for all land holders. For example, apart from freehold and leasehold, there was also a temporary occupancy of two years in Kibos. This 
was an exception since this type of tenancy was mainly found at Muhoroni. Even the leaseholds were different. Whereas almost all were of 99 years, that of the Kisumu Rubber Company was for 96 years, starting from January 1910. Finally, it also emerges that, apart from the Kisumu Rubber Company, the other Asian farms ranged between 100.5 acres to 7.0 acres. Not all Asians got 50 and above acres. There were also farmers with multiple plots of land. For instance, Jagat Singh and Surean owned both plots number 42 and 47.

The Kisumu Rubber Company was given a clear condition of developing their farms as per the lease. That is the company had to spend approximately 1,600 pounds for the first five years; in the first year, 165 acres were expected to be cultivated, 330 acres in the second year and 496 in the third year. Although this farm was engaged in growing rubber as the main crop, other crops were planted as well. For about ten years, the Kisumu Rubber Company experimented with rubber, but all in vain. ${ }^{10}$ The lease of this company raises pertinent issues. Even if they were absent landowners, it is not clear why such stringent measures were part of the lease, yet we know that many European farmers had large estates. Some were absentee landlords as well with few such strict conditions.

However, there were many cases where farmers owned several strips of land in different part of the Asian settlement. For example, a farmer could have one strip in Kibos and another at Miwani with holdings varying from fifty acres to about 800. A case in point is Maganbhai Patel who owned land at Kibigori and Miwani. In these types of farms, some of the land was held on yearly or two years occupancy from speculators. ${ }^{11}$ The farmers mostly lived on their farms and worked it, or, in some, partnership was practiced whereby one partner worked the farm in Kenya

\footnotetext{
${ }^{10}$ Joshia Osamba, “Colonial African Labour in Asian Owned Sugar Plantations in Kisumu District, 1901-1963”, M.Phil. Thesis, Moi University, 1996, 43.

${ }^{11}$ KNA: PC/NZA/3/22/1/8, Report by Magor of a visit to Indian farms in the area of Kibos-Miwani-KibigoriChemelil, $6^{\text {th }}-10^{\text {th }}$ October 1947.
} 
while the other resided in India, or did business in Nairobi or Kisumu. For instance, Dhanwant Singh, who owned a farm at Miwani, was also an advocate at Kisumu. Satbachan Singh was an inspector of police, while even Maganbhai Patel, who had several farms as earlier stated, was also a straddler. He had a flourishing business in Kisumu as a money lender. ${ }^{12}$ Furthermore, some Asians settled at Muhoroni by 1912, but under very different conditions. For instance, at Muhoroni the farmers were only initially granted farms on a two year occupation license which began on $10^{\text {th }}$ August 1912. These farmers were 21 in number, as indicated in the following data. It is not clear how and when, if at all, the licenses were renewed.

Table 4.2: Muhoroni Indian Settlement Farms Granted on Two Years Occupation License on $10^{\text {th }}$ August, 1912

\begin{tabular}{llll}
\hline Farm No. & Farmer & Acreage & Price/Rent \\
\hline 2 & Fateh Chand & 50.00 & Rs. 22/= \\
3 & Allidina Visram & 51.6 & Rs. 22/= \\
4 & Hasham Jamal \& Co. & 48.1 & Rs. 22/= \\
5 & Hussein Abdul Rassul & 51.3 & Rs. 22/= \\
7 & Rashid Khamis & 55.00 & Rs. 23/= \\
8 & Mohamed Bux & 50.00 & Rs. 22/= \\
9 & Alibhai Kassim & 50.00 & Rs. 22/= \\
10 & Mohamed Majid & 52.8 & Rs. 22/= \\
11 & Mohamed Kassim & 51.2 & Rs. 22/= \\
14 & Sheik Noor Din & 50.0 & Rs. 22/= \\
15 & K.M. Bhogaita Bros. & 50.0 & Rs. 22/= \\
16 & Moladad Dolatakha & 48.7 & Rs. 22/= \\
17 & Ava Dan & 51.3 & Rs. 22/= \\
18 & Sultani Ram & 50.0 & Rs. 22/= \\
19 & Abdul Wahid & 51.3 & Rs. 22/= \\
20 & Gulam Mohamed & 50.0 & Rs. 22/= \\
21 & Jalal Din & 52.1 & Rs. 22/= \\
\hline & Total & $863.4 a c r e s$ &
\end{tabular}

Source: KNA: DC/CN/1/5/1, KDAR 1912-13.

The above data indicates that even if a farmer had 48 and another 51 acres, a difference of three acres, they all paid the same annual rent of Rs. 22/=. This did not include Rashid ${ }^{12}$ Ibid. 
Khamis who had 55 acres and paid Rs.23/=. The tenure on this settlement was based on a temporary occupation of two years. Some of the farmers who had acquired land in Kibos also rented farms at Muhoroni, for example Allidina Visram. However, there was no big variation of acreage of the farms in Muhoroni as was found in the Kibos settlement.

The location of the Asian sugarcane farms and the few European farms is important to consider in the growth of the industry. The farms were situated to the north in Nandi district, stretching from the foot of the Nandi escarpment towards the Kenya-Uganda railway line. To the south, the farms bordered West Kano, Kisumu and East Kano locations of CN and also Kericho District. Hence, they were situated conveniently to the main railway stations from Muhoroni to Kisumu. This proved very appropriate since the rail line facilitated transportation not only of cane from the farms but also other products such as fertilizers, farm tools and labor. The fact that the farms were scattered near the railway line thus made it easier to move from one farm to the other, not only by the farmers but also for supervision by the agricultural officers. The farms were strategically located as shown in the map below. 


\section{Map 4.1: Asian Sugarcane Plantations}

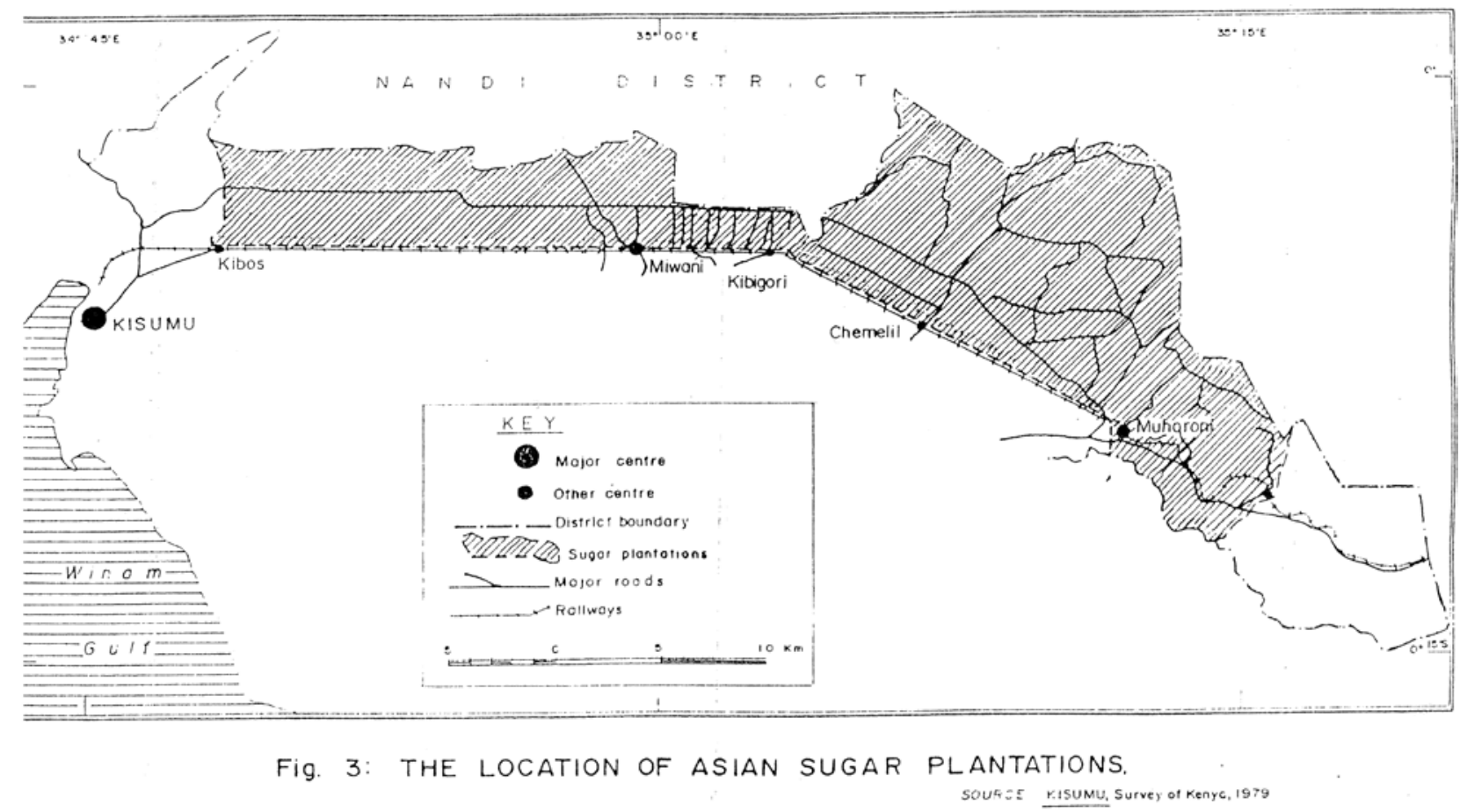

Source: Kisumu, Survey of Kenya, 1979.

From the above figure, it is evident that the farms that were within the accessibility of the railway benefited in transportation services. Moreover the location of the farms near the railway was found to be very convenient during the harvesting period as will be discussed later. Unfortunately, we find that the farms in Chemelil and Muhoroni were situated far from the main factory at Miwani. Despite the availability of the railway, growing of cane could be expensive due to costs incurred in transportation of cane. This proved significant in the sense that it revealed the colonial state's neglect of the Asian sugar industry by not taking advantage of the strategic location of the Asian sugar cane farms to boost the industry through negotiation with the Kenya-Uganda railway for subsidized transportation costs.

Be that as it may, the Asian farmers by 1913 had started growing sugar experimenting with a variety known locally as Uba, originally from Natal in South Africa. By the time the 
Asians started cane farming, Uba had long been in country. ${ }^{13}$ Sugarcane already existed in Kenya, contrary to the belief that Asians introduced sugarcane. What ensued was that when Asians started cultivation, they introduced other varieties and commercial farming. Thus they revolutionized cane farming in Kenya completely.

During the infancy stage, the farmers relied on any information and knowledge from India, and the colonial state encouraged the cane farmers. Therefore as early as 1913, the CO which was a variety imported from Coimbatore, a renowned sugar research station in India, began to be experimented on in Kenya. There were many types, such as CO 221, CO 290 and CO 421. The imported seedlings were distributed to the farmers who, apart from using trial and error methods, were assisted at this early stage by the office of the provincial director of agriculture who not only encouraged them, but was the main driving force behind the early experimental trials on the Asian farms. ${ }^{14}$ Therefore Asians, who had the majority of farms, then embarked on growing cane both at Kibos and Muhoroni.

There were also a few European sugarcane farmers in the Kibos-Muhoroni area as well. Almost all were found at Muhoroni, although later some settled at Miwani, Kibigori and Chemelil. During the early period of cane farming, most European farmers in the district were found at Muhoroni. Therefore, the Muhoroni area was not exclusively occupied by Asians; the European settlers had occupied the area as early as 1911. However, it is difficult to ascertain how many acres they had. The Europeans who settled in Muhoroni area by 1911 were just as few as the Indian farmers in that area. For instance, whereas there were 21 Indian farmers in Muhoroni, there were approximately 26 occupants in the European farms as indicated in the data below.

\footnotetext{
${ }^{13}$ Colony and Protectorate of Kenya, Department of Agriculture Annual Report (DAAR) 1919-1920 (Nairobi: Government Printer, 1921), 126.

${ }^{14}$ KNA: PC/NZA/3/3/22, Sugar Cane Industry, 1913.
} 
Table 4.3: European Settlers at Muhoroni, 1911

\begin{tabular}{|c|c|c|c|}
\hline Farm No. & Name of Farm & Name of Owner & Name of Occupier \\
\hline 642 & & Hale & Hale \\
\hline 449 & & I. Clerk & W.B. Saul \\
\hline 450 & Pendet Estate & Capt. S.H. Charrington & $\begin{array}{l}\text { Capt. S.H. Charrington, N.D. Allen, W. } \\
\text { Wilmont Eardley }\end{array}$ \\
\hline 451 & Koru Farm & C. Harvey & C. Harvey, J.P. Kotze \\
\hline 452 & Fair Garden & Play Fair and Gardner & Mr. \& Mrs. G. Hampson \\
\hline 453 & & Capt. O’Brien & Mr. \& Mrs. J. Klopper \\
\hline 454 & Soba Estate & Duirs \& Wheelock & E. Brown \\
\hline 455 & Mbogo Vale & P. Guy & E.E. Hutchins \& C.P. Hutchins \\
\hline 456 & Tinderet Estate & Seth Smith \& Tetley & E. Tarlton \\
\hline 458 & & Smith \& Faucus & H. Hannay \\
\hline $458 \mathrm{~A}$ & Usone & M.A. Harbord & Mr. \& Mrs. M.A. Harbord \\
\hline 459 & & Dunman & J.A. Randall \\
\hline 460 & Maraba Estate & J. Mckinnon & $\begin{array}{l}\text { H.M. Harries, Mr. \& Mrs. Bezedenhout, } \\
\text { Child \& Brother-in-law }\end{array}$ \\
\hline 1461 & Thousand Springs & Stocker & O.C. Harries \\
\hline 1462 & & F. Fletcher & E.A. Phelps \\
\hline 1463 & & E.A. Webb & A. Cook \\
\hline 1464 & Red Hill & J.M. Penruddock & J.M. Penruddock \\
\hline 1465 & Mberere & B.F. Webb & B.F. Webb \& J. Mortishaw \\
\hline 1466 & & Wessells & Geldenheuse \\
\hline \multirow[t]{2}{*}{1467} & Chemalich Farm & A. Montgomery & \\
\hline & $\begin{array}{l}\text { Songhor Estate } \\
\text { Kepchera Estate }\end{array}$ & $\begin{array}{l}\text { Lord Kitchner } \\
\text { Major MsMurdo \& } \\
\text { Major Fitzgerald }\end{array}$ & W.E. Perry \\
\hline 1474 & Kamassio Height & F. De Cergit & W. Cockburn \\
\hline \multirow[t]{2}{*}{1475} & Mount Seret & J.W. Wright & E.T. Behn \\
\hline & Mtete Valley & F. S. Clarke & F.C. Burmeister \\
\hline
\end{tabular}

Source: KNA: DC/CN/1/5/1, KDAR 1912-13, List of European Residents Muhoroni District.

From the above data, it is evident that in the European settlement at Muhoroni, unlike the Asian farmers, the farms had names; this was the custom for European farmers in Kenya. These were big estates owned either by individuals or companies. Unlike the Kibos-Muhoroni Indian farms, a majority of the owners were not the occupants who worked the land. For instance out of the 23 European land owners, only 5 occupied their respective farms, thus the other 18 occupants 
were not farm owners. This partly explains why the total acreage put under cultivation on European farms was far below that of the Asian farms. Moreover, this data clearly depicts how inaccurate Swainson's argument that there were no European settlers around the MiwaniMuhoroni area. ${ }^{15}$ Other European farms also were later purchased, such as the Drumeen Estate that was growing sugar and had its own jaggery factory. Also, Nottidge and Allen got a lot of land in Kisumu District, for example land registration number L R No. 3976 comprising of 1,539 acres, L R No.5977 of 2,339 acres, and another parcel of land, L R No. 3978, of 1,960 acres. ${ }^{16}$ These European cane farmers would pose as competitors to the Asian cane farmers as concerns labor recruitment as will be discussed later.

\section{Sugar Cane Farming During the World War I Period, 1914 up to 1923}

Generally the European settlers got land more easily than the Indian farmers. For example, the 1915 Crown Land Ordinance was a major boost in European farming in Nyanza as elsewhere. Due to the persistent pressure from the settlers, the outbreak of the World War I in 1914 was a boon to them since the Colonial Office feared to antagonize them partly due to the German threat that was eminent from the neighboring territory of Tanganyika with the onset of the conflict. Hence the settlers had their way and the land bill was passed. ${ }^{17}$ This greatly impacted the Asian farmers whose leases were not changed by the ordinance.

Despite this unfair treatment, Asian farmers had planted 621 acres in sugarcane by 1916. During this period, the area under cane continued to increase and the cane that was produced was

\footnotetext{
${ }^{15}$ Nicola Swainson, The Development of Corporate Capitalism in Kenya (London: Heinemann, 1980), 124. This discrepancy could have been due to the 30 year rule placed on accessing archival sources.

${ }^{16}$ KNA: BN/1/249, Survey and Registration Department to Acting (Ag.) Commissioner for Local Government, Lands and Settlement, $11^{\text {th }}$ July 1932.

${ }^{17}$ Robert Maxon, “The Years of Revolutionary advance, 1920-1929”in Ochieng’ ed., A Modern History of Kenya, 72.
} 
sold in the form of jaggery, which found a ready local market. ${ }^{18}$ The minimal production achieved was probably due to the lack of adequate farming knowledge in cane production as Asian farmers were still at an experimental stage with many crops. Secondly, the fact that there were no machines established for sugar making then meant that production was minimal since the cane that was produced was turned into jaggery (coarse sugar). The small machines that the farmers had were oxen operated crushers, which consequently determined the acreage under cane production. This view is supported by Fearn who argued that before the establishment of the Victoria Nyanza Sugar Company, the Asians mainly cultivated a small amount of sugarcane that was all turned into jaggery. They had to supplement their farming by growing other crops such as maize. ${ }^{19}$

On the other hand, European farming was also expanding as settlers continued to increase in number and acreage of land holdings, especially at the end of the war that saw the implementation of the ex-soldier settlement scheme in 1919. This scheme added 2.5 million acres to the settlers' holdings, part of which were found in Chemelil, Kibigori, Muhoroni and Koru. The farmers who were allocated farms within said areas grew wheat, coffee, sisal and maize. During this period, the contradictory nature of the colonial state was exposed for while, on the one hand, the state was supporting the Asian cane farmers, at the same time due to settler politics, Asians were restricted as to where they could obtain land. For example, Governor Sir Edward Northey, in his address to the Convention of Association in August1920, was reported in the newspaper to have said:

. . . by the time this whole settlement scheme (the soldier settlement scheme) has been readjusted, i.e. that farms which had not turned out to be what it

\footnotetext{
${ }^{18}$ DAAR 1919-20, 5.

${ }^{19}$ Fearn , An African Economy, 106.
} 
was hoped they were would be replaced by something better, there should not be a farm left worth having. ${ }^{20}$

Such statements represented the position of the colonial state, which were criticized by the Government of India. In a rejoinder, the latter sent a dispatch to the Secretary of State for India in which it pointed out the pretence and contradictory land policy. It noted that despite locking the Indians from the white highlands, even the lowlands which they had initially declined as being unsuitable for Europeans due to bad climate, was not spared since land there had also alienated to the Europeans. ${ }^{21}$

However it emerges that even Europeans from other countries did not find it easy to get land in Kenya. A case in point was when in 1919 the colonial state offered land for sale for the production of sugar through the official Gazette, General Notice number 920. It is interesting that instead of the land being offered to the Asians, it was meant for anyone to bid. Thus tenders were invited for the purchase of the lease of an area of 671.6 acres near the Kenya-Uganda railway between Kibigori and Kibos. The terms of the lease were 99 years, effective $1^{\text {st }}$ September 1920, with an annual rent of 44.15 . This amount could only be paid at the office of the Crown Agents for the Colonies in London or at the land office in Nairobi.

Needless to say what followed was the land politics in Kenya. While the settlers protested against Asians being permitted to bid for land in that area, an Italian national bid and the application was declined. This led to uproar and a petition by A.C. Cavicchioni, the Italian consul, on behalf of the Italian Government against the treatment of their national. Cavicchioni criticized the terms of the sale that required one to be a British subject to bid for land. He specifically singled out the divergent treatment between British nationals and foreigners, arguing that it was in opposition to the principle in section 5 of the General and Final Act of the Congress

\footnotetext{
${ }^{20}$ East African Standard, $14^{\text {th }}$ August 1921.

${ }^{21}$ Indian Overseas Association, East African Pamphlet, No. 45, vol 6 (1921), 10.
} 
of Berlin of $26^{\text {th }}$ February $1885 .{ }^{22}$ Regardless of the protestation, the case was dismissed by the Colonial Office on grounds that there was a misinterpretation of Article 5 of the Berlin Act. Consequently, the Governor Northey was advised to dispose of the land according to the powers accorded to him under the Crown Lands Ordinance of $1915 .^{23}$ This event portrays the discriminatory land policies that were rampant in colonial Kenya and were used often to prevent the Asian cane farmers from accessing land as well.

However, the post war era was a period marked by confusion and contradictions of policies on one hand, while tremendous efforts were noted from both Indians and the Europeans. For example, the Asian cane farmers were not discouraged by the biased soldier settlement scheme, although they complained bitterly. Thus we find that by 1919, the Asians of KibosMuhoroni had put 800 acres under cane cultivation; this was up from 621 acres in 1916. Furthermore due to challenges that they faced such as poor infrastructure, as will be discussed later, they organized themselves and formed organizations such as the Kibos Planters Association formed in 1920. These organizations were meant to help the farmers. Meanwhile, the Europeans settlers at Miwani, Kibigori, Chemelil and Koru also started planting sugar and sisal, with some focusing on one crop while others planted both.

It should be noted, moreover, that there were efforts to support sugarcane farming in its infancy stage. For example, by 1920 experimentation of sugarcane had already started in Kibos, and many farmers were becoming more interested. During this period, trials were conducted on varieties such as the Sealy seedling, Uba, B.3922 and B.1528. The last two varieties had poor results. Progress was slow as could be attested to by the negligible increase to only 640 acres that was cultivated and planted with Uba and the Striped Ribbon variety, known locally as

\footnotetext{
${ }^{22}$ KNA:AG/2/19, A. C. Cavicchioni, Royal Consul, on behalf of H M the King of Italy, to Northey, $20^{\text {th }}$ August 1919.

${ }^{23}$ KNA: AG/2/19, J.W. Barth, Attorney General, to Chief Secretary, 20 ${ }^{\text {th }}$ September 1919.
} 
kampala. $^{24}$ On the other hand, Europeans who had settled in the area also by mid 1921 had started cultivation and managed to put 691 acres under cane. ${ }^{25}$ Furthermore, during the same period, land estimated to be 6,000 acres was alienated near Kibos for sugar production and plans were already put in place for the construction of a sugar mill. By then it was believed that the sugar manufactured would be enough to meet the local demand.

Unfortunately, before the farmers in Kenya, both Asians and Europeans could be firmly established in agriculture, the colony faced economic problems in 1921 which were caused by the abnormal rainfall pattern especially in Nyanza Province, whereby most crops, such as maize and sugar, were affected due to a prolonged wet season. The situation was made worse by the fall in prices for agricultural goods which led to poor returns. Despite these problems, the sugarcane industry continued to expand. For example, in 1921, the Victoria Nyanza Sugar Syndicate (the forerunner of the Victoria Nyanza Sugar Company) was formed and engaged in clearing and planting of approximately 1,000 acres of cane. ${ }^{26}$ This initiative saw an increase in area under cultivation. A year later, the area under cane increased to 3,787 acres. ${ }^{27}$ This marked improvement was to continue, and there was a substantial increase when the acreage under cane increased from 3,787 to 4,193 in 1923 . There was now also a ready local market. ${ }^{28}$

\section{Sugar Production during the interwar Period, 1924 to 1938}

There was marked progress in sugar production when in 1923 an Australian pioneer settler, Mr.G.R. Mayers, who came to Kenya in 1920, bought land at Miwani and opened the

\footnotetext{
${ }^{24}$ DAAR 1919- 1920, 126.

${ }^{25}$ Colony and Protectorate of Kenya, DAAR for the year ended $31^{\text {st }}$ March, 1921 (Nairobi: Government Printer, 1922), 21.

${ }^{26}$ Ibid., 139. According to the Report, the whole area stretching from Kibos to Fort Ternan was engaged in sugarcane growing.

${ }^{27}$ Colony and Protectorate of Kenya, DAAR for the year ended $31^{\text {st }}$ December1922 ( Nairobi :Government Printer,1924 ), 21.

${ }^{28}$ Colony and Protectorate of Kenya, DAAR 1923 (Nairobi: Government Printer, 1924), 15. The report indicates that the year was good to farmers as even the European wheat farms at Lumbwa performed well.
} 
Victoria Nyanza Sugar Company which was very near Kibos. This was a major boost to the Indian sugar farmers since the company started to manufacture crystallized sugar. This previously was not the case, and it had limited the acreage put under cane because all sugar was turned into jaggery. The company also started growing cane, but at first did not have enough cane of its own. Since it did not have a large estate, it depended on cane brought from the Indian farmers. For example, the new company contracted with approximately $75 \%$ of the Asian farmers to supply it with cane. To attain this goal, the company was able, after applying to the authorities concerned, to lay side trolley lines as far as Kibos. Due to these efforts, the area under sugarcane plantation increased by 1,049 more acres from 4,193 in 1923 to 5,243 in $1924 .^{29}$ As cane farming became popular, more farmers started to plant the crop. Unfortunately, the farmers in Chemelil and Koru could not be accessed easily due to poor infrastructure.

In the meantime, the growing of sugarcane increased among the Indian farmers because the prospects now seemed good. ${ }^{30}$ This was as a result of the expanding local market and the colonial government support with various experimentations and improved farming methods. Secondly, by 1923, the area under cane cultivation increased due to the fact that there was a reduction in the price of sugar in the local market. It was partly because of the establishment of larger mills like the Victoria Nyanza Sugar Company. Since it produced in bulk, the cost of production during the period was lower. ${ }^{31}$ This produced lower prices and created increased demand among consumers.

\footnotetext{
${ }^{29}$ Colony and Protectorate of Kenya, DAAR 1924 (Nairobi: Government Printer, 1925), 8.

${ }^{30}$ KNA: PC/NZA/3/2/34, NIFA to Sir Robert Brooke-Popham, $28^{\text {th }}$ Sept 1937 . This letter highlights the background to Asian farming in Kibos.

${ }^{31}$ DAAR for the year ended 31st December 1923, 15-16.
} 
Moreover by 1925 Asians had managed to acquire more land with total holdings of 12,000 acres. ${ }^{32}$ Consequently, within only two years there was marked improvement in sugarcane farming since the Victoria Nyanza Sugar Company was able to acquire a large estate at Miwani and had approximately 4,500 acres under cane by 1925 . The total area under cane by 1925 was 6,556. Production also increased. For instance, during the 1924-1925 season, the infant factory was able to manufacture approximately 2,891 tons of crystallized sugar. ${ }^{33}$ The following year, another European company, Messrs. Nottidge and Allen, acquired land at Muhoroni. The owners were John Thomas Ripley Nottidge and Thomas Allen; the two had initially settled at Lumbwa. At Muhoroni they planted approximately 800 acres of cane. By 1932 Nottidge and Allen acquired more land in K-L district, about 5,838 acres. ${ }^{34}$ Both factories had milling machinery and were able to produce excellent grades of sugar that found a ready, expanding market since the Africans had started to add sugar to their diet. ${ }^{35}$ Despite the fact that there was adequate rainfall in 1926, which made sugarcane to do well and enhanced the industry's performance, there was very minimal increase in acreage under cane. It was noted that only 191 more acres were added bringing the total area of planted with cane to 6,747 acres. ${ }^{36}$

Due to the remarkable improvement in the industry, the Asian farmers started experiencing delays in the delivery of their cane to Victoria Nyanza Sugar Company. This was because the company had to cut its own cane first before accepting any from the Asian farmers. Their situation was compounded by the fact that the Nottidge and Allen mill only crushed their own cane. Thus the Asian farmers had only one mill to receive their cane. The growers at

\footnotetext{
${ }^{32}$ Colony and Protectorate of Kenya, DAAR 1925 (Nairobi: Government Printer, 1926), 17.

${ }^{33}$ Ibid.

${ }^{34}$ KNA: BV/1/249, Survey and Registration Department to Ag. Commissioner for Local Government, Lands and Settlement, $11^{\text {th }}$ July 1932.

${ }^{35}$ KNA: DC/CN/1/4/1, K-LDAR, 1925.

${ }^{36}$ Colony and Protectorate of Kenya, DAAR 1926 (Nairobi: Government Printer, 1927), 14.
} 
Muhoroni suffered more since the distance to Miwani was far. Moreover, between 1922 and 1926, a lot of attention was focused on European cane farming with the entrance of European cane farmers on the scene, Victoria Nyanza Sugar Company at Miwani and Nottidge and Allen at Muhoroni. For example, whereas the Asians wanted machinery to mill their cane, it was not easy to get permission, while the two companies had no restriction in importing machinery for their cane. The Muhoroni Indian farmers were possibly denied a permit to import a milling machine for fear of possible competition to the young factory of Nottidge and Allen.

Regardless of that, the sugar industry continued to expand. For instance in 1927 there was little increase in land under cane cultivation. The area grew from 6,747 to 6,811 acres in 1927. Furthermore, the Nottidge and Allen Company also purchased more land towards the end of the year and planted an additional 450 acres. The greatest increase in sugarcane cultivation was in 1928 when European farmers cultivated 9,403 acres while the Indian farmers, who by then were 40 in number, owned approximately 4,217 acres. They brought under cultivation another 3,693 acres of cane. ${ }^{37}$ This brought the total acreage under cane to $13,096 .^{38}$ During the same period, two other small mills were established one near Nairobi at Ruiru and the other at Ramisi near Mombasa. This period was also marked by increase in consumption of sugar by Africans which was partly as a result of the increase in the purchasing power. ${ }^{39}$ However, cultivation during the period under review was beset by challenges due to the Mosaic disease outbreak in the province, as will be discussed in a later chapter.

Meanwhile, European cane farmers also made progress by 1929. Their acreage under cane greatly increased. For instance, there was an increase of 1,753 acres, bringing the area under cane to be 11,161 acres. Thus together with the Indian farm holdings of 8,820 acres of

\footnotetext{
${ }^{37}$ Colony and Protectorate of Kenya, DAAR 1929 (Nairobi: Government Printer, 1930), 24.

${ }^{38}$ Colony and Protectorate of Kenya, DAAR 1928 (Nairobi: Government Printer, 1929), 17.

${ }^{39}$ Ibid.
} 
cane, the total of acreage under cane increased to 19,981 acres compared to the 13,096 of the previous year. ${ }^{40}$ Comparatively, we find that the major increase was registered on Asian farms which amounted to further increase of 5,127 acres on their holdings. This was partly because the number of Indian farmers increased from 40 in 1928 to 48 in $1929 .^{41}$ This was a huge increase despite the depression that the country faced. ${ }^{42}$ There was thus a great increase in sugarcane production whereby 39,900 tons of cane were cut and taken to the Victorian Nyanza Sugar Company. Nevertheless, greater losses were incurred than was normal; this was due to the mosaic disease that invaded the farms. Hence the 1928-1929 seasons were difficult for the cane farmers. Therefore, in an effort to help the farmers, the colonial state put in place heavy protection in the form of custom duties and preferential railway freights in favor farmers in the colony, including the sugar producers, so as to help them survive the difficult economic times.

The sugarcane farmers had no time to recover when they were hit again by another spate of locust invasions in 1932. During this period the agricultural officers embraced new method to fight the infestation whereby famers were taught of the use of smudge fires as protection against locusts. $^{43}$ Due to these difficulties, there was a decrease of the area under cane cultivation in 1931. The area decreased to 12,363 acres, down from $13,493 .^{44}$ Consequently the production of sugar decreased as is revealed in the data below. However, growth was steady for both Asian and European sugarcane farmers as was witnessed by the output of the sugar produced by the two factories from 1925-1932, as indicated in the following table.

\footnotetext{
${ }^{40} \mathrm{DAAR}$ 1929, 25.

${ }^{41}$ Ibid., 37.

${ }^{42}$ Ibid., 25.

${ }^{43}$ Colony and Protectorate of Kenya, DAAR 1931 (Nairobi: Government Printer), 29.

${ }^{44}$ Ibid., 27.
} 
Table 4.4: Performance of the Sugar Companies, 1925-1932

\begin{tabular}{ccc}
\hline & Victoria Nyanza Sugar Co. & Messrs Nottidge and Allen \\
Miwani & Muhoroni \\
Year & Output (tons) & Output (tons) \\
1925 & 2,833 & ---- \\
1926 & 6,570 & 560 \\
1927 & 7,302 & 847 \\
1929 & 6,200 & 310 \\
1930 & 7,450 & 700 \\
1931 & 3,500 & 250 \\
1932 & 2,833 & 310 \\
\end{tabular}

Source: KNA: DC/CN/1/4/1, K-LAR 1926.

The above data, despite the missing 1928 records, show increased performance in the sugar industry. For instance Nottidge and Allen produced 560 tons in 1926 despite the fact that the factory was closed for three months to allow installation of new machinery. ${ }^{45}$ The poor performance reflected by the output of 1929 was due to the unfavorable weather condition during the year. Not only was the rainfall erratic, but also insufficient in many months. To add to this, the year also experienced an outbreak of mosaic disease that destroyed crops and caused serious loses. ${ }^{46}$ Meanwhile, the decrease during the 1931-32 season was due to the effects of locust invasions that ravaged the area. It should be noted that the output by Victoria Nyanza Sugar Company included cane from the Asian farmers. This performance was commendable given the fact that during the same period, the farmers had to contend with diseases, locusts and inadequate labor as will be discussed in the ensuing chapters.

Due to this progress, the zeal shown by the Asian farmers, and the need for land for expansion, the lowland issue was revisited in 1925. Kenya Indians had shown interest in the exclusive settlement in the Kibos area. This led to the Colonial Office to institute the Standing

\footnotetext{
${ }^{45} \mathrm{KNA}$ : DC/CN/1/4/1, K-LDAR 1927.

${ }^{46}$ DAAR 1929, 68.
} 
Emigration Committee in 1924 to look at the possibilities. The members of this committee also included Asians such as Sir Hari Singh Gour, Chaundri Muhammad Ismail and Ramchandra Roo, among others. Unfortunately political rather than economic opinion prevailed, and these committee members objected to the idea on grounds that colonization of Kibos-Muhoroni might be misconstrued by Indians to mean acceptance of the principle of segregation. ${ }^{47}$ Therefore, after much discussion and exchange of views with London, the government of India and pressure from Indian politicians back home and the East African Indian Association, the idea was shelved completely. This meant that the Asian sugarcane farmers were not going to get land easily in the lowlands, yet the highlands had long been closed to them. ${ }^{48}$ The farmers who had initially been supported by the colonial state now felt betrayed by the government. What the Asian farmers needed was land; hence, they complained to the Kenya Land Commission, but their requests were ignored.

Be that as it may, the Asians continued to look for land from Europeans who were ready to dispose of their farms in the region. This led to the development of a very interesting phenomenon. During the 1920s and 1930s, Asian absentee landlords and land speculators became very predominant. Many purchased land from Europeans around the Kibos and Chemelil area. For example, N. J. Desai, an insurance broker in Kisumu, purchased large farms in Kibos and Chemelil. These absentee Asian land lords then leased the farms to others. For example, by 1928 there were 48 Asian farmers in the Kibos-Miwani area alone, each with approximately 200 acres under cane. ${ }^{49}$ Yet out of these farmers, $60 \%$ were absentee landlords. Most were not Sikhs. The relentless pursuit for farms continued and was witnessed in 1930 when the 4,500 acres belonging to the Walji and Sons estate (part of the former Kisumu Rubber Company) was leased

\footnotetext{
${ }^{47}$ Gregory, India and East Africa, 298-299.

${ }^{48}$ Gregory, South Asians in East Africa, 241.

${ }^{49}$ Wrigley, “Kenya: The Patterns of Economic Life”, in Harlow and Chilver eds., East Africa, 214.
} 
to Asian tenants at an annual rent of 50 cents per acre. ${ }^{50}$ The tenants planted sugarcane since the farms were very near the Victoria Nyanza Sugar Company (5 kilometers). The subdivision of the Walji estate brought the total number of Asian cane farmers to 56 in the Kibos- Miwani area alone. They occupied 15,400 acres of land, out of which 9,120 acres was under cane cultivation. $^{51}$

However, due to difficulties, such as striga weeds and locust invasions, the total area under cane cultivation was reduced almost by half, to 4,470 acres, in $1931 .^{52}$ Furthermore, the land holdings also deceased to 14,614 acres. This could have been partly as a result of a farmer selling out his land, since in 1932 the number of farmers was reduced to 55, down from 56 in 1931. ${ }^{53}$ Thus it can be argued that the Indian sugarcane farmers experienced major setbacks due to the destruction of their cane by locusts, which contributed to low sucrose content. Hence they received smaller proceeds from the cane during a period of depressed world prices. In the meantime, they also managed to put 700 acres of maize under cultivation. The situation continued till 1932, when the total area under cane for the whole district was reduced again to 12,088 acres compared to 12,363 acres under cane in $1931 .^{54}$ Many took to growing of cotton, maize and pulses. ${ }^{55}$ The frustrations of these years made the Indian farmers to diversify more. Thus by 1932, the acreage under maize increased to 1, 942 acres, which also explains the reason for reduction of area under cane. ${ }^{56}$

In the meantime, the world depression continued to affect the sugar industry as producers continued to struggle to maintain the home market as a result of threats posed by the rapid

\footnotetext{
${ }^{50}$ KNA:AGR/6/4308, Miwani Farms 1930-1956.

${ }^{51}$ Fearn, An African Economy, 105.

${ }^{52}$ DAAR 193144.

${ }^{53}$ Colony and Protectorate of Kenya, DAAR 1932 (Nairobi: Government Printer, 1933), 18.

${ }^{54}$ Ibid., 32.

${ }^{55}$ Ibid., 18.

${ }^{56}$ Ibid.
} 
increase in production from Uganda. Nevertheless, the European cane farmers made progress after the poor performances experienced over the previous two years; they were able to increase the area under cane cultivation. Hence, the total area increased from 12,088 acres to 12,704 acres during the 1933-1934 season. ${ }^{57}$ Unfortunately, Asian cane farming during the same period seemed to have declined. Not only did their number not increase, but also their land holdings dropped significantly from 14,614 acres in 1931 to 10,935 acres in $1933 .{ }^{58}$

However this changed in 1934 as a rigorous campaign was undertaken to eradicate the striga weeds that destroyed most of the crop in the district. There was also the experimentation of imported varieties from India's Coimbatore station, and this encouraged the farmers. ${ }^{59}$ Hence, the Indian farmers increased their holdings and some bought more land when the Government auctioned two farms in Kibos. These farms, one of which belonged to Major Carnegies, were bought at Shs. 23,700/= and Shs. 21,700/= respectively. Hence, the total Asian land holdings by 1934 were approximately 24,000 acres. $^{60}$ These farms were not bought individually, but rather the Nyanza Indian Farmers Association bought the farms for their members who had to reimburse the funds.

The prices were exorbitant at the time given the fact that European settlers got land cheaply. However, the fact that the Asian farmers were willing to invest their money for land meant that they were resilient and hoped to benefit from cane cultivation. Unfortunately these hopes were dashed when the Victoria Nyanza Sugar Company managing Director, B.Y. Abel, decided to arbitrarily cancel some of the contracts due to the world depression that led to the fall in the price of sugar. Thus the company took its own cane first. Furthermore, there was a threat

\footnotetext{
${ }^{57}$ Colony and Protectorate of Kenya, DAAR 1933 (Nairobi: Government Printer, 1934), 21.

${ }^{58}$ Ibid., 18.

${ }^{59}$ Ibid., 156. The varieties were experimented to find out if they were drought resistant, but this proved to be unsuccessful.

${ }^{60}$ KNA: PC/NZA/3/2/34, Nyanza Farmers Association to DC K-L, 11 ${ }^{\text {th }}$ October 1934.
} 
from Uganda, which was producing more sugar. Such factors possibly influenced the company which declined to receive cane in 1930. As a result the Indians suffered from anxiety of how to pay for their farms. The situation forced to Nyanza Farmers Association (also known as the Nyanza Indian Farmers Association or NIFA) to petition the government for an extension of payment.

Ironically, the sources are conflicting on this issue. For instance, there is documentation of Mr. Abel arrogantly refusing to accept cane, while on the other hand there is also evidence of cane being received from some farmers. Despite the conflicting views, what emerged as pertinent was that the situation at Kibos-Muhoroni was so bad that 15 out of the 56 farmers could not pay the rents and leases of their farms. ${ }^{61}$

However, during the same period, the European farmers in Nyanza were successful growing coffee, and sisal. The expansion was partly due to the boom of World War I when prices for the settler produce were lucrative. Kanogo indicates that not only did their production increase but that it was diversified as well, growing cereals such as maize and wheat. ${ }^{62}$ However this situation was to change when the world depression impacted Kenya in 1929 and the prices of commodities crumpled. For instance the prices of maize, groundnuts and sesame fell by 50\%, while those of coffee fell by $40 \%$. This effect was so bad that a number of settlers became bankrupt, and many would have been hard hit, had it not been for the state intervention through the provision of rebates, tariff concession and the creation of the land bank in 1931 that offered loan subsidies on exports. Furthermore, they were also given low railway rates for their cargo to the port of Mombasa. ${ }^{63}$

\footnotetext{
${ }^{61}$ KNA: PC/NZA/2/2/35, Crown lands Rent Premier, 1932-1945.

${ }^{62}$ Kanogo, “Kenya and the Depression”, in Ochieng’ ed., A Modern History, 112.

${ }^{63}$ Berman, Control and Crisis, 170.
} 
Therefore the period between 1930 -1932 proved to be very challenging to both European settlers and the Indian cane growers. Not only were the prices bad, but also calamities set in. Atieno Odhiambo correctly argues that these were years of depression where no marked progress was witnessed especially in Nyanza which was invaded by locusts that destroyed crops leading to the infamous famine that was known locally as "Nyangweso." ${ }^{64}$ As a result, European settlers and Indian cane farmers were affected and suffered adversely. The most affected cane areas were Songhor and Muhoroni. The effect of depression, drought and locust was noted on total sugar production. The area under cane was reduced from 13,493 acres during the 1930-1931 seasons to 12,363 acres in 1931-1932 seasons. ${ }^{65}$ Consequently, the Victoria Nyanza Sugar Company output dropped by more than a half, from 7,457 tons of white sugar produced in 1931, when it purchased 49,000 tons of cane from the Indian farmers at the cost of 26,769 pounds, to 3,000 tons of white sugar, in $1932 .{ }^{66}$

This performance was due to the fact that throughout the year, the prices of sugar remained extremely low and as such production was affected. For the following year, 1933, the production of Victoria Nyanza dropped further to a mere 2,836 tons, while the Muhoroni Sugar Company, which had managed 709 tons in 1930, produced only 250. The Indian small scale farmers were badly affected and they responded by starting to operate small shops on their farms. Those that resided at Kibigori resorted to selling fuel to the Victoria Nyanza Sugar Company just to make ends meet.

Similarly, the European farmers in Nyanza had mixed blessings; some gained while others performed poorly. For example, while the coffee farmers had a good harvest despite the

\footnotetext{
${ }^{64}$ Atieno Odhiambo, “Economic Mobilization”, 143.

${ }^{65}$ DAAR 1931, 27.

${ }^{66}$ KNA: DC/CN/1/4/3, K-LDAR 1931. See also the 1932 DAAR which indicated that the total area under cane had drastically reduced to 12,088 acres.
} 
fact that some had poor results possibly because they had planted on inferior soils, the sisal farmers at Songhor faced immense problems. Many stopped cultivating the crop altogether due to the low market prices of sisal fiber at that time. Unlike Songhor, the sisal farmers at Koru did better while the farmers growing maize and wheat at Lumbwa and Fort Tenarn were adversely affected by the ravages of locusts just like the Asian cane farmers. To help the farmers in such a difficult time, the colonial state started the Land and Agricultural Bank in 1931, since the Agricultural Ordinance had already been passed in 1930 which made provision to finance agriculture. ${ }^{67}$ Therefore the bank was to extend loan facilities to farmers during the depression period whereby they could use their land as collateral. Unfortunately the bank provided loans mostly to European farmers. The Asian cane growers' applications were turned down yet; they too had farms that could be considered as collateral. ${ }^{68}$

Moreover the colonial government, eager to revamp the economy, further tried to help the farmers. For example, the government not only gave subsidies, especially to coffee farmers, but also incentives were offered in the form of the Guaranteed Minimum Return (GMR). Even these rescue measures were not easily available to the Asian farmers. Initially they were denied the GMR on flimsy grounds that sugar cane was not an annual crop. Those who opposed it vehemently were C.G. Lloyd and the chief Executive Officer, Board of Agriculture, E.F. Martin. ${ }^{69}$ Therefore, Asian farmers had to contest the decision since the depression, bad weather and calamities like locusts invasion affected both the Asian cane farmers and the European farmers alike.

Be that as it may, the Victorian Nyanza Sugar Company made strenuous efforts to recover and replanted cane that had been destroyed by locust the previous year. Thus by 1932

\footnotetext{
${ }^{67}$ Kanogo, "Kenya and the Depression”, 117-118.

${ }^{68} \mathrm{KNA}$ : DC/KSM/1/3/123, Land and Agricultural Bank Recipients, 1932-1935.

${ }^{69}$ KNA: AK/11/51, Proposed GMR on Sugar.
} 
the company planted sugarcane on both of its estates at Miwani and Muhoroni, amounting to 8,000 acres. This performance was however affected by the fluctuating world sugar prices which impacted the local prices. The severe impact of the low prices led to the amalgamation of producers in Kenya in an effort to remedy the situation and ensure stability of the local prices in the colony. ${ }^{70}$ As such, the low sugar prices and the expansion program undertaken by the company most likely influenced Victoria Nyanza Sugar Company to reduce its intake of cane from the farmers. The company found itself in a very difficult situation for, while expanding, it could not on the other hand encourage the small farmers to plant cane for sale to the factory. Nevertheless, the small scale farmers had also started to recover and by 1934 had enough cane though they faced problems of disposing their crop. Their problem was compounded by the fact that they had no machinery to mill sugar. And on seeing that their cane was not going to be easily accepted, a deputation led by Shams ud Deen met with the governor, Sir. Joseph Byrne, and made their request about the machinery known. They were thus granted a license to import one. ${ }^{71}$ However, there was delay as they organized to get funds.

At the same time, many complaints had been made against Mr. Abel, the manager of Victoria Nyanza, especially by the Nyanza Indian Farmers Association. He was not only accused of not taking cane from farmers, but also for discrimination against those who complained on how they were treated by the company. The manager himself claimed that the allegations were not true. Despite the farmers’ complaints, some sources affirm their situation that cane was not received. Archival sources also indicate the contrary to what the farmers claimed as shown in the following table. This discrepancy may have been due to the various

\footnotetext{
${ }^{70} \mathrm{DAAR}$ 1932, 32.

${ }^{71}$ KNA: PC/NZA/3/2/34, Petition by Nyanza Indian Farmers Association.
} 
interpretations offered by different people concerned since the sources indicate on the contrary that cane was bought from the farmers as revealed by the table.

Table 4.5: Sources of sugar produced by Victoria Nyanza Sugar Coy, 1924-1934

\begin{tabular}{ccccc}
\hline Year & $\begin{array}{c}\text { Tons of sugar } \\
\text { Manufactured }\end{array}$ & $\begin{array}{c}\text { Estate cane } \\
\text { Tons }\end{array}$ & $\begin{array}{c}\text { Planters under contract } \\
\text { Tons }\end{array}$ & $\begin{array}{c}\text { Other planters } \\
\text { Tons }\end{array}$ \\
\hline $1924-25$ & 1,385 & 14,774 & ------ & 5,296 \\
$1925-26$ & 4,048 & 34,199 & ------ & 18,188 \\
$1926-27$ & 8,018 & 55,712 & 12,214 & 28,523 \\
$1927-28$ & 5,700 & 45,299 & 16,266 & 13,972 \\
$1928-29$ & 5,723 & 41,436 & 15,568 & 23,978 \\
$1929-30$ & 6,216 & 36,979 & 19,158 & 16,335 \\
$1930-31$ & 7,498 & 50,389 & 24,455 & 24,587 \\
$1931-32$ & 3,498 & 39,409 & 18,099 & 11,201 \\
$1932-33$ & 2,821 & 32,011 & 6,858 & 3,493 \\
$1933-34$ & 5,051 & 49,294 & 11,479 & 10,221 \\
\hline
\end{tabular}

Source: KNA: PC/NZA/3/2/34, Extract from the Report of the Commission of Enquiry into the Sugar Industry, Victoria Sugar Company, Ltd-Miwani, 1934.

The above data indicates that cane was received from both contracted and other farmers. Secondly it reveals that during good seasons more cane was obtained from the two groups of farmers, for example in 1930-31 and 1931-32. Furthermore, the cane obtained in 1931-32 had a difference of approximately only 10,000 tons to that of the factory estates, while during 1930-31, Victoria Nyanza Sugar Company had 50,389 tons of cane and still went ahead and purchased 49,042 tons from the Asian farmers, both contracted and those without contracts. This then refutes the claim that sugarcane was not received. Possibly the tonnage fluctuated depending on the financial performance of the factory. Furthermore, given the fact that the factory also faced problems, such as dumping of sugar in the country, these could have impacted the action of the factory as regards the amount of extra tons to be received from farmers. 
Nevertheless, the sugar industry continued to grow in the following years. Both Victoria Nyanza Sugar and Muhoroni Sugar companies had fully recovered and registered good performances after 1934. For instance, Victoria Nyanza Sugar Company, holding 9,000 acres by 1936, produced 11,180 tons of white sugar, up from 5,051 of 1934. Muhoroni Sugar also made headway after initial bad years. The company undertook an aggressive expansion and intensive planting program when it installed a system of irrigation as a measure to counteract any bad drought, having gone through the experience in the early 1930s. The irrigation facilitated by water from the Nyando River produced encouraging results. Meanwhile, the small scale farmers also increased production. The output of sugar during this period found an expanding market. This was as a result of the consumption rate that had increased from 9,100 tons during the 19321933 season to 13,100 tons during the $1935-1936$ season. $^{72}$ The manufactured sugar during this period found an already expanding local market. This was because the consumption rate rose from 9,100 tons in the $1932-33$ season to 13,100 tons during the $1935-36$ season. $^{73}$ The increase in consumption and ready market thus could be said to have motivated the farmers to grow more cane. Consequently those at Kibos and Chemelil formed the Nyanza Farmers Cooperative Society (NFCS) in 1936 which marketed their jaggery to England and managed to get good prices for it at double the price it fetched locally. Through the society, the farmers also managed to get free rail freight of their cargo to the port of Mombasa. The following year, when on their own initiative, they were able to collectively purchase 20,000 acres from European farmers and managed to increase the cane acreage by an additional $7,000 .{ }^{74}$

Meanwhile there was also improvement in the European farming within the region as well. For example the European farmers increased production of sisal in their farms, partly

\footnotetext{
${ }^{72}$ Colony and Protectorate of Kenya, DAAR 1936, Vol.1 (Nairobi: Government Printer, 1937), 16.

${ }^{73} \mathrm{Ibid}$.

${ }^{74}$ KNA: PC/NZA/3/2/34, NIFA to Brooke-Popham, 26 ${ }^{\text {th }}$ September 1937.
} 
because they were assisted by the Sisal Industry Committee, which was appointed in 1934 to look at the interests of the sisal growers. ${ }^{75}$ Furthermore, there was increase in world prices. For example, there was rise of fiber prices, which increased weekly from May 1935 to December of the same years, and an expanding market to United Kingdom. Thus the lucrative world prices were a factor that influenced the settler farmers to increase sisal production. The overseas market in sisal remained steady throughout the 1936 period. $^{76}$

During 1936, coffee farmers still languished in financial stress due to poor harvests and poor prices. Many farms in the Songhor area closed completely. These were the effects of the depression that had left the farmers struggling. For instance, the Barham Investment Trust estate, formerly Kitchener's African Estate, suffered seriously. The owners could not cope. Hence, out of frustration they uprooted the coffee, discharged the laborers and abandoned the farm with few caretakers. Other farmers included Mr. W. Maxwell who also gave up his farm at the foot of Nandi hills, while Mrs.D.A. Irvine gave up farming all together and left the District. ${ }^{77}$ Van Zwanenberg and King corroborate this stance and argued that it was a difficult period caused by the slump in world market which forced about 400 out of the 2,000 Kenya settlers to give up farming and many abandoned their farms. ${ }^{78}$ These problems led to the colonial state's intervention to save the European farming from total collapse and so in 1936, in an effort to help the farmers, the Farmers Conciliation Board was formed with an aim of assisting farmers who were experiencing financial problems. Accordingly, a farmer was allowed a grace period of 5 years to pay up his loans. The Board also provided loans for farming on condition that the farm

\footnotetext{
${ }^{75}$ Colony and Protectorate of Kenya, DAAR 1935, Vol. 1(Nairobi: Government Printer,), 11. The farmers also found a ready market exporting the produce as a result of the Italian-Ethiopian War, possibly for the manufacture of ropes and bags.

${ }^{76}$ DAAR 1936, 15.

${ }^{77}$ KNA: DC/CN/1/4/5, K-LDAR 1936.

${ }^{78}$ Van Zwanenberg with King, An Economic History of Kenya and Uganda, 39.
} 
would be supervised by the Agricultural Board. To qualify for loans, the application had to be approved by the local agricultural committee. Though helpful to European farmers, the board, just like the Land Bank, did not make any meaningful help to the Asian cane farmers. For instance less than $10 \%$ of the Asian farmers got the financial assistance. ${ }^{79}$

However, by 1938, other small mills were also manufacturing sugar. During this period there were a total of five factories. Apart from the Victoria Nyanza Sugar Company at Miwani, others were Muhoroni, Sukari Company at Ruiru near Nairobi, Manoni and the Kenya Sugar Company -Ramisi at the coast. ${ }^{80}$ Unfortunately most literature has ignored the contribution of these small mills to the development of the sugar industry in the study of economic history of colonial Kenya.

\section{Sugarcane Farming During the World War II Period, 1939 up to 1949}

The depression period left many farmers affected and many were struggling. The European farmers, however, got more assistance from the colonial state to deal with the problems of the 1930s than did the Asian cane farmers. Even with such preferential assistance from the government, European farming in the Nyanza region continued to decline. For example the coffee farms at Koru, Fort Ternan and Songhor reduced their acreage under cultivation. This fact is affirmed by Berman who argues that the European farmers faced so many difficulties that by 1939 they were unable to cultivate more than $10 \%$ of their land. Thus on average, farms of approximately 2,600 acres only managed to effectively cultivate 269 acres. ${ }^{81}$

However this changed during the Second World War. This period led to increased food production so as to meet the demands of feeding troop and prisoners of wars. The colonial state thus introduced the Increased Production of Crops Ordinance of 1942 which facilitated the

\footnotetext{
${ }^{79}$ KNA: DC/KSM/1/3/123, Application for land Rehabilitation Fund, 1952.

${ }^{80} \mathrm{KNA}: \mathrm{BV} / 6 / 613$, Sugar Export Quota.

${ }^{81}$ Berman, Control and Crisis, 134.
} 
provision of short-term credit and also the guaranteed minimum return (GMR) for all annual crops grown on European farms. Smith argues that under the GMR acreage under maize and wheat increased. ${ }^{82}$ Nevertheless, Asian agriculture also expanded tremendously; for instance there was a huge shift as the Indians began to manufacture sugar and cotton. ${ }^{83}$

The expansion was seen when in 1942 an Asian miller, Premchard Raichad and Company, bought the estate belonging to the Nottidge and Allen Company at Muhoroni (Muhoroni mills), which was approximately 4,800 acres in extent, and started processing sugar. ${ }^{84}$ This was a relief for the cane farmers in Muhoroni-Chemelil who had to deal with the distance to Miwani. This had forced many to produce jaggery. The Asian farmers also started to grow maize due to better prices that it fetched and other incentives given by the colonial government. Their efforts were encouraged when the Board of Agriculture encouraged farmers to form agricultural committees for easy dissemination of information among other services. Thus the Indian farmers organized themselves and formed committees in their areas. ${ }^{85}$ Such committees included Kibos Planters Production Sub-committee which had 40 members, the Miwani-Kibigori Production Sub-committee, with 16 members, and the Chemelil-Muhoroni Production Subcommittee that had 10 members. The sub-committees did a lot to improve farming on Asian farms. For instance, they first reviewed past performances and made plans for the coming season. Secondly, they worked together with the department of agriculture in an effort to procure loans to the farmers.

On the other hand, the European farming expanded as the world prices of sisal went up. This led to an increase of cultivated acreage on the European sisal estates at Chemelil and Koru.

\footnotetext{
${ }^{82}$ Smith, “An Overview of Agricultural Development”, 122.

${ }^{83}$ Swainson, The Development of Cooperate Capitalism, 125.

${ }^{84}$ Osamba "Colonial African Labour", 96.

${ }^{85}$ KNA: DC/KSM/1/3/122, Meeting of Kibos Planters Association, August 1942.
} 
Thus we find that with the expansion of agriculture during the war the colonial state also went further to help the farmers by enacting the Increased Production of Crops Ordinance of 1942. As stated earlier, this was helpful since it provided farmers financial assistance to break new land. The Asian cane farmers complained that the breaking grant was by no means sufficient. For example the farmers were given Shs. 40/=, yet cane was ploughed 3 times, and the amount given was for only one time. However, this was very timely due to the fact that during the war period, there was continuous demand for foods stuff, which was necessitated by the Ethiopian campaign which led to many Italian prisoners of war being held in Kenya, and the North African war. These put pressures on farmers to not only produce more towards the war effort, but also to feed the prisoners of war. The war burden thus stimulated not only the African and settler agriculture, but also the Asian farming. ${ }^{86}$ Therefore we find that by 1945 the five factories in Kenya were able to produce only 8,187 tons of sugar. This low production was due to the severe drought that affected cane in the early months of the year. ${ }^{87}$ The poor performance continued into 1946, whereby a huge drop was registered from 8,187 tons of sugar to only 5,760 tons from the five factories. ${ }^{88}$ This was caused by the poor weather conditions of the past two years and the prevalent labor shortage experienced during the year that affected harvesting.

Meanwhile the settler agriculture was reinvigorated when the colonial state came up with policies and established institutions in an effort to solve the problems faced by European farmers. For example, the 1946 development plan was adopted to intensify the use of land. To assist the settler farmers further, technical training was started at the Egerton College of

\footnotetext{
${ }^{86}$ Swainson, The Development of Corporate Capitalism, 112.

${ }^{87}$ Colony and Protectorate of Kenya, DAAR 1945 (Nairobi: Government Printer, 1946), 14.

${ }^{88}$ Colony and Protectorate of Kenya, DAAR 1946 Part I (Nairobi: Government Printer, 1948), 10.
} 
Agriculture in Njoro. The training, based on diversification, stressed the importance of mixed farming which included the grade cattle. ${ }^{89}$

However, the CN cane farmers had a major breakthrough on $16^{\text {th }}$ June 1947 when a businessman from the Kakira Sugar Works Company in Uganda, an experienced planter and miller Devjibhai Hindocha, bought the whole of Victoria Nyanza Sugar Company’s estate and factory. He renamed it Miwani Sugar Mills. Hindocha then started expansion and infused life into the moribund factory by undertaking three important steps. First, the production of the mill increased as he acquired more land. Thus within a short period the Miwani Sugar mills had three plantations: the Miwani estate with 9,300 acres, Chemelil estate with 4,252 acres and Kibigori estate with 543 acres under sugarcane. Secondly, the Company also stepped up production when it reached an agreement with the neighboring cane growers for the factory to absorb their cane. This definitely was a relief to the farmers who initially had been complaining about such issues with the former Victoria Nyanza Sugar Company. Thirdly, during the take over period the factory had inherited shortages of rails and rolling stocks for the tramway which made it difficult for farmers to deliver their cane. Therefore, to ensure that cane reached the factory, the Miwani Sugar mill was able to introduce more trolley lines to transport cane.

All these efforts made the farmers intensify their cane growing. Many sought loans from Asian money lenders. Moreover before 1945, as discussed earlier, it was not easy for Indian cane farmers to access loans. However by late 1940s, two Asian banks opened in Kisumu: the Standared Bank of India and Bank of Baroda. These became the major source of financing to the Asian farmers, which led to expansion of the sugar industry as the number of Asian farmers now increased to 83 with a total acreage of 22,071 by 1947 . Furthermore, there was heavy rainfall

\footnotetext{
${ }^{89}$ Alex Winter-Nelson, “A History of Agricultural Policy in Kenya” in Scott Pearson et al, eds., Agricultural Policy in Kenya; Application of the Policy Analysis Matrix (Utica: Cornell University Press, 1995), 35.
} 
and adequate labor in 1947; hence the farmers increased the acreage under cultivation as indicated in the table below. ${ }^{90}$

Table 4.6: The number of Asian Farmers and Acreage Held in the Kibos-Muhoroni Area, 1947

\begin{tabular}{lrc}
\hline Area & Acres & Number of Farmers \\
\hline Kibos & 11,321 & 51 \\
Miwani & 1,920 & 11 \\
Kibigori & 3,990 & 8 \\
Chemelil & 4,335 & 7 \\
Muhoroni & 505 & 4 \\
Total & 22,071 & 83 \\
\hline
\end{tabular}

Source: KNA: DC/KSM/1//3/122, Agricultural Production Indian Farms, 1947.

The above data shows the distribution of the Asian cane farmers where the high concentration was to be found at Kibos. The area also had the most land under sugar. There were few farmers at Chemelil, yet they managed to have a lot of land. The data show how there was marked improvement which was partly as a result of Miwani's aggressive policy of expansion which definitely influenced the farmers to expand as well.

During the same period, Miwani Sugar Mills, eager to expand the sugar industry, took another initiative when in 1948 it offered the colonial state part of its land near Ngeta River, 3 kilometers from Miwani, for the purposes of building another research station. The purpose of the station was to carry out research on various varieties so as to come up with a variety that was not only high yielding but also compatible to the ecology of the area. Hence the government not only established the station for trials, as will be discussed later in the chapter, but also appointed an Asian sugar expert, Sampura Gill Singh, as an agricultural assistant to help the farmers by instructing them on good farming methods. He also carried out investigational work on sugar

\footnotetext{
${ }^{90}$ KNA: DC/KSM/1/3/122, Agricultural Production on Indian farms, 1947. For more information about the Sugar research station see also KNA: AK/11/50, Memorandum of Sugar Investigation for Kisumu Area, 1948, and Colony and Protectorate of Kenya, DAAR 1947 (Nairobi: Government Printer, 1948) on the good weather conditions during the year.
} 
varieties. ${ }^{91}$ Due to his work as well as favorable weather conditions and the improvement in the procurement of labor, there was marked improvement in cane production, as the total acreage rose to 13,289 of planted cane. ${ }^{92}$

\section{Expansion of Sugarcane Farming in Post War Period, 1950 to 1963}

In the post war period, economic growth was registered generally in the agricultural sector in the colony including the sugar industry. Heyer postulates that there was a change in agricultural policy which brought about the tremendous development. The policy encouraged African agriculture to develop alongside settler farming. ${ }^{93}$ In Asian cane farming, the progress was because of the numerous amounts of experimentations that took place during this period that led to the more improved farming methods whereby farmers adopted better varieties, despite the challenges that the farmers experienced.

The farmers had mixed blessings in 1950; this was because of the poor short rains that led to severe drought. The situation was no better by the onset of the long rains, since the rains destroyed the Asian maize in Kibos-Muhoroni area, due to water logging caused by poor drainage. Furthermore, the rainfall was erratic and areas around Kibigori and Chemelil experienced drought that also led to failure of the maize crop. ${ }^{94}$ The cane farmers also suffered from the effects of water logging, though their cane crops were not adversely affected as compared to the maize. However, many cane farmers were able to cultivate more land since they got help through the use of a machinery pool as a copying strategy. Through such initiatives, many were able to use tractors to plough land and hence the number of oxen used was greatly reduced. More acres were cultivated, especially by large scale farmers and factory estates.

\footnotetext{
${ }^{91}$ Colony and Protectorate of Kenya, DAAR 1948, Part I (Nairobi: Government Printer, 1950), 32.

${ }^{92}$ Ibid.

${ }^{93}$ Heyer, “Achievements, Problems and Prospects in the Agricultural Sector”, in Heyer et al .11.

${ }^{94}$ Colony and Protectorate of Kenya, DAAR 1950, Vol.II (Nairobi: Government Printer, 1953), 28.
} 
Furthermore, experimentations had intensified during this period as farmers started to plant the CO varieties that led to increase in production. Cane farming stabilized. This stability continued up to 1952 when preliminary results from trials planted in 1950 were reported.

These trials indicated that the CO 421 was a better variety than CO 281 for the area as will be discussed in the later part of this chapter. Such information was crucial to the cane farmers for economical farming. Hence, most farmers, such as the large scale and the estates, changed over to planting of CO 421 by $1952 .{ }^{95}$ Other numerous trials were conducted during the same year on the possible use of factory made long term fertilizers which employed the use of nitrogen, potash, phosphate, molasses and filter mud press from cane. Other experiments were done on the use of herbicides to control weeds especially in young cane. ${ }^{96}$ During this period there was marked improvement in cane production, despite the problems of water logging. The acreage under maize also was increased, mainly to feed the labor on Indian farms despite the fact that the area was not suitable for maize growing due to poor drainage during the heavy rains. ${ }^{97}$

On the whole, there was marked improvement in Asian farming as they were able to produce in 1953 approximately 129,602 tons of sugarcane. Due to this increase, an old problem resurfaced again when Miwani Sugar Mills, just like it predecessor the Victoria Nyanza Sugar Company, started to frustrate farmers by not accepting their cane. Complaints had started as early as 1951. By 1952 it was apparent that some farmers' cane was not accepted. A prime example was provided by the cane of Milwant Singh and Makan Singh. These two appear to have been behind the calls for another factory at Kibos, and it seems that they were intimidated by the company. Such a situation made Milwant Singh to sell his farm. ${ }^{98}$

\footnotetext{
${ }^{95}$ Colony and Protectorate of Kenya, DAAR 1952, Vol. I (Nairobi: Government Printer, 1953), 28.

${ }^{96}$ DAAR 1952, 28.

${ }^{97}$ Ibid., 34.

${ }^{98}$ KNA: AK/11/51, Indian Sugarcane Farmers, Nyanza Province.
} 
Despite this situation, the Miwani Sugar Mills estate alone was able to harvest in 1955 approximately 97,656 tons of cane, and the mill bought 33,124 tons from the Asian farmers. This almost doubled in the next 4 years, for by 1958 the farmers produced 234,952 tons of sugarcane. $^{99}$ Due to the good performance of the Asian cane farmers, approximately six European farmers also began to grow sugarcane in the Miwani-Muhoroni area. For example a Mrs. Martin grew sugarcane at her Miwani estate and also allowed her farm to be used for experimental purposes. Of the European farmers who took to cane farming by mid 1950s there were those who initially had been cultivating sisal. This shift was partly due to the poor world prices of sisal then.

Needless to say, intensification of agriculture continued as can be attested by the colonial state implementing the Swynnerton plan in 1954 to enhance commodity production. Although meant to revamp African and European farming, the fact that it propagated for consolidation of farms and granted individual land titles helped the Asian sugarcane farmers who could use their land as collateral to secure loans. Therefore, it can be argued that the colonial state interventions during the depression, post depression period and the coming of the Asian manufacturers in the industry led to the expansion of sugarcane growing and production. Furthermore, there was a marked increase in the number of farmers who by 1960 were approximately 100 small scale and large scale farmers, holding approximately 46,000 acres. Meanwhile Miwani Sugar Mills also continued to stabilize its production with an average output of approximately 20,000 tons of Sugar annually. This stability continued until 1960 as indicated in the table below.

\footnotetext{
${ }^{99}$ KNA: AK/2/7, 1953-1958, Asian areas food crops.
} 
Table 4.7: Miwani Sugar Mills Production, 1953-1960

\begin{tabular}{cc}
\hline Year & Sugar Produced (Tons) \\
\hline 1953 & 10,587 \\
1954 & 8,554 \\
1955 & 12,005 \\
1956 & 14,465 \\
1957 & 16,706 \\
1958 & 12,693 \\
1959 & 19,015 \\
1960 & 21,582 \\
\hline
\end{tabular}

Source: The East African High Commission, An explanation of the trends and Prospects of Sugar Production and Consumption in East Africa, 1950- 1970, 5.

The above data clearly indicates that the sugar industry was growing. For example, from 1955 the increase was steady, with the greatest increase in 1959-1960. Such an achievement could not have been possible without the efforts of the farmers and the government interventions through technical support and better policies that improved agriculture generally. Therefore by 1961, the sugar industry was still improving and the Miwani Sugar Mills was at the peak of its performance. The company started to manufacture refined sugar, as will be discussed in the next chapter.

\section{Agricultural Aspects of Sugarcane growing in Colonial CN}

As highlighted in the preceding part of this chapter, the Asian sugarcane farming in CN developed over the years from a humble beginning of only a handful pioneers with a few acres to over 80 farmers by 1960 with much acreage. The industry became a successful one by the mid1950s with Asians as the main growers and manufacturers of sugar. This growth was due to the resilience and determination of the Asian farmers who learnt and adopted new varieties of cane and techniques despite the challenges that they faced such as poor ecological conditions, killer 
weeds, lack of machinery and adequate finances that were much needed in any commercial farming, to be a vibrant industry as this section seeks to demonstrate.

Needless to say, the beginning of commercial sugarcane farming started when farmers experimented with the locally known variety, Uba, as well as some varieties from India. Initially all Asian planters worked on small scale farms. However, as more farmers took to farming, three different types of farms emerged; large scale, small scale, and nuclei farms belonging to factories. Small scale farms comprised of less than twenty acres. ${ }^{100}$ Large scale farms had twenty and above acres with an average of fifty acres. For example, Mohinder Singh, who currently owns 500 acres of land at Kibos, of which 300 acres were under cane cultivation, had initially inherited 100 acres from his father Nihla Singh, a former Kenya-Uganda railway worker. His father had 200 acres at Miwani by 1922 and another 300 at Kibos. In 1964 the farms were divided among the three brothers Mohinder Singh, Ranjit Singh, and Arjit Singh when their father left for India. ${ }^{101}$

In terms of nuclei farms, sugar factories such as Victoria Nyanza Sugar Company, Muhoroni Sugar Mills and later Miwani Sugar Mills all had their own estates where they grew cane. These were relatively large estates. For example, between 1951 and 1952, the Miwani nuclei estate planted 4,800 acres of cane compared to 2,000 acres by individual farmers. By 1953, the Miwani estate cultivated 5,000 acres of cane while individual farmers cultivated 2,500, and by 1960 the Miwani Sugar estate had acquired approximately 10,000 acres, stretching from the Nandi escarpment to the railway line. Other large farms were found among the few European cane growers in Koru-Muhoroni-Songhor area. These farmers had initially planted a considerable acreage in anticipation that Uganda sugar entrepreneurs would expand and build

\footnotetext{
${ }^{100}$ Hezborn Atudo, (O.I.), former Agricultural Manager at Miwani Sugar Mills, 6 $6^{\text {th }}$ June 2009.

${ }^{101}$ Mohinder Singh, (O.I.), a large scale farmer at Kibos, $6^{\text {th }}$ June 2009.
} 
another factory near their farms. Since most of them were too far from Miwani to send their cane, much of their production was turned into jaggery. ${ }^{102}$

Moreover, sugarcane in Nyanza was grown on these varied size farms under a wide range of rainfall conditions varying from 25 inches up to 100 inches, though an even distribution of 40 inches was essential. Thorough cultivation of soils was essential for sugar cane, plowing to approximately a depth of three feet. The main reason for this was to increase soil aeration and water holding capacity. ${ }^{103}$ This was important to Kibos-Muhoroni sugarcane farms since they were basically rain fed. During cultivation and opening up of new lands, Asian farmers used oxen driven ploughs to break the land which proved to be the most arduous task, mostly done by African laborers. However, sometimes the breaking of the land was done by contracting European farmers who had tractors. The cost was out of reach of most small scale Indian farmers; hence, they devised a coping mechanism whereby they pooled their resources together by paying $£ 20$ each so as to enable them to hire the tractors from European farmers collectively. Some farmers felt that this slowed the process since the land had to be worked upon in turns. Due to the nature of the soils in the area, mechanized farming required deep cultivation, a chisel type cultivator with teeth at 10-11 inches spacing as was found in models such as IHC, model DYRR5FH, which had a lengthened, strengthened frame able to carry an additional tooth on each end with couplings attached to the tractor to allow free movement on axes and transverse to the direction of movement, lifting and clearing the ground. The IHC cultivator was efficient on black soil and functioned just like the caterpillar G series. ${ }^{104}$ Some farmers used the M.D.V. tractors. Others, like Dhanwat Singh, used a Fordson tractor which cost him Shs.31/=, to plough an acre in 1949. He found that it was not economical. Furthermore, the tractors were

\footnotetext{
${ }^{102}$ KNA: DC/CN/1/4/3, K-LDAR 1931.

${ }^{103}$ KNA: AK/11/50, Memorundum on Sugar Investigation for Kisumu Area, 1948.

${ }^{104}$ KNA: AK/3/15, Soil chemist Scott Agricultural Laboratories Nairobi to Director of Agriculture, $3^{\text {rd }}$ January 1951.
} 
problematic during the rainy season due to the heavy soil; many got stuck. ${ }^{105}$ Those who could not afford tractors had to use the oxen ploughs on their farms. In this case, it was found that in a 100 acre farm, approximately 100 oxen were kept for cultivation Moreover, since the soil was of the hard nature, the small scale farmers were not often in a position to prepare a fine seedbed as was required for sugarcane sowing. ${ }^{106}$

Needless to say, sugarcane farming also involved other types of land preparation, such as leveling, which normally was done to get the uniformity of land so as to avoid potholes that could make drainage problematic. Hence a uniform platform was important. ${ }^{107}$ Land was then harrowed which was mostly done using African labor. On previously used land, the farmers cultivated by skimming out old cane stumps and chopping them to minimum surface before a tractor or plough could be used. This was common in small scale farms. Before planting it was necessary to plough land almost three times and harrow it twice in order to attain uniformity. ${ }^{108}$

During cultivation, the land was ridged whereby the ridges had to be laid out along the contour so as to prevent erosion and conserve moisture, just like on small scale farms. For large scale farms and factory estates, a high clearance tractor was used after experimentation had been done at the Kibos estate in 1950. However, this tractor was very expensive when first imported; at the price of Shs. 29,115/= (1950) very few farmers could afford it. ${ }^{109}$ Moreover, the high clearance tractor was normally used after the land was broken by a heavier tractor. As a result of these varied conditions and difficulties, Asian farmers experienced problems during land preparations since many were poorer small scale farmers who found that it was not easy to buy

\footnotetext{
${ }^{105}$ KNA: AK/11/50, Minutes from the $70^{\text {th }}$ meeting of Agricultural Production Sub-Committee, Muhoroni-Kibos area.

${ }^{106}$ KNA: AK/11/50, Sugar Industry in Nyanza Province, Miwani-Kibos Area, 1945.

${ }^{107}$ Martin Okeyo, (O.I.), Kibos Nucleus Estate Farm Manager, 24 ${ }^{\text {th }}$ June 2009.

${ }^{108}$ KNA: AK/3/15, Notes on Sugar Industry, prepared by Sampura Singh Gill, 1948.

${ }^{109}$ Ibid.
} 
machinery. It was not until 1949 that the colonial state made efforts to solve the problem by allocating six tractors to Amar Singh and M. Baktara Singh of Kibos to help them in farming. This was far from efficient given the fact that by the 1940s there were about 56 Asian cane farmers in the area. Having the six tractors was still not conducive to better plowing.

Whatever the means used in land preparation, planting followed. Cane can be classified in two types; the noble cane that were usually high in sucrose content but required high rainfall conditions and fertile soils. As such these were not found in the area under review. On the other hand, the slender canes had strong roots and great ratoon. These slender canes adapted easily to poor soils and had high fiber content; hence these were the canes found at Kibos-Muhoroni. This type of cane could further be divided into two: hard cane such as Uba, which was drought resistant and mainly used for jaggery, and soft canes such as the CO varieties which were good for sugar production.

In this system, sugarcane normally had two seasons of planting, either in March or October-November. However, the October-November season was preferred since growth took place during the long rains where the plants made good progress for almost 6 months, although some farmers felt that planting could be done throughout the year. ${ }^{110}$ The method of planting varied according to the size of the farm. Whereas small scale farmers preferred two methods of cultivation, such as pre-planting and inter-row cultivation, especially on sandy soils where trash was left where it fell instead of removing it into an alternate row. This was found to be helpful since it not only helped limit labor costs, but this method helped in the conservation of moisture while also preventing soil erosion. Cane was planted in rows and sections separated by infill

${ }^{110}$ Ibid. 
roads which were used to control fire, transportation of inputs and also to make harvesting easier. $^{111}$

However, the large scale farmers and factory estates preferred flat planting in lines of six feet apart which was most suited for mechanized cultivation while some used ridge planting which proved to be popular in swampy areas. This type of cultivation was especially found in the Miwani sugar estate. The method of planting adopted by farmers also varied according to the nature and condition of the soil. When planting the cane, small pieces of stem known as setts, each about one foot in length and preferably from a plant crop, were used. However, only healthy young setts were to be used. The setts were then generally planted in furrows opened by a mould-board plough at a distance of between 4-6 feet. The cane setts were then placed flat touching each other in the furrows and then covered with soil. When planted in an irrigated farm, the setts were to be covered with small depth of soil of 3-4 inches. However, since KibosMuhoroni farmers relied on rain fed farming, the setts were placed deeper. To plant an acre of cane in this way, one or two tons of setts were required. ${ }^{112}$ Growth was noted from the $11^{\text {th }}$ day after planting if temperatures were high for approximately one month.

Manuring was also very important in cane production. This could be obtained from farm yard manure, green manure, and chemicals such as sulphate of ammonia, and potash. Other farms also used molasses and filter press mud. Sulphate of ammonia, when used, required to be supplied at 3 to 6 cwts per acre. However, apart from chemical application for the small scale farmers, it was recommended that the association of dairy farming with sugar production was quite beneficial; whereby molasses and cane tops were found to be useful as feeds, while the animal waste could be used as fertilizer. This practice was very common among the Indian cane

\footnotetext{
${ }^{111}$ Hezborn Atudo, (O.I.), $6{ }^{\text {th }}$ June 2009.

${ }^{112}$ KNA: AK/11/50, Sugar Industry in Nyanza Province, Miwani-Kibos Area, 1945.
} 
farmers at Kibos. Moreover, sugar needed not be rotated with other crops. For example, the practice of "resting" sugarcane land under other crops like sunflower, which was quite prevalent by the 1940s, proved not worthwhile as far as fertility of the soil was concerned.

Cane farmers also had to deal with problems of weeds, and it was necessary to control the growth of weeds from the early stages until the crop had grown sufficiently to cover the rows. Therefore, it was necessary on an average of between 4-5 hoeings and two weedings to be applied to each sugar crop until it reached maturity which in most cases was between 22-24 months for crop cane and 20-22 months for ratoon when there was an even distribution of sugar in the stem. Small scale farmers weeded manually whenever necessary. On the other hand, most large scale and estate farms, such as Miwani, used chemicals to control weeds, especially the most stubborn weeds like Digitaria Scalarum. The most common chemicals used were agroxone hormone weed killer as a pre-emergence treatment after the field was ridged. The chemical was applied using one to four gallons per acre, diluted with water to make 40 gallons of spray. ${ }^{113}$ After this process, cane had to be planted immediately or soon after. Fernoxone was used as a pre-emergent at 3 lbs. per acre and YF2618 also a pre-emergent at 27 fluid ounces per acre. Fernoxone was also used with P.C.P. oil (2 lbs. per acre) as a post-emergence application.

The first pre-emergence spray of the chemicals was done three to seven days after planting while the second pre-emergence spray was done 4-6 weeks after the first application. Post-emergence spray had to be done as soon as the grass weed emerged. ${ }^{114}$ The sprays did not exceed 30 gallons per acre. However, when using hand spray it was found necessary to use up to

\footnotetext{
${ }^{113} \mathrm{KNA}$ : AK/3/15, Agriculture Officer (AO) (experiments) to Director of Agriculture, $24^{\text {th }}$ July, 1952.

${ }^{114}$ KNA: AK/3/15, Provincial Agriculture Officer (PAO) Nyanza, to Director of Agriculture, $23^{\text {rd }}$ June 1950.
} 
80 gallons per acre so as to get the uniform coverage. ${ }^{115}$ All these treatments made sugarcane farming an expensive venture for poorer farmers.

Be that as it may, during growth some cane flowered while others did not; some flowered sooner than others. Flowering of cane is the stage when the vegetative growth changes to reproductive activity. Farmers had to ensure that before such changes there had to be a number of mature nodes in the cane. The flowering of cane was not good since it stopped the growth though the sugar content increased for about four months afterwards. ${ }^{116}$ Flowering was due to heavy soil and favorable weather as was the case in Lall Singh's farm at Kibos. Yet on this particular farm, the indigenous cane, Uba, did not flower under the same conditions as compared to the flowering varieties of CO 312 and CO 271. Moreover, these flowering varieties, being very hard, were found not to be easily spoiled by pests, wild animals, or by drought. ${ }^{117}$ Hence, they were highly recommended to be grown in the area.

Finally, harvesting was done when the cane was fully ripe. Determining factors included rainfall, the variety, and if it was a plant crop or ratoon. This could be determined by the appearance of new young shoots in the cane stool of over 18 months of age. During this period the tops were cut just above the node and removed. The length of the top depended on weather conditions. For example, in the drier period the length would be shorter than in wet weather since the plant continued to grow. Cane was then fired, especially Uba, which was difficult to strip to remove dangerous insects and animals like snakes and also to remove the leaves. This method of firing, however, destroyed the fertility of the soil, and was later abandoned.

\footnotetext{
${ }^{115}$ Ibid.

${ }^{116}$ KNA: AK/11/30, Assistant Agriculture Officer (AAO) (Sugar Research) to Sugarcane planters, Nyanza Province, $24^{\text {th }}$ September 1951.

${ }^{117}$ KNA: AK/11/30, Kibos Planters Association to Sampura Singh Gill, AAO (Sugar Research), $28^{\text {th }}$ September 1951.
} 
After firing, the blades of "pangas" were sterilized to avoid transmission of diseases and then cane was then cut with as close to the ground as possible since the lowest portion of the stem had the highest sucrose content. ${ }^{118}$ The dried materials of the crop after harvesting were then collected and put in alternative lines of cane so as to allow inter-culture in other rows. In this way, the dried waste material was left to decay and mix with soil to increase fertility; it was also found to hasten the germination of the ratoon crop, and it preserved moisture in the soil for longer periods. After cutting, the stools were allowed to grow again, i.e. a ratoon crop. It was usual to harvest a plant crop and two ratoon crops, and sometimes even a third ratoon was harvested. The first ratoon crop was referred to as the "money crop" since, in most cases, it paid off the cost of the crop. ${ }^{119}$ However, it was normal to notice a decline of about 10 to 20 percent in each successive ratoon yield. For example, in a non-irrigated well managed farm, cane would yield as follows in 1946:

16-20 tons of cane per acre from plant crop;

12 tons of cane per acre in the $1^{\text {st }}$ ratoon;

10 tons of cane per acre in the $2^{\text {nd }}$ ratoon. ${ }^{120}$

Although some poor farmers attempted to harvest even a third ratoon, this did not yield much. Therefore, it was found necessary to replant after the second ratoon. An incidence of harvesting a fourth ratoon was rare in Nyanza, as opposed to India, and was not recommended by the agricultural officers such as Mr.Sampura Singh Gill.

Once the cane was cut, it was transported to the milling factories as will be discussed in the next chapter. It is clear from this account that the cost of cultivating sugarcane was not cheap, especially to the small cane farmers as illustrated in the 1946 estimates. The 1946

\footnotetext{
${ }^{118}$ KNA: AK/11/52, Sugarcane (Saccharum Officinarum).

${ }^{119}$ Ibid.

${ }^{120}$ KNA: AK/11/50, NIFA to Chairman, Agricultural Production Board, $6{ }^{\text {th }}$ August 1946.
} 
estimates were chosen since during that year the cane farmers had problems. It was a dry season and also the production was adversely affected by labor shortages. ${ }^{121}$ These were frequent issues the cane farmers dealt with. Furthermore, the war had ended and so the pressure to produce towards that need had reduced. Therefore, the year could give estimates of cane growing under conditions that were more usual in as far as colonial Nyanza was concerned. From this illustration, it emerges that cane farming was not easily affordable to most farmers. Even after the first harvest, more money had to be spent with each consecutive ratoon crop as indicated in the following table.

Table 4.8: Estimated Cost of Cultivation of Sugar Cane per acre, 1946

\section{Tasks}

$1^{\text {st }}$ Crop

(a) Clearing and de-rooting

(b) To plough three times, harrowing and ridging by tractor

(c) Price of seed $1 \frac{1}{2}$ ton per acre at $10 /$ - per ton

(d) Transport charges of seed for one acre

(e) Labour charges for planting

(f) Hoeing four times at 8/- per acre

(g) Hoeing with cultivator and ploughing

(h) Cost of harvesting the cane at $2 /-$ per ton on the basis of 15 tons per acre

(i) Laying line, etc.

(j) Supervision and other charges

$1^{\text {st }}$ Ratoon (a) Cost of clearing trashes

(b) Cost of ploughing with oxen and harrowing

(c) Cost of hoeing with plough and planter

(d) Cost of hoeing with hand three times

(e) Cost of harvesting the cane at 2/- per ton on the basis of 12 tons per acre

(f) Laying lines etc.

(g) Supervision and other overhead charges

$2^{\text {nd }}$ Ratoon Same as $1^{\text {st }}$ Ratoon
Amount in Shillings

140.00 per acre

90-00. per acre

15-00.

5-83.

5-33. per acre

32-00.

8-00. per acre

30-00.

9-00.

20-00.

Total 355.00 per acre

4-00. per acre

$15-00$.

8-00.

24-00.

30-00.

9-00.

20-00.

Total 110-00.

$110-00$.

Source: KNA: AK/11/50, Estimated Cost of Sugarcane Production, 1946.

${ }^{121}$ DAAR 1946, 10. 
From the above information we can deduce that cane growing by 1946 was expensive to the small scale farmers since the estimates given above are just for one acre. On average, most cane farmers had 50 acres. Secondly, cane cultivation involved a lot of essential tasks such as plowing; harrowing that was done more than once added to the expense of harvesting. This translated to a lot of money as all the tasks needed labor, which required payment as indicated above.

However, cane growing picked up again in the following year, as there was heavy rainfall in 1947. The short rains fell during the early part of the year and continued until the long rains, which resulted into a period of nine months of good weather conditions. This was good for cane growing, but the rains destroyed maize on Asian farms due to flooding. ${ }^{122}$ There was also adequate labor during the year; as such production increased. Moreover, it was during this time that the new management of Miwani Sugar Mills started under Hindocha, which saw the improvement in relations between the factory and the cane farmers.

\section{Technical Aspects, State support and their Impact in Colonial Sugarcane Farming}

The foregoing sections in this chapter have illustrated how Indian cane farming developed over time. It has identified how the period up to 1930 included times of difficulties. The sections also revealed that the 1940s and 1950s were characterized by a marked increase in productivity, whereby it can be argued that the resilience of the cane farmers, coupled by World War II conditions that made the colonial state change its agricultural policy so as to meet the needs of the war was a factor in the growth of the industry since the farmers planted more cane toward the war efforts. Thus by the 1950s the sugar industry was transformed and solidly established. This was made possible due to the significant role played by the colonial state by

\footnotetext{
${ }^{122}$ DAAR 1947, 9.
} 
boosting the industry through the provision of technical support whereby numerous experimentation and trials were carried out. These trials, though started much earlier in the 1920s, reached their peak in the 1950s when major trials and experimentations were undertaken, covering almost all aspects of sugarcane farming from varieties trials of sucrose contents, spacing of cane, growth on different soils and even possible irrigation of cane. It was these trials that transformed sugarcane farming in colonial Kenya. Without the technical support the industry would probably not be where it was at independence. This was because the colonial government not only imported varieties from many countries, but also invited sugar experts from different countries to advice the farmers. Thus the growth of the industry owes much to the technical support it received from the colonial state, as will be demonstrated in this section.

The colonial state was very much involved in helping the cane farmers and played a significant role despite what current literature indicates. Archival sources abound with evidence of assistance. For example, during importation of varieties, precaution was taken by the state. For instance, there was a set procedure involved in the importation of cane varieties trials. Before importation, the cuttings had to be inspected and certified in their originating homes. For example, an authorized official of the department of agriculture of the country of origin had to certify that there was no evidence of the presence of any insect pests or plant disease before the N CO. varieties were shipped to Kenya for trials. The cuttings, once imported, were then railed to Kisumu. Upon arrival they were inspected by the PAO before being sent to the government experimental station at Kibos. The importation permit was valid for only six months, and if any contamination or disease was found, the varieties affected had to be destroyed immediately. Trials were meant to investigate major issues such as the use of different fertilizers and weed 
killers, methods of cultivation, such as spacing, ridging and irrigation, and, finally, investigation of the possible use of molasses and filter press cake as fertilizers. ${ }^{123}$

Prior to 1930, the main commercial variety at Kibos-Muhoroni was CO 281. However, small amounts of CO 290, CO 421, and Uba were also cultivated. By 1948, the colonial state was fully involved and supported farmers by facilitating variety trials that were undertaken by the department of agriculture. It was these trials that revealed that CO 421 was a better variety as regards the yield of cane and the sucrose content for Kibos-Miwani area than CO 281. Moreover, it was found that CO 421 does not bend easily on the farm from the effects of strong winds which was a desirable characteristic should mechanical harvesting be employed. ${ }^{124}$ The trials made it possible for farmers to have many varieties of sugarcane from which to choose from. This was important because farmers were very careful with the varieties of crop that they planted; hence, the need to experiment on different varieties so as to improve production. Consequently, in 1947, the Miwani Sugar Company embarked on a project of cane variety trials. The seeds were obtained from the farms of Kala Singh and Kisham Singh of Kibos and some from Badian Singh and Bharmant Singh of Miwani. This initiative was followed in 1948 when the government started its own sugar research station at Kibos as indicated earlier. The aim of the station was to try and identify disease resistant varieties suitable also to the ecology of the area and of high yielding potential. The work was supervised by an AAO (sugar) known as Sampura Singh Gill. ${ }^{125}$

These experimental farms were important for they in turn supplied cane varieties to other plantations such as Turney Sugar Estate in Bukoba and also Nachingwea Plantation in

\footnotetext{
${ }^{123}$ KNA: AK/3/15, Department of Agriculture to AO (experiments) Kisumu, $9^{\text {th }}$ April, 1951.

${ }^{124}$ KNA: AK/3/16, AO, L.J. Collings-Wells, to PAO Coast Province, $9^{\text {th }}$ November, 1955.

${ }^{125}$ KNA: AK/3/15, AO (investigation) Nyanza to E.G.P. Sherwood, Department of Agriculture, Eldoret, $27^{\text {th }}$ February 1950.
} 
Tanganyika. ${ }^{126}$ The Kibos Station also worked together with the Scott Laboratory in Nairobi where the plant pathologist, Dr. Nottrass, was based. His technical expertise was often sought. The resulting provision of improved seed varieties was a great push by the colonial state. Many of the trials were done at the research stations or on individual farms before being released to farmers. To get better results, many tests were done on different varieties from different countries in the world. By 1950s, apart from Uba, the farmers were well informed and had many choices to use as indicated by the table that follows.

${ }^{126}$ KNA: AK/3/15, Director of Agriculture to Officer in Charge, Sugar experimental station Kibos, $17^{\text {th }}$ October 1952. 


\section{Table 4.9: Different Varieties Imported and Grown at Kibos-Muhoroni by 1953}

\begin{tabular}{|c|c|}
\hline Varieties & Originating Places \\
\hline M 171/30 & Imported from Mauritius. \\
\hline M 134/32 & Imported from Mauritius. \\
\hline MF 240 & Imported from Mauritius. \\
\hline CO 281 & $\begin{array}{l}\text { Imported from Coimbatore- Ratoon canes very thin. Resistant to infection, } \\
\text { drought resistant, not suitable for small scale farmers, soft-favorite for wild pits } \\
\text { and monkeys, has weeds until it is harvested, need chemical weeding. }\end{array}$ \\
\hline CO 290 & Imported from Coimbatore- Does better in rich soils at the foot of Nandi hills. \\
\hline CO 312 & Imported from Coimbatore- Better yields, especially during first year of cutting. \\
\hline CO 408 & Imported from Coimbatore \\
\hline $\mathrm{CO} 411$ & Imported from Coimbatore \\
\hline CO 421 & $\begin{array}{l}\text { Imported from Coimbatore- Known locally as "manywele”, drought resistant, } \\
\text { resistant to mosaic disease, high sucrose content, and best cane. }\end{array}$ \\
\hline CO 419 & Imported from Coimbatore and had better yields \\
\hline CO 271 & Imported from Coimbatore, mostly favorable for making jaggery production \\
\hline CP 807 & Imported from Canal Point - Florida \\
\hline POJ 2878 & Imported from Jamaica. \\
\hline POJ 2961 & Imported from Jamaica. \\
\hline PR 803 & Imported from Puerto Rico \\
\hline В 34104 & Imported from Barbados \\
\hline В 37161 & Imported from Barbados \\
\hline B 4098 & Imported from Barbados \\
\hline В 3254 & Imported from Barbados \\
\hline N CO 334 & Imported from South Africa \\
\hline N CO 339 & Imported from South Africa \\
\hline N CO 349 & Imported from South Africa \\
\hline N CO 310 & Imported from South Africa -good yields \\
\hline N CO 79 & Imported from Tanganyika \\
\hline N CO 291 & Imported from Tanganyika-originally from South Africa \\
\hline N CO 330 & Imported from Tanganyika-originally from South Africa \\
\hline CP $34 / 79$ & Imported from Hawaii \\
\hline CP $34 / 120$ & Imported from Hawaii \\
\hline CP 36/105 & Imported from Hawaii \\
\hline CO 331 & Imported from Coimbatore \\
\hline CO 441 & Imported from Coimbatore \\
\hline CO 453 & Imported from Coimbatore \\
\hline
\end{tabular}

Source: KNA: AK/11/50, Varieties Grown at Kibos-Muhoroni area 1953.

The above table reveals that the development of sugarcane research in colonial Nyanza over the years, which started with about 3 varieties in 1913, made great progress. The data 
demonstrates how the colonial government tried to improve the yield of sugar cane through experimentation and identifying the most suitable variety for the farmer. These varieties were from many different research stations in the world. The experiments provided an enormous wealth of knowledge that was found to be necessary to improve sugarcane farming in Nyanza. Other varieties were introduced later in the early 1960s, such as CO 617 which was ready for harvest after only 17 months and did not need intensive weeding; the newest variety today is CO 808. ${ }^{127}$ Varieties used at Kibos-Muhoroni came from the following sources by 1953.

Sugar Cane Research Station, Canal Point, Florida, USA. Sugar Cane Research Station, Hawaii. Sugar Cane Research Station, Coimbatore, India. Indian Institute of Sugar Technology, Kanpur. B. W. 1 Central Sugar Cane Breeding Station, Barbados. Sugar Research Station, Mauritius. Sugar Research Station, Mt. Edgecombe, Natal, S. Africa. Agricultural Experiment Station, Mayaguez, Puerto Rico. ${ }^{128}$

All this State support improved sugar cultivation and indicated that Asian sugar farming received attention from the colonial state, contrary to existing literature.

\section{Sugarcane Variety Trials Miwani -Kibos Area}

As indicated earlier, some trials were conducted on individual Indian and European farms where a farmer would be issued with various varieties and other necessities such as fertilizers and weed killers. In some of these trials, the selected farmer had one section on trial which was closely monitored, while the other section of his farm would be worked on normal basis. Hence, the comparison made would be noted and information deduced. These sugar trials were also conducted to improve the yields. These trials on individual farms were given code 29 to differentiate them with those on research stations. For example, the trial at Kala Singh’s farm

\footnotetext{
${ }^{127}$ Mzee Hezron Kaka Muynze, (O.I.), small scale farmer at Chemelil, 80 years old; he has only 3 acres of sugar cane, $1^{\text {st }}$ July 2009.

${ }^{128}$ KNA: AK/3/15, Assistant Director of Agriculture (Research) to PAO Nyanza, $1^{\text {st }}$ July 1950.
} 
was planted in 1950 and the first ratoon was harvested in April 1954, while the second ratoon was harvested in October 1955.

Table 4.10: Trials comparing Yields of Plant Crop and Ratoon Crops, planted in 1950

\begin{tabular}{lrrrr}
\hline \multicolumn{1}{c}{ Variety } & Plant Crop & $\mathbf{1}^{\text {st }}$ Ratoon & $\mathbf{2}^{\text {nd }}$ Ratoon & Total Tons/Acre \\
\hline CO 331 & 58.76 & 33.42 & 51.09 & 143.27 \\
CO 213 & 58.10 & 25.07 & 31.93 & 115.10 \\
CO 434 & 45.29 & 28.23 & 36.52 & 110.04 \\
B 3337 & 41.21 & 24.80 & 40.71 & 106.72 \\
CO 419 & 48.10 & 19.41 & 36.79 & 104.30 \\
CO 408 & 43.81 & 19.64 & 35.80 & 99.25 \\
CO 285 & 40.91 & 19.35 & 35.95 & 96.21 \\
CO 281 & 31.07 & 22.26 & 40.14 & 93.47 \\
CO 421 & 41.72 & 18.93 & 30.93 & 91.58 \\
CO 417 & 34.98 & 19.76 & 32.68 & 87.42 \\
CO 432 & 38.34 & 16.25 & 26.82 & 81.41 \\
MF 2/40 & 35.59 & 17.37 & 28.38 & 81.41 \\
POJ 2747 & 26.96 & 15.95 & 29.41 & 72.32 \\
CO 244 & 33.18 & 13.16 & 25.42 & 71.76 \\
B 2257 & 22.17 & 11.15 & 24.15 & 57.47 \\
POJ 2714 & 20.33 & 10.37 & 21.64 & 52.34 \\
\hline Mean & 38.77 & 19.69 & 32.02 &
\end{tabular}

Source: KNA: AK/2/6, Sugar Variety Trials, Kala Singh’s Farm, Miwani-Kibos Area (29/2/2).

From the above data, the large reduction in yield of the first ratoon compared to the plant crop was due to drought experienced during the dry season of 1952-1953. However, comparing the plant crop to the second ratoon, it emerges that the mean yield reduction was only 8 percent. Hence it emerges that the second ratoon was as good as the plant crop. Another pertinent issue that emerged was that the CO 331 and CO 213 produced the highest calculated yield of sucrose per acre of the varieties. ${ }^{129}$

\footnotetext{
${ }^{129}$ KNA: AK/2/6, Experimental Farm, Kala Singh-Miwani-Kibos.
} 
These same varieties were also tested during harvesting when the canes were stripped of leaves and various differences were noticed. For instance, observations were made on cane length, thickness, and number of canes per stool and lodgings as stipulated below: varieties with largest canes were CO 331, CO 408, CO 432, POJ 2747, CO 244, CO 281, CO 417, and CO 434. While varieties with the thickest cane were: CO 419, CO 421, and POJ 2714. Varieties with the thinnest cane were: CO 244, CO 408, and CO 432. Varieties with the most cane per stool: CO 213, CO 421, CO 244, CO 285, CO 432, and, CO 331. Varieties with least cane per stool: POJ 2714, POJ 2747, MF 240, and B 3257. Varieties with most lodging were: CO 434, CO 417, MF 240, CO 281, and, CO 244. Those with the least lodging: B 3337, CO 421, CO 213, CO 408, and $\mathrm{CO} 432 .^{130}$

These trials made it possible for the cane farmers to be better informed and hence the growers were able to grow cane that was profitable. Further trials were undertaken, for example, of the sixteen varieties experimented at Kala Singh's farm. Trials were undertaken in different soils, such as the upper red soil of the Miwani Estate, and lower black soil. These trials were meant to determine which soil was more conducive to cane production, as indicated in the following two trials. The following data shows the yields in red soil of various varieties

\footnotetext{
${ }^{130}$ KNA: AK/2/216, Sugar Variety Trials, Miwani-Kibos Area.
} 
Table 4.11: Sugarcane Planted on Red Soil, Miwani Estate and Harvested 1955

\begin{tabular}{cc}
\hline $\mathbf{1}^{\text {st }}$ Ratoon & $\begin{array}{c}\text { Tons of Cane per Acre } \\
\text { (Upper Red Soil) }\end{array}$ \\
\hline Variety & Yield \\
\hline CO 331 & 31.45 \\
CO 419 & 22.74 \\
CO 421 & 22.44 \\
CO 213 & 19.42 \\
CO 408 & 19.09 \\
\hline Mean & 23.02
\end{tabular}

Source: KNA: AK/11/52, Sugar Cane Variety Trial Miwani (29/2/5).

This was important information for farmers whose farms had red soil since they were able to know the best variety to plant. Another experiment was conducted concurrently on the black soil for comparison as indicated by the following table.

Table 4.12: Trials on Yields and Sucrose Content Planted on Black Soil and Harvested, 1955 Miwani

\begin{tabular}{ccc}
\hline Variety & Yield (tons cane/acre) & $\begin{array}{c}\text { Yield of Sucrose (tons/acre) } \\
\text { (calculated by Java ration) }\end{array}$ \\
\hline CO 331 & 36.55 & 4.25 \\
CO 419 & 29.60 & 3.71 \\
CO 408 & 25.47 & 3.14 \\
CO 213 & 21.53 & 2.45 \\
CO 421 & 21.45 & 2.59 \\
\hline Mean & 26.92 & \\
Least Significant & & \\
Difference 0.05 & &
\end{tabular}

Source: KNA: AK/2/5, Sugarcane Variety Trials, Miwani (29/2/5).

The above data indicates that CO 331 gave a significantly higher yield than any other variety as was the case in the first ratoon harvest on the upper red soil. (See table 4.11) However, the significant mean fall in yield was attributed to ratoon stunting disease which was 
prevalent in the area. ${ }^{131}$ Moreover, the comparison between the yield grown in red soil and black soil revealed that sugarcane did better in black soil. For example, CO 331 did better in black soil just like the other varieties tested. These experiments were important since each successful variety was then used by the farmers in Kibos-Muhoroni area. For example, Kibos alone had approximately 68 different varieties grown by farmers who had different types of soil. Therefore, it emerges that these colonial government technical supports enabled farmers to have enough information to improve their farming by making informed choices.

Apart from the tests that determined the suitability of varieties as per the ecology of the area, the sucrose content of sugarcane was important to cane farmers. Therefore, many trials were also carried out on experimental farms, not only at Kibos but also at the Miwani Estate, to determine such factors. Hence a trial of sixteen varieties was done whereby planting took place in March 1953 on the sandy red loam soil typical of the upper part of the estate; it was harvested in January 1955. The results of the yields of cane are shown below together with the sucrose of the yields calculated in tons per acre.

\footnotetext{
${ }^{131}$ KNA: AK/2/5, Nyanza Province Agriculture Annual Report, 1956-1957.
} 
Table 4.13: Sugar Variety Trial - on Yield and Sucrose Content, Miwani Estate, 1953

\begin{tabular}{lcc}
\hline Variety & $\begin{array}{c}\text { Yield of Cane } \\
\text { (tons/acre) }\end{array}$ & $\begin{array}{c}\text { Sucrose Yield } \\
\text { (tons/acre) }\end{array}$ \\
\hline CO 411 & 52.80 & 4.78 \\
N CO 291 & 49.01 & 5.13 \\
CO 453 & 47.82 & 5.52 \\
B 37193 & 47.75 & 4.45 \\
B 41227 & 41.64 & 4.01 \\
POJ 2961 & 40.52 & 4.67 \\
N CO 79 & 40.28 & 5.26 \\
CO 290 & 39.66 & 3.54 \\
CO 421 & 39.39 & 3.58 \\
CO 281 & 37.94 & 4.84 \\
N CO 330 & 36.68 & 3.94 \\
B 3337 & 34.68 & 3.63 \\
CP 36/105 & 29.99 & 3.07 \\
B 3257 & 29.22 & 3.54 \\
CP 34/120 & 22.77 & 2.24 \\
CP 34/79 & 12.06 & 1.29 \\
\hline Mean & 37.64 & 3.97 \\
Least significant & & \\
Difference $=0.05$ & &
\end{tabular}

Source: KNA: AK/2/6, Sugarcane Variety Trial, Miwani (29/2/6)

The data reveals that the CO 411 yielded the highest, but that CO 453 had the highest sucrose content. The poorest cane was the CP 34/79 which had both low yields and sucrose content. It also revealed that the N CO 291 was a good cane since it had good yield and sucrose content. The data thus indicates there were other determinants for a good cane, such as sucrose content, which determined the tons of sugar produced from a particular cane. Such information was very crucial to the cane farmers in as far as quantity and quality of cane was concerned. Such trials attest to the keenness by which the colonial state assisted the Asian sugarcane industry in the 1950s.

Another trial was undertaken of twenty-five varieties at Miwani. It was planted in September 1954 to compare with other varieties tested. This test incorporated new varieties also. 
The crop was harvested in April 1956. Below is a table indicating the yield figures of cane and of sucrose in tons per acre.

Table 4.14: Sugar Variety Trial on Yields and Sucrose, Miwani Estate, 1954

\begin{tabular}{lcc}
\hline Variety & $\begin{array}{c}\text { Yield of Cane } \\
\text { (tons/acre) }\end{array}$ & $\begin{array}{c}\text { Sucrose Yield } \\
\text { (tons/acre) }\end{array}$ \\
\hline CO 419 & 66.01 & 7.13 \\
N CO 339 & 63.44 & 6.76 \\
CO 331 & 62.39 & 5.68 \\
N CO 334 & 62.26 & 6.42 \\
CO 301 & 61.97 & 6.47 \\
CO 434 & 61.00 & 6.18 \\
NCO 349 & 59.80 & 6.42 \\
CO 312 & 58.30 & 6.14 \\
CO 411 & 55.02 & 4.99 \\
B 41227 & 54.96 & 5.61 \\
N CO 330 & 53.49 & 6.19 \\
N CO 291 & 52.99 & 5.53 \\
N CO 310 & 52.03 & 6.05 \\
CO 281 & 50.75 & 5.26 \\
CO 452 & 50.61 & 5.15 \\
CO 421 & 48.29 & 5.13 \\
POJ 2875 & 45.95 & 4.84 \\
B 37193 & 45.90 & 4.40 \\
CO 408 & 45.82 & 5.86 \\
NCO 79 & 45.10 & 4.75 \\
POJ 213 & 43.57 & 4.14 \\
POJ 2961 & 43.08 & 4.55 \\
B 3337 & 42.23 & 4.26 \\
B 4362 & 41.09 & 5.32 \\
CO 213 & 36.59 & 3.28 \\
\hline Mean & 52.10 & \\
\hline & & \\
\hline
\end{tabular}

Least significant Difference $=0.05$

Source: KNA: AK/2/5, Sugar Cane Varity Trials -Miwani (29/2/8).

Generally the yield from this experiment was very high, whereby the variety CO 419 out yielded other varieties. NCO 399, which was a new variety, also registered a high yield and had 
the second best sucrose content; hence, the need for constant trials was important as new varieties were found. However, the data also revealed that while CO 331 was mostly favored and recommended for planting, though it had a low sucrose yield. It emerged that the highest sucrose content cane was CO 419 and the lowest CO 213. Farmers needed such information to make economical choices since they needed cane that had good yields as well as good sucrose content if farming was to be profitable. This was because cane with low sucrose content often produced less sugar and hence fetched lower prices since it was not favored by manufacturers.

Furthermore, other experiments were conducted on cane spacing during cultivation to help the farmers attain good yields. A sugar cane spacing experiment was conducted at Chemelil farms. The cane was planted in December 1949, and the crop harvested in October 1951. Here the experiment was geared towards studying three different rows of spacing, i.e. $4 \mathrm{ft} ., 5 \mathrm{ft}$., and 6 ft.; the cane used was CO 281. When the cane was harvested in 1951, there was no significant difference in yields between the three different spacing. The first ratoon harvested in June 1953 showed no major difference either. The yield figures are given below for the three crops harvested.

Table 4.15: Experiments on Sugarcane Spacing, Chemelil, 1949-1955

\begin{tabular}{lccc}
\hline Spacing & Plant Crop & First Ratoon & Second Ratoon \\
& 1951 & 1953 & 1955 \\
\hline 4 ft. rows & 40.72 & 19.41 & 15.46 \\
5 ft. rows & 41.35 & 19.40 & 17.38 \\
6 ft. rows & 41.51 & 18.75 & 17.10 \\
\hline
\end{tabular}

Source: KNA: AK/2/6, Sugarcane Spacing Experiment Trials, Chemelil (29/5).

The above data revealed that very little difference in yield was noted among the various rows. However, on the second ratoon, there was a tendency for the two wider spacing, i.e. $5 \mathrm{ft}$. 
and $6 \mathrm{ft}$, to yield more than the $4 \mathrm{ft}$ row. Hence, $6 \mathrm{ft}$. spacing was recommended to cane farmers since it was the most suitable for mechanized cultivations and in large scale farming.

\section{Experiments on the Possible Irrigation of Sugarcane farming}

Although in the Kibos-Muhoroni area cane cultivation was basically rain fed, experiments with irrigation had started in 1930 when, due to severe effects of drought, Muhoroni embarked on experimentation and got good results. These initiatives were followed in 1953 when Miwani Estates started an experimental irrigation scheme for sugar. The water was drawn from the tributary of the Nyando River near Chemelil. ${ }^{132}$ The idea was to pump water up to the top of the small hillock and then gravity fed the ditches from there. Thus in 1956, after the trials, Miwani Sugar Mills irrigated 1,100 acres of cane at the Chemelil nucleus estate. Another 500 acres was also irrigated at their Miwani estate, where they used boreholes. ${ }^{133}$ However, there was no large scale irrigation of sugarcane on individual Indian farms since the only rivers available were Kibos, which is seasonal, and the tributaries of the Nyando, which was already used by Miwani Estate. Moreover, there were no permanent streams coming from the Nandi escarpment into the sugar estates. Nevertheless the main point for experimenting with irrigation of sugarcane on Miwani Estate was to see whether the low-yielding CO canes could be replaced with the high-yielding POJ canes by one to two watering during the dry season from January to March. Storage of water on the land would have required very large dams which were expensive and needed large capital. However because it was a worthwhile venture, the colonial state could not ignore it.

There was a great push for irrigation during this period which led to the deputy hydraulic engineer to visit Kisumu in December 1953 so as to make a preliminary assessment of the

\footnotetext{
${ }^{132}$ KNA: AK/11/51, PAO Nyanza to Director of Public Works, $8^{\text {th }}$ December 1953.

${ }^{133}$ KNA: AK/2/5, Progress in Improved Farming-Asian areas.
} 
possibilities of irrigating the sugarcane in the Kibos area. ${ }^{134}$ Moreover, engineers who were contracted by the government evaluated the Kano Plains in a pilot project begun in 1954-1956. The evaluation revealed the potentialities of irrigation and swamp reclamation in Nyanza Province. The engineers' report recommended that the development of Kano plains was a priority in the development of the lake basin. The report clearly stated that it was possible to irrigate by pumping water from Lake Victoria which could be supplemented by the gravity flow from the Nyando River. ${ }^{135}$ Thus the irrigation potential of Kano plains was assessed at approximately 30,000 acres based on the possibility of two crops: sugar and rice farming. This could have gone a long way to help in sugar production in Kenya. Moreover, the report recommended the establishment of experimental farms to study the growing of sugar cane under irrigation and the construction of pilot schemes to determine, among other things, the size of holding best suited to small scale irrigated farming. ${ }^{136}$

The area estimated to benefit from possible irrigation was approximately 19,500 acres under cane and an additional 16,000 acres from Miwani Estate and the Indian farms in the Kibos-Muhoroni area where sugar cane could be grown successfully. Hence, it was possible to irrigate in total about 35,500 acres as indicated in the following data.

\footnotetext{
${ }^{134}$ KNA: AK/11/51, Public Works Department Head Office to PAO Nyanza, $8^{\text {th }}$ December, 1953.

${ }^{135}$ Bank for Reconstruction and Development, Economic Development of Kenya ( Baltimore: The John Hopkins Press, 1963), 80.

${ }^{136}$ Ibid.
} 
Table 4.16: Possible Acreage to Benefit from Irrigation, 1953

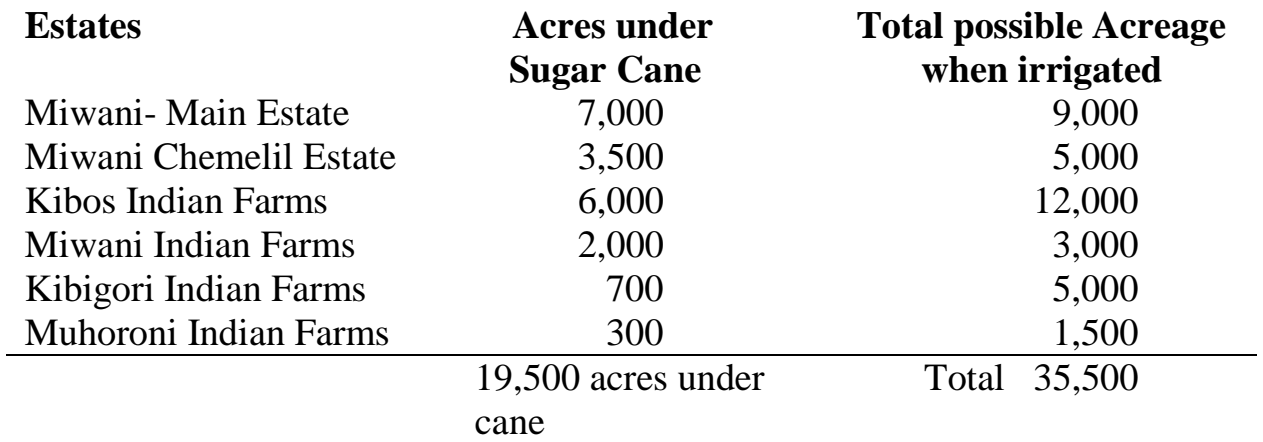

Source: KNA: AK/11/51, Irrigation of Sugarcane, Nyanza Province, 1953.

The above information revealed that if irrigation was adopted, more acreage could be planted which could have gone a along way towards self-sufficiency in sugar consumption. Furthermore, it emerges that irrigation of sugarcane could have improved productivity for Kenya as a result of additional water supplies being made available during the critical period from November to March. First, irrigation would have increased production by eliminating the effects of the dry season; secondly, the cane would grow continuously and the length of the cycle required to produce three crops would then be shortened from five years to four years,

Moreover, irrigation would have permitted the growth of improved varieties of noble canes which yield twenty-five percent more than other varieties at Kibos-Muhoroni Miwani area. However, the noble canes could not be grown since they are not drought resistant. ${ }^{137}$ It was estimated that if 20,000 acres of cane were irrigated with those varieties grown at Kibos, there would be an increase in production of 360,000 tons of cane a year, worth $£ 540,000$. Whereas if improved varieties of noble canes were grown, the increase in production would have been 510,000 tons of cane a year, worth $£ 765,000$. For example, 60 tons from 1 acre in 5 years yielding 12 tons per acre, would produce 240,000 tons per annum, valued at Shs. 301/= a ton, which would be worth $£ 360,000$. This could have made cane growing to be very profitable.

\footnotetext{
${ }^{137}$ KNA: AK/11/51, PAO Nyanza to Director of Agriculture, $4^{\text {th }}$ May 1953.
} 
Moreover, there was also a significant difference noted between ordinary cane and noble cane gown under irrigation. For example, it was noted that normal cane under irrigation could produce 120 tons from 1 acre, in 4 years which would equal 30 tons per acre per annum. 20,000 acres would produce 600,000 tons per annum. Valued at Shs. 301/= a ton, it would be worth $£ 900,000$. On the other hand, irrigation with improved noble canes could produce 150 tons from one acre in four years that yielded 37 tons per acre per annum. 20,000 acres would have produced 750,000 tons per annum, valued at Shs.301/= a ton worth, it would be worth $£ 1,125,000$.

The findings further revealed that there were some water sources that could have been used to irrigate the sugarcane farms as follows:

$\begin{array}{ll}\text { Kibos Indian Farms } & \text { by pumping water from Kibos River } \\ \text { Miwani Indian Farms } & \text { by constructing dams at the top of the } \\ & \text { Escarpment in Nandi or at the foot of the } \\ & \text { Escarpment } \\ \text { same as Miwani Indian farms } & \text { by sinking boreholes } \\ \text { Miwani Estate } & \text { by pumping water from Nyando River } \\ \text { Kibigori Indian Farms } & \text { by sinking boreholes. }{ }^{138}\end{array}$

Therefore, it emerges that irrigation could have been possible and greatly benefited the cane farmers. Moreover, some of the Indian farmers had had experience of growing sugarcane under irrigation in India. ${ }^{139}$ Although it required a large amount of capital, Miwani Sugar Mills was able to build a dam, and by 1953 it was possible to irrigate 2,000 acres at Chemelil.

Be that as it may, the findings revealed that there would not be enough water to irrigate large areas of the sugarcane plantations in the area under review. Assuming the water requirements was one cusec per 100 acres (cusec- taken here to mean a unit flow of water equal

\footnotetext{
${ }^{138}$ Ibid.

${ }^{139}$ Ibid.
} 
to one cubic foot per second) and taking the existing 1953 acreage only, the water requirement would have been as follows:

Table 4.17: Approximate Amount of water required for Irrigation, 1953

\begin{tabular}{|c|c|c|}
\hline Estates & $\begin{array}{l}\text { Continuous } \\
\text { Flow Required }\end{array}$ & $\begin{array}{l}\text { Storage for } 5 \text { Months } \\
\text { November-March }\end{array}$ \\
\hline Miwani Main Estate & 70 cusecs & 21,000 acre feet \\
\hline Miwani Chemelil & 35 cusecs & 10,000 acre feet \\
\hline Indian farms & 60 cusecs & 18,000 acre feet \\
\hline Miwani Indian farms & 20 cusecs & 6,000 acre feet \\
\hline Kibigori Indian farms & 7 cusecs & 2,000 acre feet \\
\hline Muhoroni Indian farm & 3 cusecs & 900 acre feet \\
\hline Total & 195 cusecs & 58,000 acre feet \\
\hline
\end{tabular}

Source: KNA: AK/11/51, Irrigation of Sugarcane, Nyanza Province, 1953.

From the above date it emerges that during the dry weather, flows in the rivers in the area would be very limited and far from these figures. Thus storage would have required very large dams, which would have required large amounts of capital. ${ }^{140}$ Moreover, this was the most critical period (Nov.-March), when irrigation was needed. Therefore, based on the foregoing, the irrigation of sugarcane in Nyanza was shelved due to these technicalities, and sugarcane farming continued to be rain- fed in the Asian farms.

Nevertheless, apart from the experimental trials by the colonial government, other initiatives were seen in terms of personnel, when experts were invited to visit the sugar zones. For example, in December 1952, Mr. Barnes, a sugar expert from South Africa, toured the Songhor-Muhoroni and Miwani areas where the farmers had 28,000 acres of land under cane. Unfortunately, not all were used for sugar, as some was turned to jaggery. Hence, besides discussing with the agricultural officers, he met the farmers and gave them technical advice on

\footnotetext{
${ }^{140}$ KNA: AK/11/51, B.R.C. Koch, to Member for Agriculture and Natural Resources, $29^{\text {th }}$ September 1953.
} 
how to improve cane cultivation and make it profitable. ${ }^{141}$ In his report, Barnes discouraged the establishment of a second factory in the Kibos-Miwani area on grounds that the quantity of cane produced in the area was far from adequate to maintain a separate mill economically. Instead, he recommended that communications in the area be beefed up so as to allow farmers to deliver their cane to the existing factories. ${ }^{142}$ However, later when Mr. P. O. Wiehe, the sugar research expert from Mauritius, visited CN at government invitation in 1956, he reiterated the need for irrigation to improve cultivation. He recommended that the improved varieties had to be complimented by irrigation to attain better results.

\section{Conclusion}

In this chapter, Asian sugarcane farming during the colonial period in Nyanza has been examined. The chapter has demonstrated that the Asian farmers were resilient and kept on increasing the acreage under cane. It has also revealed that this was not an easy task, since they had to contend with calamities such as drought, locusts, limited information at first and biased policies. The chapter has also demonstrated that there were a few European farmers in the area as well who also planted sugarcane while some planted other crops such as sisal and coffee. It has also examined the agricultural aspects involved in growing of sugarcane where such pertinent issues as cultivation, weed control and harvesting have been discussed. Thus the chapter showed that during the pre-World War I period, the cane farmers were still settling at the Kibos-Muhoroni area, grappling with the difficult environment and trying to determine what crops could be successfully grown. Hence, they experimented with the growing of sugar cane using the local variety Uba, whereby all their produce was turned into jaggery since there were no mills then to crush cane. During this period, farmers were also engrossed in trying to acquire

\footnotetext{
${ }^{141}$ KNA: AK/11/51, DO, CN to the Assistant Director of Agriculture Nyanza, $11^{\text {th }}$ December, 1957.

${ }^{142}$ KNA: AK/11/51, A.G. Dalgleish to Mr. A. Pritam, $18^{\text {th }}$ April, 1953.
} 
more land as some owned parcels of land in both Kibos and Muhroni, although the colonial state restricted such efforts.

The interwar period marked the beginning of commercial sugarcane farming with the establishment of the European owned Victorian Nyanza Sugar Company at Miwani which started to manufacture sugar in 1923. This was followed closely by another European factory, the Muhoroni Sugar Mills which only crushed its own cane. The Victoria Nyanza Sugar Company initiative of contracting Asian cane farmers encouraged farmers to plant more cane and from then on the industry progressed, despite many challenges faced such as the locust invasions of early 1930s. Other challenges included drought and the depression that left many farmers devastated.

However during the World War II period leading to 1949, expansion in the industry was witnessed. This was as a result of the colonial state's change of policy which was geared towards producing enough foodstuffs to meet the war demands. This was seen when the United Kingdom, pressured by the war demands, imported a lot of brown sugar from Kenya. Remarkable progress was achieved with the entrance of Asian entrepreneurs in the sugar manufacturing industry in 1947. These experienced sugar industrialists revolutionized the industry completely by buying more large estates, contracting farmers and also laying more trolley lines for cane transportation.

The expansion continued and reached its peak in the mid 1950s when many trials were conducted on various varieties through the support of the colonial state. Despite the challenges, the chapter revealed that there was massive government intervention to the Asian farmers through the provision of the technical support in terms of various variety trials that saw the successful testing of 68 varieties from various countries, and also sugar experts were invited 
from different countries to help out. Thus there was tremendous technical support accorded to cane farmers contrary to the existing literature. It emerged that cane farming underwent periodic changes due to the availability of information and trails on various varieties. As a result, the sugar industry expanded especially with the eclipse of the European millers by the 1940s. The chapter also illuminates how the European farmers in the district were given preferential treatment and favored for several decades, especially on financial matters. Finally it emerged that from the mid-1950s leading to independence, the sugar industry in colonial Kenya had overcome some obstacles that included lack of adequate finance, since they could then borrow money from the two banks, diseases, and natural calamities like the locusts to become a vibrant industry financed by Asian capital. The Asians were both growers and manufacturers as well, as will be discussed in the next chapter. 


\section{CHAPTER 5}

\section{TRANSPORTATION AND PRODUCTION OF SUGAR IN COLONIAL NYANZA}

\section{Introduction}

The previous chapter focused mainly on the growth and development of sugarcane farming in colonial Nyanza. This chapter examines the transportation and processing of sugar right from the time it was delivered to the factory, revealing the colonial state's discrimination against the Asian sugar growers who had no adequate transport to ferry their produce as compared to the European settler farmers. The colonial state's support accorded to the Asian farmers in comparison to the European settler farmers in the region favored the latter. Moreover, colonial policies were marked by confusion and contradictions whereby the colonial government supported cane farming and also inhibited its expansion. The chapter also examines how the pricing of sugar was problematic due to lack of colonial state support to fix sugar cane prices. It reveals how the pricing and payment of sugar cane was not fair, since the farmers and the manufacturers were never consulted, and portrays how the Asian farmers struggled to succeed in a relatively hostile economic and political environment as the colonial state eventually took control of the pricing of sugar. This had a negative impact because the farmers and manufacturers alike felt discouraged. This issue indicates how lack of a clear pricing policy left the cane growers in a precarious situation whereby they were exploited by both European and Asian manufacturers. The latter situation revealed that race was not the sole determinant in exploitation of the Asian cane farmers in colonial Nyanza. The chapter finally details the factory process of milling sugar, the technicalities involved, and the contribution of the Asian manufacturers in the processing of sugar. This demonstrates how the Asians producers, just like 
the cane growers, struggled to succeed in a hostile colonial economy as evidenced by difficulty in procurement of machinery.

\section{Transportation of Sugarcane}

Once the cane was harvested it was taken to the factory. Thus cane transportation becomes an important aspect of sugarcane production since poor roads and infrastructure raises costs of transport of produce and sometimes led to post-harvest loses due to delays associated with transportation. Initially, during the post World War I period, the small scale farmers transported cane from their farms, using oxen drawn carts, to the main road or railway line. The use of carts was preferred also by the African farmers later on when they started planting cane. Although found to be cheaper in transporting cane from the farms, during the wet season it was difficult. From the main road, cane was then either transported by road or rail. ${ }^{1}$

Over the years, there were generally three means of transporting cane. The first was the use of medium sized lorries, especially among the small scale farmers who found the carts problematic to use, especially during the rainy season. However, by late 1940s some cane farmers acquired ex-military lorries at the end of World War II which were reconditioned and used for transportation. These lorries were heavily built and far better than the carts. However, they too were found to be uneconomical and difficult to use, especially during the heavy rainfall since many were stuck in mud. The second method involved trucks, which were actually lorries that were reconditioned and made larger using metal frames so that they were capable of carrying heavier loads. In most cases, the trucks belonged to the factory. However, there were some Asian businessmen who were not farmers but owned a fleet of trucks transporting cane to the factories. For example, Simba Singh, who owned many trucks by the 1950s and still

${ }^{1}$ KNA: AG/25/70, Solicitors Allen and Hamilton to Colonial Secretary, 27 ${ }^{\text {th }}$ June 1922. 
operates them today, had a fleet of over 100 trucks whose purpose was just to ferry sugarcane to the factories. $^{2}$

Whichever the means used, the transport of cane to the factory was mainly the responsibility of the farmer. Those who could afford to hired the heavily built trucks which were found to be stronger than the lorries. Just like those who used the lorries, the longer the distance the more the farmers paid. Yet there were no loans extended to help the farmers transport cane or to buy their own truck. This lack of adequate funding reveals the contradictions of the colonial state's policy that was reluctant to support the cane farmers. After harvesting, a farmer had to find means to deliver cane to the trolley lines from the farm to the factory, which was very problematic. As put by Mohinder Singh, as far as transport was concerned; "itho-thoni” (you carry your cross). ${ }^{3}$ This portrays how the colonial state neglected the transport needs of the Asian cane growers as they had to struggle to ferry their cane.

Needless to say, apart from hiring the trucks the farmers had also to hire drivers and loaders who were not only responsible for loading but also unloading the cane at the factory. The loaders and truck drivers were only paid after the cane was accepted by the factory. Furthermore, when the roads were impassable during the rainy season, most of the trucks were stuck in the mud and it required that the driver had to wait until it was removed at no extra pay. Joseph Otieno, a truck driver, claimed the cane farmers suffered. For example, when stuck in the mud, the factory would send a wedge to pull the truck out and then charged the farmers by deducting from the cane payment. ${ }^{4}$ Sometimes the trucks had accidents, especially on sloppy areas; hence the need for experienced drivers. Sometimes trucks were in bad condition; the cane fell out of the trucks, and this incurred loses to the farmers.

\footnotetext{
${ }^{2}$ Martin Okeyo, (O.I.), Kibos out growers’ Farm Manager, 24 ${ }^{\text {th }}$ June 2009.

${ }^{3}$ Mohinder Singh, (O.I.), large scale farmer Kibos, $22^{\text {nd }}$ June 2009.

${ }^{4}$ Joseph Otieno, (O.I.), truck driver, Chemelil, 26 ${ }^{\text {th }}$ June 2009.
} 
Transportation was often a major problem since the roads were in poor condition. For example, the road that accessed the Muhoroni Sugar mill was in very bad shape in 1930, because it had not been repaired for two years. This meant that the cane farmers in Muhoroni experienced difficulty in transporting their crop and reveals the neglect of the colonial state towards the infant sugar industry portrayed by the colonial government's delay and reluctance to improve the roads. For example, the roads were completely worn out and reverted to the status of a mere track. The situation resulted from the collapse of the bridge over the Kapchuire River at Kibigori in 1930 which by 1931 had not been replaced. ${ }^{5}$ Moreover, the roads in Kericho, Londiani, Kibigori, and Muhoroni, though maintained by the DC, were not in good shape. It seemed that the distance from the headquarters of the Public Works Department in Nyanza, and lack of supervision might have contributed to the conditions of the roads which greatly affected the cane farmers in the area. Thus, to alleviate the situation, the executive engineer for the Public Works Department was requested to undertake the task of supervision which led to better conditions of roads by 1932. The initiative saw the construction of 18 miles of new road between Kibigori, Muhoroni, and Chemelil which then greatly helped the farmers to transport their cane. ${ }^{6}$

Due to these difficulties, the colonial government, contradicting its earlier stance, embarked on improving roads in 1933 after many complaints by the farmers. The roads in the sugarcane area were murramed throughout the year. Hence, the road between Kibigori and Londiani was upgraded to an all-weather road. Also the section from Kibigori to Songhor was improved when the construction of a track road which had stalled in 1930 was revived and

\footnotetext{
${ }^{5}$ KNA: DC/CN/1/4/3, K-LDAR 1931.

${ }^{6}$ KNA: DC/CN/1/4/3, K-LDAR1931 and 1932.
} 
widened, while the Kibos bridge, started in 1932, was also completed in $1933 .^{7}$ Many farmers transported cane to the factory using these improved roads. Companies also took the initiative to build roads to help in transportation of cane. By 1932, for example, the Muhoroni-Kericho road had been constructed by Mr. Allen of Muhoroni Sugar Factory, which was then inspected by the executive engineer and found to be satisfactory. ${ }^{8}$ The willingness of the factory owners to construct the road indicates the potentiality of the sugar industry in the area that made them willing to invest in it, unlike the colonial state that ignored the opportunity. Furthermore, it was found that the poor state of roads impacted the pricing and transportation of both cane and sugar. This phenomenon has been discussed effectively by Peter Wanyande, whose findings revealed that poor infrastructure made transportation to be expensive and hence affected the pricing of sugar and sugarcane due to the high costs incurred in the maintenance of cane haulage fleets. ${ }^{9}$

Due to lack of good roads and distance, some farmers in Chemelil and Muhoroni suffered because by the mid-1930s the Asian farms in the area did not have mills close at hand. Cane had to be transported all the way to the Miwani factory since the factory at Muhoroni did not accept cane from outside its nucleus estate; as such the Asian cane farmers in Muhoroni-Chemelil area had no choice but to turn their sugarcane into jaggery. This situation continued until 1942, when an Asian entrepreneur, Premcard Raichad and Company, bought the Nottidge and Allen factory at Muhoroni and started receiving cane from the farmers around the Muhoroni-Chemelil area. ${ }^{10}$

As the problem of sugarcane transportation to the factory persisted, the Nyanza Indian Farmers Association (NIFA) worked tirelessly during the 1930s to raise such pertinent issues with the government. They appealed for the construction and improvements of roads and

\footnotetext{
${ }^{7}$ KNA: DC/CN/1/4/4, K-LDAR 1933.

${ }^{8}$ KNA: BV/1/249, Executive Engineer to Commissioner for Local Government, Lands and Settlement, $13^{\text {th }}$ July 1932.

${ }^{9}$ Wanyande, “Management Politics”, 138.

${ }^{10}$ KNA: BV/6/605, Manager, East Africa Sugar Industries, Muhoroni, to Director of Agriculture, $7^{\text {th }}$ October 1942.
} 
proposed in 1937 that the Kisumu-Kibigori road be improved to access Indian farms, since that road had already been granted $£ 5,500$ by special warrant for that purpose, as acknowledged by the acting colonial secretary. ${ }^{11}$ Unfortunately the colonial state responded that there were no funds to undertake such development and even suggested that the route could be changed. ${ }^{12}$ Why the colonial state responded in such a manner, knowing that funds had been set aside for that purpose, could be interpreted as racial discrimination against the Asian sugar growers because the European settlers needing similar services were treated differently. This view is supported by Kanogo who argues that with the implementation of the soldier settlement scheme, the colonial state embarked on a program that extended the railway and improved roads and port facilities to ease the transportation of the settlers produce. ${ }^{13}$ Thus it emerges that settler agriculture received more support in transportation, while on the other hand, Asian cane farmers struggled with the colonial state to improve the much needed roads and generally paid heavily for transportation. Those who opted for transportation by use of factory trucks had approximately one-fourth of their total cane value skimmed off as transport charges. By 1960 the charges were Shs. $1 /=$ per ton per mile. ${ }^{14}$ Moreover, truck transportation was used by only a few, and in most cases large scale farmers. It required skilled operators and also careful maintenance to avoid breakdowns. Therefore, transportation of cane by road was a major problem that the farmers had constantly to struggle with, especially during the rainy season, due to the poor condition of roads. Transport by rail was a better option.

\footnotetext{
${ }^{11}$ KNA: PC/NZA/3/2/34, Petition by NIFA to Colonial Secretary, $6^{\text {th }}$ October 1937.

${ }^{12}$ KNA: PC/NZA/3/2/34, Colonial Secretary to NIFA, $3{ }^{\text {rd }}$ December 1937.

${ }^{13}$ Kanogo, "Kenya and the Depression”, 112.

${ }^{14}$ KNA: BV/111/119, Cane Transport, 1960.
} 


\section{Sugarcane Transport by the Kenya-Uganda Railway}

Rail transport became handy during the wet season, particularly for farms adjacent to the railway line. Thus it emerged that the railway facilitated the transportation of cane especially for farmers near the line. Even those far away needed cane to be removed from the farm to the railway for transportation to the factory. Thus the third means of transport entailed the use of rail and trolley lines that were set up by the factory. This involved the use of large wheeled metal huge containers for transportation of heavy goods. Such arrangements were made possible because the Victoria Nyanza Sugar Company laid its own tramway lines to transport cane, according to the Victoria Tramway Ordinance No.1 of 1922. This ordinance was introduced specifically to enable the company to convey sugarcane from the neighboring farms to the factory on trolley lines which were drawn by small locomotives. There were even private trolley lines that could be used, but to build such tramways, bills had to be introduced, first in Britain, to allow such measures to be taken. ${ }^{15}$

The provisions of the Victoria Tramway Bill were made through the Roads and Traffic Bill which was to ensure the license for temporary construction and operation of works on road reserves. In the construction of roads and tramways, the question of land for through-pass always arose. In the case of the sugar areas, it emerged that as far as recompense to the government in respect to public lands that might have been used by the company, the colonial state saw that due to the advantages afforded to the community by the establishment of the sugar factory, the company needed to be accorded free use of the public road for the construction of the tramway. ${ }^{16}$ Due to such a policy, there was no compensation payable to anybody on account of

\footnotetext{
${ }^{15}$ KNA: AG/25/70, Governor to Duke of Devonshire, Secretary of State for the Colonies, $3^{\text {rd }}$ January 1924.

${ }^{16}$ KNA: AG/25/70, Victoria Nyanza Company's Tramway Ordinance, 1923. Coryndon, to Colonial Office, $3^{\text {rd }}$ January 1924.
} 
right to lay trolley lines along the strips of land. However, the trolley lines did not reach most of the farms, especially those located far from the factory.

Nevertheless, a tramway was built in 1923 by Victoria Nyanza Sugar Company, starting on its own estate and running along a line of a public road, and terminating at the Kibos railway station. ${ }^{17}$ This initiative to build a tramway by the Victoria Nyanza Sugar Company instead of the colonial government illustrates how the colonial state was biased and neglected the sugar industry while it provided rail and road services to settler farmers. This was partly due to the inability of the colonial state to visualize the potentiality of the sugar industry in $\mathrm{CN}$.

According to the agreement between the Victoria Nyanza Sugar Company and the railway, the company was allowed the use of the railway siding line from Miwani railway station to the company's nearby sidings. This was meant to be used for light trolley conveyance; thus the railway provided the engine for use of the trolley. ${ }^{18}$ However the railway refused to take any responsibility for accidents which occurred upon it while being used by the company. The railway mostly preferred, and allowed the company to use, a light trolley on the railway siding line during the wet season when the roads were impassable. ${ }^{19}$ In addition, the company was to keep the siding line in good repair during its usage, and if the railway did the repairs it would recover the cost from the company. In essence, according to the agreement, the Kenya-Uganda Railway administration was relieved from all responsibility. This left a huge financial commitment on the part of the Victoria Nyanza Sugar Company. Suffice it to say, this was a necessity that could not be overlooked. For example, the provincial agrarian development officer advised that the tramway was a very crucial part of the whole sugarcane production

\footnotetext{
${ }^{17}$ KNA: AG/25/70, Ag. Director of Public Works to Colonial Secretary, 26 ${ }^{\text {th }}$ September 1923.

${ }^{18}$ KNA: AG/25/70, General Manager, Uganda Railway to Attorney General, $19^{\text {th }}$ May 1923.

${ }^{19}$ KNA: AG/25/70, Agreement made between Uganda Railway and Victoria Nyanza Sugar Company, 1923.
} 
industry and encouraged the company to install the trolley lines. ${ }^{20}$ Thus we find that the company was ready to commit its finances while both the colonial state and the Kenya-Uganda Railway shied away from the responsibility. Therefore, we can argue that the location of the sugar farms near the main line could have made the colonial government to consider reaching an agreement with the Kenya-Uganda railway on extending the line or even step in and offer subsidized rail freights for cane transportation due to the potentiality of the sugar industry. This was something that the state totally ignored, partly due to lack of appreciation of the economic importance and potential of sugar cane farming in the area.

Needless to say, farmers situated adjacent to the main railway used trolley lines to move their cane to the railway line from where it was transported to the factory. Those near the factory at Miwani used the trolley lines for transportation of cane to the factory. Cane would be cut and the farmers would deliver it to the trolley line to be conveyed to the factory. ${ }^{21}$ Unfortunately even the trolley lines were not sufficient.

As an alternative, farmers were expected to allow feeder lines to be laid and maintained in their fields for transport of cane from the adjoining farms by extension of the feeder line. Farmers also had access to portable tramlines which were connected to the nearest mainline and when not in use these were removed and returned to the nearest mainline. This arrangement by the Kenya-Uganda Railway facilitated the transportation of cane from the farms to the factory, but again it could only help those farmers whose farms were near the railway line, since the feeder lines were not very long. Furthermore the rail charges were also not cheap. Hence by 1937, NIFA requested the colonial government to reduce the railway freight charge in transportation of sugar cane and jaggery intended for export, and they wanted the freight to be

\footnotetext{
${ }^{20} \mathrm{Ibid}$.

${ }^{21}$ KNA: AK/11/30, Miwani Sugar Mills to Lalsingh Sandhu, 22 ${ }^{\text {nd }}$ April 1952.
} 
similar to that charged on exported maize. ${ }^{22}$ This was because the rail charges for sugar transportation were high. For instance, by 1944, J. T. Moon the Senior Agricultural Officer (SAO) for the province, estimated that transport of cane by the Kenya-Uganda Railway from Kibos to Muhoroni was Shs. 3/14 per ton for 10 ton lots; while from Kibigori to Miwani it was Shs. 2/24 per ton for a 10 ton lot. Hence for a 10 ton lot of cane, some farmers paid approximately thirty shillings for transport alone; yet there were other expenses such as the payment of the loaders. ${ }^{23}$ Therefore we can argue that transportation was expensive, considering the amount paid for cane and the duration of the waiting period for the proceeds as will be discussed in a later chapter.

The seriousness of transport required the colonial government's intervention and taking advantage of the presence of the Kenya-Uganda Railway to enhance sugarcane farming in colonial Nyanza. Unfortunately this was not the case. The problem persisted and affected both the small scale and large scale farmers. Even the Miwani factory experienced transportation problems. In late 1948, for example, Miwani Sugar Mills also experienced problems transporting cane from its estate at Chemelil. This was because although it had mature cane, cutting all at once was not possible since the Kenya-Uganda Railway could only provide eight wagons per day to transport the cane. The limitation of the number of wagons inhibited the transportation of cane from Chemelil which was situated far from the mill, and the farmers found that it was not economical to use road transport given the conditions of the roads. Hence, limitation of the number of wagons seemed unrealistic. Having experienced firsthand transport problems, Miwani Sugar Mills, embarked on aggressive means of reaching farmers. So during the same year, the mill extended trolley lines and took sugarcane from Asian farms up to a

\footnotetext{
${ }^{22}$ KNA: PC/NZA/3/2/34, DC K-L to PC Nyanza, $1^{\text {st }}$ October 1937.

${ }^{23}$ KNA: AK/11/50, Moon to Director of Agriculture, $2^{\text {nd }}$ October 1944.
} 
distance of about twelve miles from the factory. Therefore, even those who initially had produced jaggery turned over one-third of their produce to Miwani. ${ }^{24}$

For farmers who were unable to get labor to cut their cane, on the other hand, they could enter into an agreement with the Miwani Sugar Company which could then cut the cane, transport it to the factory, and charge the farmer. Transportation became so problematic, as such, that in 1948, the Kibos cane farmers organized themselves into seven groups to make the best use of the transport facilities that were available and overcome the transport problem. They worked closely with the factory which required that they arrange staggered planting of cane; this was to ensure that cane did not mature at the same time and made transportation easier. ${ }^{25}$

Another means the Kibos cane farmers used was to transport as much cane as possible during the dry season since most vehicles got stuck in the mud during the wet season. Three of the seven groups were assisted by the provision of more lorries, while the other four were accorded more trolley line extensions by the Miwani Sugar Mills. It required then for the farmer to undertake the cutting of cane as soon as it matured so as to avoid idle lines and trolleys. ${ }^{26}$ Despite the fact that both Miwani Sugar Mills and Muhoroni had their own trolley lines for transportation of sugarcane to the factories by 1947, these were not sufficient to serve all the farms. Moreover, obtaining the metal sleepers was very difficult, and the problem was compounded by the fact that the wooden ones were frequently stolen. However, it was not the responsibility of the millers to provide transport. ${ }^{27}$

The millers argued that it was uneconomical for them to send lorries into the farmers' fields to collect cane; hence, they only received cane delivered to their trolley line. Secondly, the

\footnotetext{
${ }^{24}$ KNA: PC/NZA/3/22/1/8, Regional Officer, Regional Distribution Board, Kisumu, to PC Nyanza, $4^{\text {th }}$ November 1948.

${ }^{25}$ Ibid.

${ }^{26}$ Ibid.

${ }^{27}$ KNA: PC/NZA/3/22/1/8, Report by Magor of the visit to the Indian Farms, $6^{\text {th }}-10^{\text {th }}$ October 1947.
} 
Muhoroni mill was small and so most farmers, whenever possible, took their cane to Miwani which had a greater milling capacity. This over-reliance on the Miwani mill generated a lot of tension between the Asian small scale farmers and the manufacturer. The cane farmers felt that the manufacturer did not always accept cane whenever the farmers had harvested. The millers, on the other hand, complained that the feeder rails which they constructed, and the number of trucks used, involved a heavy financial outlay. Moreover, this was not economical since the feeder rails could receive as little as three tons of cane per day. This lack of harmony between the farmers and manufacturers affected production ${ }^{28}$

Nevertheless, Miwani Sugar Mills abided by their undertaking to accept cane delivered to their trolley lines but claimed it was uneconomical to send lorries to the farmers' fields to collect cane. The company asserted that it was impossible, especially during the wet season. ${ }^{29}$ Hence, some farmers were stranded with ready cane in the field due to unavailable means of transport. For example, in 1952, Milwant Singh Sandhu could not get some 90 acres of cane from his farm to the mills. This left such farmers with the only option of converting the cane into jaggery. This in itself was problematic since once a farmer installed a jaggery mill it became difficult to take sugar to the factories. A jaggery factory was expensive, especially to small scale farmers. For instance, by 1952, the approximate cost of installing an average size jaggery factory was $£ 1,250.00 .^{30}$

From the foregoing discussion, it is evident that Asian cane farmers faced discrimination when it came to transport services offered by the colonial state. By contrast, European farmers were greatly assisted. As noted earlier, the government assisted the settlers by improving and

\footnotetext{
${ }^{28}$ KNA: AK/11/30, District Agriculture Officer (DAO) CN to PAO Nyanza, $14^{\text {th }}$ May 1952.

${ }^{29} \mathrm{KNA}$ : AK/11/30, PAO Nyanza to Member for Agriculture and Natural Resources, $2^{\text {nd }}$ June 1952.

${ }^{30}$ KNA: AK/11/30, Milwant Singh Sandhu to Chairman, Agriculture Production Committee, $22^{\text {nd }}$ April 1952.
} 
extending railway, road, and port facilities to make it easy for them to transport their produce. ${ }^{31}$ Even more important, the European settlers were given low rail freight rates for wheat and maize. Smith examined such phenomena and arrived at the conclusion that Europeans controlled transport policy and freight rates so as to protect their agriculture. Smith portrays how the

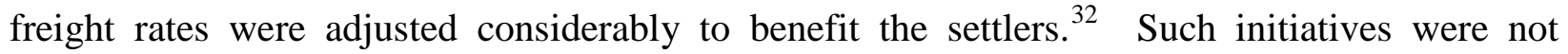
accorded to the Asian sugarcane farmers who had to struggle to deliver their produce to the factories. It emerges then that settler agriculture received tremendous attention by the government at the expense of Asian farmers in colonial Kenya. It has also been demonstrated how the colonial state failed to take advantage of the Kenya-Uganda Railway line, yet many farms were near the line. This could have gone a long way to reduce transportation problems. Such measures could be said to be contradictory of the colonial state's insistence on financial self-sufficiency, a view supported by Berman and Lonsdale who argue that the state's roles were contradictory because its regulation of competition among capitalist groups often led to disputes within the classes. ${ }^{33}$ This analogy fits into the Asian -settler quest for transport services.

\section{The Conveyance and Acceptance of Cane by the Miller}

During the harvesting period, farmers were also expected to pre-arrange with the factory so as to fix a program for harvesting their cane. In most cases, it was found that the factory fixed the dates and times of harvesting to fit their convenience. This was because the factory had first to harvest its own cane, and secondly it was to avoid overlapping demands by different farmers. However, the arrangements were not fair to the cane farmers since the factory accepted no liability for any delays of harvesting dates, which were often frequent, and farmers incurred losses. Furthermore, there were conditions laid down for supplying of cane to the factories. For

\footnotetext{
${ }^{31}$ Kanogo, "Kenya and the Depression”, 112.

${ }^{32}$ Smith, “An Overview of Agricultural Development Policy”, 119.

${ }^{33}$ Berman and Lonsdale, "Coping With the Contradictions", 79.
} 
instance, the Victoria Nyanza Sugar Company initially insisted on prior arrangements and also that the cane had to be loaded to maximum capacity to avoid weight discrepancies. Meanwhile, Miwani Sugar Mills, by the 1950s, preferred fresh cane that had been cut within the last 24 hours, and also insisted that the cane supplied must not be burnt, be of CO and POJ varieties, and not Uba. ${ }^{34}$

Such stringent conditions did not work well with the farmers. Despite the fact that a farmer had to receive a written consent before the cane was accepted, there were cases where such consent was received to cut cane and later canceled. This resulted in losses incurred by the farmers. For example, between 1943 and 1944, the Victoria Nyanza Sugar Company canceled the orders of eight farmers who lost a total of 12,670 tons over that period. The gross was valued at Shs. 9/= per ton: hence a loss of Shs. $114,000 /=.^{35}$ Thus it emerged that the farmers, though willing to supply cane, were sometimes dissatisfied with the form of contract, since they were at the mercy of the company and hence struggled to remain in business as the manufacturers did as they wished due to lack of supervision by the colonial state.

Be that as it may, cane having been transported to the factory, the focus now shifted to the activities at the factory where certain requirements had to be met before the cane was accepted. The quality and type of cane determined the price of cane offered by the factory, though the price was meant to be determined by the world prices, which frequently was not the case. The Victoria Nyanza Sugar Company set regulations for acceptance of cane delivered. For example, once the cane was transported to the factories, it was received at the weigh bridge, where it was weighed and tested to affirm that it was good for milling. The test included the sucrose content of cane, which was not supposed to be less than 10 percent, and the purity of the

\footnotetext{
${ }^{34}$ KNA: AK/11/51, Miwani Sugar Mills to PAO Nyanza, $12^{\text {th }}$ October 1953.

${ }^{35}$ KNA: PC/NZA/3/88/1/8, Petition presented to the PC Nyanza by a deputation from Kibos-Manpower Committee on $5^{\text {th }}$ August 1944 .
} 
juice, not less than 78 percent. Any sugarcane below these minimum standards was not accepted by the factory. ${ }^{36}$ Moreover, cane delivered to the factories in dirty condition was often rejected or sidetracked to be cleaned first and made fit for crushing before being accepted. ${ }^{37}$

During the process, first the cane and truck was weighed; a second weighing was for sugarcane alone. The weighing of cane was done at the factory whereby delivery was preferred in the evenings, since it made it easier to start weighing and testing the next day. Farmers and truck drivers had to attend when their cane was checked and weighed; thus the weighbridge, in most cases, had to be installed in a suitable place. However, some farms had weighbridges installed, especially the large scale farmers, for fear of being cheated on the weight. Big estates, like those belonging to Miwani, had weighbridges installed. After the checking and weighing, and ascertaining that all requirements were met, cane was received by the millers. It was at this point that the drivers and loaders were paid by the farmer, per ton of the cane load. ${ }^{38}$ Previously, paying the driver and loaders was much easier since the farmers were also paid promptly. This was because before 1934, when the colonial state was not fully involved in the marketing of sugar, the Victoria Nyanza Sugar Company paid for cane it received from the farmers within a short period of time; the farmers were paid on the $15^{\text {th }}$ of the month following delivery of cane. ${ }^{39}$ Therefore, the later delay in payment was detrimental to cane growers since they had pressing financial obligations, such as payment for vehicles hired, drivers and loaders who were to be paid immediately cane was accepted.

\footnotetext{
${ }^{36}$ Rama Mohan, (O.I.), Chief Chemist, Kibos Sugar and Allied Industries, $22^{\text {nd }} J u n e ~ 2009$.

${ }^{37}$ Joseph Otieno, (O.I.), Chemelil, truck driver, $26^{\text {th }}$ June 2009.

${ }^{38}$ Ibid.

${ }^{39}$ KNA: PC/NZA/3/2/34, DC K-L to Ag. PC Nyanza, $3^{\text {th }}$ October 1934.
} 


\section{Payment and Pricing of Sugarcane}

As indicated earlier, the payment of sugarcane received from growers changed by 1934 when the farmers started to be paid much later. This was because the millers too were not paid promptly by the marketing agency that received the sugar on behalf of the state ready for distribution. There was a waiting period of 150 days laid down by the colonial state before payment was made to millers who in turn paid the farmers. Thus, in most cases, the farmers had to wait longer. This was in accordance to the Government Notice No. 619 of 1934 Section 7, which was meant to regulate the sale and distribution of sugar. ${ }^{40}$ This was a long period to wait for proceeds since the farmers had to continue with cultivation of the ratoon crop, and it was frustrating. $^{41}$ Most farmers preferred to wait for 30 days instead since a majority of them had loans to pay for the land they had acquired. Taking into account the short duration of time involved in manufacturing sugar, they felt the 150 days waiting period was excessive. This new regulation thus generated a lot of tension between the farmers and the millers, though the millers did not control the payment of proceeds. Such regulations that discouraged cane farmers could only be interpreted as lack of appreciation of the economic potentiality of the sugar industry by the colonial state that seemingly was indifferent to the cane farmers.

Likewise, the state also failed to assist those Asian cane growers who dealt with the Victoria Nyanza Sugar Company in the early 1930s. This was because in 1931 the cane farmers had put a lot of acreage under cane and hoped that they would get a fair deal in the price of their produce which could have been commensurate with the then market price of sugar. Unfortunately most cane was damaged by locusts and the harvested cane did not pay well either because the cane farmers were left at the mercy of the factory which offered prices not

\footnotetext{
${ }^{40}$ Ibid.

${ }^{41}$ KNA: PC/NZA/3/2/34, NIFA to DC K-L, $11^{\text {th }}$ October 1934.
} 
commensurate with the then market prices. The prices offered for cane were far below even the cost of cutting the cane, leave alone other expenses such as labor and fertilizers. Consequently the farmers at Kibos found themselves confronted with disastrous financial losses partly due to manipulations by the Victoria Nyanza Sugar Company. ${ }^{42}$ This was because the colonial government was reluctant to solve the problem existing between the two parties by fixing the price of cane or ensuring that the international prices are adhered to. Hence the state left the Asian cane farmers to struggle with the European sugar manufacturer, a trend that was harmful to the growth and survival of the sugar industry.

The colonial state did not step up to help the farmers as far as pricing was concerned, partly due to the colonial government's policy that laid emphasis on European interests and partly because of its desire to control the pricing of commodities in colonial Kenya. This policy was resisted, and Asians in major urban centers of East Africa, especially Mombasa, Nairobi and Dar as Salaam, organized themselves to form a more inclusive political organization, the East Africa Indian National Congress (EAINC) in March 1914 to fight such injustices. ${ }^{43}$ The EAINC was modeled on the national congress of India and was meant to serve as a forum to express opinions, make resolutions and serve petitions to local government, the Colonial Office and the government of India. ${ }^{44}$ The EAINC aimed for the political and economic betterment of Asians in East Africa generally, and Kenya in particular. Therefore, in 1923 when the European settlers wanted to stifle the Asian economic activity in Kenya, the congress called for boycott and noncooperation as the only way to fight for their rights. This was when the Europeans formed an organization known as the European and African Traders Organization whose main objective was to obstruct Indian commercial activities in the colony, including sugarcane growing. The

\footnotetext{
${ }^{42}$ KNA: NZA/3/2/34, Resolutions passed at the EAINC meeting on $10^{\text {th }}$ January 1931.

${ }^{43}$ Gregory, India and East Africa, 93.

${ }^{44}$ Ibid., 94.
} 
organization's objective was clearly captured in its racial motto that read: "Every European and every African is an asset to Africa and everyone else is a liability." ${ }^{45}$ Such objectives and motto expressed the threat that any Asian entrepreneurship was bound to face. These threats were portrayed in the European and African Trading Organization newsletter No.1 which stated that:

... to include the Asiatic in our economic situation is to include an element whose only ideas are the making and removing from the country whatever monetary gains it is able to accumulate and our destruction. ${ }^{46}$

Due to such racist agitation, it is evident that the Asian cane farmers had to struggle for economic space. Thus the congress fought political and economic injustices in Kenya. For example, the Congress in 1928 boycotted the Executive and Legislative councils whereby four of the five seats in the LegCo reserved for Indian elected members remained vacant. ${ }^{47}$ Hence, it was in line with the objectives, that the EAINC was forced to intervene on behalf of the cane farmers who were suffering because during 1930 since the crops had failed due to locusts and drought. Thus on $10^{\text {th }}$ January 1931, the Congress requested the government to extend financial aid to the sugarcane farmers at Kibos, just as it had done to the European farmers, and give the Indian cane farmers the fullest benefit for the protective duty which by then was given to the European sugar manufacturers. Furthermore, the Congress petitioned the government to fix the price of sugarcane so that farmers were not cheated and also to a grant subsidy to Indian cane farmers during the depression period as was done for the settlers. ${ }^{48}$ The colonial state did not help the cane growers during the depression and dragged its feet. The cane farmers had to wait for a decade and a half before new cane prices were agreed upon in 1947, as illustrated in Table 5.1. Therefore, we can argue that whereas European wheat and maize production seem to have

\footnotetext{
${ }^{45}$ KNA:PUB.1/1/1/6, EAINC papers, Part 11, 37.

${ }^{46}$ KNA:PUB.1/1/1/6, European and African Trading Organization newsletter No.1 as quoted in EAINC Papers, Part $11,38$.

${ }^{47}$ Gregory, India and East Africa, 369.

${ }^{48}$ KNA: PC/NZA/3/2/34, PC Nyanza to Colonial Secretary, 24 ${ }^{\text {th }}$ February 1931.
} 
been aided by an official rise in their price, it was difficult to justify the colonial government's failure to protect the sugar growers by similar means.

As this example shows, the pricing of sugarcane continued to be controversial and over the next decade caused friction between the cane growers and the manufacturers as the two parties could not easily reach an agreement. That is why it was prudent for the colonial state to issue guidelines or fix the price of cane and save the farmers from anxiety. For example, in 1946, when W. Wood was appointed the Manager of the Victoria Nyanza Sugar Company, he tried to negotiate and offered a flat rate of Shs. 10/= for hard and Shs. 11/= for soft cane. The growers insisted on Shs. 12/= for hard and Shs. 13/= for soft cane respectively. ${ }^{49}$ Hence, no suitable agreement was arrived at. The farmers were adamant that the prices offered for cane were insufficient to cover the cost involved in growing of sugarcane while the factory insisted that the low sugar prices made it impossible to comply with the farmers' requests. ${ }^{50}$ Once again, the colonial state neglected the sugar industry and failed to give price guidelines which could have solved the impasse.

As pricing of sugar continued to be a serious issue ignored by the colonial state, the new Asian management that took over the Miwani Sugar Mills in 1947 (also refered to as Miwani) felt that the problem had to be addressed for the good of the industry. Thus Hindocha started to advocate for changes in the sugar industry in Kenya, drawing from his own successful ventures in Uganda. He not only revamped the factory, replacing the old machinery, but also insisted that the colonial state come up with guidelines on sugar prices. He reiterated that there was a dire need for the colonial state to fix the price of sugar, arguing that it was impossible to guarantee the price of sugar cane to the farmers until there was a guarantee of the price of sugar from the

\footnotetext{
${ }^{49}$ KNA: AK/11/50, NIFA to Chairman, Agricultural Production Board, $6{ }^{\text {th }}$ August 1946.

${ }^{50}$ Ibid.
} 
colonial government to enable the industry to progress. Consequently during the same year, the whole sugar production position came under the review by the deputy PC and the agriculture department. $^{51}$

Due to such initiatives and the stability in world prices, the Governor in Council fixed the prices on the recommendation of the East African Production and Supply Council. The price of sugar was then increased to Shs. $17 /=$ per ton. Unfortunately, the governor did not fix the price of cane and as such the growers were left in a financial limbo again, risking exploitation by the manufacturers. The situation between the two groups worsened. The cane growers felt that they were given a raw deal by the manufacturers who still paid low prices for cane. As a result, many cane growers resorted to the only option left and turned half of their produce into jaggery as a way of protest during $1947 .^{52}$ This had repercussions; the factory started receiving less cane while Uganda was overproducing sugar which led to the dumping of cheap sugar in the country. The situation made the Miwani appeal to the Government to fix the price for cane to correspond to that of sugar so as to protect the Kenyan manufacturers from their Ugandan counterparts. ${ }^{53}$

Due to pressure from Miwani, the colonial government realized that a solution had to be found after a decade of struggle by cane growers. Hence, for the first time a meeting was called between the representatives of the Production Board Local Committee, the sugarcane planters, and Miwani Sugar mills in July 1947. ${ }^{54}$ The meeting decided that there was a need to revise the prices payable for sugarcane supplied to Miwani on a sliding scale as shown in the table below.

\footnotetext{
${ }^{51}$ KNA: PC/NZA/3/22/1/8, Regional Distribution Officer to the Executive Officer, Central Distribution Board, $26^{\text {th }}$ August 1947.

${ }^{52}$ KNA: DC/CN/1/3/1, CKDAR 1947.

${ }^{53}$ Gilbert Muyumbu, “A Historical Study of State Policies in Kenya Sugar Industry”.,M.A. Thesis, Egerton University, 2006, 51.

${ }^{54}$ KNA: PC/NZA/3/22/1/8, D .K. Hindocha to Chairman, Production Board Local Committee, $28^{\text {th }}$ July 1947.
} 
For example, if sugar sold at the rates given below, the corresponding prices of cane would be as indicated in the following table.

Table 5.1: Proposed Prices of Sugar and Cane, 1947

Price of sugar per ton Price of cane per ton

Shs. $\quad 300$

320

340

360

380

400

420

440

460

480

500
Shs. 8.50

9.20

9.90

10.60

11.30

12.00

12.70

13.40

14.10

14.80

15.50

Source: KNA: PC/NZA/3/2/1/8 Extract from letter from D.K. Hindocha to Chairman, Production Board Local Committee, $28^{\text {th }}$ July 1947.

The above prices were, however, for hard cane such as Uba, while with the price for soft cane, such as POJ varieties, 50 cents was added per ton. For instance, when Uba fetched Shs. 12/= per ton, the price for the POJ would be Shs. $12 / 50$ per ton. Those prices were to remain in force until 1950, despite the fact that Kenyan manufacturers also kept on demanding for revision of prices of sugar due to cut throat competition from Uganda. ${ }^{55}$ Unfortunately, the colonial government's delay compelled the Kenyan manufacturers to pay low cane prices so as to remain in business. The colonial state could not protect them, revealing the contradictory nature of the colonial state whose decision could be said to have been blinded by racial bias grounded in protecting the European settler interest that led to poor legislation. This failure to protect the manufacturers inhibited the expansion of the sugar industry.

${ }^{55}$ Ibid. 
However, we can also argue that what made pricing problematic was not relying on the world market prices as indicators in the consideration of local prices in Kenya. As indicated earlier, this was often ignored. Secondly, even when adopted it had to be used carefully because the world sugar prices were not always conducive, since the price of sugarcane paid to farmers varied from country to country and it depended on variables such as the cost of cultivation of sugarcane, transport, and the quality of the cane. For example, in the previous chapter it emerged that irrigation of cane could be expensive; hence, the price of irrigated cane could not be the same as the rain fed. Furthermore, the distance to the factory was an important factor to consider. Comparatively, in India all sugarcane grown within a ten mile radius of a factory was called "gate cane" and was always accepted at the factory delivery. Cane grown out of that zone was bought by the factory through contractors and its rates were lower than factory delivered canes. ${ }^{56}$ This seemed to have been where contestation was based. The Kenyan Asian growers felt strongly that the price of sugarcane could only be decided after a discussion with all the concerned parties which, unfortunately, was only achieved in 1947.

The problem persisted even when Asian companies started manufacturing cane. Initially the Asian sugarcane farmers had complained about the European owned Victoria Nyanza Sugar Company offering very poor prices for cane, and one might have thought that racial politics, as usual in Kenya, were at play. Ironically, it emerges, that even the Miwani Sugar Mills (an Asian firm) in 1948 was accused by farmers of being unreasonable and paying low prices for the sugarcane supplied. ${ }^{57}$ Hence, a close examination of pricing has revealed a fundamental factor that exploitation of cane farmers was not just defined by racial inclinations but rather was a product of capitalist mode of production that saw the Asian cane farmers struggle with both the

\footnotetext{
${ }^{56}$ KNA: AK/11/51, AAO (Sugar) S. Singh Gill to PAO Nyanza, 24 ${ }^{\text {th }}$ September 1953.

${ }^{57}$ KNA: AK/11/173, M. J. Patel to Chairman Supply Board, 27 ${ }^{\text {th }}$ November 1948.
} 
colonial state and the manufacturers, regardless of race, to succeed in an unfavorable colonial economy that lacked supervision.

\section{Production of Sugar: Within the Factory Processing}

The previous section dealt with pricing and payment of cane which was very crucial to both the cane farmers and the manufacturers. However, once cane was received, the production process began; a process that was difficult and delicate if the correct grades of sugar were to be attained. The process entailed proper coordination of different sections and was labor intensive, taking into account the machinery maintenance, fuel, labor and finances for auxiliaries like bagging which made the whole process expensive. It becomes imperative that such issues should ultimately be considered and the opinion of both farmers and manufacturers be recognized to harmonize the finances involved by both parties before the colonial state could determine the prices and marketing of sugar. Unfortunately this was not the case.

Be that as it may, once the cane had been received and weighed, as indicated previously, the factory then checked to ascertain the quality. This sampling took place outside of the factory gate before being taken inside. After that, a ground cane carrier put the cane into machines whereby the cane was cut into small pieces. These pieces were then fed into the mill's crushers. The mill contained mostly five rollers and four pans that served as a tank for receiving juice. The Miwani factory used heavy duty crushers with a channel iron tram and fine teeth gears to make the running of the mill durable and noiseless. At the mills, the juice was extracted from the cane by passing it through a series of roller mills and the baggasse removed and taken to the boiler to be used to produce steam that was needed for generating power to boil the juice. During the 
boiling process, lime and sulfur were added to make the juice clearer and create molecules that absorbed matter in the juice to make it settle down. ${ }^{58}$

The next step involved the contraction of the juice, whereby the boiled juice was channeled and passed to the pan station where it was boiled again until the grain was formed and developed into the required grade. From here, the grain was taken to crystallizer machines where the crystal and molasses are separated. During the process, the developed sugar by products, such as baggasse, molasses, and filter press mud, were separated to be used in different ways. The grain was then sieved by the grader to get the different grades and then forwarded to the bagging section from where it was ready for distribution. In cases where refined sugar failed to achieve the required standard, it was usually re-melted and processed again as other grades.

The process involved detailed machinery that was expensive and needed financial support as well as skilled labor, as will be discussed in Chapter 6. Unfortunately, more often than not, the millers experienced difficulties and delays in getting the required personnel and machinery due to lack of appreciation of the sugar industry and unnecessary bureaucracy created by the colonial government, despite the rapidly expanding local market.

\section{Types and Grades of Sugar}

Milling was a very crucial part of the process that required utmost care to achieve the desired grades of sugar. Miwani Sugar Mills, with the biggest crushing capacity, produced most of the sugar among the five milling factories in colonial Kenya. By the start of 1960s, the sugar industry had progressed and manufactured different types of sugar, for example, brown sugar, cube sugar, mill white, castor sugar, icing sugar, and, later refined sugar which was a local sugar

\footnotetext{
${ }^{58}$ Engineer J.S. Cheema Singh, (O.I.), Factory Manager at Kibos Sugar and Allied Industries, $23^{\text {rd }}$ June 2009.
} 
of quality. ${ }^{59}$ There were also lower grades of mill white sugar such as grade II and grade III. By 1961, the colonial state started giving penalties to millers for the lower grades of sugar produced, while at the same time using incentives to improve the quality of cane. Such initiatives could have been implemented much earlier not only to improve quality, but also to show the state's involvement in the promising industry. This was because the lower grades were partly due to the poor varieties of cane harvested. However, the colonial state claimed the scheme was expensive and abandoned it as soon as it was initiated. ${ }^{60}$

Despite the need to encourage the cane farmers and manufacturers, we find that the colonial government tightened its grip during this period, and instead introduced price control on icing sugar produced by Miwani Sugar Mills, while on the other hand imported icing sugar had no restriction. Furthermore, imported cube sugar was also free from control as per the legal notice number 284/61. ${ }^{61}$ These were double standards that could only be seen in the contradictory policies that were prevalent during the colonial period.

Be that as it may, the Miwani Sugar Mills started to produce refined sugar by late 1961 and the price was Shs. 967/75 per long ton, exclusive of excise duty. Granulated white sugar was considered to be of refined quality too and was supposed to have moisture content not less than 0.04 percent. However, the colonial state did not want Miwani to produce refined sugar. The colonial government preferred to import it from outside, for instance from South Africa or Hong Kong. Thus, according to a confidential dispatch to P.H. Jones, Ministry of Agriculture, Animal Husbandry and Water Resources, G.D. Parkin, the Deputy Secretary for Commerce, Industry and Communication was very stern on the possible quality of refined sugar that Miwani intended to produce. It emerges clearly that Parkin had his own doubts about Hindocha and his

\footnotetext{
${ }^{59} \mathrm{KNA}$ : AE/3/916, Miwani Sugar Mills to Director of Economic Coordination, $9^{\text {th }}$ October 1961.

${ }^{60}$ KNA: AK/11/173, PAO Nyanza to DC CN, $11^{\text {th }}$ April 1950.

${ }^{61}$ KNA: AE/3/916, J.P. Starling to Director of Trade and Supplies, $16^{\text {th }}$ September 1961.
} 
proposed refined sugar. Stressing on the issue in July 1961, he asserted: “we must pin him down to selling refined sugar of the quality we desire, and not let him get away with mill white.”62 This was significant because it revealed the lack of encouragement by the colonial state, and it shows how, despite the struggles that the sugar industry faced in colonial Kenya, the Miwani mill had progressed and improved in quality production and technology to surpass Uganda, the main producer in the East African colonies, and was ready to be the first to manufacture refined sugar in the region. Yet the colonial government refused to acknowledge such an accomplishment and turned a blind eye to the economic potential of the sugar industry as portrayed by the above sentiment. This clearly showed the negativity mostly influenced by racial discrimination that the company had to contend with on the part of the colonial officials as demonstrated by Mr. Parkin.

However, due to the determination and meeting the prerequisites within a short period, Miwani was allowed to refine sugar on very strict conditions. First, it was required that the degree of refinement be equivalent to British refined sugar or that of quality similar to that imported from Hong Kong. Secondly, it was required that sampling had to be undertaken. The sampling was tedious and entailed the Miwani factory to supply a minimum number of 12 sampling containers and ensure that the samples were not tampered with until they arrived at the required destination where tests were conducted. These tests, among many, required that one sample of five pounds of refined sugar be forwarded to the Government Chemist each week for analysis, which was very demanding. Yet Miwani Sugar Mills complied. The Chemist then sent the results to the director of trade and supplies and a copy to Miwani. ${ }^{63}$

\footnotetext{
${ }^{62}$ KNA: AE/3/916, Parkin to Jones, confidential, $10^{\text {th }}$ July 1961.

${ }^{63}$ KNA: AE/3/916, Proposed Analytical Standards for Refined and Mill white sugar, $4^{\text {th }}$ July 1961.
} 
As for the completed product, after milling the factories also packed the sugar. It was recommended by the public health rules for food that bagging materials used had to prevent both dirt and dust; hence, the use of multiple wall paper bags or even the use of a polyethylene liner in the large jute sacks. Sometimes the factories also packed the sugar in open-weave sisal bags (gunny bags). ${ }^{64}$ There were also cases where distributors and traders complained of insufficient weights. This shows that there was a problem in packaging; however it was controlled through the efforts of local committees and the district officers. ${ }^{65}$ Thus it must be admitted that the colonial administration in this case was helpful, especially protecting the consumers.

The state also introduced regulations to insure the safety of the produce. However, according to the Public Health (Labeling and Advertisement of Food) Rules Amendment of 1958, sugar was exempted from some provisions. For example, it was not required to state the name of the food on the package, name and address of the manufacturer, or name and address of the packer, since sugar was mostly packed by the manufacturer. ${ }^{66}$ However, Miwani Sugar Mills was required to comply with other rules within the act; for example, it was required to observe the limits on the amount of preservatives that could be added to sugar. The company used for packing brown paper bags with polyethylene lining which had a capacity to hold 112 pounds or the gunny bags with a capacity of $224 \mathrm{lbs} .{ }^{67}$ The quantity packed had to conform to the amount permitted by the weights and measures rules. This show how the Asian sugar industry had regulations to follow, which it complied with and only needed the colonial government to play its part by being supportive to enhance sugar production. Nonetheless, Miwani’s persistence and

\footnotetext{
${ }^{64}$ KNA: BV/111/119, Confidential Report on Kenya Sugar Industry, 1967.

${ }^{65} \mathrm{KNA}$ : DC/KSM/1/3/58, Chairman, Gem Location Committee to DC CN, 5 th July 1954.

${ }^{66}$ KNA: AE/3/916, Parkin for Permanent Secretary (PS) Commerce, Industry and Communication to Hindocha, Director, Miwani Sugar Mills, $26^{\text {th }}$ August 1961.

${ }^{67}$ KNA: AE/3/916, Refined Sugar.
} 
resilience made it possible for it to achieve such a goal and be the only East African factory that installed the refinery and produced refined sugar in the region by $1961 .^{68}$

The implication of this was that the Asian sugar industry indeed had great economic potential. If had been fully supported, it could have greatly reduced the over dependence on imported sugar and saved the funds to be channeled to other pressing needs such as infrastructure, education or even health. This was an opportunity that the colonial state missed, yet the colony was interested in the policy of self-sufficiency and this should have included a self-sustaining sugar industry. Thus this section shows how the Miwani Sugar Mills followed the regulations in the manufacture of sugar as was required by the colonial state. These included rules of manufacturing refined sugar, to bagging of the finished product indicating even the weight. However, there were instances of weight irregularity that could have been solved by colonial government supervision and support.

\section{Conclusion}

The chapter demonstrated the first process in sugar production that entailed transportation of cane from the farms and the acceptance procedures. It emerged that the colonial state was discriminative in offering transportation services and favors to the settler farmers instead. Thus it revealed how the cane farmers struggled to have such services. The reluctance of colonial state was indicated when it failed to take the lead and left the Victoria Nyanza Sugar Company to install the tramway on its own and even failed to take advantage of the railway that lay adjacent to the cane farmers, a move that could have boosted the industry. The failure can be construed to mean lack of perception of the potential of the sugar industry by the colonial state that was willing to strangle the industry through its biased policies as well. Other pertinent issues also

\footnotetext{
${ }^{68}$ KNA: AE/3/916, Managing Director, Henckell du Buisson (E.A) to Mr. Starling, Department of Trade and Supplies, $10^{\text {th }}$ July 1961.
} 
emerged which indicated lack of clear regulations and guidelines on the pricing of cane. As such, the cane growers were left in a vulnerable position to be exploited by the manufacturers who took advantage of the lack of concern by the colonial state. The chapter also described the process of milling sugar where it emerged that it was a sensitive process if the desired goals had to be achieved. Milling entailed skilled labor and intense work as will be discussed later in Chapter 7. The chapter also revealed the struggle that the millers had with the colonial state, especially in an attempt to start the production of the refined sugar. The struggle showed racial discrimination and the contradictory stance of the colonial government when it tried all means to discourage the Miwani Sugar Mills from manufacturing refined sugar.

Despite challenges and tough regulations by the colonial state, the Asian manufacturers were ready to manufacture refined sugar. The chapter also has demonstrated how sugar production was neglected by the colonial state. Hence Kenya fell short of the consumption requirements during the colonial period due to lack of support of the sugar industry in the area. Thus Kenya never attained self-sufficiency, forcing the colony to make up the deficit by importation of sugar from Uganda and other sources whose large quantities could have greatly been reduced and funds saved to be channeled to other pressing needs of the colony. 


\section{CHAPTER 6}

\section{MARKETING OF SUGAR IN COLONIAL NYANZA}

\section{Introduction: Background to marketing in colonial Nyanza, 1930-1940}

The marketing of sugar is the last part of the process of manufacturing. This chapter discusses marketing as a crucial component of that process. Thus the chapter examines state's intervention in the marketing of sugar as part of the wider colonial policy which was geared towards control over marketing of produce, especially maize, in colonial Nyanza and Kenya generally which started in 1930s. ${ }^{1}$ These policies led to contradictions whereby the sugar industry could not perform to its maximum due to over regulation imposed by the colonial state. The chapter strives to portray how both the cane growers and the manufacturers struggled for the market in a hostile colonial economy. The chapter also seeks to demonstrate how the Asian cane farmers were discriminated against by the state refusing them a chance to import machinery to manufacture sugar while giving a monopoly to the European manufacturers who were protected by the state.

The discrimination was to continue and impacted production of sugar as Ugandan sugar was preferred. The chapter reveals how this preference for Ugandan sugar led to exploitation of the farmers, consumers, manufacturers and the Kenya government by Ugandan manufacturers. Finally the chapter reveals how the Asian cane growers and manufacturers struggled to draw the attention to an indifferent colonial state, as they faced challenges of marketing in colonial Nyanza which included illegal importation and non-effective tariff systems. This was due to neglect of the sugar industry by the colonial government that denied the cane growers and manufacturers profit. This revealed the contradiction imbedded in the colonial policies which

\footnotetext{
${ }^{1}$ Maxon, Going their Separate Ways, 66.
} 
inhibited sugar cane farming, hence a contributing factor for Kenya's lack of self-sufficiency despite the potential of sugarcane farming in the area.

To appreciate the Asian cane producers struggle for market, it is important to have a colony- wide view of what was happening as far as marketing was concerned in colonial Nyanza so as to understand the state's intervention in the market of sugar in CN and the contradictions that emerged. We find that the colonial state began to control the market colony wide by the early 1930s, which included the market for sugar. The colonial state used the war period to intensify its control; these controls that began in early 1930s coincided with intensification of production and increased prices of maize that was brought along by severe food shortages due to famine in Kenya and the demands created by World War II. ${ }^{2}$ The colonial state came up with a policy where the agricultural industry was boosted to meet the war needs; however controls were put in place to regulate the marketing of foodstuffs in Kenya. Likewise controls were also put in place to regulate the sugar industry. During this period, the colonial state focused on improving its budget position and so encouraged African agriculture especially seeking improvement of the quality of the produce, having realized that the colony cannot just rely on settler farming alone.

Governor Sir Joseph Byrne (1931-36) was of the view that for improvement in the quality of produce to be effective, the colonial state had to control the market through regulations. This stance, according to Maxon, was shared also by the officials of the Colonial Office in London who believed that rural markets in Kenya were not efficient. ${ }^{3}$ Therefore many regulations came into effect to control the market. Moreover, Asian traders seem to have borne the accusation of poor marketing in Nyanza since it was alleged that they did not care for quality which then led to poor prices. Thus the market needed restructuring; hence agricultural officers were posted to

${ }^{2}$ Ibid., 61.

${ }^{3}$ Ibid., 63. 
Nyanza to supervise the market. Their work led to the reduction in the number of markets and petty traders meant to reduce competition that was believed to have been responsible for the poor maize prices. ${ }^{4}$ In areas such as the Gusii highlands in South Kavirondo, market controls were intensified. For example, the AO, E.W. Gaddum, implemented the system of central inspection of maize, which not only improved the quality but also eliminated colored maize by $1935 .^{5}$ However, it interesting, as will be discussed later, that in sugar production the state was only keen on the quality of refined sugar and not the other grades. Also the colonial state toyed with the idea of giving the cane farmers an incentive to increase the quality only to abandon it citing financial constraints.

However, the colonial state was relentless in the control of the market. For instance, the colonial state introduced the Marketing of Native Produce Ordinance in 1935, aimed at increasing the quality of African produce meant for exportation. The desire to control the market culminated in the appointment of the Marketing Officer for African produce, C.O. Oates, in 1936. This appointment, we can argue, sheds light on the seriousness of the colonial state's desire to control the market. For example, by 1939 Oates opposed the small traders entering the buying and selling of grains on the ground that it would lead to unhealthy competition with some ending bankrupt. ${ }^{6}$ Furthermore, in the case of maize quality, the agricultural officers stepped up and even introduced cleaning machines in Gusii market centers where all produce had to pass. ${ }^{7}$ Other control measures required traders to post on a board the price offered. To ensure success

\footnotetext{
${ }^{4}$ Ibid. Maxon also demonstrates how such measures were also affected in Vihiga in North Kavirondo District, where the petty traders were eliminated in various market places.

${ }^{5}$ Ibid., 66.

${ }^{6}$ Ibid., 116.

${ }^{7}$ Ibid., 67.
} 
of the measures, the colonial state introduced the cess of three cents per bag of produce inspected in 1936 to finance the inspection system. ${ }^{8}$

Therefore, we find that there were comprehensive market controls in colonial Nyanza generally by the end of the 1930s. The colonial state controlled the extension of the market in almost all the produce in Kenya generally and Nyanza in particular and managed to do that through the introduction of various policies that were translated to the sugar industry. ${ }^{9}$ Hence the colonial state also placed regulations on the distribution and marketing of sugar that began in the 1930s, intensified during the war period, and continued throughout the colonial period as will be discussed.

\section{The Colonial State and the Sugar Market 1930-1940}

Having looked at how marketing of produce was treated in colonial Nyanza during the decade we now focus to the sugar industry to examine how marketing worked. Once the packing was done, sugar was ready to be released for marketing. The control of the sugar market involved the pricing and distribution of the produce. The price offered should have corresponded to the world sugar prices, but in most cases this was found not to be so.

During the early 1920s, the Asian farmers grew sugarcane mainly for jaggery since there was no mill. When the Victoria Nyanza Sugar Company started crushing cane in 1924, the Asians took their cane to the factory and some of them also doubled up and hawked sugar and jaggery in the African reserves since there were no regulations for marketing of sugar in place. The price of sugar in 1924 was good since it was sold at Shs. 17/= per ton plus bonus, and the farmers at that time felt encouraged to grow more cane. During the world depression period, the prices collapsed and in 1930, the Victoria Nyanza Sugar Company paid farmers only Shs. 2/31

\footnotetext{
${ }^{8}$ Ibid., 68.

${ }^{9}$ Kitching, Class and Economic Change, 9
} 
per ton of cane. This made the farmers complain bitterly. During the same year, the deputy director of agriculture, $\mathrm{H}$. Wolfe, reiterated that the world depression had impacted the prices of produce so much that a sound financial strategy was necessary to rescue the agricultural industry in Kenya as a whole. This sentiment culminated in the enactment of the Agricultural Advances Ordinance of May 1930. ${ }^{10}$ Moreover, when the effect of the depression became acute in 1932, the cane farmers suffered adversely. It was only after negotiation in 1933 with the Manager, H.E. Moffit, that there was an increase in the price of sugarcane. Farmers were paid Shs. 7/50 per ton plus bonus. ${ }^{11}$ But even then, only a few contracted farmers were paid this amount. A majority of farmers were ignored and not offered any agreements.

By the early 1930s, however, the colonial state started to be more involved in the marketing of sugar. For example, by January 1932 an excise duty was introduced in the colony on sugar and tea. This was as a recommendation of the Sir Wilfred Woods' Report. ${ }^{12}$ Accordingly, the duty of two cents a pound on sugar was increased to four cents a pound. This increment was justified on the grounds of generating more revenue in the colony. ${ }^{13}$ This was followed up in 1933, when the colonial state started to introduce policies to control sugar production. According to Government Notice Number 46 of 1933, restrictions were put on importation of all milling and crushing machinery for processing sugar, which in essence curtailed the expansion of the young industry. However, given the fact that both the European sugar companies then had imported machinery, this possibly was meant to stop importation of all crushing and milling machinery for processing sugar by Asians, which in essence discouraged

\footnotetext{
${ }^{10}$ Colony and Protectorate of Kenya, DAAR 1930, (Nairobi: Government Printer, 1931), 5-7.

${ }^{11}$ KNA: AK/11/50, Dhanwant Singh on a brief History of cane growers presented at a meeting between the Indian cane growers and Manager of Victoria Nyanza Sugar Company, $22^{\text {nd }}$ June 1946. During the meeting the new manager Mr. Wood was briefed on what had been agreed upon by Moffit.

${ }^{12}$ KNA: PC/NZA/3/22/1/8, Extract from Sir Wilfred Woods' Report on Fiscal Survey, 1932.

${ }^{13}$ Ibid.
} 
the Asian cane farmers. Furthermore, the government notice number 49 of 1933 was also enacted and prohibited the importation of distilling apparatus and machinery without a permit from the chief secretary. These two policies not only restricted the manufacturing of sugar, but also jaggery. ${ }^{14}$ This was done to protect the European manufacturers, namely the Victoria Nyanza Sugar Company at Miwani and Nottidge and Allen of Muhoroni. By denying the Asian farmers the possibility of erecting their own mill to produce sugar, the colonial state gave a monopoly to the two European companies, while the restriction on jaggery production was meant to ensure that the Asian cane farmers had no options but to supply cane to Victoria Nyanza Sugar Company. This way the European owned company benefited at the expense of the Asian cane growers. These policies seemed not to reflect any economic consideration of the cane farmers because they appear to have been based on racial discrimination against the Asians through market control mechanisms employed by the colonial state. ${ }^{15}$

Due to such favoritism and monopoly, the European manufacturers were not eager to offer reasonable cane prices as discussed in an earlier chapter. The prices of cane and sugar continued to a contentious issue that, despite the firm grip on marketing, the colonial state was not willing to solve. In theory, the Kenya sugar price structure was based fundamentally on the Commonwealth Sugar Agreement prices which were fixed annually and were normally controlled by the price control ordinance. The retail price was calculated by equating the price paid to local producers, the cost of imported sugar from Uganda, and the cost of sugar imported from overseas, through the Sugar Equalization Fund, so as to reach an average cost per ton of all sugar supplies on the market. Added on top of the equated price were also the commission for

\footnotetext{
${ }^{14}$ Muyumbu, “A Historical Study of State Policies”, 34-35.

${ }^{15}$ Probably the state did not want any involvement in importation of machinery during the depression period so as to preserve the foreign exchange.
} 
the main agents, sub-agents and a margin for retailers' profit. Prices were further adjusted to cover transport charges and other miscellaneous expenses, such as gunny bags. ${ }^{16}$

Unfortunately this was not the case for the sugar industry in Nyanza during the 1930s. Thus to improve marketing of their produce, the Indian farmers, many of whom belonged to the NIFA established in the early 1930s, resolved to form a group purposely charged with the responsibility of marketing their produce. Hence, they formed the Nyanza Farmers Cooperative Society (NFCS) in January 1936, composed almost completely of cane farmers, which played a significant role in the struggle for market as will be discussed later in Chapter 8. This showed how the farmers were keen to sell their produce for good prices, especially when the Victoria Nyanza Sugar Company stopped taking cane from farmers in $1936 .{ }^{17}$ The cane farmers realized they had to struggle to survive in a hostile economic environment perpetrated by the indifferent colonial government.

\section{Colonial State Control Over the Sugar Market 1940-1950}

The formation of NFCS was quite timely. It worked closely with the NIFA whose activities were influential in the next decade. For example, the Indian farmers through the NIFA requested the colonial state to reduce the railway freight in the transportation of cane since this affected the prices. Furthermore, sugar was overproduced in the world before World War II, which impacted the prices greatly; the prices were so low that restriction became necessary since

an increase in cane growing in colonial Kenya was tied to the international agreement. ${ }^{18}$ In addition, excise duty was also added to the basic price payable by manufacturers in late 1941.

\footnotetext{
${ }^{16}$ KNA: AE/3/916, Hindocha to PS Ministry of Agriculture, Animal Husbandry and Water Resources, $25^{\text {th }}$ July 1961.

${ }^{17}$ KNA: PC/NZA/3/2/34, Department of Agriculture, Nyanza to H .G. Pilling, $3^{\text {rd }}$ February 1936.

${ }^{18}$ KNA: AK/11/50, Director of Agriculture to Ag. SAO Nyanza, $17^{\text {th }}$ December, 1945.
} 
This discouraged more production of sugar due to the inflated costs of production. ${ }^{19}$ Yet this was contradictory to the earlier policy of May 1941 which had boosted the production of sugar when the local War Supplies Board issued a directive that all sugar machinery, in not only Kenya but East Africa as whole, be put to full operation. This was because there was an increase in demand in consumption due to the needs brought by the war efforts. This shows how the colonial policies during the war period were marked by confusion where they were on one hand, boosting the sugar industry and on the other discouraging the local production.

Other policy changes were the result of Sir Wilfred Woods’ fiscal survey. The report had been completed in January 1932. The survey was geared towards finding means of generating revenue for the three British East African territories. Thus it advocated for excise duties to be introduced on sugar, tea, cigarettes and tobacco. Based on the report and wartime conditions, another tax was introduced in 1943; the sugar consumption tax of one cent was imposed on all sugar consumed in Kenya with the specific objective of raising additional revenue so as to subsidize the sugar industry. ${ }^{20}$ This tax was collected by the Commissioner of Customs and Excise or his agent and was paid by the manufacturers or the importers who recovered it from the consumers. ${ }^{21}$

Other legislations were also put in place to control the production and marketing of sugar. For example, according to the control of sugar regulations of 1944, nobody was allowed to manufacture sugar without a permit issued by the controller. It also required that no manufacturer of sugar was allowed to sell, transfer or dispose of sugar without a permit, and

\footnotetext{
${ }^{19}$ Muyumbu, “A Historical Study of State Policies”, 41.

${ }^{20}$ KNA: PC/NZA/3/22/1/8, Extract from Sir Wilfred Woods Report on a Fiscal Survey 1932.

${ }^{21}$ KNA: PC/NZA/3/22/1/8, Sugar Excise Duty.
} 
finally it required that anyone who sold sugar to furnish the office of the controller with information in regard to his stock at hand and sales of Sugar. ${ }^{22}$

Furthermore, price control was placed on castor and icing sugar during the same period. Unfortunately there was no documentation as to why the price control was imposed. ${ }^{23}$ Most probably this was due to shortage at the time since a small amount of the two sugar brands was produced locally in the 1940s. ${ }^{24}$ These taxes imposed during 1941-1943 period affected the price of sugar and caused much confusion and impacted cane production. Thus according to the research conducted later by the statistical accountant to the board of agriculture in 1950, the only way to increase sugarcane performance was to increase the price paid by the consumer and also to increase the subsidies to growers ${ }^{25}$

It is clear also that in this period the colonial state did not give the Asian farmers and producers of sugar leeway as they did to European settler farmers. Settlers were accorded different marketing arrangements to export their crops whereby centralized marketing boards were created to increase efficiency in marketing. Under the Sale of Wheat Ordinance of 1933, for example, all wheat was taken by the Kenya Farmers Association (KFA). ${ }^{26}$ Alex WinterNelson argues that the European wheat growers in Kenya acted as local monopolists who not only sold wheat locally at an inflated price but also exported surpluses at lower than world market prices. Coupled with the tariff placed on imported wheat this provided advantages to European growers. ${ }^{27}$ Comparatively the Asian sugar producers did not have such a monopoly;

\footnotetext{
${ }^{22}$ KNA: AG/16/186, Government Notice Number 320, Defense Control of Sugar Regulations, 1944.

${ }^{23}$ KNA: AE/3/916, A. C. Kinner to P. J. Riley, Price Controller, $28^{\text {th }}$ September 1961.

${ }^{24}$ Ibid.

${ }^{25}$ KNA: AK/11/173, PAO to DC CN, $11^{\text {th }}$ April 1950.

${ }^{26}$ Alex Winter-Nelson "A History of Agricultural Policy in Kenya” in Scott Pearson et al, eds. Agricultural Policy in Kenya: Application of the Policy, 34.

${ }^{27}$ Ibid.
} 
neither was the industry protected by tariffs on Ugandan sugar. Hence sugar prices were not stable and were marred by the politics of control.

Thus it can be argued that pricing of sugar was important to the growth and expansion of the market. John de Wilde contended that there is need to intervene in market places to ensure success of agricultural developments which if ignored could lead to ineffectiveness. As such he concluded that the urgency of pricing policy was crucial for successful marketing. ${ }^{28}$ Therefore, for the industry to survive there was a need for revision of policy and subsidy in the sugar industry. The colonial state waited for over a decade to make any changes. These took place in 1947, as discussed in the preceding chapter.

During the same period, there were some irregularities in prices paid for sugarcane that was not impacted by the action of the colonial state. For example, it was found that the Miwani Sugar Mills was cheating the farmers. This was because by 1947 it was established that in their calculations not only did they offer Shs. 12 /= per ton of cane as stated earlier, but they also insisted that it took 15 tons of cane to manufacture one ton of sugar. This was not in line with practice in other countries; for example in India 10 tons of cane made one ton of sugar while in South Africa, eight tons of cane made one ton of sugar. Thus we can argue that Miwani's rate was a complete rip off for the farmers. ${ }^{29}$ When Bresler was the accountant of Victoria Nyanza Sugar Company, the measurement was 10 tons of cane for one ton of sugar. ${ }^{30}$ Such discrepancies were found to be ironic given the fact that although initially the farmers had

\footnotetext{
${ }^{28}$ J. C. de Wilde, "Price Incentives and Agricultural Development” in R. H. Bates and M .F. Lofchie eds., Agricultural Development in Africa: Issues of Public Policy (New York: Praeger Publishers, 1980), 46. See also Martin Ravallion who argues that prices offered by the market have a strong effect on the economic decisions and choices made by farmers. Martin Ravallion, Markets and Famines (Oxford: ClarendonPress,, 1987), 20.

${ }^{29}$ KNA: PC/NZA/3/22/1/8, Sugarcane cultivation in Miwani-Muhoroni area October 1947.

${ }^{30}$ Ibid.
} 
complained about the European milling firm, it emerged that they were equally exploited by their fellow Asian miller.

Such irregularities and sugar policies could be argued to have been caused by the lack of colonial state supervision of the marketing mechanism, and this clearly demonstrated how the colonial state was not fair, especially when it came to pricing of sugar in colonial Nyanza. This was a short sighted policy, since it had a negative impact on sugar production in its own colony. This fact was supported by W. Lyne Watt, the PAO, who reported in 1949 that compared to South Africa, Kenya’s prices were 29\% less. Due to such insensitivity and poor sugar legislation, many farmers and millers registered their dissatisfaction with how the government handled sugar prices. The Indian farmers in particular felt that due consideration had to be given to them in as far as the pricing of cane and white sugar was concerned, as was done to the coffee and maize farmers. This they argued would help them to counter balance against any rise in the cost of machinery and wages. ${ }^{31}$

In the meantime, the government kept on making many regulations. For instance, in March 1948, the colonial state enacted the sugar consumption tax so as to fund the subsidy paid to the manufacturers for each ton of crystallized sugar manufactured in the country. This led to an increase in production amounting to 12,784 tons of sugar produced during the year for the whole colony. ${ }^{32}$ Despite the fact that sugar fetched low prices at the time and also that the industry lacked the government's strong support, this was marked improvement. The increase was also made possible by Hindocha's take over of the factory. He not only revamped the operations by installing new machines, but also accepted almost all the cane delivered, unlike his predecessors. This assurance of disposal of cane encouraged to farmers to plant more. Hence,

\footnotetext{
${ }^{31}$ KNA: AK/11/173, W. M. Lyne Watt to chair, Central Commodity Distribution Board, $2^{\text {nd }}$ March, 1949.

${ }^{32}$ Colony and Protectorate of Kenya, DAAR 1949 (Nairobi: Government Printer, 1950), 12.
} 
there was marked increase in the production of sugar as more and more farmers took their cane to the mills, and this reduced the amount of jaggery produced. A close examination of the 9 Asian cane producing areas in Nyanza during 1948 revealed how much cane and sugar was produced. This is summarized in the following table.

Table 6.1: Production of Sugar and Jaggery in the nine areas, 1948

$\begin{array}{cccccc}\begin{array}{c}\text { Sugarcane } \\ \text { Areas }\end{array} & \begin{array}{c}\text { Approximate } \\ \text { total Acreage }\end{array} & \begin{array}{c}\text { Acreage of } \\ \text { mature cane }\end{array} & \begin{array}{c}\text { Mature cane } \\ \mathbf{1 9 4 7 - 4 8} \text { tons }\end{array} & \begin{array}{c}\text { Annual } \\ \text { Jaggery } \\ \text { output }\end{array} & \begin{array}{c}\text { Annual } \\ \text { White Sugar } \\ \text { Output }\end{array} \\ 1 & 8,000 & 1,940 & 63,000 & - & \\ 2 & 6,000 & 2,250 & 55,000 & 85 & 4,840 \\ 3 & 6,060 & 2,000 & 36,000 & 2,400 & 4,230 \\ 4 & 2,400 & 1,100 & 19,000 & 120 & ------- \\ 5 & 5,120 & 500 & 9,000 & 600 & ------- \\ 6 & 4,480 & 400 & 7,200 & 480 & ---- \\ 7 & 2,400 & 2,000 & 40,000 & 1,330 & 1,540 \\ 8 & 1,000 & 150 & 1,000 & 78 & ------ \\ 9 & 4,800 & 975 & 15,000 & ------ & 1,000 \\ \text { Total } & 40,260 & 11,315 & 245,200 & 5,093 & 11,610\end{array}$

Source: KNA: AK/11/50, Description of Sugarcane Areas 1948.

The above data show that there was an increase in production generally, where the first four areas had a lot of mature cane. This was a good performance compared to only 5,760 tons of sugar in 1946 and 9,171 tons in $1947 .{ }^{33}$ The poor performance in 1946 was due to the dry weather and the prevalent labor shortage. ${ }^{34}$ The substantial increase in 1948 was attributed to an increase in acreage of planted cane, favorable weather conditions and improvement in the procurement of available labor as well as the factors noted earlier. The table also suggests that few farmers were turning their produce into jaggery. For example, out of 55,000 tons of mature cane in area 2 only 85 tons was converted into jaggery. The decrease in jaggery production in 1948 led to the increase in sugar production resulting in 12,900 tons of white sugar in that year.

\footnotetext{
${ }^{33}$ DAAR 1947, 9.

${ }^{34}$ Colony and Protectorate of Kenya, DAAR 1946 (Nairobi: Government Printer, 1947), 10.
} 
The shift from jaggery production to delivering cane to the factory indicates the adaptation and success made by the cane farmers as they struggled for the market.

\section{Colonial State Control of Sugar Market, 1951 -1963}

The previous section has demonstrated how the sugar industry picked up in the late 1940s whereby the total acreage increased tremendously. Contradictions emerged due to the fact that the industry was revamped as a new lease of life was injected by the Asian manufacturers, despite the neglect by the colonial state. The contradictory nature of the colonial state is discussed by Berman and Lonsdale who portray the paradox of colonial rule in Kenya whereby peasant commodity production, instead of being destroyed, flourished despite the dominance of settler production. ${ }^{35}$ This analysis could also be applied to Asian farming where contradiction ensued whereby the Asian cane farming experienced both support and neglect during the colonial period.

By early 1950s, the colonial state seems not to have been so keen on the sugar industry as compared to Kenya's neighboring territories. This could be seen when in 1950, the colonial state did not want to engage in international sugar discussions, and as such did not want to join the conference in London that was called to discuss export quotas. The colonial state, instead of attending to see how it could benefit the Asian farmers, dismissed the whole conference, arguing that Kenya had no prospects of exporting sugar in any foreseeable future. ${ }^{36}$ This decision was partly because the colonial state saw that there was a constant demand for sugar due to the fast growing population, a rise in purchasing power among Africans and the new trend of adaptation of a varied diet. As such, the state adopted a policy geared towards self-sufficiency and not exports of sugar. Therefore in 1951 the government set up prices for sugar whereby grade I was

\footnotetext{
${ }^{35}$ Berman and Lonsdale, "Coping with the Contradictions", 84

${ }^{36}$ KNA: AE/3/296, Secretary, Commerce and Industry to the Economic Secretary, East Africa High Commission, $12^{\text {th }}$ September 1949.
} 
sold at Shs. 6/09 per pound while grade II fetched Shs. 4/85 per pound. ${ }^{37}$ To attain their goal of self sufficiency by 1953, the government further granted the sugar millers an increase in the price of Kenya's white sugar in 1953, which also led to an increase in the price of sugarcane given to the growers by Miwani Sugar Mills for various varieties as follows:

$\begin{array}{ll}\text { Uba } & \text { Shs. } 29 / 71 \text { cents per ton } \\ \text { CO } & \text { Shs. } 30 / 11 \text { cents per ton } \\ \text { POJ } & \text { Shs. } 30 / 71 \text { cents per ton. }\end{array}$

Such prices were eagerly awaited since the cost of production had risen in terms of the cost of farm implements and for wages. Unfortunately, there was further reduction in the price of sugar by 1954 . For example, the wholesale price of sugar produced at Miwani, including excise duty, sold at Kibos for Shs. 100/22 per 224 pound bag, while sugar from other sources sold at Shs. 92/01 per $224 \mathrm{lb}$. bag. Sugar sold at a retail price of 57 cents per pound. ${ }^{39}$ This meant that the sugar produced in Kenya was expensive, and as such did not compete effectively with imports. The presence of cheap imported sugar from Uganda during this period led to some price irregularities. This was compounded by the fact that within a short period, in 1956, there was another increase according to Sugar Prices Order No. W.15 of $20^{\text {th }}$ March 1956. Accordingly, the wholesale price at Kisumu railway station for imported sugar from overseas was Shs. 93/11 per bag, while that of East Africa, excluding Kenya, sold at Shs.102/11 for the 224 pound bag. In addition there was the sub-agent fee of Shs. 3/= and 50 cents for transport from the railway station to the main agent's godown. Hence, this translated to a gross wholesale price of Shs. 114/43 cents per 224 pound bag for imported sugar and Shs. 114/52 cents for the 224 pound bag of the East African sugar. ${ }^{40}$

\footnotetext{
${ }^{37}$ KNA: AK/11/30, PC, Nyanza to Member of Agriculture, $21^{\text {st }}$ June 1951.

${ }^{38}$ KNA: AK/11/51, Miwani Sugar Mills to PAO Nyanza, $5^{\text {th }}$ January 1953.

${ }^{39}$ KNA: DC/KSM/1/3/58, DC CN to Chief John Muganda, North Ugenya Location, $21^{\text {st }}$ June 1954.

${ }^{40}$ KNA: DC/KSM/1/3/58, Sugar Prices, Order No.W.15 of $20{ }^{\text {th }}$ March 1956.
} 
There was a further increase the following year in May 1957, when the wholesale price of sugar in the colony and imported sugar from overseas was increased again within a short span of time. This was in line with the commonwealth prices that went up worldwide by Shs. 5/93 per bag. ${ }^{41}$ Thus the imported sugar sold at Shs. 121/22 per $224 \mathrm{lbs}$. bag, while the sugar produced at Miwani sold at Shs. 121/17 per 224 lb. bag, and that of Uganda was sold at Shs. 102/11 per 224 pound bag. ${ }^{42}$ These prices shows that the Miwani sugar was expensive compared to that of Uganda, which affected marketing of the local sugar. Moreover the subsidy given to both the growers and the manufacturers was reduced by half. For example, the growers' subsidy was reduced from Shs. 1/87 to 94 cents per ton of cane supplied, while the manufacturers' sugar subsidy was also reduced from Shs. $4 / 48$ to Shs. 2/24 per bag. ${ }^{43}$ Thus we find that the minimal increase by the colonial state failed to adjust prices according to the increase of the commonwealth prices of sugar and instead reduced the subsidy which impacted the industry negatively. In view of the above minimal increase, Miwani Sugar Mills was forced to revise the sugar cane prices based on the price stated by the colonial government, and this led to serious problems with the Asian cane farmers who were well aware that the prevailing market prices in 1957 were good. The unreasonable control of market through the reduction of the subsidy in the face of stiff competition from the Ugandan sugar made things worse for Asian cane farmers and manufacturers since they had to struggle to sell their expensive sugar in the local market, exposing the contradictory nature of state policy. It will be recalled that the state had embarked on rigorous experimentation to improve quality of cane, yet went ahead to control the sale of sugar and even failed to protect the industry from unfair competition.

\footnotetext{
${ }^{41}$ KNA: AK/11/52, Miwani Sugar Mills to PAO Nyanza, $12^{\text {th }}$ December, 1957.

${ }^{42}$ KNA: KSM/1/3/58, DC CN to all District Officers, CN, $20^{\text {th }}$ March 1957.

${ }^{43}$ KNA: AK/11/52, Miwani Sugar Mills to PAO Nyanza, $12^{\text {th }}$ December, 1957.
} 
Thus we can argue that the local price of sugar in Kenya should have been correlated with the average world prices, rather than with the price of sugar grown under more favorable conditions in Uganda by a more established industry. Furthermore, if Kenya could not produce enough sugar to meet her domestic needs, as was the case, it would have been more expedient to impose an import duty on the Ugandan sugar so as to bring the price up and hence minimize the difference. Unfortunately this was not the case. The importation of sugar without duty then could be said to have hindered the progress of the industry in colonial Kenya.

In terms of consumer prices, on the other hand, the DC of CN, P.D. McEntee, authorized that sugar be regulated in the district in 1957 . Hence a new order was issued that detailed the retail price of sugar in each location in accordance to the regulation of the Defense Control prices of 1945. This brought a slight increase in the price of sugar; the retail price went up from 57 cents per pound paid in 1956, to 59-62 cents in 1957. Moreover the new regulation controlled the prices in all markets and trading centers. Such initiatives were imposed by the colonial state in an effort to control the local market and also protect the local consumers from the inflated prices by the local traders. Hence, the maximum prices were affected as indicated in the following table. 
Table 6.2: Markets/Trading Centers with Prices of Sugar per Pound, CN, 1957

$\begin{array}{lcccc}\text { Locations } & \mathbf{5 9} \text { cents } & \mathbf{6 0} \text { cents } & \mathbf{6 1} \text { cents } & \mathbf{6 2} \text { cents } \\ \text { West Kano } & 7 & 3 & --- & --- \\ \text { Kisumu } & 9 & 6 & --- & --- \\ \text { Kajulu } & 3 & 1 & --- & --- \\ \text { East Kano } & --- & 7 & 1 & --- \\ \text { Nyakach } & --- & 7 & 3 & --- \\ \text { Seme } & --- & 13 & --- & --- \\ \text { Gem } & --- & 14 & 4 & --- \\ \text { Asembo } & --- & 2 & 5 & --- \\ \text { Sakwa } & --- & 1 & 9 & --- \\ \text { Miwani } & --- & 2 & --- & --- \\ \text { North Ugenya } & --- & --- & 8 & 2 \\ \text { Yimbo } & --- & --- & 4 & 2 \\ \text { Uyoma } & --- & --- & 7 & --- \\ \text { Alego } & --- & --- & 12 & 4 \\ \text { South Ugenya } & --- & --- & 5 & --- \\ \text { Samia } & --- & --- & --- & 12\end{array}$

Source: KNA: DC/KSM/1/3/58, Control of Prices Order, 1957.

The above data reveals the different prices at different market and trading centers. We find that the cheapest prices were found in Kano, Kisumu and Kajulu. For example, nine markets and trading centers in Kisumu sold sugar at 59 cents per pound, while the most expensive price was found in Samia location where all the markets sold sugar at 62 cents a pound. From the data we can deduce that the markets near Kisumu Municipality, where the agent's store was based, sold cheaply, as compared to Samia, which was further away at Port Victoria. Hence, we can argue that distance was a major determinant in these prices. Such detailed distribution of the prices to the location level meant that the traders could not go above the stated prices regardless of difficulties they encountered, such as transportation costs, and it reveals how the colonial state controlled the market even in the African reserves. 
Even with the new prices, irregularities continued. For instance in 1957, notorious retailers were found at Rabour, Yala and Nyangweso who sold sugar at Shs. 1/= per pound instead of 60 cents. Such cases were rampant in almost all the locations; for instance, similar incidences were found among the retailers of Alego location which culminated in a public outcry that forced the colonial chief Amoth-Kowira to order an investigation that revealed that some traders were charging 80 cents per pound. Such irregularities continued over the years and also involved magnates in the industry. In 1960, D.K. Hindocha was found to be charging Shs. 120/30 for a $224 \mathrm{lb}$. sack, which was the correct price for a sub-agent to charge as indicated in the Price Control (Sugar Amendment) of 1959 legal notice number 427 of 1959. Hindocha was a main agent, and this was not the correct price for the main agent; hence it appears as though he was doubling also as sub-agent. ${ }^{44}$ By 1961, the colonial government stopped purchasing sugar directly from the local factories; instead it was done through the main agents. ${ }^{45}$

At the end of the colonial period, the distribution of sugar was controlled by the colonial state, even in the African reserves. There was an expanding market that had to be satisfied by the Asian cane farmers. Archival sources indicate that many colonial chiefs constantly requested for more sugar for their respective areas. For instance, Chief Amoth Kowira of Alego, Chief Abok of West Alego, and Chief John Oloo of Yimbo location, wrote to the district officers in their division requesting for more allocation of sugar supplies. ${ }^{46}$ The colonial state could have taken advantage of this expanding market and supported the Asian cane farmers so as to produce more for the home market. The state, by contrast, placed more emphasis on the control of distribution of sugar, even in the African reserves, than in stimulating Asian sugar growers to expand production.

\footnotetext{
${ }^{44}$ KNA: DC/KSM/1/3/57, Inspector of weights and Measures, to Director of trade and supplies, $13^{\text {th }}$ May 1960.

${ }^{45}$ KNA: AE/3/916, .G. D. Parkin to P. H Jones, confidential, $10^{\text {th }}$ July 1961.

${ }^{46}$ KNA: DC/KSM/1/3/58, Sugar Allocation-African Reserves 1958.
} 


\section{Imported Sugar}

The controls placed on the sugar industry by the colonial state due to lack of appreciation of the economic importance and potential of the Asian sugar industry led to greater deficiency than could have been the case, making the colony to over rely on importation from other countries that set a dangerous precedent. It led to exploitation through irregularities as mentioned earlier. The overall deficit in domestic production caused sugar to be imported into Kenya and distributed alongside the locally produced sugar. Small quantities of refined sugar were imported from Hong Kong, but the bulk of it came from the United Kingdom and was imported to the colony by a company known as Tate and Lyle Ltd. On the other hand, mill white sugar was imported from Uganda and Tanganyika.

Historically, here was a steady trend of importation of sugar into the colony especially

from 1919. Initially the importation involved supplies for the Uganda Protectorate. However by 1928, the focus was mainly on importation into Kenya as is indicated in the following table. 
Table 6.3: Imports of Sugar into Kenya 1919 up to 1933

\begin{tabular}{ccr}
\hline Year & Amount - Tons & Value $£$ \\
\hline 1919 & 3,580 & 126,849 \\
1920 & 2,400 & 167,554 \\
1921 & 3,300 & 129,869 \\
1922 & 3,270 & 82,288 \\
1923 & 1,580 & 54,041 \\
1924 & 1,370 & 42,904 \\
1925 & 1,360 & 31,475 \\
1926 & 978 & 20,265 \\
1927 & 481 & 10,661 \\
1928 & 4,010 & 68,903 \\
1929 & 2,400 & 38,576 \\
1930 & 1,730 & 23,510 \\
1931 & 328 & 6,688 \\
1932 & 221 & 4,182 \\
1933 & 128 & 2,389 \\
\hline
\end{tabular}

Source: DAARs, 1919-1933.

The above data present the changing trends of imports due to the sugar consumption needs of the colony and the development of the sugar industry as was discussed earlier in Chapter 4. We find that Kenya imported a large amount of sugar between 1919 and 1923. This was because during that period Kenya had not started to manufacture her own sugar. The importation of sugar considerably decreased in 1926. This was because the Victoria Nyanza Sugar Company started crushing sugar in 1924. The opening of Victoria Nyanza Sugar Company caused the Asian farmers, who initially made jaggery, to acquire more land and the cultivation of cane increased. This explains the low importation in 1926 and 1928. The greatest decrease in 1927 was also due to the increase in acreage of cane of the European cane farmers as Nottidge and Allen Company acquired land in Muhoroni and started to grow and produce sugar. 
On the other hand, the decrease in importation of sugar in 1929 was also partly due to increase in acreage as the number of Asian farmers increased from 40 with 3,693 acres of cane to 48 farmers in 1929 with 8,820 acres under cane. ${ }^{47}$ This meant more sugar was produced hence decrease in importation.

By 1931, with the impact of the great depression clearly felt in terms of decreased purchasing power among Kenya consumers, imports into Kenya from overseas continued to decline. For instance, there was a decrease from 1,733 tons in 1930 to only 318 in $1931 .{ }^{48}$ The table also shows a decline in imports in 1933; this was because in the face of depressed state of world sugar market, export was discouraged. ${ }^{49}$ Thus we can infer that the idea to retain sugar in the colony led to the decrease in imports in an effort to secure the home market. Moreover, the Asian cane farmers by the early 1930s had increased their production of sugarcane. Unfortunately we can argue that despite the resilience shown by the Asian cane growers and the expanding local market demonstrated by the increase of African consumption needs, the colonial state failed to see the economic potential of the sugar industry in $\mathrm{CN}$ and did very little during this period to support the industry. The data presented is important; it indicates the development of the industry in relation to viability of market and shows how the local market remained undersupplied by the local sugar. ${ }^{50}$ Thus we can argue that the colonial state failed to understand the potential of the existing domestic market and did not support the sugar industry instead of over-reliance on Ugandan sugar. Encouraging Asian production could have led to financial gains for both the farmers and the colonial state since the sugar industry was part of the wider colonial economy.

\footnotetext{
${ }^{47}$ DAAR 1929, 37.

${ }^{48} \mathrm{DAAR} 1931,33$.

${ }^{49} \mathrm{DAAR} 1933,6$.

${ }^{50}$ Ibid.
} 
However, in 1937, the International Sugar Restriction Scheme was entered into by the United Kingdom on behalf of the crown colonies, and, as such, an export quota of 27,000 tons was allocated to East Africa as a whole. As a result, a meeting was convened in July 1937 to discuss the allocation of the quota among the three colonies. This however did not take place since the allocated quota was exceeded by the increase in consumption rate of the three colonies and so the quota was not necessary. ${ }^{51}$ Consequently, a restriction scheme was implemented by September 1937 through an order issued under the Customs Management Ordinance of 1937 that prohibited the export of sugar outside the three territories except with the permission of the director of agriculture..$^{52}$

Unfortunately records of the war period were missing, possibly due to focus of most colonial officials towards the war. Hence correct evaluation of the progress on importation during the period is difficult.

In the post war period, on the other hand, Uganda exports resumed. For example, in 1949, it was estimated that Uganda exported into Kenya 17,000 tons of white sugar, while during the same period Kenya produced 9,000 tons. However, the annual requirement was 36,000 tons; hence, there was need to import a further 10,000 tons so as to meet the domestic demand. ${ }^{53}$ Therefore Kenya had to import sugar from other countries such as Tanganyika. Furthermore, by 1951 Kenya was compelled to import sugar from overseas, which cost more than the local price payable to Miwani. Yet the colonial state was not ready to give the Kibos farmers some bonus to cover transport charges so as to induce farmers to grow more. This depicted the confusion that beset production and marketing in colonial Kenya. Ironically, the millers did not want to pay the

\footnotetext{
${ }^{51}$ Colony and Protectorate of Kenya, DAAR 1937 (Nairobi: Government Printer, 1938), 17.

${ }^{52}$ Ibid.

${ }^{53}$ KNA: AG/16/186, H .L .Adams, Chairman, Kenya Supply Board to Accountant General, Produce Controller and to Chairman, Central Commodity Distribution Board, $7^{\text {th }}$ June 1949.
} 
farmers good prices for cane yet the United Kingdom paid funds through a scheme known as Colonial Sugar Preference Certificates to manufacturers in Kenya for each financial year between 1946 and 1948 to help with the production costs. Accordingly, during the period of 1946-1947, the Victoria Nyanza Sugar Company benefited to the amount of Shs. 6,035/= while Ramisi at the coast got Shs. 14,394/=. The following season Miwani got Shs. $19,000 /=$ and Muhoroni Sugar Company got Shs. 2,600/=. ${ }^{54}$ With this type of financial help, the millers could have also extended fair prices or given bonuses to the cane farmers. Therefore we can argue that it was the sugarcane farmers who suffered most because we do not see such subsides given to them as compared to the manufacturers. Furthermore, due to bare minimal tariffs, if any, that were occasionally applied, it emerges that Kenya spent a huge amount of money importing sugar. In 1954 alone the cost of importation of sugar was $£ 1,653,116 .{ }^{55}$ This was a significant figure bearing in mind that there was the possibility of increasing production of sugar in the colony to meet the local demands if the Asian cane farmers were accorded the preferential treatment given to settler wheat and coffee farmers during the same period.

In the meantime, the Kenyan sugar prices continued to stabilize overtime despite the competition from Uganda. Most cane farmers and manufacturers felt that there was a need to restrict the importation of Ugandan sugar, and expressed this desire to the colonial state. However, their request was denied on grounds that the Asian production had not reached the required quality, and as such the farmers and manufacturers were urged to improve production. ${ }^{56}$ Hence, it emerges clearly that favor was accorded to Ugandan sugar by the colonial state. For

\footnotetext{
${ }^{54}$ KNA: DC/CN/1/3/1, DC CN to W. Lyne Watt, 2 ${ }^{\text {nd }}$ December 1947.

${ }^{55}$ KNA: BV/6/1704, T.M. Loudon to Major, Hon .F. W. Cavendish-Bentinck, Minister for Agriculture, Animal Husbandry and Water Resources, confidential, 25 ${ }^{\text {th }}$ April 1955.

${ }^{56}$ KNA: AK/11/50, Sugar Repot by PAO Nyanza, August 1947.
} 
example, when the government in 1961 imposed the excise duty of 11 cents per pound or 246/40 per ton, the prices were as follows:

Table 6.4: Comparative Prices of Imported Ugandan and Kenyan-Miwani Sugar, 1961

$\begin{array}{llll}\text { Price of Uganda Sugar } & 944 / 60 & \text { Price of Miwani Sugar } & 924 / 58 \\ \text { Excise duty } & 246 / 40 & \text { Excise duty } & 246 / 40 \\ \text { Total } & 1,191 \text { per } & \text { Total } & 1,170 / 98 \\ & \text { ton } & & \text { per ton }\end{array}$

Source: KNA: AE/3/916, Extract from a memorandum by G.D. Parkin, dated July 28, 1961.

The above sugar prices indicate that Uganda Sugar was bought by the government expensively. Yet when the Kenyan manufacturers complained that the government was paying more for the Uganda sugar, which was affecting the local production, the government dismissed their claim. ${ }^{57}$ Meanwhile the colonial state reaffirmed, in a secret dispatch, her commitment to Ugandan manufacturers that the price paid by Kenya to Uganda was an arrangement between the two governments. ${ }^{58}$ This was because the East African Production and Supply Council had established an inter-territorial agreement covering staple foodstuffs, particularly wheat, maize, rice and sugar. According to the agreement, Kenya had to ensure the security of markets for her agricultural produce, specifically the need to safeguard the local wheat industry, as such there was an understanding that Kenya buys sugar from Uganda and Tanganyika while Kenya, being the main grower of wheat, exported wheat products to her two neighbors. ${ }^{59}$ Due to such arrangements, the Kenyan sugar manufacturers continued to suffer from the stiff competition of the Ugandan sugar which was also a much larger industry.

Despite the hurdles faced by the Kenyan manufacturers, the Miwani Sugar Mills was able to make strides and became the only factory producing refined sugar in East Africa by 1961.

\footnotetext{
${ }^{57}$ KNA: AE/3/916, Miwani Sugar Mills to PS Commerce and Industry, July $25^{\text {th }} 1961$.

${ }^{58} \mathrm{KNA}$ : AE/3/916, G. D .Parkin, Office of PS for Commerce, Industry and Communication to PS Commerce and Industry, Uganda, confidential, $26^{\text {th }}$ July 1961.

${ }^{59}$ KNA: BV/6/1704, Secret Minutes of Meeting to Discuss the Problems of East African Self-Sufficiency in Staple Foodstuffs, September 1954 (sic).
} 
Furthermore, we find that the refined sugar, and even the special sugar produced in Kenya during this period, sold very competitively despite earlier doubts by the government as indicated in the data below.

Table 6.5: Comparative Prices of Imported Refined and Miwani Refined Sugars, 1961

\begin{tabular}{|c|c|c|c|}
\hline Imported/refined & Retail Price & Miwani & Retail pric \\
\hline $\begin{array}{c}1 \mathrm{lb} \text {. pack/carton } \\
56 \times 1\end{array}$ & Shs. 1/40cents & ---------- & ---------- \\
\hline 2 lb. pack & Shs.1/05 & Pack 30 x 2 & .80 cents \\
\hline 5 lb. pack & Shs.1/90 & Pack 12 x 5 & .80 cents \\
\hline Cube sugar $56 \times 1$ & Shs.1/50 & $60 \times 1$ & $1 / 25$ \\
\hline Icing sugar & Shs. $1 / 40$ & $60 \times 1$ & $1 / 10$ \\
\hline
\end{tabular}

Source: KNA: AE/3/916, Miwani Sugar Mills, Retail Price of Specialty Packs in Sugar.

The above data show that by 1961, Miwani refined sugar was cheaper than other imported special sugars, despite the fact that prices were determined by the general rule of supply and demand. For example, the five pound pack of Miwani refined was cheaper than the imported one, while the icing sugar and the cube sugar were cheaper by almost 25-30 cents. This was encouraging to the millers and growers alike, and if such a trend was to continue, sugarcane farming in Nyanza would have been more profitable.

As the population increased, moreover, the domestic demand for sugar was unrelenting, which forced the colonial state to import from other countries, such as the United Kingdom, Madagascar, Tanganyika, Mauritius and South Africa. The high demand for importation was occasioned not only by population increase and rise in purchasing power among the Africans, but also by new business ventures in the colony such as factories processing cakes and sweets. For example, Vasani Products, based in Kisumu, started manufacturing candy in 1957 and used approximately 250 bags of refined sugar monthly for making sweets such as peppermints. Before that time, a lot of sweets were imported into Kenya from Madhvani Nagar Sugar Works 
in Jinja, Uganda. In the meantime, hotels, for instance the Pirani Tea Room, also needed a lot of sugar. ${ }^{60}$ Other hotels, such as the Hindu Hotel owned by Himatlal K. Vyas, needed large amounts of sugar.

Businesses such as these were using sugar in large quantities, and Miwani, Muhoroni and Ramisi could not meet the local demand. Thus by 1957, Kenya became so desperate for sugar that it pressed Uganda to export more. The pressure caused Uganda manufacturers to take advantage of the situation and start to dictate terms on how their sugar supplies were to be distributed, dictating even the amount to be paid for the Ugandan sugar. ${ }^{61}$ Frustrated by the Ugandan unreasonable demands before delivery, the Kenya Government was forced to turn to South Africa which initially had only been supplying refined sugar in the country.

Uganda's behavior finally prompted Kenya to launch an investigation as to why the Ugandan sugar industry was performing better than that of Kenya. The findings revealed that it was due to the good ecological conditions in Uganda coupled by the fact that Ugandan manufacturers were paid better by the Kenya government which acted as an incentive. Consequently, the government in 1957 revisited the whole pricing structure in the Kenya sugar industry, and set the prices given to Kenyan millers equal to those it accorded Ugandan millers. In essence it removed the advantage that Ugandan millers had over Kenyan manufacturers and as such minimized the competition. Moreover, Kenya started to have contacts with Ethiopia to learn more about the sugar industry there with an aim of emulating it. ${ }^{62}$ Therefore it emerges that the colonial state could not listen to Asian sugarcane farmers and manufacturers and had to wait for Uganda manufacturers to actually exploit the cane farmers, manufacturers and the Kenyan consumers before it intervened to save the sugar industry.

\footnotetext{
${ }^{60}$ KNA:DC/KSM/1/3/57, R. G. Waller, Executive Officer, CCDB to G. M. Vasani, Kisumu, $1^{\text {st }}$ March 1957.

${ }^{61}$ KNA: AE/11/30, Director of Trade and Supplies, Kenya to Director of Trade, Uganda, $2^{\text {nd }}$ May 1957.

${ }^{62}$ Muyumbu, "A Historical Study of State Policies”, 75.
} 
Needless to say, the Kenyan manufacturers and traders were not happy with the treatment accorded to Ugandan millers whose sugar sold cheaply in Kenya. Asian entrepreneurs felt that the government hindered their effort in the import of special sugar into the country. Bhagwanji and Company complained during 1957 that the colonial government favored Europeans when issuing licenses for sugar importation. ${ }^{63}$ By granting import licenses to Europeans, the colonial state deliberately discriminated against Asian traders who were struggling for economic space. The restriction of importation of sugar to one race was an attempt to control the market and the expansion of the Asian sugar industry through restriction of sales.

\section{Illegal Importation of Sugar}

The colonial government's neglect of the sugar industry through lack of supervision and imposition of effective tariff regulation affected the industry and could have encouraged illegal importation of sugar. Thus there were instances where illegal sugar was imported into the country from Uganda. This was partly because there was such a marked price differential between that produced in Kenya and the Uganda sugar. ${ }^{64}$ Ugandan sugar sold cheaply in Kenya due also to subsidized rail freight rates that the cane producers enjoyed as compared to their Kenyan counterparts as well as lack of effective tariff protection. The lack of supervision and the continued neglect by the colonial state made is easy for the illegal trade to take place.

It was found that sugar was smuggled through the town of Kitale in Western Kenya during the 1950s. By 1956 the price of smuggled sugar was Shs. 10/= lower per bag than the Kenyan price. ${ }^{65}$ During the same period, it was estimated that approximately 1,500 bags of

\footnotetext{
${ }^{63} \mathrm{KNA}$ : AE/1/30, Director, Bhagwanyi and Co. to Secretary of Commerce, $15^{\text {th }}$ January 1957.

${ }^{64} \mathrm{KNA}$ : DC/KSM/1/3/57, DC CN to Executive Officer, CCDB, $6^{\text {th }}$ March, 1956.

${ }^{65}$ KNA:DC/KSM/1.3/58, Executive Officer CCDB, to DCs Kisumu, Kitale, Bungoma and Kakamega, $28^{\text {th }}$ February 1956.
} 
sugar were smuggled per month. ${ }^{66}$ The illegal sugar from Uganda got into the colony through road transportation and not the railway which was the route for the officially imported sugar. Colonial administrators were informed of the activity, but were slow in responding. Thus it is evident that colonial state failed to take measures that could have stopped such importation, probably through inspection at the border towns. The failure of the state to take charge of the situation so as to protect the home industry contributed to the illegal movement of sugar along the Kericho-Kisii and Kisumu-Kisii roads. This movement caused immense setbacks for the Kenya industry since it resulted in a lot of sugar in both Central and South Nyanza districts being uncollected. ${ }^{67}$ Such unconventional means of trading undercut the profits of the agents, the Kenyan manufacturers, and also disrupted the distribution of sugar not only in Nyanza but in the colony at large. The illegal trade indirectly affected the Asian cane farmers because failure of the millers to get the anticipated profit definitely contributed to the low prices offered to the farmers.

Another illegal trade involved the manipulation of the use and or term of the word “sugar.” Sugar, as defined in the Essential Commodities Control of Distribution No. 2 of 1943, included such products as "sugar water”, "sugar honey”, "artificial honey,” and "golden syrup” which are all solutions of sugar in water and as such were covered under the term sugar. ${ }^{68}$ However archival sources abound with evidence of unscrupulous dealers misusing the terms to their advantage so that it meant only crystallized sugar, and so they imported the sugar solutions into the country illegally. This trade thrived during the war, and the government had the task to warn and clarify as the importation of sugar water from Uganda in large quantities gained momentum. A firm in Nairobi, known as the Nairobi Produce Store, used to import 400 four

\footnotetext{
${ }^{66}$ Ibid.,

${ }^{67}$ KNA: DC/KSM/1/3/58, DC South Nyanza to DC CN, 24 ${ }^{\text {th }}$ January 1958.

${ }^{68}$ KNA: AG/16/186, Deputy Sugar Controller to Attorney General's Office, Legal Department, $17^{\text {th }}$ September 1943.
} 
gallon tins from Jinja in Uganda every month. It was discovered that each tin contained $40 \mathrm{lbs}$ of sugar with the rest water. Consequently each consignment of 400 tins translated to 16,000 pounds or 70 bags of illegal sugar. ${ }^{69}$ Such activities were rampant, especially during the war. It is interesting to note that even when Miwani, the only factory with a refinery in the region, started to manufacture refined sugar whose main markets were Uganda and Tanganyika, no evidence was found to indicate that such a valued commodity was smuggled from Kenya into Uganda as was the case with mill white sugar from the latter. This only reinforces the argument that the colonial state failed to protect the home market, and as such sugar could easily be smuggled into the colony and not out. If there was any, it must have been very minimal since there are no records of such transactions.

The section has demonstrated how the Asian farmers were affected due to failure of the colonial state to protect the home market. The need to stop the illegal importation of sugar was important because it not only discouraged production of sugar by the Asian farmers and manufacturers in $\mathrm{CN}$, but it also interfered with the circulation and marketing of sugar because it undercut the profits meant for the local producers which impacted the growth of the sugar industry in Kenya.

\section{Sugar Import Tariffs}

Lack of measures to prevent illegal sugar imports made the Asian cane farmers and manufacturers struggle for the market as they had to compete with the illegal cheap sugar that was also finding its way into the colony. This was because, prior to 1922, import duties were mostly designed for revenue collection and not for protective intent of Kenya's agricultural industries. As such, the sugar industry suffered. However, later this was to change when the

${ }^{69}$ Ibid. 
colonial state realized that the large scale farmers, especially the European settlers, whose livelihood depended on the export of their produce, or production for the local market, had to be protected. Hence it was found that tariffs against the import of foodstuffs were very essential to protect such locally grown food crops. ${ }^{70}$ This was the case with European wheat growers when tariffs on wheat imports were imposed to protect the local production, since the locally produced wheat exceeded the world prices by a wide margin. Unfortunately, the same could not be said of the sugar industry, despite passionate calls by the Kenyan manufacturers for tariffs to be placed on imported Ugandan sugar. Thus we can conclude again that the colonial state neglected the Asian sugar industry through its failure to protect it from outside competition by imposition of a tariff. This created a hostile economic environment that made it difficult for the industry to thrive.

On the other hand, preference for European farmers in the levy of import duties began relatively early in Kenya's history. Under the influence of Lord Delamere in 1922, a series of import duties were imposed on specific items such as beer, cheese and butter, wheat and manufactured goods. These duties remained in effect until 1930 but did not affect sugar at that time. The state found it challenging to effect tariffs and so a cost of living commission was set up in 1924 to review the tariff system in the country and monitor prices. In 1929, the commission gave its report which was accepted in the LegCo. ${ }^{71}$ Ironically, the new tariff system that was adopted was geared towards protecting only certain local industries and was not inclusive. It was purposely tailored to favor the Europeans since it reduced duties on mostly items which were consumed by the Europeans. Hence, we can argue that the tariff structure in the colony, just like most policies, was racial in structure. This view is supported by Swainson who argues that there

\footnotetext{
${ }^{70}$ Swainson, The Development Of Corporate Capitalism, 41.

${ }^{71}$ Ibid.
} 
was a tendency to reduce tariffs on goods consumed by Europeans since they were the ones who formed the membership of the cost of living commission. The import duty on refined sugar was thus drastically reduced. ${ }^{72}$ At the same time, a tariff could not be placed on the Ugandan manufactured mill white sugar that flooded the Kenyan market.

To be fair, however, it emerges that it was problematic to compute an appropriate customs tariff that was fair and was subject to variations. This was because, between 1954 and 1955, the cost of imported sugar through the port of Mombasa varied from approximately $£ 37$ to $£ 46$ per long ton, a difference of 9 pounds per ton. Such variations were found to occur time and again and were also affected by the overall production of sugar in the world and the consumer demand. Moreover, it was also compounded by the convertibility of the world currencies. As such the policy makers felt that it was difficult to fix an appropriate customs tariff which was equitable to producers and fair to consumers. The argument here then is that when a tariff for wheat was imposed, the affordability for the consumer was not a factor. However, it was generally believed that if tariffs were to be imposed, a fixed period of 6-12 months would be

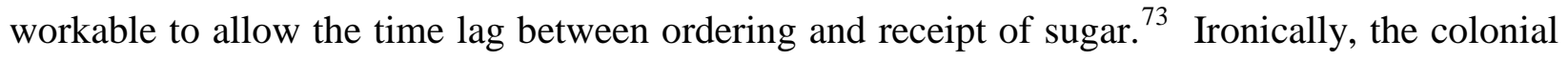
state rarely put tariffs on mill white sugar, and the sugar industry was not protected from adverse competition from outside sources, especially from Uganda. Perhaps if greater protective measures had been introduced for the Asian sugar industry through import tariffs, Uganda sugar could not have been cheaper and could have reduced the competition. The lack of effective tariffs affected the marketing of sugar which in turn affected the price offered to cane growers indicating lack of concern and how unfriendly the colonial was towards the sugar growers in Nyanza.

\footnotetext{
${ }^{72}$ Ibid., 42.

${ }^{73}$ KNA: BV/6/1704, Confidential Report by Committee of Economic Co-operation on the Future of the East African Sugar Industry, $29^{\text {th }}$ August1955.
} 


\section{Export of Sugar}

The exportation of sugar from Kenya shows again the contradictory policies imbedded in the colonial administration. Kenya had a deficit of sugar supply as indicated by imports from Uganda, yet the state found it prudent to allow exportation of sugar. Exportation could only have been viable if the colonial state supported the local industry to perform to its capacity. Kenya started to export sugar in 1924; this was because the Victoria Nyanza Sugar Company had just started crushing cane in 1924. Thus, the first export amounted to 149 tons valued at $£ 6,268$. $^{74}$ The following year there was an increase in the amount exported, which amounted to 277 tons valued at $£ 9,614 .^{75}$ The exportation of sugar continued over the years concurrently with importations. For instance, Kenya exported sugar to Tanganyika and other areas. The export to Tanganyika amounted to 1,266 tons in 1927 valued at £37,052 and 597 tons valued at £19,258 in

1928. ${ }^{76}$ By 1933, faced by the depressed state of world sugar market, the colonial state discouraged the exportation of sugar until the prices stabilized. ${ }^{77}$ According to the Sugar Control Bill of 1938, the director of agriculture authorized that sugar be exported to the Italian East African territory through the town of Moyale in the Northern Frontier (today's North Eastern

Province). The exportation was to be in small quantities by traders and not manufacturers. ${ }^{78}$ Furthermore, by the early 1940s, Kenya was also exporting its manufactured brown ugar to the United Kingdom where it was in great demand. ${ }^{79}$ The sale was conducted through Dalgety and Company. Thus it emerges that between 1924, after Victoria Nyanza Sugar Company started

\footnotetext{
${ }^{74} \mathrm{DAAR} 1924,6 \mathrm{a}$.

${ }^{75} \mathrm{DAAR}$ 1929, 651.

${ }^{76} \mathrm{DAAR}$ 1928, 17.

${ }^{77} \mathrm{DAAR} 1933,6$.

${ }^{78}$ KNA: BV/6/613, DC, Moyale to Director of Agriculture, $3{ }^{\text {rd }}$ August, 1939.

${ }^{79}$ KNA: BV/6/613, Dalgety and Company to Director of Agriculture, $8^{\text {th }}$ January, 1941.
} 
crushing sugar, and the year 1952, which marked the height of great experimentations undertaken by the sugar, Kenya exported sugar as indicated in the following table.

Table 6.6: Exports of Sugar from Kenya, 1924-1952

\begin{tabular}{ccc}
\hline Year & Amount - Tons & Value $£$ \\
\hline 1924 & 149 & 6,268 \\
1925 & 277 & 9,614 \\
1926 & 1,120 & 29,553 \\
1927 & 1,270 & 37,052 \\
1928 & 597 & 19,258 \\
1929 & 782 & 25,503 \\
1930 & 752 & ----- \\
1931 & 1,060 & 24,930 \\
1932 & 802 & 17,879 \\
1933 & 4,130 & 66,963 \\
1934 & 3,670 & 57,781 \\
1935 & 4,300 & 52,976 \\
1936 & 6,600 & 76,301 \\
1937 & 4,640 & 51,341 \\
1938 & 6,520 & 73,998 \\
1939 & 4,070 & 50,308 \\
1940 & ------ & ----- \\
1941 & 2,370 & 32,586 \\
1942 & 2,850 & 9,902 \\
1943 & 1,610 & 27,320 \\
1944 & 858 & 16,088 \\
1945 & 1,380 & 27,521 \\
1946 & 636 & 14,464 \\
1947 & 1,450 & ----- \\
1948 & 538 & ----- \\
1949 & 185 & 4,508 \\
1950 & 440 \\
1951 & & 1,746 \\
1952 & 2,412 \\
\hline & & 2,800 \\
\hline & &
\end{tabular}

Source: DAARs, 1924-1952.

From the above data, we find that Kenya exported sugar despite the fact that the country was far from attaining self-sufficiency in sugar production. There was a substantial export 
between 1933 and 1939. However, export performance overall was erratic. There was a marked decrease from 1948 to 1952, partly because there was an increase in the local consumption during the period as a result of the increase in the purchasing power of the Africans. There were numerous causes for fluctuating export performance. For instance, in 1928 export to Tanganyika dropped from 1,270 tons to 597 tons, a decrease that was occasioned by drought that led to reduction in sucrose content. ${ }^{80}$ The decrease in tons for export in 1930-1931 could be attributed to poor harvests due to the effects of locusts that had destroyed much of the crop. The rise in 1933, on the other hand, was due to increases in acreage as both the Asian and European cane growers expanded the area under cane despite the depression of the world market. The increase was likely due also to the struggle to secure the home market that was threatened by Uganda. ${ }^{81}$ The huge export witnessed in 1935 was a result of increased demand created by the ItalianEthiopian war. ${ }^{82}$ The presence of these soldiers created market for sugar. This continued until the out break of the Second World War. On the other hand, the decrease of sugar exported in 1946 was as a result of low production due dry weather and the labor shortage experienced at the time. $^{83}$

The significance of these years to the study is that it traces the export of sugar and the expansion of the industry right from infancy when the first milling factory started crushing cane in 1924 to 1952 . 1952 marks the period of intensification of experimentation supported by the colonial state which revolutionized cane farming not only in Nyanza, but in the whole colony with the other four small factories also playing a part, though minimal. The support with cane experimentation that led to such a growth shows the contradictory nature of the state action in

\footnotetext{
${ }^{80}$ DAAR 1928, 17.

${ }^{81}$ DAAR 1933, 6.

${ }^{82}$ DAAR 1935, 4.

${ }^{83}$ DAAR 1946, 10.
} 
that on one hand it supported the industry while on the other it inhibited the sale of sugar via export. Furthermore, the growth of the industry, as indicated by the data, shows that the potential was there, but that it was curtailed since it emerges that the Asian cane farmers had to struggle to survive in a colonial state that was not always supportive.

Comparatively, Kenya also exported other crops such as wheat. However, it emerged that both wheat and wheat flour had no ready expanding market in the colony and hence had no deficiency. Therefore exportation of the produce could be interpreted as a rational decision by the colonial state unlike the sugar export which revealed the contradictory nature of the states' policy of attaining selfsufficiency in sugar through the exportation of sugar despite underproduction and insufficiency. The Sugar exports (Table 6.6) could be compared to wheat and wheat flour exports as indicated in the following data. 
Table 6.7 Export of Wheat and Wheat Flour from Kenya 1924-1946

\begin{tabular}{rrrrrr} 
Year & Wheat - tons & Value $\boldsymbol{E}$ & $\begin{array}{c}\text { Wheat Flour - } \\
\text { tons }\end{array}$ & Value $\boldsymbol{E}$ & $\begin{array}{c}\text { Total Value } \boldsymbol{~} \\
\text { Wheat \& Flour }\end{array}$ \\
\hline 1924 & & & ----- & ----- & 1,520 \\
1925 & 36 & 1,520 & 94 & 1,588 & 2,070 \\
1926 & 21 & 482 & 165 & 3,385 & 3,407 \\
1927 & 2 & 22 & 275 & 6,038 & 6,238 \\
1928 & 14 & 200 & 886 & 17,549 & 92,744 \\
1929 & 6,832 & 75,195 & 1,601 & 31,996 & 101,247 \\
1930 & 1,480 & 69,281 & 1,927 & 33,150 & 124,597 \\
1931 & 3,182 & 15,313 & 1,404 & 20,263 & 35,576 \\
1932 & 86 & 525 & 1,511 & 18,777 & 19,302 \\
1933 & 6 & 50 & 2,054 & 25,158 & 25,208 \\
1934 & 100 & 591 & 2,371 & 30,603 & 31,194 \\
1935 & 51 & 479 & 3,878 & 49,730 & 50,209 \\
1936 & 2,300 & 22,883 & 3,094 & 40,540 & 63,423 \\
1937 & 390 & 4,746 & 3,470 & 45,264 & 50,010 \\
1938 & 4 & 39 & 2,907 & 43,319 & 43,358 \\
1939 & 49 & 393 & 1,194 & 50,655 & 51,048 \\
1940 & ------ & ----- & ----- & ---- & ---- \\
1941 & ------ & ----- & ----- & ---- & ---- \\
1942 & ------ & ----- & ----- & ---- & ----- \\
1943 & 45 & 794 & 5,194 & 117,750 & 118,544 \\
1944 & 223 & 3,214 & 7,933 & 181,612 & 184,826 \\
1945 & 10,059 & 116,319 & 6,001 & 153,950 & 270,269 \\
1945 & 1,691 & 27,351 & 9,634 & 233.205 & 260,556
\end{tabular}

Source: DAARs, 1924-1946.

The above data shows that the export of wheat and wheat flour indicates profit value when combined. The data also indicates that the value of sugar was better between $1924-1927$ (see Table 6.6). Moreover, the data shows that the difference in export value of the two crops in 1932 was minimal while in 1939 the value of the two crops was almost the same. Although wheat did better between 1928-1931, it was overtaken by sugar again in 1933-1938. This shows that sugar was competitive. Sugar exports competed effectively with wheat before 1943 and so there seems to have been no reason as to why wheat farming was supported more than sugarcane 
by the colonial state. The table indicates clearly that wheat and wheat flour exports only attained steady growth in value beginning in 1943 when it became more profitable over sugar. From comparative analysis of these two tables (6.6 and 6.7), we can deduce that sugar was profitable before 1943 which might have influenced the colonial state to export the little that was produced despite deficiency. On the other hand, the export of wheat and wheat flour was occasioned by the fact that there was no ready expanding market hence no deficiency, and by the 1940s wheat was more profitable.

\section{Marketing and Distribution of Sugar in Colonial CN}

This section on the marketing and distribution of sugar in $\mathrm{CN}$ is important to the study as it reveals how the colonial state intervened in the market; an intervention that was not beneficial to the sugar industry. In any case, marketing is a very crucial stage in all agricultural production and includes many activities such as collecting produce, acting as wholesalers and even providing credit to the producers. In the sugar industry, once the sugar was processed it was conveyed into the hands of appointed agents and sub-agents who then distributed the sugar to retailers according to the instructions issued by the local board. From the 1940s, the price was fixed by the government. However, we find that during the period when the Victoria Nyanza Sugar Company started milling, there was no clear distribution policy for sugar which impacted on marketing, despite the fact that organized marketing of other produce had started by the 1920s.

By the early 1930s, therefore, marketing of sugar was haphazard and required regulation. During this period, the produce was sold by Asian traders in major trading centers or by hawking it in the African reserves, and as such they acted as middlemen between the factories and consumers, especially the African buyers. Hence to improve marketing of their produce, the 
Indian farmers formed the NFCS, as earlier stated. The cooperative society felt that the colonial government was not taking a keen interest in the Asian farmers' affairs. The colonial state supported the white wheat and maize growers with railway rates at very minimal levels. This was not done in the transportation of cane. ${ }^{84}$ Such biases made the NFCS to organize, and the society succeeded in the sale of jaggery but not sugar. Thus we can argue that the Asian cane farmers depicted market consciousness and felt the need to be involved in marketing through their cooperative. However, these types of transactions did not attain the desired results due to lack of supervision and regulations. This position is supported by Talbott who argues that unorganized marketing of produce often led to poor returns as opposed to what would be expected in a structured marketing system. ${ }^{85}$

This called for state intervention if the sugar industry was to improve its performance. Hence to solve the problem, the colonial government appointed agents to distribute sugar and started to grant licenses to sub-agents and retail traders for the purchase of sugar. This started during a period of rationing and control of sugar that was carried out under the defense regulations during the World War II period. By 1943, the distribution had been streamlined. Accordingly, the internal distribution of sugar was placed squarely on the hands of the deputy sugar controller, and this worked well until 1949 when there was an acute shortage of sugar in the world. The colonial state then allowed factories to nominate main agents to distribute sugar. ${ }^{86}$ However, the effects of the restriction on the sale of sugar soon began to be felt. The idea of seeking permission to sell sugar restricted the movement and sale in local markets and exposed the dilemma of the colonial state since restricting the movement of sugar curtailed the growth of the market and the expansion of the sugar industry. Although Miwani Sugar Mills

\footnotetext{
${ }^{84}$ KNA: AK/11/173, NFCS to Director of Agriculture, $17^{\text {th }}$ January 1941.

${ }^{85}$ Talbott, “Agricultural Innovation”, 150.

${ }^{86}$ KNA: AG/16/186, Produce Disposal -Sugar Control 1949.
} 
requested the government to relax the restriction order for sugar and it's by products, nothing much was achieved. Thus we can argue that the granting of licenses was a means of control, a view supported by Makana, who argues that the colonial state policy with respect to market laid emphasis on limitation of the quantity of market outlets and as such this was meant to curtail rural capital accumulation, which was occasioned by the need to protect the European settler farming from possible competition. ${ }^{87}$

Such controls were witnessed when it was decided that with effect from June 1949, the government of Kenya would purchase all sugar allocated to Kenya. Sugar produced in Kenya and in Ugandan factories and that imported from outside East Africa was controlled by the deputy sugar controller as earlier mentioned. The controller then issued instructions to various mills on how to dispose of their sugar output and the imported sugar at different points in the country under the control of local boards as covered by section 3 paragraph 1 of the sugar regulations. ${ }^{88}$ Sugar was then passed to appointed wholesalers who in turn distributed it to traders. Accordingly, factories were required, on receipt of a disposal order, to rail immediately quantities stipulated in the order, which after full payment for the consignment required them to distribute sugar to the agents. Hence it became the prerogative of the controller and Kenya government to arrange for distribution of sugar.

However, section 3 paragraph 2 of the regulations was contradictory and problematic in implementation. For example, it required that the deputy sugar controller ensure that no person or wholesaler could deliver sugar to retailers except by his directions whereby he was to issue monthly allocations for different districts in the province. This proved to be cumbersome since it meant that every month the controller had to write to every wholesaler, approximately 300 in

\footnotetext{
${ }^{87}$ Makana, “Changing Patterns”, 259.

${ }^{88}$ KNA: AG/16/186, Produce Disposal-Sugar control 1949.
} 
number. Miwani Sugar Mills then was supposed to supply sugar only to those parities identified by the controller in the quantities specified, which in essence was time consuming. ${ }^{89}$ Furthermore, some of the distributors who had close ties with Uganda sugar factories complicated matters. Due to restrictions enforced by the colonial state, they wanted to get sugar from both sources. For example, the Anandji Group and R.K. Bhanyani wanted to get sugar from Miwani and Uganda. ${ }^{90}$

Despite such stringent policies and complaints from sugarcane farmers, manufacturers, and traders, other regulations were put in place. For instance, CN district, including Kisumu municipality, became a prohibited area in 1953 under the provision of section 14 of the sugar ordinance, government notice numbers 936 and 937 of 1946. When a district was declared a prohibited area under the sugar ordinance, it meant that no person was allowed to import sugar into the prohibited area without a permit from the controller. Furthermore no person was to possess or sell any sugar in excess of 10 pounds in weight without a permit in writing from the controller. This overregulation of the market meant that traders often had to seek permission to sell more than 10 pounds. Yet there were areas where sugar was highly consumed, for instance in areas where there were many government departments such as the police, agriculture and veterinary and mission schools and hospitals, such as the Yala area. This meant that the distributor in Yala had to constantly seek permission to sell the required amount. ${ }^{91}$ Such controls were not cost effective. It can be argued that in the absence of sufficient economic incentives and lack of consultation of the cane growers and manufacturers in marketing, the colonial state curtailed the distribution and hence stifled the market for sugar in $\mathrm{CN}$.

\footnotetext{
${ }^{89}$ KNA: PC/NZA/3/15/142, Miwani Sugar Mills to DC CN, $1^{\text {st }}$ November 1949.

${ }^{90}$ KNA: DC/KSM/1/3/57, J. S. Courtenay-Bishop, Officer of Trade and Supplies to PC Nyanza, $8^{\text {th }}$ July, 1959.

${ }^{91}$ KNA: DC/KSM/1/3/57, Notice, Sugar Ordinance Cap.194 -Laws of Kenya.
} 
Due to such problems and complaints from the sugar manufacturers, the colonial government in 1955 instituted the Control of Import and Export Order, which was followed closely by the Control of Essential Supplies (Sugar) Order of 1958, by which the government took the control of distributing sugar from the office of the deputy controller and appointed of sub agents instead. ${ }^{92}$ D. K. Hindocha was appointed as the authorized agent for sugar distribution for both the municipality of Kisumu and the whole of $\mathrm{CN}$ district. In addition, various retailers were appointed by the colonial state through the office of the DC to distribute sugar in their respective areas as indicated in the following table.

Table 6.8: Sugar Retailers and Merchants in CN by 1959

$\begin{array}{llcc}\text { Sugar distributors } & \text { Area } & \begin{array}{c}\text { Year } \\ \text { Appointed }\end{array} & \begin{array}{c}\text { Quantity of 224 lb. } \\ \text { bags per month }\end{array} \\ \text { Hasham Brothers } & \text { Kisumu } & 1954 & 5 \\ \text { Dhamecha Brothers } & \text { Kisumu } & 1954 & 12 \\ \text { Sidi Ahmed } & \text { Kisumu } & 1954 & 5 \\ \text { Jeremiah Ochieng } & \text { Kisumu } & 1955 & 10 \\ \text { Sgt. Major Were Mukudi } & \text { Ukwala } & 1955 & 1 \\ \text { Blake Muswa } & \text { South Gem } & 1956 & 4 \\ \text { Damodar Jamnadas \& Co. } & \text { Kisumu } & 1957 & 10 \\ \text { Hassanali Brothers } & \text { Kisumu } & 1957 & 20 \\ \text { Shivji Karim Surani } & \text { Kisumu } & 1957 & 20 \\ \text { Ramzans Diamond Stores } & \text { Kisumu } & 1957 & 10 \\ \text { Madatali Fancy Stores } & \text { Kisumu } & 1957 & 6 \\ \text { K.R. Soratha } & \text { Kisumu } & 1957 & 20 \\ \text { Messrs Thakarshi } & ----- & ---- & 10 \\ \text { Ranchhod \& Sons } & \text { Yala } & 1959 & \text { Nil } \\ \text { R.K. Bhayani } & \text { Kisumu } & 1959 & 20 \\ \text { L.P. Malde \& Co. } & \text { Kisumu } & 1959 & 20 \\ \text { Jamnadas \& Sons, Ltd. } & \text { Kisumu } & 1959 & \text { Nil } \\ \text { Anandji Stores, Ltd. } & \text { Kisumu } & 1959 & 31 \\ \text { Nyanza Produce Stores } & \text { Kisumu } & 1959 & 30 \\ \text { Saif Hashid } & \text { Yala } & 1959 & 20 \\ \text { R.P. Rana } & \text { Ukwala } & 1959 & \\ \text { D.K. Hindocha, Ltd. } & \text { Kisumu Municipality } & & \end{array}$

Source: KNA: DC/KSM/1/3/57, Sugar, Newcomers Quotas 1959.

\footnotetext{
${ }^{92} \mathrm{KNA}$ : AE/1/60, Director of Trade and Supplies Board to Secretary of Commerce, $2^{\text {nd }}$ August 1958.
} 
The above data indicates that there were numerous retail distributors in $\mathrm{CN}$, all appointed by colonial officials. The data indicates that out of 22 retailers, 18 were Asians. The data also shows that not all applicants were given sugar allocations. For example, the R .K. Bhayani and Anandji Stores applications were rejected since both traders were found to be receiving sugar from Uganda. It also emerged that traders appointed by 1954-1955 received very few bags of sugar. For instance, Sgt. Major Mukudi of Ukwala, got only 1 bag per month despite the high population of the area. ${ }^{93}$ In a span of only four years the allocations increased. For example, R. P. Rana, operating in the same area as Mukudi in 1959, was allocated 20 bags. $^{94}$ This could be explained by an increase in population and the African purchasing power over the period. For instance, Ukwala division had the highest population in the district by 1957 (see Table 5.5). This fact could also explain why the allocations by 1959 were high compared to the earlier years. For example Saif Hashid of Yala was allocated 30 bags as the major distributor to the Arab population.

Both the agents and retailers in CN received letters of appointment from the director of trade and supplies embodying their responsibilities. These retail traders also faced control of in that the sub-agents were not allowed to distribute sugar beyond the limits of their existing areas of distribution, and they were also not allowed to sell sugar to retailers after the $19^{\text {th }}$ of each month. ${ }^{95}$ This meant that if they had any surplus, then disposing of it would not be easy. Furthermore, they could not even sell in the neighboring locations even if they had a surplus. Such stringent measures by the colonial state were counterproductive since they curtailed the progress of the industry, by restricting the movement of sugar and hence controlling the market

\footnotetext{
${ }^{93}$ KNA: DC/KSM/1/3/57, Sugar, Newcomers Quotas.

${ }^{94}$ KNA: DC/KSM/1/3/58, DC CN to R. P. Rana, $18^{\text {th }}$ June 1959.

${ }^{95}$ KNA: DC/ KSM/1/3/5/57, The Defense (Control of Distribution and Rationing of Foodstuff) Regulations, 1944, Sugar Distribution.
} 
as well. This view is postulated by Amitabha Sadangi who argues that there is need for all legal or policy barriers which bring inefficiencies and monopoly to be removed for proper functioning of the market. ${ }^{96}$ Though his work was based among Indian peasant farmers, his argument that to improve market, it is important to reduce the over-regulations is very applicable to the sugar industry in colonial Nyanza. His views correlate to the colonial control whereby it clearly emerges that both the Asian cane farmers and the manufacturers had minimal say in the distribution and marketing of sugar which was characteristic of the colonial state's administrative policy. This view is corroborated by Ndege who arrived at the conclusion that marketing regulations in colonial Kenya were designed to allow the state to exercise control over all aspects of marketing. ${ }^{97}$ This view is shared by Bates who postulates that the bureaucratic measures and marketing institutions were imposed by those in control to ensure who the winners and losers were in the economic scene by stifling possible competition. ${ }^{98}$ In the struggle for the market between the state and the Asians, the latter were the losers. This shows the Asian sugar producer's dilemma because the marketing mechanisms and policies created by the colonial state had a decisive impact on the industry since such policies curtailed production and sale.

As the colonial state tried to control the sugar market, the annual consumption needs for sugar increased. As already suggested, this was occasioned by population increase and an increase in the Africans purchasing power. ${ }^{99}$ There was more demand for sugar; hence more traders asked for permits. Thus by 1959 the Government issued letters of appointment to new distributors of sugar after their applications were successful. The new allocations, like the

\footnotetext{
${ }^{96}$ Amitabha Sadangi, “Integrating the Poor into Market System” in B. Debroy and A. U. Khan, eds., Integrating the Rural Poor into Markets (New Delhi: Academic Foundation Press, 2004,) 21.

${ }^{97}$ Ndege, "Struggle for Market”, 254. Ndege discusses in depth the role played by the colonial state in the control of the market forces in his work whereby he illustrates how everything was controlled, for example the market buildings, specification of the days and hours when markets were to be held.

${ }^{98}$ Bates, Beyond the Miracle of the Market, 10-11.

${ }^{99}$ Heyer, Agricultural Development, 334.
} 
previous ones, were on a monthly basis. These new traders were expected to purchase and hold sugar in reserve stock for a period of one and a half months. This was difficult as millers and traders wanted to sell sugar as long as there was demand. ${ }^{100}$ Moreover, most stores were too small to hold stock because besides sugar, other goods were also sold. These rules showed the firm grip that the colonial state had on the market. These regulations caused the traders, Asian cane farmers, and the millers unhappy. For example, while the millers detested the sugar regulations, claiming they were too hasty and often enacted without consultations, the cane growers, on the other hand, lamented that because of the many rules, the once lucrative market for jaggery became chaotic. This was because jaggery got into hands of businessmen who paid the minimum price for the produce while much of it ended in the black market. ${ }^{101}$ Hence they wanted to be consulted before any rules were passed.

The colonial state continued with such controls over the years, only to meet opposition as the Indian cane producers struggled for the removal of some of the regulations. Such requests were ignored, and it was only in 1960 that the colonial state claimed that the rules were "temporary" in streamlining the sugar Industry. ${ }^{102}$ This was not the case; overregulation could not streamline the market. Hence, we can infer that most probably such argumentation by the colonial state was meant to tame the agitated sugar producers. This was necessary at that particular time due to the Kenyan political scene. As Africans pushed for independence, the colonial state did not want to antagonize the Asian entrepreneurs who included those in the sugar industry, for fear of possible Asian alignment with the African "agitators".

\footnotetext{
${ }^{100}$ Muyumbu, “A Historical Study of State Policies”, 89.

${ }^{101}$ KNA: PC/NZA/3/22/1/8, Report on a visit to the Indian farms in the area of Kibos-Miwani-Kibigori-ChemeliMuhoroni by Mr. Magor, $6^{\text {th }}-10^{\text {th }}$ October 1947.

${ }^{102}$ KNA: BV/125/10, PS Ministry of Agriculture to Chairman, Nyanza Sugar Planters Association, $2^{\text {nd }}$ November 1960.
} 
The market consciousness demonstrated by the Asian cane farmers and producers, who felt a need to be involved in the market process, and their persistence yielded fruits when the colonial state for the first time involved them. This was seen when the state established the Sugar Industry Board and, although farmers were not represented, the initial membership included two representatives of the sugar millers. Ironically, the function of the board still stifled the sugar cane industry. The board's functions, among many, included regulation of cane planting that was never there before. The board started to issue planting licenses in conjunction with the Minister of Agriculture. This was detrimental to the sugar industry, and pertinent questions emerged as to why the Asians now needed licenses to plant cane. Yet we know that the European settlers in the same district did not require a license to plant wheat that was not even competitive. The board also went further as to determine the price at which millers bought sugarcane from farmers and in addition recommended to the ministry of agriculture that there was a need to impose a levy on every ton of sugar manufactured. ${ }^{103}$ This was not only ridiculous but also contradictory to the colonial state's policy of invigorating agriculture as stipulated in the Swynnerton Plan of 1954.

Needless to say, we find that the colonial state controlled the marketing of sugar. The association was only limited to selling of jaggery. This was found to be the opposite of what was happening with the sale of the produce of European and African farmers, especially the sale of maize. This view is portrayed by Makana whose work on the Bukusu of North Kavirondo revealed how the local native councils were active and facilitated the collection and sale of the farmers produce in bulk. ${ }^{104}$ Such opportunities were not accorded to the Asian farmers, despite the fact that they were also organized in groups such as the Nyanza Indian Farmers Association

\footnotetext{
${ }^{103}$ Muyumbu, “A Historical Study of State Policies”, 81.

${ }^{104}$ Makana, "Changing Patterns”, 112-113.
} 
and other production committees which constantly worked to improve their lot. The colonial state failed to acknowledge their efforts and give them an opportunity to be involved in the sale of their produce as they did to settler wheat and maize growers in the colony. Hence we can argue that the state put in place mechanisms that ensured that the Asian farmers and manufacturers were in a position where they could not effectively bargain, since pricing and marketing was controlled totally by the colonial government. Therefore, the marketing of sugar in $\mathrm{CN}$ could be said to have performed poorly due to the racial bureaucracy put in place by the colonial state that curtailed the efficiency of marketing of sugar.

These stringent regulations seem to have been put in place due to the fact that between 1958 and 1960, the output of sugarcane had increased in CN, and the colonial state imposed the regulations to restrict more cultivation of cane. Ironically, the increased production continued until the independence period, and the rationale for restriction was not valid since sugar was still imported into the country due to the increased annual growth rate in demand. Consumption needs in the colony had to be met as indicated in the following table.

Table 6.9: Production, Consumption and import of Sugar in Metric tons, 1955-1963

\begin{tabular}{cccc} 
Year & $\begin{array}{c}\text { Domestic Sugar Produced } \\
000 \mathrm{MT}\end{array}$ & $\begin{array}{c}\text { Consumption } \\
\text { 000 MT }\end{array}$ & $\begin{array}{c}\text { Imports } \\
\text { 000 MT }\end{array}$ \\
\hline 1955 & 17 & 55 & 28 \\
1956 & 20 & 65 & 45 \\
1957 & 20 & 69 & 49 \\
1958 & 28 & 71 & 43 \\
1959 & 28 & 78 & 43 \\
1960 & 30 & 88 & 58 \\
1961 & 33 & 93 & 60 \\
1962 & 33 & 100 & 67 \\
1963 & 38 & 98 & 60
\end{tabular}

Source: M.O. Odhiambo, "Sugarcane Procurement Problems in Kenya: The case of The Nyanza Sugar Belt”, East African Agricultural and Forestry Journal 53 (1987): 29-41. 
The data above shows statistics for the whole colony portraying how there was a steady increase in cane production and how the consumption capacity continued to outstrip the output. This was significant since during the colonial period, Nyanza was the major producer of sugar; the other mills at the coast and near Nairobi had very small crushing capacities. This meant that Nyanza, the main producer, faced the challenge of trying to meet the local demand. The data reveals how the country continuously increased the quantity of sugar imported to meet the local needs over the years. The table shows that by 1963, the country produced 38 metric tons during the season, but the consumption was 98 metric tons; hence a deficit of 60 metric tons had to be imported to meet the domestic demand.

With such demands, the need to regulate cultivation of sugarcane, marketing and distribution of sugar as required by the colonial state was not viable and ill conceived. The situation created more problems. For example, in 1961, the Miwani Sugar Mills refused to enter into a contract with the government as it had been demanded to give advance notice of three months to supply a definite monthly quota of refined sugar in bulk. ${ }^{105}$ This was a difficult condition given the fact that the amount of sugar available could be affected by natural calamities, such as drought and locust invasions as had occurred in the early 1930s. In such instances, the manufacturers could not be in a position to ascertain the amount to be received from the cane growers. Such directives meant to control marketing and distribution of sugar were challenged by the company. On the other hand, the government unrelentingly and reiterated that Miwani Sugar Mills had to understand that it had to comply with the distributional Bulk Control Order regarding bulk supplies to sub agents. ${ }^{106}$

\footnotetext{
${ }^{105}$ KNA: AE/3/916, P. H. Jones to Miwani Sugar Mills, $26^{\text {th }}$ August 1961.

${ }^{106} \mathrm{KNA}$ : AE/3/916, Sugar Supplies from Miwani, 1961.
} 
Therefore, we can argue that the Asian sugarcane farmers and manufacturers in colonial Nyanza had their hands tied and were reduced to mere spectators as far as marketing of their produce were concerned. They rarely succeeded in the struggle to put pressure on the colonial state to change the overregulation of the sugar industry. However, such uncalled for restrictions did not discourage the Asian cane farmers who continued to produce more cane and needed more outlets for their produce. The increased production generated fresh calls by 1961 for another sugar factory to be built since the Muhoroni factory had ceased to operate, and Miwani Sugar Mills could not cope with the output. By 1961, when Miwani started producing refined sugar, the factory's annual output of mill white sugar was greatly reduced.

Therefore, by 1962, the colonial state changed its policies towards the distribution system, and so moved ahead and decontrolled sugar distribution. This move was meant to get rid of all the agents and sub-agents and hand over distribution to the manufacturers, which could have been done much earlier to benefit the millers and the farmers. Unfortunately, before results were realized, the colonial government again, in early 1963, came up with a new rule and introduced the stockholding policy that required Miwani to hold stock of 3,000 tons of sugar at the beginning of each month. ${ }^{107}$ The main reason for such a policy was to counteract against sugar shortages which could be caused by possible strikes and other incidences as the clamor for independence gained momentum. Within a short period, the colonial state increased the stock to be withheld by Miwani to 4,500 tons, and prohibited locally manufactured sugar from leaving the area. ${ }^{108}$ Miwani rejected the stockholding policy since it prohibited the company from selling all sugar when there was demand for it. The company preferred to sell its sugar as soon

\footnotetext{
${ }^{107}$ KNA: AE/22/630, PS Commerce and Industry to Minister for Commerce and Industry, $23^{\text {rd }}$ March 1963.

${ }^{108}$ Ibid.
} 
as it was produced. ${ }^{109}$ This was because they needed to pay the sugarcane farmers who had supplied them with cane. Hence the company petitioned the government to allow it to sell sugar as before. Despite the plea, the colonial government refused, arguing that it had a right to compel Miwani to follow the policy since it guaranteed to buy all its sugar. ${ }^{110}$ Thus we find that the colonial state was determined to control the market and was not amused by Miwani’s request. The colonial state started to intimidate the owners of the company, accusing them of repatriating large sums of money to their sugar firms back in India. ${ }^{111}$ It appears that throughout the colonial period the colonial state was not keen on the sugar industry which was, after 1948, solidly in the hands of the Asian capital as they prepared to relinquish their power in the colony and grant Kenya self-government in June 1963.

From the foregoing discussion we have seen how the cane farmers and manufacturers struggled for the market in a hostile economic and political environment. Thus it can be argued that the control of the market through tight regulations impacted the sugar industry. The regulations had drawbacks in the sense that they provided no competition or incentives to efficiency. On the other hand, they provided a measure of protection to the consumer in relation to the prices, but in as far as the market was concerned the same could not be said as to the desired quantity required by the consumer and traders. Thus we can argue that state intervention in the market affected the growers who needed a more functional market of sugar so that they could benefit, as did growers of other agricultural produce such as maize or wheat.

\section{Conclusion}

In this chapter an analysis of marketing of sugar during the colonial period in Nyanza has been undertaken. The chapter demonstrates how the colonial state controlled the sale and

\footnotetext{
${ }^{109}$ Muyumbu, “A Historical Study of State Policies”, 89.

${ }^{110}$ Ibid.

${ }^{111}$ Ibid.
} 
distribution of sugar in $\mathrm{CN}$ by implementing policies that were marred by contradiction and racial biases. The regulations were intense and involved even distribution in the African reserves. It has also shown how the Asians played no significant role in marketing of sugar since everything was controlled by the government. From the analysis, it was evident that the colonial government neglected the Asian sugar industry while it favored Uganda's sugar and imported a huge amount of sugar from Ugandan manufacturers, despite repeated appeals from the local producers for protection. The importation was costly and probably it might not have been necessary if the Asian cane farmers had been offered some bonus to cover their transport cost and thus induce the farmers to grow more cane. Such actions by the colonial state revealed the contradictions and consequences of the policies that it pursued vigorously. Policies that made Ugandan manufacturers to take advantage of the lack of sugar self-sufficiency in Kenya and manipulate the Asian producers, the consumers and government. It was only when the state realized too late the exploitation by Uganda manufacturers that it was compelled to revisit and prioritize the needs of the sugar industry. Furthermore, the policies discriminated against the Asian cane farmers which demonstrated the lack of appreciation of the viability of the sugar industry.

The chapter also draws attention to other challenges of marketing sugar in the colony such as irregular importation and the ineffective tariff system that all contributed to denying the industry a substantial profit. Finally it revealed that despite the great strides made by the sugar industry, Kenya was far from attaining self-sufficiency in sugar production, partly due to the contradictory and biased colonial policies that stifled the market which impacted cane production in Nyanza. The state failed to see the role played by the sugar industry in the wider colonial economy and the presence of an expanding local market as the population increased. The extent 
to which such policies affected agricultural labor and how it impacted cane farming constitutes the subject of analysis in the next chapter. 


\section{CHAPTER 7}

\section{LABOR IN NYANZA SUGAR FARMING}

\section{Introduction}

In any agricultural production process the issue of labor is very important, more so in commercial farming. Asian and European cane farmers needed laborers to work on their farms. This chapter examines the question of labor in the sugar industry in its varied aspects. Included in the discussion are issues of recruitment of farm and factory labor, methods used and the colonial policies that impacted the process. Policies that were put in place so as to ensure the availability of labor, especially to the settler farmers, and the contradictions that emerged are also examined. Thus the chapter also seeks to demonstrate how the colonial state turned pre-colonial households into peasants and workers. It also shows how early labor problems experienced by Asian cane farmers paralleled those of European settler farmers. Although the role of the colonial state features prominently in this analysis, archival records do not provide sufficient data for a detailed study of numbers of employed over time. Rather the first portion of the chapter gives attention to state policies and their impact on the Nyanza sugar industry.

Unfortunately, as in marketing discussed in the earlier chapter, the colonial government discriminated against the Asian cane growers and millers. The chapter examines how the Asian farmers had to compete for labor with the settlers and the colonial government to get their farm hands and the few who worked in the factory. Labor recruitment efforts affected the sugar industry, and labor conditions were impacted by the changes in the colonial economy marked by the two wars and the great depression. The chapter also describes working conditions including wages, the tasks undertaken by laborers, such as planting, cutting of cane and factory work. Housing of the workers, wages, and food rations were also significant factors impacting the 
recruitment and retention of labor in the sugar industry. This was because housing and rations were found to be inadequate and wages generally low, resulting in difficulties in recruitment and desertion as a way of protest. Following World War II, in particular, worker protest took the form of work stoppages and strikes.

\section{Early Labor Recruitment}

The introduction of wage labor, though meant to meet the needs of European settlers and the colonial state, also benefited the Asian farmers and other potential employers such as the Magadi railway. Initially, the settlers did not give attractive salaries since most of them, just like the Asians, were poor during the pre-World War One period. During this period, most of the Africans did not engage in wage labor since they were economically satisfied in their indigenous economies, as cash had little value and the payment of taxes was often in kind; moreover, taxes had not been increased exorbitantly. ${ }^{1}$

Needless to say, the pioneer Asian cane farmers experienced problems in getting labor, first because the Africans did not want to go out and work, and secondly because they had to compete with the European owned estates and European farmers in the region. Thirdly, they had to compete for labor with the colonial government which required workers for public projects such as construction of roads, bridges and administrative centers. ${ }^{2}$ This problem was compounded due to the fact that the colonial state and settlers needed to retain the laborers and ensure that they worked satisfactorily. However, during the pre-World War I period, most farmers, especially the small scale, relied on casual, short term laborers from the surrounding locations of Kajulu, Karateng, and Kano. These were paid on a daily basis. Most of these

\footnotetext{
${ }^{1}$ Fearn, An African Economy, 51.

2Zeleza, "The Establishment of Colonial Rule”, 50.
} 
workers preferred to commute from their homes due to other family obligations such as attending to their shambas' and looking after their cattle. ${ }^{3}$

In order to create a larger and more stable work force, the colonial state came up with policies that forced the Africans into wage labor. First, the colonial state introduced taxation to induce the Africans to seek wage labor. This resulted in contradiction for, according to Zeleza, taxes served two purposes in that they encouraged wage employment, but also encouraged peasant commodity production. ${ }^{4}$ Many Africans produced more so that they could have a surplus to trade and meet the tax obligation without necessarily going out to seek wage employment. Such was the contradiction of the colonial policies. ${ }^{5}$ For instance, instead of decline in agriculture, it was found that peasant commodity production increased, particularly in areas that were considered labor exporting zones such as Nyanza. That being the case, it was not easy to get labor since the tax obligation could easily be met by proceeds from the sale of commodities. As such coercion was used by chiefs and headmen to recruit labor for construction of roads and even for settler farms. Furthermore the working conditions in most places were inhumane and so could neither attract nor retain workers, especially from the areas where African commodity production excelled, hence the use of coercion. Zeleza argues that this method was used widely during the early years of colonial rule because both the state and settlers were undercapitalized. ${ }^{6}$ Thus taxation was used to make the Africans to work, as attested by Governor Belfield who asserted that:

It was the duty of the native to contribute something either by means of labour...We consider that taxation is the only possible method of compelling the

\footnotetext{
${ }^{3}$ Joseph Ouma, (O.I.), $12^{\text {th }}$ June 2009.

"Zeleza, "The Establishment of Colonial Rule", 50.

${ }^{5}$ Ibid.

${ }^{6}$ Ibid.
} 
native to leave his reserve for the purpose of seeking work . . . only in this way can the cost of living be increased for the native. ${ }^{7}$

Thus the state introduced a hut tax of one rupee per dwelling place annually in $1901 .^{8}$ The tax was levied on dwellings which a man had; thus the more houses one had in his compound the more taxes one paid. However, the hut tax was eventually increased in 1903 to 3 rupees per annum; this increased the burden on Africans who found it necessary to seek wage labor since failure to pay, meant harsh punishment such as burning of huts and granaries. The colonial chiefs used coercion to force out labor. Some were ruthless, and were therefore seen as agents of oppression. However, there were some who were respected by the local people; for example, Chief Oriri Kamidigo who was loved by the people of Kajulu location since he understood his people and encouraged them to seek wage labor to meet the tax obligation but did not force them.

Thus before 1908, the colonial Government allowed chiefs and headmen to recruit labor, and the greater number of workers one recruited, the more he was seen as effective. As such, some chiefs abused their power, as indicated above, and used coercion to bring out more laborers. This generated a lot of problems that forced the colonial state to rescind this policy and adopt a policy of "encouragement" where chiefs and headmen were deterred from direct recruitment of labor, and the work was taken over by professional and private labor recruiters. ${ }^{9}$ The recruiters were given a license for 12 months by the DC to conduct their business. These recruiting agents were registered under the Labour Agents Ordinance of $1910 .^{10}$ Because such agents still had to be guided by the chiefs who knew their areas well, coupled with the fact that

\footnotetext{
${ }^{7}$ Clayton and Savage, Government and Labour, 41. See also Wolff, The Economics of Colonialism, 99 for more discussion of the governor's speech.

${ }^{8}$ Clayton and Savage, Government and Labour, 28.

${ }^{9}$ Stichter, Migrant Labour, 38.

${ }^{10}$ Fearn, An African Economy, 54.
} 
some chiefs were paid according to numbers of laborers they recruited, hence there were no major changes. ${ }^{11}$ Therefore, complaints continued since there was not much difference so long as the chiefs and headmen were still consulted. Moreover even the agents were seen by the Africans as part of the oppressive colonial government.

Meanwhile, the colonial government introduced another tax in 1908; this was a poll tax of three rupees per annum paid by all males aged 16 years and above. ${ }^{12}$ This was meant to increase the financial burden on Africans so as to force them to seek wage labor. However, during 1912-1913, many Africans were found to be able to meet their tax obligation from income generated from household production. ${ }^{13}$ But as the tax continued to be increased, as was witnessed when tax was raised to 5 rupees in 1915 and to 8 rupees by 1920, many people in Kisumu district were forced to go and seek employment in the Asian sugar farms, especially between the months of September and March when taxes were collected. These increases made taxation burdensome and forced many to seek wage labor.

Moreover, the issue of accessibility to land for peasant production was also a factor. It was found that the continued access to land proved to be a factor for causing Africans not to join wage labor. ${ }^{14}$ Thus to maintain the flow of the laborers, the colonial government introduced a land alienation policy and the creation of African reserves as a way of shrinking land so as to make it difficult to sustain the family, hence pushing the Africans to wage labor. Therefore, we can argue that these colonial policies deprived Africans of their basic means of production and forced some people to seek labor as pressure increased on land. Reserves acted as labor reservoirs as expressed through the views of a European settler who asserted that:

\footnotetext{
${ }^{11}$ Stichter, Migrant Labour, 38.

${ }^{12}$ Ibid., 42.

${ }^{13}$ Berman and Lonsdale, “Coping with the Contradictions”, 91.

${ }^{14}$ David Siddle and Kenneth Swindell, Rural Change in Tropical Africa From Colonies to Nation States (Oxford: Basil Blackwell Ltd, 1990), 27.
} 
...the ideal reserve is a recruiting ground for labour, a place from which able bodied go out to work, returning occasionally to rest and beget the next generation of labourers. ${ }^{15}$

However, this had its own paradox in the sense that most young men who were found to have voluntarily joined the labor force came from areas that witnessed aggressive peasant commodity production. Despite the government regulations on land alienation and insistence that taxes could no longer be paid in kind in the form of grain, goats, sheep, or chickens as initially was the case, African commodity production increased. This helped to spur an interest in wage labor as some people saw the opportunity to enter wage labor as means to get money to buy European hoes (jembes) to improve peasant farming. Hence we can deduce that some people joined wage labor to intensify their own production. For instance, between 1913 and 1914 approximately 30,000 hoes were sold in the district. ${ }^{16}$ These were found to be more effective than the traditional wooden tools.

This situation produced another contradiction for while men in Nyanza sought wage labor for enhancement of household production; such commodity production meant that African laborers were not easily available throughout the year. This was because most workers preferred to work on their own farms during the planting, weeding, and harvesting periods. Thus according to Berman and Lonsdale, instead of the peasant commodity production being destroyed as a result of preference to settler production, it expanded. ${ }^{17}$

These were not the only reasons for seeking wage labor, however, as the need to buy consumer goods, such as cloths, bicycles, and other obligations such as payment of dowry also brought men out to work. Nevertheless, the turnout was not sufficient due to some of the reasons

\footnotetext{
${ }^{15}$ Wrigley, "Kenya: The Patterns of Economic Life”, 246.

${ }^{16}$ KNA: DC/CN/1/51, Agriculture.

${ }^{17}$ Berman and Lonsdale, "Coping with the Contradictions", 84.
} 
mentioned earlier. But laborers were made available due the cooperative role played by the local chiefs towards the labor recruitment effort. ${ }^{18}$

From the foregoing it is evident that Africans were reluctant to enter wage labor since their indigenous economies were sufficient. Many were only drawn into it due to the various colonial policies that were put in place. Thus although both the Asian cane farmers and the European settlers experienced problems, it was much more difficult for the Asian cane farmers to get labor a situation that became worse with the onset of World War I.

\section{World War I and Post War Labor Conditions}

World War I had direct impact on labor issues in colonial Nyanza. The war put more pressure on the need for labor as more Africans were required to serve as porters in the carrier corps and also as askari (soldiers). Unfortunately the Africans were not keen in offering their services towards the war efforts because of the poor working conditions of the askari and carrier corps. According to Zeleza, many more died due to the poor conditions than the actual combat. ${ }^{19}$ This was one of the factors that also forced Luos to work on the Asian farms. Those afraid to serve towards the war effort opted to seek wage labor on Asian and European farms. Meanwhile, the settlers continued to demand for more labor. Thus it appears as though the Asian farmers had to compete to get labor not only with the settlers but also the colonial state. As shortages continued to be acute, the colonial state resorted, after 1916, to armed raids to replenish the diminishing numbers of the carrier corps. This unleashed a period of forced labor since that was the only reliable method for the government to secure labor. During the said period, the colonial state needed a large labor force for public works. ${ }^{20}$ There was need for the construction of roads and bridges to facilitate the movement of the troops. Thus the labor

\footnotetext{
${ }^{18}$ Stichter, Migrant Labour, 39.

${ }^{19}$ Zeleza, “The Establishment of Colonial Rule”, 50.

${ }^{20}$ Ibid.
} 
demands of the war fuelled the Asian cane farmers' competition with the state in acquisition of labor.

The war also made it possible for the settlers to bargain and benefit from available labor. This was seen in 1916 when the War Council was formed. Once the European farmers achieved membership in the War Council, they used it to serve their purpose in labor recruitment and retention. For example, they were able to change the Master and Servant Ordinance in 1916 whereby desertion was now treated as crime liable to arrest without any warrant by the police. ${ }^{21}$ This was meant to stop laborers from leaving employment regardless of the conditions. Moreover, the War Council was able to reduce the wages of the carrier corps from 10 -15 rupees per month to 5-6 rupees per month. ${ }^{22}$ Wages were reduced to be at par with what the settler farmers were offering. This was to minimize the competition for labor between the government and the settlers, since it no longer made sense to risk life in the carrier corps when one could make the same amount of money in settler farms. Thus we can see that the settlers capitalized on the war to get what they wanted. The policies that favored the settlers meant that the Asian cane farmers were left in a precarious situation to struggle with the settlers over labor. Moreover, this portrayed racial discrimination as settlers were favored by the War Council which had no Asian members.

As the war progressed, the severe famine that hit $\mathrm{CN}$ also influenced some people to join wage labor, particularly the sugar farms. During 1917-1918, severe droughts, known locally as “Kanga”, caused famine in the district. ${ }^{23}$ The famine continued into 1919 and the areas most affected were Kano and Nyakach locations. The people of these locations were thus forced to move to other areas, such as Nandi and Kericho, to look for food, while others went to work on

\footnotetext{
${ }^{21}$ Ibid.

${ }^{22}$ Ibid.

${ }^{23}$ Osamba, “Colonial African Labour”, 58.
} 
the sugar farms. This improved slightly the labor situation on the farms. Unfortunately many of those who got to the farms were found to be malnourished and too weak to work. ${ }^{24}$ Many, according to Van Zwanenberg, also flocked to Kisumu to look for food and work. ${ }^{25}$ It is estimated that about 300 families from the Ramogi clan in Nyakach location moved to Muhoroni and entered wage labor. ${ }^{26}$

However, this did not make things easier for the Asian cane farmers as they had to compete for labor with the construction work such as building of roads and extension of the railway which created a rise in demand of labor after the war. For example, the recruitment of labor for the construction of the Uasin Gishu railway complicated issues since it offered higher wages: instead of the normal Shs. 12, the laborers were offered Shs.16 instead per month. ${ }^{27}$ As such many laborers deserted the sugar farms to seek employment where better wages were offered. This meant that most laborers would be attracted to seek work on the railway rather than on the sugar farms, which made it difficult for both the Asian and European cane farmers to get labor especially the small scale Asian cane farmers who were undercapitalized and so could not offer attractive wages. As such, the problems of labor continued.

Moreover, people in Nyanza were hesitant to work during the war and in the post war period as a result of the forced methods used for recruitment of the carrier corps. They only engaged in labor as last resort, and Asian cane farmers continued to experience scarcity. Attempts to solve the labor problems in CN saw the colonial government's intervention when during the period 1917-1922 professional labor recruiters were barred from Nyakach and Kano locations. These two locations were set aside by the colonial government to provide laborers to

\footnotetext{
${ }^{24}$ Chanan Singh, (O.I.), $2^{\text {nd }}$ July 2009.

${ }^{25}$ Roger Van Zwanenberg, Colonial Capitalism and Labor in Kenya 1919-1939 (Nairobi: East African Literature Bureau, 1975), 108.

${ }^{26}$ Osamba, “Colonial African Labour”, 58.

${ }^{27}$ Van Zwanenberg, Colonial Capitalism, 50.
} 
the Asian farms due to the stiff competition that existed. Thus most wage seekers from these locations were absorbed by the Kibos-Muhoroni sugar plantations. ${ }^{28}$

Meanwhile in other parts of $\mathrm{CN}$, especially in European farms, professional labor recruiters were engaged to recruit labor. However, the professional labor recruiters were found to flout many requirements such as ascertaining if a laborer was fit medically. Cases were reported where they sent sick laborers to employers. The recruiters would persuade a man to leave his home, sign his registration certificate and provide transport to the work station. These recruiters were Europeans, Asians and privately employed Africans who used any methods to obtain labor. Van Zwanenberg argues that not only were the European professional recruiters from a low social class, but that also many were alcoholics. He gives a detailed account of the nature of business conducted by recruiters like John Riddoch, Andrew Boustead and Miss Mclean who also employed the use of agents. ${ }^{29}$ Furthermore people believed that the recruiting agents were government officials. The fact that the labor argent used dubious means to get labor and the cruelty involved, indicated their desire to get more workers. Hence the presence of the labor agents and their actions exposed the struggle that the Asian cane farmers faced to get labor as a result of competition for labor with African households, colonial government, and European farmers in the area, some of who also were cane growers. Thus Asian small scale farmers found it increasingly hard to obtain labor, a fact that was compounded by their undercapitalized situation that made the Asian cane growers not to be in a position to offer higher wages.

Due to the cruelty employed by professional recruiters and their associates, like the chiefs and headmen, the colonial government faced a lot of criticism. The professional recruiters were condemned and their activities were opposed by the Native Labour Commission of 1912-1913.

\footnotetext{
${ }^{28}$ KNA: PC/NZA/3/20/4/4, Inquiry on Free Flow of Labour from Nyanza.

${ }^{29}$ Van Zwanenberg, Colonial Capitalism, 172.
} 
Both the Economic and Finance committee in 1925 and the Labor Commission in 1927 recommended that the professional agents be abolished. ${ }^{30}$ Hence District Officers were given the responsibility of getting labor by encouraging the Africans to enter wage labor.

The struggle for labor with Europeans continued, especially after World War I. First, the settlers came from the war more assertive in their demands that included availability of cheap labor. Second, the implementation of the ex-soldier settlement scheme at the end of the war made the labor issue crucial. This was because the establishment of the scheme saw more than 15 European ex-soldiers settled in the Kibigori-Chemelil area which was already settled by some Asian farmers. This coincided with the expansion of the Asian farming when 8,000 acres were put under cane. Meanwhile, other Europeans in the area and Koru were also cultivating sugarcane, coffee and sisal. $^{31}$ All these groups needed labor. This in essence meant that the Asian cane farmers continued to struggle for labor as the competition increased. This was compounded by the fact that shortage had started to have its toll as many people shied away from wage labor as earlier indicated. According to Maxon, the war experiences, forced recruitment and diseases contributed to the fall in numbers of wage seekers. ${ }^{32}$

The European settlers, sensing the situation, called upon the government to employ the same means used for recruiting the carrier corps during the war that had worked so well to solve the labor problem. Thus in 1919, Governor Sir Edward Northey, eager to please the settlers whose support he needed in his administration, thought that he could achieve his aim to institute forced recruitment of labor as was the case in World War I. Hence he issued the 1919 Labour Circular which directed that the local administration be directly involved in recruitment of labor. The fact that Northey was bent to help the settler farmers at the expense of the Asian cane

\footnotetext{
${ }^{30}$ Ibid., 176.

${ }^{31}$ Osamba, “Colonial African Labour”, 65.

${ }^{32}$ Maxon, Struggle for Kenya, 146.
} 
farmers portrays the discrimination that the Asian cane farmers had to face in dealing with a colonial state that was not very receptive to their needs. It also reveals how the colonial state continued to ignore the sugar industry as part of the wider colonial economy despite the state desire to be self-sustaining. The Northey Circular was significant in that it made it easier for professional labor recruiters to get labor, especially for settlers and the large scale sugar farmers and estates, at the expense of the small scale farmers who were left struggling to get labor as competition stiffened in a colonial state that ignored their fate.

Needless to say, the circular generated a lot of tension since it was tantamount to forced labor. Hence many called for its withdrawal. Those demanding its removal included missionaries in the whole of East Africa and not Kenya alone. Greatest criticism and persistent condemnation came from Archdeacon W. E. Owen of Nyanza Province. Thus the Northey Circular captured the contradictions that beset the colony since it revealed the different perspectives of administrators, settlers and the missionaries on the issue of labor. What was appalling about the circular was that it recommended that women and children be included in wage labor, especially those whose reserve was near the settler farms. Moreover, the coercive methods used for recruitment were inhumane as people were forced out for labor against their will. This view is supported by Zeleza who argues that labor coercion just changed its form and acquired a new name; hence it was baptized "encouragement”, though the underlying motive was the same as compulsory labor was legalized. ${ }^{33}$ Despite the protestation, Northey was adamant due to his desire to please settlers whose agriculture could not have survived without cheap labor as noted by Berman:

The Kenya settlers could not have operated within or indeed survived a market in which demand for free labour exercised an upward pressure on real wages. They had to rely on extra-economic coercion to produce forms of

\footnotetext{
${ }^{33}$ Zeleza, "The Establishment of Colonial Rule”, 51.
} 
semi-servile labour extracted from the peasant sphere at a price below its costs of production. $^{34}$

Northey was bothered by the plight of the settlers who were the protectorate's main exporters, but not that of Asian cane growers. ${ }^{35}$ Thus during the inter-war period, the labor phenomenon continued to affect the Asian cane growers. This was because during the period, the Asian sugar plantations witnessed expansion, despite periods of economic depression in the 1920s and 1930s, in that more acreage was cultivated. For instance, the approximately 8,000 acres cultivated during these decades required more laborers. The huge increase was made possible when in 1923 the Victoria Nyanza Sugar Company was established at Miwani in Kisumu District. The company consequently purchased cane from the Asian farmers at Kibos which led to increased production. Furthermore, the Victoria Nyanza Sugar Company also acquired a large sugar cane estate as discussed in earlier chapters; all of which needed labor. Hence the demand for labor increased in the 1920s. Thus we can argue that the entrance of European cane growers such as the Victoria Nyanza Sugar Company made it more difficult Asian small scale cane farmers to get labor as they had to compete for labor from a disadvantaged position as they were grossly undercapitalized.

Needless to say, the demand for labor became more acute in Nyanza when the soldier settlement scheme was implemented during the inter-war period, as earlier indicated. The demand made the colonial government intervene to ensure that there was sufficient labor through the introduction of the kipande system (pass) which was implemented in $1920 .^{36}$ Under the ordinance, every adult Africa male over the age of 16 years was to obtain the kipande. It contained personal information of the bearer, such as name, ethnic group, district, location and

\footnotetext{
${ }^{34}$ Berman, Control and Crisis, 143.

${ }^{35}$ Maxon, Struggle for Kenya, 182.

${ }^{36}$ Kanogo, "Kenya and the Depression”, 113-114.
} 
even the village. Furthermore, the employer also recorded the type of work the laborer performed, duration of employment, locality and wages. The system thus helped to contain rampant desertion since it made it easy to track down a deserter.

The introduction of the kipande did not immediately end labor shortages. The situation became even worse with the economic recession of 1921 which affected the colony. It led to fall in prices of the agricultural produce and high prices of manufactured goods. This led to reduction of wages of African laborers by almost one third. ${ }^{37}$ Such a situation discouraged many laborers who found it more beneficial to work in their farms. As a result there was acute labor shortage in the farms in the Kisumu district. In an effort to get the Africans back to work, and also in an attempt to contain the financial crisis that had befallen the colony as a result of the war and postwar recession, the colonial state decided to exploit the Africans further and raised the hut and poll taxes to a total of Shs. $16 /=$ per person annually. ${ }^{38}$

This led to an outcry from Africans who were becoming more politically conscious at the time. For example, the taxation issue was voiced by the Young Kavirondo Association which was formed in 1921 at a meeting held in Lundha in CN by mission educated men. ${ }^{39}$ The association was composed of educated Luo and Luyia men, led by Jonathan Okwiri and Simeon Nyende, among others, who advanced the African grievances and furthermore were concerned with ameliorating the working conditions of the African laborers. The association was able to secure a meeting with the Governor Northey at Nyahera near Kisumu in July 1922 and presented their grievances. Northey agreed to abolish labor camps and the reduction of taxes from Shs.

\footnotetext{
${ }^{37}$ McGregor Ross, Kenya From Within, 234.

${ }^{38}$ Ibid.

${ }^{39}$ Maxon, “The Years of Revolutionary Advance”, 81.
} 
16/= to Shs. 12/= per annum. However, Northey refused to abolish the kipande system, asserting that it was introduced for identification purposes of which were to benefit the Africans. ${ }^{40}$

The Young Kavirondo Association also protested against the forced recruitment of women, children and old men, especially when it came to the odious compulsory labor such as working on road construction. They also demanded an increase in wages among other grievances. Northey did not concede to the changes because he had "seen the light" that forced labor was wrong, but rather because the association was a threat. Maxon corroborates this view and argues that the colonial state could not risk dealing with a situation similar to the protests of Harry Thuku's East African Association. The protests of early 1920s by Africans in Nyanza were significant because it posed a threat to settler dominance. The need to retain the status quo influenced Northey. ${ }^{41}$

Due to the support from missionaries and pressure from the 1920s protests, things began to change. The British Secretary of State for the colonies Winston Churchill sent a dispatch to the colonial government stating that forced labor could only be used for essential services. Furthermore, government officials were prohibited from taking part in recruitment of labor for private employment. This in essence meant that forced labor was not totally abolished as stated in part of the circular:

. . . when unemployed young men are found in the Reserves enquiries should be made as to whether they have paid their Poll tax . . . no actual force can be employed to compel a man to go out to work, he can however be made to pay his tax ${ }^{42}$.

\footnotetext{
${ }^{40}$ McGregor Ross, Kenya From Within, 19.

${ }^{41}$ Maxon, "The Years of Revolutionary Advance", 82.

${ }^{42}$ Osamba, “Colonial African Labour”, 71.
} 
Such content indicates that though the Northey circular was amended, it still contained loopholes that could be manipulated to force people into wage labor. ${ }^{43}$ The burden of taxation and low prices induced some people to enter wage labor such that by 1923, approximately 1,500 Africans from the nearby reserves took up employment in the sugar farms. ${ }^{44}$

Nevertheless, Asian farmers struggled with the colonial state to get labor as the government diverted African labor through its policy that encouraged the African farmers to grow cotton in Nyanza, especially CN. This was seen when in 1920 the state distributed 1,500 seeds in Kano and Kajulu locations of CN district. Unfortunately, the initiative registered little success because the crop was labor intensive and the price offered was not lucrative. For instance, by 1922 the price offered ranged from 25-30 cents per pound, and this kept on declining. The cotton scheme failed, despite engaging labor that could otherwise be used in the Asian sugar plantation. ${ }^{45}$

The mid-1920s also brought further labor demands as the new factory at Muhoroni, the Nottidge and Allen Sugar Company, acquired land and stated milling sugar. The company was able to employ a workforce of 400 by $1927 .{ }^{46}$ This increased the competition for labor as more Europeans joined the sugar industry. However, the procurement of labor was not easy during the post World War I period due to new difficulties, notably the depressed financial state of the colony.

\footnotetext{
${ }^{43}$ Clayton and Savage, Government and Labour, 134 - 136.

${ }^{44}$ Colony and Protectorate of Kenya, Native Affairs Department Annual Report 1923 (NADAR) (Nairobi: Government Printer, 1924), 28.

${ }^{45}$ Osamba, "Colonial African Labour", 82. For how the colonial state implemented the cotton scheme in Nyanza see the discussion by Fearn, An African Economy, 68-78

${ }^{46}$ Colony and Protectorate of Kenya, NADAR 1927 (Nairobi: Government Printer, 1928$), 86$.
} 


\section{Depression Period and Labor Shortages on Sugarcane Farms}

During the depression period starting in 1929 and including the early 1930s, cane farmers, both small scale and large estates, found it difficult to remain solvent due to the slump caused by the depressed market, fluctuations of prices and locust visitations. ${ }^{47}$ This view is shared by Kanogo who indicated how the prices of primary commodities collapsed in the world market and continued to fall until $1935 .^{48}$ Wages dropped significantly as a result of the depressed market. $^{49}$ Farmers found it difficult to retain laborers as wages were expensive especially to the small scale Asian cane farmers. This was necessitated by the Minimum Wage Ordinance that was passed in 1932, following the ratification of the International Labor Organization Convention on minimum wages by Britain in 1928. As such, all her colonies had to re-evaluate wages given to workers. ${ }^{50}$ The colonial state also intervened to keep the settler farmers solvent. For example, in 1931 the rail freight for wheat, maize and barley was reduced. $^{51}$ Such help was not extended to Asian cane growers and goes further to illustrate the racial discrimination that the cane farmers faced during hard economic times. Moreover, this assistance meant that the settlers could technically afford to pay for laborers and so the Asian farmers had to struggle to get laborers as they were forced to offer a lower wage as will be discussed later in the chapter.

The situation changed by 1933 as there was improvement in the colonial economy. The Asian cane farmers had adequate labor which was as a result of economic pressure exerted in the reserves by the tax collectors, a situation that was partly made possible due to the presence of $\mathrm{W}$.

\footnotetext{
${ }^{47}$ Colony and Protectorate of Kenya, NADAR 1931 (Nairobi: Government Printer, 1932), 129.

${ }^{48}$ Kanogo, “Kenya and the Depression”, 115.

${ }^{49}$ Ibid., 116.

${ }^{50}$ Van Zwanenberg, Colonial Capitalism, 56.

${ }^{51}$ Ibid., 118.
} 
P. Shields, a labor officer who resided in Kisumu during that particular year. ${ }^{52}$ The state was keen to get revenue from taxes during the depression. It was ironical that despite the difficult economic situation the colonial state did not find it prudent to adjust the tax obligation of Africans. Taxation was even pursued vigorously and, according to Kanogo, Africans contributed approximately $37 \%$ of the colony's revenue. ${ }^{53}$ The effect impacted Africans who resorted to take up wage labor. Hence by 1933 it was reported that labor supply exceeded the demand in Kisumu-Londiani district. ${ }^{54}$ For example, during 1933-1934, the Victoria Nyanza Sugar Company employed about 1,400 laborers, while Muhoroni also increased its laborers to about 500. However, due to the depression, the large estates and by extension the small scale farmers both experienced hardships caused by the depressed market of sugar in the world and locust visitations which meant that the small scale farmers faced a cut in profits which forced them to reduce the number of their laborers. ${ }^{55}$

However, the shortage of labor in the Nyanza sugar industry started again by 1934 and persisted for a long time. This was partly as a result of the large number of Africans, some Asians and Europeans, who flocked to Kakamega to seek employment and try their luck in the goldfields. ${ }^{56}$ For example, most of the Europeans farmers who rushed to Kakamega were those hard hit by the depression and had become bankrupt. ${ }^{57}$ In the following year, the effects of labor shortages were minimal. For example, in 1935 as there was adequate labor as the Victoria Nyanza Sugar employed approximately 1,400 workers while both Muhoroni Sugar Mills and the

\footnotetext{
${ }^{52}$ Colony and Protectorate of Kenya, NADAR 1933 (Nairobi: Government Printer, 1934), 122.

${ }^{53}$ Kanogo, "Kenya and the Depression", 116.

${ }^{54}$ KNA: DC/CN/1/4/4, K-LDAR 1933.

${ }^{55}$ NADAR 1933,129.

${ }^{56}$ Ibid., 122. See also KNA: DC/CN/1/4/5, K-LDAR, 1936 which indicates how the sugarcane farmers faced problems, as shortages continued to be felt. The farmers had now to compete also with miners with the discovery of gold in Kakamega.

${ }^{57}$ Kanogo, “Kenya and the Depression”,116.
} 
small scale Indian farmers employed each about 500 laborers. ${ }^{58}$ Unfortunately the situation was to change in 1936 and labor shortages once again were felt. There were incessant complaints by European cane and coffee farmers especially from those at Songhor and Koru, who complained of indiscipline and prolonged unauthorized leave. ${ }^{59}$ The Victoria Nyanza Sugar Company also suffered acute shortages. Thus the Labor Officer in the district was informed of the situation so as to assist. ${ }^{60}$ However, this information was found to contradict the NADAR of the same year which indicated that there was sufficient labor supply. For example, the Victoria Nyanza Sugar Company employed about 1,400 laborers. ${ }^{61}$

Be that as it may, labor shortages continued as peasant production proved to be more rewarding. For example, in 1937 there was marked improvement in peasant production in the whole province as agricultural produce fetched higher prices. Hence many people were encouraged to work on their own farms. For example, the maize prices that had started rising by end of 1936 remained high even in 1937 partly as a result of speculative buying by Asian traders. This motivated the peasant grain growers in the province as a whole to produce more. For example, Maxon argues that during the same period, the Gusii planted and sold more maize than before. ${ }^{62}$ As such, men wanted to work their farms and this could have contributed to a situation where either laborers overstayed during leave or simply deserted. To control the situation, the colonial state introduced the "leave/pass" legislation which greatly reduced the number of deserters. ${ }^{63}$

\footnotetext{
${ }^{58}$ Colony and Protectorate of Kenya, NADAR 1935 (Nairobi: Government Printer, 1936), 184.

${ }^{59}$ KNA: DC/CN/1/4/5, K-LDAR 1936.

${ }^{60}$ Ibid.

${ }^{61}$ Colony and Protectorate of Kenya, NADAR 1936 (Nairobi: Government Printer, 1937), 177.

${ }^{62}$ Maxon, Going Their Separate Ways, 61.

${ }^{63}$ KNA: PC/NZA/4/4/88, Labour in Kisumu 1938.
} 
Despite the legislation, there were many complaints, especially from the farmers at Songhor and Koru, who reported that, the situation did not improve much as laborers either still overstayed their leave or performed poor quality of work. Thus the farmers requested the assistance of the DC to curb the vice. Hence a system was adopted whereby the DC would send a notice to the chiefs in the reserve stating that the laborer had overstayed at his home and the chiefs asked the workers to go back. ${ }^{64}$ This example suggests that the increase in peasant production impacted labor in Asian sugar farms as African labor was tied down in the reserves. Therefore, the Asian cane growers faced another challenge as they had to compete for labor with the African commodity producers. However, the situation improved in 1938 and labor was reported as plentiful in the sugar plantations which were made possible by the introduction of a bonus for work done. ${ }^{65}$ From the forgoing, it emerges clearly that labor supply was erratic and was far from stable. With the outbreak of the World War II in 1939, the labor situation worsened as discussed in the ensuing section.

\section{World War II and Post War Labor Issues}

The World War II period was also marked by challenges of getting labor as the colonial state recruited many Africans for the war against Italy in Ethiopia and Somaliland. ${ }^{66}$ Thus World War II created labor shortages through military efforts as many Kenyans were recruited to join the King's African Rifles. Secondly, the war created demand for more food production to meet the war needs, hence agricultural production increased. ${ }^{67}$ Changes were undertaken by the colonial state that provided the settlers with fertilizers, capital and technical efficiency; hence

\footnotetext{
${ }^{64}$ KNA: DC/CN/1/4/5, K-LDAR 1936.

${ }^{65}$ Colony and Protectorate of Kenya, NADAR 1938 (Nairobi: Government Printer, 1939), 107.

${ }^{66}$ Maxon , East Africa, 213.

${ }^{67}$ Ibid., 214.
} 
mechanized settler farming now became possible. ${ }^{6}$ Furthermore, large numbers were conscripted to work on much needed crops such as sisal and rubber just to mention a few. As such, both the settlers and peasant farmers were engaged in commodity production which meant that getting labor, especially for the small scale Asian cane farmers, became more difficult. The government's action revealed discrimination against the Asian cane farmers who during the same period were not accorded the same support as the settlers, and were still struggling to acquire machinery, especially for breaking the land.

Thirdly, the war conditions, just as in World War I, created an opportunity for the settlers once again to demand state support in getting labor and other services. The colonial state cooperated with the settlers to avoid antagonism during the war. Hence money was used to build roads and help settlers with fencing of their land. ${ }^{69}$ The state also used coercion to acquire labor which was made possible through the Defence (Native Personnel) Regulations of 1940 that empowered the PC to produce labor quotas for military and essential services. ${ }^{70}$ The essential services included working on private employers; many people were captured by chiefs on DC's orders. All this support accorded to the settlers portrayed how biased the colonial state was. The support seems also to have deliberately benefited the settlers to prevent effective competition from African peasant commodity production. Unfortunately, contradictions emerged instead because despite the extensive support the increase in yields of wheat and barley were minimal. The colonial state was forced to change its policy and support peasant production by the mid1950s. ${ }^{71}$ The change in policy meant that the African labor would be tied down in the reserves and as such the Asian cane farmers had to continue struggling to get labor since the colonial state

\footnotetext{
${ }^{68}$ Van Zwanenberg with King, An Economic History, 44.

${ }^{69}$ Ibid., 46.

${ }^{70}$ Zeleza, “Kenya and the Second World War, 1939-1950”, in Ochieng, A Modern History of Kenya, 147.

${ }^{71}$ Van Zwanenberg with King, An Economic History of Kenya and Uganda, 46.
} 
was not very supportive. Neither did it acknowledge that the sugar industry needed attention just like the settler and African produce production as part of the wider colonial economy.

Fourthly, we find that apart from the military services and labor for farms, many Africans were recruited for government projects such as in construction of airfields, roads, and military camps. $^{72}$ This meant that the cane growers had to struggle even with the state as they competed for labor. However, by 1940, most of the laborers on the Asian farms were either casual or on long-term contracts. Labor recruitment for Miwani was done by African clerks and headmen. Most of these workers were unskilled and some came from far away. For example, the mills transported casual laborers from as far as Nyakatch, Ahero, and, Awasi daily. ${ }^{73}$

Another critical factor during World War II was the expansion experienced by the sugar industry. This called for more labor. For instance Miwani Sugar Mills expanded its nucleus estate and employed about $60 \%$ of the total labor force in the industry. ${ }^{74}$ Asian farmers were also able to acquire more land from the profits of their businesses. For instance, the European farmers who had settled at Chemelil were eventually bought out by the Asian farmers in $1942 .^{75}$ In the same year, an Asian entrepreneur also bought the 4,800 acre Muhoroni Sugar Plantation and factory. However, this expansion of Asian sugar growing was not commensurate with the number of workers available. This was because a large number of African males were recruited towards the war effort as already mentioned. According to the colonial government's defense regulations of 1940, the PC had powers to enlist people for military and essential purposes.

\footnotetext{
${ }^{72}$ Zeleza, “Kenya and the Second World War”, 148.

${ }^{73}$ Osamba, “Colonial African Labour”, 105.

${ }^{74}$ Ibid., 95.

${ }^{75}$ KNA: DC/KSM/1/3/122, Kibos Planters Association.
} 
When the provincial administration used these powers later in the war, the Asian farmers and the European owned Victoria Nyanza Sugar Company faced labor shortages. ${ }^{76}$

The ceaseless search for labor made the colonial government to search for ways of drawing Africans into the labor market to solve the labor crisis; those found unfit for the military were sent to work at the European and Asian farms. Furthermore, due to the number of men enlisted in the army, the provincial administrators encouraged women to seek wage labor in the farms because of the pressure of the wartime needs. Before this time, women were usually left at home to work on the shambas. ${ }^{77}$

Ironically, after the war, in spite of the large number of eligible male laborers in reserves surrounding the Victoria Nyanza Sugar Company, it was not easy to get sufficient labor since the labor market was made free with the removal of the conscript labor regulation in September, 1946. ${ }^{78}$ Furthermore, the ex-soldiers still had some funds to live on and thus many not enter wage labor after the experiences of army life. Therefore, shortages of labor continued to be felt. Miwani Sugar Mills that had just taken over from the Victoria Nyanza Sugar Company, decided to minimize its problem. When Hindocha moved to Miwani from his sugar estate at Kakira in Uganda, he brought along approximately 350-400 of his former Ugandan workers. ${ }^{79}$ Most of these workers were semi-skilled and skilled such as drivers and artisans; many were Acholi. Apart from Miwani, it was found that some employers, like the large scale farmers, preferred migrant laborers from outside the colony since this group normally signed up for long contracts of three years. Furthermore, they were more reliable since in most cases they brought along their

\footnotetext{
${ }^{76} \mathrm{KNA}$ : DC/KSM/1/1798, Regulations regarding African labor for essential work, 1945.

${ }^{77}$ KNA: DC/KSM/1/17/22, Recruitment of women labour, 1944.

${ }^{78}$ KNA: DC/CN/1/3/2, K-LDAR 1946.

${ }^{79}$ Mohinder Singh, (O.I.), $22^{\text {nd }}$ June 2009.
} 
families and were provided with food rations, accommodation and with train tickets or travel warrants back to their homes. ${ }^{80}$

Moreover, labor continued to be a problem because yet again after the war more white farmers were given land in the white highlands through the Agricultural Settlement Board that was established in $1946 .{ }^{81}$ The board also arranged for special agricultural courses at Egerton College that taught about the local agricultural conditions. The implication of this was that first, it meant more laborers were needed for the latest white settler arrivals which put more pressure on cane growers; secondly it revealed the discriminatory nature of the colonial state in that it envisaged that it was only the white settlers who were meant to benefit from the agricultural courses taught at Egerton College despite the fact that the Asian cane growers and the African peasant commodity producers formed part of the bigger colonial economy and had demonstrated that their productive activities were as viable as the settler agriculture.

This was significant in the sense that the labor shortage during the war and in the post war period revealed contradictions in that the state reverted again to the use of coercion whereby recruiters used conscription that had initially been abolished. The other contradiction that emerged was that despite the discrimination and neglect of the Asian sugar growers and millers by the government, by late 1940s the industry was solidly financed by Asian capital which was expanding and needed more labor.

Be that as it may, towards the end of 1940s the sugar industry was revamped as earlier indicated. A lot of land was brought under cane and even Muhoroni Mills had started to receive cane from the farmers. These increased production and more labor was needed. Yet by 1952, approximately $62 \%$ of men in $\mathrm{CN}$ district were already contracted as laborers, so for the

\footnotetext{
${ }^{80}$ Ibid.

${ }^{81}$ Van Zwanenberg with King, An Economic History of Kenya and Uganda, 45.
} 
expanding sugar industry to meet its work force, the mills such as Miwani (former Victoria Nyanza) had to engage recruiters and open centers for such purposes. For instance, Miwani established a recruiting office at Kisii and Migori where the Gusii and the Abakuria were recruited. But the undercapitalized small scale cane growers did not engage recruiters. Despite such initiatives, employers still faced shortages as demonstrated by desertion that affected sugar cane producers.

\section{Desertion and Labor Shortages}

Desertion and lack of adequate labor were problems experienced by sugarcane employers. These actions were a form of protest against poor wages and working conditions. The former entailed leaving work place before expiration of the contract. Several factors could be attributed to such a phenomenon ranging from ill-treatment, excess tasks and poor living conditions. Many workers deserted after a few days work and others even before arrival; the latter were arrested. Some of those who left were found to have justification such as inadequate food ration. Also there were cases where desertion was caused by employers who granted large advances on engagement sometimes up to 6 months pay. ${ }^{82}$ John Ainsworth, the PC of Nyanza in 1907-1908, believed that the desertion and labor shortage in the plantations within the province was due to poor working conditions, poor rations, cruelty, poor housing, long working hours, and the “advance system” method of payment. The advance method was particularly detrimental since once the money was spent, the laborer was not motivated to work. Although the practice was common and was used to attract more laborers, it was found to be self-defeating on the part of the employer. ${ }^{83}$

\footnotetext{
${ }^{82}$ KNA: DC/CN/1/4/1, K-LDAR 1922.

${ }^{83}$ Ibid.
} 
Desertion, on the other hand, became a crime in early colonial Kenya and when caught the offender could be fined Shs. $100 /=$ or sentenced to jail for two months. ${ }^{84}$ To enforce such measures, the colonial state introduced the Registration of Natives Ordinance in 1915 which became law in 1920 and required every male that was over 15 years to be registered. ${ }^{85}$ The registration required the Africans to carry a certificate of identity which had his personal details which served the best interest of the employer. This certificate or kipande was meant to curb desertion as it allowed the laborers to be easily traced. Thus, as observed by Anderson, it benefited the employers, mostly settlers, while it was injurious and hated by the African workers since it not only hindered the bargaining power of the laborers for better wages, but also restricted their movements to the locality of employment. ${ }^{86}$ Moreover, the government refused to let employers contract any African laborer without a kipande.

Even with the enforcement of the kipande to contain desertion, shortages were experienced. Retention of labor was a huge problem, especially in settler farms as opposed to the Indian farmers who were found to retain labor as they treated their workers fairly. ${ }^{87}$ Although the Asian small scale farmers faced labor shortages, this was not greatly affected by desertion as compared to the European plantations since most Asian small scale farmers employed casual workers paid on a daily basis. Moreover, most small scale farmers did not use professional recruiters as most of their laborers came on their own accord due to reasons discussed. Furthermore, the small scale farms were found to have lax regulations and there was interpersonal relationship with the employer which was lacking in large estates. ${ }^{88}$ Hence there

\footnotetext{
${ }^{84}$ Norman Leys, Kenya (London: Frank Cass, 1973), 13.

${ }^{85}$ David Anderson, “Master and Servant in Colonial Kenya 1895-1939”, Journal of African History 41 (2000): 459485.

${ }^{86} \mathrm{Ibid}$.

${ }^{87}$ NADAR 1934, 174.

${ }^{88}$ Colony and Protectorate of Kenya, NADAR 1936 (Nairobi: Government Printer, 1937), 178.
} 
were very few cases of deserters in small scale Asian sugar cane farms as compared to the large sugar estates and settler farms. Those who deserted from small scale farms mainly did so due to low wages, poor rations and delayed payment due to the insufficient finances of the small scale farmers. On the other hand, majority of deserters were from large estates and settler farms and were mainly due to ill treatment.

Be that as it may, it can be argued that the ill treatment on large scale sugar farms could be attributed to neglect of the industry by the colonial state. This was revealed in 1928 when it was found that inspections carried out by the Labor Office indicated that the sugar industry was inspected only three times while that of coffee and sisal were inspected 172 and 65 times respectively. ${ }^{89}$ This negligence by both the labor office could have contributed to lack of retention of laborers as mistreated workers deserted.

Labor continued to be scarce for in the early 1930s though desertion was not the only factor responsible. The Asian cane growers had also to compete for labor with the Kericho tea plantations that also got most of its laborers from CN. The neighboring Kipsigis community was not keen on wage labor and was found unreliable. Thus by 1933 the tea estates had employed about 8,000 workers, most coming from Central and South Nyanza. ${ }^{90}$ The demand created by the tea plantations made Africans to have more options, and this affected the cane farmers as competition for wage labor increased. These options could be said to have increased the occurrence of desertions witnessed over the years.

Therefore, desertion continued to became a significant labor issue for large scale cane growers later; by the 1950s, desertion was so high at Miwani Sugar Mills askaris were stationed at the Miwani railway station to ensure that the deserters did not board the train. The majority of

\footnotetext{
${ }^{89}$ Colony and Protectorate of Kenya, NADAR 1928 (Nairobi: Government Printer, 1929), 109.

${ }^{90}$ NADAR 1933, 127.
} 
the deserters were Gusii, Abakuria and Luos of South Nyanza. ${ }^{91}$ The laborers were basically employed as cane cutters and loaders. Many Abakuria did not anticipate the nature of the work that awaited them, found it difficult and many deserted after working for only a few days at Miwani. The problem was so severe that it needed the attention of the colonial state. For example, in 1951 alone, out of 1,412 recruited labor force, 499 deserted. ${ }^{92}$ These examples demonstrate that desertion was an issue that had an impact on the Nyanza sugar industry. The recruitment and retention of labor were impacted by the issue. In a similar manner, working conditions on the farms and in the factories also effected recruitment and retention.

\section{Working Conditions in Sugarcane Plantations and Factories}

In the sugar industry, just like any agricultural industry, the issue of working conditions remains a major factor in the success of the industry. These working conditions entailed many aspects. For our analysis, these include issues that deal with terms of service, wages, housing, different types of tasks performed, and labor unrest. All these issues impacted sugar production in the sense that they were the major determinant to the engagement and retention of labor in the industry.

\section{Terms of Service for Laborers in the Sugar Industry}

Labor in the sugar farms was composed mostly of African workers, although there were Asians who were employed too. The latter were mainly the new arrivals, mostly young and poor who were ready to do any work before saving enough money to venture into entrepreneurship. Some were called upon from home by relatives to help them in the sugar plantations, especially those who had agricultural experience. The African workers comprised men, women and juveniles (as casuals), while some men were on long contract. There were different types of

\footnotetext{
${ }^{91}$ KNA: Lab/2/1895, Labour Inspection Report, 1951.

${ }^{92}$ Ibid.
} 
labor contracts for these African workers. The verbal contract, which entailed 30 working days, piece work, whereby laborers were paid wages according to the task performed, and the long term written contract, which involved several months service. Most Africans in the sugar farms preferred a 30 day working contract. ${ }^{93}$ This was convenient for the laborers who apart from family obligations were also involved in peasant production. The number employed on a farm varied according to the size of the farm. For most farms, between 15 and 300 people were employed.

Other terms of service included supply of provisions. Both the small scale cane farmers and the large scale provided rations as means of encouragement and retention due to the odious and busy schedule involved in cane production. For example, once the laborers were employed they were provided with rations and other basic necessities. The large estates which employed larger numbers also provided their labor with tools. The Victoria Nyanza Sugar Company may be used as an example. Upon employment, the employer provided the laborers on contract with a blanket, a basin, eating bowl, a plate, a sleeping mat, and working tools such as cutlass (panga) or digging hoe. ${ }^{94}$ The cutlass and the hoe were returned by the workers at the end of the contract, while the other provisions, like the blanket and plates, etc., were kept by the laborer. Just like Muhoroni, Victoria Nyanza Sugar Company also provided rations as follows:

2 pounds Posho (maize flour) per day

1 pound of sugar and salt per week

Beans and cooking oil. ${ }^{95}$

By 1952, the rations at Miwani consisted of a slightly different mixture.

16 ozs. Of posho (maize flour) per day

4 ozs. of beans per day

$1 / 2 \mathrm{lb}$. of sugar per week

\footnotetext{
${ }^{93}$ NADAR 1923, 29-30.

${ }^{94}$ KNA: Lab 9/2132, Miwani.

${ }^{95}$ NADAR 1933, 129.
} 
6 ozs. of vegetable oil per week

4 ozs. of salt per week

90 cents per month for meat ${ }^{96}$

However, the ration was found not to be adequate. As a result, the laborers brought foodstuffs such as vegetables from home and also grew their own vegetable gardens in the estates. $^{97}$ This inadequacy has been illustrated by van Zwanenberg's findings that revealed that the diet in the reserves was much better than in the labor camps since it was more varied and nutritious. $^{98}$ The rations were found to be slightly different from those found in settler farms. For example the workers in the coffee farms were given two pounds of posho per day, ration of beans weekly and salt. ${ }^{99}$

These rations were found to remain unchanged over the years. Thus even when compared to what the Victoria Nyanza Sugar Company was offering during the same period, the ration in settler farms was found to be much insufficient in that the workers were neither offered sugar nor cooking oil. The reason given for the small ration in settler farms was that as opposed to the Asian farms, there was enough room for laborers to grow their own food. ${ }^{100}$ Comparatively, Magadi Soda Company was found in 1923 to have offered the best rations which included the basic 2 pounds of posho daily, a pound of beans weekly, a pound of meat weekly, salt weekly and 1 lemon weekly. ${ }^{101}$ This was significant in the sense that Magadi Soda Company thus emerged as a strong competitor for labor. Not only did it provide better wages, but also a more diverse ration. These factors made it difficult for the Asian small scale farmers

\footnotetext{
${ }^{96}$ KNA: Lab 9/256, LIR, Miwani, $29^{\text {th }}$ November 1952.

${ }^{97} N A D A R$ 1935, 184.

${ }^{98}$ Van Zwanenberg, Colonial Capitalism, 39.

${ }^{99}$ NADAR 1933,128.

${ }^{100}$ NADAR 1923, 28.

${ }^{101}$ Ibid.,27. According to the report, it was noted that the Magadi Soda workers were in physically good condition during the period of employment.
} 
to acquire labor. So also did the types of tasks for which workers were recruited impact efforts to acquire workers.

\section{Types of Tasks in the Sugar Industry}

Before discussing the varied tasks involved on farms and factories, it is important to recognize that labor was hierarchically organized in the sugar plantations. In terms of tasks there was racial division of labor; Africans did more strenous, menial, and urgent tasks than the Asian workers. In terms of hierarchy, the Asian or European farmer stood at the top; then there was the supervisor. In Asian farms, the supervisor or nyapara was in most cases Asian. These supervisors were mostly cruel and handled the workers badly. For example, insults were very common and as colonized people in a three tier racial hierarchy, the Africans withstood the cruelty due to their need for money to pay taxes. The Asian farm owners normally invited friends and relatives from India to come and work as a nyapara on their farms. Most of these overseers were trained; a few had studied agriculture at Punjab University. However, they had to apply for immigration permits for entry into Kenya which could be turned down by the colonial state.

The nyapara was responsible for making sure work was performed and production efficient. Some had exceptional abilities and knew much more about sugarcane farming than the farm owners. ${ }^{102}$ Other Asians worked at the weighbridges, drove tractors, and worked as farm assistants. Once in the country, especially the skilled Asians had to apply for a temporary employment pass in order to take up employment. For example, Rattan Singh had to apply to work on the farm of Shamji Harji and Bros. as specialists in machine maintenance. ${ }^{103}$

\footnotetext{
${ }^{102}$ Vitalis Ogolla, (O.I.), Agriculture Manager, Kibos Large scale Farms, $6{ }^{\text {th }}$ June 009.

${ }^{103}$ KNA: DC/KSM/1/19/270, DC CN to Principal Immigration Officer, $7^{\text {th }}$ October, 1958.
} 
In the factory, a similar hierarchy applied; all the senior posts were occupied by Asians and Europeans. Africans basically did the manual work, though there were also African skilled workers, like artisans, who despite their skills were paid less for the same qualifications and same tasks as the Asians. Many recognized the discrimination involved in this system, and not just the African workers. In 1955, the DC of CN, A. D. Shirreff, felt strongly enough to complain that this was prejudicial to local people. ${ }^{104}$

It should be noted, nevertheless, that Asian workers also faced discrimination. The colonial state's discriminative immigration policies denied Asian farmers and manufacturers much needed skilled labor, as for example supervisors. This could be costly since some of the cane farmers had no knowledge or expertise of sugarcane growing, and so seeking skilled manpower was reasonable. But unfortunately the colonial state failed to see the urgency of supervision and made it difficult for the skilled workers to come from India as will be discussed in the next chapter.

Turning now to specific tasks, it is clear that sugar cane farming was demanding and the farmers needed labor that performed different tasks throughout the year. The peak period was between March-November. This was the time for planting, weeding, and harvesting. Miwani Sugar Mills, having the largest plantation, needed laborers throughout the year, both on the farm and at the mill. ${ }^{105}$ This meant a more organized system to ensure that there was constant supply of laborers. For instance, they had to employ the workers during the field preparations in tasks such as tree-felling and de-rooting, which were done manually due to lack of machines which by then were very expensive. Labor was also needed in the factory. There was a clear division of labor; work was allocated based on gender and also age. There were a few instances that women

\footnotetext{
${ }^{104}$ KNA: Lab 9/256, Labour in Sugarcane farms, 1955.

${ }^{105}$ Osamba, “Colonial African Labour”, 95.
} 
were engaged. However, most workers were men. They did odious jobs like de-rooting, clearing bushes, breaking of land using the plough, hoeing which had to be ready before the onset of rainfall cane cutting, manuring as well as loading and off loading of cane. Furthermore, it was only men who worked in the factories and jaggery plants. According to one large scale farmer, Mr. Mohinder Singh, the colonial laborers were better than the current ones, since they used to work from 6 a.m. to 5 p.m. compared with today's workers who work only till midday. ${ }^{106}$ Mohinder's account, however, differs from the NADARs, which indicate that laborers not only had a 2 hour lunch break but also left the field at $4 \mathrm{p}$. m. which appears to have been very generous terms. ${ }^{107}$

Be that as it may, it was recalled by planters and workers that daily work on the farm began at 6 a.m., and the laborers worked for an average of six hours daily due to the odious nature of the work such as weeding and cane cutting and the fact that they worked in hot weather. During weeding, the laborers were supposed to manually remove weeds that could not be completely cleared by the mechanical weeder. The workers normally worked from Monday to Saturday except for emergency cases such as loading already harvested cane to the factory, when they could work on Sunday. ${ }^{108}$

Cane cutting was the most difficult and risky task. It was done in rows. During the manual cutting, total concentration was needed to avoid cutting oneself. ${ }^{109}$ Occasionally, laborers had accidents of flying pieces of cane striking them. Secondly, when then firing of cane was stopped, there were cases where some people were bitten on the hands by spiders, and also the presence of snakes made the work risky. Cane knives were sterilized during the cutting

\footnotetext{
${ }^{106}$ Mohinder Singh, (O.I.), Kibos large scale farmer, $22^{\text {nd }}$ June 2009.

${ }^{107} N A D A R$ 1934, 174.

${ }^{108}$ Absalom Apondi, (O.I.), Cane Cutter, Muhoroni, 26 $6^{\text {th }}$ July 2009.

${ }^{109}$ Chanan Singh, (O.I.), $26{ }^{\text {th }}$ July 2009.
} 
season. The blades could be left overnight in a sterilizer to be used the next day. This was done to prevent the spread of ratoon stunting disease. ${ }^{110}$

Another important task in the productive process involved transport. Some men worked as lorry drivers, and they were in great demand during the harvesting period. They basically transported cane either to the trolley lines or the sugar mills. By 1948 approximately 80 African drivers were employed in the Asian sugar farms. ${ }^{111}$

The factory workers, on the other hand, had a different working schedule from farm hands. They worked on 3 eight hour shifts, from 8 a.m. to 4 p.m., 4 p.m. to midnight and midnight to 8 a.m., alternating weekly. This was because during the rolling season, the furnace was kept burning for 24 hours. The factory had many workers, unskilled and skilled, who not only worked different shifts, but also in different places. The minimum manpower in a factory with capacity of producing 1000 tons of sugar per annum was approximately 55, as indicated in the following data.

\footnotetext{
${ }^{110}$ KNA: AK/11/52, Report on a visit to Potential Sugarcane areas in Kenya by P.O. Wiehe, $1^{\text {st }}$ December 1956, 20.

${ }^{111}$ Mohinder Singh, (O. I.), $26^{\text {th }}$ July 2009.
} 


\section{Table 7.1: Factory Labor Force}

Technicians

1 factory engineer - mechanical

1 factory Superintendent - manufacturing

1 electrician

1 Chemist

Skilled Laborers

1 engine driver

3 engine drivers

3 skilled men

1 sugar boiler

1 chief pan boiler and 1 assistant

Areas/task

Cane unloading and conveying

Crushing plant

Juice treatment plant

Evaporating plant

Vacuum pans

1 engine driver

1 skilled man

Condensing plant and cooling pond

3 skilled men

Crystallizers

Centrifugals

2 skilled men

1 boiler attendant and 1 assistant

Storage and bagging room

Boiler plant

6 mechanics

Total - 25 skilled men

Workshop

Unskilled men - about 30

Source: KNA: AK/11/52, Extract from a letter from P.O. Wiehe to L.H. Brown Department of Agriculture Nairobi, $29^{\text {th }}$ May 1957.

The above data indicate that many laborers were needed in the factory. Secondly, it emerged that more skilled workers were needed to man the various sections. This labor force excluded those who worked as cane inspectors, accountants and general administrators. However, it was not uncommon for some personnel to double up duties. For example, the factory chemist could also be the cane inspector.

However, in 1943 the colonial government introduced the task system in agricultural work on sugar farms. This was meant to protect both the worker and employer against possible exploitation in the industry. The system required a laborer to perform a given task per day. It was hoped that the task system would increase production. In most instances, work was measured. For example, three men would be expected to cut cane to fill two trucks per day. ${ }^{112}$

${ }^{112}$ Ibid. 
According to Elkan, organized daily tasks worked as follows:

Each man is set a daily task, when he has completed it he may go, even if it has only taken two hours to complete it. Each completed task is recorded on a ticket with which he is issued at the commencement of the contract. This ticket states his daily (task), rate of pay, and the contract is either for a month or forty-two days. The monthly contract has twenty six working days and the forty two day contract has thirty working days. Each worker is paid at the expiry of his contract. $^{113}$

Elkan's argument was that the task system was productive since it rewarded the worker for his extra effort and diligence by setting him free once the task was done. Despite the fact that his work was based on Uganda, this method was applied in the CN Asian plantations and farms. According to Mohinder Singh (Kibos), this system was useful to both the farmer and the worker since the work was done on time. ${ }^{114}$ This was significant because it has emerged clearly that working conditions were found to be among the major determinant for return to wage employment. This view is supported by Zwanenberg, who posits that where many of laborers were migrant workers, conditions such as adequate food and housing could not be ignored as this was important for retention. ${ }^{115}$

\section{Wages in Sugarcane Farms and Factories}

The issue of wages was always a significant one for employment in the Nyanza sugar farms and estates. There was no standardized wage at any time. The wages paid differed due to many reasons, not only in areas of employment, the employer (Asian or European), but there were also differences based on gender and age. For instance, the few women employed were paid less than men. Apart from that, there was also difference in wages paid for farm hands and that of factory workers. It goes without saying that Asians paid low rates compared to most European farmers. This was because the Asian cane farmers, especially the small scale farmers,

\footnotetext{
${ }^{113}$ W. Elkan, Migrants and Proletarians (London: Oxford University Press, 1960), 113-114.

${ }^{114}$ Mohinder Singh, (O.I.), $22^{\text {nd }}$ July 2009.

${ }^{115}$ Van Zwanenberg, Colonial Capitalism, 60.
} 
were undercapitalized and had little support from the colonial state. For instance, by 1910 when many Asians paid 3-5 rupees, European farmers paid 6-7 rupees. ${ }^{116}$ By 1912, the African laborers in Kibos-Muhoroni numbered approximately 700 who were paid between 5-7 rupees. ${ }^{117}$ Although Asian employers, paid low wages compared to European farmers, they extended credit facilities as inducement to the laborers.

Needless to say, the 5-7 rupees paid was not enough to pay for the tax and also meet the families' basic needs. Hence, many only sought wage labor during the off-peak season. Furthermore, European employers at this time were not willing to pay good wages either, arguing that an increase in wages did not improve their condition, but rather made the African laborers to engage in bad habits. ${ }^{118}$ Consequently, farmers generally continued to have labor shortages. Regardless of the low rates, many people were recruited. Sharon Stichter argues that by 1915 , approximately $36 \%$ of the people of Kisumu area entered wage labor due to two factors; first was the proximity of the Asian plantations and secondly it was due to the cooperative role played by the local chiefs towards the labor recruitment effort. This was thus not entirely the result of the attraction of high wages. ${ }^{119}$

In addition, the level of wages fluctuated over the years. By 1928 wages had increased and varied from Shs.12-14 per 30 day work ticket plus rations with the price of cane at Shs. 12/ per ton. ${ }^{120}$ However, the depression impacted wages so that by 1933 the average wage for farm workers had dropped and ranged from Shs. 8-12 for a 30 days working contract while factory workers were paid between Shs. 12-14 under the same contract. ${ }^{121}$ However, the effects of

\footnotetext{
${ }^{116}$ Osamba, “Colonial African Labour”, 56.

${ }^{117}$ KNA: DC/CN/1/5/1, Kisumu District Quarterly Report (KDQR), 30 June 1912.

${ }^{118}$ Van Zwanenberg, Colonial Capitalism, 41.

${ }^{119}$ Stichter, Migrant Labour, 47,56.

${ }^{120}$ NADAR 1928, 99.

${ }^{121}$ NADAR 1933, 129.
} 
depression led to an increase in those seeking wage labor. For instance in 1934 there were about 700 workers on the small scale Indian farms up from 500 of the previous year. ${ }^{122}$ As the effects of depression took a toll, there was reduction in wages due to poor cane prices. The price of cane fell from Shs. $12 /=$ a ton to Shs. $6 /=$ a ton while that of jaggery slumped from Shs. $5 /=a$ frasila to Shs $2 /=$ a frasila. Hence wages decreased varying from Shs. $7-9 /=.{ }^{123}$ The drop in prices and wages signified how the Asian cane growers struggled to remain in business during the hard times. The hardships created by the falling price of sugar meant that the small scale farmers faced a cut in profit and so had to lower wages. With low wages, the struggle to obtain and retain labor became prominent.

By 1935, the situation had not improved and labor supply in Muhoroni, Songhor and Koru farms was found to be far below what was expected, possibly because wages remained low. They had stagnated for a long time between Shs. 6/= to Shs. $8 /=$ per month plus posho (maize meal) due to the effects of the depression. ${ }^{124}$ These were the rates offered in the Asian farms for farm hands. However, Victoria Nyanza Sugar Company offered higher wages for the same workers at the rate of Shs. $8-12$ a ticket for 30 days in $1933 .{ }^{125}$ By 1935 the wages in the Indian small scale farms still remained at the rate of Shs. 6-8 a ticket, while the large estates, in particular the Victoria Nyanza Sugar Company, paid its workers higher wages. For example, the average wage in the company during the same period was Shs. $13 / 50$ for a 30 day ticket. ${ }^{126}$ This slightly increased and in 1938 the wages in the large estates ranged from Shs.12-14. ${ }^{127}$

\footnotetext{
${ }^{122}$ NADAR 1934, 174.

${ }^{123}$ Ibid.

${ }^{124} \mathrm{KNA}$ : PC/NZA/3/1/465, Intelligence Report K-LD, September 1935.

${ }^{125}$ NADAR 1933, 129.

${ }^{126} \mathrm{Ibid}$.

${ }^{127}$ NADAR 1938, 107
} 
Wages also differed depending on tasks. For example, cutting, which was strenuous, attracted few laborers. Hence the farmers started a system whereby laborers were paid 75 cents per day for cutting and loading cane on a truck. Thus we can deduce that if one worked for 30 days at the rate the wages would be Shs. 22/50. ${ }^{128}$ However, the NADAR and the archival sources differed sometimes on wages offered to laborers. For example, the archival records indicated that by 1941 the Victoria Nyanza Sugar Company increased wages and paid laborers between Shs. 9-15 for a 30 days working contract while the Asian cane farmers paid between Shs.6-10. ${ }^{129}$ A close examination of these wages indicates that they were far below those offered by Victoria Nyanza Sugar Company in 1935 as indicated by NADARs. The discrepancy could have been as a result of the officer's desire to present a view that the situation was not all that bad. Moreover, a complete analysis of wages was not possible because detailed statistics of the war time period were not available for this research.

Be that as it may, by 1950 unskilled laborers were paid between Shs. 18-25 per 30 days work on Asian farms. ${ }^{130}$ Furthermore, wages differed according to the worker's skills and as well as type of employer. For example by 1955, Miwani Sugar Mills paid the unskilled laborers between Shs. 20-30 per monthly ticket, while other Asian farms paid between Shs.18-20 for the same ticket. ${ }^{131}$ However, wages continued to go up slowly. For example, by 1963, due to the activities of the trade union as will emerge in ensuing section, the farm workers and unskilled factory laborers were paid Shs. $85 /=$ per month. ${ }^{132}$

From the foregoing discussion it is evident that the cane farm laborers did not earn much. This was impacted by the fact that the colonial state did not put in place good policies to carter

\footnotetext{
${ }^{128}$ NADAR 1935, 184

${ }^{129}$ KNA: DC/KSM/1/7/95, Miwani, 1941.

${ }^{130}$ KNA: Lab 9/ 2132, LIR, Miwani, $15^{\text {th }}$ April 1950.

${ }^{131}$ Chanan Singh, (O. I.), $26{ }^{\text {th }}$ July 2009.

${ }^{132}$ Michael Juma, ( O.I), $6^{\text {th }}$ July 2009
} 
for the workers as they were more concerned about pleasing the settler farmers as indicated in the Master and Servant Ordinance as earlier discussed. The policies were full of contradictions and failed to have clear guidelines on plantation workers' wages and as such laborers could easily be exploited as wages varied on different farms. Wages offered by the sisal and maize farms were different from those offered in the sugar plantations. For example, by 1923 the sisal estates paid Shs. $24 /=$ without food for 1,000 leaves cut or Shs. $12 /=$ with food for 1,500 leaves. ${ }^{133}$ During the same period workers on maize plantations in Nyanza were paid Shs. 10/= per month with rations ${ }^{134}$ The wages for maize laborers were lower than other agricultural sector apart from the sugar industry, and the reason given for that by employers was due to the “picking” (stealing maize) during harvest. ${ }^{135}$ These wages were higher than those paid by small scale Indian farmers in 1935 as indicated earlier; thus it became apparent that cane farmers faced stiff competition in labor procurement. Secondly we can argue that the discrimination against the Asian sugar growers by the colonial state could have contributed to the poor wages in the Asian cane farms as farmers were heavily undercapitalized and could not afford their laborers good wages. So the Asian cane growers had to struggle not only to get laborers but also to retain them. Despite the fluctuating rates, wages were a key variable in the attraction and retention of labor, more important than housing.

\section{Housing in the Sugar Plantations}

Housing is also considered here as one of the significant conditions of labor as in the case of its impact on the retention or return of workers. Although available sources provide something of mixed message for the researcher, housing on the Asian farms and estate plantations was not very adequate. Until the 1930s, Asian farmers used traditional huts for

\footnotetext{
${ }^{133}$ NADAR 1923, 27.

${ }^{134}$ Ibid., 32 .

${ }^{135}$ Ibid.
} 
housing of their workers as did the Victoria Nyanza Sugar Company. These were made of mud and wattle or mud and grass thatched roofing, but those were not maintained as in the reserves. Moreover, they were single roomed with one serving as kitchen, dining and bedroom. The NADARs from the 1930s indicate that sanitary conditions were good in all the camps on the estates. ${ }^{136}$ This was probably because it was easy to maintain the outside compound which was constantly swept and trash burnt, but the maintenance of individual huts was challenging since as many as three people shared a structure. On those farms where housing was found to be inadequate, some laborers were granted permission to build their own houses, especially in the large estates such as Miwani.

Housing was a sensitive issue since labor laws stipulated that employers were expected to provide housing. Most probably it was the need to protect the employers by some official that led to contradictory reports on the issue. For instance, contrary to NADARs, housing was generally overcrowded and posed great health risks since structures were built haphazardly. According to the Labor Officer's report in 1933, the shortage of housing in sugar plantations was so rampant, that 2-3 people shared a hut while juveniles shared housing with adult laborers, mostly women. The report also indicates that houses were so poor that they in most cases were unable to adequately shield the occupants from cold, wind and even rain. The situation was so bad that a report of the Labor Officer as early as 1933 recommended gradual erection of permanent houses. ${ }^{137}$ The NADAR of that year, on the other hand, paints a good picture of the living arrangement, citing a satisfactory sanitary system and installation of the piped drinking

\footnotetext{
${ }^{136}$ NADAR 1934, 173.

${ }^{137}$ KNA: PC/NZA/3/13/8, Labour Officer to Provincial Labour Inspector, Nairobi, $66^{\text {th }}$ May 1933.
} 
water. The report asserted that despite the depression, the Victoria Nyanza Sugar Company had promised to set aside $5 \%$ of its profits for construction of permanent houses. ${ }^{138}$

This was not the case, however, as archival sources abound with information on how the large estates such as Victoria Nyanza Sugar Company were reluctant to build permanent dwellings for their workers, citing financial constraints as the main reason. This forced the Chief Labor Inspector, Dr. Fisher, to intervene in the 1920s, when the Victoria Nyanza Sugar Company refused to improve the housing conditions of its workers. ${ }^{139}$ The Victoria Nyanza Sugar Company’s head office in Sidney, Australia was also adamant and refused to cooperate with the labor office in Kenya as regards the poor housing and health conditions in their labor camps. Yet according to the Master and Servant Ordinance of 1910, servants were to be properly housed, fed and given an adequate supply of medicine. Furthermore, it gave authority to medical officers and labor inspectors to enforce laws in regard to workers health. ${ }^{140}$ This view is also advanced by David Anderson who acknowledges that the amendment of 1920 set basic regulations on the welfare of the laborers ${ }^{141}$.

Due to the unwillingness of the company to rectify the situation, Dr Fisher pressed on and managed to get a copy of the Sidney Bulletin which indicated the profits that the company had made from its sugar investments in Kenya. The newspaper revealed that from 1923, when the company started crushing cane, to 1931 the Victoria Nyanza Sugar Company had extracted $£ 331,246$ in profits of which $£ 265,000$ had been exported to Sidney. ${ }^{142}$ Such information made it possible for Dr. Fisher to push ahead and engage the company to improve the housing condition despite the difficulties he faced. Unfortunately, very minimal measures were taken to

\footnotetext{
${ }^{138}$ NADAR 1933, 129.

${ }^{139}$ Van Zwanenberg, Colonial Capitalism, 59.

${ }^{140}$ Ibid., 60.

${ }^{141}$ Anderson, "Master and Servant”, 462.

${ }^{142}$ Van Zwanenberg, Colonial Capitalism, 59.
} 
improve housing. The houses continued to be temporary structures and it was only later in early 1960s that the successor company Miwani Sugar Mills embarked on building of permanent houses for its labor. However, the NADAR were found to be accurate about the out ward general cleanliness of the labor camps.

Moreover, housing on the larger sugar operations in Nyanza as at Miwani and Muhoroni were divided into estates. For example, by 1954 Miwani had five housing estates; as shown in Table 7.2. These were one roomed huts measuring 15 by 17 feet. The housing was congested often leading to outbreak of diseases such as typhoid and dysentery. Osamba's work reveals the living conditions of the workers as pathetic since there were no adequate disposal systems, while the inappropriate use of bucket latrines posed a great health danger. ${ }^{143}$ These findings differ from the view presented by the NADARs which portray how the living conditions were good with adequate accommodation, good latrines and piped water. ${ }^{144}$ Osamba's findings are supported by archival documentation that reveals how congested the living arrangements were as illustrated by Miwani Sugar Mills housing estates in 1954 as shown in Table 7.2.

Table 7.2: Housing space at Miwani Sugar Company, 1954

\begin{tabular}{lllll}
\hline Camp & Number of Rooms & Men & Women & Juveniles \\
\hline Factory & 401 & 845 & 228 & 156 \\
Camp & & & & \\
Section 1 & 117 & 185 & 54 & 95 \\
Section 2 & 112 & 109 & 33 & 79 \\
Section 3 & 112 & 196 & 32 & 110 \\
Ox-Camp & 32 & 21 & 5 & 7 \\
\hline Total & 774 & 1,356 & 352 & 447
\end{tabular}

Source: KNA: Lab 9/ 256, LIR, $13^{\text {th }}$ May 1954.

\footnotetext{
${ }^{143}$ Osamba, “Colonial African Labour”, 117-118.

${ }^{144} N A D A R$ 1934, 173.
} 
The above data indicate that housing was divided into five zones. It emerges that a total of 2,155 laborers had to share 774 rooms excluding possible infants brought along by the women workers. This depicted the degree of congestion in the housing estates. Most of these housing estates had piped water supplies except Section 1 estate. However the situation remained inadequate and the houses were not improved to permanent status. The housing estates also had no hospital despite recommendations from the medical department. Former workers interviewed alleged that the General Manager refused to spend money on improvement though the situation

was bad, and cases of laborers dying of dysentery were reported. ${ }^{145}$ Congestion in the labor camps worsened as the huts continued to be depleted over the years. For example, the Factory Camp had the worst housing and sanitation such that there were serious outbreaks of bubonic plague in 1947 and 1952. The same disease broke out in Section 3 of the camps that claimed 7 lives. ${ }^{146}$ Such poor living conditions as well as low wages and poor working conditions caused labor unrest to emerge among the cane workers as means to draw attention of their employers to their plight.

\section{Labor Unrest in the Sugar Industry}

Labor unrest was not unique to the sugar industry. There were general unrests in the whole country as early as the 1930s which culminated into widespread strikes. These early strikes marked a change in type of protest and initially were mostly found in the urban areas and were organized by highly skilled manual workers. ${ }^{147}$ For example, in 1934 strike took place in Mombasa when the port workers of Kenya Landing and Shipping Company demanded a stoppage of the proposed wage reduction as wages offered were not even commensurate to the

\footnotetext{
${ }^{145}$ Peter Abwogo, (O.I.), Miwani, $21^{\text {st }}$ June 2009.

${ }^{146}$ Joseph Okongo, (O.I.), Miwani, $21^{\text {st }}$ June 2009.

${ }^{147}$ Stichter, Migrant Labour, 122.
} 
increasing prices of commodity and rent. The colonial government's findings agreed with the workers that there was need to increase the wage. ${ }^{148}$

However, there were also rural discontents as demonstrated by the successful strike by employees of Asian fish merchants at Kisumu in 1935 which secured an increase of Shs.2/= on their wages. ${ }^{149}$ This set precedence and was soon followed by another successful strike by the boatmen at Asembo bay in $1936 .{ }^{150}$ In the meantime, labor unrests continued in the urban areas, for instance the stone masons in the quarries near Nairobi went on strike in May 1937. Thus the year 1937 was marked by labor unrests all over the country as African workers demanded better wages and terms of service. Consequently there were strikes even at the sisal farms at Mwatate at the coast, the Shell Oil Company installation site at Mombasa, while in CN there were also labor unrests at railway marine workshops in Kisumu and at the Victoria Nyanza Sugar Company’s plantation estate at Miwani. ${ }^{151}$ Although these early strikes met minimal success they were significant in the sense that they marked the growth of consciousness among workers in Kenya as they occurred all over the country.

However, not all the strikes were successful. This was the case of the Kenya Bus Company workers in Nairobi when the bus drivers and conductors went on strike in 1938 demanding better wages unsuccessfully. ${ }^{152}$ However, Stichter does not agree and indicates that the strike earned the workers Shs. 10/= after the strike. ${ }^{153}$ Mombasa was a hot bed of strikes in 1939 as there was the successful general strike by port workers that began on $1^{\text {st }}$ August and

\footnotetext{
${ }^{148}$ Ibid., 166.

${ }^{149}$ Clayton and Savage, Government and Labour, 214.

${ }^{150}$ Ibid.

${ }^{151}$ Ibid., 215.

${ }^{152}$ Ibid.

${ }^{153}$ Stichter, Migrant Labour,122.
} 
lasted four days which earned the workers the eight hour day working schedule. ${ }^{154}$ Thus we find that there was general labor unrest in the whole country by the end of the 1930s.

Needless to say, after World War II there was general labor unrests in the whole country and the Nyanza unrest, particularly those found in the sugar industry, were no different from those found in post war Kenya. Clayton and Savage argue that this was necessitated by the increased prosperity which led to higher living costs; hence the constant demand for better wages. ${ }^{155}$ However, the 1940 s strikes were also found to be more organized as trade unions that had emerged by mid 1930s had become more effective. Among the earliest was the Labour Trade Union formed on $18^{\text {th }}$ April 1935 with Makhan Singh as the Secretary. This union called the 62 days strike in the motor service industry and won wage increase in $1937 .{ }^{156}$ Another significant general strike took place once again in Mombasa on $13^{\text {th }}$ January 1947 led by Chege Kibachia, a salesman for East African Clothing Company. The strike that had initially been started by dock workers and railway men spread quickly and Africans from different sectors joined, such as houseboys and workers of Ramisi Sugar Company on the mainland. The 1947 Mombasa strike was serious and it took colonial government intervention. It was only after the state sent African LegCo member Eliud Mathu to talk to the strikers that the workers agreed to go back to work having secured minimum wage of Shs. 40/= per month. ${ }^{157}$

The sugar industry was also not spared the unrest that swept across the country. Like other workers, the cane workers too had grievances. Labor unrest in the sugar plantations and factory were related to poor or delayed wages, sometimes even uncalled for deductions. These coupled by poor rations, terms of service and the depleted dwelling places in some of the sugar

\footnotetext{
${ }^{154}$ Clayton and Savage, Government and Labour, 222, 223.

${ }^{155}$ Ibid., 215.

${ }^{156}$ Ibid., 212.

${ }^{157}$ Ibid., 276-279.
} 
farms led to labor unrest. These affected production due to lack of sufficient labor as work stoppages proved to be expensive, especially in the factory during the rolling season. Thus the Asian farmers could be said to have suffered due to their undercapitalized status that made it hard for them to offer their laborers sufficient wages.

However, during the post-World War II period, a marked difference was found in the attitude of laborers to work stoppages. This could partly be said to have been because such workers were more sensitized of their rights. One can argue that the joining of the ex-soldiers into the labor force and the level of agitation in country during the post war period impacted the workers. The strikes, in most cases, were spontaneous and lacked proper organization. The initial ones involved only a few laborers. For example, in 1942, about 50 laborers at an Asian sugar farm in the Miwani area downed their tools for three days demanding an increase in wages. ${ }^{158}$ Unfortunately, the strike did not yield fruits since it was contrary to the Defence Regulations that forbade any strikes by essential services workers during the war. As such their demands were rejected and the laborers forced to resume work unconditionally.

However, as discontent grew, workers in the sugar plantations for the first time were able to organize themselves into a bargaining position. For example, in 1946, workers at the Victoria Nyanza Sugar Company's Chemelil plantation went on strike for two days complaining about deductions from their wages and the amount of tasks allocated. Many laborers were discontented and did not perform a good job. According to Lyne Watt, many field hands by 1947 were coming out of the field as early as 10 a.m., having worked for only 2-3 hours. ${ }^{159}$ Investigation by the labor office revealed that the deductions were not justified. Within a short span of time, the Victoria Nyanza Sugar Company suffered another strike from the factory

\footnotetext{
${ }^{158}$ KNA: Lab 9/1895, LIR Miwani, $22^{\text {nd }}$ July 1942.

${ }^{159}$ KNA: PC/NZA/3/22/1/8, Lyne Watt to Labour Office, $11^{\text {th }}$ November 1947.
} 
workers who demanded higher wages and did not resume work until an agreement was arrived at based on a more work, more pay policy. ${ }^{160}$

Be that as it may, there were two other strikes reported at the Miwani Sugar Estate in 1947, after the takeover by the Asian manufacturer. The strikers protested against the new regulations put in place by the new management. For example, previously laborers were not restricted from chewing cane during working hours in the farms. ${ }^{161}$ Thus, the workers were against the rule that denied then to chew cane, when at work in the farm, as they were accustomed to. ${ }^{162}$

As for the issue of wages, those who were in the best position to bargain effectively were skilled artisans produced by mission schools. Missions in Kenya produced artisans such as carpenters, masons and plumbers who easily found jobs in the sugar plantations and factories. Moreover, at the end of the World War II, some ex-servicemen also came back with skills such as drivers; hence there was an increase in skilled laborers, such as artisans, who obtained employment in Asian farms. Such opportunities were occasioned by the fact that some Asian farmers had acquired ex-military lorries that were reconditioned and used for transporting sugarcane. For example, by 1948, about 80 Africans, mostly ex-servicemen were employed as drivers in the Asian sugar farms. ${ }^{163}$ The entrance of the ex-soldiers into the labor force in the sugar plantations could be said to have sensitized the workers as they were aggressive. Thus we find that in the sugar industry, most strikes occurred after the war. Their entrance into wage labor was significant because it ushered in a change in type of protest. The workers started to face the employers and bargained for better working conditions and wages instead of deserting

\footnotetext{
${ }^{160}$ KNA: DC/CN/1/3/2, CKDAR 1946.

${ }^{161}$ NADAR 1933,129.

${ }^{162}$ KNA: DC/CN/1/3/1, CKDAR 1947.

${ }^{163}$ KNA: DC/KSM/1/17/34, Skilled labour.
} 
work place as before. Moreover this group of workers could be said to have been more persistent and aggressive in their demands especially the ex- soldiers who were militant.

Therefore, we find that within three years, another strike occurred at Miwani Sugar Mill in 1950 which involved many workers. Approximately 570 laborers went on strike demanding higher wages and better working conditions, but their demands were also rejected. ${ }^{164}$ Despite the frustrations, the laborers continued to press for better wages. In 1952, to cite another example, the casual laborers refused to work and demanded an increase of their daily pay from Shs. 3/= to Shs.5/=. But even this was not successful. Nevertheless, the farmers felt the drain since the lorries sent out to pick up the casual laborers went back almost empty. ${ }^{165}$

The most effective strike affecting the post war Nyanza sugar industry took place in December 1959. The numbers involved were high since the stoppage involved laborers from Miwani Sugar Mills and the other Asian farms. Osamba's findings reveal that unlike other protests, the 1959 strike brought cane production to a halt for almost a week and was to show solidarity with the railway workers. ${ }^{166}$ Although it was not successful in achieving its goal, it was better organized but other factors militated against the workers in the sense that they had no union and furthermore, according to Osamba the presence of many unemployed workers who could be used as strike breakers through quick employment also made the Asian cane employers unresponsive to demands. ${ }^{167}$

However, despite the initial setbacks, the strikes were significant in the sense that the cane laborers had started to organize and saw the need of collective bargaining as a better

\footnotetext{
${ }^{164}$ Osamba, “Colonial African Labour”, 129.

${ }^{165}$ Zakaria Olang, (O.I.), Miwani, $26^{\text {th }}$ July 2009.

${ }^{166}$ Osamba, “Colonial African Labour”, 130.

${ }^{167}$ Ibid.
} 
response to solve their grievances. Consequently this led to change in the following year as the workers formed their trade union, the Kenya Union of Sugar Plantation Workers. (KUSPW)

The formation of KUSPW in 1960 coincided with many labor unrests due to the political fever that was sweeping across the country as Africans demand for independence increased. According to Amsden, the fever gave rise to a new spirit of militancy among the workers. ${ }^{168}$ Workers started to demand for better conditions. There was change of tact as the strikes were now called by the workers trade unions. For example in 1960, the strike by workers of the coffee industry was successful and was only brought to an end with an agreement on the picking rates between the workers union the Coffee Plantation Workers Union and the Kenya Coffee Growers Association. ${ }^{169}$ In Nyanza the situation was similar to the rest of the country as workers no longer tolerated any labor injustice. For example, a bitter strike took place in the Macalder mines in South Nyanza during 1961 where condition were worse as workers were exposed to racial hatred and only agreed to go back to work after some supervisors were removed. ${ }^{170}$ Similarly in 1962 and 1963, the cane workers through their union KUSPW also organized and a strike was averted only after the cane growers and manufacturers agreed to increase wages as will be disused later. Thus we can argue that trade unionism led to new ways of bargaining for the laborer as will be discussed.

These strikes were significant in the sense that they portrayed a nascent form of labor consciousness among the workers as they bargained for wages despite minimal success. Furthermore, the implication of this was that as the laborers in cane plantations had become sensitized and cooperated with other laborers in the district. This was the case when they

\footnotetext{
${ }^{168}$ Alice Hoffenberg Amsden, International Firms and Labour in Kenya 1945-1970 (London: Frank Cass and Company Ltd 1971), 75.

${ }^{169}$ Ibid.

${ }^{170}$ Ibid., 79.
} 
associated with the railway workers. Such solidarity meant that they had attained collective responsibility of bargaining and as such the Asian cane farmers and manufacturers were bound to reassess their wages as competition stiffened. Unfortunately the strike also did not achieve much because the workers were not properly organized. Thirdly, it can be argued that the strikes in the sugar plantations were as a result of the neglect of the sugar industry by the colonial government that did not appreciate it economic potential. There was little supervision as emerged earlier, neither do we see government intervention as was the case when it sent Mathu to Mombasa, which portrays the discrimination and lack of support of Asian sugar industry as the workers became more militant and more organized in their trade union.

\section{Trade Union in the Sugar Industry}

In Kenya formation of trade unions to articulate the interests of workers began in by mid 1930s. During this period, as indicated earlier, the Labour Trade Union was formed under Makhan Singh. ${ }^{171}$ This early union, though meant to be multi-racial, was largely composed of Asian workers. ${ }^{172}$ Other trade unions that emerged included the Nairobi African taxi drivers Union formed in 1943 and the Kenya houseboys’ Association formed in 1946 just to mention but a few. ${ }^{173}$

Therefore the emergence of trade union in the sugar plantation of $\mathrm{CN}$ was not an isolated issue but rather part of an ongoing phenomenon in the whole country. However, the need to form a trade union started to emerge among the cane workers around 1953. Unfortunately, it was a slow process because it was bedeviled by suspicion from the Asian employers who resented such a move while, on the other hand, the workers were hesitant in joining for fear of

\footnotetext{
${ }^{171}$ Clayton and Savage, Government and Labour, 211.

${ }^{172}$ Ibid.

${ }^{173}$ Ibid., 326.
} 
repercussion from the employers. Workers also were reluctant to pay the dues of monthly subscription of Shs. 2 /= for fear that the money would be pocketed. ${ }^{174}$

However, KUSPW was formed in early 1960, as earlier indicated, and was composed of both manual and skilled workers of the sugar industry. ${ }^{175}$ The main objective of the union was to improve the terms and service of the cane workers, better the relationship between workers and employers and engage in settlement of disputes between the two. ${ }^{176}$ According to informants, people responded slowly but the officials were hard working and many more started to join. This view is corroborated by Osamba whose findings indicated that by 1960 the members were only approximately 2,125 out of a possible work force of about 12,000 workers. ${ }^{177}$ According to Osamba, it was difficult to get the workers join the union due to intimidation by the cane farmers. He gives an example of how the different Asian cane grower groups such as the Nyanza Indian Farmers Association, Kibos Planters Association and the various Production Sub Committees forged a unity of purpose and opposed vehemently the emergence of trade union among the workers. ${ }^{178}$ The fear and resentment of KUSPW by the Asian cane farmers and factory owners was witnessed when the Secretary General of the Trade Union, J. Ongundha, was accused of trespassing when he visited Miwani Sugar Mills and was arrested and sent to prison for two years in $1961 .^{179}$

The arrest of the Secretary General did not hinder the increased recruitment of members. Instead the arrest of Ongundha made the union popular as many joined the trade union and

\footnotetext{
${ }^{174}$ Zablon Wakiaba ( O.I), June $20^{\text {th }} 2009$.

${ }^{175}$ Office of the Attorney General, Kenya Registrar-General Annual Report (Nairobi: Government Printer 1960), 377.

${ }^{176}$ Martin Otieno, (O.I.), $20^{\text {th }}$ June 2009.

${ }^{177}$ Osamba, “Colonial African Labour”, 183. Osamba gives a detailed account of the strong opposition that the trade union officials faced that led to the sugar employers also organizing and forming their union, the Kenya Sugar Employers Union (KSEU), in April 1960 for better bargaining power.

${ }^{178}$ Ibid., 170.

${ }^{179}$ Ibid., 183.
} 
demanded his immediate release. ${ }^{180}$ Thus despite the frustrations and slow take off , once the workers had built up trust, it was easy to organize because the workers stayed in the same camps and so reaching out to them or dissemination of information was fast. While on the other hand it was tricky since the employers could regulate those visiting their premises. However as the political situation in the whole country became increasingly charged as the quest for independence grew, people became more conscious of their rights and more were willing to join the trade union. All over the country trade unions were active.

In Nyanza, the sugar industry workers became more active especially after the rallies held at Miwani by the nationalist politicians Oginga Odinga and Tom Mboya. It is alleged that after the rallies the number of KUSPW rose from about 2,125 members in 1961 to 4,500 by $1964 .{ }^{181}$ Meanwhile, the struggle for better terms of service continued. Hence during the 1962 period the union achieved one of its major milestones when it was able to organize, negotiated and won a pay increment for the workers through collective bargaining where more workers were willing to down their tools. This achievement made the union strong and popular and many members joined the union. ${ }^{182}$ The following year the union was able to engage the Asian employers once again which led to better working conditions for the workers and better wages. For example, the minimum wage for the unskilled worker was fixed at Shs. 85/= per month. ${ }^{183}$ The union continued to articulate the workers grievances that led to improved housing. For example, pressure from the union made Miwani to start the construction of permanent housing. In the meantime, through the relentless efforts of KUSPW officials, mistreatments such as beatings by

\footnotetext{
${ }^{180}$ Martin Otieno, (O.I.), $20^{\text {th }}$ June 2009.

${ }^{181}$ Michael Juma, (O.I.), 6 ${ }^{\text {th }}$ July 2009.

${ }^{182}$ Osamba, “Colonial African Labour”, 183.

${ }^{183}$ Ibid., 186.
} 
the nyapara were brought to an end through constant prosecution. ${ }^{184}$ These were no mean achievements and the union became increasingly popular so that by 1963 other branches were opened at Kibos, Miwani, Muhoroni, Chemelil and even Ramisi at the coast with the National headquarters at Kisumu. ${ }^{185}$

The success of KUSPW was due to the fact that it acted in concert with other organizations that supported it. For example, the Kenya Federation of Labour (KFL), which today is known as Central Organization of Trade Unions (COTU) and the Plantation Workers International Federation (PWIF). These organizations extended funding which helped the union to build its offices in Kisumu and other areas and also offered scholarships to officials to enable them undertake labor courses at the Labour College in Kampala. ${ }^{186}$

Therefore we can argue that the rise of trade unionism in the sugar industry led to new methods of addressing grievances. In most cases it involved dialogue with the cane farmers and employers. This was significant in the sense that such negotiations helped promote improved wages and working conditions that led to retention of labor since desertion was no longer needed as a response to labor disputes.

\section{Conclusion}

This chapter has discussed the issue of labor in Asian farms, whereby it emerges that the Asian cane farmers struggled, for much of the colonial period, to get labor as many Africans did not want to engage in wage labor for a variety of reasons, ranging from a lack of economic incentives, to poor wages and working conditions. The chapter demonstrates that many factors, such as the unpredictable weather also effected African entry into the labor market.

\footnotetext{
${ }^{184}$ Michael Juma, (O. I.), $6{ }^{\text {th }}$ July 2009.

${ }^{185}$ Register-General Annual Report, 26.

${ }^{186}$ Osamba, “Colonial African Labour”, 190.
} 
The chapter also demonstrated how economic and political conditions in the colony, such as the world wars and great depression, impacted labor in the Asian sugar plantations. European settlers capitalized in these circumstances more successfully than did the Asian cane growers. For the most part, Asian cane farmers struggled for labor. They had to contend with an unhelpful colonial state as well as issues such as desertion which was interpreted as a means of protest by workers. More often than not, this was due to poor working conditions and terms of service that affected cane farming.

Therefore, the chapter revealed that during the period prior to the 1950s that labor shortages were a constant problem for Asian sugar growers. The generally poor working conditions and the fact that employers made very minimal measures to improve the working conditions of the workers were primarily responsible for this. Such conditions not only led to shortages of labor; they were responsible for two strikes at the Victoria Nyanza Sugar Company as a new method of protests.

After World War II as labor unrest swept the whole country, including the sugar industry in $\mathrm{CN}$, with strikes and trade unionism manifesting worker unhappiness. The cane farmers found themselves in a precarious position of dealing with aggressive workers as well as with often hostile environmental and economic conditions and an unresponsive colonial state. Thus we can argue that the factors discussed in the chapter together with the undercapitalization of the Asian farmers and discriminative colonial policies prevented the Asian cane producers from adequately competing for labor in colonial Nyanza. However, the sugar industry struggled and managed to survive despite the biased policies and other handicaps. 


\section{CHAPTER 8}

\section{CHALLENGES OF SUGARCANE GROWING IN COLONIAL NYANZA}

\section{Introduction}

This chapter examines other challenges faced by the Asian cane farmers besides transport, marketing and labor that have been discussed in the preceding chapters. Thus the chapter examines challenges faced by cane farmers that reflected the lack of colonial state support, discrimination, problems such as poor ecology of the region, such as frequent droughts and water logging during the heavy rains that affected the crops. The chapter also examines the undercapitalization of the Asian cane farmers and how that impacted cane production, especially funds to jumpstart the industry after the devastating effects of drought and locusts. The colonial state's inadequate role in extending loans to the farmers became important as the Asian cane farmers struggled to produce cane. Yet they had to contend with other problems of diseases that were prevalent and destroyed the cane crop. The chapter also examines how the Asian cane farmers had to deal with biased and contradictory colonial state policies on land and issues such as the dumping of sugar from other countries, such as Uganda, that affected the growth of the sugar industry. On the other hand, the farmers had to deal with manufacturers who more often than not were uncooperative, while at the same time dealing with the minor problems that included outbreak of fires, theft of cane, and immigration difficulties. Finally, the chapter discusses the efforts made by the Asians to solve the problems they faced in an unfriendly colonial state.

\section{Colonial State Policies and Their Impact on Cane Farming}

Colonial policies were very important in determining the success the sugar industry in colonial Nyanza. The policies affected a wide range of issues that were the core of production, 
such as land and marketing among others. The Asian cane growers faced immense problems as a result of the policies of colonial state. This was because most of the policies directed toward Asian cane farmers were biased. For example, the policy on land that locked the Asian farmers out of the fertile highlands in Kenya right from the start. According to Sorrenson, the colonial state by 1908 had enforced a policy that restricted Indian agriculturalist to the lowlands area of Nyanza only. ${ }^{1}$ Other restrictions and biases were witnessed by the enactment of the Crown Lands Ordinance of 1915 that denied the Asians access to the white highlands as discussed in earlier chapters. The Ordinance was also biased in the sense that the European settlers had 999 years leases while the Asian leases were restricted to 99 years only, despite their protestation. Maxon captures this struggle for Kenya between the two migrant races and reveals how by 1919 Governor Northey was convinced that all suitable land be brought under European cultivation, believing it was beneficial to the colony. ${ }^{2}$ This was a misguided belief that the economy of the colony could solidly rest on European cultivation. Getting land for expansion was a great problem for Asian farmers. Thus it is evident that the biased land policies made the Asian cane growers to struggle to get land for expansion due to the limitation put on land accessibility.

In most cases it was even difficult to buy or sell land. As late as 1953, H.R. Bhatt could not even easily sell his farm to another Asian, Mohanlal Kanji, who was ready to buy. Unfortunately, he was not allowed to do so, on the grounds that selling the farm to another Asian would be prejudicial to the local Africans. Yet the same did not apply to European buyers. Therefore, Bhatt was advised to find an African buyer, despite the fact that he had already tried and found it difficult to get an African buyer since the farm was being sold at Shs. $18,000 /=.^{3}$ Denying Bhatt an opportunity to sell to a willing buyer on grounds that the buyer was not in the

\footnotetext{
${ }^{1}$ Sorrenson, Origins of European Settlement, 168.

${ }^{2}$ Maxon, Struggle for Kenya , 62.

${ }^{3}$ KNA: DC/KSM/1/19/270, H.R. Bhatt to Chairman, Miwani-Kibigori Production Board, $17^{\text {th }}$ June 1953.
} 
colony could be seen as an effort to discourage the transaction because we know that the same rules did not apply to Europeans. Moreover, the idea of him seeking an African buyer was also motivated by race discrimination, knowing too well that most Africans could not raise the amount. In any case, Europeans in $\mathrm{CN}$ were not discouraged from doing so; they could sell to anyone. For example, when the Europeans became bankrupt or no longer wanted to engage in farming, they sold their land to willing buyers as was demonstrated when the Asians collectively bought out farm number 1595 at Kibos that was owned by Major Carnegies. ${ }^{4}$ Therefore, it emerges clearly that policies on land were full of discrimination and were constantly changed to suit the settlers.

Other policies, which involved restriction on procurement of farm and factory machines, also proved discouraging. When the Indian farmers wanted another mill in 1936 so as to challenge the monopoly position enjoyed by the European owned Victoria Nyanza Sugar Company, which had stopped taking cane, the DC of K-L was not helpful. The DC sided with the European manager, despite the Asians' genuine grievances, and asserted that he would vehemently oppose the granting of permission to erect a new mill. He assured the manager that he would be supported by many administrators. Stressing on this point the DC wrote: "Even if the Indian farmers could establish an unimpeachable moral claim to have a mill, I should consider that the government would be failing in its duty if it allowed capital to be poured out on a project which was foredoomed, as far as one can judge, today a failure...in my opinion the Indian growers should be treated as peasant farmers, not as component [sic]" ${ }^{5}$

These sentiments from a government official demonstrated the obstructions that the Asian farmers had to contend with. The sentiments portrayed the discrimination that the cane

${ }^{4}$ KNA: NZA/3/2/34, NIFA to DC K-L, $11^{\text {th }}$ October 1934.

${ }^{5}$ KNA: PC/NZA/3/2/34, DC K-L to PC Nyanza, 27 ${ }^{\text {th }}$ February 1936. 
growers faced. It is apparent that the colonial state's officials were biased because whereas the Asian farmers were denied permission for another mill, we find that during the same period, apart from being given monopoly in sugar production, the Victoria Nyanza Sugar Company was given permission to build a road to serve the transport needs of the company. Thus the fact that the state was not receptive to Asian cane growers demonstrates the struggles that the farmers faced.

Although the colonial government later allowed the Asians to import machinery to manufacture jaggery, still a regulation was put in place that controlled the marketing of jaggery. The state appointed a single selling agent. Asians were restricted from exporting jaggery based on flimsy grounds that Africans could have access to it, leading to drunkenness. Such a policy restricted the sale of sugar and its by-products. By this means, the government stifled the production of jaggery, which was a major outlet for some farmers. Thus we find that colonial policies, characterized by contradictions, were a major drawback to the progress of the sugar cane industry in colonial Nyanza. The colonial state discriminatively found it prudent to allow the importation of the machine for jaggery production and not for milling sugar so as to protect the European millers.

The colonial state also came up with regulations that prohibited the export of sugar as per the Government Notice No. 670 of 1937. The notice dealt with the international agreement for the regulation of the production and marketing of sugar. However, calls for revocation of the sugar control were made as early as 1939 as the war needs put pressure on the notice. The regulations came into effect in 1941 due to acute sugar shortage. Despite this, the colonial state, 
during the same year, imposed an excise duty on local sugar which seriously discouraged production due to the high cost. ${ }^{6}$

During the World War II period, however, the inadequate supply of sugar in the country caused the colonial government to change its policy and support jaggery production. Realizing that jaggery was more profitable and cheap to produce, the government shifted its stance and enacted the Defence (Control of Sugar) Regulations in 1944, which was geared towards the prompt shifting by cane growers and producers to jaggery production. Thus pressure was put on the Muhoroni factory, which was producing jaggery, to shift focus and manufacture white sugar. The shift could also have been due to the fact that most Asian cane growers could easily manufacture jaggery on their farms which could deny the European owned Victoria Nyanza Sugar Company an increased profit.

With the increased interest in sugar production by 1950, on the other hand, the colonial government set out to solve the challenges facing the industry. Many obstacles were identified, such as disposal of cane. A problem noted in preceding chapters was how the manufacturers were unwilling to accept all the cane from growers. The sugar industry also faced many problems due to contradictory government policies. For instance, the government's indirect restrictions on cultivation whereby Asians were given inadequate financial support for breaking land. Thus expansion of planting was limited, and furthermore the colonial state controlled the price of sugar. In most cases, the prices offered were not commensurate with the world market.

Therefore, the farmers and the millers registered losses. The sugar industry lost approximately 8,000 tons of sugar during the World War II period. ${ }^{7}$ This in essence meant that

\footnotetext{
${ }^{6}$ KNA: BV/6/612, Chief Secretary to Director of Agriculture, $9^{\text {th }}$ October 1941.

${ }^{7}$ East African Standard, $9^{\text {th }}$ May 1947.
} 
despite the fact that the sugar industry formed part of the wider colonial economy, the farmers and the millers were not major players as they were constantly ignored by the state.

Needless to say, colonial state's control of the market was found to be full of contradictions in the sense that, although the colonial government imposed controls over importation, distribution and pricing of sugar, control over quality of sugar supplied to the local market was ignored for a long time. For example, during the four months of July-October 1952, sugar offered for the local market ranged from dirty dark brown low grade to a high grade white crystallized sugar. The dirty sugar contained impurities and bagacillo. ${ }^{8}$ Much of this sugar, which was sold in the month of July, was found to be unfit for human consumption. ${ }^{9}$ Thus it emerges that by 1952, there was no clear policy on quality and sugar grading. It appears ironical that controls were placed on production and distribution and no measures on grading and the quality of sugar. Factories with the capacity to produce pure clean sugar were under no obligation to do so. This meant that it was the consumers in $\mathrm{CN}$ who were penalized in respect of the quality of their purchase. This was because sugar of $80 \%$ purity could be sold as that of $100 \%$ purity. ${ }^{10}$

Be that as it may, it can be argued that it was difficult for the cane farmers to have a proper plan in growing of sugarcane due to the many state policies put in place, and the constant change of policies. By the early 1950s, the colonial state started to pursue aggressively a policy of self-sufficiency in sugar production due to Uganda's manipulation. Hence farmers were encouraged to produce for the domestic market as opposed to export. Towards such initiatives, the sugar manufacturers received government subsidies to improve the quality of sugar

\footnotetext{
${ }^{8}$ KNA: BV/6/1704, Confidential Memorandum on the Sugar Industry from Ag. Administrator of East Africa High Commission to Member for Agriculture and Natural Resources, $3^{\text {rd }}$ March 1954.

${ }^{9}$ Ibid.

${ }^{10}$ Ibid.
} 
produced. ${ }^{11}$ What the colonial government forgot was that the quality of sugar depended also on the quality of cane, and as such it was imperative that both the farmers and the manufacturers benefit from the subsidies. This shift of emphasis by the colonial state on quality of cane was as a result of a research conducted by Douwes Dekker, a sugar expert from South Africa, who was invited to Kenya by the committee of economic coordination of the East Africa High Commission in 1959 to investigate ways of improving the sugar industry in Kenya. The results of his findings, released in 1960, emphasized the issue of quality of cane and led to the establishment of the Sugar Equalization Fund which was financed by sugar taxes in the colony. The findings led to the restructuring of sugar prices based on the Commonwealth Sugar Agreement. ${ }^{12}$ Hence the colonial government finally made sugar prices given to Asian millers equal to those given to Ugandan millers.

By 1961, the colonial government policy was geared towards expansion of the sugar industry. The Director of Agriculture commissioned a working party to come up with resolutions of problems confronting the sugar industry. One of its major recommendations was the need for providing loans for expansion of the industry, though only few Asians farmers were able to access the loans for farming. ${ }^{13}$ Therefore we can argue that the many and frequent colonial policies that were enacted to control sugar production in CN inhibited the growth of the sugar industry at least until the very end of the colonial period.

\footnotetext{
${ }^{11}$ KNA: AE/3/925, Report for the Committee of Economic Coordination for East African Sugar Industry, $17^{\text {th }}$ December 1952.

${ }^{12}$ KNA: AE/3/916, Report for the East Africa Sugar Manufacturers Association on Quality of Sugar in East Africa, $5^{\text {th }}$ March 1960.

${ }^{13} \mathrm{KNA}$ : BV/125/10, Minutes of the first meeting of the working party set to investigate the development of the Sugar Industry, $14^{\text {th }}$ August 1961.
} 


\section{Ecological Problems and Natural Calamities}

Agriculture was the main economic backbone of Kenya during the colonial period and has remained so up to the present. Yet for a meaningful agricultural industry to thrive, arable land becomes an important issue. The Asian cane farmers unfortunately were forced to settle in a less than fertile area. The Kibos-Muhoroni area experienced many ecological problems, such as poor soils with very unpredictable weather that made it difficult to produce sufficient sugar to compete with the two neighboring territories. The main soils found in the area under review are red sandy loams, black swamp soils and grey-black clay soil, the latter being the poorest in the area which was partly a result of bad soil management due to improper cultivation. ${ }^{14}$ Secondly, the area, which experienced two rainy seasons, had poor drainage, and so during the long rains, the farmers suffered as their crops were destroyed due to water logging. For example, the heavy rains in 1946 left a lot of flooding that affected the cane and destroyed the Asian maize farms. ${ }^{15}$

Land, especially in Kibos, was swampy and prone to flooding during heavy rain. The Miwani area in particular had poor drainage. Thus the colonial state contacted surveyors who were working on the Kano plains between lake Victoria and Ahero towards raising the lake level to also examine the Miwani area, especially at the foot of the Nandi Escarpment, so as to put a complete drainage system in place. This was necessary since there was a bad run off from the escarpment that caused soil erosion and flooded the land in Miwani, particularly at the factory area. ${ }^{16}$ For example, 1947 was a year of extraordinary weather with erratic rainfall. The long rains started early in January and continued until the month of June, and the rainfall exceeded the normal average of the area. This caused flooding, and in the low lying area of Kibos-Muhoroni, crops were destroyed. Particularly the mill at Muhoroni was affected by the

\footnotetext{
${ }^{14} \mathrm{KNA}$; AK/3/15, Soil Chemist, Scott Agricultural laboratories to Director of Agriculture, $3^{\text {rd }}$ January 1951.

${ }^{15} D A A R, 1946,9$.

${ }^{16}$ KNA: DC/CN/1/3/1, K-LDAR 1947.
} 
floods and stopped operations for two months because all the bridges were washed away. Before resuming production, new bridges had first to be built. ${ }^{17}$

Ironically, during the second half of the year, a few showers were experienced between July and September, and a period of drought followed from October to December that also led to crop failure. ${ }^{18}$ Heavy flooding was also experienced in 1952 during the long rains that were in excess. For example, according to the DAAR, the Kibos-Muhoroni area was declared unsuitable for maize growing due to the annual water logging that occurs in the area during April. ${ }^{19}$

Nevertheless, drought was a frequent and major problem that the farmers had to contend with. Immediately they started cane farming, they faced drought challenges, despite the fact that Lake Victoria impacted the region due to its effects of conventional rainfall patterns. ${ }^{20}$ This often affected the production of sugar as in 1928 when the sugarcane yield was not good because of the decrease in sucrose content. ${ }^{21}$ The situation did not improve during the following year when the climatic conditions were also unfavorable; hence, there was a significant decrease in cane production and other export crops colony wide. ${ }^{22}$ Drought was a common feature in the area and the cane crop was badly affected. Extreme drought occurred periodically such as Kanga and Otonglo as earlier indicated. For instance in 1940, rainfall was not adequate at the beginning of the year, which was followed by a period of drought that was so severe that it affected the sugarcane ${ }^{23}$ Drought occurred at the beginning of 1940 and in September. The cane was badly affected as much of the young cane died, and the rest of the cane was in such bad

\footnotetext{
${ }^{17}$ KNA: AK/11/173, Muhoroni Sugar Company to SAO Nyanza, $10^{\text {th }}$ June 1947.

${ }^{18} \mathrm{KNA}: \mathrm{DC} / \mathrm{CN} / 1 / 3 / 1$, CK and K-LDARs, 1947.

${ }^{19}$ DAAR 1952, 34.

${ }^{20}$ Tiyambe P. Zeleza, A Modern Economic History of Africa: The $19^{\text {th }}$ Century, Vol. I (Dakar: Codesria, 1993), 25.

${ }^{21}$ DAAR 1928, 17.

${ }^{22}$ DAAR 1929, 25.

${ }^{23}$ KNA: AK/2/17, CK Agriculture AR 1940.
} 
shape that it was worsened by sprouting of shoots. Those plants that were harvested had very light and hollow canes. ${ }^{24}$

Furthermore, the severe drought of 1945 that hit the entire colony affected the yield of cane. Harvested cane dropped from 8,187 tons to 5,760 tons. ${ }^{25}$ This, however, was followed by adequate rainfall that fell during the early part of 1946 and which later merged into the long rains that resulted in a period of nine months of good weather that saw an increase in harvest. Unfortunately the heavy rains also caused havoc and destroyed the Asian maize crop due to water logging. ${ }^{26}$ In 1948 favorable weather conditions led to improvement in cane production. The good weather conditions prevailed until 1950 when again there was excess rainfall, as a result of which the acreage under cane increased though the area had to contend with the problem of water logging. ${ }^{27}$ Heavy rains were also experienced in 1952 which led to an increase in the acreage under cane production. However, it also caused more problems due to poor drainage.

These kinds of conditions obviously caused problems for sugar farmers. They also experienced difficulties in 1953 when a prolonged drought made the cane farmers to incur serious loses as the crop dried up. ${ }^{28}$ For example, it was estimated that the area that lay to the north of the Kibos-Muhoroni-Chemelil road lost 20\% of the crop since the farms were situated adjacent to the Nandi escarpment which, as indicated earlier, had a good climate, while the farms to the south of the road lost $80 \%$ to the drought which was made severe due to the poorer ecology. ${ }^{29}$ Thus we find that despite the fact that cane farmers increased the area under

\footnotetext{
${ }^{24}$ Ibid.

${ }^{25}$ DAAR 1945, 14.

${ }^{26}$ DAAR 1946, 9.

${ }^{27}$ DAAR 1950, 6.

${ }^{28}$ KNA: AK/11/51, Amar Singh, to Member for Agriculture and Natural Resources, $23^{\text {rd }}$ February 1953.

${ }^{29}$ KNA: AK/11/51, DAO CN to Director of Agriculture, $27^{\text {th }}$ February 1953.
} 
cultivation in 1952, they experienced a lot of problems with flooding and drought. Hence, we can argue that though the Asian farmers tried very hard, the ecology of the area under review was poorer for cane farming as compared to Uganda and as such was a constraint on the sugar industry which made the Kenyan sugar not to be competitive compared to Uganda sugar. This fact was also arrived at by the Committee for Economic Coordination which met in Dar es Salam in 1955 to discuss the future of the East African sugar industry. According to the committee, Kenya produced less sugar than Uganda and Tanganyika due to its poorer climatic and soil conditions. ${ }^{30}$

Thus we can draw conclusions that the sugar industry, as any other agricultural industry in Kenya, was dependant on good weather conditions. Hence, despite the improved varieties of cane introduced to farmers, use of fertilizers, good methods of cultivation and the vast outlay of labor, the success of the industry depended mostly on adequate rainfall, well distributed throughout the year, which was far from being the case in Kibos -Muhoroni area.

Apart from the ecology of the area, the farmers also had to contend with natural calamities, such as the locusts that often invaded the Nyanza Province. For example, there was an onslaught of locusts in 1931 which destroyed the sugar plantations. Especially the farmers around the Kibos and Miwani area suffered heavily as the locusts destroyed almost 50\% of the cane crop. ${ }^{31}$ Due to the serious destruction by the locust invasion of 1931, the colonial state intervened and appointed G. C. Brown as the locust officer who was to ensure that the problem was contained. Farmers were also advised by the agricultural officers to destroy the locusts' eggs. However, just within a few months later, in 1932, a large swarm appeared again which moved from Kisumu to the Muhoroni area, and by September had destroyed most of the crops.

\footnotetext{
${ }^{30} \mathrm{KNA}$ : BV/6/1704, Draft paper of the CEC on the future of the East African Sugar Industry, 1955.

${ }^{31}$ KNA: DC/CN/1/4/3, K-LDAR 1931.
} 
The greatest casualty was the maize crop. Sugarcane was also not spared and the most affected areas were between Kibos, Muhoroni and Kedowa. ${ }^{32}$ Thus farmers were seriously affected by the destruction of their cane. Harvests were poor and this threatened the farmers, most of whom had loans to repay. The drastic effect of the locust invasion can be portrayed by the declining figures in production of the two milling factories as indicated in the following table.

Table 8.1: Impact on sugar production by locusts, 1929-1932

Victoria Nyanza Sugar Coy. Muhoroni Sugar Company

\begin{tabular}{lllll}
\hline Year & Estimated tons & Actual tons & Estimated tons & Actual tons \\
1929 & ------- & 6,200 & ------- & 310 \\
1930 & -------- & 7,450 & ------- & 700 \\
1931 & 9,000 & 3,500 & 1,000 & 250 \\
1932 & 9,000 & 2,500 & 900 & 310 \\
\hline
\end{tabular}

Source: KNA: DC/CN/1/4/3 K-LDAR 1932.

From the above data it emerged that for the years before the locusts' attack production was on the increase. However, in 1931, after the invasion, cane production was reduced almost by half. For instance, the Miwani Sugar Mills that had produced over 7000 tons of sugar by 1930 produced a very small quantity of sugar in 1932. This disparity was due to the locusts' invasion of 1931 and 1932. In November 1932, for example, locusts were reported to have lain on Indian farms at Kibos, whereby the locust officer advised the farmers to destroy the eggs. ${ }^{33}$ The sugar industry experienced retardation and had a slow recovery the following year. This was complicated by lack of rain.

Therefore, rainfall problems and locusts forced the farmers to incur loses sometimes that meant replanting. Yet in most cases the small scale farmers experienced financial constraints that hindered their attempts to cope with these ecological problems. Nevertheless, after the

\footnotetext{
${ }^{32}$ KNA: PC/NZA/3/1/465, K-LD Intelligence Report, September 1932.

${ }^{33}$ KNA: PC/NZA/3/1/465, K-LD Intelligence Report, November 1932.
} 
1930s, the locust menace seems to have been brought under control. Thus we can argue that due to the poor ecology, which occasionally was compounded by locusts' visitations which limited the potential of the area, the Asian sugar industry produced less sugar than the two neighboring territories. Furthermore, the ecological situation exposed how the cane growers struggled to succeed in a poor area which made production to be expensive as intensive use of fertilizers had to be adopted. Yet the colonial state did not advance the Asian cane growers financial assistance that was much needed. Furthermore, it revealed the biased, contradictory policies pursued by the state that failed to bail out farmers during crop failure through the provision of the GMR to Asian cane farmers as discussed in the earlier chapters. The settler farmers were given such subsidies during the difficult times. Unfortunately, the Asian cane farmers were denied such financial assistance on flimsy grounds that cane was not an annual crop. ${ }^{34}$ Due to the need to buy fertilizers, cane growing was expensive in $\mathrm{CN}$, yet the government's policy instead of protecting both the farmers and consumers was more interested in seeing that the consumer did not pay unduly higher prices for the local sugar as compared to the imported sugar. This indicated how the colonial state neglected the cane farmers,

\section{Financial Constraints of the Asian Cane Farmers}

Although the Asian farmers struggled with policies and ecological issues, the Asian cane growers were also undercapitalized. This was compounded by the fact that they lacked financial assistance from the colonial government as indicated in an earlier section. Hence they had to contend with lack of capital which was a major factor, as in any agricultural sector, and this affected cane farming in colonial Nyanza. The farmers had insufficient funds to buy land, and in most cases bought the land through loans which they struggled to pay. Most of these loans were

${ }^{34}$ KNA: AK/11/51, Board of Agriculture to DC CN, 6 ${ }^{\text {th }}$ February 1953. 
not from the colonial government or banking institutions, but from money lenders. Other strategies were also adopted where in most cases, farms were bought collectively. Even this did not reduce pressure on farmers. For example, in 1930 a number of Asians purchased farms at speculative prices hoping to gain from cane farming and repay their loans only to have their crops destroyed by the locusts in 1931. Due to this catastrophe, they needed financial assistance to get back on their feet. ${ }^{35}$ Unfortunately, the colonial state was reluctant to assist the cane growers as indicated earlier.

Secondly, it has emerged from the preceding chapters that the small scale farmers had financial problems and many could not afford to buy tractors, especially for breaking land. For example, by 1950 the high clearance tractor was priced at Shs. $29,115 /=.^{36}$ This was very expensive; it was only the large scale farmers and sugar estates that could afford it. The majority of the farmers had to struggle getting help. Many relied on bullocks to cultivate the land and even with the introduction of the machine pool system, they still relied on the bullocks since some found that waiting for their turn to use the machine was not economical since the farms had to be prepared before the rains set in. Furthermore, the Asian cane farmers found it difficult to buy the much needed fertilizers. They also needed money to buy weed control chemicals ${ }^{37}$

Moreover, it was not easy for the Indian cane farmers to access loans from government institutions. For example, during the depression period, the colonial state came up with institutions to help the farmers such as the Land and Agricultural Bank established in 1931. ${ }^{38}$ However, the help was mainly meant for the settler farmers and many of Asian applications were

\footnotetext{
${ }^{35}$ KNA: DC/CN/1/4/3, K-LDAR 1931. See also KNA: DC/KSM/1/3/123 for the Report on Land and Agricultural Bank recipients, 1932-1935.

${ }^{36}$ KNA: AK/3/15, PAO Nyanza to Director of Agriculture, 30 ${ }^{\text {th }}$ March 1950.

${ }^{37}$ KNA: AK/3/15, C. C. Webster to A. Lacey, $12^{\text {th }}$ August, 1952.

${ }^{38}$ Kanogo, "Kenya and the Depression”, 117-118.
} 
rejected. ${ }^{39}$ Even when the committee started to re-examine the applications after complaints by the cane farmers, the process was very slow because majority of the members had rushed to Kakamega with the discovery of gold. For instance, by the end of the year in December 1936, only one application had been dealt with. ${ }^{40}$ The Asian farmers thus faced discrimination. It could be argued that there were some biases since the applications had to go through the local committee whose members were mainly composed of Europeans, mostly large scale farmers such as Messrs T. Allen and J. Fullen, who could not devote much time in such matters. Hence the local committees working with the land bank were found to be ineffective and discrimination made most Asians not opt for such assistance. Yet the farmers needed money to buy things like agro-chemicals and fertilizers. ${ }^{41}$ Moreover, the farmers' situation was made worse, as already indicated in earlier chapters, when the government changed the payment of proceeds to 150 days instead of the 30 days waiting period. ${ }^{42}$ The long wait contributed to the undercapitalization of the Asian sugar farmers, who unlike other farmers, had continuous activities on their farm due to the ratoon crops and as such they needed capital.

Therefore, we find that it was not easy for Asian farmers to get loans from the colonial government or banking institutions until the late in the 1940s, when Asian owned banks, the Standard Bank of India and Bank of Baroda, started operating in the colony. These became the main source of financing the cane farmers. ${ }^{43}$ Thus we find that by the late 1940 s cane growing had increased because of these institutions. However, it is evident that undercapitalization of the cane farmers was a major constraint since almost all aspect of cane farming are linked with it. For example, the buying of land for expansion, mechanization and labor all depended on the

\footnotetext{
${ }^{39}$ KNA: DC/CN/1/4/5, K-LDAR 1936.

${ }^{40}$ Ibid.

${ }^{41}$ Mohinder Singh, (O.I.), $22^{\text {nd }}$ June 2009.

${ }^{42}$ KNA: PC/NZA/3/2/34, DC K-L to Ag. PC Nyanza, $13^{\text {th }}$ October 1934.

${ }^{43}$ KNA: DC/KSM/1/3/122, Agricultural Production on Indian Farms, 1947.
} 
financial position of a farmer. Hence we can conclude that the financial constraints over many years, caused in part by colonial state's neglect of the sugar industry, hindered the rapid expansion of the industry in colonial Nyanza.

\section{Dumping of Sugar}

In Chapter 6 we discussed the problem of illegal importation of sugar into Kenya that was found to have interfered with distribution of sugar. Apart from this, there was also the legal importation that took advantage of Kenya's precarious sugar industry and led to what appears clearly as dumping of sugar in the colony. In particular, the Asian cane growers and manufacturers were constantly threatened by the incessant dumping of sugar into Kenya from Uganda, especially after South Africa withdrew from the Commonwealth due to pressure mounted on her apartheid system. Uganda took advantage as the sole supplier of sugar, and a lot of its sugar found its way into Kenya legally and illegally, as earlier discussed. All this curtailed the efficiency of sugar production in colonial Nyanza due to interference with prices as Ugandan sugar was cheaper and also distribution was affected. The fact that the colonial state allowed such a practice to take place indicates the lack of appreciation of the economic potential of the industry in $\mathrm{CN}$ that denied the local producers profits.

The dumping of sugar into Kenya has been discussed by Frank whose work reveals how Uganda had a consistent surplus of production over her own consumption during the period 1955 up to 1963 with production ranging between 10,000-50,000 tons while Kenya had a persistent shortfall over the same period. ${ }^{44}$ Such a situation raises pertinent questions as to why Uganda constantly overproduced. We can argue that this was made possible due to the ready market in Kenya. As a result, the Miwani Sugar Mills protested to the Ministry of Commerce and Industry

\footnotetext{
${ }^{44}$ Frank, The sugar Industry, 2.
} 
about the colonial government paying highly for Ugandan sugar, arguing that prices should be the same irrespective of the origin. ${ }^{45}$ Secondly, dumping could also be attributed to lack of support by the colonial government.

A meeting in 1955 well illustrates this problem. In the meeting held in the month of September, the Kenya government failed to stand firm and protect the cane producers in Kenya which led to resolutions being amended to favor the dumping of Uganda's surplus of into Kenya and Tanganyika. The Uganda representative, W. Padley, categorically explained that he was negotiating on behalf of the Ugandan manufacturers and did not hesitate to lay his terms clearly that should the two territories not take up the surplus, he would tell the manufacturers to export to Sudan. ${ }^{46}$ This was not unique as rarely did the colonial state come out openly to protect the Asian cane farmers. For example, in a previous CEC meeting on self-sufficiency, the Kenyan representative and Member for Agriculture and Natural Resources Major F. W. CavendishBentinck did not challenge the small sugar quota allocated to Kenyan producers that limited their production and relegated the colony to be the main importer of Ugandan sugar. A prominent European settler himself, Cavendish-Bentinck was more interested in securing wheat market for settlers in the region rather than biding for the Asian cane farmers. ${ }^{47}$ Such sentiments were also shared by another Kenyan representative, the civil servant, K. W .S. Mackenzie, who reiterated that Kenya was anxious to import as much sugar as possible from Uganda. ${ }^{48}$ It emerges clearly that the European representatives discriminated against the Asian cane growers as they failed to protect them. It was no wonder that Mackenzie was so much disliked by Asian cane growers

\footnotetext{
${ }^{45}$ KNA: AE/3/916, Miwani Sugar Mills to PS Commerce and Industry, $28^{\text {th }}$ July 1961.

${ }^{46} \mathrm{KNA}$ : BV/6/1704, Minutes of meeting to discuss arrangements regarding sugar and economic cooperation held in Dar es Salam, $7^{\text {th }}$ September 1955.

${ }^{47}$ Ibid.

${ }^{48}$ Ibid.
} 
who blamed him for the dumping of sugar as bitterly expressed by Mohinder Singh; "Mackenzi nene onego wa" (Mackenzie Killed us). ${ }^{49}$

Therefore, racial discrimination and colonial polices that were tailored to favor settler production made the colonial state not to come out forcefully and protect the home industry as Uganda did. This example portrays how the colonial state ignored the industry. Therefore we can argue that Kenya was hoodwinked into allowing the dumping of surplus sugar into the colony partly due to the desire to protect her wheat market, and possibly due to lack of selfsufficiency which the state was not eager to address, despite the potential. For example, in 195556, Kenya became the dumping ground of most of Uganda’s 9,800 ton surplus as indicated in the following table.

Table 8.2: Comparative Ugandan Exports to Kenya and Tanganyika, Dec 1955-Feb. 1956

$\begin{array}{llcc}\text { Year } & \text { Month } & \text { Uganda to Kenya (tons) } & \text { Uganda to Tanganyika (tons) } \\ 1955 & \text { December } & 2,000 & 400 \\ 1956 & \text { January } & 3,500 & 400 \\ 1956 & \text { February } & 3,500 & ----\end{array}$

Source: KNA: BV/6/1704, Extract from the Confidential Report on ECE meeting, $7^{\text {th }}$ September 1955.

From the above data it emerges that out of Uganda's surplus of 9,800 tons, 9,000 tons was dumped into Kenya in a span of only three months. It is ridiculous that Tanganyika received only 800 tons comparatively. ${ }^{50}$ Thus it appears that dumping was outrageous and undermined the efforts of the Asian cane farmers in CN. During the same period, Kenya faced a deficit of

\footnotetext{
${ }^{49}$ Mohinder Singh, (O.I.), $26^{\text {th }}$ July 2009.

${ }^{50}$ Ibid.
} 
approximately 5,500 tons. ${ }^{51}$ The flooding of the Kenyan market at times like this affected the industry as farmers had to contend with cheap sugar which was further aggravated by the importation of sugar from Tanganyika which started as early as $1936 .{ }^{52}$

However, it appears that the deficiency was partly as a result of the racial discrimination against Asian growers and producers because we find that the state deliberately pursued policies that discouraged maximum sugar production in Kenya. Production was discouraged through bureaucracy that hindered machines and spare parts from being procured easily which led to inadequate milling capacity. Furthermore, the colonial state was reluctant to start another sugar factory in the 1950s, yet cane growing had expanded and farmers were struggling in Nyanza to have their cane accepted. There was a need for another mill in the area as Miwani alone could not serve the farmers adequately. Insufficient mills have been found to affect production by its very limiting nature. This being the case, the colonial state could easily be blamed for deliberately allowing dumping of sugar in the colony to destroy the local industry that was Asian owned and financed.

\section{Lack of Harmony: Farmers and Manufacturers}

Apart from dumping of sugar, the sugar industry also faced a challenge in the sense that the there was no harmony between the two major players that parallels the lack of cooperation by the colonial state. Consequently, Political economy has been used to amplify how Asian cane farmers, in particular, faced problems from the millers, (both European and Asian) partly due to neglect and lack of support in supervision by the colonial state and also the discriminative policies that the farmers had to endure. This was because the Victoria Nyanza Sugar Company, being the only miller that took cane from farmers in CN from the mid-1920s, for sometime

\footnotetext{
${ }^{51}$ KNA: BV/6/1704, Sugar supplies; East Africa High Commission Memorandum, $2^{\text {nd }}$ September 1955.

${ }^{52}$ KNA: DC/CN/1/4/5, K-LDAR 1936.
} 
enjoyed virtual monopoly and took advantage of the situation supported by the colonial state. For example, the Victoria Nyanza Sugar Company started giving farmers problems by 1934 . During this period, the Kibos Indian farmers complained that they had a large quantity of cane but were not able to dispose it since the Victoria Nyanza Sugar Company was not accepting cane. The limited cane that was taken was paid at a low price of Shs. 6/= per ton. ${ }^{53}$ The constant low prices offered to cane farmers could be interpreated as a manifestation of capitalist exploitation where the millers' interest predominated. This stance was portrayed through the manipulation of the farmers by the manager, Mr. Abel, categorically made his standpoint clear that his company was determined to grow all cane that the mill required for its production and consequently would no longer buy any cane from the farmers at the expiration of the farmers' contracts. He even suggested that the Indians cane farmers should have a license to mill their own cane, knowing very well that this could not happen due to the monopoly accorded to the company. ${ }^{54}$ Moreover, this was contrary to the earlier position prior to 1931, when the same company had persuaded the cane planters to discontinue making jaggery and accepted all sugar cane that was offered. ${ }^{55}$

Such arrogance and monopoly discouraged many farmers since by then in Nyanza, the Victoria Sugar Nyanza Company was the only mill that took cane. Yet when the Asian cane farmers realized their plight and requested for a license to start their own mill, the same Mr. Abel arrogantly stated that such a proposition was only made as a bluff to make him accept the Indian cane. ${ }^{56}$ Records abound in the archives that reveal the numerous communications that took place between the DC and the PC as regards the Asian cane disposal problem in this period. This was

\footnotetext{
${ }^{53}$ KNA: PC/NZA/3/2/34, PC Nyanza to Colonial Secretary, 27 $7^{\text {th }}$ November 1934.

${ }^{54} \mathrm{KNA}: \mathrm{PC} / \mathrm{NZA} / 3 / 2 / 34$, Indian Cane Growers 1931.

${ }^{55}$ KNA: PC/NZA/3/2/34, Victoria Nyanza Sugar Company to PC Nyanza, $13^{\text {th }}$ May 1931.

${ }^{56}$ KNA: PC/NZA/3/2/34, DC K-L to Pilling, $3{ }^{\text {rd }}$ February 1936.
} 
a situation that was aggravated by the Government Notice No. 619 of 1934 that regulated the sale and distribution of sugar since it restricted the sale of sugar and jaggery and so inhibited the disposal of cane. For example, in 1934 out of approximately 45,000 tons of cane, the Victoria Nyanza mill was only prepared to take 12,000 tons. ${ }^{57}$ Hence, the farmers were stuck with the rest of which could only be used in producing jaggery.

Moreover in Kenya the sugar industry had other problems in quota allocation. In most countries it emerged that the mill owners were not large scale land owners as was the case in colonial Nyanza. Hence when a quota on a mill was imposed, it became a grower's quota. But in Kenya under the sale of sugar ordinance, the large land owning millers would most likely absorb the whole quota from their nucleus estates. Therefore, it was logical when the Indian farmers requested that either the growers be given a quota so that the mills could be forced to take up a portion of their cane or they be permitted to erect a mill and have their own millers quota. This was because, there being no other mill where farmers could take cane before 1942, the cane growers were left at the mercy of the Victoria Nyanza Sugar Company who offered them any price without regard to the worldwide market prices of sugar. Hence, the farmers acquired disastrous financial losses. According to Heyer and Senga, sugar pricing policy has long been a problem in Kenya. This problem continued even in independent Kenya. The policy has remained inadequate, and more often than not the growers were paid too little which affected the supply of sugar cane to the factories. This in turn resulted in great underutilization of the factory capacity. ${ }^{58}$ Therefore it emerges that pricing was critical to the industry and had to be done taking into consideration the prevailing world prices which were based on Commonwealth

\footnotetext{
${ }^{57}$ KNA: PC/NZA/3/2/34, DC K-L to Ag. PC Nyanza, 13 ${ }^{\text {th }}$ October 1934.

${ }^{58}$ Heyer, "The Marketing System” in Heyer et al. eds, Agricultural Development in Kenya, 336.
} 
Sugar Agreement Price. ${ }^{59}$ Thus, according to Frank, the relation between the internal price of sugar and the world market prices become important policy issues that cannot be ignored. ${ }^{60}$ As such we can argue that the Asian cane farmers in $\mathrm{CN}$ had genuine grievances in disposing of cane. The problem was grave and necessitated an investigation. Consequently the DC, Hamilton-Ross, arranged for agricultural officers who visited Miwani and Muhoroni area to assess the situation with an aim of reaching a fair solution to the Indian case. ${ }^{61}$

However, we find that there was no lasting solution, and the cane farmers kept on experiencing problems of selling their cane over time. We find that there was a brief period starting from when Hindocha took over the Miwani mill in 1947 from the Victoria Nyanza Sugar Company. The new owner installed more tramways that facilitated transportation of sugar, installed new machinery and started to take almost all the cane from the farmers who were able to take it to the factory. Even during this period, it emerged, as discussed earlier, that Miwani cheated farmers of their cane by deliberate wrong calculation of the number of tons required to make a ton of sugar. However, even the farmers were not blameless. For example, farmers belonging to the Kibos-Muhoroni Production Sub-Committee were found in 1949 to be holding up delivery of their cane to the Miwani Sugar Mills in anticipation of an increased price, though the price had not been increased. ${ }^{62}$ Such activities explain the lack of trust and ineffective communication that existed between farmers and manufacturers.

Furthermore, it was unfortunate when, by the early 1950s, Miwani also started to frustrate farmers just like its predecessor, the Victoria Nyanza Sugar Company. Miwani refused to accept cane of those farmers who had no contract, something they never did before. The company also

\footnotetext{
${ }^{59}$ Frank, Sugar Industry, 2.

${ }^{60}$ Ibid., 1.

${ }^{61}$ KNA: PC/NZA/3/2/34, DAO CN to Pilling, confidential, 27 ${ }^{\text {th }}$ January 1936.

${ }^{62}$ KNA: PC/NZA/3/22/16, R .O. Hennings to DC CN, $12^{\text {th }}$ August 1949.
} 
refused cane from those who complained that the company was underpaying farmers, and those who tired of arm twisting by the company fronted for the establishment of a second factory at Kibos. ${ }^{63}$ The complaints against Miwani led to an investigation conducted by the AAO who ascertained that by 1953 the company had refused to accept cane from certain farmers who advocated for another factory, such as Milwant Singh and Makan Singh. ${ }^{64}$ Yet it was only logical and proper for the farmers to request for another mill since Miwani had refused to accept cane from many farmers. Milwant Singh was forced to sell his farm out of such frustrations, though his farm was situated near the factory.

Furthermore, tension emerged also because the farmers felt that the manufacturers received a greater proportion of the subsidy, yet they did not always accept cane when the grower wanted to cut it. ${ }^{65}$ On the other hand, the manufacturers had laid out eight miles of rail with more trucks which involved a huge financial outlay; they claimed that the rail received as little as only three tons of cane per day from the farmers which was not economical. ${ }^{66}$ It clearly emerges that there was lack of cooperation between the two parties. This lack of harmony among the stake holders can be compared to the colonial state's lack of support towards assisting the cane producers; for instance the state's refusal to fix the price of cane over a long period of time, as discussed in earlier chapters. ${ }^{67}$ If the colonial government had acted accordingly, it could have benefited the cane growers and reduced tension between the two dissatisfied groups.

Existing literature illustrates how the inability to have sufficient mills impacted sugar production. For example, findings by Allen Ezra, in Liberia, clearly demonstrate how sugar agriculture was affected by lack of such facilities in regions that could produce sugar. Thus Ezra

\footnotetext{
${ }^{63}$ KNA: AK/11/51, DAO CN to Member for Agriculture and Natural Resources, 30 ${ }^{\text {th }}$ April 1953.

${ }^{64}$ Ibid.

${ }^{65}$ KNA: AK/11/30, DAO CN to PAO Nyanza, 14 ${ }^{\text {th }}$ May 1952.

${ }^{66}$ Ibid.

${ }^{67}$ Muyumbu, “A Historical Study of State Policies”, 51.
} 
concluded that the absence of sufficient mills prevented the potential sugar manufacturing regions from producing enough sugar for commercial transactions. ${ }^{68}$ The same findings applied to the sugar industry in Kenya. The problems of insufficient mills and obsolete machinery persisted to the independence period in the early 1960s. Wanyande argues that it was only in 1966 that another mill, the East African Sugar Industries Limited, was opened as part of the post independence sugar settlement scheme at Muhoroni. ${ }^{69}$ However, the problem remained due to inability of the factories to synchronize cane supply from farmers with factory operations.

\section{Sugarcane Diseases}

Apart from the above problems, there were other major risks borne by cane growers such as diseases and fire. Sugar cane diseases were rampant in cane growing and needed urgent responses to combat the infection. The Asian cane farmers in $\mathrm{CN}$ had to contend with various diseases that attacked the plants. Diseases were prevalent in most of the farms. By the late 1920s, already some farms had cane that was infected by various diseases. For instance, Mosaic disease was common and very serious since it attacked many varieties. Its outward characteristics included a mottling of leaves in the form of white blotches and streaks. The greatest effect it had on cane was that it reduced the yield, though the sucrose content of the juice was not much affected. The first serious attack was noticed in 1923, which forced the colonial government to come up with regulations to control it. ${ }^{70}$ This was done through the Disease of Plants Prevention Ordinance. The ordinance advocated for the planting of the more disease resistant Uba variety within a prescribed period as a measure to eradicate the disease. The Mosaic disease continued to draw the attention of the department of agriculture despite the

\footnotetext{
${ }^{68}$ Ezra, "Sugar and Coffee”, 92.

${ }^{69}$ Wanyande, “ Management Politics in Kenya’s Sugar Industry”, 126.

${ }^{70} \mathrm{DAAR}$ 1926, 14.
} 
efforts undertaken to eradicate the disease. For instance, the inspection report of 1927 indicated that it had spread and the area affected was larger than initially assumed. ${ }^{71}$

The problem of Mosaic continued to bother the cane farmers in the following year, and new measures were undertaken to stop the spread of the disease whereby a system of quarantine was put in place in 1928. Arrangements were made so that the new imported varieties meant for the experimental trials were first to be grown in quarantined plots set up under the close supervision of the Scott Agricultural Laboratories, before they were released to farmers as disease-free. ${ }^{72}$ The quarantine system made it easier for the imported cane to be inspected frequently without necessarily going to the sugar plantations. Moreover, in the farms it was difficult to find nurseries where suitable quarantine conditions could effectively be imposed. The seriousness of the disease forced the mycologist, Dr Storey of the East Africa Agricultural Research Station Amani, to visit the Asian sugarcane farms in Kibos, Miwani, Kibigori, Muhoroni, and the neighboring Koru and East Lumbwa. He carried out the campaign to eradicate the Mosaic disease which involved thorough inspection. ${ }^{73}$ Due to the persistent nature of the disease, farmers were advised to plough out the susceptible cane as measures to control the disease and stop the infection of other varieties. ${ }^{74}$ Apart from uprooting the rogue crop, other measures were also enforced whereby the department of agriculture in 1929 introduced improved varieties of cane that were more resistant to Mosaic disease and had them distributed to farmers. ${ }^{75}$ These varieties were POJ 2714, POJ 2725, POJ 2727 and POJ 2878. ${ }^{76}$ Many farmers were encouraged to adopt the new varieties, which were immediately taken up by large scale

\footnotetext{
${ }^{71} D A A R$ 1927, 13.

${ }^{72}$ DAAR 1928, 95.

${ }^{73}$ Ibid., 187.

${ }^{74}$ Ibid., 195.

${ }^{75}$ DAAR 1929, 26.

${ }^{76}$ DAAR 1932, 132.
} 
farmers, probably because financially they were able to embrace the changes faster. Towards the end of the year, there was great reduction of the disease in the district.

Despite the efforts over the years to eliminate it from sugarcane in the district, Mosaic reappeared again in 1931 as a result of action taken by certain Asians in the Kibos-Miwani area who imported from Uganda a variety known as Kampala which was a non-resistant cane. ${ }^{77}$ For an effective eradication process, it necessitated Mr. Naismith Jones, the Plant Inspector, to reside in the Songhor area for most of 1931 to keep a close check on Mosaic. However, the threat continued for in 1932, Mosaic disease attacked many farms in the Kibigori area. The restrictions were such that there would be no importation of any varieties from the neighboring African reserves. Thus to combat the spread of the disease, the senior mycologist suggested that it was crucial for information to be well disseminated. Hence, copies of information were distributed to the whole province through agricultural offices. The notices were also displayed on administrative offices, post offices, the railway stations and some were sent to the farmers association. $^{78}$ The colonial government acted quickly to contain the spread of the disease by enforcing the Government Notice No. 754 of November 1932 that prohibited the planting of Kampala and other soft canes imported from the African reserves. ${ }^{79}$ It was also recommended for farmers to remove the stool of the crop affected as control measures, something that farmers were reluctant to do. The reason for the order to eradicate all of the Kampala cane was that it was believed that the gain to be achieved by destruction was far more beneficial than leaving the cane in fields.

However, complete eradication of Mosaic was not attained easily, and it continued to bother farmers. For example, by mid 1953, an extremely high infection rate of the Mosaic virus

\footnotetext{
${ }^{77}$ KNA: PC/NZA/3/2/34, AO Nyanza to Mycologist Nairobi, $12^{\text {th }}$ August 1932.

${ }^{78}$ KNA: PC/NZA/3/2/34, Senior Mycologist to AO Nyanza, $21^{\text {st }}$ December, 1932.

${ }^{79}$ DAAR 1933, 130.
} 
was reported to have reappeared at Kisumu and Miwani farms. The infection was so severe that the much preferred variety of cane (the CO 281) which had been resistant to infections at Miwani was also affected and transmitted the disease to other varieties. ${ }^{80}$

Another disease that threatened the production of sugar was the Chlorotic Streak Disease, also known as ratoon staunting, due to its effects. The disease was characterized by the presence of a yellowish streak found at the veins on the leaf. The disease made the leaf stiff and appears more erect than the healthy ones. In severe cases, the Chlorotic Streak caused considerable stunting infection on the stool. ${ }^{81}$ This disease was suspected to have been brought by the cane imported from Natal. By 1954, it was found also to have interfered with the trials that were taking place in some of the varieties especially when the rainfall was not adequate. The disease continued to be a menace to farmers until the mid-1950s when a comprehensive scheme for the eradication of the disease was put into effect. ${ }^{82}$ It was recommended that no more materials were to be imported from Natal. Due to the seriousness of the disease, the Senior Plant Pathologist was of the opinion that a study under glasshouse conditions had to be undertaken immediately to find ways to eradicate the disease. ${ }^{83}$ The findings established that thermostatic bath treatment was the best solution for all planting materials. Towards such an initiative, the department of agriculture imported such a bath and had it installed at Kibos where supplies of seedlings were treated, while the large scale farmers and sugar estates ordered large tanks meant for the said treatment. ${ }^{84}$ Farmers were also advised to stop the spread of the disease by treating cuttings to be used in planting in hot water at fifty degrees Celsius for two hours.

\footnotetext{
${ }^{80}$ KNA: AK/11/51, East African Agriculture and Forestry Research Organization to Director of Agriculture, $16^{\text {th }}$ June 1953.

${ }^{82}$ KNA: AK/2/5, Report by M. E. H. Vickers on Export Crops 1957.

${ }^{83}$ Ibid.

${ }^{84}$ KNA: AK/2/4, Assistant Director of Agriculture, Nyanza to Director of Agriculture, $16{ }^{\text {th }}$ December 1957.
} 
While these measures proved effective, Smut Disease also proved to be problematic to farmers. It was a fungal disease whose effective treatment entailed uprooting the whole crop which the small scale farmers found problematic. The disease was noted by Sampura Singh to be prevalent in the B 35345 and CO 4621 varieties, and it was believed to have originated from Uganda. ${ }^{85}$

The various diseases impacted cane farming in colonial Nyanza in the sense that they forced the destruction of sugarcane. These reduced the yield and also reduced the sucrose content of cane which meant that a lot more cane had to be used to make sugar. However, we find that the state intervened whereby the Chlorotic Streak disease was controlled by the pilot observation under glass house conditions before information was released to the farmers. ${ }^{86}$ Other measures taken included a vigorous campaign meant to discourage farmers from growing the Kampala variety that was prone to diseases, and replacing it with the more resistant POJ varieties. These setbacks were overcome through the combined efforts of the plant pathologist and senior mycologists who worked closely with the cane farmers. In this instance, another facet of the colonial state's contradictory nature was revealed when the state responded satisfactorily to arrest the situation and stopped the spread of the diseases as opposed to their reaction to other issues. Thus we find that with disease colonial state support was accorded to the cane farmers.

\section{Machinery and Maintenance}

The cane farmers and the manufacturers alike also faced problems in procurement of machinery needed in the production of cane. The inability to purchase machinery was due to financial constrains and colonial beauracracy. It has emerged in the preceding chapters that by the 1920s most of the small scale cane farmers could not afford tractors and so they used ox-

\footnotetext{
${ }^{85}$ KNA: AK/11/52, Report by Wiehe on a visit to Potential Sugarcane areas in Kenya, $6{ }^{\text {th }}$ November 1956.

${ }^{86}$ KNA: AK/11/51, Senior Plant Pathologist to Director of Agriculture, $29^{\text {th }}$ April 1953.
} 
drawn ploughs for many years. ${ }^{87}$ Even for those who could later afford them, it was not easy to get the machines. For example, Amar Singh, who had total acres of 500 at Kibos and Miwani, applied in 1943 for a tractor and by the time his farm was visited by D.O. Magor, in 1947, he was still waiting for one. ${ }^{88}$

It has emerged that tractors were expensive for individual farmers to purchase. Hence later they organized and started using tractors from the machinery pool collectively. This was not efficient since farmers had to wait patiently for their turn, yet the farmers had to be ready before the onset of the rains since sugar cane farming in colonial Nyanza was rain fed. It was not until 1949 that the colonial government allocated six tractors to be used by 56 farmers which were far from being adequate.

Secondly, we find that the farmers could not afford harvesting machines and so cutting of cane was done manually, which was slow, dangerous and difficult. Thus we can argue that the undercapitalization of the Asian cane farmers made it difficult for them to afford machines that could have brought efficiency in the industry.

Thirdly, it was not easy to get machinery for milling sugar. We have seen how the colonial government refused Asian cane growers an opportunity to import machinery needed to start their own mill, in the mid 1930s. To make matters worse, by 1936 there were restrictions placed against the importation of sugar machinery. This was as result of worldwide limitation of sugar. ${ }^{89}$ These restrictions did not allow farmers to produce to the maximum capacity and were not viable since there were no enough mills to cater for the cane farmers. This was significant as it portrayed how the government ignored the cane producers in the colony since the same

\footnotetext{
${ }^{87}$ KNA: AK/3/15, Notes on sugar Industry 1948.

${ }^{88} \mathrm{KNA}: \mathrm{PC} / \mathrm{NZA} / 3 / 22 / 1 / 8$, Report by Magor on a visit to Indian farms in the area of Kibos-Miwani-KibigoriChemelil, $6^{\text {th }}-10^{\text {th }}$ October 1947.

${ }^{89}$ KNA: PC/NZA/3/2/34, Secretariat Nairobi to S. H .Fazan, 20 $0^{\text {th }}$ January 1936.
} 
regulations were challenged by the government of Uganda, while Kenya did not even give it a thought.

Moreover, in 1942 when the Muhoroni sugar operation was taken over by Asians millers, Premchard Raichad and Company, the new owners requested the colonial government to help in procuring two locomotives. Although the colonial government granted the request, since it recognized that agricultural machinery was badly needed to improve agriculture in the colony, the supplier based in the United States of America refused to release them on grounds that they could be intercepted by enemies who could remodel them for military purposes. ${ }^{90}$ Such an excuse was discriminative given the fact that the European owned Victoria Nyanza Company did not encounter such problems. Moreover, we can argue that such hurdles caused delays in the delivery of machinery which impacted the sugar industry. Furthermore, the factories faced problems of old machinery that needed repairs which had to be brought in from overseas. For example, in 1952 the Miwani factory had to suspend its operations due to the annual overhaul of machinery and this caused delay in cutting of the mature cane. ${ }^{91}$ By early 1953 the factory had not started receiving cane from the farmers who wanted to dispose of their cane; hence farmers requested the Director of Trade and Supplies for a permit to be allowed to manufacture jaggery instead of their cane going to waste. ${ }^{92}$

The lack of machinery and spare parts that were needed was a significant problem. It required a lot of attention and was never overcome and continued throughout the colonial period and into the independence period. First it was a factor that determined the acreage put under cane. Those who managed to get them faced problems of how to get spare parts. For instance, it was found that a number of tractors in the Kibigori area were not in working condition by 1947

\footnotetext{
${ }^{90}$ KNA: BV/6/605, East African Sugar Industry, Muhoroni to Director of Agriculture, $7^{\text {th }}$ October 1942.

${ }^{91}$ KNA: AK/11/30, DAO CN to PAO Nyanza, $14^{\text {th }}$ May 1952.

${ }^{92}$ KNA: AK/11/51, A .G. Dalgleish to A. Pritam, $18^{\text {th }}$ April 1953.
} 
because they needed spares. Furthermore, it was found that the spare parts work done by Gailey and Roberts Company was not satisfactory. ${ }^{93}$ This could be blamed on colonial government's lack of supervision that led to farmers being exploited, even by engineering firms. Odhiambo's findings corroborate this view. His work demonstrated how a lack of machinery impacted cane farming in the sense that insufficient machinery for land preparation gave rise to additional land lying fallow, especially among the small scale farmers which reduced production. ${ }^{94}$ Such problems made farming difficult.

Obsolete machinery in the factories also posed a problem as it led to proliferation of over-mature cane on farms. This was because it took many months to repair the machinery if they were left for a long period without maintenance. It emerges that the Miwani Sugar Mills suspended its operations in May 1952, and by April of the following year the factory had not started to receive cane from farmers. ${ }^{95}$ In the meantime the farmers had to wait as they watched their cane over-mature in the farms. The crops not only deteriorated in milling quality, but it also prolonged the crop cycle. Such a situation portrays the undercapitalization of the industry in the sense that the state did not infuse money to build another factory such that during the annual overhaul of machinery at Miwani, there would be an alternative factory with almost the same crushing capacity to continue receiving the cane and avoid wastage. Such shortcomings could be attributed to the lack of appreciation of the economic importance of the cane industry. The neglect proved to be expensive on the part of the cane farmers.

\section{Immigration Problems}

Although there were other problems faced by the Asian cane farmers, such as dealing with obsolete machinery, they also struggled to get skilled manpower to work in the farms and

\footnotetext{
${ }^{93}$ KNA: PC/NZA/3/22/1/8, Report by Magor, $6^{\text {th }}-10^{\text {th }}$ October 1947.

${ }^{94}$ Odhiambo, "The Sugarcane Procurement Problems in Kenya”, 34.

${ }^{95}$ KNA: AK/11/51, A. G. Dalgeleish to A. Pritam, $18^{\text {th }}$ April 1953.
} 
especially the factory. Yet in an agricultural country, the agricultural sector forms the very backbone of its economic structure, and any hindrance to any part of its growth is counterproductive. Like any other industry, the sugar cane industry needed skilled laborers to progress. However, there was discrimination in immigration policy fuelled by European settlers who feared that an influx of the Indians into the colony posed a possible threat to the white highlands. Therefore, they brought pressure to minimize such an influx so as to control the size of the population. Specifically the settlers feared that Indian immigration could lead to agricultural settlement even outside the lowlands, something that they detested. ${ }^{96}$ This belief was deeply entrenched within the settler society as portrayed by Lord Delamere, one of the leading settler politicians, who explained their position when he asserted that:

In all new Countries the backbone of the country is the small man, the white colonist with small means, but there is no place for him in a country when once the Asiatic is there ... all the vegetable growing for the towns is done by Indians, all the butchers with one or two exceptions are Indians, all small country stores are kept by Indians and most town shops, all lower grade clerks are Indians, nearly all the carpentering and building is done by Indians. They fill all occupations and trade which would give employment to the poorer white colonist. ${ }^{97}$

The above sentiments clearly showed how the Europeans feared the influx of the Asians. Wolff argues that this fear was due to possible Indian competition, and it was that fear that made the settlers strive to keep the Indian population in the protectorate at the minimum. ${ }^{98}$ Despite such hurdles, the Asian cane producers still made efforts to get the needed skilled work force which they sought from their home country. These included artisans, accountants, technicians and agriculturalists, among many. However, both the growers and the manufacturers faced great problems with the immigration department. The colonial state, as early as 1919, objected to

\footnotetext{
${ }^{96}$ Wolff, The Economics of Colonialism, 95

${ }^{97}$ Ibid.

${ }^{98}$ Ibid.
} 
Asians coming to the colony and dubiously claimed that the restriction of the Asian immigrant was meant to protect the Africans interests. During this early period the Asian farmers needed assistance since they were experimenting with sugar growing and had little knowledge about the crop. Unfortunately, this view was shared by the officials at the Colonial Office in London, except L.S. Amery who believed that the Indian agriculturalist had something to offer. ${ }^{99}$ Amery believed that restricting Indian immigration could not lead to rapid development of the colony. This attitude was not shared by the officials of the colonial state throughout the period under review. Thus it was not easy to bring a relation or workers from India to help with the farming. Many rules and regulations were put in place that made it very difficult, and these difficulties revealed how the Asian cane farmers, right from the infancy of the industry, had to face discrimination.

Immigration issues kept on resurfacing throughout the colonial period. However, it appears that the strong position assumed by settlers at the end of World War II pushed the wheel into motion for just at the end of the war in 1946, an immigration bill was published. The Immigration (Control) Ordinance of 1946 placed permanent restrictions on immigration. ${ }^{100}$ This bill was discriminative in nature since it did not apply to European settlers coming into the colony. Seidenberg criticized it and argued that although the bill was non-racial in context, it was discriminatory in conception and effect. ${ }^{101}$ Although the Asians protested against the bill, after two years of protracted struggle, the Immigration (Control) Ordinance was passed into law, which controlled Indian immigration. With this law in effect, the colonial state made it very difficult for the Asian farmers to get skilled labor into the country due to the terms and conditions put in place.

\footnotetext{
${ }^{99}$ Maxon, Struggle for Kenya, 162.

${ }^{100}$ Seidenberg, Uhuru and the Kenya Indians, 34.

${ }^{101}$ Ibid.
} 
The first difficulty was what the producers and growers termed as undesirable conditions which were imposed on entry passes by the colonial government. There were three types of passes as follows: the Temporary Entry Pass, (TE Pass) which was granted for only two years. Cane being a long term crop whose full circle ranged between 5-6 years, it meant that even when technicians were granted the TE Pass, the period was too short and did not benefit either the farmers nor the millers. ${ }^{102}$ Secondly, there was the Entry Permit and thirdly, the Dependants Pass for family members of needed staff. This discrimination towards Indian workers has been discussed by Gregory who argues that by 1951, even the Labour Secretary of State, Arthur Creech Jones, and the Colonial Office supported the colonial state that claimed that the exclusion of Asians from jobs was on the grounds that it was only the British who were charged with transmission of the tenets of Western Civilization. ${ }^{103}$ Thus we can argue that the colonial state found it prudent not to restrict the European immigrants while controlling the Asian inflow into the colony.

It was not easy for Asian workers or their families to be granted the immigration passes or permits. A lot of archival sources indicate that there were many refusals, especially for the issuance of the TE Pass for qualified and experienced farm and factory workers that were much needed in the industry. This was a huge problem and Miwani in particular called attention to this problem in the early 1950s. It was not only the denial that was challenged, but also the unreasonable conditions set for Asian immigrant workers. For example, there was the notorious condition that required that a TE Pass could only be issued when the dependants of the applicant, such as his family members, were not granted a pass. ${ }^{104}$ In petitioning the colonial state during 1952, Miwani revealed how their estate doctor, Apabhai R. Patel, was denied the privilege of

\footnotetext{
${ }^{102}$ KNA: AK/11/30, Miwani Sugar Mills to PAO Nyanza, $10^{\text {th }}$ August 1952.

${ }^{103}$ Gregory, South Asians, 189.

${ }^{104}$ Ibid.
} 
having his family come with him. Similarly, the assistant plantation manager, trained in agriculture at the University of Bombay with 10 years experience in the sugar industry in Uganda, had just been offered employment by Miwani, but was ordered by the colonial government to send his family away to India. ${ }^{105}$ Such discriminative policies affected farming as it denied the Asian sugarcane farmers and manufacturers the much needed workers, especially the factory skilled manpower.

However the Asian immigrants also were found to flout the regulations and engage in other activities not initially intended when they applied for entry, and this complicated the matter. For example, in 1953 it emerged that Milwant Singh, who had entered Kenya on a permit to run his father's farm, was found to be working for Ingersoll Rand in Kisumu, and he had applied for a permit for Sikandar Singh to come and manage his father's land. ${ }^{106}$ However, we find that the same rules did not apply to European settlers as nobody bothered with what economic activities they tried their hands on.

The immigration problem persisted throughout the colonial period and became a thorny issue among the Asians at large. The cane farmers and manufacturers continued to struggle with lack of skilled labor, especially in the factory where technicians, chemists and engineers were needed. Such inadequacy was purported by the colonial state's lack of recognition that the industry was important as was demonstrated through the employment of only one Asian sugar specialist, Sampura Singh, who had to help over 80 Asian cane farmers, while denying other qualified personnel entrance into the colony. ${ }^{107}$ This clearly demonstrated racial discrimination against the Asian farmers. It appears as though the immigration regulations were exclusively

\footnotetext{
${ }^{105}$ Ibid.

${ }^{106}$ KNA: DC/KSM/1/19/270, R .E Wainwright to Milwant Singh, $19^{\text {th }}$ January 1953.

${ }^{107} D A A R$ 1948, 32. For the number of Asian farmers that Singh was to work with, see KNA: AK/11/50, Report by Lyne Watt on Sugar Investigational work, August 1947.
} 
meant for the Asians growers as they did not apply to settler farmers. Whatever the motivation, they hindered the progress of cane growing in $\mathrm{CN}$.

\section{Minor Challenges}

These sections demonstrate that cane farmers had major problems to contend with. They experienced also minor problems that entailed a monkey menace, theft of cane, and fire outbreaks. Monkeys and baboons destroyed cane, especially the soft varieties. Such a menace continued for a long time. This was witnessed when by mid-1950, the DC was forced to intervene and help the farmers, especially after there was massive destruction reported in Miwani farms. The DC was forced to solicit the help of the local honorary game wardens who assisted in the control of the monkeys and the baboons at Miwani. ${ }^{108}$

The problems of theft and fire were also identified. There were cases whereby cane was stolen from the farms by the local people for consumption; in other instances it was the workers who just took cane to chew though there were regulations on different farms that required workers not to chew cane. This occurred mostly in farms where the employers were very strict and also the food ration was bad. ${ }^{109}$ The fires were in most cases accidental, but it was feared that there were instances when they were set by dissatisfied workers, probably due to wage contestation.

From the foregoing, it is evident that the cane farmers and manufacturers faced many difficulties. Among the most serious ones being the colonial policies that in most cases were found to be biased and contradictory and limited the growth of the industry. For example, the overregulation of the market has been found to have been harmful to the industry. Another problem was found to be that of undercapitalization of the Asian farmers that made it difficult for

\footnotetext{
${ }^{108}$ KNA: AK/11/30, DC CN to Game Department, $20^{\text {th }}$ July 1950.

${ }^{109}$ Mohinder Singh, (O.I.), $22^{\text {nd }}$ June 2009.
} 
other concerns to be solved. For instance, the cane farmers did not have even enough money to transport cane to the factory at Miwani especially those that had farms around the Muhoroni and Songhor area. Moreover, ecological problems were just as catastrophic. Drought and locusts destroyed the farmers' crops, putting them under a lot of pressure as they struggled to pay for labor and continue with farming. Despite the challenges, the sugar industry survived partly because the Asian cane farmers and manufacturers realized that the problems could not be left to the colonial state to solve as it was not very keen. Thus the Asian cane farmers had to devise means to cope with the challenges.

\section{The Asian Cane Farmers' Initiatives Towards Meeting the Challenges}

From the forgoing discussion it is clear that the Asian cane farmers in colonial CN faced a lot of diverse problems. Some of the problems were so serious that they impacted cane farming. For example, the problem of non-acceptance of sugarcane by millers and the need for another milling plant were issues that were urgent and affected the industry. Thus it becomes pertinent that we examine how the farmers faced the challenges. It emerges that in efforts to solve their numerous problems, the farmers organized themselves into various organizations which included, but were not limited to, the Nyanza Indian Farmers Cooperative Society (also known as the NFCS), Agricultural Production Sub-Committees and the Nyanza Farmers Association (also known as the Nyanza Indian Farmers Association or NIFA). Similarly they also got support from the EAINC. These different groups tried to tackle the various problems in the best way they could within their area of specialty. Hence we find the cooperative society basically handling the marketing issues while the EAINC was more concerned with injustices and policy issues just to mention but a few. However, their various work complimented each other, and no evidence was found of them working in opposition. This cooperation by the 
various groups helped find solutions to some of the problems and facilitated the growth of the Asian sugar industry in colonial Nyanza.

The Asian farmers also organized themselves into self-help groups to solve some of the problems collectively. For example, in 1930 the Asian farmers collectively joined hands, bought land belonging to Walji and sons, and subdivided it amongst themselves. This demonstrated how collective action was effective. ${ }^{110}$ The same method was used to purchase Major Carnegies' land which was expensive; so pooling resources together made economic sense. Other help also came from the Asian leaders. This was seen when in 1934 the Asian cane farmers experienced disposal problems; their representative in the LegCo, Shams ud Deen, led a farmers' delegation to present their grievances to Governor Sir Joseph Byrne which was fruitful as they were granted their request.

The colonial state also offered assistance to the farmers. It has emerged in earlier chapters how the state employed a sugar specialist, Sampura Singh, who not only gave technical advice to farmers but also carried out experimentation that solved some of the problems the farmers faced. Moreover, the colonial state as demonstrated earlier, facilitated the experimentation on different varieties that were needed. This became crucial because it determined the best variety that could not only cope with the weather conditions of the area but also be resistant to most diseases as was found among the POJ varieties. ${ }^{111}$ To this end, we can argue that the colonial state helped the farmers because the intensification of trials and experimentation led to the success of the sugar industry. Nevertheless, apart from such assistance, individual organizations that were formed mostly out of necessity helped the Asian cane farmers and manufacturers as exemplified by the few in the ensuing discussion.

\footnotetext{
${ }^{110}$ KNA: AGR/6/4308, Miwani Farms 1930-1958.

${ }^{111}$ KNA: AK/3/15, Director of Agriculture to PAO Nyanza, $1^{\text {st }}$ July 1950.
} 


\section{The Nyanza Farmers Cooperative Society (NFCS)}

The Nyanza Farmers Cooperative Society was formed in January 1936, by the Kibos Indian farmers; the society's office was based in Kisumu and the organization was composed of mainly cane farmers as earlier stated. ${ }^{112}$ The cooperative was formed as a coping mechanism during a crucial period of the sugar industry when the Victoria Nyanza Sugar Company had started to refuse accepting the cane from the farmers and was mainly concerned with the sale of jaggery. All members sold their produce through the society which was granted a monopoly of selling jaggery in the country and also for exportation. The society received a commission for produce sold through it. Hence the cooperative mainly dealt with the sale of jaggery in bulk and managed to negotiate for better prices. ${ }^{113}$ For example, before the formation of the society, the price of jaggery was low, selling at 65 cents per frasila. ${ }^{114}$ After the formation of the society, jaggery was sold at Shs. 3/= per frasila since the society controlled the marketing of jaggery, and even found markets whereby the society exported about 1,000 tons of jaggery annually to United Kingdom, India and Uganda. ${ }^{115}$ The society not only sold the members' produce, but also provided them with farm implements. As such, the farmers felt encouraged and increased the acreage under cane. In 1941, the cooperative made headway and sold low grade No. 2 brown sugar to the United Kingdom where it had a market. ${ }^{116}$ The cooperative was also concerned with the grading of the jaggery so as to improve the quality for export.

Other initiatives were seen when by 1959 many Africans had entered the sugar industry in Nyanza. The Asian growers started feeling competition from African producers. This competition was exploited by local merchants in Kisumu who formed a ring to exploit the two

\footnotetext{
${ }^{112}$ KNA: PC/NZA/3/2/34, Department of Agriculture Nyanza to H. G. Pilling, $3{ }^{\text {rd }}$ February 1936.

${ }^{113}$ KNA: DC/CN/1/4/5, K-LDAR 1936.

${ }^{114}$ KNA: PC/NZA/1/3/122, Minutes from the meeting of NFCS held on $6{ }^{\text {th }}$ April 1940.

${ }^{115}$ Osamba, “Colonial African Labour”, 81.

${ }^{116}$ KNA: BV/6/613, Dalgety and Co. to Director of Agriculture, 8 th January 1941.
} 
groups in the marketing of jaggery. This trend was exposed by the NFCS who recommended to the colonial administrators for a joint scheme of marketing jaggery with African cane producers. Unfortunately the administrators rejected this, claiming that the Sugar Board only handled African grown produce. ${ }^{117}$ The suggestion of the farmers seemed viable but was not considered because the colonial state was not interested enough in the industry to have bothered to solve the problem. Although the NFCS was found to be operating under a very unreceptive government; they managed to remain steadfast and championed the farmers cause right to the independence period.

\section{The Agricultural Production Sub-Committees}

The Asian cane farmers also organized themselves into various production subcommittees in their respective areas so as to help them in their farming endeavors. These subcommittees were formed in 1947, but officially registered in October 1949. They were: the Kibos-Muhoroni Production Sub-committee chaired by Sham Singh, the Muhoroni-Chemelil Production Sub-committee chaired by Bhanji Valji, and the Miwani-Kibigori Production SubCommittee chaired by M.U. Patel. ${ }^{118}$ These organizations were active. For example, we find that the Kibos-Muhoroni Production Sub-Committee, at its inception in 1947, met with the Miwani Sugar Mills when Hindocha took over to negotiate a new price of sugarcane on behalf of the cane growers. During the meeting, Hindocha arrived at the conclusion that since the sugar price then was Shs. 400/= per ton minus excise duty, the company was ready to offer Shs. 10/40 per ton for hard cane. ${ }^{119}$ Unfortunately, the farmers insisted on Shs. 17/50 per ton and explained that they would continue to produce jaggery if their demands were not met. ${ }^{120}$

\footnotetext{
${ }^{117}$ KNA: BV/14/401, Hughes-Rice to PS Ministry of Agriculture, $12^{\text {th }}$ May 1959.

${ }^{118}$ KNA: DC/KSM/1/19/270, N. G. Hardy to Production Sub-committees, $2{ }^{\text {nd }}$ November 1949.

${ }^{119}$ KNA: AK/11/50, Minutes from the Special Meeting of Kibos-Muhoroni Production Sub-Committee held on $18^{\text {th }}$ July 1947.
} 
The Kibos-Muhoroni Production Sub-committee was relentless in serving the members, for immediately after meeting the Miwani ownership, they also organized and met the company management with colonial officials such as W. Lyne Watt and C.F. Atkins. They deliberated on the issue of fixing the price of sugarcane. The cane farmers' spokesman was Mr. Bresler (a European cane farmer) who insisted that the price offered for cane was low. ${ }^{121}$ Following the discussion, it emerged that there were represented 55 Asian cane farmers who also manufactured jaggery on their farms, the Muhoroni Sugar Company, and Messrs. Bresler and Starr. In the discussion it became clear that there was fear from some of the administrators that the price of cane had to be fixed and that the solution was not the control of sale of jaggery, which if effected would still lead to a black market of the product. ${ }^{122}$ Moreover, the Kibos-Muhoroni Subcommittee challenged the Shs. 40/= per acre grant that was offered by the state for breaking land. The sub-committee argued that it was insufficient since the rate for ploughing three times and harrowing twice was approximately Shs. $72 /=$ per acre. $^{123}$

The ceaseless efforts of the organization was witnessed again in 1950 when the KibosMuhoroni Production Sub-committee requested the Central Commodity Distribution Board to give them permits so as to allow the farmers to export jaggery to Uganda and Tanganyika or to the Persian Gulf where there was a market. Unfortunately the chairman of the Central Commodity Distribution Board rejected the request on grounds that if jaggery was exported then it would encourage the production of it at the expense of white sugar, and that most farmers would take very little cane to the factory for sugar. ${ }^{124}$

\footnotetext{
${ }^{120}$ Ibid.

${ }^{121}$ Ibid.

${ }^{122}$ KNA: AK/11/50, Deputy Price Controller Nyanza to Kenya Commodity Distribution Board, $10^{\text {th }}$ April 1947.

${ }^{123}$ KNA: AK/11/50, Minutes of the Kibos-Muhoroni Production Sub-Committee, $6^{\text {th }}$ September 1949.

${ }^{124}$ KNA: DC/KSM/1/19/270, N. G. Hardy to Kibos-Muhoroni Production Sub-Committee, $10^{\text {th }}$ May 1950.
} 
Furthermore, in 1953, the sub-committee also pushed forward for the cane farmers to be accorded the principle that the GMR be also applied to the sugarcane crop. Because when the GMR program was started by the colonial state, cane was not included on the grounds that it was not an annual crop like maize. However, the cane farmers argued that cane, just like other crops in the district, suffered from adversities such as locusts and drought; hence the cane farmers wanted the GMR applied due to risks that they bore. ${ }^{125}$ This was necessary because the Indian cane farmers had suffered considerably from loses caused by drought, locusts and accidental fires on individual farms. These negatively affected their activities since they had no insurance of any kind such as the GMR accorded to maize farmers. ${ }^{126}$

During the same period, we find that the Chemelil-Muhoroni Production Sub-committee also voiced opposition against the sugar legislation that was to control production of jaggery. The committee argued that, by 1953, most of its members were producing jaggrey. They took little cane to the factory due to the long distance to Miwani; hence farmers were anxious about the legislation that could put a stop to jaggery production. ${ }^{127}$ In the meantime, the MiwaniKibigori Production Sub-committee also protested and boycotted a meeting called by the Miwani Sugar Mills to discuss the legislation that barred the production of jaggery. ${ }^{128}$ It seems that the farmers did not want to put themselves in a situation where they had to take their cane to the factory with no other option because in the past they had been exploited.

Despite the efforts, the activities of the production sub-committees were marred by divisions that hindered their proper functioning. The division was based on tension and class conflict between large scale farmers and small scale Asian farmers who felt they were taken

\footnotetext{
${ }^{125}$ KNA: AK/11/51, DAO CN to Secretary, Board of Agriculture, $5^{\text {th }}$ January 1953.

${ }^{126} \mathrm{KNA}$ : AK/11/51, DAO CN to Director of Agriculture, 6 ${ }^{\text {th }}$ March 1953.

${ }^{127}$ KNA: AK/11/51, G. M. Vasani, Chairman, Chemelil-Muhoroni Production Sub-committee to DAO CN, $12^{\text {th }}$ June 1953.

${ }^{128}$ KNA: AK/11/51, Laljibhai Hindocha to Miwani-Kibigori Production Sub-committee, $14^{\text {th }}$ May 1953.
} 
advantage of. For example, the Chemelil-Muhoroni Production Sub-committee had internal divisions that threatened its functions. Most of the discontent came from the small scale farmers who rejected domination of the official positions by large scale farmers. In some production sub-committees, the bone of contention was the fact some officials came from even outside the sub-committee’s zone. For instance, some members of Chemeli-Muhoroni Production Subcommittee were not happy with that and challenged the election of G.M.Vasani as their chairman because Vasani came from the Muhoroni-Songhor area. Moreover, he was a sisal farmer, representing the Muhoroni Sisal Company. Also the election of N. M. Mehta as an official in the same production body was challenged since Mehta was also a sisal farmer from Volo Sisal Limited in Kibigori. ${ }^{129}$

The muddle in these elections was partly due to the colonial administration who though present did not advise the members accordingly because of their lack of concern with the industry. However, some government officials took responsibility. For instance, R.E. Wainwright, the then DC, lamented that due to the muddle, the two successful sisal farmers were left to hold positions that could have rightly been held by the cane farmers. ${ }^{130}$ Other reasons that created the confusion could be blamed on the farmers themselves who elected officials not because they were cane farmers, but because of their ability to speak English and the influence that they allegedly wielded. Some members believed that this would enhance their bargaining power. ${ }^{131}$ Despite the internal disagreements, we find that the production subcommittees were fully involved in farmers' affairs and did all they could to improve sugar cane farming in their respective areas by championing the growers’ cause.

\footnotetext{
${ }^{129}$ KNA: PC/NZA/3/22/1/8, Report by Magor, $6{ }^{\text {th }}-10^{\text {th }}$ October 1947.

${ }^{130}$ KNA: AK/11/13/13, DC CN to Chief Executive Officer, Board of Agriculture, $21^{\text {st }}$ April 1952.

${ }^{131}$ KNA: PC/NZA/3/22/1/8, Report by Magor, $6^{\text {th }}-10^{\text {th }}$ October 1947.
} 


\section{The Nyanza Indian Farmers Association (NIFA)}

The NIFA (sometimes known as Nyanza Farmers Association) also worked tirelessly for farmers. For example, in 1934 they sent a petition to the DC of K-L where they addressed the issue of refusal of their cane by the Victoria Nyanza Sugar Company though they had an agreement with the company to supply it with cane. ${ }^{132}$ Secondly, they also rejected the period laid down of 150 days for payment of cane proceeds to the farmers by the colonial government's agency and insisted on 30 days waiting period. Furthermore, they demanded that the Indian cane farmers be given adequate representation of their interests on the agency, and that the staff should not be confined to a single race, in this case, Europeans.

As discussed earlier, the association presented their request to Sir Joseph Byrne for a license to import machinery and erect a mill in 1936. The farmers felt that there was a dire need for another mill in order to process their cane and also get a fair share of the sugar quota allocation. $^{133}$ The request was granted on condition that the machinery could not exceed the capacity of crushing 5,000 tons of sugar per annum. ${ }^{134}$ Also during the same period the association had come up with a modality that would allow all the Asian cane growers in the area to deliver cane to the proposed mill on equal terms so as to avoid the problems witnessed by the Victoria Nyanza Sugar Company. ${ }^{135}$

Unfortunately, the director of agriculture felt that the three years given for the license was too long and attempted in 1937 to shorten it. The Indian cane farmers were given a limit of three months to come up with the funds to import the machinery or have the license revoked. ${ }^{136}$ This was wrong since earlier on, they had been given three years beginning June 1936; so in essence

\footnotetext{
${ }^{132}$ KNA: PC/NZA/3/2/34, NIFA to DC K-L, $11^{\text {th }}$ October 1934.

${ }^{133}$ KNA: PC/NZA/3/2/34, R. G. L. Rumus to Sir. Joseph Byrne, $18^{\text {th }}$ February 1936.

${ }^{134}$ KNA: PC/NZA/3/2/34, Ag. Colonial Secretary to NIFA, $3^{\text {rd }}$ December 1937.

${ }^{135}$ Ibid.

${ }^{136}$ Ibid.
} 
they had until June 1939 and to change the duration in 1937 was uncalled for because the farmers were still in the process of raising funds. Such actions portray the frustrations that the Asian cane farmers had to deal with. Thus the association decided to act and sent a petition through the acting colonial secretary to the governor in 1937, requesting that the colonial state give the cane farmers an assurance that the license that had been awarded to Kibos farmers to erect a mill for a period of three years would not revoked. ${ }^{137}$ In their petition, NIFA explained clearly that the delay in getting funds soon enough to import the machinery was due to ravages caused by locust visitations and the drought that followed which had made the farmer's financial situation difficult. ${ }^{138}$ The request was eventually granted though the plan never materialized.

However, the association also made a request during the same period that funds be made available for upgrading the road that served the area between Kibos-Chemelil and Miwani where most of the Asian cane farmers were situated so as to ease the transport problems of the cane farmers. ${ }^{139}$ This road was eventually upgraded since funds had already been earmarked for it, but it seemed that the colonial state was just dragging its feet. The association also requested the colonial state to lower the railway freight charges on jaggery that was destined for export; a request that was turned down on grounds that jaggery was not one of the essential industries. ${ }^{140}$

Despite the difficulties experienced faced dealing with the unreceptive state, the group still stood up for what they felt was not justified. For example, in 1946 the NIFA challenged the terms of contract agreement with the Victoria Nyanza Sugar Company that they felt was not fair. They challenged the decision of the factory to close the mill without prior information to the farmers. Hence they demanded that the farmers be given at least one week notice of intention to

\footnotetext{
${ }^{137}$ KNA: PC/NZA/3/2/34, Ag. Colonial Secretary to Director of Agriculture, $6{ }^{\text {th }}$ October 1937.

${ }^{138}$ KNA: PC/3/2/34, NIFA to Sir Robert Brooke-Popham, $28^{\text {th }}$ September 1937.

${ }^{139}$ KNA: PC/NZA/3/2/34. DC K-L to PC Nyanza, $1^{\text {st }}$ October 1937.

${ }^{140}$ KNA: PC/NZA/3/2/34, SAO Nyanza to Colonial Secretary, 6 ${ }^{\text {th }}$ October 1937.
} 
stop crushing during repairs or annual overhauls. This was important since farmers would organize not to cut cane during the said period. Moreover, they requested that the agreements be translated into Hindustani for the benefit of farmers who did not understand English. ${ }^{141}$

The NIFA was relentless in its pursuit to help the farmers; this was seen in 1950 when the DC for CN placed a restriction on the sale of jaggery within the district. This led to a pile up of jaggery stock that needed an outlet. Hence, the situation left the Asian cane farmers with no option of disposal other than export. The association came up with a plan to export jaggery by use of dhows to the Arabian countries where there was acute shortage and a ready market besides exporting to the United Kingdom. ${ }^{142}$ The farmers argued that it was unrealistic for the colonial state to insist that every stick of sugarcane be converted into white sugar. Such impossibility was partly due to the insufficient transport that connected the Asian farms and the milling factories. ${ }^{143}$ Furthermore, the small scale farmers had scattered patches of cane fields that the millers found uneconomical to transport, and so transportation was basically left for the farmers. Transport problems continued and the association worked with other groups to improve the situation. This was because the farmers' predicaments affected the entire Asian community, hence we find that the EAINC also made efforts to try and get the colonial state to help the farmers.

\section{The East Africa Indian National Congress}

The Congress, formed in March 1908 at Mombasa, was modeled on the Congress of India as a response to the colonial state policy that laid emphasis on European interests. Though formed specifically to address more of political issues and bring together the Indian leaders of

\footnotetext{
${ }^{141}$ KNA: AK/11/50, Minutes of Meeting of NIFA with Manager of Victoria Nyanza Sugar Company, $22^{\text {nd }}$ June 1946.

${ }^{142}$ KNA: DC/KSM/1/19/270, NIFA to Chairman, Central Commodity Distribution Board, $14^{\text {th }}$ March 1950.

${ }^{143}$ KNA: DC/KSM/1/19/270, M.C. Kashap to Chairman, Central Commodity Distribution Board, $4^{\text {th }}$ March 1950.
} 
the three East African territories, it also served as a forum to express opinions and present petitions to the colonial government, the Colonial Office and the Government of India. ${ }^{144}$ The congress was also concerned about the economic affairs of Indians in the three colonies. ${ }^{145}$ Some of the interests included the colonial land policy. Thus the congress was active from its inception and in 1910 passed comprehensive resolutions on Indians in the colonies and especially attacked the segregation policy in the White Highlands. Thus we find that the congress also intervened to assist the Asian cane farmers in $\mathrm{CN}$ whenever they felt things were not right. For example, as early as 1931 the congress appealed to the colonial state to help the infant sugar industry by reducing the railway fright charges so as to encourage the farmers. During the same year when the cane farmers were affected by the locusts that destroyed the sugar crop, the congress asked the colonial government to help the farmers and also requested for the extension of government aid to the cane farmers by giving them the benefit of protective duty which by 1931 was already enjoyed by the European manufacturer, the Victoria Nyanza Sugar Company. ${ }^{146}$ The colonial government was reluctant to commit any funding to help the farmers.

During the same period, the EAINC also requested the colonial state to investigate and fix the price of sugar because the prices offered were far below the cost used in growing of cane. ${ }^{147}$ But even such a request was ignored. Unfortunately before the farmers could recover from the effects of locust visitation, there followed the prolonged drought of 1933, and the loss was overwhelming. Many farmers were frustrated and some even contemplated switching to grow other crops. However the change to other crops was not easy. They had to apply to the local agricultural credit board.

\footnotetext{
${ }^{144}$ Gregory, India and East Africa, 94.

145 Ibid.

${ }^{146}$ Ibid.

${ }^{147}$ KNA: PC/NZA/3/2/38, Resolutions Passed by the EAINC, 1931.
} 
Due to the problem and the bad status of the Asian farmers, the EAINC was forced to step in again and sent a petition to the colonial secretary stating the bad situation of the Asian farms at Kibos-Muhoroni. The congress suggested that the colonial government bail out the farmers by providing a subsidy or loan to help the farmers to replant. ${ }^{148}$ The colonial state adamantly refused to oblige on grounds that the loan would have no security. It was interesting to note how inconsiderate and racially biased the colonial officers were in the face of adversity. For example, the director of agriculture suggested that the only remedy that the farmers had was to persuade some Indian capitalist to erect a small factory. One wonders what a factory had to do with locusts' visitation. ${ }^{149}$ Thus we find that the Asian farmers were frustrated by such racial inclinations that were not helpful. As the racial tension continued to build up, the congress took charge and fought the anti-Indian attitude that the Europeans had adopted in misleading Africans that the Indian community wanted economic domination and should be resisted at all costs. ${ }^{150}$ This was important since the economic activities of Asians included cane farming.

However due to a turn of political events and with the independence of India in 1947, the political impact that saw the division of India and Pakistan unleashed bitter disagreement in Kenya between Hindus, Muslims and Sikhs in various organizations in Kenya. This affected the various groups including the cane farmers. For example, in November 1946, Shams ud Deen, a Muslim and once a staunch supporter of the Asian cane growers, not only resigned from the LegCo but also from Indian organizations due to disillusionment with division between Muslims and Hindus. ${ }^{151}$ Thus the congress was threatened with division among the members and focused

\footnotetext{
${ }^{148}$ KNA: DC/CN/1/4/5, K-LDAR 1936.

${ }^{149}$ Ibid.

${ }^{150}$ Seidenberg, Uhuru and the Kenya Indians, 33.

${ }^{151}$ Ibid., 58.
} 
more on politics. Hence we do not see much activity in helping the cane farmers from the early 1950s.

Due to such divisions in 1952, the congress became limited to Kenya where most of the leaders resided. It was renamed the Kenya Indian Congress which worked with affiliated Indian associations in Nairobi, Mombasa, Nakuru and Kisumu. ${ }^{152}$ Consequently by the mid- 1950s, the Kenya congress was focused more on politics and information in its support for Asian cane farmers during the period was scanty. Needless to say, we can argue that the congress assisted the cane farmers in every possible way it could. Also it managed to forge solidarity for a long time that was much needed for the Asian economy to survive. However, other local organizations such as the Kibos Planters Association stepped up also in helping the cane farmers.

\section{Kibos Planters Association}

The Kibos Planters Association, formed in early 1930s, was a very active advocacy group that also made efforts to back issues for its members in solving some of the problems. For example, the association in 1934 challenged the proposed Government Notice No 619, which was meant to regulate the sale and distribution of sugar. ${ }^{153}$ In particular the association opposed the fact that the sale of jaggery was to be by one individual and also challenged the colonial government arguing that the fixture of the price of cane must be governed by definite procedures that must provide a specific return to both cane growers and manufacturers alike. ${ }^{154}$ But the colonial state kept dragging its feet, as discussed earlier. It did not appreciate the economic importance of the sugar industry. The proposed bill appeared to cripple the prospects and aspirations of cane farmers. The bill was designed to protect the European manufacturers by making the monopolists reap enormous profits at the expense of the Asian cane farmers.

\footnotetext{
${ }^{152}$ Ibid., 15.

${ }^{153}$ KNA:PC/NZA/3/2/34, DC K-L to PC Nyanza,13 ${ }^{\text {th }}$ October 1934.

${ }^{154}$ KNA: PC/NZA/3/2/34, NIFA to DC K-L, $11^{\text {th }}$ October 1934.
} 
Moreover, when the Kibos Planters Association realized the seriousness of the cane transportation problem, the group requested the Miwani Sugar Mills to send lorries to help farmers out. Unfortunately, Miwani rejected the proposal, citing financial constraints, and the problem continued. ${ }^{155}$ From their experience negotiating with both the manufacturers and the state, the group realized that to have a strong bargaining front they needed support of all the cane farmers. To attain this, the planters first sought solidarity. Thus, in a meeting in 1953, they unanimously agreed that there should be compulsory registration for all sugarcane growers so as to attain a united front necessary for bargaining, which they were able to achieve. ${ }^{156}$

Other concerns that the Kibos Planters Association addressed included issues of pricing and cane transportation. They advocated that before any prices were arrived at, it was necessary for all stake holders to be involved in the discussion. This was important because in most cases both the farmers and the manufacturers were ignored before decisions were made. Thus to ensure that they were not taken advantage of, the members agreed to resist any efforts by manufacturers that could divide them with the purpose of exploiting them. This was important as it has emerged in earlier discussions that Asian cane growers were exploited by the European and Asian manufacturers alike as these occasionally refused to take cane whenever the farmers wanted and also offered low prices for cane.

The Kibos Planters Association, on behalf of growers, also challenged some of the regulations passed by the state. For example, when the legislation to control the production of jaggery was passed they petitioned the state to relax the regulations since altering the jaggery plants meant incurring losses. In 1953, they also requested for ample time to improve the jaggery plants that were found to be unhygienic. Due to the prolonged drought that impacted

\footnotetext{
${ }^{155}$ KNA: AK/11/30, PAO Nyanza to Member for Agriculture and Natural Resources, $2^{\text {nd }} 1952$.

${ }^{156}$ KNA: AK/11/51, Kibos Planters Association to DAO CN, $16^{\text {th }}$ April 1953.
} 
harvest, they had not enough capital then to embark on the improvement immediately. The request was granted due to the efforts of the DAO who saw the rationale of their arguments. ${ }^{157}$ The request shows how undercapitalization affected the cane farmers since they could not maintain their machinery as required.

Despite the numerous problems that the cane farmers faced, they remained resilient and continued to struggle to survive within a hostile colonial economy that necessitated the formation of the Kibos Farmers Association as a coping strategy. Thus like the other groups, we find that the Kibos Planters Association was involved with the activities of the farmers within its locality and contributed to the success of the industry.

\section{Conclusion}

The chapter has revealed that the Asian cane farmers experienced a lot of problems. It has also shown the role of the Indian agency through formation of different groups to solve the problems. These groups were found to complement each other and therefore helped the cane farmers. As a result of joint action, the Indian cane farmers were able to overcome some of the challenges. For instance, the problem of diseases was contained due to the cooperation of the cane growers and the quick response by the colonial state. Though most of the diseases were not completely eradicated, they were brought under control. Throughout the colonial period, the question on land for expansion continued to be a problem. However, the Asian farmers managed to collectively purchase land when available. On the other hand, the issue of inadequate funds continued to affect the farmers throughout the colonial period. It was not easy for the colonial financial institutions to finance the Asian cane farmers, and the Asian cane growers relied on Asian money lenders until Asian banks started operating in the region by the mid-1940s.

${ }^{157}$ Ibid. 
However, the problem was not solved as costs of production kept increasing and in most cases was not commensurate with the prices offered for cane, as such lack of capital continued to be a problem for the cane farmers throughout the colonial period.

The farmers were also able to solve some problems. For example, they were able to market jaggery successfully through the NFCS and even negotiate for better jaggery prices. Despite challenges of disposal, they were able to deal with the problem through collective withdrawal from delivering cane to the factory in the 1950s and producing jaggery instead. This not only saved losses, but also forced the manufacturers to accept cane. Other problems, such as the inability to get tractors to break land, were overcome through getting machines from a pooling resource on rotational basis. Therefore it emerges that despite the challenges the cane farmers had a clear view of what to do under the circumstances, they did not give up but resorted to help themselves in unfriendly colonial state. Thus through the various organizations that they formed, they were able to handle the problems the best way they could. Their determination and resilience saw them overcome many of the challenges and led the sugar industry to remain vibrant during the colonial period. 


\section{CHAPTER 9}

\section{SOCIAL AND ECONOMIC IMPACT OF ASIAN CANE FARMING IN COLONIAL NYANZA}

\section{Introduction}

The previous chapter discussed some of the challenges that the Asian cane farmers and the manufacturers faced. They had to contend with various issues which included, but were not limited to, lack of adequate finance, dumping of sugar and diseases. It also emerged that the colonial government stepped up and tried to solve some of the problems. The chapter also discussed how the Asian farmers made efforts to help themselves through the various organizations that they had formed or were affiliated to, such as the East Indian National Congress. Despite the challenges, the sugar industry was vibrant and solidly under Asian capital at the end of the colonial era in Nyanza.

This chapter seeks to evaluate the impact of this sugar industry among the local people, specifically at Kisumu and its environs. The impact of Asian sugar cane farming in colonial Nyanza had a tremendous effect on the region. These could be divided into economic and social transformations that took place in the area under review. Thus the chapter examines how Asian cane farming economically impacted the area. First, through the introduction of commercial cane farming that was adopted in earnest by the local African population which in turn led to social differentiation that started to emerge especially among the pioneer group of African cane farmers who were able to make great strides despite the slow take off. Commercial cane farming subsequently spread to other parts of the province and continued into the independence period. Secondly, it contributed to the introduction of wage labor. Thirdly, the Asian cane farmers were 
also responsible for influence on the African traders who became involved in the distribution of sugar in the African reserves.

The chapter also examines the social contribution of Asians in Kisumu and its environs, specifically the Asians role in education and health facilities and the provision of other social amenities that the Asian community provided for the local people as away of giving back to the community. The examination provides confirmation for Gregory's conclusion that the Asians obviously made positive and negative contributions to African progress; hence the pertinent

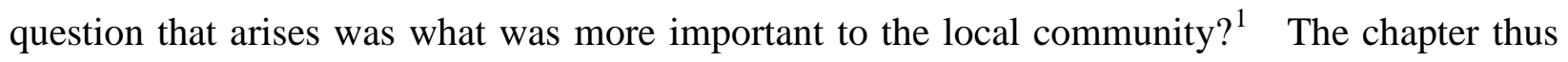
finally examines the negative impact brought along by the settlement of Asians in KibosMuhoroni and Asian sugar industry in $\mathrm{CN}$ as it contributed to the use of jaggery to make the illicit brew that led to problems in the African reserves.

\section{Asian Impact on Commercial Sugarcane farming: African Cane farmers 1930s-1963}

The settlement of Asians at Kibos led to the subsequent introduction of commercial cane growing that had a lasting effect the area. This commercial cane growing could be said to have impacted the area both positively and negatively in many ways. Nevertheless, we can argue that Asians contributed to the growth of commercial agriculture in colonial CN by pioneering in cane growing. This view is corroborated by Fearn who argues that the Asians contributed to the growth of the economy of Nyanza as early as 1930 due to the introduction of export crops such as sugar. Fearn contends that Asians aided the economy through experimentation of various crops. $^{2}$ In the African areas, plans for sugar development were contained in the Swynerton plan

\footnotetext{
${ }^{1}$ Gregory, India and East Africa, 497.

${ }^{2}$ Fearn, An African Economy, 106.
} 
of 1954, which provided for the development of a jaggery industry with a capacity of producing up to 2600 tons. $^{3}$

Be that as it may, sugarcane had been grown by the Africans, especially Nubians in Kibigori, who were influenced by Asians as early as the 1930s. For example, the Nubian communities in Lumbwa and Kibigori grew cane using the Kampala variety. However, the variety was found to be prone to Mosaic diseases. Furthermore, their problem was compounded by the fact that most of the Nubians were poor and could not afford the new varieties. They also were initially ignored and could not get access to the new resistant varieties that were being used by the Asian farmers. ${ }^{4}$

Other African communities in the neighboring regions, such as the Luos of $\mathrm{CN}$, also took to cultivation of sugar cane. However, the take off for the Africans in $\mathrm{CN}$ was a slow venture since most people regarded it as an "Asian crop." 5 Initially, the government was unsupportive about African cane farming. However, by the 1950s, the colonial state had changed its policy toward cane farming which saw numerous experimentations, as earlier discussed. Likewise, the new approach was geared towards encouraging African farmers to pick up cane farming so as to boost the sugarcane industry. Thus farmers were given free seeds and a subsidy. For example, in 1951 alone, the colonial government provided the African cane farmers with 150 tons of seeds. Unfortunately, the rains came late that year resulting in crop yields that were not very good. ${ }^{6}$ However, the first ratoon was better, and the African farmers in 1953 got approximately Shs. 8, 993/= from cane sold to the Miwani Sugar Mills. ${ }^{7}$

\footnotetext{
${ }^{3} \mathrm{KNA}$ : BV/14/401, Sugar growing in Nyanza.

${ }^{4}$ KNA: DC/KSM/1/19/270, AO Nyanza to Mycologist, Nairobi, $12^{\text {th }}$ August 1933.

${ }^{5}$ Thomas Okeyo, (O.I.), Kibos small scale farmer, July $3^{\text {rd }} 2009$.

${ }^{6}$ KNA: DC/KSM/1/3/22, Sugar Production Report 1954.

${ }^{7}$ Ibid.
} 
As more Africans became involved in commercial cane farming, the farmers around Chemelil formed a cooperative society in 1954 to assist in transportation of their cane to the factory. During the same period, the African cane growers managed to sell 130 tons of cane worth Shs. 5,163/= to the Miwani Sugar Mills. ${ }^{8}$ Due to encouragement by provision of free cane seedlings and subsidy on transportation, more Africans started growing cane in the area under review and in the rest of Nyanza generally. For example, by 1957 the number of African cane farmers in $\mathrm{CN}$ had increased to 47 who were registered in the cooperative society. They collectively cultivated 51 acres of land. ${ }^{9}$ By 1960 the area under cane grown by the African farmers in the area rose to 300 acres. There was significant growth since by 1963 farmers in East Kano location alone cultivated 700 acres of cane. ${ }^{10}$

Therefore, this trend shows that African farmers were taking to growing of sugar cane as a commercial crop. Due to cane farming some farmers prospered and even bought more land to cultivate sugarcane and employed workers, in most cases casual laborers, to help them. ${ }^{11}$ The entrance of Africans into cane cultivation brought prosperity to some people. Osamba's investigation revealed that one of the pioneer cane farmers, Eli Onyuro, prospered. He even bought more land and a tractor to intensify his cane farming, which proved rewarding since he not only educated his children but also built himself a good brick house. This was by no means a small achievement in the early 1960s. ${ }^{12}$ With this example in mind, we can argue that with commercial cane farming, social differentiation began to emerge among the Africans in CN. The beginning of cane growing by Africans also led to competition, especially with the Asian small scale cane farmers who now had to compete with the African cane farmers for labor and in

\footnotetext{
${ }^{8}$ Ibid.

${ }^{9}$ Osamba, "Colonial African Labour”, 166.

${ }^{10} \mathrm{KNA}$ : DC/KSM/1/3/32, African Cane Production, 1963.

${ }^{11}$ Osamba, “Colonial African Labour”, 167.

${ }^{12}$ Ibid.
} 
production and marketing of jaggery. The competition caused the NFCS to request the colonial administrators in the district to allow a scheme of joint marketing of jaggery with African cane producers. The request was turned down on grounds that there was a special board that handled only African produce. ${ }^{13}$

Despite the fact that Africans picked up commercial cane farming, the number remained small. There were factors that could be said to have contributed to this. First, there was the fact that sugar cane took long to mature as compared to grains like maize that matured within a short while. Maize was also very marketable. Secondly, transportation was a huge problem; potential African farmers shied away as it was difficult to get cheap reliable means of transport to ferry their produce to Miwani especially for cane growers who were far from the factory.

Despite all this, we find that the success of the Asian cane farming in colonial Nyanza continued to attract many peasant producers. After independence many Africans took to cane farming in CN. For example, the number of African small scale farmers increased, and by 1964 such cane growers were organized into 4 zones: Mitete, Chemasis (both in Nandi) settlement scheme, and Luoland. The Luoland area was further divided into God-Abuoro and Songhor zones. ${ }^{14}$ Some of the small scale farmers had as little as one acre of cane. ${ }^{15}$

Moreover, the Kenya government, in its endeavor to attain self-sufficiency in sugar production, inaugurated the Muhoroni scheme where commercial cane farming began in earnest. The government went further and established another factory, the East African Sugar Industries (Muhoroni), in 1966. It was funded in conjunction with international capital. Another factory, the Chemelil Sugar Company, was established in $1968 .{ }^{16}$ The establishment of these two

\footnotetext{
${ }^{13}$ KNA: BV/14/401, Hughes-Rice to PS Ministry of Agriculture, $12^{\text {th }}$ May 1959.

${ }^{14}$ Grace Nandi, (O.I.), $4^{\text {th }}$ July 2009.

${ }^{15}$ Ibid.

${ }^{16}$ Nasongo, “Multilateral Imperialism”, 57.
} 
factories enhanced commercial cane farming in $\mathrm{CN}$ as they served the areas that were hard hit by transportation problems during the colonial times due to distance from Miwani Sugar Mills.

Although the independent state had plans to develop the sugar industry in CN by giving land to the poor people in the scheme and encouraging commercial cane farming, unfortunately, like its predecessor the colonial state, its policies were contradictory. This was found when many rich people employed far from the scheme also got land. These straddlers operated as absentee landlords leading low productivity of the land. ${ }^{17}$

Be that as it may, we find that commercial cane growing expanded to the rest of Nyanza as Africans in areas such as Konyango, Sare and Oyani in South Nyanza started cane farming. Meanwhile, in North Nyanza commercial cane farming also started in Kakamega, MumiasWanga and Kabras. In these areas, the climate was more conducive, and African cane farming progressed quickly so that by 1957 the farmers were demanding their own factories. According to the Director of Agriculture, L.H. Brown, efforts were being made to attract outside capital for such ventures. ${ }^{18}$ Thus from such a humble beginning of commercial farming by Asian in KibosMuhoroni and Nyanza generally and Kibos-Muhoroni in particular was transformed into a thriving sugar belt. This portrayed the potential of cane farming in Nyanza that the colonial Government had failed to grasp as important to the economy of the whole country.

\section{African Wage Labor}

The Asian cane plantations employed many African people as already discussed in the preceding chapter. Most laborers in the sugar plantations came from the neighboring reserves. As early as 1923, Africans were found to be working in the sugar farms and also at the Victoria Nyanza Sugar factory where approximately 1,500 Africans were employed on a monthly

\footnotetext{
${ }^{17}$ Grace Nandi (O I) $4^{\text {th }}$ July 2009.

${ }^{18}$ KNA”AK/11/52, L. H. Brown to Registrar of Co-operative Societies, 23 ${ }^{\text {rd }}$ December 1957.
} 
contract. $^{19}$ Thus we can argue that the introduction of the Asian commercial sugar cane farming introduced a labor market and set in pace the process of turning some Africans into wage laborers.

Needless to say, as the sugar industry expanded, more opportunities emerged for Africans to join wage labor. For example, in 1927, additional Africans joined the labor force at work on the new Nottidge and Allen sugar plantation and factory which employed 400 laborers. By 1928 the total number employed at the two large estates was approximately 2,000. ${ }^{20}$ Over the years, other challenges made the Africans to seek wage labor in the sugar industry. For instance, it was found that during the depression many people ventured into wage labor as the prices of commodities fell. The effect of the depression and famine caused by locusts in early 1930s had great influence on workers to enter the labor force. The NADAR for 1933 indicates that the effects were so severe that people came out on their own. The sugar factories no longer had to rely on the professional recruiting agents. ${ }^{21}$ Those who secured employment were able to pay taxes and eased their burden because during the depression taxes were collected vigorously to increase the government revenue that had dwindled. ${ }^{22}$

Thus the colonial state had to tax the Africans more. For example, Kanogo argues that by 1930, Africans in Kenya generally contributed about 37\% of the colony’s total revenue through taxes. $^{23}$ This view is shared by Swainson who reveals the colony's debt became increasingly a burden to the colonial administration in 1930 as the CO gave minimal support. ${ }^{24}$ Thus most of the revenue had to come from within the colony. As such the taxes were collected indirectly

\footnotetext{
${ }^{19}$ NADAR 1923, 28.

${ }^{20} N A D A R$ 1928, 99.

${ }^{21}$ NADAR 1933, 129.

${ }^{22}$ Ibid.,122.

${ }^{23}$ Kanogo, "Kenya and the Depression”, 116.

${ }^{24}$ Swainson, The Development of Corporate Capitalism, 23-24.
} 
through customs and exercise duty and through Local Native Councils. (LNC) Therefore, we can argue the taxes paid by the workers especially in the form of LNC levies in 1930s helped to sustain the local government in $\mathrm{CN}$ through provision of basic needs such as education.

Furthermore, as maize was the mostly grown crop by the peasants, the collapse in maize prices during the depression affected many households. According to Kanogo, the price of maize fell by $50 \%$ in 1931 which led to a reduction in household incomes. ${ }^{25}$ Yet the Africans still had to meet their tax obligations. Thus by 1934 the number of Africans seeking employment was still on the rise. For example, Muhoroni increased the number of its laborers from 400 to 500, while the small scale sugar cane growers were found to have engaged between 600-700 laborers ${ }^{26}$ Thus on the average it translated into approximately 2,500 Africans employed in the sugar industry annually. Those who secured employment in Asian and European farms during the depression of the 1930s benefited. For example, such engagement offered the Africans the opportunity not only to diversify the family's source of income, but also to act as a safety valve, especially the during fall in commodity prices and during the famine period. Hence the low market prices for maize during the period made wage labor to be more viable in supplementing the household income during the difficult times. Thus wage labor kept on increasing as the sugar industry expanded. For example, by 1947, Miwani alone had a labor force of about 4,200 workers, while by 1960 Miwani had employed approximately 4,700 laborers as it moved into the new phase of producing refined sugar. ${ }^{27}$

As the colonial era wore on, many Africans sought wage labor as the pressure on land increased. For example, at the prime of the industry by 1960, it was estimated that the large

\footnotetext{
${ }^{25}$ Kanogo, “Kenya and the Depression”, 116.

${ }^{26}$ NADAR 1934, 174.

${ }^{27}$ East African Standard, 25 ${ }^{\text {th }}$ July 1960.
} 
scale and small scale farms employed approximately between 5,000-8,000 Africans annually. ${ }^{28}$ There were other reasons that led to this. First, there was the fact that weather was erratic and so employment was seen as security when crops failed. Secondly, wage labor was seen as a source of accumulation which was important to meet the family obligations such as dowry payment. This view is supported by Hay who postulates that the Africans saw agriculture as a means of subsistence while many entered wage labor as a source to accumulate wealth. ${ }^{29}$

Therefore, it emerges that wage labor contributed significantly in enhancing the economy of CN because monies sent home to relatives from wages earned led to intensification of peasant farming through purchase of farm implements. The contribution of wage labor to household economies also led to the expansion of trade in $\mathrm{CN}$ as peasant farmers within the region felt motivated by the opportunity of a ready market. Hence they produced more and sold the produce to the large estates for rations that were needed for the laborers. Thus the sugar industry could be said to have increased the volume of local trade as there was money circulation and the purchasing power of Africans increased. Thus we can argue that that the introduction of wage laborer acted as stimuli for both trade and peasant production. The remittances, as acknowledged by Fearn, indeed were significant as these not only supplemented peasant household income, but also provided capital for expansion of trade as well as a means of wealth acquisition and accumulation. ${ }^{30}$

\section{African Sugar Traders}

A particular economic activity that emerged due to the sugar industry was that of distribution and sale of sugar. Trading was introduced by the Asian cane growers. During the

\footnotetext{
${ }^{28}$ Chanan Singh, (O.I.), 26 ${ }^{\text {th }}$ July 2009.

${ }^{29}$ Margaret Jean Hay, “Economic Change in Luoland: Kowe, 1890-1945”, Ph.D. Dissertation, University of Wisconsin, 1972, 226-230.

${ }^{30}$ Fearn, An African Economy, 55.
} 
period when sugar cane crops were destroyed due to effects of locusts and drought, especially in the early 1930s, many small scale Asian farmers resorted to being petty traders on their farms. They sold sugar and other goods to the Africans in the reserves. African traders picked up from the Asian hawkers and became involved in the sale and distribution of sugar in the African reserves. ${ }^{31}$ These hawkers were issued with licenses by the CN African District Council, and their activities threatened other African shopkeepers in the market centers. ${ }^{32}$ As discussed in the preceding chapters, African sugar traders were scattered in different market centers in various locations. Eventually, the traders stopped hawking and erected stalls to sell sugar in various market centers. Over the years, the numbers of such African traders increased and many were members of the Nyanza African Chamber of Commerce which was concerned with the interests of the African traders. For example, by 1957, the chamber sent a petition to the DC highlighting the plight of the African sugar traders in Chemelil and East Kano who were experiencing difficulties in getting their sugar allocation to supply the African consumers in the area. ${ }^{33}$ Moreover, archival sources indicate that many Africans were involved in the sale of sugar in various markets in different divisions and locations. The data presented for Alego in Table 9.1 provides a good example.

\footnotetext{
${ }^{31}$ KNA: DC/KSM/1/3/57, DC CN to Senior Health Inspector, $2^{\text {nd }}$ November 1956 . Hawking is referred to here as the selling of goods by moving from place to place.

${ }^{32}$ KNA: DC/KSM/1/3/58, Nyanza African Chamber of Commerce to DC CN, 23 $3^{\text {rd }}$ January 1958.

${ }^{33}$ KNA: DC/KSM/1/3/57, Nyanza African Chamber of Commerce to DC CN, $4^{\text {th }}$ February 1957.
} 
Table 9.1: Sugar Traders in Alego Location, and the monthly allocation, May 1954

\begin{tabular}{llc}
\hline Trader & Market & $\begin{array}{c}\text { Bags allocated } \\
\text { per month }\end{array}$ \\
\hline Samson Omondi & Boro & 1 \\
Silvanus Omondi & Boro & 4 \\
Joseph Munjal & Boro & 2 \\
Philip Owira & Boro & 1 \\
Mkulo Ogaye & Boro & 2 \\
Thomas Okelo & Mwer & 1 \\
Okoth Odhiambo & Mwer & 1 \\
Andrea Olute & Rabar & 1 \\
Omondi Ayika & Rabar & 1 \\
Ambiro Abworo & Nyawita & 1 \\
Nikodemo Osiemo & Hawinga & 1 \\
Patris O. Otip & Kadenge & 1 \\
N. Okumu & Bar Olengo & 1 \\
Kuandia Wambiya & Siaya & 1 \\
Wanyande Nyakoko & Siaya & 1 \\
Odiedo Agola & Siaya & 1 \\
Alois Liewa & Barding & 1 \\
Nyanja Onyango & Barding & 1 \\
Joseph Mboha & Randago & 1 \\
Modi Ochodo & Randago & 1 \\
Mrs. Roda Obuogo & Ngiya & 1 \\
Joel Obare & Ngiya & 1 \\
Naphtali Opiyo & Ngiya & 1 \\
Arthur Oduor & Umala & 1 \\
Marselus Rajula & Nyagoma & 1 \\
Samuel Oloo & Nyagoma & 1 \\
Gideon Odera & Nyalgunga & 1 \\
Harmanus Adhiambo & Uranga & Total \\
\hline & & 34 bags \\
\hline
\end{tabular}

Source: KNA: DC/KSM/1/3/58, Increased Sugar Allocation Alego Location, 1954.

The above data shows that there were many African traders in Alego location alone. The table shows that Alego location, by 1954, had 28 Sugar traders among who was one woman, Mrs. Rhoda Obougo. However the distribution was good since there were sugar traders in almost all the markets and trading centers in the location. This data is significant since it gives a 
clue to the fact that there were many traders in the various divisions of CN. Going by the numbers of Alego sugar traders alone, one can deduce that indeed many Africans were involved in the sale and distribution of sugar in the African reserves.

Needless to say, it also emerged that the sale and distribution of sugar was hampered by limited working capital to buy sugar. Not all traders could buy large amounts. Many African customers suffered from lack of sufficient sugar supply. ${ }^{34}$ This necessitated the location councils to intervene when shortages were biting. For example, in 1957 the Seme Location Council was forced to replace the former sugar distributor with Mr. Josephat Amolo who had sufficient funds to facilitate distribution. ${ }^{35}$ During the same period in the same location, shortages were so acute such that the DC was obliged to increase sugar allocation with an additional fifty-two bags. ${ }^{36}$ Despite these difficulties, it is clear that African traders were involved in the distribution of sugar, having been influenced by the Asians who used to hawk it in the African reserves.

By late 1950s there were over 200 African sugar traders in CN. However there were some retailers found in the African reserves that were allocated sugar but failed to take up full allocations as indicated from the returns of January 1958 in the following table.

\footnotetext{
${ }^{34}$ KNA: DC/KSM/1/3/57, D O Maseno to D C CN, 26 ${ }^{\text {th }}$ February 1958.

${ }^{35} \mathrm{KNA}$ : DC/KSM/1/3/57, D O Maseno to D C CN, $13^{\text {th }}$ December 1957.

${ }^{36}$ KNA: DC/KSM/1/3/57, A. G. Pearsall to D. K. Hindocha, $19^{\text {th }}$ December 1957.
} 
Table 9.2: African Sugar Distributors-Uncollected Sugar, Jan 1958

$\begin{array}{lrlrrr}\text { Traders } & \begin{array}{c}\text { Permit } \\ \text { No. }\end{array} & \text { Location } & \text { Amount Uncollected for 3 Months } \\ & & & \text { Nov } & \text { Dec } & \text { Jan } \\ \text { Eliakim Mbalo } & 45 & \text { East Kano } & 57 & 27 & 30 \\ \text { Josephat Abwao } & 44 & \text { Seme } & 56 & 56 & 105 \\ \text { Tolo Achola } & 170 & \text { West Kano } & 3 & 2 & 7 \\ \text { Christopher Owiro } & 48 & \text { Kisumu } & ---- & 8 & 8 \\ \text { Jason Okeyo } & 160 & \text { Asembo } & ---- & ----- & 3 \\ \text { Ojwang Warinde } & 57 & \text { South Ugenya } & ---- & 4 & 13 \\ \text { Elisha Wagade } & 49 & \text { Kisumu } & 4 & ----- & 9 \\ \text { Benjamin Alouch } & 53 & \text { Kajulu } & 22 & 16 & 9 \\ \text { Fresto Ogindo } & 168 & \text { West Kano } & 23 & 13 & 10 \\ \text { Naftali Otiende } & 47 & \text { Kisumu } & ----- & 2 & 19 \\ \text { Amwata Onono } & 55 & \text { Nyakach } & 11 & ----- & 21 \\ \text { Nicholas Okoth } & 43 & \text { Alego } & 6 & ---- & 21 \\ \text { James Owek } & 46 & \text { Kisumu-lela } & ----- & 20 & ----- \\ \text { Jairo Mbume } & 2 & \text { Samia } & 1 & 1 & 1 \\ \text { Kusa Trading } & 59 & \text { Asembo } & 6 & 6 & 6\end{array}$

Source: KNA: DC/KSM/1/3/58, Extract from the letter from the DC CN, to District Officers, Ukwala, Maseno, Bondo, Winam and Nyando, $20^{\text {th }}$ February 1958.

The above data shows how some African traders rarely picked all the allocation. The table shows that the collectors with the biggest drop were Eliakim Mbalo, Josphat Abwao and Naftali Otiende while on the other hand those who performed well Jairo Mbume, Tolo Achola Jason Okeyo and Kusa Trading. The data shows that between November 1957 and January 1958, 606 bags were not collected. ${ }^{37}$ These uncollected allocations impacted distribution in the sense that the consumers did not get the sugar and the holding wholesale stores also had to deal with the problem of storage.

The reasons for failure in collecting sugar allocations by the African distributors were varied. The majority cited limited capital as the main reason for reducing their stock. This was because the majority relied on whatever capital they had at hand to make the purchases.

\footnotetext{
${ }^{37}$ KNA: DC/KSM/1/3/58, DC CN to DOs: Ukwala. Bondo, Maseno, Winam, and Nyando, $20^{\text {th }}$ February 1958.
} 
Secondly, it emerged that some of the African distributors were frustrated due to difficulties encountered in transportation of the sugar from the stores to their shops due to bad roads, especially during the rainy season. Furthermore, their problem was compounded due to lack of their own vehicles. When traders constantly failed to collect their allocation, the DOs had the prerogative to reduce the allocation of an area or dealt with it by reallocating sugar to traders within those divisions who had the capacity and were more efficient in distribution.

African involvement in the sale and distribution of sugar thus was not without problems, but it was significant as it provided an important economic support to people in CN. It was an alternative source of income to the households. Those involved in trade could use the resources to meet family obligation such as paying taxes, school fees and even expand agriculture through acquisition of better tools from the monies got from trade. Furthermore, it could be argued that the Asian sugar industry through its influence on the sale and distribution of sugar in the African reserves also facilitated the adoption of new diets among the people. Many people started taking tea instead of porridge or used both.

\section{The Social Impacts of Sugar Cane Growing in Nyanza}

Asians also contributed immensely to social aspects in Kisumu. The monies that they got from cane sale, they joined hands with their brothers running shops in Kisumu and put up social amenities such as schools, hospitals, social halls, various club facilities, and their various temples. They also introduced new architectural designs of building houses. However, one of the most valuable services which the Asians offered to the people of Kenya was the numerous libraries and reading rooms in major towns including Kisumu. Some of these libraries started modestly in small rooms to become big reading rooms. Some were turned into institutions that hosted functions. 


\section{Contribution towards Education}

In the early years of the colonial rule, the colonial state did not pay much attention to the educational needs of the growing Asian population. Thus the Asians, specifically the Hindus, stepped in and made plans to educate their children. ${ }^{38}$ The Asian schools adopted not only a religious but also a linguistic pattern. ${ }^{39}$ This was not evidence of Asian disunity but rather portrayed more of their religious inclinations. Therefore, when schools were built, religious education linked with vernacular languages became a major consideration. By 1920, a number of Asian schools had been opened in Kisumu, and owing to the deep seated religious differences of the various sects, many schools initially began and were run on sectarian basis.

At Miwani there was a small Indian school that operated at a building constructed by the Sikh farmers of the area. At Muhoroni the school was built by public contributions, and the colonial state initially paid half of the teachers' salary. ${ }^{40}$ However, in CN most of these schools were concentrated at Kisumu town. Even the Asian farmers at Kibos-Muhoroni preferred to send their older children to school in Kisumu. Some of the schools built in the district included the Arya Samaji Girls School that by 1936 had staff of one principal and three teachers. The school had an average of 61 Indian girls, and provided education from sub-standard A to standard 6. The media of instruction were Hindi and English. By 1938 another school, the Siri Guru Singh Sabha Girls, was operational and had approximately 35 girls and 2 teachers with classes going up to standard 5. The medium of instruction in this school was Gurmukhi. ${ }^{41}$ The school in 1938 was able to get a grant in aid amounting to 59 pounds from the colonial

\footnotetext{
${ }^{38}$ Hollingsworth, The Asians of East Africa, 151.

${ }^{39}$ KNA: PUB/1/1/6, EAINC Paper "New Plans to blot out the very Existence of Indians”,53.

${ }^{40} \mathrm{KNA}$ : PC/NZA/3/22/1/8, Report on a visit to Indian farms 1948.

${ }^{41}$ KNA: DC/CN/1/5/4, K-LDAR 1938.
} 
government. ${ }^{42}$ Other grants and donations were received from rich people within the Asian community. Other schools got external support. For example, schools built by the Ismaili Khoja sect got grants from His Highness the Aga Khan. ${ }^{43}$ These grants were instrumental in the building and maintenance of schools in Kisumu town such, as the Aga Khan nursery school and the Aga Khan Girls School which had their own premises. The latter school was by far the best in Kisumu; it had 5 teachers and approximately 65 students. They performed well in the junior Cambridge examinations. The medium of Instruction was Gujarat up to standard 5, and the upper classes used English. Also there was the Ismilia Girls School which was also managed by the H. H. Aga Khan Education Board and provided education to approximately 65 pupils belonging to the Khoja sect; it and had 4 teachers and was housed in a former hostel.

Apart from the Asian owned schools there was also the Government Indian School in Kisumu that was the largest of all. The school was housed at the Sikh Library and the Sanatan Hindu Union Building at an annual rate of £252. This was a boy’s school and provided education for Asian boys of all denominations. Due to lack of schools for the Christian Goan children, 15 Goan boys and 2 girls were admitted also in the school in $1936 .{ }^{44}$ At the time, the school included classes from sub-standard (nursery) to elementary. This school had approximately 211 pupils whereas the primary section had 79 pupils and Secondary 10 in 1938. Here the medium of instruction was English from standard 1 upwards. ${ }^{45}$ This school introduced hockey, cricket and scouting among its activities.

Meanwhile, Asian Muslims also had their own school in Kisumu which was open to Arabs and African Muslims. It was housed in a building owned by the Moslem Association

\footnotetext{
${ }^{42}$ Ibid.

${ }^{43}$ Hollingsworth, The Asians of East Africa, 151.

${ }^{44}$ KNA: DC/CN/1/4/5 K-LDAR, 1936.

${ }^{45}$ KNA: DC/CN/1/5/4 K-LDAR, 1938.
} 
during the 1930s, and the furniture was donated by the Muslim community. It had a total of 91 boys in 1936, among them 17 Arabs, 3 Somalis with the rest Asians and few Muslim Nubians. ${ }^{46}$ The boys here were taught the Koran, Arabic and arithmetic. ${ }^{47}$ These separate Asian schools benefited from a healthy and friendly rivalry that led to improvement of both the facilities and the academic performance. ${ }^{48}$

It is clear that in colonial Nyanza Asians left a land mark in the various schools that they built. Although these schools were initially meant for Asian children, as independence approached they were opened to a few African students. The Asians contributed to building of schools not only by collecting monies and building materials. Among them contribution towards social welfare was considered as a duty owed to their gods and fellowman. ${ }^{49}$ The Asians had a belief that it was honorable for a person to sacrifice his own comfort and donate money and time

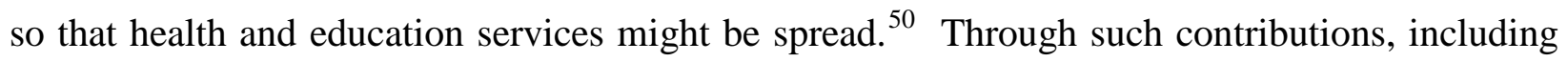
the buying of books and stationary and payment of other fees that were levied in schools, the Asian cane growers and manufacturers in the Kibos-Muhoroni area by extension could be said to have contributed to the building and maintenance of schools as most of their children attended schools in Kisumu especially at the upper primary and the secondary level. With the political transformations at independence, these different Asian schools eventually were opened to all races. ${ }^{51}$ Today the schools which are operational, especially those built in Kisumu, are among the best performers in the area.

\footnotetext{
${ }^{46}$ KNA: DC/CN/1/4/5, K-LDAR, 1936.

${ }^{47}$ Ibid.

${ }^{48}$ KNA: PUB/1/1/6, EAINC Paper "New Plan to blot out the very Existence of Indians”,54.

${ }^{49}$ Ibid., 52.

${ }^{50}$ Ibid.

${ }^{51}$ Ibid., 54.
} 


\section{Contributions To Health Facilities}

The Asian initiative of offering of social services in medicine began during the depression period due to the need created when some Asians living in major urban centers like Nairobi and Mombasa lost their jobs while others had businesses that had collapsed. To address such problems the Asian community came together, especially in the major towns of Nairobi, Mombasa and Kisumu, and formed a voluntary organization known as the Social Service League in early 1930s. ${ }^{52}$ The league provided assistance during the depression which included medical help where trained Asian doctors in the various towns offered their services to the affected people freely, while medicine was donated by the league. This social service soon became permanent as Asians were contributing towards it, and soon afterwards the league opened dispensaries and hospitals in various parts of the country, including Kisumu. ${ }^{53}$

Therefore, the Asians used their money to build clinics and hospitals that served even the local communities before independence. The community continued to expand the medical facilities; by the late 1950s, Aga Khan Hospitals opened in Nairobi, Mombasa and Kisumu. Initially serving Asians, these were later opened to the public. Delf argues that specifically the Ismailia community set an excellent example in providing medical facilities. ${ }^{54}$ Another hospital was also built by the Indians in Kisumu. This was the Jalaram Nursing Home which was built partly by funds donated by two brothers; Sheth Haridas Chhagnal and Morzaria Chhagnal of Messrs Haridas Chhagnal Ltd of Kericho, who donated Shs. 5,101 towards the building cost in

memory of their father. ${ }^{55}$ The opening of the nursing home was performed by Devjibhai Karmshi Hindocha, the manager of Miwani Sugar Mills, on $4^{\text {th }}$ April 1948. Later, in 1957, the

\footnotetext{
${ }^{52}$ Ibid.

${ }^{53}$ Ibid.

${ }^{54}$ Delf, Asians in East Africa, 47.

${ }^{55}$ Vajv Sundra, (O.I.), $5^{\text {th }}$ July 2009.
} 
Miwani Sugar Mills and the Hindocha family trust donated Shs. 25,000/= and 10,000/= respectively to the nursing home. Meanwhile, the Guru Nanak Dispensary was built in Kisumu by the Siri Guru Singh Sabha fraternity. ${ }^{56}$

Thus we can argue, by extension, that capital accrued from the sugar industry led to the construction and maintenance of some hospitals in Kisumu and its environs as demonstrated by the donations to the Jalaram Nursing home by D. K. Hindocha a renowned sugar manufacturer and the trust fund he established. These health facilities were later to benefit the Africans and other races in CN as well as people living in Nyanza Province.

\section{Social Halls and Architecture}

The Asians also put up buildings in Kisumu which also could be said to have introduced new architectural design in the area. The communal buildings were erected by the different castes. It is in these buildings where some of the early schools were housed such as Siri Guru Singh Sabha and Sanatan Hindu Union; the schools rented the buildings annually at a rent of 252 pounds. ${ }^{57}$ The Asians living in Kisumu and its environs also built sports clubs such as the Sikh club, Simba club and the Goan institute where various sporting events took place. Thus we find that the Sikhs, who were mostly the farmers at Kibos, invested their hard earned money in putting up social amenities where they could spend leisure time after hard work on the farms. ${ }^{58}$ These venues have continued to serve all races after independence as socializing places.

During the year 1938, a significant Asian activity included the erection of the Kisumu clock tower by the family of the late Kasim Lakha. The tower was presented to the Kisumu council in his memory. This clock tower was unveiled by the Duke and Duchess of Gloucester. ${ }^{59}$

\footnotetext{
${ }^{56}$ Ibid.

${ }^{57}$ KNA: DC/CN/1/4/5, K-LDAR 1936.

${ }^{58}$ Mohinder Singh, (O.I.), $26^{\text {th }}$ July 2009.

${ }^{59}$ KNA: DC/1/5/4, CKDAR 1938.
} 
There were also various social halls that were built to host functions such as parties and wedding ceremonies, for instance, the Simba club. ${ }^{60}$ Most of these halls at independence were opened to all races and are used as recreation facilities. Other halls were built by the Asian community as donations to institutions in the area. For example, when Siriba teachers college was built, Asians, courtesy of the Hindocha Trust, built the expansive beautiful Hindocha Hall as a way of giving back to the community. This building is now part of Maseno University. ${ }^{61}$

The assessment of the Asian contribution in Kisumu and its environs would not be complete without mentioning the type of architecture that emerged in Kisumu. Thus we can argue that cane farmers and producers, also by extension, contributed to the new architectural design of making houses that emerged in Kisumu since many were found to have invested in building of residential houses around Kisumu and Kibos. Many who had children schooling in Kisumu built such houses and settled part of their family there to avoid traveling long distances daily to school. ${ }^{62}$ The designs were oriental style whereby many rooms are built within an enclosed wall with a main entrance. For example, Vajv Sundra, a resident of Kisumu town, still lived in the family house in Kisumu where he was born in 1945. His grandfather was the first to arrive in Kenya with the coolies who built the Kenya-Uganda railway while his father came later to Kisumu in 1924. They both worked for the Victoria Nyanza Sugar Company in 1930s as skilled workers; later they moved to Kisumu and started body work for vehicles. Together the two were able to build the family residence in $1934 .{ }^{63}$ To date, the house is occupied by Mr. Vajv, his wife and mother; his children are grown and live in Britain and Canada. The Asian

\footnotetext{
${ }^{60}$ Vajv Sundra, (O.I.), $5^{\text {th }}$ July 2009.

${ }^{61}$ Mohinder Singh, (O.I.), $26^{\text {th }}$ July2009.

${ }^{62}$ Vajv Sundra, (O.I.), $5^{\text {th }}$ July 2009.

${ }^{63}$ Ibid. Vajv acknowledges that he is a Kenyan Indian proud of the fact. He says he only visits India the way he visits his children in America. Having been born, raised, educated, worked, and now ageing in Kenya, to him Kenya is home.
} 
housing style also influenced Africans who later copied the designs in building of rental houses in Kisumu and the neighboring areas such as Ahero.

\section{Social Interaction}

Socially Asians did not intermarry with Africans of CN nor were there any known liaisons such as those found among the Asians who settled in Zanzibar and Dar es Salam that gave rise to the jotawa, which was a derogatory term for Afro-Asians in East Africa. ${ }^{64}$ However, in the interior of Kenya, Bharati points out that the Sikhs, who came earlier from India with no wives and had lived and traded with the Maasai, were known to have established quasi- liaison relationships with Maasai women that produced children. ${ }^{65}$ But generally no interracial marriages took place, especially in the Kibos-Muhoroni area and its environs. However, this should not be misinterpreted as racial discrimination since Asians did not even intermarry among themselves due to the strict caste system. ${ }^{66}$ For example, when Tom Mboya once asked the Indian leader J. Nehru how he expected the Asians to be accepted in Kenya if they could not marry Africans, Nehru replied: "we do not even marry each other, why should we marry nonIndians.” ${ }^{67}$ Such sentiments showed how the Asians were a closed society within which interracial marriage was unimaginable. Moreover the Asians also believed that Africans were spendthrifts who could not handle money and goods properly; hence they were incompatible. Asians also looked down upon the Africans referring to them as kala kala, meaning "black black" $^{68}$ On the other hand, Africans also mistrusted Indians, especially when it came to trade. They also looked down upon the Asians and referred to their women as banyani and Sikhs

\footnotetext{
${ }^{64}$ Bharati, Asians in East Africa, Jayhind and Uhuru, 160.

${ }^{65}$ Ibid., 163.

${ }^{66}$ Ibid., 160.

${ }^{67}$ Ibid.

${ }^{68}$ Ibid., 159.
} 
generally as kalasingah (derived from Kala Singh). ${ }^{69}$ Despite this, the two communities lived in harmony in Kisumu and its environs.

\section{Negative Aspects of Asian Settlement}

Despite the prosperity brought by the sugar industry, it also impacted the area negatively. The negative impact included both social and economic areas. For example, the establishment of the Asian sugar industry led to more people being involved in wage labor at the expense of agriculture in the reserves, which suffered in turn. Not only did the absence of the male labor force impact agriculture in the sense that male labor was needed to clear virgin lands for cultivation. The women who were left at home had more tasks to do such as taking over the responsibility of looking after livestock that was traditionally a male domain. Moreover, some of the laborers were engaged on 3or 6 months contract, which duration was bound to affect agriculture especially during the farming season. These could also have led to instances where a piece of land was overused, leading to further problems of soil erosion.

It is generally recognized that $\mathrm{CN}$ was, during the colonial period, characterized by poor agricultural performance. Kitching gives an overview of the poor performance during the postwar period. For example, the author indicates that the production of food commodities, like maize, sorghum and eleusine, declined in CN between 1946 and 1951. His findings reveal that in 1946 the maize produced in CN was 4,690 tons and 272 tons of sorghum while in 1951 the District produced only 3,385 tons of maize and 107 tons of sorghum. ${ }^{70}$ Various reasons have been advanced by scholars for this situation. For example, Professor Anyang' Nyong'o argued

\footnotetext{
${ }^{69}$ Ibid., 169. The term Banyani has been used in some scholarship to refer to the Indian money lenders, especially those that were found at the coast.

${ }^{70}$ Kitching, Class and Economic Change, 132.
} 
that the absence of the labor force had devastating consequences on the African economy in $\mathrm{CN}^{71}$

However, the decrease in peasant production in $\mathrm{CN}$ during the postwar period could also be attributed to other factors. First, there was the decline in demand for the peasant produces as the war came to an end. The second reason, advanced by Maxon, was that of competition from Gusii peasant producers; it is more convincing. The Gusii highlands unlike, CN, have good ecology. Thus by 1946, the region produced large volumes of maize that was exported. ${ }^{72}$ This increase was due to the pressure from the colonial state that was eager to avert the ravages of food shortages. The farmers were also encouraged by the good market prices offered for maize that had shot up from Shs. $10 /=$ by the end of the war to Shs. $21 /=$ per bag in $1949 .^{73}$ Thus the higher prices of maize supported by good weather acted as an incentive to the Gusii peasant farmers who produced more for market. For example, in 1949 the Gusii had a record harvest of maize that was sold outside the district, a trend that continued over the years transforming Gusii highlands into a major exporter of maize. ${ }^{74}$ This in turn generated competition to the peasant farmers in $\mathrm{CN}$, which partly explains the decline in production there during the period.

Thus we can argue that the stiff competition from the Gusii and the erratic climate of Kibos-Muhoroni area that was prone to drought could have influenced many to seek alternative sources of income such as migrant labor which led to some land being underdeveloped. Due to alternative sources of revenue that made some people to be away from home and in turn reduced the acreage under cultivation, land became a commodity for sale. Consequently the value of land increased in the area under review as more Asian farmers sought land for expansion. For

\footnotetext{
${ }^{71}$ Anyang’ Nyong’o, “Middle Peasantry”, 108-109.

${ }^{72}$ Maxon, Going Their Separate Ways, 229.

${ }^{73}$ Ibid., 230.

${ }^{74}$ Ibid.
} 
example, the price of land at Kibos increased and by 1956; then an acre of land was sold between $£ 12-15 .^{75}$

We can also argue that the establishment of the Asian sugar farms in CN further impacted the area negatively, especially as the pressure of population began to be felt in the district by the 1940s. The Luo people needed land for expansion, contrary to Fearn's argument that the area around Kibos- Miwani was most suitable for cane farming. He viewed alienation of land to Asians as more beneficial to the area than if the Africans had the land for subsistence farming. ${ }^{76}$ Fearn forgot that it didn't have to be Asians alone getting the land for cane or that Africans could not have taken up to cane farming if given an opportunity with state support as was done for cotton farming in the district. Moreover, the occupation of the Asians on the fertile lands at the foothills of the Nandi Escarpment can be said to have denied the Luos of Kajulu the opportunity of expanding to the only fertile lands near Kajulu location as the population increased since their reserve was restricted to the much drier area. However, Fearn at least acknowledges that the Kajulu area became densely populated as a result of the alienation. ${ }^{77}$ This increase was significant as it contributed to land squeeze. For example, by 1948 Kajulu location registered the highest population density in the whole of $\mathrm{CN}$ district as indicated in the following table.

\footnotetext{
${ }^{75}$ KNA: AGR/6/4576, Sugar Production in Nyanza, 1956.

${ }^{76}$ Fearn, An African Economy, 105.

${ }^{77}$ Ibid.,
} 
Table 9.3: Distribution and Density of African Population CN District, 1948

\begin{tabular}{lccc}
\hline Location & African Population & Area in sq. miles & Density per sq. miles \\
\hline Alego & 55,859 & 211 & 265 \\
Asembo & 19,153 & 58 & 330 \\
Gem & 54,961 & 168 & 327 \\
Kadimu & 7,145 & 100 & 71 \\
Kajulu & 7,790 & 14 & 569 \\
East Kano & 36,601 & 155 & 236 \\
West Kano & 36,783 & 112 & 328 \\
Nyakach & 36,793 & 143 & 257 \\
Kisumu & 34,860 & 84 & 415 \\
Sakwa & 20,831 & 162 & 128 \\
Samia & 42,521 & 206 & 128 \\
Seme & 33,829 & 108 & 313 \\
North Ugenya & 33,930 & 103 & 329 \\
South Ugenya & 8,368 & 23 & 364 \\
Uyoma & 17,822 & 99 & 180 \\
\hline
\end{tabular}

Source: Fearn, An African Economy, 237.

The above data shows how Kajulu location had the smallest area compared to other locations in CN. The data also portrays how, on the other hand, Kajulu location had the highest population density per square mile by 1948 followed by Kisumu location. As such it can be argued that the land alienated to the Asians cane farmers in Kibos denied the Kajulu people room for expansion as their population increased and led to land squeeze over time. Furthermore, being a patrilineal society, sub divisions of land took place all male members of Luo households; hence land was scarce and household production was affected. Secondly, part of the alienated land at the foot of the Nandi Escarpment was the most fertile land in the area. It meant that the Kajulu people were denied an opportunity to have the best land for farming. Thus we can argue that land shortages resulting from Asian settlement affected peasant production and forced many people in Kajulu area to enter wage labor in Kisumu town and at the nearby Asian farms. ${ }^{78}$

\footnotetext{
${ }^{78}$ KNA: DC/CN/1/4/5, K-LDAR 1936.
} 
Another negative phenomenon that emerged was that of drunkenness that was prevalent in the African reserves. Asian farmers produced jaggery and used it to make their alcoholic drinks in small quantity, but it emerged that the farmers at Kibos sold jaggery to Africans who not only consumed it as sugar but also used it to manufacture Nubian gin. ${ }^{79}$ This view is also advanced by Gregory who argues that Africans learnt to manufacture jaggery which they used to make tembo (African local beer) from the Asians. ${ }^{80}$ Thus the colonial administration associated the sale of molasses and jaggery from the Miwani and Muhoroni factories to the drunkenness that led to lawlessness in the area under review as people engaged in brewing illicit drink. ${ }^{81}$ The problem was compounded by the fact that the youth, both male and female, started drinking too. Hence, it emerged by the 1940s that sale of the Nubian gin and other local brews were a major cause of problems in the African reserves. There was excessive drinking, especially at the Nubian settlement at Kibos, which was so popular that even Asians were found to be frequenting the drinking dens. This led the police to carry out raids in the area. ${ }^{82}$ Unfortunately, it was difficult for the police to make arrests and obtain evidence of sale of native liquor on farms because the Africans found in the drinking houses denied sale or purchase of the liquor since in most cases money was not exchanged. Payment was made later and many drank on credit. Such cunning frustrated the police efforts. ${ }^{83}$

The DCs were also alarmed at the increase of the consumption of the liquor by the Africans in the reserves. For example, in 1938 the DC of K-L district reported that young men had taken to more drinking than was the case ten years earlier and that the trade in liquor was

\footnotetext{
${ }^{79}$ KNA: DC/KSM/1/3/57, DC CN to PC Nyanza, $23^{\text {rd }}$ August 1954.

${ }^{80}$ Gregory, South Asians, 279.

${ }^{81}$ KNA: PC/NZA/3/15/142, PC Nyanza to Chief Secretary, $26^{\text {th }}$ March 1949.

${ }^{82}$ KNA: PC/NZA3/15/142, PC Nyanza to Superintendent of Police Nyanza, confidential, $18^{\text {th }}$ June 1946.

${ }^{83}$ KNA: PC/NZA/3/15/142, Superintendent of Police Nyanza to PC Nyanza, $7^{\text {th }}$ January 1938.
} 
flourishing. ${ }^{84}$ Then and later, it was found that large quantities of molasses and jaggery were purchased by the Africans from the Asian sugarcane farms. ${ }^{85}$ Hence measures taken by the administration to curb drinking included the restriction of the sale of jaggery to Africans, but even such a move was not effective since it was found that gin could also be made from ordinary sugar. Hence sugar started to be rationed in the reserve so that there would be no excess sugar that could be used to make the Nubian gin. ${ }^{86}$ Furthermore, the native tribunals heard many cases of drunken behavior, and even headmen stepped up and tried to prohibit the supply of liquor to unmarried males and females in an effort to control bad behavior, such as lack of respect by the young people some of whom started engaging in theft of livestock, that resulted from excessive drinking. ${ }^{87}$

The brewing of illicit drink was widespread in the African reserves all over $\mathrm{CN}$ which led to many problems. For example, in 1955 the DO of Bondo division lamented that there were a considerable number of assaults due to increased drinking of the Nubian gin manufactured in the division. According to the DO, the effect started to be felt after the increase in sugar allocation in the division. Through the DO's effort, the sugar allocation was reduced from 134 bags to 60 bags per month in the division so that there would be no excess for use in brewing. ${ }^{88}$

Moreover, the sale of Nubian gin not only offered competition but also interfered with the sale of licensed local beer. For example, licensed traders who had beer shops selling native beer complained that the manufacture of Nubian gin affected their business since most people went to the Nubian villages to drink even when the manufacture of it was prohibited by the

\footnotetext{
${ }^{84}$ KNA: PC/NZA/3/15/142, DC K-L to PC Nyanza, 29 ${ }^{\text {th }}$ November 1938.

${ }^{85}$ KNA: PC/NZA/3/15/142, PC Nyanza to Chief Secretary, $20^{\text {th }}$ January 1949.

${ }^{86}$ KNA: PC/NZA/3/15/142, Nubian Gin and Application of Sugar Ordinance to Central Kavirondo.

${ }^{87}$ KNA: PC/NZA/3/15/142, Chief John Paul Olola to DC CK, $21^{\text {st }}$ June 1948.

${ }^{88}$ KNA: DC/KSM/1/3/58, DO Bondo to DC CN, $4^{\text {th }}$ April 1955.
} 
colonial government. ${ }^{89}$ Thus the problem of excessive drinking in the reserves continued for a long period of time. The availability of jaggery and sugar for residents of CN obviously played a part in producing this problem.

\section{Conclusion}

This chapter has discussed the various impacts that the introduction of Asian sugar cane farming had in $\mathrm{CN}$, whereby it has revealed that there were both positive and negative implications of the economic and social impacts of sugar cane farming. Economically, the chapter concluded that the introduction of commercial cane farming in the area spread to Africans. Adoption by the Africans greatly improved their lot and led to the beginning of social differentiation in the area. This commercial cane farming continued to the independence period. It has also emerged that the sugar industry led to increased earnings from wages and earnings as those who could not cultivate the crop were involved as wage laborers on the sugarcane farms while some were distributors of the produce. The cultivation of sugar cane, wages and sale of sugar raised peoples' purchasing power which led to other benefits as the accumulated monies were used to increase peasant agricultural production through the buying of farm implements. Others purchased land while some met family obligation such as payment of taxes and dowry.

The chapter also examined the Asian contribution in the social spheres, whereby it demonstrated how they built schools, hospitals, health centers and social halls that benefited Africans and others in the region after independence. The Asians also contributed to the new architectural design that emerged in Kisumu.

Despite all these, there were negative consequences that included the land squeeze in the Kibos area which curtailed the African expansion specifically to the fertile area near the Nandi

\footnotetext{
${ }^{89}$ KNA: PC/NZA/3/15/42, Chief John Paul Olola to DC CK, $21{ }^{\text {st }}$ June 1948.
} 
Escarpment. Furthermore, land became a commodity for sale which led to some people being left with smaller portions of land. However, the most damaging impact of cane farming in $\mathrm{CN}$ was the use of jaggery to make the illicit drink that led to many problems such as drunkenness, lawlessness by the youth, assaults and stock theft. That said, we can argue that there was a lot of good that resulted from the introduction of the Asian commercial sugar cane farming in CN which was more important to the local community than these negatives.

The next chapter gives the summary of the findings and recommendations arrived at from the research and advances solutions that were viable then to the Sugar industry, in lieu of the possibility that they correlate to the current challenges to the sugar situation in Kenya today. This becomes necessary since the Industry has continued to suffer despite efforts from cane farmers. 


\section{CHAPTER 10}

\section{SUMMARY AND CONCLUSIONS}

The sugar industry in Western Kenya and Central Nyanza in particular has the potential to play a significant role in the country's economic development. However, the colonial government largely ignored the potential of the sugar industry. Secondly the sugar industry has also been neglected by the scholarly accounts of Kenya's economic history. This study set out to examine the neglect of the industry through the various historical epochs of the development of the Asian sugar industry in colonial Central Nyanza. The work has revealed the contradictory measures that were put in place that inhibited and spurred the growth of the industry at the same time.

The period analyzed starts in 1903 with the official inauguration of the scheme at Kibos which sets the pace of analysis through different historical epochs that led to the development of the sugar industry. It begins with the recognition that Asians moved into Kenya in different waves over a long period of time, settling first at the coast before they moved to the interior with the building of the railway. The eventual settlement at Kibos followed the completion of the Kenya-Uganda railway. From that beginning, the work examines the pre-World War I and the War period, the depression period, the World War II, the post war period leading to independence in 1963. The discussion of the pre-World War I period includes the beginning of Asian agriculture in Kenya when Asians settled in the Kibos area. It emerged clearly that the Asian cane farmers were discriminated against in land acquisition. This happened because of the politics of land in Kenya, instigated especially by the European settlers. Due to the politics of land, the Asians had no choice but to settle at Kibos which was not as fertile as the best lands in the White Highlands. Despite this, their settlement saw experimentation of various crops that 
eventually led to the genesis of commercial sugarcane farming in the area despite the fact that the indigenous economies existed.

As background, the study also provided detail on the indigenous economies in $\mathrm{CN}$ before the penetration of the Asian cane farming and capital. The description revealed the salient features of the African economies that were diverse and meant primarily for subsistence needs. It also revealed the abundance of land, its tenure system and the kinship mode of production that prevailed before the establishment of colonial rule and the penetration of the Asian capital in CN.

The study then details and analyses the agrarian and economic transformations that took place in $\mathrm{CN}$ with the growth of the Asian cane farming. In this analysis, the study employed the rational choice theory in order to interpret the Asian agricultural initiatives and the progress of the sugar industry. This explains the adoption of commercial cane farming over other crops, such as maize or sisal, and the use of the ox-plough to bring acres of land under cultivation. The Asian cane farmers made rational choices and utilized the available resources of land and labor to produce sugarcane in the Kibos-Muhoroni area. The Asians adapted to the hostile environment and changed the swampy mosquito infested area into a thriving sugar belt. By the early 1920s, the Asian commercial cane farming steadily progressed with the establishment of the European owned Victoria Nyanza Sugar Company that milled sugar. Hence, the Asian farmers started to produce for the market, and not only jaggery for home consumption, despite the fact that the colonial state neglected the Asian farmers and favored the European settlers through provision of state loans for breaking land. The study indicates clearly that the beginning of commercial cane farming was not easy as the colonial state discriminated against the Asian cane farmers through biased policies that prevented them from getting more suitable land. 
Moreover, the entrance of the European manufacturers revealed other forms of discrimination against the Asian cane farmers. The colonial state favored the European manufacturers who were granted a monopoly over sugar milling, and the colonial authorities repeatedly rejected the Asian request to erect their own sugar mill. Even when faced by the problem of disposal of their produce, the colonial government neglected the Asian cane farmers and did not intervene as the Victorian Nyanza Sugar Company not only refused to collect cane from the farmers but also exploited them by paying low prices for cane. These actions portrayed discrimination against the Asian cane growers by both the state and the European company, and it demonstrates the lack of appreciation of the potential of the sugar industry by the colonial government.

The study also identified economic changes that took place in $\mathrm{CN}$ with the establishment of the Asian sugar industry. Sugarcane farming facilitated the entrance of Africans into wage labor. The tax demands imposed by the colonial ruler forced Africans into wage labor on the Asian and European sugar plantations. As such the Africans were forcefully thrust into wage labor that later proved to be viable, especially due to the erratic climatic condition of the area that made it prone to drought and famine. Also wage labor provided a means for an alternative source of income to households in CN. However, in the colonial state's attempt to provide labor, especially to the settlers, salient issues, such as the undercapitalization of the Asian cane farmers, emerged. That undercapitalization made the Asian cane growers struggle to get labor as competition ensued from various quarters. Overall, the Asian farmers faced a very unresponsive state that also put in place discriminative policies that favored the settlers who took advantage of the World Wars to change the labor regulations. 
Labor also emerged as a key consideration during the great depression period. It presented a scenario where the peasant commodities collapsed so those in wage employment had an advantage. Nevertheless, the period saw many Asian and European farmers struggling to remain solvent despite the availability of labor. The early 1930s revealed how the colonial state once again failed to provide any subsidy, such as the GMR, to the cane farmers as it did to settler maize and wheat growers. Moreover, even credit facilities were not extended to the cane farmers through the land bank. The failure of the colonial state to come to the help of the cane farmers, who had land that could have been used as collateral, shows how the Asian cane farmers struggled to succeed in a hostile economic environment during the depression. It again depicted the lack of appreciation of the economic potential of the sugar industry as part of the wider colonial economy. Despite these difficulties and handicaps, the work showed that during the interwar period commercial cane farming had begun in earnest and progressed despite catastrophes caused by the locust visitations of the early 1930s.

The work also examined how, building on the foundation laid by 1940, expansion was witnessed during the World War II period. The account exposed the contradictory nature of the colonial state as it now supported intensification of cane farming as part of the wider colonial economy due to pressure from United Kingdom to fulfill the war needs. Hence, by the mid1940s there was rapid expansion of the sugar Industry. Expansion of planting and sugar production continued in the post war period as Asian capital penetrated the sugar manufacturing sector. The most significant manifestation of this saw the taking over of the Victoria Nyanza Sugar Company in 1947 by Hindocha. The Asian cane growers had experienced many frustrations from the unreceptive colonial state that had earlier favored the European manufacturers and denied the Asian cane farmers an opportunity to own milling factory. 
Therefore, the entrance of the Asian capital in manufacturing revolutionized cane farming and infused life in the sugar industry in $\mathrm{CN}$ as more Asian cane farmers were contracted to supply cane to the factory than when the Miwani mill was under European ownership. This expansion reached its peak by the mid-1950s as Asian cane farmers overcame some obstacles to establish a vibrant industry in Central Nyanza.

The success was also partly because of the colonial government's change of agricultural policy. This change took place by the mid-1950s as the colonial state realized the exploitative nature of the Ugandan manufacturers and also that settler farming alone could not sustain the economy of the colony. The study demonstrated the positive response of the colonial state whereby the colonial government stepped up efforts to reinvigorate the sugar industry through provision of technical assistance that saw the importation and rigorous experimentation in the form of many variety trials. These led to improved cane farming. Furthermore, the response by the colonial government led to identification of the best cane varieties suitable for the area. This boosted the growth of the sugar industry as cane farmers intensified farming with better varieties of cane to plant.

However, as cane farming intensified, other pertinent issues emerged, such as lack of sufficient machinery for breaking of land due to the undercapitalization of the cane farmers who could not afford the tractors. Their situation was compounded by the fact that they could not access loans from private banks or colonial state institutions to meet their needs. Thus the study employed the conceptual framework of innovation and adaptation to examine the Asian cane farmers' response to such challenges. It emerged that the Asian cane farmers used two methods: first, they got machinery from the machinery pool and secondly they pooled resources and hired machinery from European farmers, especially for the breaking of land. This further 
demonstrated the contradictory nature of the colonial state in dealing with the sugar industry. It was willing to boost cane farming through various experimentation, while at the same time the state pursued policies that hindered the procurement of machinery through biased regulations and lack of financial support. The fact that the Asian farmers resorted to their own coping mechanisms revealed the neglect of Asian cane farming by the colonial state and portrayed the determination of the Asian cane farmers.

Owing to the technical assistance given that invigorated cane farming and the resilience of the Asian cane farmers, there was great improvement in cane farming. The work revealed how commercial cane farming expanded over the years in comparison to settler farming in the area and exposed how the colonial state favored the settler farmers. Despite the discrimination, Asian cane farming expanded so that by the mid-1950s, more land was planted in sugar and labor was in great demand. The issue of labor also revealed contradiction within the colonial state as the state put in place measures that favored the settlers. A result of this highlighted by this study was scarcity of labor, which was persistent, and Asian cane farmers continued to struggle to get labor due to lack of sufficient capital partly as failure by the colonial state to extend credit facilities to Asian cane farmers. This led to stiff competition to get and retain labor and to labor unrests that ensued due to poor wages, housing and working conditions. The poor working conditions and low wages led to the emergence of labor organization and trade unionism as a collective bargaining method by the cane workers.

However, by the early 1960s, labor supply had stabilized as the industry expanded and started producing refined sugar, fully financed by Asian capital. The fact that laborers were sufficient towards the end of colonial rule, and even came from the neighboring countries, 
supports the argument that the sugar industry was indeed well established as part of the wider colonial economy, despite the neglect by the colonial government.

The study also demonstrated how the Asian farmers struggled with issues such as land, transport, insufficient funds and diseases among others. In the analyses of the problems, the study employed the use of political economy to show how the Asian cane farmers used political linkages with Indian associations such as EAINC to address some of the issues through petitioning of the colonial state. Transportation was crucial, for example, as the colonial state discriminated against the Asian cane farmers and failed to take advantage of the Kenya-Uganda railway to provide better services to the cane farmers. Thus the Asian farmers struggled to get reliable sufficient means of transport to ferry their produce from the farms to the factory. In interpreting how the Asian farmers solved the transport problem, the concept of innovation was used whereby it emerged that they first organized into various transport groups where some used trolley lines while some used roads. Secondly the Asian cane farmers, in agreement with the manufacturers, staggered planting seasons so that cane would not mature at the same time. This strategy eased transportation difficulties. Such innovations were necessary as the government failed to provide the much needed reduction in rail freight rates to the Asian farmers as they did to the European farmers. This and the failure to utilize the Kenya-Uganda railway line in support of the Asian cane growers was another example of the neglect and lack of appreciation of the sugar industry as part of the wider colonial industry that marked state policy. The implications were that the sugar industry in $\mathrm{CN}$ was denied its full potential by the state.

Due to the resilience of the Asian cane growers and manufacturers, simultaneous measures were undertaken to expand sugar production as was witnessed through the processing of sugar and the financial outlay that was involved in terms of machinery and labor without the 
government's assistance. Like the growers, manufacturers were discriminated against. The work revealed how the Asian manufacturers experienced problems of procurement and obsolete machinery due to bureaucratic government policies that curtailed the process of machinery importation which in turn was responsible for underproduction of the sugar factories. Such prohibitive measures were experienced later when the manufacturer attempted to install a refinery. The negative response by the colonial government depicted the lack of perception on the economic potential of the sugar industry.

Similar lack of appreciation of the economic potential of sugar is revealed through the state's interventionism with market forces. The colonial state determination to control the marketing of sugar, which included pricing, sale and distribution, ensured that the Asian sugar growers and producers played no significant role in marketing. The neglect of the Asian cane farmers and insufficient marketing policies culminated in failure of the colonial state to fix the price of sugar cane for a long time which was detrimental to the cane farmers and affected production of sugar. Even in production the study revealed discrimination as the colonial state preferred Ugandan sugar over the locally produced sugar. Hence, the Asian cane growers and manufacturers struggled to market their produce due to unfair competition from Uganda that was enhanced by the colonial state's failure to put in place effective protective tariff systems that not only denied the Asian cane growers and producers a meaningful profit margin, but also led to dumping of sugar into Kenya. This worsened the situation for the cane farmers and manufacturers. Such biased policies stifled the maximum performance of the sugar industry.

It has been demonstrated in this study that there was inadequate response by the colonial state towards the Asian sugar industry particularly in marketing, first due to discriminative marketing policies and secondly due to settler politics. This clearly emerged as demonstrated by 
Cavendish-Bentinck's, a leading settler, and Mckenzie’s submissions at the conference which reiterated that the colonial state was most eager to secure the market for European wheat farmers in the other two territories of East Africa at the expense of the Asian cane growers. Hence the pertinent issue was for settlers to get a market for wheat in return for sugar importation and the dumping of sugar into Kenya. Therefore, the desire to help the European settlers relegated the Asian cane growers and producers to a state of near economic oblivion as they struggled to survive in a hostile economic and political environment.

Despite these difficulties, the study revealed that the Asian sugar industry contributed to the economic growth of $\mathrm{CN}$ through the agrarian transformations that took place. The work has shown how the local community eventually responded to the new crop. Although initially slow in viewing sugarcane as attractive since they saw it as an Asian crop, the Luo community later adopted cane farming. Some peasant farmers excelled, leading to the emergence of social differentiations. Those who could not farm took to trading of sugar, and this contributed to the household economies that led to the development of CN. Furthermore, the Asian sugar industry contributed to the growth of Kisumu town and its environs. Most significant were the contributions through education, medical facilities, architecture and the many social amenities provided by the Asian communities, among them the cane farmers of Kibos-Muhoroni area.

However, in an assessment of these Asian contributions, it emerges that the sugar industry was beset by contradictions. Whereas the Asian sugar industry made important economic contributions, such as the adoption of cane farming, sale and distribution of sugar, and wage labor in $\mathrm{CN}$, it also had a negative impact. The sugar industry, at the same time, could be said to have helped provoke negative economic performance since it brought land shortages in some parts of CN, such as the Kajulu area that was densely populated. Land shortage remains a 
critical issue for the Luo living adjacent to the sugar belt. It is also clear that although the opportunity to sell sugar provided some Africans with a chance to enhance their incomes, ironically that sale led to drunkenness in the reserves. Contradiction was also witnessed specifically by the colonial states policies that were marked by confusion due to settler politics, internal divisions and tension within the colonial state and the the postwar development thrust that ensued.

Besides such a balance sheet, this study demonstrated how the Asian agricultural initiative was impacted by the political struggle in Kenya. The significance of political economy was revealed in the description of how it was difficult for Asian cane farmers to get land for expansion due to racial discrimination and the political clout of the settlers in Kenya. Furthermore, despite the promising potential of sugarcane farming in $\mathrm{CN}$, such efforts were curtailed due to the role of the colonial state that found it prudent to control not only land but also labor through policies that favored settlers. The state also took firm control of the marketing and distribution of sugar through policies that were discriminative and contradictory. Yet the determination and resilience of the Asian growers and manufacturers saw the sugar industry overcome the obstacles and remain vibrant, solidly financed by Asian capital at the end of the colonial period.

This study has also clearly sustained the argument that the Asian cane farmers were resilient and adaptable to agrarian initiatives like any other community in Kenya. This presents an indictment to the notion that Asians are nothing but traders or "dukawalas." The study has demonstrated how persistence and hard work of the Asians cane growers led to success of commercial cane farming in Kenya in an increasingly discriminative and authoritarian colonial state. The Kibos settlement scheme that led to introduction of commercial cane farming in 
Kenya has continued to date and is by no means a failed agricultural initiative. Rather I posit that it was a success because the Asian cane farmers adapted and turned the area into a sugar belt. Where failure occurred, it was due to environmental factors, such as drought and locust visitations, and the deliberate neglect of the unresponsive colonial state. Therefore, to disregard the success of the Asian cane farmers and focus on the failures is to deny their economic contribution to western Kenya and $\mathrm{CN}$ in particular and consequently deny them their rightful position in economic history of Kenya.

In that regard, this study has made a significant contribution to the historiography of Kenya’s colonial economy. First, most scholars confined their work to peasant and European agriculture and ignored the Asian initiative. Those who attempted to describe Asian history focused on entrepreneurship. Therefore, this study forms the missing link in Asian economic history in Kenya as the study set out to investigate Asian farming enterprise. The study has demonstrated clearly that western Kenya, and $\mathrm{CN}$ in particular, had the potential of a sugar belt and the Asian farmers successfully brought this to realization. Secondly, the study has contributed to the micro-orientation approach whereby it focused on situation-specific analyses of the economic historical experiences of the Asian cane farmers which was part of the larger colonial economy.

Another major contribution of this study relates to the sugar industry itself. From the findings, the work has identified problems that beset the colonial sugar industry, including lack of adequate transport, obsolete machinery, undercapitalization and lack of credit facilities for cane farmers, environmental factors such as drought, pests and diseases and marketing problems that were enhanced by lack of effective tariffs which led to dumping of sugar in the colony. Most important in terms of problems was the lack of the political will on the part of the colonial 
state that neglected the sugar industry. This contributed to a lack of effective performance and failure to fulfill potential. Today the fate of the sugar industry in Kenya is unfortunately the same since the findings mirror most of the current problems faced today by cane farmers in Kenya, particularly the out growers. The findings of Odhiambo corroborate this conclusion and reiterates the fact that today the Kenya sugar industry still faces the same problems as in the colonial period, such as the high cost of hiring farm machinery, among others. ${ }^{1}$

Therefore, the study recommends that these problems be addressed adequately if Kenya is to improve the sugar industry to fulfill the great potential in western Kenya's sugar belt. Towards such a noble task, the Kenya government needs to review its policies as concerns the sugar industry and ensure it does not favor interest groups that are behind the persistent dumping of cheap sugar into the country. State policies should be geared towards promoting sugarcane production at the farm level through provision of subsidies and incentives so as to encourage intensification of cane farming. This way the government would reduce the amount of money used in importation of sugar that could otherwise be channeled to more crucial issues such as provision of clean water and medicine to the people

\footnotetext{
${ }^{1}$ Odhiambo, “The Sugarcane Procurement Problems in Kenya”,35.
} 


\section{BIBLIOGRAPHY}

\section{MANUSCRIPTS AND PRIMARY SOURCES}

\section{KENYA NATIONAL ARCHIVES (KNA), NAIROBI}

\section{AGRICULTURAL OFFICE, KISUMU (AK)}

AK/2/4. N N N N N $\quad$ Nonza Province: Agricultural Quarterly Reports (1957).

AK/2/5. Nyanza Province Annual Reports (Dec. 1956-1957).

AK/2/6. Nyanza Province Annual Reports (1956).

AK/2/7. $\quad$ Nyanza Province Annual Report (1955).

AK/2/17. Central Kavirondo Annual Report (1934-1935).

AK/2/19. Central Kavirondo Monthly Reports.

AK/3/15. Investigation Work General Crops-Sugar.

AK/3/16. Investigation Work General Crops-Sugar.

AK/11/30. Sugar General (1949-1952).

AK/11/50. Sugar General (1935-1949).

AK/11/51. Sugar General (1953).

AK/11/52. Sugar General (1956-1958).

AK/11/73. Jaggery General (1940-1953).

AK/11/74. Jaggery General (1954-1955).

AK/13/13. Farming Indian Areas (1950-1953).

\section{MINISTRY OF AGRICULTURE}

AG/2/2. S S Sugar Ordinance Cap 134 .

AG/2/19. Sugar Ordinance Development of Sugar Industry in Kenya.

AG/16/186. The sale of Jaggery: Sugar General.

AG/25/70. The Victoria Nyanza Sugar Company’s Tramway Ordinance (1923).

AGR/6/4308. Miwani Farms 1930-1958. 
AGR/6/4576. Sugar Production in Nyanza, 1956.

BV/6/178. Crops and Production Sugar Jaggery Marketing Control.

BV/1/249. Grants Muhoroni Sugar, Ltd.

BV/6/613. Sugar International Restriction Scheme (1939-1942, Vol. II).

BV/6/615. Colonial Sugar Committee.

BV/6/619. Ordinance Sugar Control Ordinance.

BV/6/1704. International Sugar Agreement Regulations and Control of Sugar.

BV/6/1713. Sugar.

BV/14/401. Ranger Farm Management, Jaggery Including Disposal.

BV/111/119. Report of Kenya Sugar Industry.

BV/125/27. Sugar Research Station Kibos.

\section{MINISTRY OF COMMERCE}

AE/3/916. Secret Sugar Policy

AE/3/952. African Chamber of Commerce (1944-190)

\section{DISTRICT COMMISSIONER KISUMU-LONDIANI}

DC/CN/1/3/1. Central Kavirondo Annual Report (1947).

DC/CN/1/3/2 Central Kavirondo Annual Report (1946)

DC/CN/1/4/1. Kisumu-Londiani Annual Report (1921).

DC/CN/1/4/3. Kisumu-Londiani Annual Reports (1931-1932).

DC/CN/1/4/4. Kisumu-Londiani Annual Report (1933).

DC/CN/1/4/5. Kisumu-Londiani Annual Report (1936).

DC/CN/1/5/1. Kisumu District Annual and Quarterly Reports (1909-1918).

DC/KSM/1/3/22 Sugar Production Report 1954.

DC/KSM/1/3/32 African Cane Production 1963.

DC/KSM/1/3/57 Crop Production.

DC/KSM/1/3/58. Sugar Distribution. 
DC/KSM/1/3/128. Production and Settlement.

DC/KSM/1/19/270. Sugar Ordinance (1949-1950).

\section{LABOUR DEPARTMENT}

Lab 9/256 Labour for Sugar Industry

Lab 9/1895 Labour Protests at Miwani

Lab 9/ 2132 The Miwani Sugar Mills 1921-1926

\section{PROVINCIAL COMMISSIONER COAST}

PC/COAST/1/1/3. Railway Survey (1892-1895).

PC/COAST/1/17/44. Return of Railway Employees Deaths and Accidents (1890-1901).

PC/COAST/1/18/44. Uganda Railway (1912).

PC/COAST/1/1/21B. Outward File: Uganda Railway.

PC/COAST/1/14/101. Labour For Uganda Railway.

\section{PROVINCIAL COMMISSIONER NYANZA}

PC/NZA/1/1/2. Nyanza Province Annual Report (1906-1907).

PC/NZA/1/3/43/1. Uganda Railway General Matters (1925-1927).

PC/NZA/2/2/35. C Crown Lands Rent Premier (1932-1943).

PC/NZA/2/12/108. Crop Production (1943-1951).

PC/NZA/2/19/35. Hut and Poll Tax Receipts from Muhoroni.

PC/NZA/3/1/465. Intelligence Reports Kisumu-Londiani Districts (1931-1935).

PC/NZA/3/2/34. Indian Cane Growers (1931-1958).

PC/NZA/3/2/182. Commodity Distribution (1947-1950).

PC/NZA/3/3/22. Sugar Industry (1940-1950).

PC/NZA/3/7/1. Lime.

PC/NZA/3/10/2/1. Proposed Asiatic Schools in Kisumu (1924-1926).

PC/NZA/3/13/8. Native Affairs (1940-1955).

PC/NZA/3/13/35. District Labour Committee (1942-1943). 
PC/NZA/3/15/142. Native Liquor (1931-1958).

PC/NZA/3/22/1/2. Kibos Indian Settlement (1910-1916).

PC/NZA/3/22/1/5. Kibos Indian Settlement (1910).

PC/NZA/3/22/1/9. Kibos Indian Settlement (1910-1912).

PC/NZA/3/22/4/1. Sugar Factories (1925-1928).

PC/NZA/3/41/3/1. Buildings Kisumu Districts (1940-1955).

PC/NZA/4/4/88. Kisumu-Londiani Annual Report (1938).

\section{GOVERNMENT PUBLICATIONS}

Department of Agriculture Annual Report, 1919-1920. Nairobi: Government Printer, 1921.

Department of Agriculture Annual Report, 1921. Nairobi: Government Printer, 1922.

Department of Agriculture Annual Report, 1922. Nairobi: Government Printer, 1924.

Department of Agriculture Annual Report, 1923. Nairobi: Government Printer, 1924.

Department of Agriculture Annual Report, 1924. Nairobi: Government Printer, 1925.

Department of Agriculture Annual Report, 1925. Nairobi: Government Printer, 1926.

Department of Agriculture Annual Report, 1926. Nairobi: Government Printer, 1927.

Department of Agriculture Annual Report, 1927. Nairobi: Government Printer, 1928.

Department of Agriculture Annual Report, 1928. Nairobi: Government Printer, 1929.

Department of Agriculture Annual Report, 1929. Nairobi: Government Printer, 1930.

Department of Agriculture Annual Report, 1931. Nairobi: Government Printer, 1932.

Department of Agriculture Annual Report, 1932. Nairobi: Government Printer, 1933.

Department of Agriculture Annual Report, 1933. Nairobi: Government Printer, 1934.

Department of Agriculture Annual Report, 1934, Vol. II, Nairobi: Government Printer, 1936.

Department of Agriculture Annual Report, 1935, Vol. I. Nairobi: Government Printer, 1936.

Department of Agriculture Annual Report, 1936, Vol. I. Nairobi: Government Printer, 1937.

Department of Agriculture Annual Report, 1937, Vol. I. Nairobi: Government Printer, 1939. 
Department of Agriculture Annual Report, 1938, Vol. I \& II. Nairobi: Government Printer, 1939.

Department of Agriculture Annual Report, 1945. Nairobi: Government Printer, 1946.

Department of Agriculture Annual Report, 1946, Parts I \& II. Nairobi: Government Printer, 1948.

Department of Agriculture Annual Report, 1947, Parts I \& II. Nairobi: Government Printer, 1949.

Department of Agriculture Annual Report, 1948, Parts I \& II. Nairobi: Government Printer, 1950.

Department of Agriculture Annual Report, 1949, Parts I \& II. Nairobi: Government Printer, 1951.

Department of Agriculture Annual Report, 1950, Vol. II. Nairobi: Government Printer, 1952.

Department of Agriculture Annual Report, 1952, Vol. I. Nairobi: Government Printer, 1953.

Department of Agriculture Annual Report 1956 Vol. 1 Nairobi: Government printer , 1957.

Native Affairs Department Annual Report 1923.

Native Affairs Department Annual Report 1926-28.

Native Affairs Department Annual Report 1931-1938.

Native Affairs Department Annual Report 1939- 1945.

Native Affairs Department Annual Report 1950.

Kenya Registrar- General Annual Report 1960.

Report of the Kenya land Commission, 1934

\section{DISSERTATIONS/THESES}

Bennett, Charles. "Persistence Amid Adversity: The Growth and Spartial Distribution of the Asian Population in Kenya 1902-1963,”Ph.D. diss., Syracuse University, 1976.

Bhatt, Purnima Mehta. “A History of Asians in Kenya, 1900-1970,”Ph.D. diss., Howard University, 1976.

Breen, Rita "The Politics of Land: Kenya land Commission (1932-1933) and its effects on Land Policy in Kenya,” Ph.D. diss., Michigan State University, 1976.

Ezra, Allen William. "Sugar and Coffee: A History of Settler Agriculture in $19^{\text {th }}$ Century Liberia”, Ph.D. diss., Florida International University, 2002.

Haribhai.Patel H., "Race, Class, and Citizenship in Uganda: Power, Politics and the Indian Minority, 1900-1972,” Ph.D. diss., University of California, 1977. 
Makana, Nicholas. "Changing Patterns of Indigenous Economic Systems: Agrarian Change and Rural Transformation in Bungoma District 1930-1960,”Ph.D. diss., West Virginia University, 2005.

Muyumbu, Gilbert H, “A Historical Study of State Policies in Kenya Sugar Industry1940-2006,” M.A. Thesis, Egerton University, 2006.

Nangulu, Anne K. "Food Security and coping Mechanisms in Kenya's Marginal Areas: The Case of West Pokot,” Ph.D. diss., West Virginia University, 2001.

Ndege, Peter O. "Struggle for the Market: The Political Economy of Commodity Production and Trade in Western Kenya 1929-1939,’Ph.D. diss., West Virginia University, 1993.

Okumu, John J. “Kenya 1900-1930: A Study in Conflict,” Ph.D. diss., University of California, 1966.

Osamba, Joshia. “ Colonial African Labour in Asian Owned Sugar Plantations in Kisumu District 19011963,” M.Phil, Thesis Moi University, 1996.

Seidenberg, Dana April. "The Asians and Uhuru: The Role of a Minority Community in Kenya Politics, 1939-1963,” Ph.D. diss., Syracuse University, 1979.

Shanguhyia, Martin. "The State Ecology and Society in Western Kenya: Soil Erosion and Conservation in Vihiga, 1930-1950,” Ph.D. diss., West Virginia University, 2007.

Talbott, Irvin D. “Agricultural Innovation and Policy Change in Kenya in the 1930s,”Ph.D.diss., West Virginia University, 1976.

Zarwan, John I. "Indian Businessmen in Kenya during the Twentieth Century: A Case Study,” Ph.D. diss., Yale University, 1977.

\section{PERIODICALS}

East Africa Indian Congress

Indian Review

Hindustan Review

Young India

\section{PAPERS}

Osamba, Joshia Otieno. “A Forgotten Minority: The Case of Asian Sugar Plantation Owners in Nyanza Province, Kenya.” A paper presented to the Historical Association of Kenya Annual Conference, Moi University Eldoret, Kenya, July 1998.

\section{$\underline{\text { BOOKS }}$}

Aloo, Ojuka, and William Ochieng ed. Politics and Leadership in Africa. Nairobi: East African Literature Bureau, 1974.

Andrews, C.F. The Indian Question in East Africa. Nairobi: Swift Press, 1921. 
Atieno-Odhiambo, E.S. Siasa: Politics and Nationalism in East Africa. Nairobi: Kenya Literature Bureau, 1981.

Bank for Reconstruction and Development. Economic Development of Kenya. Baltimore: The John Hopkins Press, 1965.

Bates, Robert H. Markets and States in Tropical Africa: The Political Basis of Agricultural Policies. Berkeley: University of California Press, 1984.

Beyond the Miracle of Market: The Political Economy of Agrarian Development in Kenya. Cambridge: Cambridge University Press, 1989.

Beyond the Miracle of Market: The Political Economy of Agrarian Development in Kenya. new ed. Cambridge: Cambridge University Press, 2005.

Bates R.H. and M.F. Lofchie ed. Agricultural Development in Africa: Issues of Public Policy. New York, Praeger,1980.

Beinant, W. and J. McGregor., ed. Social History and African Environment. Oxford: James Currey, 2003.

Bennett, George. Kenya: A Political History. London: Oxford University Press, 1963.

Berman, Bruce. Control and Crisis in Colonial Kenya: The Dialectic of Domination. London: James Currey, 1990.

Berman, B. and J. Londsdale. Unhappy Valley: Conflict in Kenya and Africa, Book One: State and Class. London: James Currey, 1992.

Bharati, Agehananda. Asians in East Africa: Jayhind and Uhuru. Chicago: Nelson-Hall Company Publishers, 1972.

Bunker, Stephen. Peasants Against the State: The Politics of Market Control in Bugisu Uganda. Chicago: The University of Chicago Press, 1991.

Chambers, Robert. Rural Development: Putting the Last First. London: Longman Publishers 1983.

Chattopadhyaya, Haraprasad. Indians in Africa: A Socio-Economic Study. Calcutta: Bookland Private, Ltd., 1970.

Chazan, Naomi and T.M. Shaw ed. Coping With Africa's Food Crisis. Colorado: Lynne Reinner, 1988.

Chirot, Daniel, and Anthony Reid ed. Essential Outsiders: Chinese and Jews in the Modern Transformation of Southeast Asian and Central Europe. Seattle: University of Washington Press, 1997.

Clayton, Anthony, and Donald Savage. Government and Labor in Kenya 1895-1963. London: Frank Cass and Company, Ltd., 1974.

Collier, Paul, and Deepak, Lal. Labour and Poverty in Kenya 1900-1980. New York: Oxford University Press 1986. 
Debroy, B, and, A.U. Khan ed. Integrating the Rural Poor in Markets. New Delhi: Academic Foundation Press, 2004.

Delf, George. Asians in East Africa. London: Oxford University Press, 1963.

Dilley, Majorie. British Policy in Kenya Colony. New York: Thomas Nelson and Sons, 1937.

Ellis, Frank. Peasant Economics: Farm Household and Agrarian Development. Cambridge: Cambridge University Press, 1988.

Eliot, Charles. The East Africa Protectorate. London: Edward Arnold Publishers, 1905.

Enloe, H. Cynthia. Ethnic Conflict and Political Development. Boston: Little Brown and Company, 1972.

Fearn, Hugh. An African Economy: A Study of the Economic Development of the Nyanza Province of Kenya, 1903-195. London: Oxford University Press, 1961.

Frank, Charles S. The Sugar Industry in East Africa. Nairobi: East African Publishing House, 1965.

Fumagalli, Carl T. “An Evaluation of Development Project Among the East African Pastoralists” in Phillips Stevens ed. Social Sciences Involvement in African Development Planning. Waltham: Crossroads Press, 1978.

Ghai, Dharam P., eds. Portrait of a Minority. Nairobi: Oxford University Press, 1965.

Gregory, Robert. India and East Africa: A History of Race Relations Within British Empire, 1890-1939. Oxford: Clarendon Press, 1977.

. South Asians in East Africa: An Economic Social History. Boulder: West View Press, 1993.

. Quest for Equality: Asian Politics in East Africa 1900-1967. New Delhi: Orient Longman, Ltd., 1993.

Hancock, Willam K. Survey of British Commonwealth Africans: Problems of Nationality. Latham: Oxford University Press, 1942.

Harlow, V. and E.M. Chilver eds. History of East Africa. Oxford: The Clarendon Press. 1965

Heyer, Judith, J. K. Maitha and W.M. Senga ed. Agricultural Development in Kenya: An Economic Assessment. Nairobi: Oxford University Press, 1976.

Higgins, B. Economic Development: Principles, Problems, and Policies. New York: W.W. Norton and Company, 1968.

Hill, Polly. The Migrant Cocoa Farmers of Southern Ghana: A Study in Rural Capitalism. Oxford: International African Institute, 1997.

Hill, M.F. Permanent Ways, Story of Kenya-Uganda Railway and Harbours. Nairobi: East Africa Railways and Harbours, 1949. 
Himmelstrand Ulf et al ed. Perspectives on Development: Controversies, Dilemma and Opennings.Nairobi: East African Educational Publishers, 1994.

Hoffenberg, A. Alice. International Firms and Labour in Kenya 1945-1970. London: Frank Cass and Company, 1971.

Hollingsworth, L.W. The Asians of East Africa. London: Macmillan and Company, Ltd., 1960.

Ikiara, Gerishon. Development and Society: The Dynamics of Social Change. New York: St. Martins Press, 1964.

Kitching, Gavin. Class and Economic Change in Kenya: The Making of an African Petit Bourgeoisie 1905-1970. New Haven: Yale University Press, 1980.

Leys, Colin. The Rise and Fall of Development Theory. London: James Currey, 1996.

Leys, Norman. Kenya.London: Frank Cass and Company, 1973.

Hailey, Lord. An Africa Survey: A Study of Problems Arising in Africa South of Sahara. London: Oxford University Press.

Mackenzie, D.Fiona. Land, Ecology and Resistance in Kenya 1880-1952. Portmouth: Heineman, 1998.

Makoha, Joseph. The District Focus: Conceptual and Management Problems. Nairobi: American Press Research Bureau, 1985.

Mangat, J.S. A History of the Asians in East Africa 1886 to 1945. Oxford: Clarendon Press, 1969.

Maxon, Robert. East Africa: An Introductory History. Morgantown: West Virginia University Press, 1994.

. Going Their Separate Ways:Agrarian Transformation in Kenya 1930-1950. London: Associated University Presses, 2003.

. Struggle for Kenya:The Loss and Reassertion of Imperial Initiative 1912-1923.London: Associated University Presses, 1993.

John Ainsworth and the Making of Kenya.Lanham: University Press of America, 1980.

Maxon, R and T. Ofcansky. A Historical Dictionary of Kenya. 2nd ed.London: The Scarecrow Press Inc, 2000.

McCormack, Richard T. Asians in Kenya: Conflict and Politics. Brooklyn: Theo. Gaus’ Sons, Inc., 1971.

McGregor, W. Ross. Kenya from Within: A Short Political History. London: Cass Publishers, 1968.

Morris, H.S. The Indians in Uganda. London: Weidenfeld and Nicolson, 1968.

Mosley, Paul. The Settler Economies: Studies in the History of Kenya and Southern Rhodesia. Cambridge: Cambridge University Press, 1983 
Norman, Humphery. Liguru and the Land: Sociological Aspects of Some Agricultural Problems of North Kavirondo. Nairobi: Government Printer, 1947.

Novak, D.E, and R. Lekachman.ed. Development and Society: The Dynamics of Social Change. New York: St. Martin’s Press, 1964.

Ochieng', W. R., and R.M. Maxon. ed. An Economic History of Kenya. Nairobi: East African Educational Publisher, 1992.

Ochieng', W.R. ed., A Modern History of Kenya 1895-1980. Nairobi: Evans Brothers (Kenya) Ltd, 1989.

Ochieng’, W.R. An Outline History of Nyanza up to 1914. Nairobi: East African Literature Bureau, 1974.

Orvis, Stephen. The Agrarian Question in Kenya. Gainesville: University Press of Florida, 1997.

Pandit, Shanti. Asians in East and Central Africa. Nairobi: Panco Publishers, 1963.

Pearson, Scott et al ed. Agricultural Policy in Kenya: Application of the Policy Analysis Matrix. Utica: Cornell University Press, 1995.

Richards, P. Indigenous Agricultural Revolution: Ecology and Food Production in West Africa. London: Hutchinson and Company, 1985.

Rodney, Walter. How Europe Underdeveloped Africa. Dar es Salam: Tanzania Publishing House, 1992.

Rothchild, Donald. Racial Bargaining in Independent Kenya. New York: Oxford University Press, 1973.

Seidenberg, Dana April. Uhuru and The Kenya Indians: The Role of a Minority Community in Kenya Politics 1939-1963. New Delhi: Vikas Publishing House, 1983.

Sorrenson, M.P.K. Origins of European Settlement in Kenya. Nairobi: Oxford University Press, 1968.

Stichter, Sharon. Migrant Labour in Kenya: Capitalism and African Response 1985-1975. Harlow: Longman publishers, 1982.

Swainson, Nicola. The Development of Corporate Capitalism in Kenya 1918-1977. California: University of California Press, 1980.

Timmer, C. Peter. Getting Prices Right, the Scope and Limits of Agricultural Price Policy. Ithaca: Cornell University Press, 1986.

Van Zwanenberg, R. M. with Anne King. An Economic History of Kenya and Uganda. Atlantic Highlands: Humanities Press, 1975.

Van Zwanenberg, R.M. Colonial Capitalism and Labour in Kenya. Nairobi: East African Literature Bureau, 1975.

Wagner, Gunter. The Bantu of Western Kenya with Special Reference to Vugusu and Logoli: Economic Life. London: Oxford University Press, 1956. 
Wolff, R.D. The Economics of Colonialism, Britain and Kenya 1870- 1930. London: Yale University Press. 1974.

Worthington, Stella, and E.Bernard Worthington. Inland Waters of Africa. London: Macmillan and Co Ltd, 1933.

\section{ARTICLES, NEWSPAPERS AND JOURNALS}

\section{NEWSPAPERS}

Colonial Times

Kenya Daily Mail

East African Standard

\section{JOURNALS}

Anderson, David M. “Master and Servant in Colonial Kenya, 1895-1939.” Journal of African History 41 (2000): 459-485.

Anyang' Nyong'o, Peter. “The development of Middle Peasantry in Nyanza.” Review of African Political Economy 8 no 20 (1981): 108-120.

Berman, Bruce and John Lonsdale. "Coping with Contradictions: The development of the Colonial State in Kenya 1895-1914.”Journal of African History 20 no. 4(1979): 487-505.

Immergut, M.Ellen. “The Theoretical Core of the New Institutionalism.”Journal of Politics and Society 26 no. 1(1981): 5-34.

Meredith, David. "The British Government and the Colonial Economic Policy 1919-1939." The Economic History Review 28 no.3 (1975): 484-499.

Nasong'o, Shadrack. “Multilateral Imperialism in Kenya's Sugar Industry: The Political Economy of Transnational Corporations.” Nigerian Journal of International Affairs 26 (2000): 56-77.

Odhiambo, M.O. "The Sugar-cane Procurement Problems in Kenya: The Case of the Nyanza Sugar Belt.” East African Agricultural and Forestry Journal 53 no.1 (1989): 29-49

Petersen William “A General Typology at Migration.” American Sociological Review 23 (1958): 256266.

Plessis, S., and Sophia du Plessis. "Explanation for Zambia’s economic decline.” Development Southern Africa 23 no.3 (2006): 327-369.

Wanyande, Peter. "Management Politics in Kenya's Sugar Industry: Towards an Effective Framework” African Journal of Political Science 6 no. 1 (2001): 123-140. 


\begin{tabular}{|c|}
\hline Informants Name \\
\hline Joseph Ouma \\
\hline Chanan Singh \\
\hline Mohinder Singh \\
\hline Harjit Singh \\
\hline Ranuhan Singh \\
\hline Martin Okeyo \\
\hline Martin Otieno \\
\hline Joseph Otieno \\
\hline Eng. J.S. Cheema \\
\hline B. Rama Mohan \\
\hline Vitalis Ogola \\
\hline David Odongo \\
\hline Hezborn Atudo \\
\hline C.B. Ombogo \\
\hline Absalom Apondi \\
\hline Peter Abwogo \\
\hline Joseph Okongo \\
\hline Hezron Kaka Muynze \\
\hline J. Kiprono \\
\hline Grace Nandi \\
\hline Manase Nandi \\
\hline Thomas Okeyo \\
\hline Tom Ogada \\
\hline Michael Juma \\
\hline Zakaria Olang \\
\hline Vajv Sudra \\
\hline Amira Sudra \\
\hline Rajiv Khan \\
\hline Zablon Wakiaba \\
\hline
\end{tabular}

\section{Place of Interview}

Kibos

Kibos

Kibos

Kibos

Kibos

Miwani

Chemelil

Chemelil

Kibos

Kibos

Kibos

Kibos

Kibos

Muhoroni

Muhoroni

Muhoroni

Muhoroni

Kibigori

Kibigori

Chemelil

Chemelil

Kibos

Chemelil

Chemelil

Miwani

Kisumu town

Kisumu town

Kisumu town

Kibigori

\section{Date}

06/12/2009

07/02/2009, 07/26/2009

06/06/2009, 06/22/2009, 07/26/2009

06/06/2009

06/27/2009

06/24/2009

06/20/2009

$06 / 26 / 2009$

06/23/2009

06/22/2009

06/06/2009

06/06/2009

06/06/2009, 06/22/2009

06/25/2009

07/26/2009

$06 / 21 / 2009$

06/21/2009

07/01/2009

07/01/2009

07/04/2009

07/04/2009

07/03/2009

07/06/2009

07/06/2009

07/26/2009

07/05/2009

07/05/2009

07/05/2009

06/20/2009 